\title{
Geology and petrology of the Lower Tertiary plateau basalts of the Scoresby Sund region, East Greenland
}

Lotte Melchior Larsen, W. Stuart Watt and Margrethe Watt
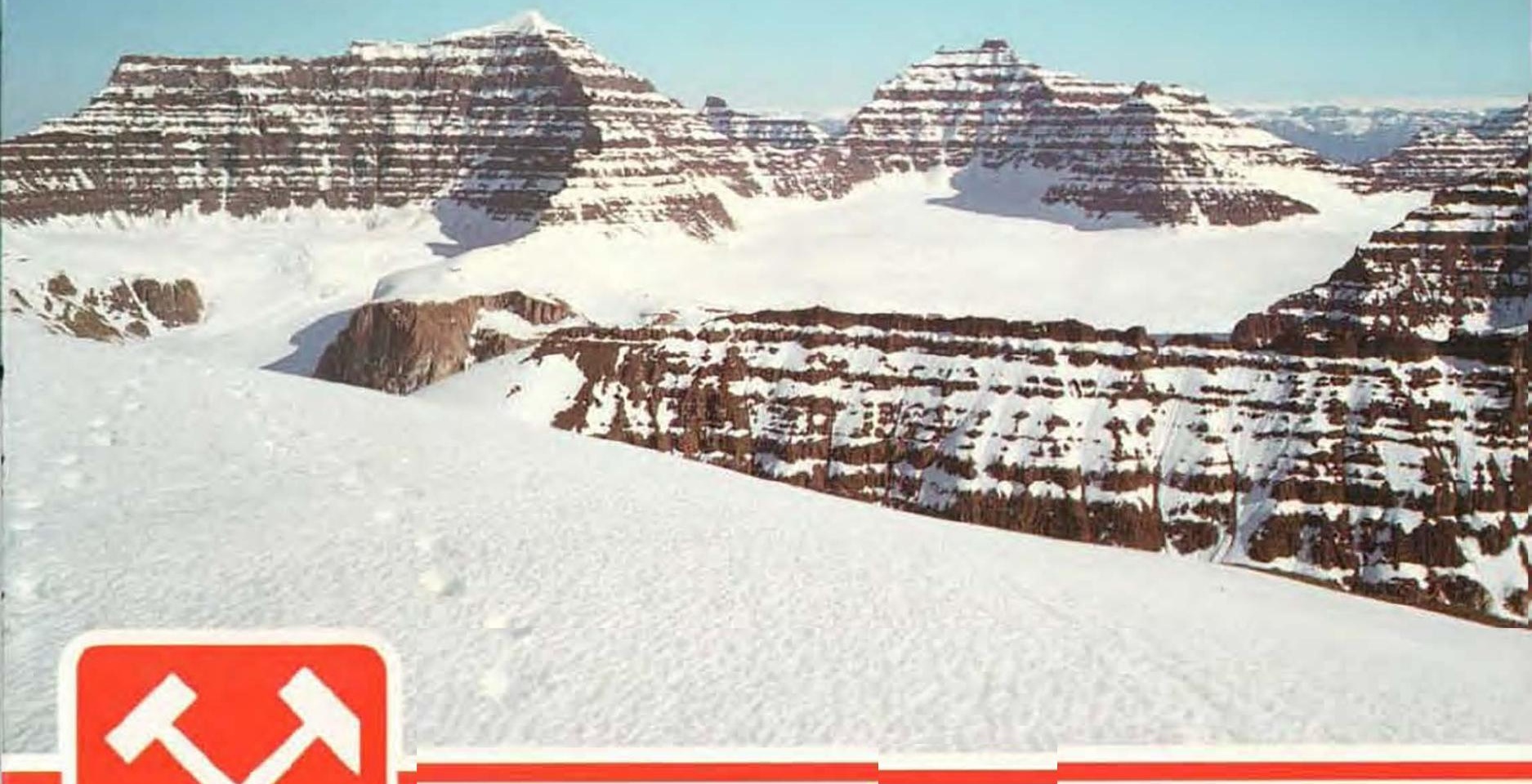

GRØNLANDS GEOLOGISKE UNDERSøGELSE

GGU Bulletin 157 
GRØNLANDS GEOLOGISKE UNDERSøGELSE

Bulletin No. 157

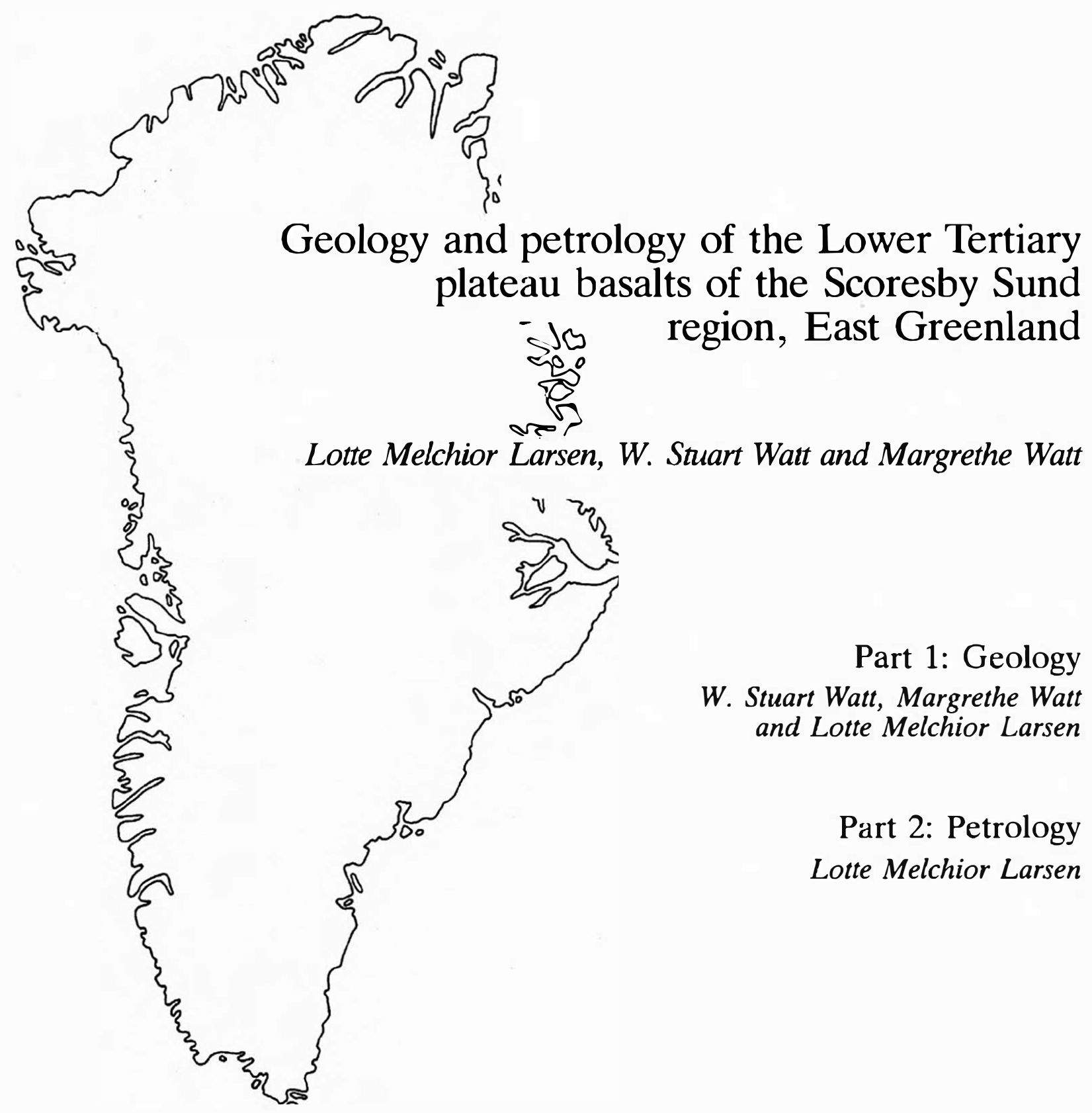




\section{Abstract}

The early Tertiary plateau basalts in East Greenland are situated on a continental margin and were erupted during continental break-up and initiation of sea-floor spreading in the North Atlantic. In the region stretching from Scoresby Sund southward to $69^{\circ} \mathrm{N} 40000 \mathrm{~km}^{2}$ of basalts with an average thickness of $1.5 \mathrm{~km}$ have been investigated by measuring and flow-to-flow sampling of 130 profiles, followed by major element geochemical analysis and microprobe analysis, trace element analysis and some $\mathrm{Sr}$ isotope data.

The basalts rest on Mesozoic sediments in the east and on Precambrian gneiss in the west. Six basalt formations are defined: the Magga Dan, Milne Land and Geikie Plateau Formations form a lower regional sequence erupted in one volcanic episode from sites in the NW part of the region; the Rømer Fjord and Skrænterne Formations form an upper regional sequence erupted in a subsequent volcanic episode in which eruption sites moved SE to centres east of the present Atlantic coast; the Igtertivâ Formation and a coast-parallel dyke swarm formed in a third volcanic episode only recorded at the Atlantic coast. The lavas are essentially flat-lying; a narrow strip along the Atlantic coast is extensively block faulted. Single lava flows are extensive $\left(\max .11000 \mathrm{~km}^{2}\right.$ ) and voluminous (max. 300 $\mathrm{km}^{3}$ ). They are well preserved, with metamorphism of the low zeolite facies.

All the lavas and most of the dykes are fractionated tholeitic basalts with $\mathrm{Mg} /\left(\mathrm{Mg}+\mathrm{Fe}^{2+}\right)$ ratios of $0.66-0.39$ and $\mathrm{TiO}_{2}=$ $1.2-4.5 \%$. The major part (the 'main basalts', $96 \%$ by volume) have $\mathrm{Mg}$ ratios of $0.56-0.39$, while only 4 vol. $\%$ are $\mathrm{Mg}$-rich basalts with $\mathrm{Mg}$ ratios of $0.66-0.57$. A nephelinitic tuff layer occurs at the base of the second sequence. A few dykes are alkaline.

The Mg-rich basalts have microphenocrysts of olivine (Fona-70) and chromite, while the main basaits comprise both aphyric and porphyritic sequences. Phenocrysts of plagioclase $\left(A n_{58-37}\right)$ are abundant, of olivine $\left(\mathrm{Fo}_{50-57}\right)$ are sparse but ubiquitous, and of augite $\left(\mathrm{Fs}_{\mathrm{s}_{-20}}\right)$ sparse and often absent. Groundmass phases are olivine (to $\mathrm{Fo}_{37}$ ), plagioclase (to $\mathrm{An}_{13}$ ), augite (to $\mathrm{Fs}_{\mathrm{\sigma}_{2}}$ ), pigeonite $\left(\mathrm{Fs}_{26-50}\right.$ ), titanomagnetite and ilmenite. All rocks contain several per cent fine-grained mesostasis. The phenocrysts frequently show disequilibrium textures and a wide range of compositions within one sample.

Extrusion temperatures are calculated to $1280-1110^{\circ} \mathrm{C}$, and densities to $2.68-2.78 \mathrm{~g} / \mathrm{cm}^{2}$, increasing with fractionation.

The volcanic episodes are demonstrated in systematic compositional variations with height in the basalt sequence. Each of the two major episodes started with a variety of lava compositions including $\mathrm{Mg}$-rich basalts, followed by a thick sequence of 'main basalts' showing a systematic decrease of $\mathrm{TiO}_{2}$ and other incompatible elements with height, and ending with a reversal to higher $\mathrm{TiO}_{2}$ values. The third episode is not cyclic, and its products have changed incompatible element ratios. The Mg-rich basalts comprise depleted MORB type basalts, relatively enriched olivine tholeiites, and very enriched tholeiites (Mikis type basalt). $\mathrm{Sr}$ isotopes show ${ }^{67} \mathrm{Sr} /{ }^{36} \mathrm{Sr}$ ratios of 0.7034 in most basalts and 0.7045 in the Mikis type basalt, while some Si-rich basalts have ratios up to 0.7079 . The East Greenland basalts are 'initial rifting' basalts very similar to those in Deccan.

The magmas have equilibrated at low pressures in crustal magma chambers. The main basalts have fractionated ol $+\mathrm{pl}$ $+c p x$ no matter whether they are aphyric or porphyritic. Simple crystal fractionation can account for sub-trends but not for the complete compositional variation of the main basalts. This is considered as resulting from fractionation in open magma chambers which were repeatedly filled, mixed and tapped. The decrease in $\mathrm{TiO}_{2}$ with height in each volcanic episode indicates increasing magma input rate and shorter residence time in the chamber, while the final reversal indicates the decline and cessation of activity. There is evidence for widespread crustal contamination $(1-4 \%)$ in the magma chambers of the two lowest formations. Crustal contamination of magmas on the way to the surface occurred sporadically throughout both sequences. One case of magma mixing occurred when a $\mathrm{Mg}$-rich basalt magma invaded the regional main basalt magma chamber.

The Mg-rich basalts cannot be directly related to each other or to the main basaits. A petrogenetic scheme is suggested where the Mikis type basalt originated in, or contains an addition from, an undepleted or enriched mantle source. All the other magma types originated in a depleted mantle source by varying degrees and possibly depths of melting. Increasing degrees of melting are indicated for the types nephelinite enriched olivine tholeiite - main basalt parent - MORB type basalt. The MORB type basalt may also be produced by melting of a residuum. The basalts of the third volcanic episode include another component of mantle or basaitic crust.

The three recorded volcanic episodes are related to rifting events during the break-up of the North Atlantic continent, viewed as repeated attempts to straighten out a bend in the original line of opening. The two first rifting events failed while the third for a short while produced oceanic crust. Compared to other regions of the North Atlantic volcanic province the Scoresby Sund basalts are similar to basalts from Kangerdlugssuaq, northern East Greenland, West Greenland, the Faeroes, the Voring Plateau and some basalts on Iceland. The main magma source for the North Atlantic province was similar to that of the Iceland hotspot, but enriched subcontinenal lithosphere may also have participated in the stage of initial rifting. A correlation for the volcanic episodes throughout East Greenland and the Faeroes is proposed.

Auhors' address:

Grønlands Gcologiske Undersøgelse, Øster Voldgade 10 , DK-1350 Copenhagen K, Denmark 


\section{Contents}

PART 1. GEOLOGY

W. S. Watt, M. Watt \& L. M. Larsen

Introduction........................... 5

Previous work on the Scoresby Sund basalts ...... 5

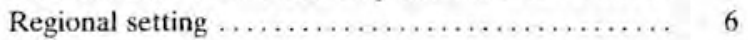

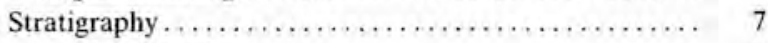

Field work $\ldots \ldots \ldots \ldots \ldots \ldots \ldots \ldots \ldots \ldots \ldots$

General structure of the basalts............. 7

Geochemical work and defined rock types ..... 7

Volcanic episodes...................... 8

Pre-basaltic topography.................. 9

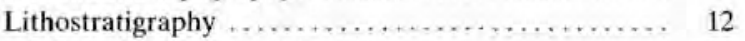

Magga Dan Formation ................. 13

Milne Land Formation .................... 16

Geikie Plateau Formation................ 21

Rømer Fjord Formation ................. 26

Skranterne Formation ................. 30

Igtertivâ Formation ...., ..., ............. 35

Kap Dalton Formation ..................... 37

Kap Brewster Formation. ................ 37

Dykes ............................ 37

General features ...................... 41

Tectonics ............................ 41

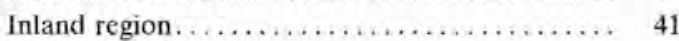

Coastal zone $\ldots \ldots \ldots \ldots \ldots \ldots \ldots \ldots \ldots \ldots \ldots, 41$

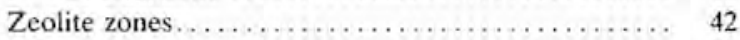

Lava volumes ........................ 44

Calculated volumes of the basalt formations.... 44

Volumes of the various basalt types ......... 45

Volumes of individual lava flows............ 45

Productivity ......................... 46

Correlation south of $69^{\circ} \mathrm{N} \ldots \ldots \ldots \ldots \ldots \ldots \ldots, 47$

\section{PART 2. PETROLOGY}

\section{M. Larsen}

Petrography .

General.

Phenocrysts ....................... 50

Groundmass ......................... 50

Mikis type basalt $\ldots \ldots \ldots \ldots \ldots \ldots \ldots \ldots \ldots \ldots . \quad 52$

MORB type basalt and olivine tholeiite $\ldots \ldots \ldots \ldots .53$

Hjørnedal marker flow ................... 53

Main basalts .......................... 54

High-Si basalts ..., ..................... 56

Alkaline rocks......................... 57

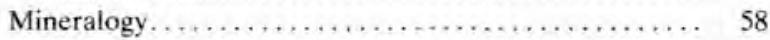

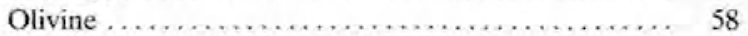

Chromite ............................... 60

Plagioclase .............................. 64

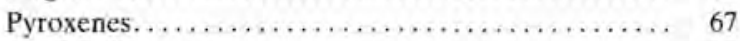

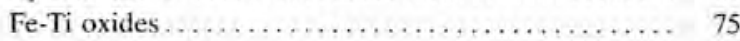

Residual products..................... 78
Secondary minerais $\ldots \ldots \ldots \ldots \ldots \ldots \ldots \ldots \ldots, 78$

Minerals in alkaline rocks................... 80

Glassy rocks and geothermometry ............ 81

Calculation of equilibrium phenocryst compositions

and liquidus temperatures................ 82

Geochemistry ............................ 85

Effects of alteration, and recalculation of analyses 85

Effects of crystal accumulation ............ 86

General classification and divisions............ 86

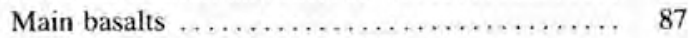

Mg-rich basalts ....................... 87

High-Si basalts ....................... 89

General properties of the magmas ............. 90

Temperatures..................... 90

Phase relations $\ldots \ldots \ldots \ldots \ldots \ldots \ldots \ldots \ldots \ldots, 91$

Densities ............................ 92

Discussion of major elements ................ 94

Compositional variations within the basalt pile and dykes......................... 94

Phase diagrams ...................... 96

Simple oxide variation diagrams ............ 98

Trace elements .......................... 103

Strontium isotopes .......................... 108

Comparison with other basalt areas ............. 109

Petrogenesis........................... 111

Magma chambers ....................... 111

Shape and size of magma chambers and volcanic systems ......................... 111

Temporal development of magma chambers and eruption sites...................... 113

Processes in the magma chambers ............ 114

Crystal fractionation .................... 114

Magma mixing and open magma chambers....., 116

Origin of the Hjørnedal marker flow . . . . . . . . 119

Crustal contamination ................... 120

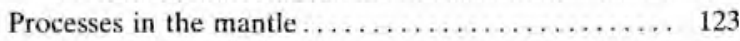

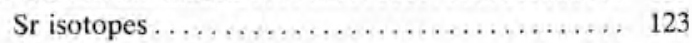

Minor and trace elements................. 124

Petrogenetic scheme ....................... 126

North Atlantic Tertiary igneous province .......... 127

East Greenland in relation to continental break-up . . 127

North Atlantic regions. . . . . . . . . . . . . . 128

Discussion ............................ 138

Regional correlation ..................... 138

The occurrence of primitive and evolved basalts . 138

Petrogenetic models for the North Atlantic ..... 139

Concluding remarks ...................... 140

Acknowledgements ....................... 140

References............................... 140

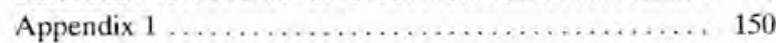

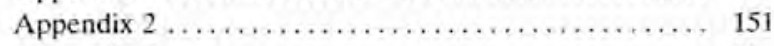

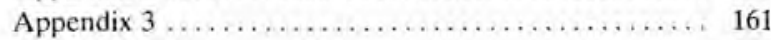




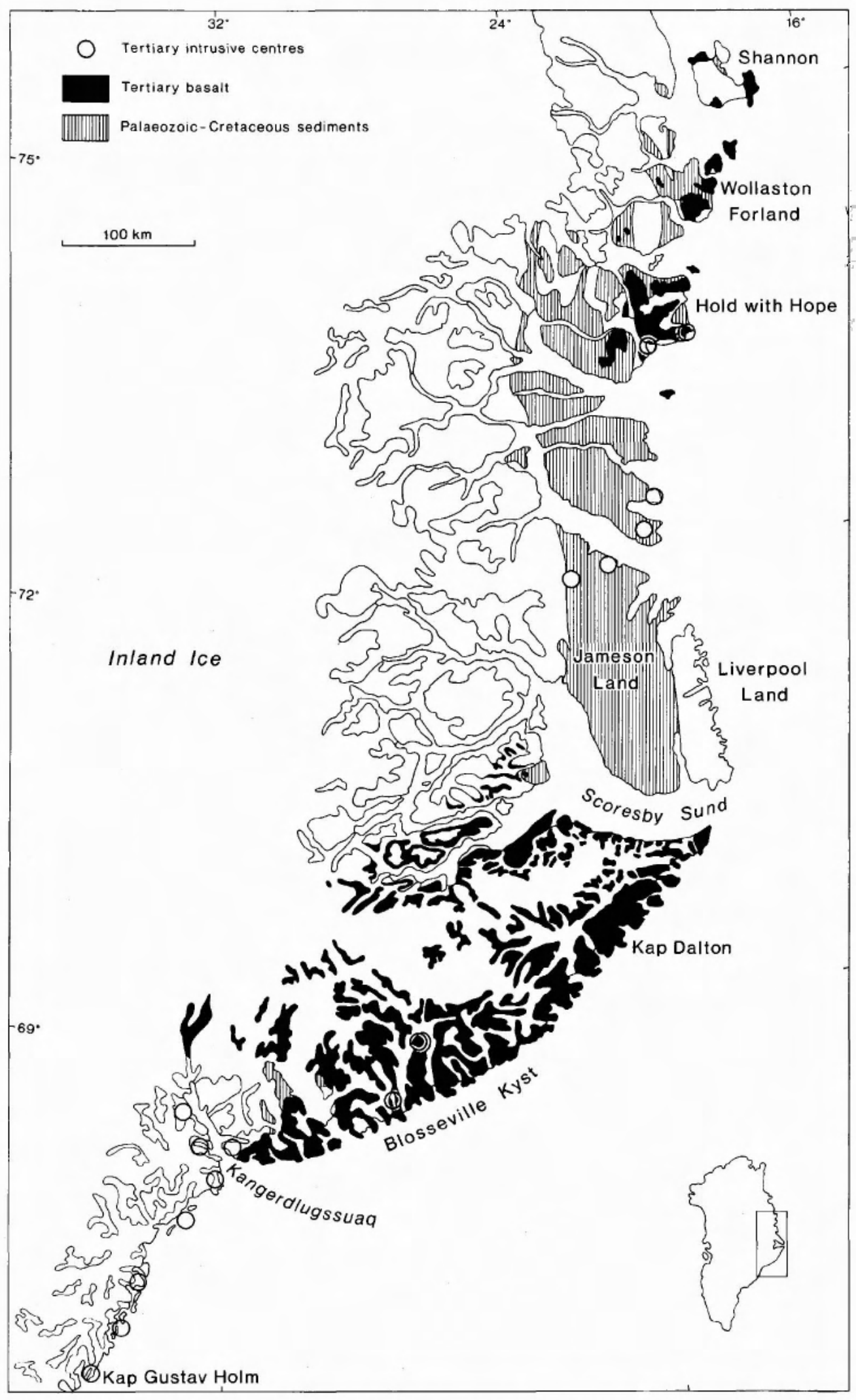

Fig. 1. East Greenland basalt province. Further place names appear on fig. 2. 


\section{PART 1. GEOLOGY}

\section{Introduction}

The East Greenland Tertiary magmatic province stretches from Kap Gustav Holm in the south to Shannon in the north, a distance of approx, $1200 \mathrm{~km}$ (fig. 1). General descriptions of the province are found in Haller (1970), Brooks (1973), Noe-Nygaard $(1974,1976)$ and Deer (1976).

In the region between Kangerdlugssuaq and Scoresby Sund the magmatic activity gave rise to a $2-5 \mathrm{~km}$ thick extensive cover of plateau basalts. Only the general features of this basalt cover have been known for some time, because the area presents severe logistic problems: it is partly glaciated, the climate is harsh and the topography rugged. It is thus of very difficult access.

During the years 1968 to 1972 The Geological Survey of Greenland (GGU) conducted systematic geological mapping of the Scoresby Sund fjord zone in East Greenland between $70^{\circ} \mathrm{N}$ and $72^{\circ} \mathrm{N}$ with the aim of producing geological maps at a scale of 1:100 000. This area includes the northern extension of the plateau basalt cover. Because key areas to the basalt stratigraphy were located south of $70^{\circ} \mathrm{N}$, mapping was extended southwards, in particular along the Blosseville Kyst in 1975 and 1978. Together with airborne reconnaissance work in 1974 and 1980 southwards to $69^{\circ} \mathrm{N}$ this work also provided data for the geological map 1:500 000 sheet 12, Scoresby Sund. The six 1:100 000 geological maps covering the plateau basalts are $70 \varnothing 1 \mathrm{~S}$ Kap Brewster, $70 \varnothing 2 \mathrm{~S}$ Vikingebugt, $70 \varnothing 3 \mathrm{~S}$ Găsefjord, 70 $\varnothing 4 \mathrm{~S}$ Vestfjord, $70 \varnothing 2 \mathrm{~N}$ Kap Leslie and $70 \varnothing 3 \mathrm{~N}$ Rødefjord.

This bulletin presents the results of the systematic investigation of the plateau basalts. It includes both field and laboratory work, the combination of which have proved indispensible for deciphering the volcanic history of the region. The field work was carried out by W. S. Watt and M. Watt who established the six basalt formations defined here. The petrographic, mineralogical and geochemical work, with the resulting subdivisions of the basalt formations, was carried out by L. M. Larsen.

\section{Previous work on the Scoresby Sund basalts}

The first geological observations from the area were reported by the whaling captain William Scoresby
(1823) who collected samples from the lavas at Kap Brewster. In 1891-92 the Danish East Greenland expedition led by C. Ryder investigated the Scoresby Sund fjord system, and Bay (1896) published a short description of the basalts and their substrata on Gaseland, Milne Land and along the south coast of Scoresby Sund. Bay also produced the first geological map of the area. Further observations were made during the Carlsbergfondets expedition to East Greenland led by G. Amdrup and N. Hartz in 1900, during which the Blosseville Kyst from Kap Brewster to Kap Dalton was investigated, and the Eocene fossiliferous sediments at Kap Dalton were discovered (Hartz, 1902). Geological and petrographical descriptions of the basalts, and a suggestion of their division into two series, were given by Nordenskjöld (1907), while Bøggild (1909) gave detailed mineralogical descriptions of some amygdale minerals from the basalts. Holmes (1918) published the first chemical analysis of a plateau basalt from the area, which indicated that the basalts were what was later called tholeiites.

The Scoresby Sund Committee's 2nd expedition in 1932 led by $\mathrm{E}$. Mikkelsen investigated the Blosseville Kyst from Kangerdlugssuaq to Kap Dalton. The general geology and structure of the basalts of the Blosseville Kyst were described by Wager $(1934,1947)$ with accompanying chemical analyses, and the geology of the Eocene sediments and underlying basalts at Kap Dalton was described in detail by Wager (1935).

The British East Greenland expeditions in the 1930s led by L. R. Wager and others investigated the Tertiary rocks in the region centered on the Kangerdlugssuaq fjord, while the Danish expeditions led by L. Koch in the 1930 s and 1950 s were chiefly concerned with the region north of Scoresby Sund, so that the region in between, i.e. the present area of investigation, was for a long time the least known part of the East Greenland Tertiary magmatic province. Wenk (1961) described basalt lavas, pyroclastics and dykes from Gảseland, where the lava flows cover the deeply dissected crystalline basement.

A petrological account of some of the basalts in the Scoresby Sund area was made by Fawcett et al. (1973) based on field reconnaissance by the Oxford University expedition in 1965, and Brooks et al. (1976) reported on the petrology of basalts from the Blosseville Kyst area. 
Works on specific properties of the basalts such as palaeomagnetism and age include those of Tarling (1967), Beckinsale et al. (1970), Hailwood et al. (1973), Soper \& Costa (1976), Soper et al. (1976) and Odin \& Mitchell (1983).

Previously published reports from the present mapping are Watt (1969), Watt \& Watt (1971), Watt et al. (1972), Watt \& Watt (1973), Watt (1975), Watt et al. (1976), Watt \& Watt (1979 and 1983), Watt \& Wrang (1984) and Watt et al. (1986). Larsen \& Watt (1985) presented some of the general conclusions from the present work.

\section{Regional setting}

During Mesozoic time a N-S elongated sedimentary basin developed in East Greenland, partly bounded by faults towards the Caledonian and older high-lying crystalline basement to the west and east (Surlyk et al., 1981). Sediments of this basin occupy extensive areas in Jameson Land, immediately to the north of the basalts, and are also found on Milne Land where they are partly covered by basalts. Geophysical investigations (B. Larsen, 1980; H. C. Larsen, 1985) have indicated that the sediments exposed on Jameson Land extend south beneath Scoresby Sund to the southern shore where they are covered by the basalts at depths of $200-400 \mathrm{~m}$ below sea level. A small exposure of Cretaceous sediments is found below the basalts on the south side of Scoresby Sund at Savoia Halvø (R. A. Fensome in Watt \& Watt, 1983), but the extension of the sedimentary basin to the south, below the basalts, is unknown. Cretaceous to lower Tertiary sediments underlie the basalts at Kangerdlugssuaq (Deer, 1976; Nielsen et al., 1981) $400 \mathrm{~km}$ to the south, and we believe that the sedimentary basin may be continuous and underlie the whole eastern part of the lava pile. This is supported by the occurrence of methane, presumably sediment-derived, in the warm springs in the lavas at Rømer Fjord on the Blosseville Kyst, and the occurrence of migrated hydrocarbons in the lavas on Savoia Halvø (Watt \& Wrang, 1984). H. C. Larsen (1984, fig. 7, and 1985, fig. 15) likewise invokes Mesozoic sediments beneath the basalts along the Blosseville Kyst.

The plateau basaltic volcanism is related to the initiation of rifting and sea floor spreading in the North Atlantic (e.g. Brooks, 1973). The age of the basalts is bracketed biostratigraphically between Sparnacian and Ypresian: a shale horizon in the lowest part of the Lower Basalts in the Kangerdlugssuaq district contains a microplankton flora referable to the late Paleocene (Sparnacian; Soper, Higgins et al., 1976), while a shale horizon in the Igtertivâ Formation $300 \mathrm{~m}$ from the top of the basalt pile at Kap Dalton contains a microplankton flora of lowest Eocene age (lowest Ypresian, Soper \& Costa, 1976). The post-basaltic Kap Dalton Formation is of upper Eocene to Oligocene age (Ravn, 1933, Hassan, 1953, Birkenmajer, 1972).

Berggren et al. (1985) discussed the age of the East Greenland basalts at some length. The basalts are confined to the nannoplankton zones upper NP 9 to NP 11 (Foraminifera zones P5-P6), which is correlated to geomagnetic polarity chron $\mathrm{C} 24$. This correlation has also been inferred by several previous authors who noted that all the basalts are reversely magnetised (Tarling, 1967; Hailwood et al., 1973). The basalts were therefore erupted in the approximately three million years time interval between geomagnetic polarity anomaly 24 and $25(\mathrm{C} 24 \mathrm{R})$. Only the volumetrically insignificant Igtertivâ Formation and the associated coastal dyke swarm may be normally magnetised and correlate with anomaly 24 (C24N) (Larsen \& Watt, 1985).

The time scale of Berggren et al. (1985) ascribes an absolute age of 55.6-58.6 Ma for C24R. This is in conflict with other time scale calibrations (Tarling \& Mitchell, 1976, Butler \& Coney, 1981, Curry \& Odin, 1982) who all ascribe younger ages from 49 to $56 \mathrm{Ma}$ for $\mathrm{C} 24 \mathrm{R}$, and the Berggren et al. time scale has been challenged by Odin \& Curry (1985). Radiometric dating of the basalts themselves has not been very helpful: two data sets exist, one giving ages of 55-60 Ma (Beckinsale et al., 1970), and one giving ages of 48-53 Ma (Odin \& Mitchell, 1983). This discrepancy cannot be resolved at present.

The basalt pile is thickest in the Kangerdlugssuaq region and thins both northwards and westwards. Nielsen \& Brooks (1981) estimated the maximum thickness in the Kangerdlugssuaq region as $7 \mathrm{~km}$, compared with a maximum stratigraphic thickness of $3.5 \mathrm{~km}$ for the Scoresby Sund region. From Kangerdlugssuaq to Scoresby Sund the lavas cover approximately $80000 \mathrm{~km}^{2}$ with an average thickness of $1.5-2 \mathrm{~km}$; this yields a total lava volume of $1.2-1.6 \times 10^{5} \mathrm{~km}^{3}$ (Nielsen \& Brooks, 1981).

Stratigraphic studies of the basalts have been made in the Kangerdlugssuaq area by Soper, Higgins et al. (1976) and Nielsen et al. (1981). Here, a Lower Basalt Group is present which is around $2 \mathrm{~km}$ thick and contains lavas and tuffs of picrites and olivine tholeiites, strongly contrasting to the overlying $4-5 \mathrm{~km}$ of plateau basalts. The correlation between the stratigraphy in the Kangerdlugssuaq region and that in the Scoresby Sund region established in this work, is tentative. Detailed work is needed in the interjacent area south of $69^{\circ} \mathrm{N}$. 


\section{Stratigraphy}

\section{Field work}

The investigated area covers approximately 40000 $\mathrm{km}^{2}$ from Scoresby Sund southwards to $69^{\circ} \mathrm{N}$. Of this area, however, only $24000 \mathrm{~km}^{2}$ in the northern part has been investigated in detail (fig. 2). Exposure in the northern and eastern part of the area is good (e.g. figs 14 and 16), but in the southern and western part more than $90 \%$ of the total area is covered by permanent snow and ice, leaving free only narrow, nearly vertical strips along the sides of glaciers (e.g. fig. 26). The majority of the field work was based on helicopter transport supported by work from boat, which made it possible to obtain a reasonable geographical as well as stratigraphic coverage.

North of $70^{\circ} \mathrm{N}$ the mapping was done on Geodetic Institute maps at a scale of 1:200 000 enlarged to 1:50 000; these also cover the Blosseville Kyst as far south as Kap Barclay. For the inland areas south of $70^{\circ} \mathrm{N}$ the only maps available were AMS (American Map Service) maps at a scale of 1:250 000. No vertical aerial photographs were available at the time. Oblique aerial photographs cover the coastal areas north of $70^{\circ} \mathrm{N}$; only one route existed south of $70^{\circ} \mathrm{N}$. During reconnaissance flights large numbers of photographs were taken as an aid for the mapping.

Owing to the dissected and partly glaciated character of the area, with many glacier tongues reaching from the ice cap down to the coast, single lava flows can usually only be followed laterally for short distances in the field, and marker horizons are conspicuously absent. The basalts were mapped by detailed measuring and sampling of numerous profiles, and of correlation between these of characteristic properties, such as phenocryst content and mode, flow thicknesses and morphology, colour and weathering appearance. In this way characteristic flows and sequences of flows can be followed laterally over large areas. The field divisions proved later to be good geochemical divisions, too. A total of 52000 metres of profile were measured distributed over 130 traverses. The location and numbering of these are shown on fig. 2.

\section{General structure of the basalts}

The general structure of the basalt pile in the Scoresby Sund region appears from the cross sections in Plate 1. The basalts are essentially flat-lying, with a regional dip of $1 / 2-1^{\circ} \mathrm{SE}$. They lap on to an elevated gneiss area in the north-west, while their base drops below sea level to the east. A $10-30 \mathrm{~km}$ broad zone along the Atlantic coast is extensively block faulted with downthrows to the SE in excess of $1500 \mathrm{~m}$.

Five basalt formations of regional extent are established: the Magga Dan, Milne Land, Geikie Plateau, Rømer Fjord and Skrænterne Formations. A sixth and youngest formation, the Igtertivâ Formation, is only preserved as downfaulted fragments at Kap Dalton. The stratigraphic thickness of the lava pile is $3500 \mathrm{~m}$. Actual thicknesses are greatest at the Atlantic coast (around $2000 \mathrm{~m}$ ) and decrease inland to $1500 \mathrm{~m}$ around Gåsefjord and to $300-800 \mathrm{~m}$ on Gåseland and Milne Land.

Owing to the slight SE dip of the basalts, the lower part of the basalt pile resting on the basement is only exposed in the inner fjord region on Milne Land, Gaseland and south of Gasefjord. East of Terrassevig the Magga Dan and Milne Land Formations have sunk below sea level, and the south coast of Scoresby Sund is dominated by high, steep basalt cliffs of the Geikie Plateau Formation. The middle part of the Geikie Plateau Formation is the lowest stratigraphic level exposed along the northern part of the Blosseville Kyst (Plate 1). The overlying Rømer Fjord Formation tends to form a snow or gravel covered plateau, while the Skrænterne Formation forms steep cliffs. The Skrænterne Formation forms the top of the basalt pile and is covered by large areas of permanent ice on the Geikie Plateau. The Igtertivâ Formation in the downfaulted block at Kap Dalton is not in continuation with the Skrænterne Formation although the missing part is believed to be small.

The faulted area along the Atlantic coast hosts a 200 $\mathrm{km}$ long swarm of coast-parallel basalt dykes. In the inland areas ENE-trending dykes occur in a broad region in Milne Land, Gåseland and south of Gåsefjord.

\section{Geochemical work and chemically defined rock types}

The description of the chemical variations within the large volume of basalts has required a large number of analyses. For analysis, primarily long profiles with complete flow-to-flow sample coverage were chosen, supplemented with some shorter profiles to obtain good areal coverage and with single selected samples of specific basalt types. The location of the analysed profiles appears from fig. 2. The investigation of the geochemistry of the basalts is based on around 400 analyses of lavas and 100 analyses of dykes. 


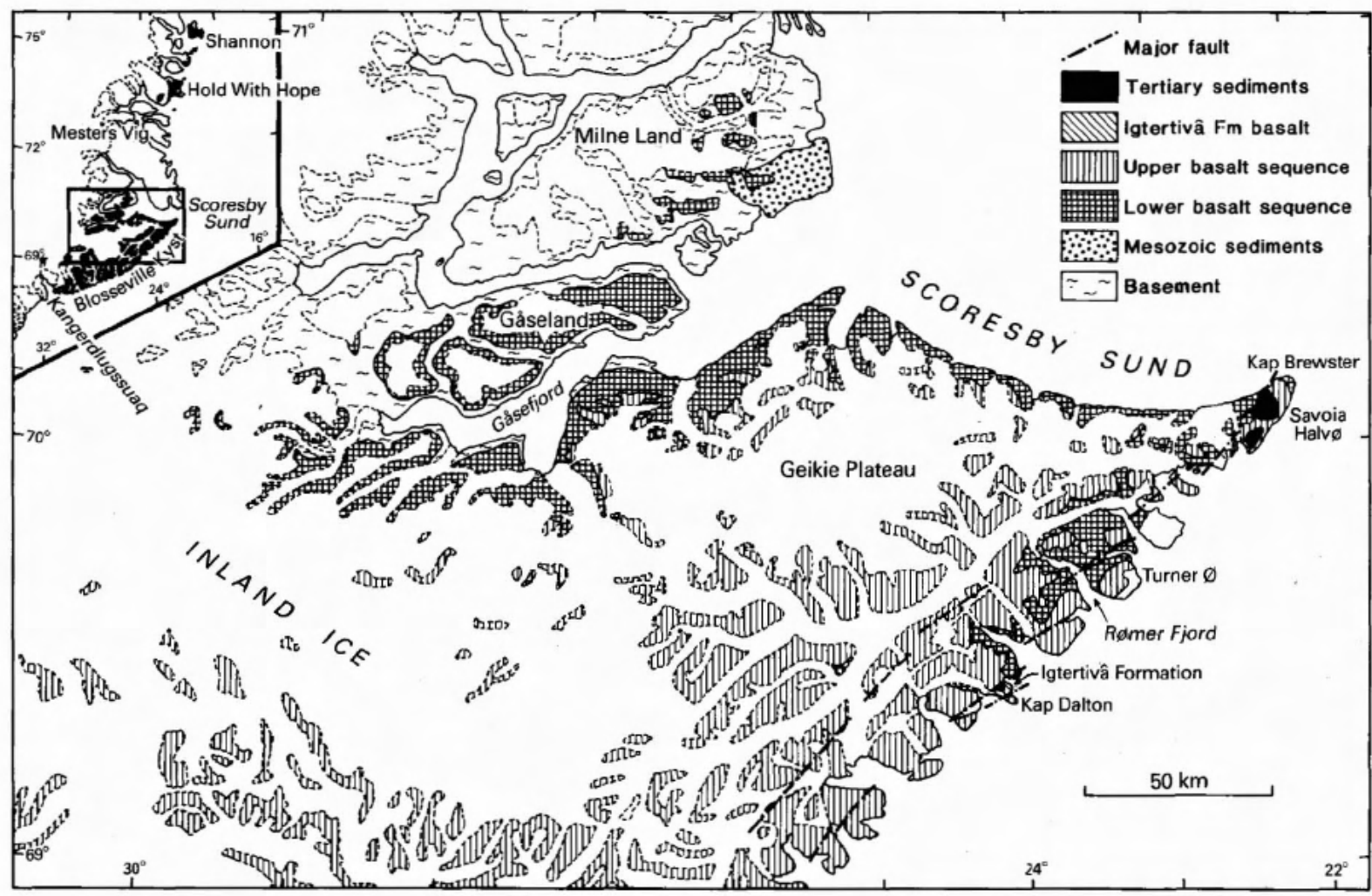

Fig. 2. Above: Geological map of the Scoresby Sund region showing the distribution of the two regional basalt sequences and the Igtertivâ Formation. Opposite: The same region showing the positions of measured profiles and names used in the text. Numbers indicate analysed or discussed profiles; the coordinates for these are given in appendix 1 and the chemical data in appendix 2.

The lavas and most of the dykes are tholeiitic basalts. Based on the chemical analyses they have been divided into nine types, as defined in Table 19 and discussed in the geochemistry section. The 'main basalts' which make up the bulk of the lavas have $\mathrm{Mg}$ ratios $<0.57$ and are divided into four types based on the $\mathrm{TiO}_{2}$ contents: the low-Ti, medium-Ti, high-Ti and titano-tholeiite types. The 'Mg-rich basalts' have $\mathrm{Mg}$ ratios $>0.57$ and occur as a few specific lava units or single flows: olivine tholeiites, MORB type basalts, Mikis type basalts and the Hjørnedal marker flow. Lastly, high-Si basalts have $\mathrm{SiO}_{2}>51 \%$. See Table 19 for details.

Alkaline rocks are only found as rare dykes and a tuff layer. The dykes include 'lamprophyres' s.l., alkali basalts and hawaiites, and the tuff layer is nephelinitic.

Most of the tholeiitic lava types cannot be recognised in the field, and often not even under the microscope. They are, however, important elements of the stratigraphy of the basalts because their occurrence and distribution show significant stratigraphical variations set out in the next section, and shown in Plate 2.

\section{Volcanic episodes}

In an earlier paper (Larsen \& Watt, 1985), we concluded that the basalt volcanism in the Scoresby Sund region took place in two major and one minor episode. This conclusion is built on the stratigraphical distribution of the various geochemical lava types, as illustrated in fig. 3. This shows the variation with height of $\mathrm{TiO}_{2}$, $\mathrm{MgO}$ and normative $\mathrm{ol} / Q$ in a composite profile through the whole lava pile. The first major episode gave rise to the Magga Dan, Milne Land and Geikie Plateau Formations (lower basalt sequence), and the second gave rise to the Rømer Fjord and Skrænterne Formations (upper basalt sequence). Excepting the Magga Dan Formation, which is probably best regarded as an initial phase, the two episodes evolved analogously with a first phase characterised by very variable eruption products including $\mathrm{Mg}$-rich basalts (Milne Land and Rømer Fjord Formations) followed by a phase of main basalts showing a systematic development towards less $\mathrm{TiO}_{2}$-rich and generally less differentiated compositions with height (Gei- 


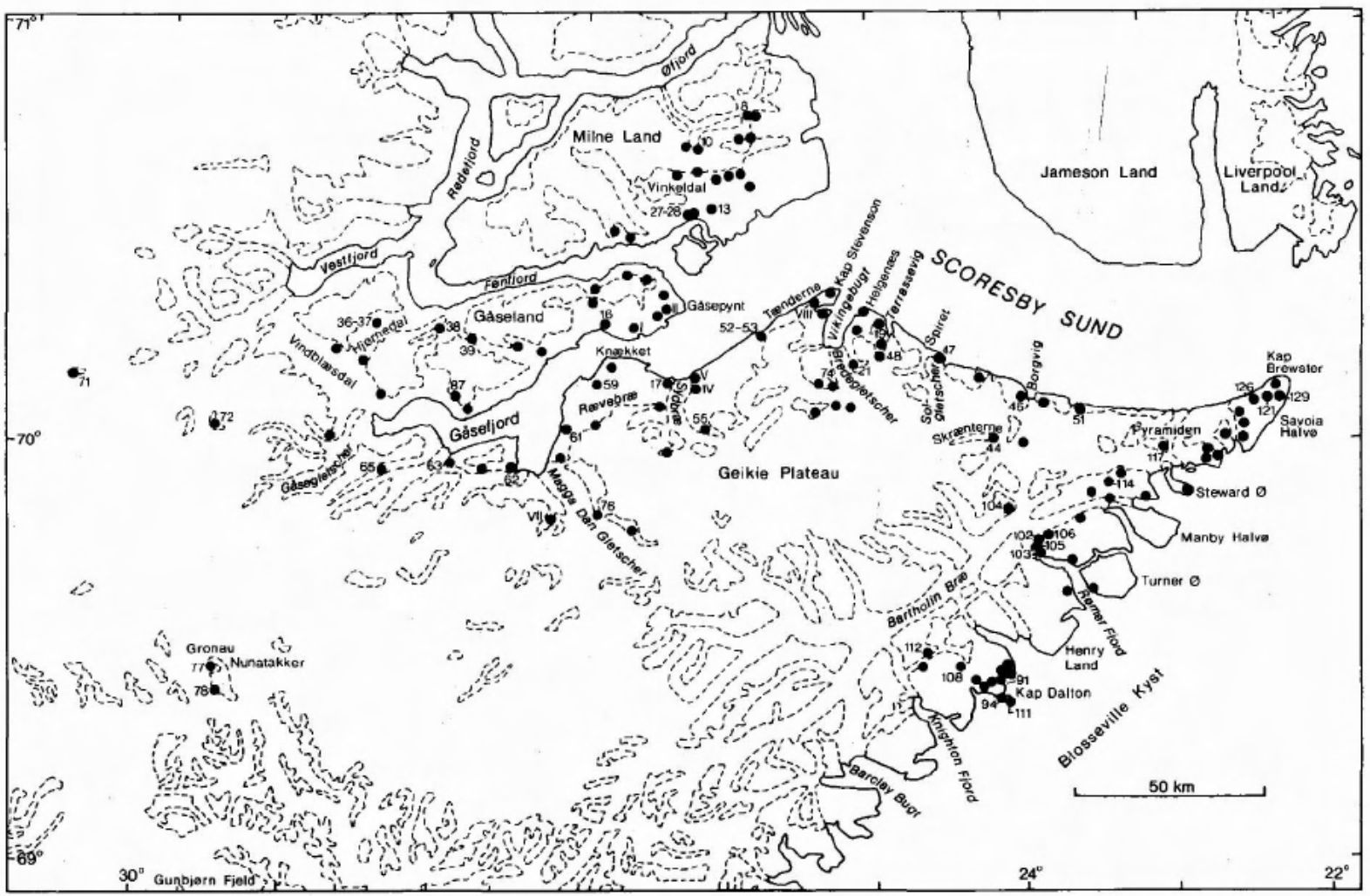

Fig. 2. cont.

kie Plateau and Skrænterne Formations). Each episode closed with a reversal to more $\mathrm{TiO}_{2}$-rich and evolved compositions. The two major volcanic episodes thus have a cyclic character.

Because of detailed compositional relations, discussed later, the Igtertivâ Formation and the associated coastal dyke swarm are considered to be produced in a third separate episode. There is no evidence of cyclicity.

\section{Pre-basaltic topography}

At the onset of volcanism the pre-basaltic landscape consisted of two very different elements: a high gneiss country in the west and north-west, and a relatively flat, lower-lying plain with Mesozoic sediments in the east and south-east. The pre-basaltic topography of the gneiss highland can be reconstructed partly from a contour map of the sub-basalt surface and partly from the distribution of the lowest basalt formation.

A contoured map of the sub-basaltic surface (fig. 4) can be constructed where there is sufficient exposure and relief in the present surface to give a three dimensional view, as is the case for most of Gåseland and SE Milne Land. The map gives an impression of the gneiss highland in the north-west, while the fault-controlled escarpment towards the sedimentary basin in the east is seen clearly on Milne Land. Gasseland apparently formed a gneiss ridge with steep slopes to the north and south into what is now Fønfjord and Gåsefjord, suggesting that these fjord systems are pre-basalt features of considerable age. Hansen (1985) showed that the Milne Land - Gåseland area had a marked uplift and renewal of the relief developed around $200 \mathrm{Ma}$ ago (Early Jurassic time), and the major pre-basalt relief features may be as old as this, or even older. This is supported by the fact that many side valleys had had time to form prior to the influx of lava. Lava-filled gorges and steep-sided valleys with locally derived, interbasaltic sediment wedges indicate continued erosion of the exposed basement ridges during the period of volcanic activity. Such narrow, deeply incised side valleys are especially frequent on the south side of Gasseland and Milne Land (fig. 5). The largest of these valleys is situated on the escarpment in southern Milne Land and is $1500 \mathrm{~m}$ wide and at least $12 \mathrm{~km}$ long with a depth of $700 \mathrm{~m}$. It largely follows the course of present-day 'Vinkeldal'. The major pre-basalt relief features of Gåsefjord, Fønfjord, 'Vinkeldal', 'Menageløsdal' and probably VindblæsdalHjørnedal are still reflected in the present topography, while the smaller features are not. 

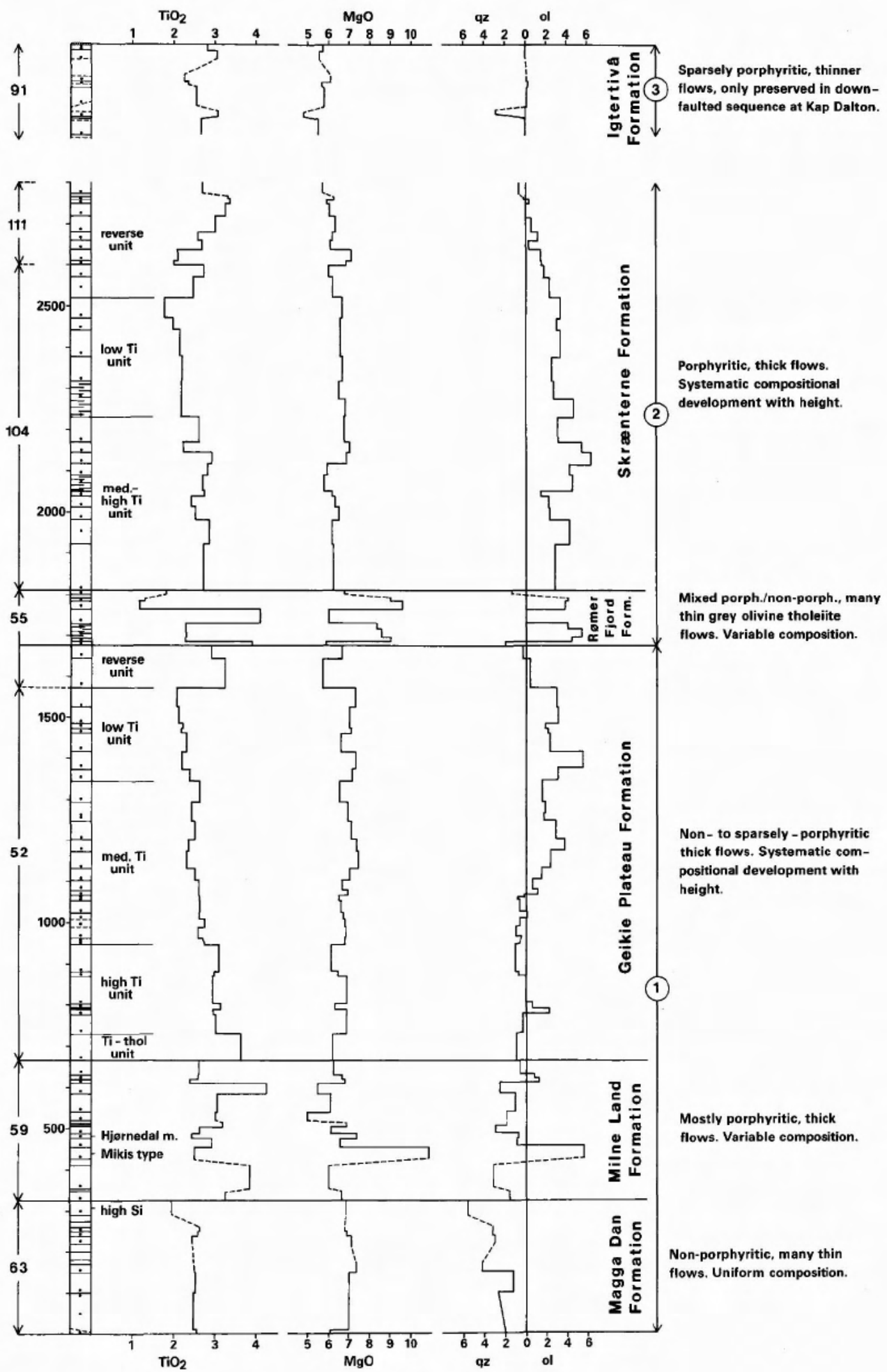


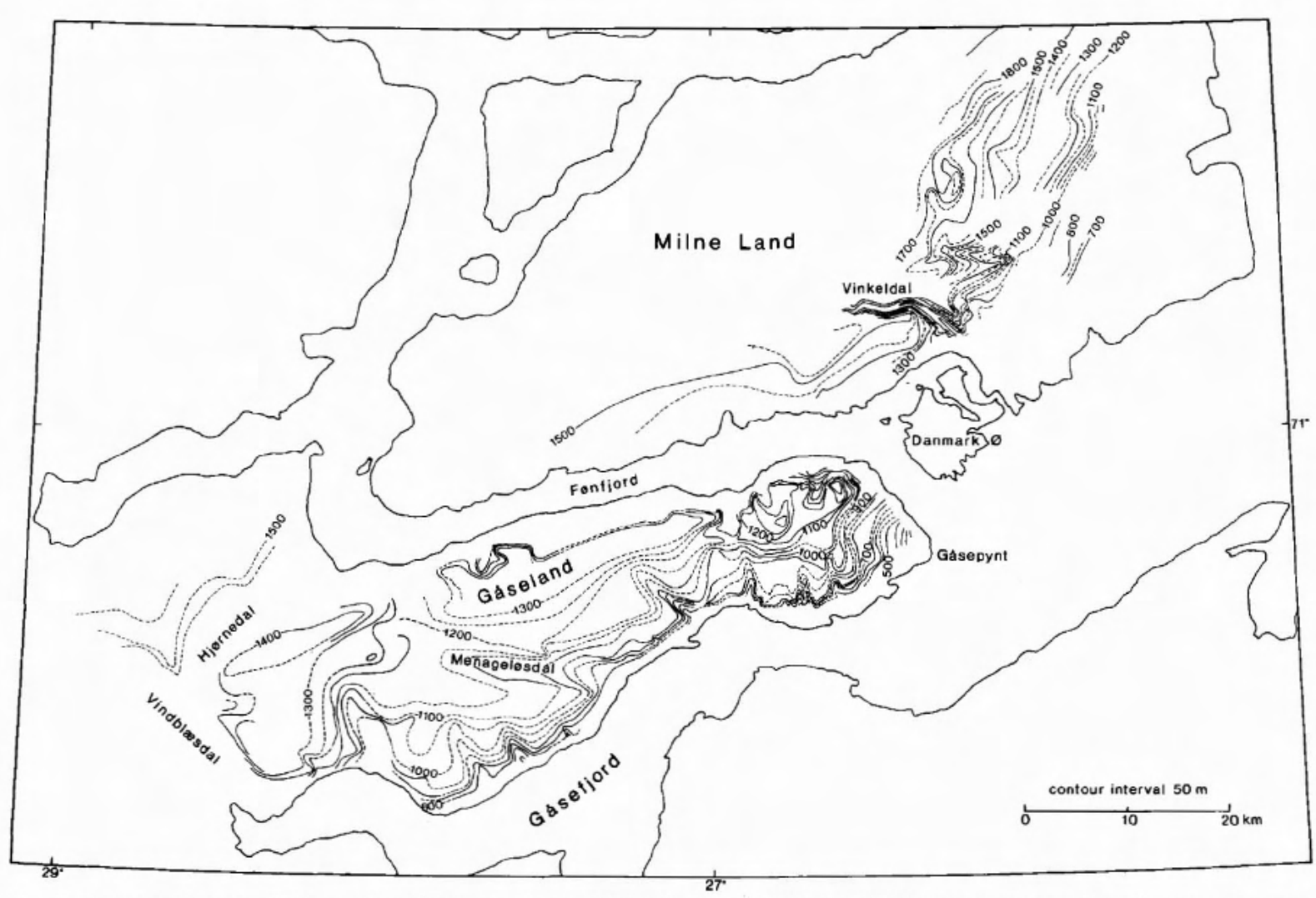

Fig. 4. Contoured map of the pre-basalt topography on Milne Land and Gåseland. The contours are dotted where they are interpolated over longer distances. Heights in metres above sea level, contour interval $50 \mathrm{~m}$.

In the inner part of Gåseland and south of Gåsefjord the present relief is not conclusive to the construction of a pre-basalt relief map, but further information can be gleaned from the distribution of the lowest of the basalt formations, the Magga Dan Formation (fig. 8). The formation is not present on the gneiss highland of Milne Land and outer Gåseland, but in inner Gåseland it fills up the basins between a series of two or three ENEorientated gneiss mountain ridges which extend the Gåseland highland towards the WSW (fig. 4). The gneiss highlands acted as a barrier to lava from the south except in the lower lying Vindblæsdal area where the lavas were able to penetrate and fan out onto lower ground north of the ridge. However, some lavas in this northern basin seem to be local eruption products, and the highland barrier may have been effective throughout the length of Gåseland.
South of Gåsefjord the basement gneiss has declined in height and is overlain by the Magga Dan Formation. It is not possible to reconstruct the pre-basaltic surface map for this region, but the fact that in two minor separate areas the gneiss rises so high as to exclude the presence of the Magga Dan Formation (fig. 8) probably indicates the southern extension of the ENE gneiss ridge system.

The basalts normally overlie deeply weathered gneiss, but on SE Milne Land and at Gåsepynt basalts of the Milne Land Formation overlie Jurassic marine sediments. The basalts have filled erosional valleys in the sediments, just as they have filled the gneiss valleys. The upper parts of the sediments are partly Lower Cretaceous in age (Callomon \& Birkelund, 1980), so that the uplift and erosion of the sediments must have taken place after the Lower Cretaceous but before the

Fig. 3. Compositional variations in a combined profile through the whole lava sequence. Compositional features shown are wt $\%$ $\mathrm{TiO}_{2}$, wt $\% \mathrm{MgO}$ and normative $Q$ or $\mathrm{ol}$. The profiles used are indicated to the left. The stratigraphical column shows the individual lava flows, and each dot represents an analysed sample. Heights are given in metres above the base. Some lava flows were not sampled, and the curves are dashed where they pass through these parts. The division into formations is based on field criteria; the subdivision into units is based on the $\mathrm{TiO}_{2}$ profile. The ringed figures 1-3 to the right indicate the three volcanic episodes described in the text. Modified from Larsen \& Watt (1985). 


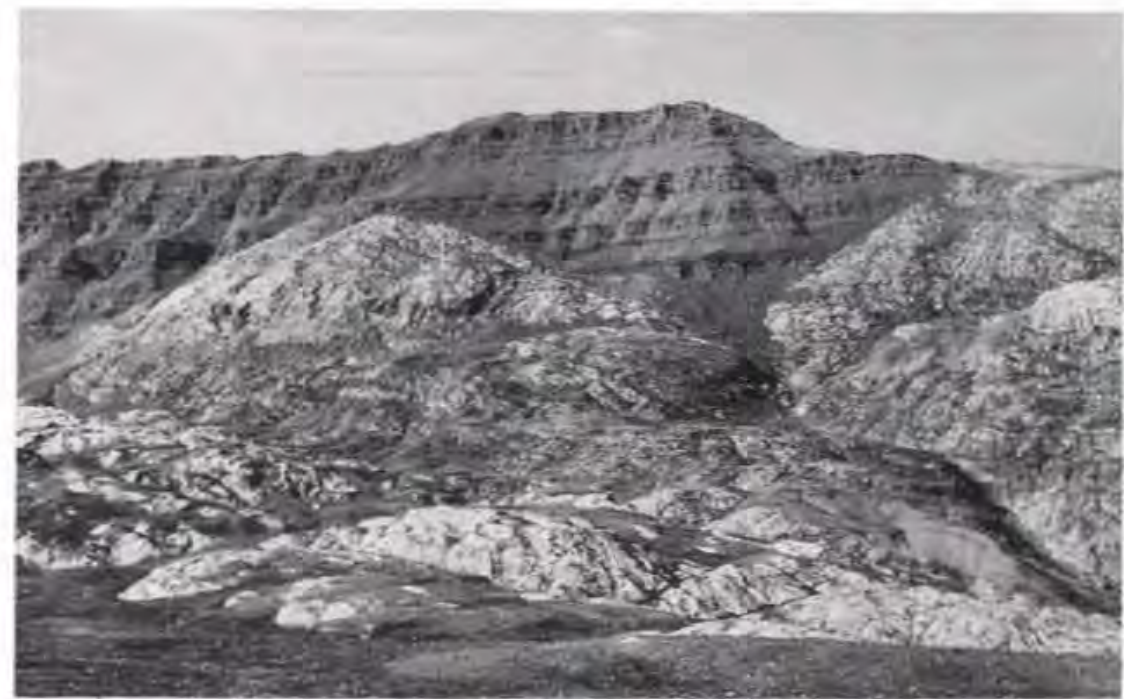

Fig. 5. A pre-basalt valley $c$. 200 $m$ deep filled with basalt lavas belonging to the Milne Land Formation. South side of Gáseland.

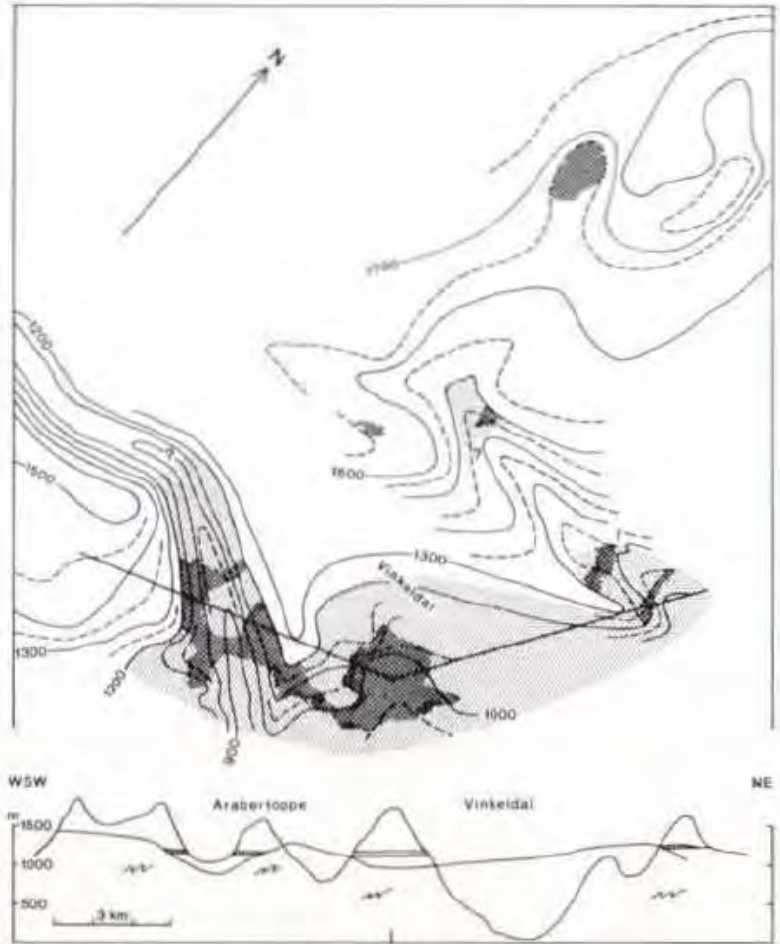

Fig. 6. Detail of the pre-basaltic topography in east Milne Land. Old valleys are filled with hyaloclastic deposits at one major and two minor horizons at $c .1200 \mathrm{~m}, 1500 \mathrm{~m}$ and $1650 \mathrm{~m}$ altitudes. Light stipple: inferred original extent of the hyaloclastic deposits. Dark stipple: present day extent of hyaloclastites, dependent on the present topography as shown in the cross section. The cross section was made along the heavy line on the map and shows only the lower, major hyaloclastite horizon. extrusion of the basalts. That the gneiss escarpment of eastern Milne Land already existed in Jurassic time is proved by the shoreline facies of the Jurassic sediments occurring at the base of the escarpment. On Milne Land the basalts in one place overlie a local unconsolidated conglomerate consisting of large (up to $30 \mathrm{~cm}$ diameter), rounded quartzite boulders with traces of sandstone and shale in the scree. Conglomerates with boulders of this size are unknown in the local Jurassic sediments. It is interpreted as locally derived, either a river deposit or a shore line deposit formed in association with uplift along the boundary fault at the gneiss escarpment.

The rugged pre-basaltic topography indirectly led to the local formation of thick deposits of basaltic hyaloclastites. These are found in some of the old pre-basaltic valley bottoms (fig. 6) and are interpreted as the results of lava flowing into lakes which themselves were formed when the river systems in the valleys were blocked by onlapping lava flows. Hyaloclastites are widespread in the pre-basaltic valleys of Hjørnedal and Vindblæsdal which would have been broad, open valleys with numerous shallow lakes and water courses.

\section{Lithostratigraphy}

In the following section the succession of Tertiary lithostratigraphic units in the investigated area is described in ascending order. The location of the profiles is given in fig. 2 and in appendix 1 . 


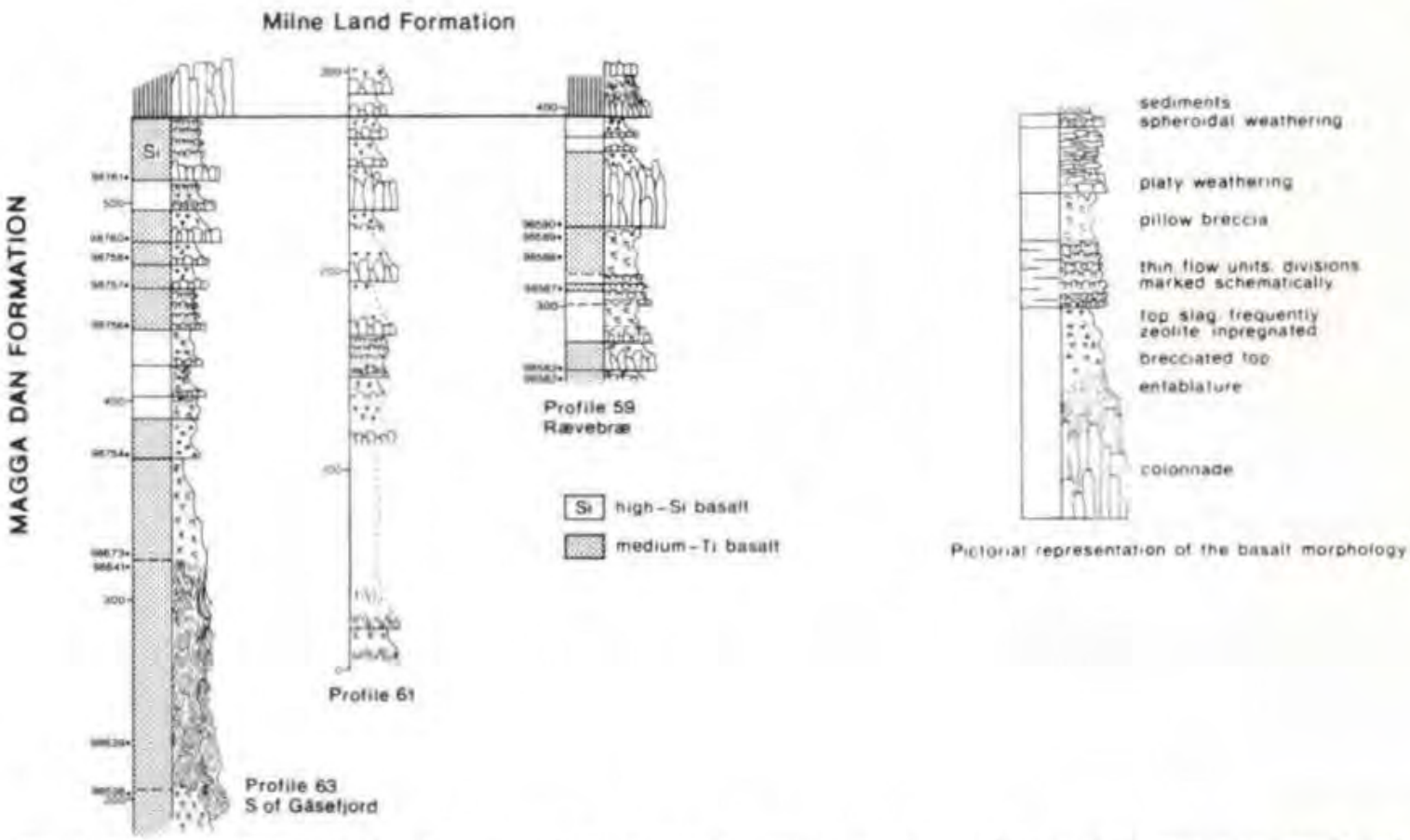

Fig. 7. Profiles of the Magga Dan Formation. Right part of columns = lithology. left part of columns = compositional type. Samples are indicated by numbered dots. Heights are metres above sea level.

\section{Magga Dan Formation}

new formation

General. The lavas of this formation were first described by Watt \& Watt (1973) as a few basal, slightly porphyritric flows overlain by $c .150 \mathrm{~m}$ of thin, non-porphyritic flows. The formation was provisionally termed formation 1 by Watt \& Watt (1983), and Magga Formation by Larsen \& Watt (1985), Watt et al. (1986), Henriksen (1986), and on the 1:100 000 map sheet series.

Name. From Magga Dan Gletscher, Gảsefjord, Scoresby Sund (fig. 2).

\section{Type profile. Profile 63 south of Gásefjord (fig. 7).}

Reference profiles. Profiles 59 and 61 on the south coast of Găsefjord (fig. 7).

Analysed profiles (number of analyses): 37 (2), 59 (6), 63 (9); single samples: 2 (pillow breccias).

Distribution. The lavas of the Magga Dan Formation were extruded over the irregular surface of inner Gảseland and the region south and west of Gåsefjord where the formation now covers an area of at least $135 \mathrm{~km}$
NE-SW and $60 \mathrm{~km}$ across strike (fig. 8). Its limits to the north and west are controlled by the high basement, while to the south its limits are unknown as it disappears below the level of exposure and to the east disappears below sea level east of Sydbra.

The irregular distribution in Gaseland is caused by a system of NE-SW oriented gneiss ridges rising above the upper boundary of the formation. In western Gaseland the lavas filled a high-lying basin that was partly isolated from the main occurrences to the south. A narrow passage was probably open in Vindblasdal (fig. 8).

Thickness. The formation is thickest in the SE and thins as it laps onto the high gneiss country in the NW. A maximum thickness of a little over $300 \mathrm{~m}$ is reached around the outlet of Magga Dan Gletscher (profile 63). This includes a single (ponded?) flow of at least $100 \mathrm{~m}$ in thickness. The average thickness in the SE is $200 \mathrm{~m}$, in southern Gaseland it is $80 \mathrm{~m}$, and in the partly isolated basin in western Gasseland it is only $40 \mathrm{~m}$. A mean figure for the formation as a whole is estimated as $130 \mathrm{~m}$.

Lithology. The Magga Dan Formation is composed of a series of thin flows or flow units which may be as thin as a few centimetres; generally the flows are in the order of 6 to $8 \mathrm{~m}$ thick (fig. 10). The thinner flows and units are 


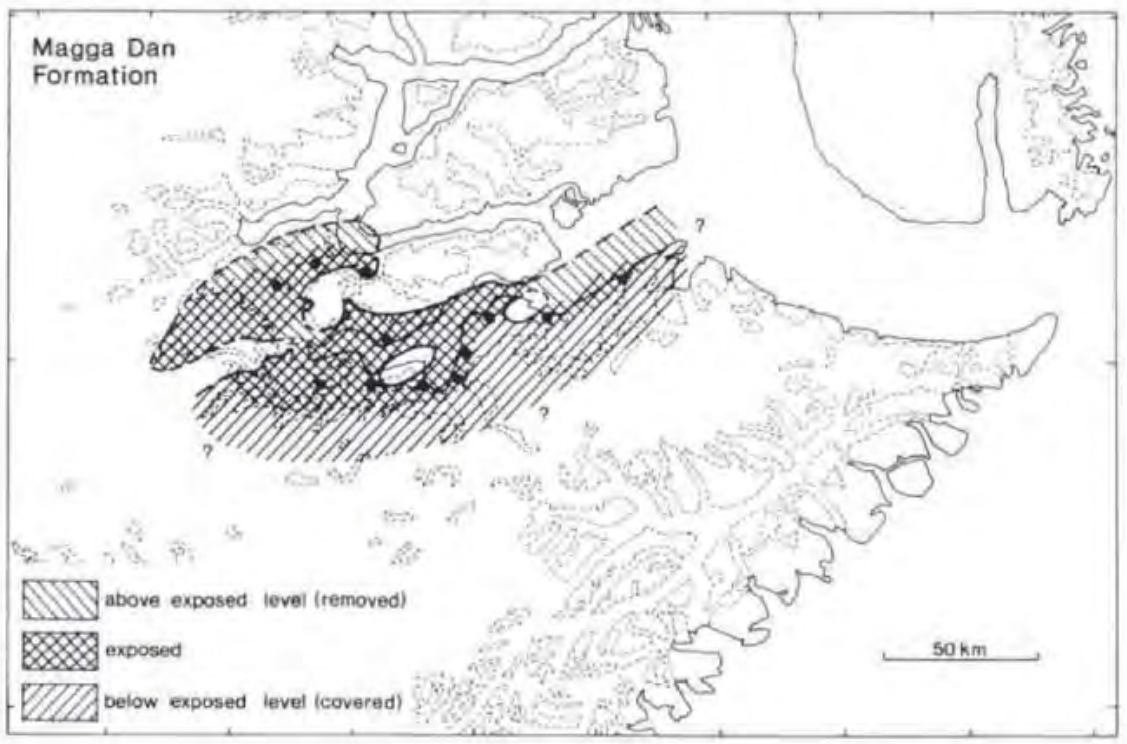

Fig, 8, Distribution of the Magga Dan Formation. Measured profiles are marked with dots. Full lines indicate original limit of extent; they are broken where they are inferred.

often vesicular throughout or made up of horizontal to subhorizontal, vesicular bands separated by more massive basalt. Pipe amygdales are common at the base of the flows; and where the tops of the flows are exposed, ropes and other pahoehoe features are well developed, and the tops may be oxidised red. Rounded or spheroidal weathering is common; the weathering colour is grey, pale brown, or even slightly pink. Red boles are uncommon, but $20-50 \mathrm{~cm}$ thick brick red deposits may be found locally. A $30-40 \mathrm{~cm}$ thick tuff layer occurs south of Gåsefjord (profile $63 \mathrm{at} 400 \mathrm{~m}$ ).

The lavas are generally fine grained and aphyric in appearance. Single porphyritic flows occur in a couple of profiles east of Magga Dan Gletscher.

In Hjørnedal the Magga Dan Formation is represented by three flows. They are divided into flow units and are very vesicular. Amygdales with zeolites occur at the base of the flows; but otherwise vesicles are empty. Horizontal traces of empty vesicles are abundant, giving a planar arrangement to the rock. Vertical 'gas pipes' of vesicular basalt are common. There is a $1 / 2 \mathrm{~m}$ sandstone horizon in the profile with feldspar, quartz, garnet and magnetite grains of even grain size. There are also traces of tuff.

Hyaloclastic material is prominent in the Magga Dan Formation. In profile 63 it amounts to as much as $40 \%$ of the total thickness. This, however, is exceptional and the presence and volume of hyaloclastic material varies considerably from place to place, largely controlled by the topographic relief prior to the outpouring of the lavas. The frequency and thickness of the hyaloclastic horizons decrease towards the top of the formation.
In profiles examined the base of the Magga Dan Formation is frequently a hyaloclastic deposit. These profiles were chosen to give the maximum thickness, which means that they frequently lie in the lows of the pre-basaltic relief, i.e. in the old valleys with lavadammed lakes. Upwards the hyaloclastic deposits may give way to a subaerial lava flow where the lakes have been filled with lava. Sometimes there are later hyalo-

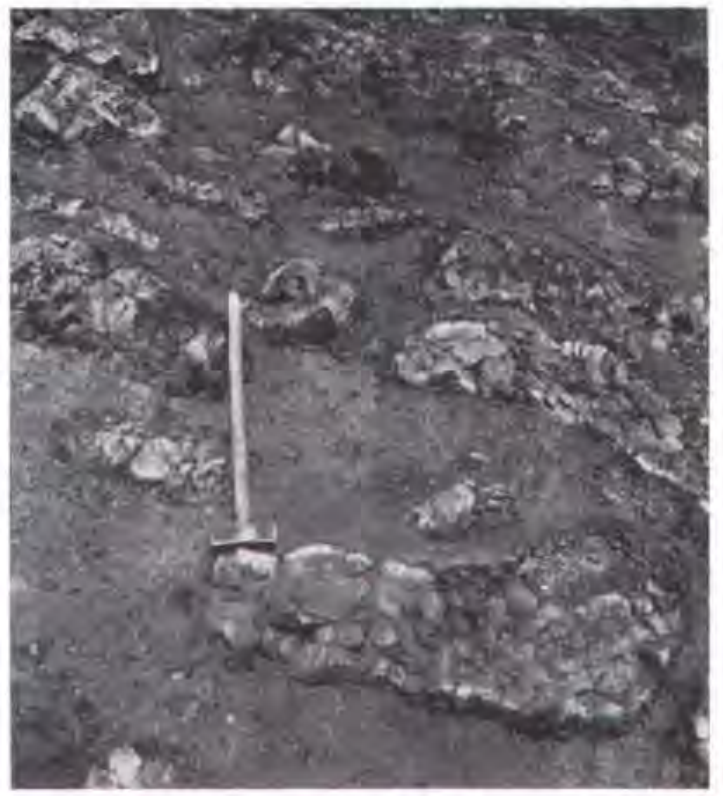

Fig, 9. Hyaloclastite with pillows and dipping 'cross bedded' structure. Magga Dan Formation near profile 65, south side of Găsefjord $\left(69^{\circ} 57^{\prime} \mathrm{N}, 28^{\circ} 29^{\prime} \mathrm{W}\right)$. 
Table 1. Representative compositions of lavas from the Magga Dan and Milne Land Formations

\begin{tabular}{|c|c|c|c|c|c|c|c|c|c|c|}
\hline \multirow[b]{2}{*}{$\begin{array}{l}\text { Profile No. } \\
\text { GGU No. } \\
\text { Type }\end{array}$} & \multicolumn{3}{|c|}{ Magga Dan Formation } & \multicolumn{7}{|c|}{ Milne Land Formation } \\
\hline & $\begin{array}{c}63 \\
98641 \\
\text { med-Ti }\end{array}$ & $\begin{array}{c}63 \\
98761 \\
\text { high-Si }\end{array}$ & $\begin{array}{c}65 \\
98788 \\
\text { high-Si }\end{array}$ & $\begin{array}{c}\text { V } \\
96205 \\
\text { Mikis }\end{array}$ & $\begin{array}{c}38 \\
96913 \\
\text { Hjørnedal }\end{array}$ & $\begin{array}{c}59 \\
98571 \\
\text { med-Ti }\end{array}$ & $\begin{array}{c}8 \\
96403 \\
\text { high-Ti }\end{array}$ & $\begin{array}{c}59 \\
98592 \\
\text { Ti-thol }\end{array}$ & $\begin{array}{c}59 \\
98600 \\
\text { Ti-thol }\end{array}$ & $\begin{array}{c}72 \\
98838 \\
\text { high-Si }\end{array}$ \\
\hline $\mathrm{SiO}_{2}$ & 50.78 & 53.79 & 56.15 & 49.24 & 50.08 & 49.59 & 49.82 & 49.11 & 49.21 & 52.13 \\
\hline $\mathrm{TiO}_{2}$ & 2.47 & 1.95 & 1.65 & 2.43 & 2.26 & 2.61 & 3.11 & 3.85 & 4.28 & 2.97 \\
\hline $\mathrm{Al}_{2} \mathrm{O}_{3}$ & 14.13 & 13.71 & 13.29 & 12.42 & 14.55 & 14.76 & 13.91 & 13.51 & 12.61 & 12.93 \\
\hline $\mathrm{Fe}_{2} \mathrm{O}_{3}$ & 1.54 & 1.35 & 1.36 & 1.59 & 1.47 & 1.63 & 1.64 & 1.90 & 1.94 & 1.57 \\
\hline $\mathrm{FeO}$ & 10.30 & 8.98 & 9.10 & 10.61 & 9.83 & 10.90 & 10.93 & 12.64 & 12.94 & 10.47 \\
\hline $\mathrm{MnO}$ & 0.18 & 0.16 & na & 0.17 & 0.17 & 0.19 & 0.18 & 0.21 & 0.20 & 0.17 \\
\hline $\mathrm{MgO}$ & 6.87 & 6.85 & 5.99 & 11.23 & 8.09 & 6.29 & 6.64 & 6.03 & 5,44 & 6.81 \\
\hline $\mathrm{CaO}$ & 11.01 & 10.03 & 9.10 & 9.57 & 10.91 & 11.13 & 10.80 & 9.76 & 9.82 & 9.59 \\
\hline $\mathrm{Na}_{2} \mathrm{O}$ & 2.26 & 2.55 & 2.41 & 2.06 & 2.19 & 2.49 & 2.39 & 2.22 & 2.50 & 2.39 \\
\hline $\mathrm{K}_{2} \mathrm{O}$ & 0.27 & 0.45 & 0.80 & 0.44 & 0.24 & 0.20 & 0.28 & 0.41 & 0.66 & 0.66 \\
\hline $\mathrm{P}_{2} \mathrm{O}_{5}$ & 0.19 & 0.17 & 0.15 & 0.24 & 0.21 & 0.21 & 0.30 & 0.36 & 0.41 & 0.30 \\
\hline Mg ratio & 0.543 & 0.576 & 0.540 & 0.654 & 0.595 & 0.508 & 0.520 & 0.460 & 0.428 & 0.537 \\
\hline $\mathrm{FeO}^{*}$ & 11.69 & 10.19 & 10.32 & 12.04 & 11.15 & 12.37 & 12.41 & 14.35 & 14.69 & 11.88 \\
\hline \multicolumn{11}{|l|}{ CIPW norm } \\
\hline Q & 2.54 & 5.53 & 9.76 & & 0.56 & 0.48 & 1.76 & 3.01 & 2.46 & 4.74 \\
\hline or & 1.60 & 2.66 & 4.73 & 2.60 & 1.42 & 1.18 & 1.65 & 2.42 & 3.90 & 3.90 \\
\hline$a b$ & 19.12 & 21.58 & 20.39 & 17.43 & 18.53 & 21.07 & 20.22 & 18.78 & 21.15 & 20.22 \\
\hline an & 27.61 & 24.64 & 23.08 & 23.34 & 29.16 & 28.51 & 26.40 & 25.69 & 21.23 & 22.60 \\
\hline di & 21.17 & 19.67 & 17.36 & 18.29 & 19.26 & 20.92 & 20.75 & 16.89 & 20.61 & 18.89 \\
\hline hy & 20.59 & 19.88 & 19.23 & 23.71 & 24.16 & 20.04 & 20.23 & 22.31 & 18.75 & 21.02 \\
\hline ol & & & & 7.15 & & & & & & \\
\hline $\mathrm{mt}$ & 2.23 & 1.96 & 1.97 & 2.31 & 2.13 & 2.36 & 2.38 & 2.75 & 2.81 & 2.28 \\
\hline il & 4.69 & 3.70 & 3.13 & 4.62 & 4.29 & 4.96 & 5.91 & 7.31 & 8.13 & 5.64 \\
\hline ap & 0.44 & 0.39 & 0.35 & 0.56 & 0.49 & 0.49 & 0.70 & 0.83 & 0.95 & 0.70 \\
\hline
\end{tabular}

All analyses have had the oxidation ratio adjusted to $\mathrm{Fe}_{2} \mathrm{O}_{3} / \mathrm{FeO}=0.15$ and have been recalculated to $100 \%$ on a volatile-free basis. The original analyses are in appendix 2 and trace element analyses in appendix 3 .

98788: Pillow breccia with orthopyroxene phenocrysts.

na Not analysed.

The various chemical types are defined in Table 19.

clastic horizons where new lakes have been formed (fig. 6).

The hyaloclastic deposits have a high concentration of pillows and pillow fragments in the lower part of the sections with little glassy matrix to give a pillow breccia. Higher in the sections the number of blocks decrease so that the upper parts only consist of the fragmented groundmass. The hyaloclastites may show a foreset bedding structure with flattened pillows with a considerable dip (fig. 9).

Chemical compositions. (Chemical basalt types are defined in Table 19.) Most lavas of the Magga Dan Formation belong to the medium-Ti type of the main basalts and have relatively uniform chemical compositions (fig. 3 and 72). They are all quartz normative. High-Si bas- alts with $51-56 \% \mathrm{SiO}_{2}$ are frequent, constituting five out of nineteen analysed samples, and occurring at all stratigraphic levels in the formation. In contrast to most high-Si basalts from the later formations those in the Magga Dan Formation have low $\mathrm{TiO}_{2}$ contents and high $\mathrm{Mg}$ ratios and cannot be related to any of the four main basalt types. Representative compositions are shown in Table 1.

Eruption sites. There is no direct evidence for the source of the Magga Dan Formation in the form of feeders, but the fact that the pre-basalt topography is 'closed' to the north, combined with a northerly component of dip of the foreset bedding in the hyaloclastic deposits, makes a source somewhere to the south most likely. An airfall tuff in profile 63 has a clast size that indicates an erup- 
tion site within a distance of $20 \mathrm{~km}(\mathrm{~K}$. $\AA$. Jørgensen, personal communication), i.e. in the inner Gassefjord region.

The lowest lavas in profile 37 (western Gåseland), resting on basement $1400 \mathrm{~m}$ a.s.l., are ascribed to the Magga Dan Formation because of their field appearance and chemical composition. However, they occur on a higher stratigraphic level than other parts of the Magga Dan Formation and must be local eruption products in the partially isolated West Gáseland basin.

Boundaries. Where the lower boundary is exposed the formation rests everywhere directly on basement gneisses. It is inferred that to the SE, where the lower boundary is below sea level, the formation partly rests on Mesozoic sediments. The upper boundary is defined by the appearance of distinctly plagioclase porphyritic, thicker lava flows of the Milne Land Formation. There is also a marked change in weathering slope at the upper boundary, the thinner flows of the Magga Dan Formation being more susceptible to weathering (fig. 10).

\section{Milne Land Formation}

new formation

General. Lavas of this formation were described and illustrated by Watt \& Watt (1971) and form the units e to $i$ on their fig. 9 (near profile 27) and the unit I-III on their fig. 10 (near profile 39 ). The formation was described as the lower porphyritic sequence by Watt et al. (1972) and Watt \& Watt (1973). It was provisionally

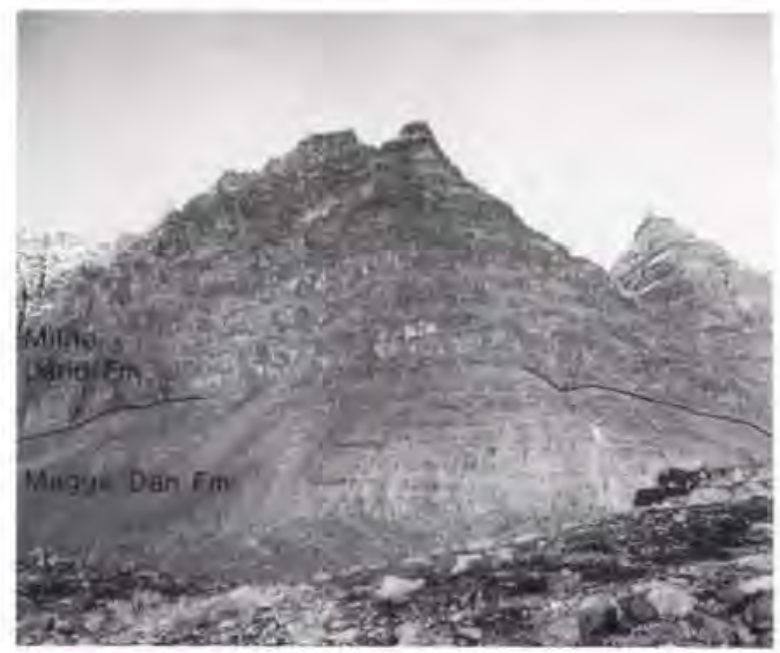

Fig. 10. The Magga Dan and Milne Land Formations on the south side of Gasefjord. The Magga Dan Formation forms the lower third of the profile, comprising thin. partly scree-covered flows. named formation 2 by Watt \& Watt (1983), and Milne Land Formation by Larsen \& Watt (1985) and Watt et al. (1986).

Name. From Milne Land, Scoresby Sund (fig. 2).

\section{Type profile. Profile 59 (Ravebræ) (fig. 11).}

Reference profiles. Profiles 16 (Knækket, Gãseland), 27/28 (Arabertoppe, S. Milne Land), and 52/53 (valley west of Tænderne) (fig.11).

Analysed profiles (number of analyses): 8 (2), 16 (7), 27/28 (12), 37 (6), 52 (5), 59 (13), 63 (1), 71 (5), 72 (10).

Single samples: 6 .

Distribution. The Milne Land Formation is present in SE Milne Land, in Găseland and in isolated outcrops west thereof, and in the region south and east of Gasefjord (fig. 12). The formation is present in all profiles which span the appropriate stratigraphic levels. The lavas of this formation continued the infilling of the irregular land surface that was begun with the Magga Dan Formation lavas. The Milne Land Formation lavas overflowed the Gasseland gneiss ridge and overstepped the Magga Dan Formation lavas onto the high gneiss country towards the north. The limits to the north are thus controlled by the rising basement, while to the south the limits are unknown because the formation disappears below the level of exposure. The western limits are likewise uncertain due to the extensive snow cover, the formation only being exposed in isolated nunataks. To the east the formation dips below sea level at Solgletscher. Between Solgletscher and Kap Brewster the formation is apparently present below sea level, forming a broad, shallow syncline, because at Kap Brewster (Bopladsdalen) the formation seems to reappear, resting on Cretaceous sediments.

Some individual lava flows are very extensive (fig. 13).

Thickness. The maximum thickness is more than $450 \mathrm{~m}$, attained on Milne Land (profile 27/28; fig. 11). A thickness of around $350 \mathrm{~m}$ is fairly common over large areas (Plate 2), especially in the southern parts around Gâsefjord. Towards the north, on Găseland and Milne Land, the thickness is more variable, depending on the prebasalt relief. It is, therefore, especially the lower half of the formation that is variable, and sometimes completely absent, as in central Gãseland (Plate 2, profiles 16,37 and 39 ), where as a result the formation is only around $200 \mathrm{~m}$ thick.

The average thickness is estimated to around $300 \mathrm{~m}$. 


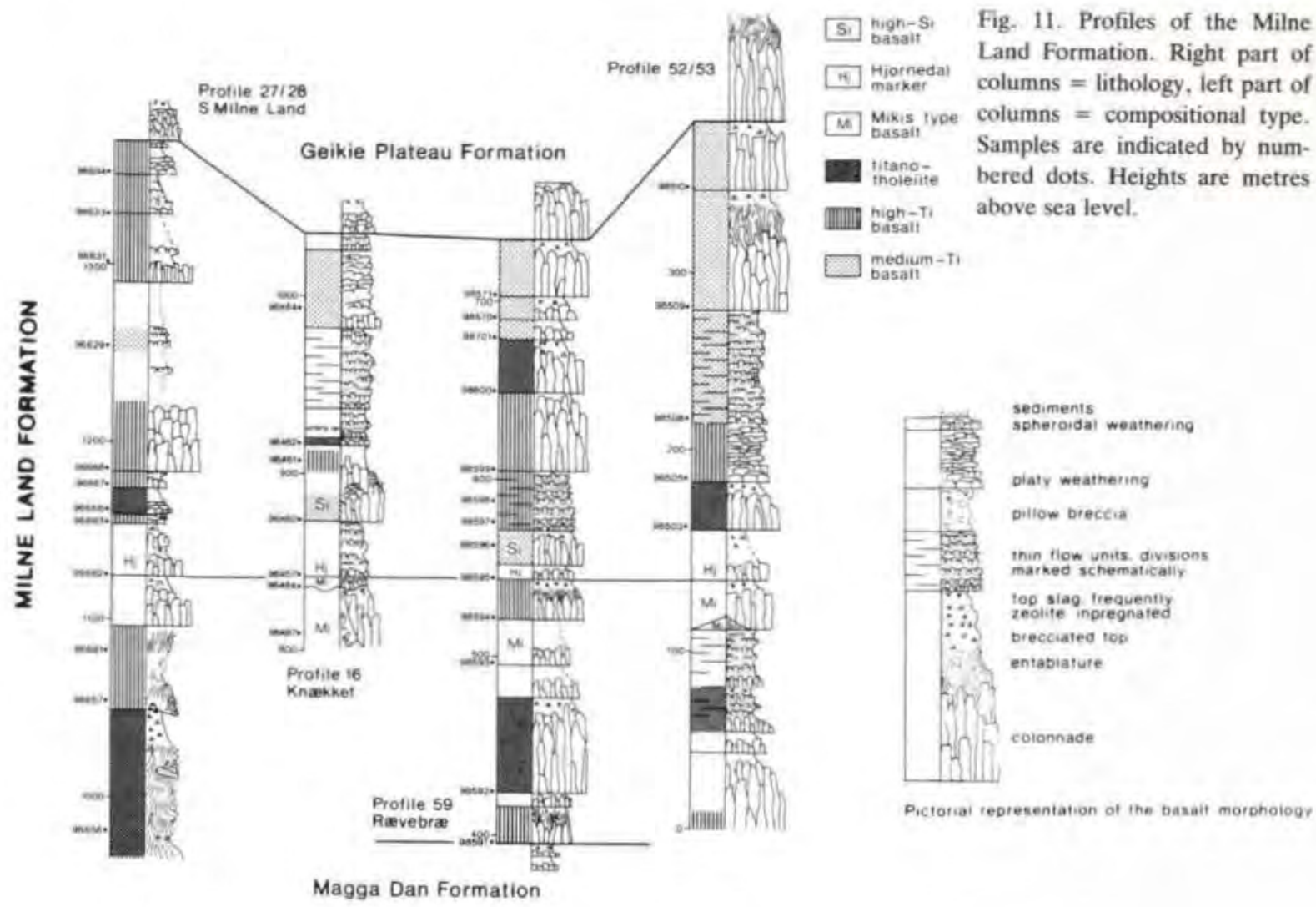

Lithology. The Milne Land Formation (fig. 14) forms a typical sequence of step-forming flows occasionally separated by discontinuous groups of thin flows or flow units where a flow has broken into units. In the thicker flows regular columnar jointing is common. The thickness of individual flows varies considerably from flow units only a few metres thick to single flows of $50 \mathrm{~m}$ thickness, average about $20 \mathrm{~m}$, with the majority of flows of about average thickness. Individual flows that are considered as having ponded in lows in the terrain may be up to $100 \mathrm{~m}$ in thickness. These show spectacular columnar jointing (fig. 15).
Fig. 12. Distribution of the Milne Land Formation. Measured profiles are marked with dots. Full line indicates the original NW limit of the formation, broken line where inferred.

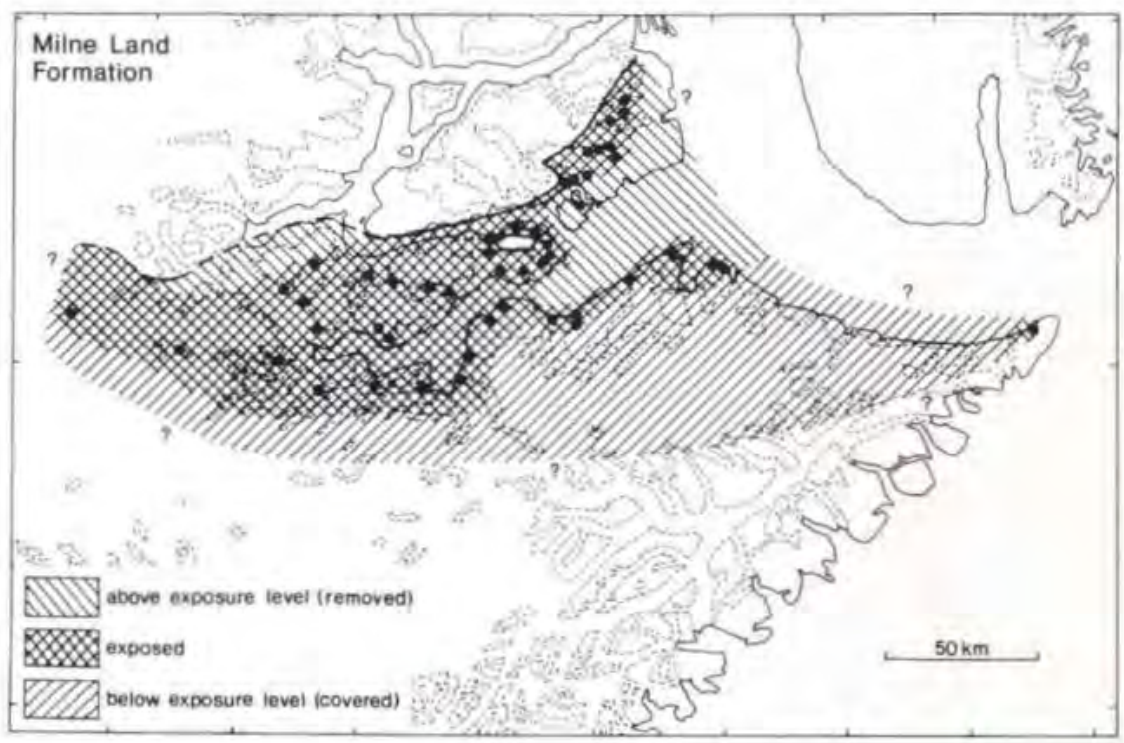



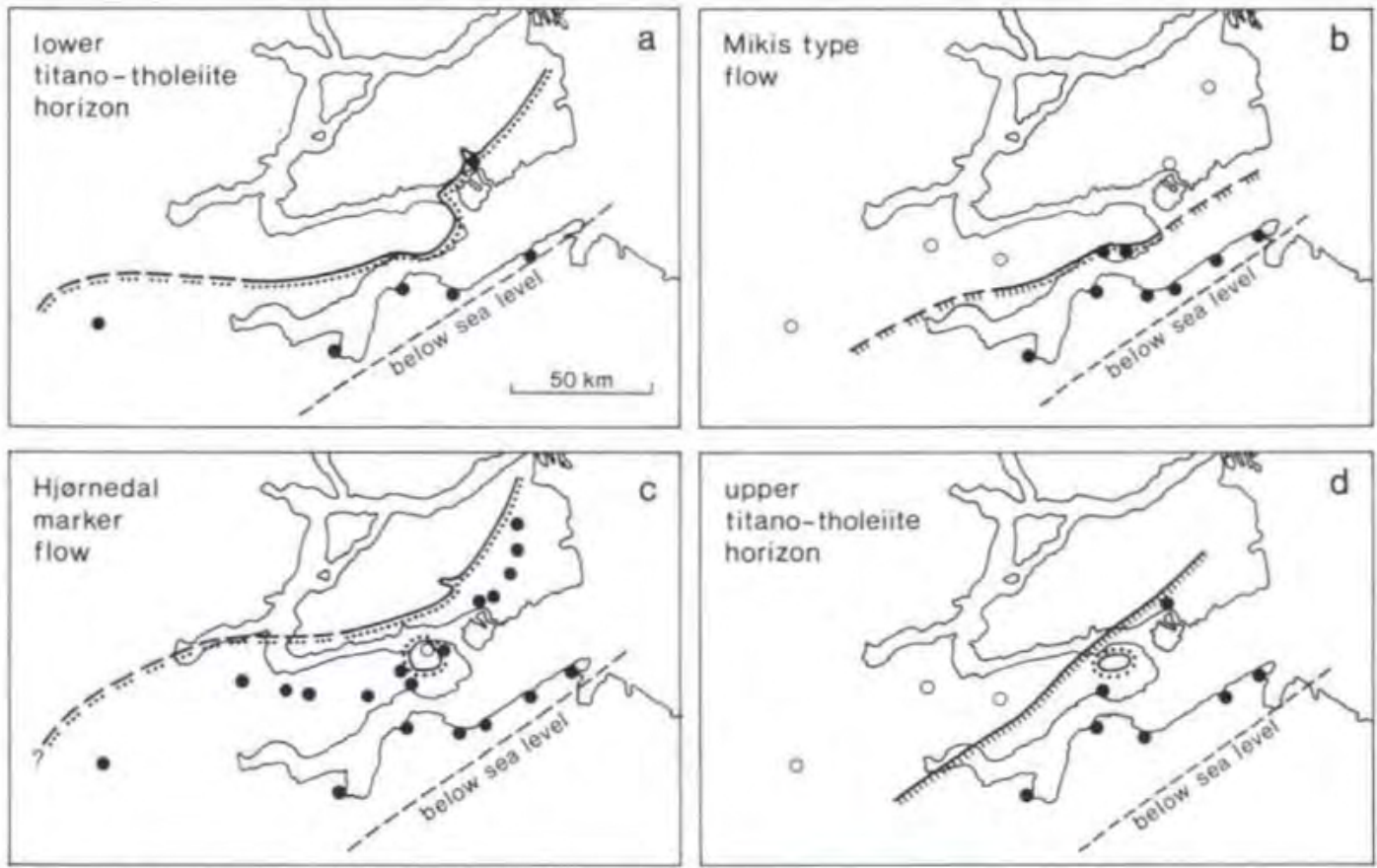

- horizon present

O horizon absent

$\hat{f}$ horizon limited by basement topography

F horizon limit not controlled by basement topography

Fig. 13. Distribution of four extensive lavas in the Milne Land Formation. The stratigraphical position of the lavas appears from fig. 11 and Plate 2.

Red boles between lava flows are frequent on Gaseland and sparse on Milne Land and south of Gåsefjord, where they tend to occur on the higher flows of the formation. Redeposited tuff layers occur on at least two levels in the higher part of the formation.
The Milne Land Formation consists mostly of quite markedly plagioclase porphyritic flows, some of them sufficiently characteristic for detailed correlation on the basis of phenocryst arrangement and frequency. In some flows, particularly those in the lower part of the

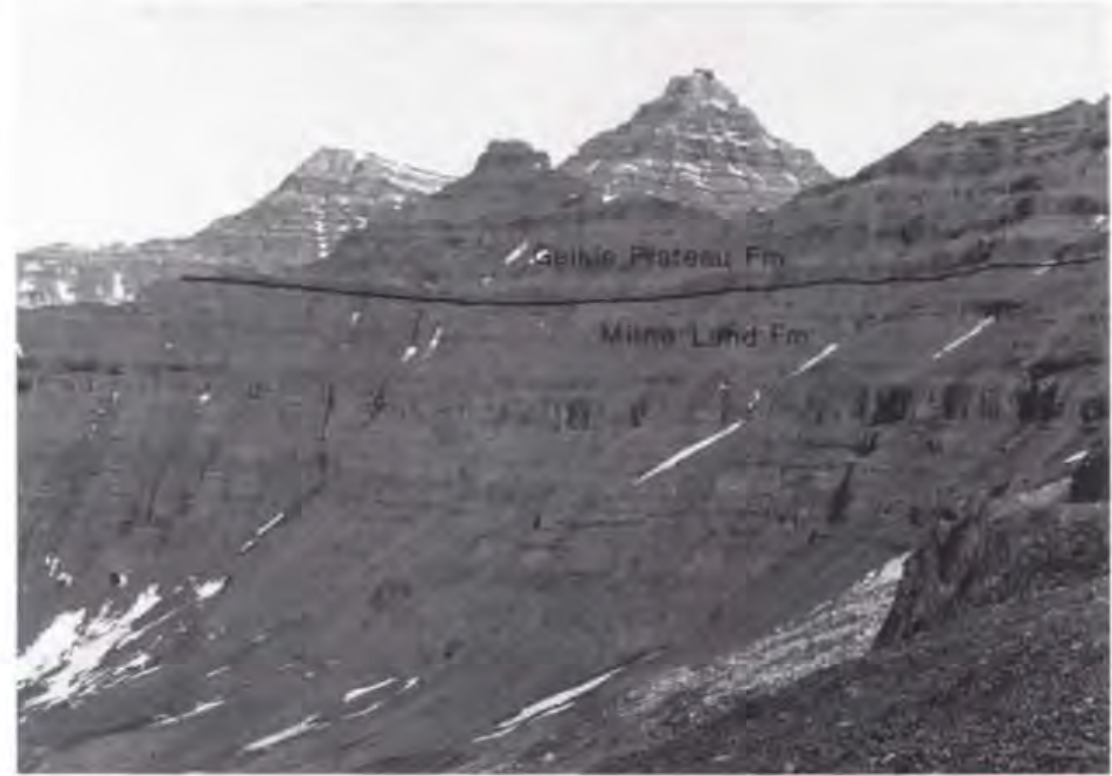

Fig. 14. Characteristic exposure of the Milne Land Formation. South face of top 1500 . Milne Land. 


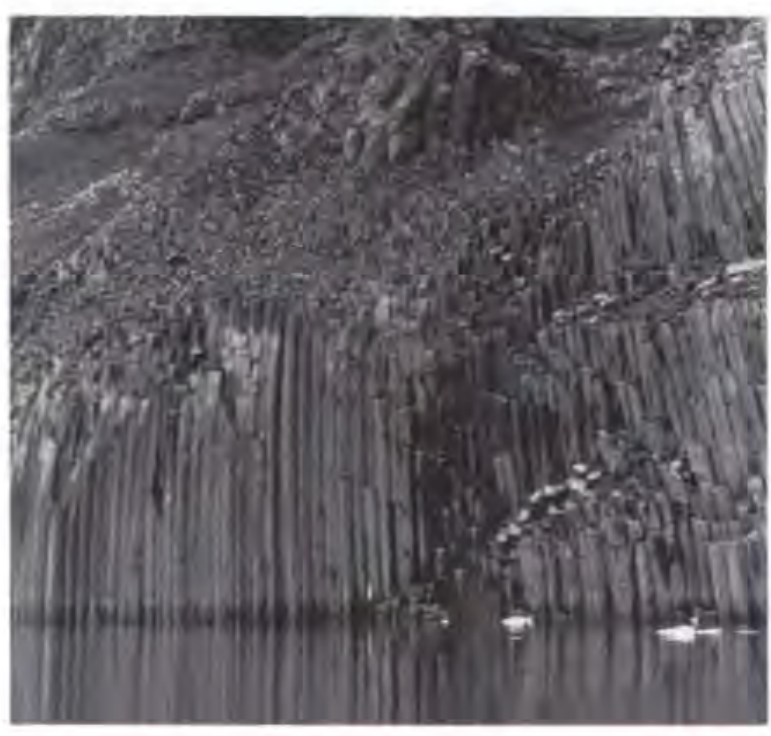

Fig. 15. Basalt columns are typically developed in the Milne Land Formation. East of Terrassevig. Note person standing at the water's edge.

sequence, the plagioclase phenocrysts form stellate aggregates up to $25-30 \mathrm{~mm}$ in diameter. Most commonly, however, the phenocrysts occur either as single laths or loose aggregates, decreasing in size and frequency from a maximum of about $10 \%$ of the total rock at the base to about $2 \%$ towards the top of the formation.

Hyaloclastic horizons are relatively common throughout the formation, though never as frequent or as thick as in the Magga Dan Formation. They are normally thin, discontinuous horizons, or lenses between flows, Quite thick, but local piles of hyaloclastic material were recorded at Gásepynt and on Milne Land north of Danmark $\emptyset$. These, and a number of smaller outcrops, are generally associated with areas of irregular (low) prebasalt topography. Only in the Vikingebugt area is there a thick, hyaloclastic horizon approaching $50 \mathrm{~m}$ in thickness, which can be followed for at least $10 \mathrm{~km}$. The material in this horizon becomes finer upwards, but otherwise there is no structure to the rock. A $20 \mathrm{~m}$ hyaloclastic horizon occurs $6 \mathrm{~km}$ east of Hjørnedal, with pillows and pillow fragments indicating a local SE dip of 'foreset' beds.

Sedimentary horizons, mostly of basaltic sandstone, are most common on Milne Land which is situated at the periphery of the basalt area. Silicified wood is common in association with these sediments on Milne Land where tree trunks $30-40 \mathrm{~cm}$ in diameter are by no means unusual. These tree trunks have never been found in situ, so it is unknown whether they are embedded in the interbasaltic sandstone horizons or engulfed in the lava flows, but they do indicate that on Milne Land there has been time for mature forest to develop between eruptions of the lava flows.

Chemical compositions. The Milne Land Formation is compositionally variable and includes basalts of several chemical types as defined in Table 19. The majority of the lavas are main basalts of medium-Ti type, high-Ti type and titano-tholeiites. They are nearly all quartz normative, and only a few samples from the upper part of the formation have small amounts of normative olivine. A few high-Si basalts occur (Plate 2), and they can all be related to either the med-Ti or high-Ti basalt type by slight modifications of their chemical composition. Two large flows of $\mathrm{Mg}$-rich basalt are found, one of Mikis type basalt and one the Hjornedal marker flow. The Mikis type basalt is olivine normative, while the Hjørnedal marker despite its high $\mathrm{Mg}$-content is quartz normative except in the two westernmost profiles (37 and 72). Representative compositions are shown in Table 1 .

Lateral correlation. Owing to a lateral persistence of the compositional pattern, and especially owing to two compositional and petrographic marker flows (the Mikis type flow and the Hjørnedal marker), a detailed intra-formational correlation has been established for the Milne Land Formation, extending for more than 200 $\mathrm{km} \mathrm{E-W}$ and $60 \mathrm{~km} \mathrm{~N}-\mathrm{S}$. This correlation appears from Plate 2, in which the Hjørnedal marker flow is used as a reference level. Some of the apparent irregularities are due to the profiles being projected both from $\mathrm{SW}$ and NE.

The lower part of the formation consists of high-Ti basalts and one horizon of titano-tholeite. The analysed samples from this titano-tholeiite horizon have very similar compositions (fig. 72), indicating that this is probably one flow which is then very voluminous ( $\mathrm{min}$. $300 \mathrm{~km}^{3}$, see Table 8 and fig. 13). The upper part of the formation consists of med-Ti and high- $\mathrm{Ti}$ basalts and likewise one horizon of titano-tholeiite. The upper titano-tholeiite is thinner than the lower and its composition is more variable (fig. 72), It may be more than one lava flow though still the result of one magmatic event.

In the middle of the formation occur the Mikis type flow and the Hjornedal marker flow. These two flows are petrographically, chemically and petrologically unique and are therefore described in some detail below.

Mikis type flow. This flow can be identified by its chemical characteristics (Table 19) and in thin section by its high olivine content, but it cannot be identified with certainty on field criteria. It is present south of Gase- 
fjord but dies out westwards, is just present on southern Gåseland as a basal flow preserved in a pre-basaltic valley, and is not present on Milne Land in spite of the relevant stratigraphic level being exposed (fig. 13). Eastwards it drops below sea level. Its normal thickness is $25 \mathrm{~m}$; but in several places it forms a pool-forming flow overlying the basement gneisses and therefore often is considerably thicker. It is aphyric, rather vesicular, weathers easily and is often scree-covered.

Hjornedal marker flow. A single flow forms a marker horizon recognisable in the field, named after its typical occurrence in Hjørnedal. In hand sample it is recognisable by up to $20 \%$ plagioclase phenocrysts and by the presence of phenocrysts of platy to acicular olivine crystals up to $5 \mathrm{~mm}$ in length and relatively large pyroxene phenocrysts. Morphologically the flow is usually indistinguishable from other flows of the formation. In profile 72 (western nunatak) there are two adjacent flows of the same type.

The Hjørnedal marker overlies the Mikis type flow either directly or with a single flow of main basalt between. It was one of the first flows that almost completely overflowed Gåseland. It is present in all profiles that cover the appropriate stratigraphic level (Plate 2 and fig. 13), and it has a distribution as wide as the Milne Land Formation itself (Savoia Halvø disregarded). Its average thickness is $25 \mathrm{~m}$. A maximum thickness of $70 \mathrm{~m}$ is reached in profile 17 (east of Găsefjord) where the flow appears to have ponded. It is one of the largest flows known in the region $\left(\min .285 \mathrm{~km}^{3}\right.$, see Table 8 ).

We regard the Hjørnedal magma as having been formed by mixing of the Mikis type magma with main basalt (med-Ti type) magma, as elaborated in the later discussion of magma mixing.

Savoia Halvo (Watt \& Watt, 1983), On Savoia Halvø the flows immediately overlying the Upper Cretaceous mudstones at Bopladsdalen are similar to the flows of the Magga Dan and Milne Land Formations to the west, and are indicated as Milne Land Formation on the map. The lowest $50 \mathrm{~m}$ is a series of flow units, the massive parts divided by horizons of vesicular basalt, and capped by a thin grey-green baked shale. These have petrographical characters similar to flows of the Magga Dan Formation, but since a definite stratigraphic correlation to the Magga Dan Formation is impossible, they are treated here along with the Milne Land Formation.

On top of these flow units follow six porphyritic lava flows with a total thickness of $100 \mathrm{~m}$, ascribed to the Milne Land Formation. The boundary towards the overlying $800 \mathrm{~m}$ Geikie Plateau Formation is marked by a 5-6 $\mathrm{m}$ thick yellow sandstone horizon. The chemical analyses (appendix, profile 126) are consistent with this stratigraphy, all the lavas below the sandstone horizon being quartz normative.

In hand samples the lowest flow units overlying the Cretaceous mudstones are all aphyric. Most of the flows of the Milne Land Formation have numerous to scattered plagioclase phenocrysts of 1 to $3 \mathrm{~cm}$ as clusters and single crystals.

The interbasaltic sandstone is dominantly composed of quartz with a few grains of feldspar and basalt.

The Milne Land Formation on Savoia Halvø only outcrops on the ridge due west of the houses at Bopladsdalen (profile 126). Here there is a westerly dip of about $3^{\circ}$ so that the formation dips below sea level westwards, and is quickly lost under permanent ice and landslips.

Eruption sites. No feeders for the lavas of the Milne Land Formation are known. The distribution of individual large lava flows (fig. 13) shows flow terminations towards the NW in Gåseland and Milne Land and makes a source in the Gassefjord region or to the SE most likely. A tephra layer in profile 71 (westernmost nunatak) is within around $30 \mathrm{~km}$ from the eruption site (K. Å. Jørgensen, personal communication) which may have been in the Gåsefjord region.

Boundaries. The lavas of the Milne Land Formation overlie everywhere those of the Magga Dan Formation and to the north and west overlap directly onto the basement gneisses, flooding the pre-basaltic relief on Gåseland and Milne Land. On Gåsepynt and eastern Milne Land the formation overlies Jurassic sandstones of the Charcot Bugt and Kap Leslie Formations.

On Savoia Halvø the lavas attributed to the Milne Land Formation overlie mudstones of Upper Cretaceous age (R. A. Fensome, personal communication, 1980 ).

The upper boundary of the formation is marked by one or more flows characterised by the presence of numerous small aggregates of plagioclase phenocrysts of 1-2 mm in diameter. An exception to this is a small group of flows, mostly westerly, but also on Milne Land, which have characters more like those of the overlying Geikie Plateau Formation but which are placed in the Milne Land Formation according to their chemical composition. In fig. 16, showing southern Găseland, the upper boundary is clearly seen at a distance.

The largely aphyric lavas of the Geikie Plateau Formation overlie the Milne Land Formation without any signs of pauses in the volcanic activity. 


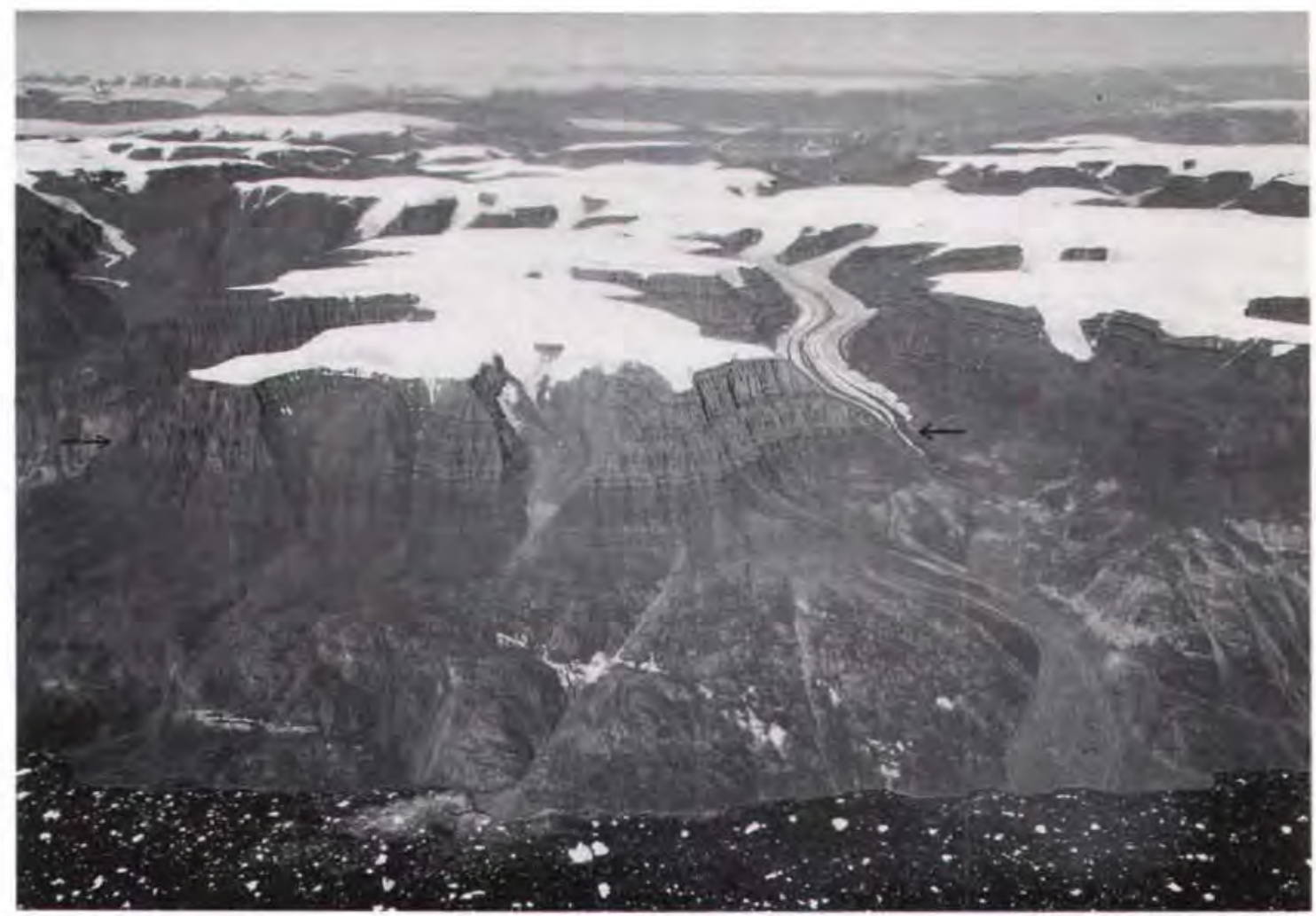

Fig. 16. A general view of the Milne Land and Geikie Plateau Formations on the south side of Gáseland, looking west across Găsefjord. Arrows indicate the position of the boundary between the Milne Land and Geikie Plateau Formations. Geodetic Institute route $6546-\mathrm{N}$, no. 12159 (A.200/87).

\section{Geikie Plateau Formation}

new formation

General. Lavas from this formation were described and illustrated by Watt \& Watt (1971) and form the units a-d on their fig, 9 (near profile 27) and the units IV-VI on their fig. 10 (near profile 39). The formation was described by Watt et al. (1972) and Watt \& Watt (1973) as a non-porphyritic sequence $1000 \mathrm{~m}$ and $800 \mathrm{~m}$ thick respectively, and by Watt et al. (1976) as a sparsely porphyritic sequence $500-600 \mathrm{~m}$ thick (the remainder below sea level). The formation was provisionally named formation 3 by Watt \& Watt (1983), and Geikie Formation by Larsen \& Watt (1985), Watt et al. (1986), Henriksen (1986), and on the 1:100 000 map sheet series.

Name. From the Geikie Plateau on the south side of Scoresby Sund.

Type profile. Profile 52 (valley west of Tænderne) (fig. 17).
Reference profiles. Profiles IV (Sydbræ), 27 (southern Milne Land), 47 (below Spiret), 59 (Ravebræ), 102/103 +105 (head of Rømer Fjord) (fig. 17).

Analysed profiles (number of analyses): $16(14), 27 / 28$ (10), 39 (11), 47 (25), 48 (3), 51 (12), 52 (33), 55 (7), 59 (15), 76 (3), 102/103/105 (17).

Distribution. The Geikie Plateau Formation extends over the entire area investigated (fig. 18). The lavas were extruded over the even surface of the underlying Milne Land Formation, and only in central Milne Land do they lap onto the irregular, rising surface of the crystalline basement. The lavas of this formation cap the highest tops in southern and central Milne Land and Gasseland (fig. 16), and the formation forms the top of the existing succession in the Gåsegletscher region to the west. To the south and east it is largely hidden below the overlying basalt formations and the ice cap. It is well exposed in the steep cliffs along the south coast of outer Gåsefjord and Scoresby Sund (fig. 19), where its lower boundary disappears below sea level around Sol- 
Fig. 17. Profiles of the Geikie Plateau Formation. Right part of columns $=$ lithology, left part of columns $=$ compositional type. Samples are indicated by numbered dots. Heights are metres above sea level.

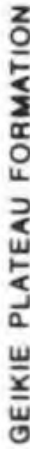

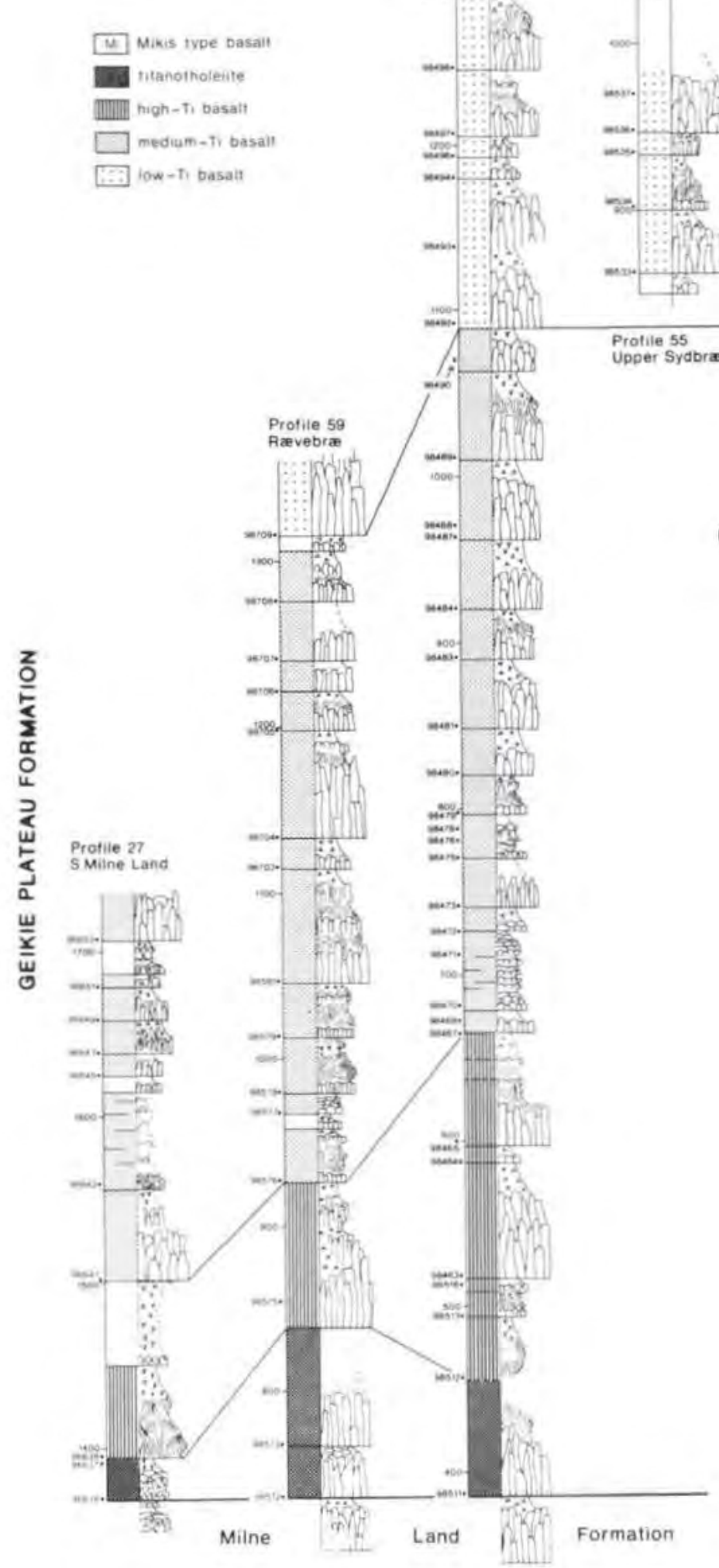

告
Romer Fjord Formation
Prafite 52

W of Tanderne

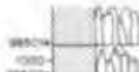

$m$

ising

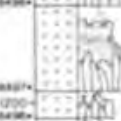

1....
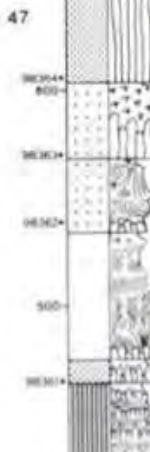

ton

2

20
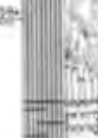

Hing

$-\cdots$

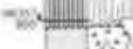

s.t.

洜

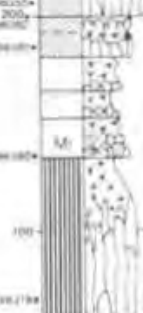

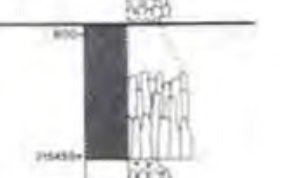
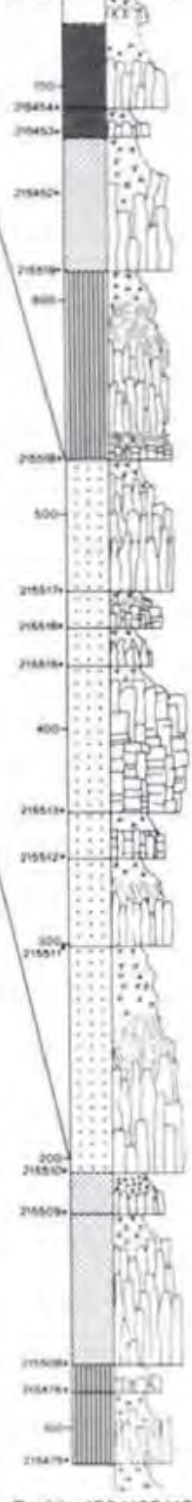

Profile $105 / 102 / 103$ inner Remer Fjord 
Fig. 18. Distribution of the Geikie Plateau Formation. Measured profiles are marked with dots. Full line indicates the original NW limit of the formation. broken line where inferred.

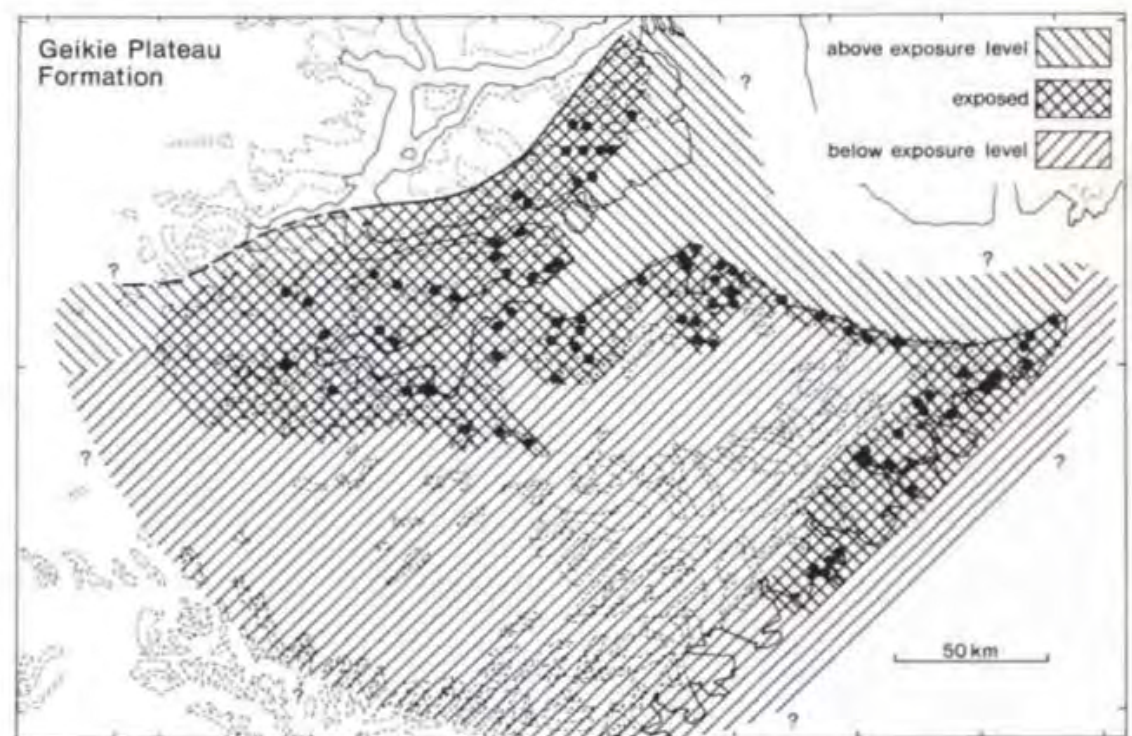

gletscher and probably re-emerges to the east at Kap Brewster (Bopladsdalen). On the Blosseville Kyst only the upper part of the formation is exposed above sea level (Plates 1 and 2). South of Knighton Fjord the formation completely drops below sea level, and its extension towards the south is unknown.

Thickness. The Geikie Plateau Formation reaches a maximum thickness of about $1100 \mathrm{~m}$ east of Sydbræ and exceeds $1000 \mathrm{~m}$ over the whole of the region where it is fully exposed or nearly so, i.e. in the region between Magga Dan Gletscher and Solgletscher on the south side of Scoresby Sund. On Gåseland and Milne Land $300-600 \mathrm{~m}$ of the formation is present, and no upper boundary is preserved. From correlation within the formation (Plate 2) it appears that there is a real thickness reduction of the formation on Gaseland and Milne Land, where the original thickness is estimated at 500-
Fig. 19. The Geikie Plateau Formation exposed east of Magga Dan Gletscher. The plateau top is at an altitude of $1600 \mathrm{~m}$. The overlying Rømer Fjord Formation is just visible in the highest peak. $\mathrm{gn}=$ basement gneiss.

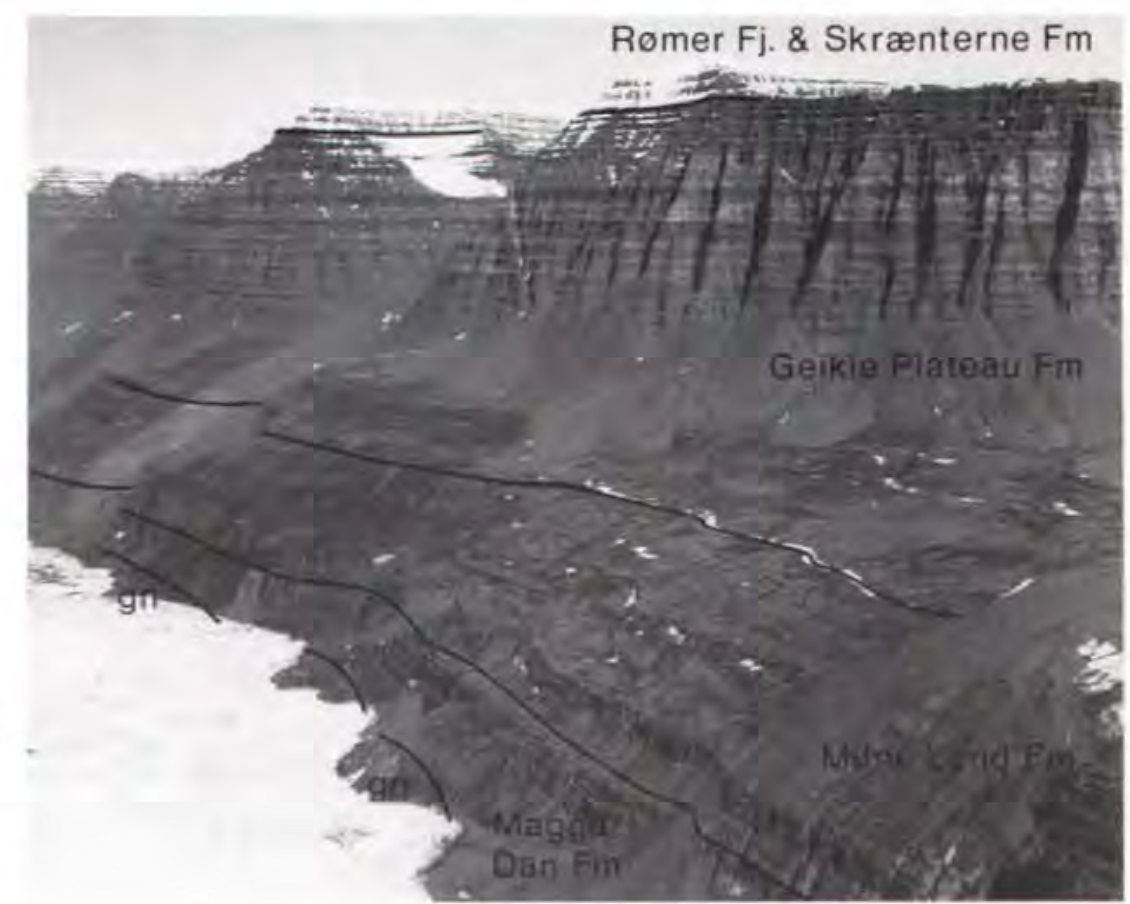


$700 \mathrm{~m}$. East of Solgletscher and along the Blosseville Kyst up to $750 \mathrm{~m}$ of the formation is exposed, and its thickness is probably in the order of $1000 \mathrm{~m}$.

The average thickness of the flows is about $20 \mathrm{~m}$ on Milne Land and increases in a fairly regular manner to about $50 \mathrm{~m}$ on the Blosseville Kyst. Within this steady increase in the average flow thicknesses there is a wedge with thinner flows along the southern side of Gasefjord and a second wedge in the northern part of the Blosseville Kyst from Savoia Halvø to Turner $\emptyset$. This could suggest that there was more than one source for the flows of the Geikie Plateau Formation.

Lithology. The Geikie Plateau Formation consists almost entirely of massive, bench-forming flows of a very uniform appearance. Where the formation is fully exposed the total number of flows or groups of flow units is 25-30 (Plate 2), and the average flow thickness is around $35 \mathrm{~m}$. Occasionally, particularly in Gåseland and Milne Land, the massive flows appear to have broken up into groups of thinner flows or flow units.

Typical flows of this formation have a lower massive colonnade, usually between 50 and $70 \%$ of the total thickness of the flow, followed by an entablature which, particularly in the thicker flows, may occupy as much as $50 \%$ of the total thickness, and topped by a vesicular and often brecciated or rubbly top. Nearly all the flows of this formation belong to the aa type. In some flows there is a repetition with an upper and a lower colonnade and in a few places a complete repetition of both a colonnade and an entablature.

The lavas of the Geikie Plateau Formation are fine grained and largely aphyric in appearance. However, single flows or small groups of flows may contain scattered, mostly small, plagioclase phenocrysts. In profiles in the northeastern part of the area (47-51) the proportion of porphyritic flows is higher than elsewhere and hence gives the formation a somewhat different character.

Hyaloclastic horizons occur locally in the formation. On Milne Land local hyaloclastic deposits are associated with steep pre-basalt topography just as in the preceding formations. In the Vikingebugt area thick hyaloclastic horizons are found at several levels in the lower part of the formation. One at $100 \mathrm{~m}$ above the base is thickest in the Vikingebugt area ( $>25 \mathrm{~m})$ and thins towards the southwest. It can be followed over 25 $\mathrm{km}$. Another horizon occurs about $400 \mathrm{~m}$ above the base and is marked by a terrace which can be followed around Vikingebugt and Helgenæs. It thins towards the $\mathrm{SW}, \mathrm{S}$ and $\mathrm{E}$. The hyaloclastic material is finer grained in the north (Kap Stevenson) than in the south. Lava flows following the hyaloclastic horizons are thicker than elsewhere and even out the irregular top surface of the hyaloclastite deposits.

A feature seen in the steep walls of the southern part of Vikingebugt is what could be examples of old tunnels in the sub-columnar top parts of the lava flows. These 'tunnels' are about $2 \mathrm{~m}$ across and marked by poor columns swinging around near circular areas.

Many flows have thin but prominent brick red tops consisting of lateritised, redeposited tuffaceous material. They are relatively frequent throughout the formation, particularly on Milne Land. In cases the red colouration has seeped down into the brecciated top zone giving the whole a speckled purple effect from a distance. Other interbasaltic sediments are rare.

Chemical compositions. The lavas of the Geikie Plateau Formation belong almost exclusively to the four types of main basalt (Table 19). Out of 150 analysed samples there are one Mikis type basalt from low in profile 47 and one high-Si basalt from profile 39 in central Gåseland. The lavas in the lower part of the formation are usually quartz normative, while the lavas in the middle and upper parts are olivine normative (fig. 3). Representative compositions are shown in Table 2.

Subdivisions. The Geikie Plateau Formation shows a systematic vertical development from titano-tholeiites at the bottom to low-Ti basalts at the top, with a short reversal to more Ti-rich lavas at the very top (fig. 17). In detail, the variation is discontinuous (fig. 3 and fig. 72), and the formation can be sub-divided into five units from bottom to top: a titano-tholeiite unit, a high- $\mathrm{Ti}$ unit, a med-Ti unit, a low-Ti unit, and a 'reverse' unit with mixed chemistry. The lateral distribution of these units appears from Plate 2 . They are particularly evident in profiles from the western and central areas, while the more easterly profiles show more mixed relations of the high-Ti and medium-Ti units.

The units are purely chemically defined and cannot be distinguished in the field. Their importance for the interpretation of the volcanic history was outlined in the earlier section on volcanic episodes, and they will also be discussed later.

Eruption sites. No dykes have been observed feeding the lavas of the Geikie Plateau Formation. However, the inland tholeiitic dykes that form a loose swarm on Gåseland, Milne Land and south of Gåsefjord (fig. 32) have chemical compositions identical to the lavas of the Geikie Plateau Formation (see later). These dykes are seen cutting the basement, the Magga Dan, Milne Land and sometimes lower Geikie Plateau Formations, and we believe that they fed the lavas of the Geikie Plateau 
Table 2. Representative compositions of lavas from the Geikie Plateau Formation

\begin{tabular}{|c|c|c|c|c|c|c|c|c|c|}
\hline $\begin{array}{l}\text { Profile No. } \\
\text { GGU No. } \\
\text { Type }\end{array}$ & $\begin{array}{c}47 \\
98380 \\
\text { Mikis }\end{array}$ & $\begin{array}{c}52 \\
98497 \\
\text { low-Ti }\end{array}$ & $\begin{array}{c}52 \\
98493 \\
\text { low-Ti }\end{array}$ & $\begin{array}{c}52 \\
98480 \\
\text { med-Ti }\end{array}$ & $\begin{array}{c}52 \\
98471 \\
\text { med-Ti }\end{array}$ & $\begin{array}{c}52 \\
98464 \\
\text { high-Ti }\end{array}$ & $\begin{array}{c}48 \\
98397 \\
\text { high-Ti }\end{array}$ & $\begin{array}{c}52 \\
98511 \\
\text { Ti-thol }\end{array}$ & $\begin{array}{c}102 \\
215455 \\
\text { Ti-thol }\end{array}$ \\
\hline $\mathrm{SiO}_{2}$ & 50.47 & 49.49 & 49.23 & 49.27 & 49.14 & 49.07 & 48.82 & 49.31 & 48.09 \\
\hline $\mathrm{TiO}_{2}$ & 2.48 & 2.13 & 2.32 & 2.50 & 2.76 & 2.98 & 3.22 & 3.63 & 3.64 \\
\hline $\mathrm{Al}_{2} \mathrm{O}_{3}$ & 11.57 & 13.96 & 13.99 & 13.58 & 14.07 & 13.39 & 12.63 & 13.16 & 13.53 \\
\hline $\mathrm{Fe}_{2} \mathrm{O}_{3}$ & 1.62 & 1,64 & 1.70 & 1.70 & 1.68 & 1.88 & 2.08 & 1.78 & 1.85 \\
\hline $\mathrm{FeO}$ & 10.85 & 10.92 & 11.31 & 11.34 & 11.18 & 12.49 & 13.85 & 11.93 & 12.36 \\
\hline $\mathrm{MnO}$ & 0.18 & 0.22 & 0.22 & 0.20 & 0.21 & 0.21 & 0.24 & 0.19 & 0.21 \\
\hline $\mathrm{MgO}$ & 10.73 & 7.04 & 6.62 & 7.00 & 6.82 & 6.48 & 5.59 & 6.21 & 5.97 \\
\hline $\mathrm{CaO}$ & 9.33 & 11.78 & 11.81 & 11.60 & 11.58 & 10.62 & 10.42 & 10.38 & 11.03 \\
\hline $\mathrm{Na}_{2} \mathrm{O}$ & 2.02 & 2.36 & 2.41 & 2.34 & 2.15 & 2.30 & 2.42 & 2.53 & 2.55 \\
\hline $\mathrm{K}_{2} \mathrm{O}$ & 0.54 & 0.29 & 0.20 & 0.25 & 0.20 & 0.31 & 0.43 & 0.54 & 0.41 \\
\hline $\mathrm{P}_{2} \mathrm{O}_{3}$ & 0.21 & 0.17 & 0.20 & 0.22 & 0.21 & 0.27 & 0.30 & 0.34 & 0.36 \\
\hline Mg ratio & 0.638 & 0.536 & 0.510 & 0.525 & 0.521 & 0.481 & 0.419 & 0.482 & 0.463 \\
\hline $\mathrm{FeO}^{*}$ & 12.31 & 12.40 & 12.84 & 12.87 & 12.69 & 14.18 & 15.72 & 13.53 & 14.03 \\
\hline \multicolumn{10}{|l|}{ CIPW norm } \\
\hline$Q$ & & & & & 0.69 & 0.71 & 0.62 & 0.93 & \\
\hline or & 3.19 & 1.71 & 1.18 & 1.48 & 1.18 & 1.83 & 2.54 & 3.19 & 2.42 \\
\hline$a b$ & 17.09 & 19.97 & 20.39 & 19.80 & 18.19 & 19.46 & 20.48 & 21.41 & 21.58 \\
\hline an & 20.91 & 26.64 & 26.76 & 25.81 & 28.15 & 25.30 & 22.33 & 22.96 & 24.26 \\
\hline di & 19.49 & 25.29 & 25.22 & 24.98 & 23.01 & 21.23 & 22.91 & 21.74 & 23.29 \\
\hline hy & 30.96 & 16.60 & 16.80 & 18.67 & 20.61 & 22.46 & 21.30 & 19.51 & 15.67 \\
\hline ol & 0.81 & 2.97 & 2.32 & 1.54 & & & & & 2.36 \\
\hline $\mathrm{mt}$ & 2,35 & 2.38 & 2.46 & 2.46 & 2.44 & 2.73 & 3.02 & 2.58 & 2.68 \\
\hline iI & 4.71 & 4.05 & 4.41 & 4.75 & 5.24 & 5.66 & 6.12 & 6.89 & 6.91 \\
\hline ap & 0.49 & 0.39 & 0.46 & 0.51 & 0.49 & 0.63 & 0.70 & 0.79 & 0.83 \\
\hline
\end{tabular}

All analyses have had the oxidation ratio adjusted to $\mathrm{Fe}_{2} \mathrm{O}_{3} / \mathrm{FeO}=0.15$ and have been recalculated to $100 \%$ on a volatile-free basis. The original analyses are in appendix 2, and trace elements analyses in appendix 3.

Most analyses are from the well-discriminated trends of fig. $72 \mathrm{~b}$.

The two titano-tholeiite analyses illustrate the difference between the quartz normative titano-tholeites at the bottom of the formation and the olivine normative ones at the top.

The various chemical types are defined in Table 19.

Formation. This may also be the case for some of the dykes on Jameson Land.

Variations in the thicknesses of lava flows, with thinner flows along the southern side of Gåsefjord and from Savoia Halvø to Turner $\emptyset$, indicate that individual eruption areas may be centred on Gåseland and in the eastern and south-eastern part of the Geikie Plateau.

Tuff layers with primary structures, from which the distance to the eruption site can be estimated, have been found on Milne Land (profile 10 lies within $15 \mathrm{~km}$ from an eruption site), on central Gåseland (profile 39 lies within $30 \mathrm{~km}$ from an eruption site) and on the south coast of Scoresby Sund (profile 46 lies within 50 $\mathrm{km}$ from an eruption site) (K. $\AA$. Jørgensen, personal communication).

In conclusion, the lavas of the Geikie Plateau Formation seem to have been erupted over widely spaced areas. Towards the SE the eruption sites cannot be delimited because the relevant stratigraphic levels are not exposed. Observations along the south coast of Scoresby Sund indicate that dykes are indeed scarce east of Vikingebugt (fig. 32), and it appears that the major part of the eruptive activity was centred in the inland regions, as with the preceding formations, It is probable that the activity in the south-east increased with time - the latest flows in the Geikie Plateau Formation in the Kap Dalton - Rømer Fjord area have no counterparts in the inland areas (Plate 2: titano-tholeiites in profile 102) and are considered local eruption products.

Boundaries. The Geikie Plateau Formation conformably overlies the Milne Land Formation except in central Milne Land, where it rests directly on the crystalline 
basement. The lower boundary is characterised by a decrease in phenocryst content from the porphyritic Milne Land Formation to the largely aphyric Geikie Plateau Formation. In some cases the decrease is gradual over a few flows, and the position of these may be arguable. They have usually been placed according to their chemical composition.

The upper limit of the formation is marked in most places by a thin sedimentary horizon (sandstone, siltstone or mudstone) commonly associated with discontinuous pillow lavas formed at the base of the lowest flow of the overlying Rømer Fjord Formation. The sedimentary layer is stratigraphically placed within the Rømer Fjord Formation. West and north of the Geikie Plateau the Geikie Plateau Formation is directly overlain by the thin grey lavas of the Rømer Fjord Formation.

\section{Rømer Fjord Formation}

new formation

General. This formation was termed the 'lower grey series' by Watt et al. (1972), the 'grey series' by Watt \& Watt (1973) and was described as a $200 \mathrm{~m}$ thick horizon of thin grey flows by Watt et al. (1976). It was provisionally named formation 4 by Watt \& Watt (1983), and
Rømer Fjord Formation by Larsen \& Watt (1985) and Watt et al. (1986).

Name. From Rømer Fjord in the northern part of the Blosseville Kyst.

Type profile. Profile 106 (head of Rømer Fjord) (fig. 20).

Reference profiles. Profiles 48 (peak 1290 south of Terrassevig), 55 (upper Sydbræ), 108 (Kap Dalton Valley) and 114 ('Tærskelsøerne' NW of Manby Halvø) (fig. 20).

Analysed profiles (number of analyses): 48 (6), 55 (8), 74 (3), 76 (3), 102 (6), 104 (3), 106 (5), 108 (8), 117 (8). Single samples: 4 . Profiles 108 and 117 are not included in the chemistry diagrams.

Distribution. The Rømer Fjord Formation is present in the area SE of Gasefjord from Magga Dan Gletscher to the Blosseville Kyst as far south as Barclay Bugt where it drops below sea level (fig. 21). Whereas Gåsefjord probably marks the original north-westward extent of the formation (see below), its southward extent is unknown.

The formation weathers readily to a gravelly scree. It tends to form a snow or gravel covered recess on top of

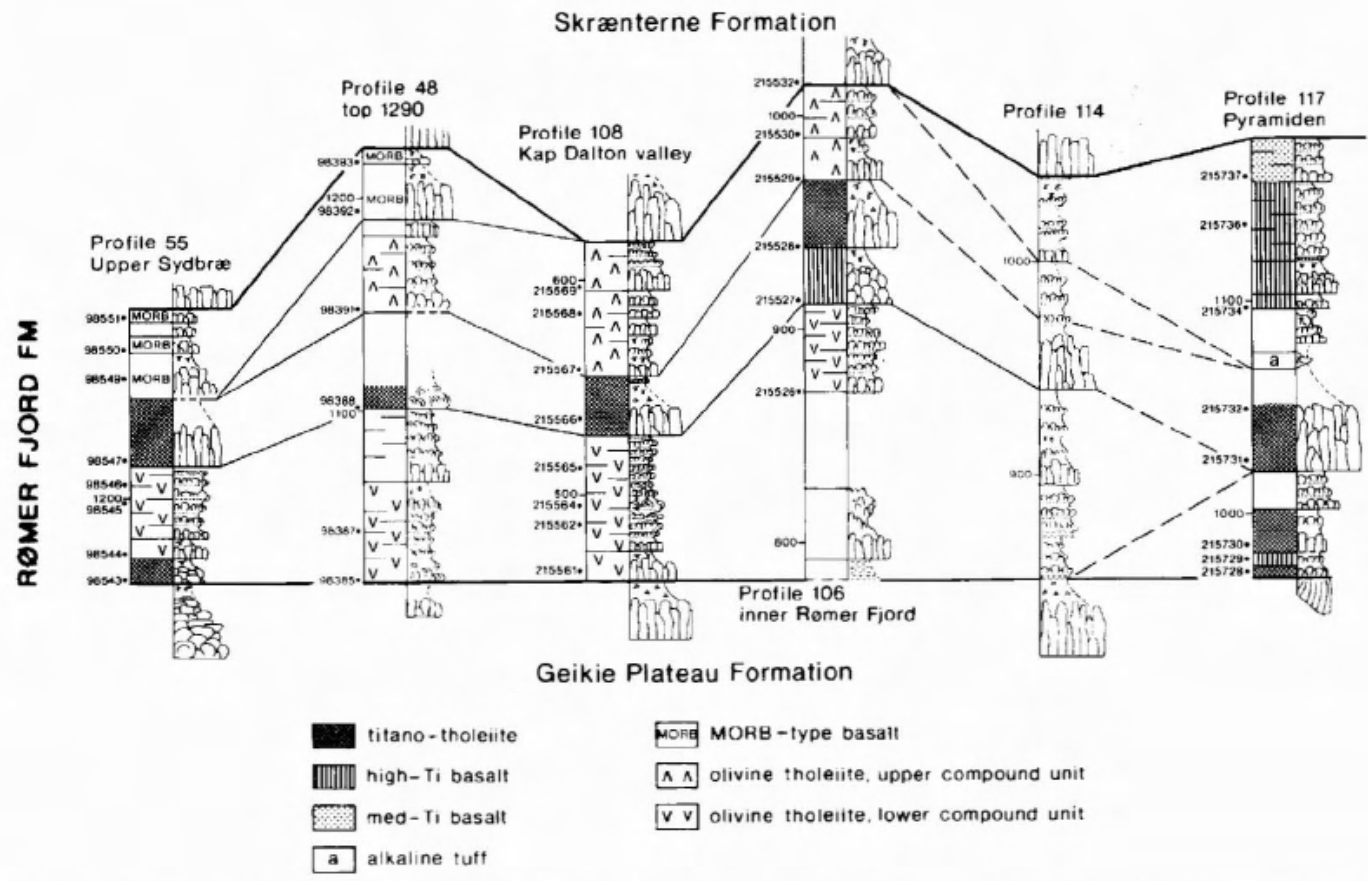

Fig. 20. Profiles of the Rømer Fjord Formation. Right part of columns = lithology, left part of columns = compositional type. Samples are indicated by numbered dots. Heights are metres above sea level. 
Fig. 21. Distribution of the Romer Fjord Formation. Measured profiles are marked with dots. The broken line indicates the inferred original NW limit of the formation.

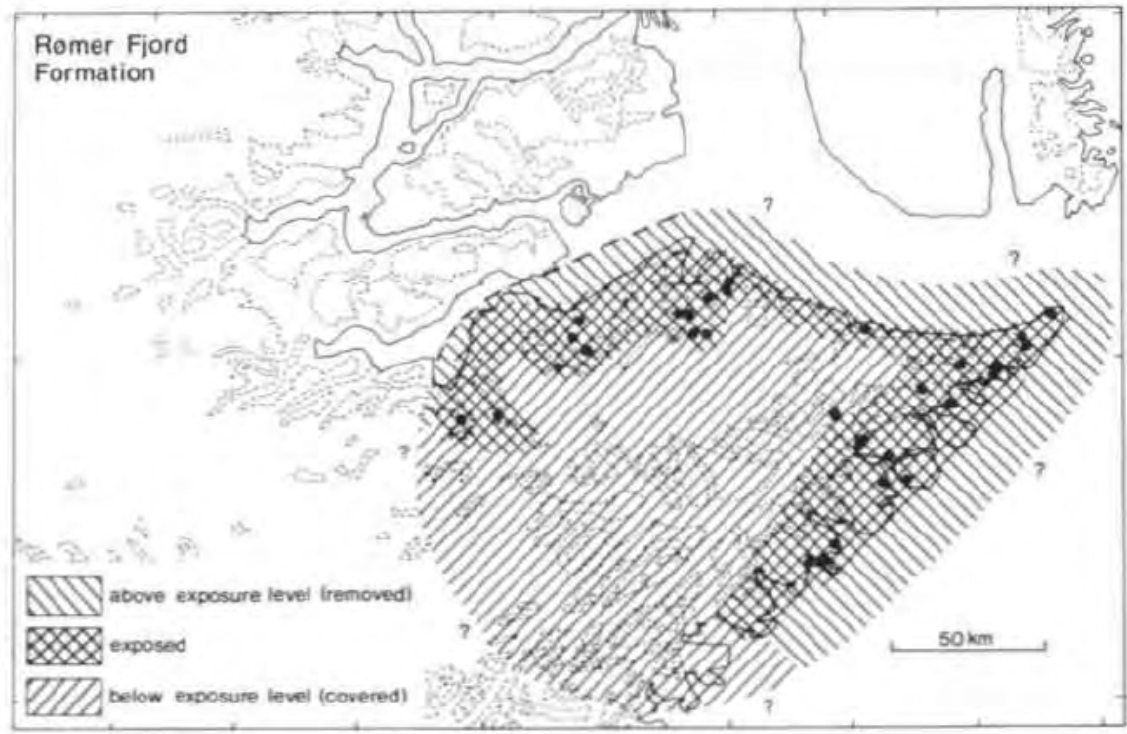

the Geikie Plateau Formation (fig. 19) and hence is often very poorly exposed.

Thickness. The Romer Fjord Formation reaches a thickness of 200 to $220 \mathrm{~m}$ on the Blosseville Kyst where the thickness is fairly constant. The formation thins gradually inland to 150 to $100 \mathrm{~m}$ between Bredegletscher and Sydbra, and to 50 to $20 \mathrm{~m}$ between Sydbræ and Magga Dan Gletscher. The thinness of the formation in its western part indicates that this is close to the original north-western limit of the formation.
Lithology. The Romer Fjord Formation is characteristically heterogeneous, being composed of sequences of thin grey-weathering flows interspaced with massive, brown-weathering flows. The formation often appears as two grey rubbly-weathering sequences divided by a massive brown bench (fig. 22). This is especially evident in the Blosseville Kyst area.

The grey sequences consist of thin, very vesicular, usually aphyric flows or flow units down to a few centimetres in thickness (compound flows). Pipe vesicles at flow bases are common, as are ropy top zones, often
Fig. 22. The Romer Fjord Formation on the south side of Henry Land. The formation here is well developed and has a dark weathering central flow dividing it into two. At this southern locality the dark central now appears to be a series of flow units.

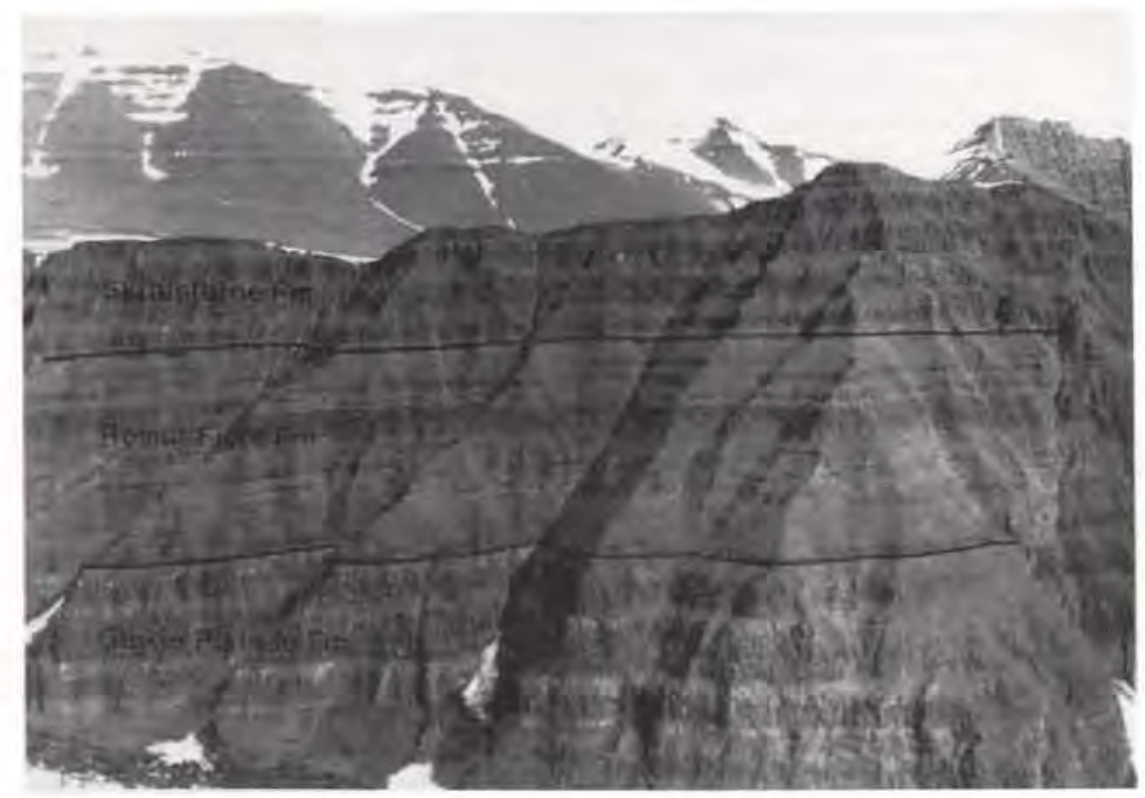


red-baked. The grey colour is due to widespread zeolite impregnation, which gives the vesicular rocks a speckled appearance. The weathering forms are rounded or even 'onion shell' like, and the grey sequences often form rubble slopes in which thin flows are seen as a series of horizontal lines where the outcrop penetrates the rubble. The sequences only crop out continuously in near vertical cliff faces.

The massive brown lavas are usually heavily feldsparphyric. For convenience the brown bench in the centre of the formation has been named the big feldspar divide'. It is known over the whole extent of the Rømer Fjord Formation. It consists of one or two flows with rather variable phenocryst size and frequency, yet with sufficient features in common to stand out as a distinctive unit.

Other feldspar-phyric brown flows occur at the bottom of the formation in the Kap Dalton - Rømer Fjord area and in profile 55 at Sydbre.

In hand specimen the lavas of the Romer Fjord Formation are generally coarser grained than the surrounding formations. This is true for both the aphyric and the porphyritic types. In the porphyritic flows plagioclase phenocrysts often form large, stellate aggregates up to 3 $\mathrm{cm}$ in diameter. Occasional aggregates up to $10 \mathrm{~cm}$ have plagioclase laths $4-5 \mathrm{~cm}$ long. Pyroxene phenocrysts of $3-5 \mathrm{~mm}$ are frequently associated with the plagioclase aggregates. Sometimes a considerable difference in phenocryst frequency was noted between top and bottom of a flow, with numerous plagioclase aggregates collecting at the top.

In a $20 \mathrm{~km}^{2}$ area east of Sydbræ the bottom of the Rømer Fjord Formation is constituted by a layer of coarse tuff of nephelinitic character up to $12 \mathrm{~m}$ thick (it is indicated on the 1:100 000 map Gassefjord $70 \emptyset .6 \mathrm{~S}$ as 'interbasaltic sandstone'). The formation is heavily eroded in this area, and the tuff layer is seen as rounded gravelly slopes on the highest tops and ridges (fig. 23).

Hyaloclastics are sparse. On Savoia Halvø and west thereof (profile 117) several thick hyaloclastic horizons are found in the upper part of the formation.

Sedimentary horizons of yellow-brown mudstone and tuffaceous material, red and black shale and basaltic sandstone occur occasionally throughout the formation.

Chemical compositions. (Chemical types defined in Table 19.) This relatively thin formation is compositionally the most diverse of all the basalt formations. Most of the grey, compound aphyric flows are Mg-rich basalts, either olivine tholeiites relatively rich in incompatible elements, or depleted MORB type basalts, while the massive brown feldspar-phyric flows are main basalts of high-Ti type or titano-tholeiites. Occurrences of a strongly alkaline nephelinite tuff and an alkaline tuff in profile 117 contribute to the variability of the formation.

The lavas of the Rømer Fjord Formation have relatively low $\mathrm{SiO}_{2}$-contents (fig. 73) and are all olivine normative (an exception seen in fig. 3 is a lava that has lost alkalies). The low $\mathrm{SiO}_{2}$ contents bring the titanotholeiites close to the Hawaiian division line between tholeiites and alkali basalts in the alkali-silica diagram (fig. 73), and four samples even plot in the alkaline field. These still contain large amounts of normative hypersthene $(10.5-15.5 \%)$ and are transitionally alkaline according to Jakobsson $(1979$, p. 77$)$. They classify as tholeiites according to Irvine \& Baragar (1971). The four samples are from three different sections and varying stratigraphical positions (98884 (76), 215458-59 (102) and 215528 (106)). We see no reason to suppose that they are principally different from the other titanotholeites in the formation.

Representative analyses are shown in Table 3.

Subdivisions. Owing to the heterogeneity of the Rømer Fjord Formation, both morphologically and composi-

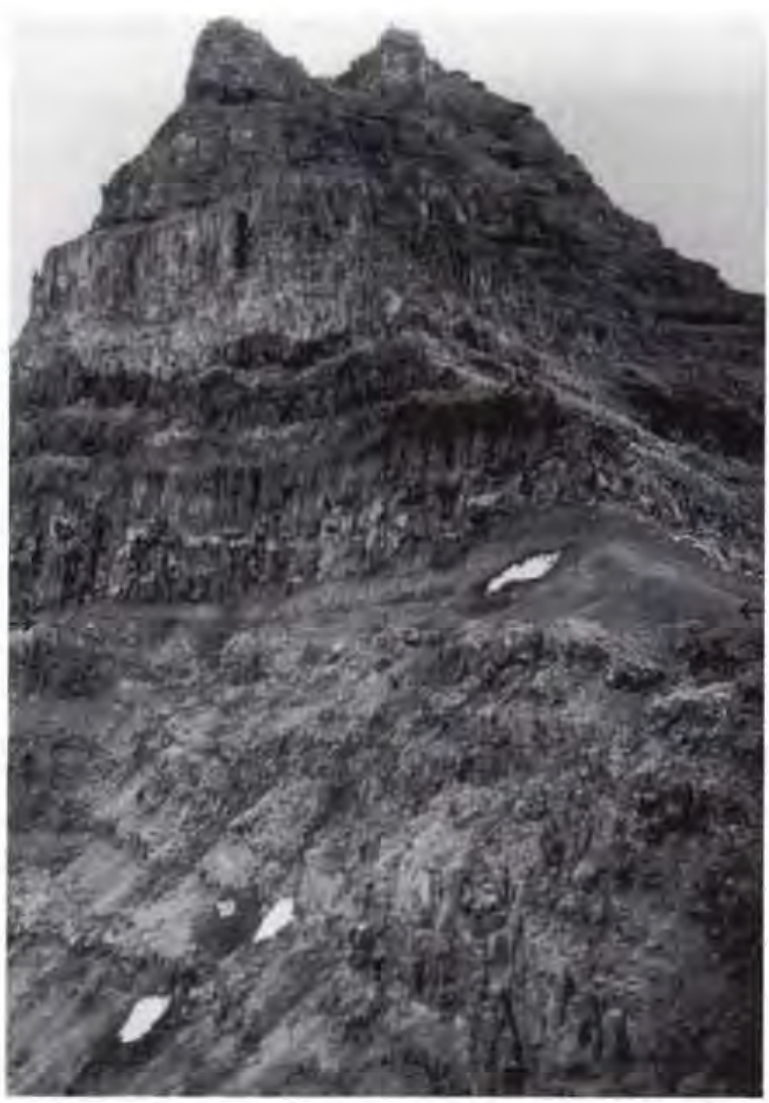

Fig. 23. Nephelinite tuff at the base of the Romer Fjord Formation. East of Sydbra at $1480 \mathrm{~m}$ altitude. 
Table 3. Representative compositions of lavas from the Rømer Fjord Formation

\begin{tabular}{|c|c|c|c|c|c|c|c|c|c|}
\hline $\begin{array}{l}\text { Profile No. } \\
\text { GGU No. } \\
\text { Type }\end{array}$ & $\begin{array}{c}55 \\
98549 \\
\text { MORB }\end{array}$ & $\begin{array}{c}48 \\
98392 \\
\text { MORB }\end{array}$ & $\begin{array}{c}102 \\
215464 \\
\text { l.c.u. }\end{array}$ & $\begin{array}{l}74 \\
98871 \\
\text { I.c.u. }\end{array}$ & $\begin{array}{c}106 \\
215529 \\
\text { u.c.u. }\end{array}$ & $\begin{array}{c}104 \\
215484 \\
\text { u.c.u. }\end{array}$ & $\begin{array}{c}74 \\
98873 \\
\text { high-Ti }\end{array}$ & $\begin{array}{c}55 \\
98547 \\
\text { Ti-thol }\end{array}$ & $\begin{array}{c}102 \\
215459 \\
\text { Ti-thol }\end{array}$ \\
\hline $\mathrm{SiO}_{2}$ & 49.32 & 49.49 & 48.33 & 48.20 & 48.13 & 47.65 & 48.23 & 47.66 & 47.69 \\
\hline $\mathrm{TiO}_{2}$ & 1.17 & 1.72 & 1.99 & 2.26 & 2.64 & 2.91 & 3.15 & 4.12 & 3.60 \\
\hline $\mathrm{Al}_{2} \mathrm{O}_{3}$ & 14.82 & 14.71 & 13.88 & 13.59 & 14.38 & 14.44 & 14.09 & 13.19 & 13.35 \\
\hline $\mathrm{Fe}_{2} \mathrm{O}_{3}$ & 1.38 & 1.61 & 1.49 & 1.58 & 1.59 & 1.68 & 1.80 & 1.98 & 1.82 \\
\hline $\mathrm{FeO}$ & 9.22 & 10.77 & 9.94 & 10.55 & 10.59 & 11.26 & 11.98 & 13.21 & 12.15 \\
\hline $\mathrm{MnO}$ & 0.17 & 0.18 & 0.18 & 0.19 & 0.18 & 0.19 & 0.17 & 0.21 & 0.23 \\
\hline $\mathrm{MgO}$ & 9.60 & 6.61 & 9.62 & 9.17 & 7.75 & 7.81 & 6.59 & 6.01 & 6.93 \\
\hline $\mathrm{CaO}$ & 12.59 & 12.32 & 12.27 & 12.03 & 11.67 & 11.57 & 10.93 & 10.38 & 10.77 \\
\hline $\mathrm{Na}_{2} \mathrm{O}$ & 1.58 & 2.35 & 1.95 & 2.02 & 2.47 & 1.93 & 2.48 & 2.36 & 2.47 \\
\hline $\mathrm{K}_{2} \mathrm{O}$ & 0.07 & 0.12 & 0.20 & 0.21 & 0.32 & 0.26 & 0.29 & 0.46 & 0.62 \\
\hline $\mathrm{P}_{2} \mathrm{O}_{5}$ & 0.074 & 0.12 & 0.16 & 0.19 & 0.27 & 0.29 & 0.28 & 0.41 & 0.36 \\
\hline Mg ratio & 0.651 & 0.524 & 0.633 & 0.608 & 0.566 & 0.553 & 0.495 & 0.448 & 0.504 \\
\hline $\mathrm{FeO}^{*}$ & 10.46 & 12.22 & 11,28 & 11.97 & 12.02 & 12.77 & 13.60 & 14.99 & 14.99 \\
\hline
\end{tabular}

CIPW norm

\begin{tabular}{lrrrrrrrrrr} 
Q & & & & & & & 0.10 \\
or & 0.41 & 0.71 & 1.18 & 1.24 & 1.89 & 1.54 & 1.71 & 2.72 & 3.66 \\
ab & 13.37 & 19.88 & 16.50 & 17.09 & 20.90 & 16.33 & 20.99 & 19.97 & 20.90 & 23.51 \\
an & 33.14 & 29.23 & 28.53 & 27.40 & 27.21 & 29.97 & 26.46 & 24.04 & 2.72 \\
di & 23.49 & 25.70 & 25.45 & 25.32 & 23.69 & 20.94 & 21.43 & 20.56 & 22.72 \\
hy & 21.34 & 15.54 & 12.42 & 13.19 & 9.03 & 18.69 & 16.63 & 20.97 & 12.12 \\
ol & 3.87 & 3.05 & 9.61 & 8.73 & 9.34 & 3.90 & 3.54 & 6.77 \\
mt & 2.00 & 2.33 & 2.16 & 2.29 & 2.31 & 2.44 & 2.61 & 2.87 & 2.64 \\
il & 2.22 & 3.27 & 3.78 & 4.29 & 5.01 & 5.53 & 5.98 & 7.83 & 6.84 \\
ap & 0.16 & 0.28 & 0.37 & 0.44 & 0.63 & 0.67 & 0.65 & 0.95 & 0.83 \\
\hline
\end{tabular}

All analyses have had the oxidation ratio adjusted to $\mathrm{Fe}_{2} \mathrm{O}_{3} / \mathrm{FeO}=0.15$ and have been recalculated to $100 \%$ on a volatile-free basis. The original analyses are in appendix 2 and trace element analyses in appendix 3.

The two MORB type rocks represent the least and the most differentiated part of the trend in fig. 72 .

I.c.u. = lower compound unit.

u.c.u. = upper compound unit.

98873 and 98547 come from the 'big feldspar divide' between the lower and upper compound units (Plate 2). They have $7.5 \%$ and $4 \%$ phenocrysts, respectively.

215459 is from a titano-tholeiite sequence at the bottom of the formation in profile 102.

The various chemical types are defined in Table 19.

tionally, it has been possible to divide this relatively thin formation into a number of units, as shown on Plate 2. The compositional groups except the nephelinite appear from fig. 72 .

In the eastern region the lowest lavas are a sequence of sparsely-porphyritic thin flows which morphologically form a grey, rubbly sequence, but which compositionally are titano-tholeiites. This unit is not present in the inland region.

The nephelinite tuff at the bottom of the formation east of Sydbræ (profile IV) is another separate unit. A tuff layer in the upper part of the formation in profile 117 contains a strongly alkaline component, but there is no connection between the two occurrences, these being $120 \mathrm{~km}$ apart and at different stratigraphic levels.
Being of local origin it is possible that more nephelinites exist and may be found in the future.

The lower compound unit is a rubbly sequence of grey, compound flows of olivine tholeiite. It is thickest in the inland region where it forms the lowest lavas of the formation, and it thins towards the coast where it overlies the lower titano-tholeiites with slight or no morphological contrast. The unit is absent in the easternmost region (Savoia Halvø and surroundings), which is dominated by titano-tholeiites.

The overlying 'big feldspar divide' of one or two massive, brown, strongly porphyritic lavas in the middle of the formation consists of high-Ti basalts and titanotholeiites, and a single flow is either not very widespread or strongly compositionally heterogeneous. 
Above the 'big feldspar divide' follows another rubbly sequence of grey, compound flows. This is divided into two units with strongly contrasting chemical compositions, the upper compound unit and the MORB type unit (Plate 2). The upper compound unit occurs both in the coastal and inland regions, but thins towards the west. The lavas form a distinct compositional group in fig. 72; because they have $\mathrm{Mg}$ ratios below 0.57 they classify strictly speaking as medium-high-Ti basalts. They have, however, higher $\mathrm{Mg}$ ratios than all other main basalts with similar $\mathrm{TiO}_{2}$ contents, and we consider that they are differentiated olivine tholeiites.

The MORB type unit is a sequence of a few grey, rubbly flows that form the top of the formation in three inland profiles (VII, 48 and 55). The lavas have rather variable differentiation states, with $\mathrm{Mg}$ ratios of 0.52 0.65 , and they all have markedly low contents of $\mathrm{TiO}_{2}$, $\mathrm{P}_{2} \mathrm{O}_{5}$ and alkalies (fig. 72).

Eruption sites. The various units of the Rømer Fjord Formation appear to have been erupted from different, widely spaced centres, with the major activity concentrated towards the Atlantic coast relative to the underlying formations.

At the bottom of the formation, the titano-tholeiites of the Kap Dalton - Rømer Fjord area are not found elsewhere and must have been erupted locally like the preceding ones in the Geikie Plateau Formation.

The nephelinite tuff at the bottom of the formation east of Sydbræ was formed by explosive activity from a local vent which has not been identified, but which must be situated within the confines of the $20 \mathrm{~km}^{2}$ ash layer.

The lower compound unit is thickest in the Vikingebugt area (profile 48) and is not present west of Sydbra. To the east it thins rapidly from Rømer Fjord towards Savoia Halvø where it is completely absent. It thus appears to have a shield-like form, and eruption sites are inferred to be in the Vikingebugt - Kap Dalton area.

Eruption sites for the 'big feldspar divide' are more unconfined and may be seattered over the region. The big feldspar basaits are thick and prominent on Savoia Halvø where they form the base of the formation, but it is not clear whether this indicates proximity to an eruption site or is an effect of ponding.

The upper compound unit is not present west of $\mathrm{Vi}$ kingebugt. Its maximum thickness is reached in the east Geikie Plateau - Rømer Fjord area where the eruption sites were probably located.

The MORB type unit is only found in three inland profiles (VII, 55 and 48 ) situated along a $100 \mathrm{~km}$ long NE-SW line parallel to the strike of the basalts. The small volumes of this basalt type are believed to have been erupted along this line, if not from the same site then at least from the same reservoir.

Boundaries. The base of the Rømer Fjord Formation marks a break in the magmatic activity in the region. A slight disconformity is marked by a sedimentary horizon of sandstone or siltstone of variable thickness. This is best developed in the Blosseville Kyst area where it may be up to $5 \mathrm{~m}$ thick and contain leaf imprints of a Cercidiphyllum-Metasequoia assemblage (W. Friedrich, personal communication, 1985). Actual erosion of the underlying Geikie Plateau Formation has not been seen, and if present can only have been slight. In the inland areas the sediment horizon is often absent, and the lavas of the Rømer Fjord Formation overlie directly those of the Geikie Plateau Formation.

The upper limit is marked by a change from the vesicular thin grey lavas to the thick, massive, redbrown weathering porphyritic flows of the Skrænterne Formation. Where the grey lavas are absent, as in profile 76 east of Magga Dan Gletscher, the brown feldspar-phyric lavas of the Rømer Fjord Formation may still be discerned from the formations above and below by their coarser grain size.

\section{Skrænterne Formation}

new formation

General. Lavas from this formation were described by Watt et al. (1972) whose 'upper grey series' in the present work is the lower part of the low-Ti unit in the middle of the formation. The formation was described by Watt \& Watt (1973) as markedly porphyritic, and by Watt et al. (1976) as an upper mainly porphyritic sequence. It was provisionally termed formation 5 by Watt \& Watt (1983), and Skrænterne Formation by Larsen \& Watt (1985) and Watt et al. (1986).

Name. From the mountain ridge Skrænterne that forms a series of nunataks on the Geikie Plateau.

Type profile. Profile 104 (Bartholin Bræ) (fig. 24).

Reference profiles. Profiles 44 (Skrænterne), 55 (upper Sydbræ), 77 (Gronau Nunatakker), 112 (Kap Dalton Valley) (fig. 24).

Analysed profiles (number of analyses): 44 (16), 48 (1), 55 (8), 74 (6), 76 (3), 77 (4), 104 (19), 106 (3), 111 (9), $112(25), 117$ (129, not included in diagrams). 


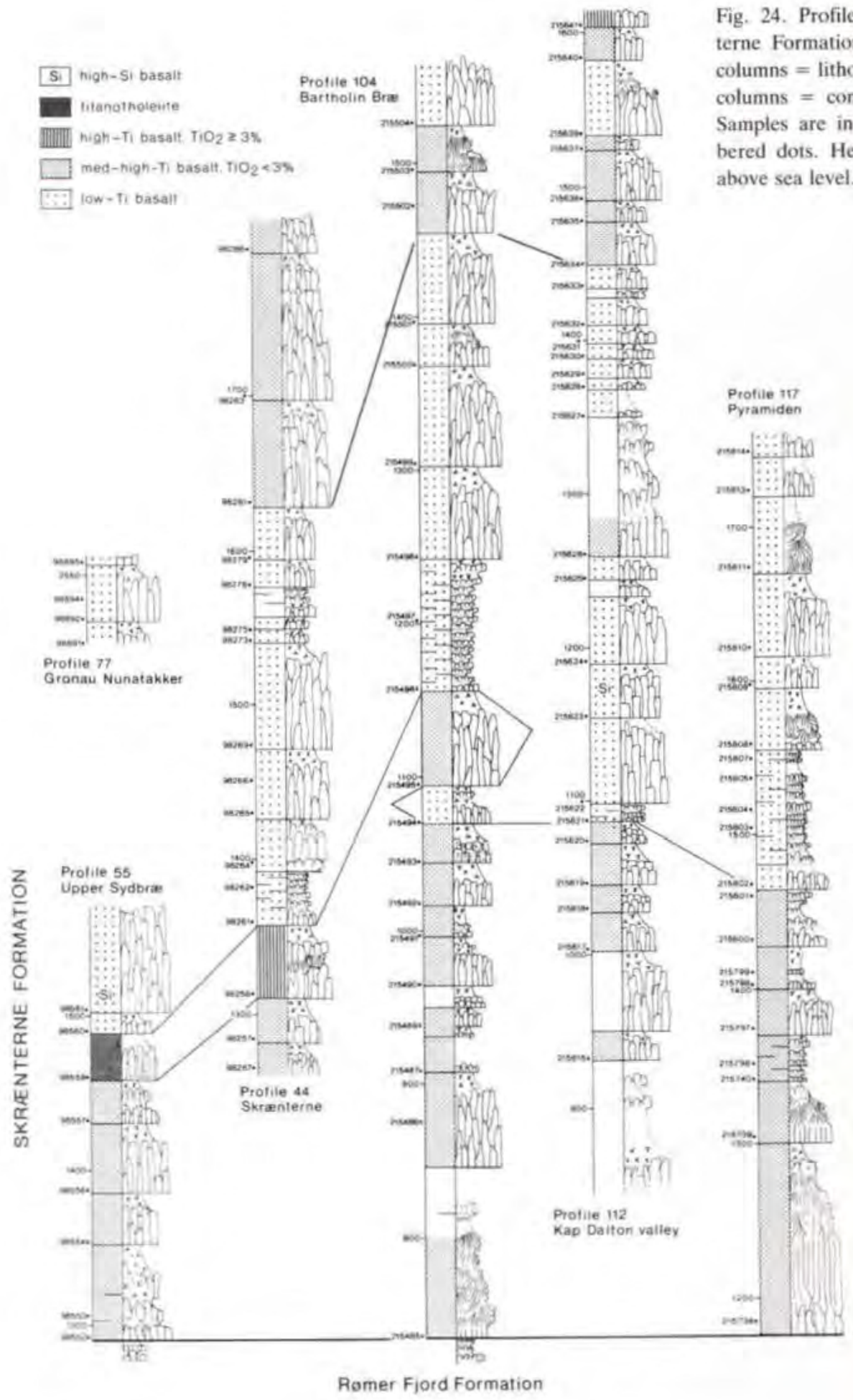

Distribution. The Skranterne Formation is present in the area between Gassefjord and Blosseville Kyst (fig. 25). Near Gasefjord it is only present on the highest tops (above $c .1500 \mathrm{~m}$ ). It is the basalts of this formation that crop out in the high nunataks on the Geikie Plateau and south of it (fig. 26). Along the Blosseville Kyst the Skrænterne Formation makes up a large proportion of the total lava mass, increasing towards the south as the 


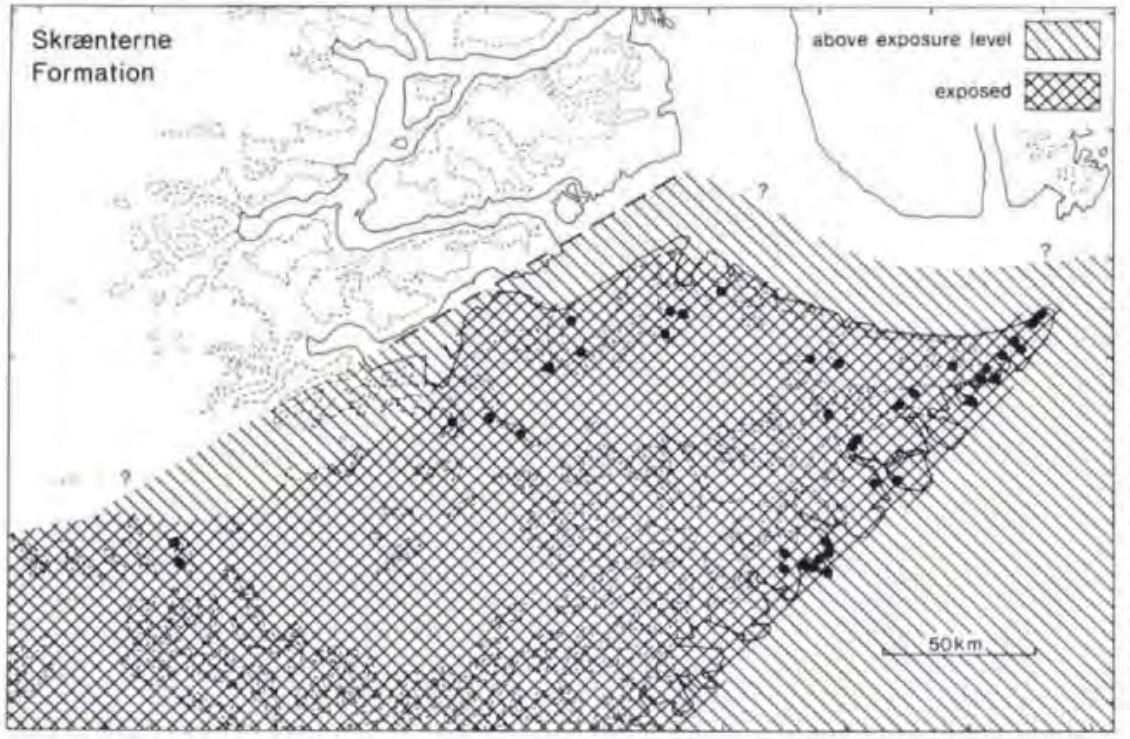

Fig. 25. Distribution of the Skrænterne Formation. Measured profiles are marked with dots. The broken line indicates the inferred original NW limit of the formation.

underlying formations drop in height. South of Barclay Bugt it is the only formation above sea level. Its southern limit is unconfined; aerial reconnaissance has shown that it extends well south of $69^{\circ} \mathrm{N}$. In the west Gronau Nunatakker certainly lie within the Skrænterne Formation. In the east we have inferred that the formation originally extended far beyond the present coast line (see below),

Thickness. In the area investigated the Skrænterne Formation reaches a maximum thickness of close to $1000 \mathrm{~m}$ in the Kap Dalton region. The general thickness in the coastal region is around $800 \mathrm{~m}$. The thickness decreases inland to around $500 \mathrm{~m}$ at Bredegletscher and to $100-$ $300 \mathrm{~m}$ in the Magga Dan Gletscher - Sydbræ area. An average thickness figure is $600 \mathrm{~m}$.

The upper boundary of the formation is the present level of erosion. The lava pile has been peneplaned after it was tilted, and the original thickness of the formation is greater than stated above. Based on the zeolite zonation the removed thickness is estimated to be $200-400 \mathrm{~m}$ (see section on zeolite zones).

The formation is subdivided into three units, and the decrease in thickness towards the inland areas is brought about by a decrease in thickness of the lower unit, and a decrease in the preserved number of flows in

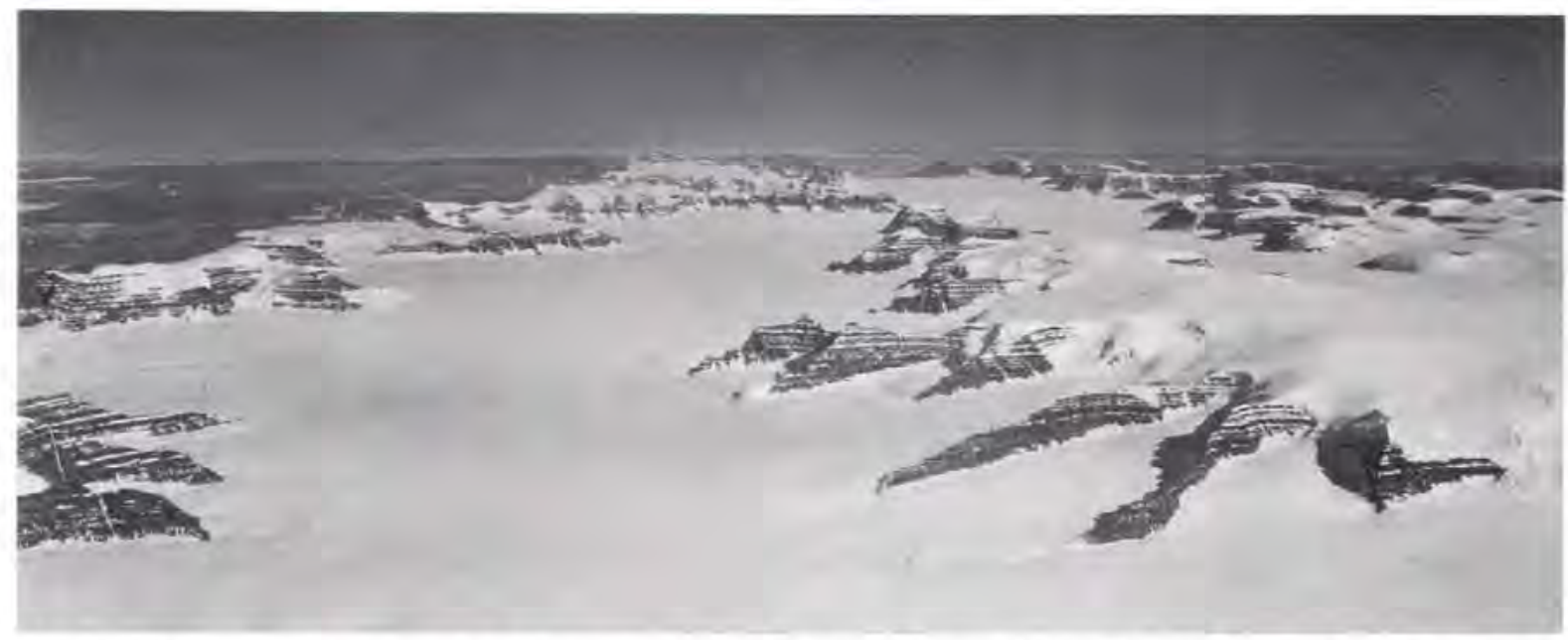

Fig. 26. The Skranterne Formation on the northern edge of the Geikie Plateau. Geodetic Institute route $660 \mathrm{E}-\varnothing$, no.12698A (A.200/87). 
Fig. 27. Typical appearance of the Skranterne Formation. South-facing wall, eastern Skranterne.

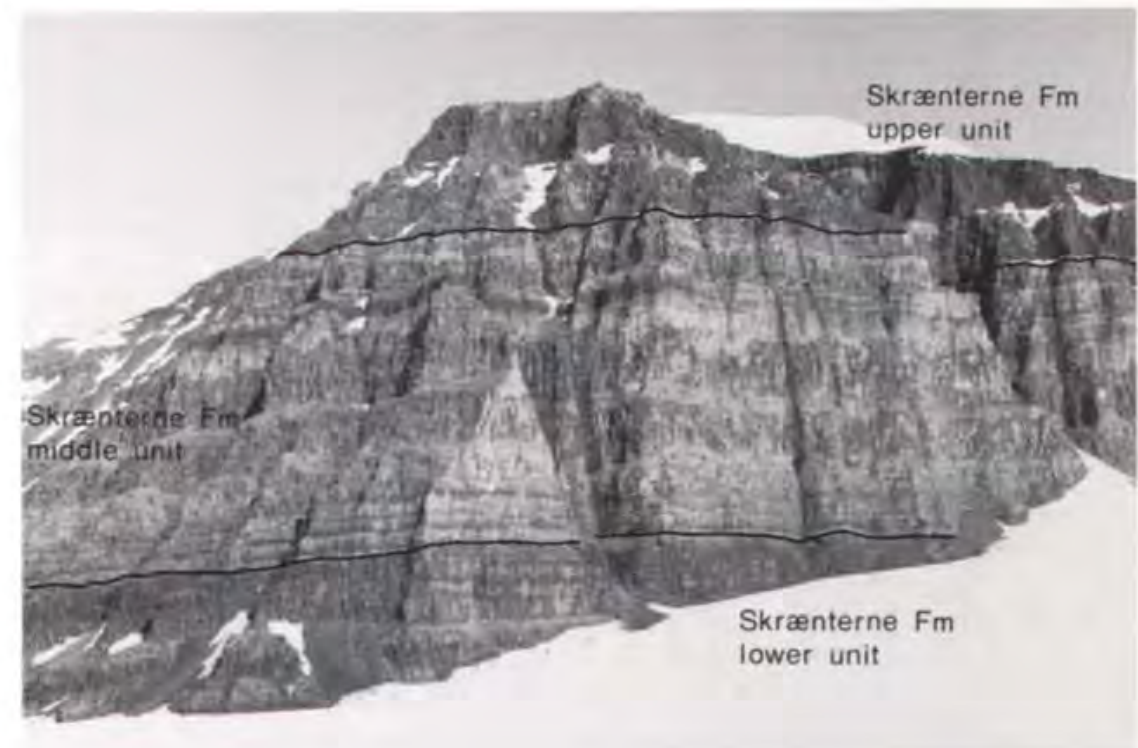

the two successive units. The upper unit only reaches 70 $\mathrm{km}$ inland from the coast (Plate 2) as opposed to the 150 $\mathrm{km}$ of the lower unit.

Lithology. The Skrænterne Formation consists of a very uniform sequence of massive red-brown weathering lava flows. The lower two thirds of each flow is normally made up of an irregular colonnade while the upper third is a grey or purple breccia zone (fig. 27). Thin red top zones are common. Individual flows average around 40 $\mathrm{m}$ in thickness, but $70-80 \mathrm{~m}$ thick flows are quite common, and flows up to $120 \mathrm{~m}$ thick occur (fig. 24) although some of these may be ponded.

At certain levels flows appear to have broken into groups of flow units, some of which show considerable lateral extent. There is no noticeable change in rock type. One of these sequences of compound flows occurs at the base of the middle unit as a grey sequence traceable over more than $2600 \mathrm{~km}^{2}$.

The basalts of the Skrænterne Formation are all porphyritic (fig. 28). Plagioclase phenocrysts form small compact clusters commonly $4-6 \mathrm{~mm}$ in diameter, and constitute $1-10 \%$ of the rock. Most flows also contain scattered 1-2 mm large pyroxene phenocrysts. The phenocryst size and frequency decrease gradually through the upper part of the formation.

Sedimentary horizons and hyaloclastites are rare within this formation.

Chemical compositions. The lavas of the Skrænterne Formation belong without exception to the four types of main basalt (Table 19).
In contrast to the lower formations there is no clear geochemical distinction between the medium-Ti and high-Ti basalts (fig. 72), so that in the Skrænterne Formation these two types are grouped together as medhigh-Ti basalts.

One or two high-Si basalt flows are just slightly modified low-Ti basalts. Apart from these, nearly all basalts of this formation are olivine normative; a trend towards Si-saturation is seen at the top of the formation (fig. 3).

Representative analyses are presented in Table 4.

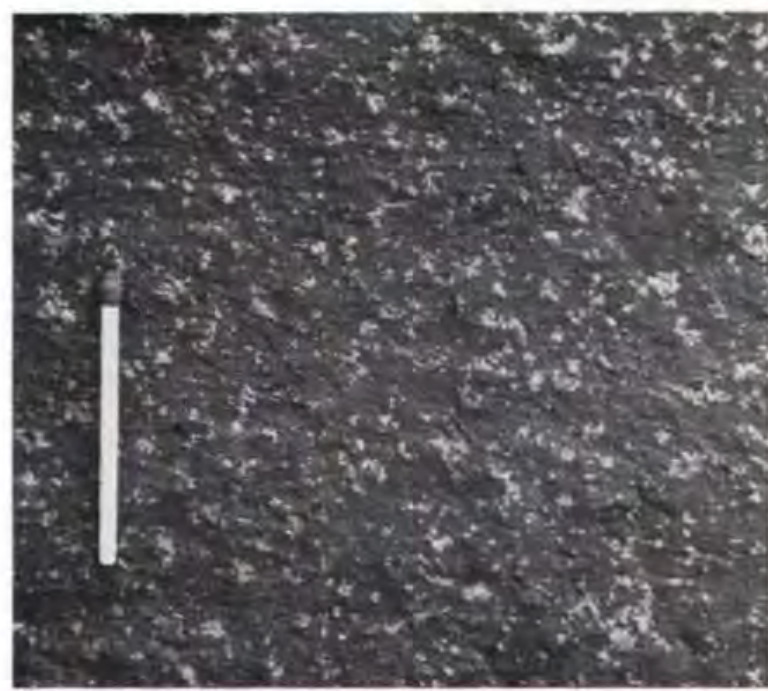

Fig. 28. Typical appearance of the rock face of the lavas of the Skranterne Formation showing the distribution of the feldspar phenocrysts. 
Table 4. Representative compositions of lavas from the Skranterne and Igtertiva Formations

\begin{tabular}{|c|c|c|c|c|c|c|c|c|c|}
\hline \multirow[b]{2}{*}{$\begin{array}{l}\text { Profile No. } \\
\text { GGU No. } \\
\text { Type }\end{array}$} & \multicolumn{7}{|c|}{ Skrænterne Formation } & \multicolumn{2}{|c|}{ Igtertivâ Fm } \\
\hline & $\begin{array}{c}112 \\
215633 \\
\text { low- } \mathrm{Ti}\end{array}$ & $\begin{array}{c}104 \\
215501 \\
\text { low-Ti }\end{array}$ & $\begin{array}{c}55 \\
98561 \\
\text { low-Ti } \\
\text { high-Si }\end{array}$ & $\begin{array}{c}104 \\
215495 \\
\text { med- } \\
\text { high-Ti }\end{array}$ & $\begin{array}{c}44 \\
98286 \\
\text { med- } \\
\text { high-Ti }\end{array}$ & $\begin{array}{c}111 \\
215605 \\
\text { med- } \\
\text { high-Ti }\end{array}$ & $\begin{array}{c}55 \\
98559 \\
\text { Ti-thol }\end{array}$ & $\begin{array}{c}94 \mathrm{a} \\
116382 \\
\text { low- } \mathrm{Ti}\end{array}$ & $\begin{array}{c}91 \\
116347 \\
\text { med- } \\
\text { high-Ti }\end{array}$ \\
\hline $\mathrm{SiO}_{2}$ & 48.89 & 49.28 & 51.50 & 48.82 & 49.34 & 48.76 & 47.68 & 49.72 & 49.12 \\
\hline $\mathrm{TiO}_{2}$ & 1.93 & 1.79 & 1.98 & 2.62 & 2.55 & 3.27 & 4.37 & 2.09 & 3.06 \\
\hline $\mathrm{Al}_{2} \mathrm{O}_{3}$ & 15.12 & 14.74 & 14.26 & 14.33 & 13.38 & 13.28 & 12.44 & 14.18 & 13.91 \\
\hline $\mathrm{Fe}_{2} \mathrm{O}_{3}$ & 1.64 & 1.67 & 1.50 & 1.69 & 1.89 & 1.86 & 2.10 & 1.66 & 1.88 \\
\hline $\mathrm{FeO}$ & 10.95 & 11.14 & 10.00 & 11.24 & 12.56 & 12.45 & 13.97 & 11.01 & 12.50 \\
\hline $\mathrm{MnO}$ & 0.15 & 0.19 & 0.18 & 0.18 & 0.24 & 0.17 & 0.22 & 0.20 & 0.23 \\
\hline $\mathrm{MgO}$ & 6.96 & 6.70 & 6.53 & 6.77 & 6.38 & 6.08 & 5.47 & 6.23 & 5.58 \\
\hline $\mathrm{CaO}$ & 11.92 & 11.80 & 10.94 & 11.45 & 10.60 & 10.99 & 9.98 & 11.75 & 10.32 \\
\hline $\mathrm{Na}_{2} \mathrm{O}$ & 2.10 & 2.30 & 2.50 & 2.00 & 2.47 & 2.46 & 2.70 & 2.53 & 2.73 \\
\hline $\mathrm{K}_{2} \mathrm{O}$ & 0.16 & 0.23 & 0.43 & 0.28 & 0.37 & 0.35 & 0.63 & 0.40 & 0.28 \\
\hline $\mathrm{P}_{2} \mathrm{O}_{5}$ & 0.17 & 0.15 & 0.17 & 0.23 & 0.23 & 0.32 & 0.44 & 0.23 & 0.38 \\
\hline $\mathrm{Mg}$ ratio & 0.531 & 0.517 & 0.539 & 0.518 & 0.475 & 0.465 & 0.412 & 0.503 & 0.444 \\
\hline $\mathrm{FeO}^{*}$ & 12.43 & 12.64 & 11.35 & 12.76 & 14.26 & 14.12 & 15.86 & 12.50 & 14.19 \\
\hline \multicolumn{10}{|l|}{ CIPW norm } \\
\hline Q & & & 1.93 & & & 0.11 & & & 0.32 \\
\hline or & 0.95 & 1.36 & 2.54 & 1.65 & 2.19 & 2.07 & 3.72 & 2.36 & 1.65 \\
\hline$a b$ & 17.77 & 19.46 & 21.16 & 20.31 & 20.90 & 20.82 & 22.85 & 21.41 & 23.10 \\
\hline an & 31.36 & 29.22 & 26.42 & 27.50 & 24.33 & 24.16 & 19.96 & 26.15 & 24.87 \\
\hline di & 22.00 & 23.44 & 22.03 & 22.92 & 22.22 & 23.45 & 22.24 & 25.36 & 19.85 \\
\hline hy & 19.18 & 16.97 & 19.59 & 16.53 & 21.36 & 19.74 & 16.68 & 15.27 & 20.78 \\
\hline ol & 2.30 & 3.37 & & 3.13 & 0.90 & & 2.18 & 2.54 & \\
\hline $\mathrm{mt}$ & 2.38 & 2.42 & 2.18 & 2.45 & 2.74 & 2.70 & 3.04 & 2.41 & 2.73 \\
\hline il & 3.67 & 3.40 & 3.76 & 4.98 & 4.84 & 6.21 & 8.30 & 3.97 & 5.81 \\
\hline ap & 0.39 & 0.35 & 0.39 & 0.53 & 0.53 & 0.74 & 1.02 & 0.53 & 0.88 \\
\hline
\end{tabular}

All analyses have had the oxidation ratio adjusted to $\mathrm{Fe}_{2} \mathrm{O}_{1} / \mathrm{FeO}=0.15$ and have been recalculated to $100 \%$ on a volatile-free basis. The original analyses are in appendix 2 and trace element analyses in appendix 3.

The lower, middle and upper units of the Skrænterne Formation are represented by samples 215495, 215633 and 215501 , and 98286 and 215605 , respectively.

The high-Si flow belongs to the middle unit, and the Ti-tholeiite flow occurs on top of the lower unit.

The various chemical types are defined in Table 19.

Subdivisions. The Skrænterne Formation has been divided into three units based on the $\mathrm{TiO}_{2}$-content of the lavas. The lateral distribution of these units appears from Plate 2 . The units are purely chemically defined and cannot be distinguished in the field. The analogy to the subdivisions in the Geikie Plateau Formation is evident from fig. 3 and Plate 2.

The lower unit consists of med-high-Ti basalts and one flow of titano-tholeiite. Immediately below this flow occurs a lava flow with high $\mathrm{Mg}$ ratio compared to the other flows in this unit, and a flow with this feature is present at the same stratigraphic level in all five analysed profiles. If this is one lava flow, it has covered an area of at least $2400 \mathrm{~km}^{2}$. The five analyses are indicated in fig. 72 .
The middle unit consists with a few exceptions of low-Ti basalt. Within this unit, profiles 55 and 74 both contain a very thick $(>70-100 \mathrm{~m})$ high-Si flow, obviously one and the same. Profile 112 contains a very similar flow at the same stratigraphic level (Plate 2), but due to the distance to this profile $(80-90 \mathrm{~km})$ and the absence of high-Si basalts in the intervening profiles 44 and 104, we cannot know whether this is the same or another flow.

The upper unit is a sequence of med-high-Ti basalts which compared to those in the lower sequence have generally lower $\mathrm{Mg}$ ratios and trend towards higher $\mathrm{TiO}_{2}$ contents in the upper parts (profile 111). The unit also contains 1-2 flows of typical low-Ti basalt. 
Eruption sites. No dykes which could have acted as feeders to the lavas of the Skrænterne Formation are known.

The lavas on the Geikie Plateau can be traced laterally over considerable distances $(50-80 \mathrm{~km})$. Flow edges are seen in some instances, and judging from these the lavas came from the south, south-east and south-west. Flows become thicker in the same directions.

It is possible that there were eruption sites on the Geikie Plateau and south of it, but there is little chance of ever finding any feeders. On the other hand the general thickening and contraction of the formation towards the Blosseville Kyst with time suggests activity centred there. We believe that the major eruptive activity took place south-east of the present coast line.

Boundaries. The Skrænterne Formation conformably overlies the Rømer Fjord Formation. The boundary is marked by a change in morphology from thin flow units to massive bench-forming flows, and by a change from nearly aphyric to highly porphyritic rocks.

The upper boundary is the present level of erosion except on Savoia Halvø where deeply eroded lavas of this formation are overlain by conglomerates of the Kap Dalton and Kap Brewster Formations. Erosion of the lava pile has thus taken place in at least three stages: locally in the early Tertiary, a general peneplanation after the tilting of the lava pile, and glacial erosion during the Quaternary.

\section{Igtertivâ Formation}

new formation

General. The lavas and sediments of this formation were first described by Soper \& Costa (1976) who identified dinoflagellate cysts in the sediments indicating a basal Ypresian age. The formation was provisionally named Igtertivâ Formation by Larsen \& Watt (1985) and Watt et al. (1986).

Name. Igtertivâ is the Greenlandic name for Kap Dalton.

Type profile. Profile 91 on the Kap Dalton peninsula (fig. 29).

Reference profile. Profile 94a on the Kap Dalton peninsula (fig. 29).

Analysed profiles (number of analyses): 91 (8), 94a (5).
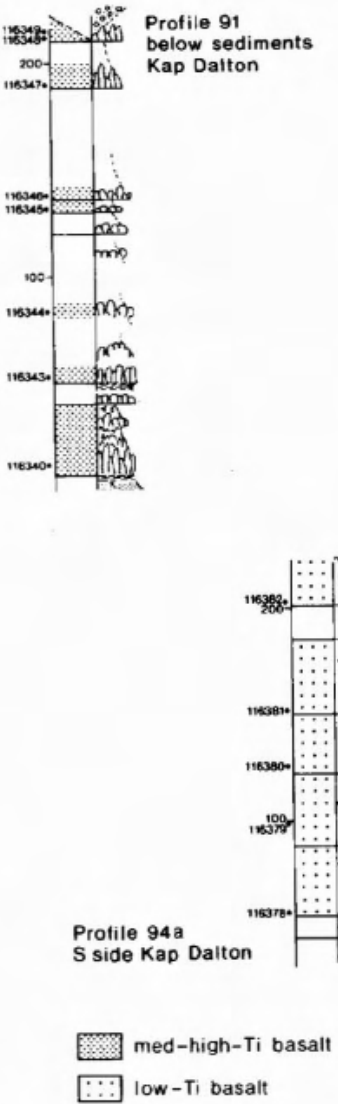

Fig. 29. Profiles of the Igtertivâ Formation. Right part of columns $=$ lithology, left part of columns $=$ compositional type. Samples are indicated by numbered dots. Heights are metres above sea level.

Distribution. Basalts of the Igtertivâ Formation are only known to be present in the small downfaulted area of the Kap Dalton peninsula (fig. 30). The formation may also be present at Kap Brewster, where a few downfaulted and tilted lava flows south-east of the main fault represent a very high stratigraphic level and perhaps belong to the Igtertivâ Formation. The chemical analyses (profile 129, appendix) are inconclusive.

The original distribution of the formation is unknown. Because the coastal dyke swarm fed the lavas of the formation it probably originally formed in a more or less continuous strip along the coast where now the dyke swarm occurs.

Thickness. The two measured profiles through the formation at Kap Dalton are each around $210 \mathrm{~m}$ long. Due to the faulting the two sequences are not correlatable in the field. Lithologically (compositionally) the lavas in the two profiles differ, and thus the two profiles repre- 


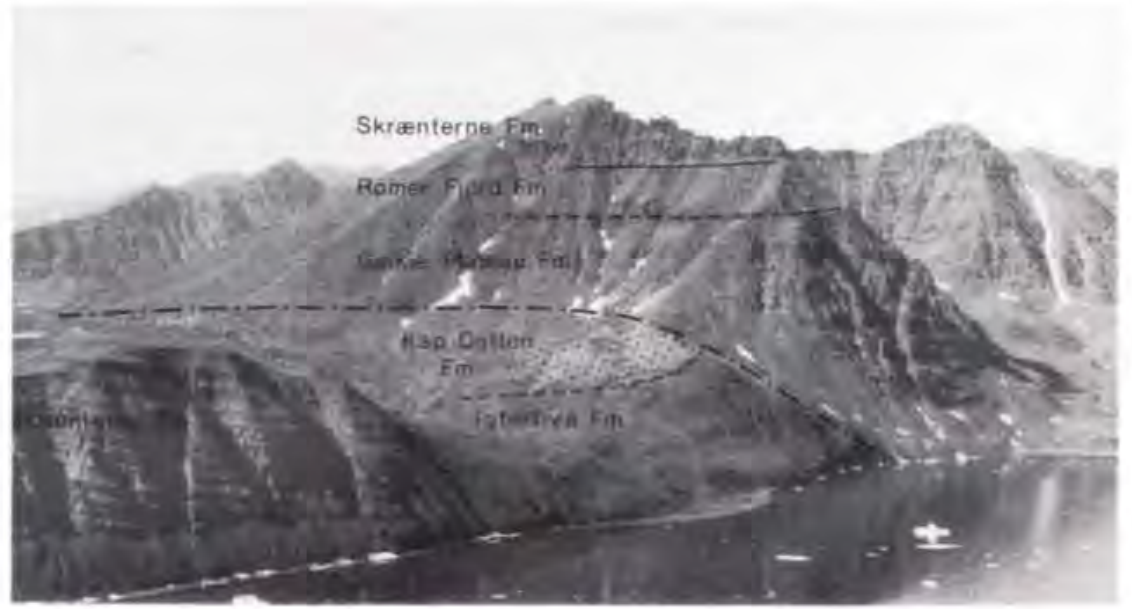

Fig. 30. Igtertivâ Formation basalts overlain by sediments of the Kap Dalton Formation preserved in the graben at Kap Dalton peninsula. A major fault separates lavas of the Geikie Plateau Formation from those of the Igtertivâ Formation, indicating a vertical displacement of more than $1500 \mathrm{~m}$.

sent different sections through the formation, which must be at least $420 \mathrm{~m}$ thick in the Kap Dalton area. The 3-4 lavas at Kap Brewster, which may belong to this formation, represent a thickness of $60-70 \mathrm{~m}$.

Lithology. The Igtertivâ Formation consists of relatively thin massive lava flows often interbedded with sediments. Due to extensive faulting in the area as well as the presence of crumbling interbasaltic sediment, exposures are poor compared with other formations. The average flow thickness does not exceed $20 \mathrm{~m}$ and may well be less, as many flow boundaries are concealed by scree.

In hand sample most basalts of the Igtertivâ Formation are aphyric or sparsely porphyritic with small plagioclase phenocrysts and sometimes also tiny pyroxene phenocrysts. When present, the plagioclase phenocrysts form small aggregates which rarely exceed $2 \mathrm{~mm}$ in diameter and normally make up less than $1 \%$ of the total rock. The general appearance of the plagioclase phenocrysts and the presence of the pyroxene phenocrysts show considerable similarity to the uppermost part of the Skrienterne Formation, where flow thicknesses decrease and the feldspar glomerophyres decrease in size and frequency. This may indicate that the lacuna between the two formations is not great.

At the bottom of profile 91 occurs a minimum $7 \mathrm{~m}$ thick layer of lapilli tuff from a strombolian-type (i.e. moderately explosive) eruption. The size of the lapilli indicates an eruption site within $10 \mathrm{~km}$ (K. A. Jørgensen. personal communication).

The interbasaltic sediments are shales and partly volcanogenic sandstones and siltstones. Thin coal-rich layers also occur. Soper \& Costa (1976) found marine microplankton in one shale layer. Most sediment samples contain only terrestrial fossils, and the massive basalts appear to be subaerial although red flow tops are absent. Occasional pillow structures do point to the presence of water. The environment during the deposition of the Igtertivâ Formation is thus indicated as terrestrial to shallow aqueous, sometimes marine.

Chemical compositions. The analytical coverage of the Igtertivâ Formation is limited because it is of such restricted occurrence. It is therefore not known whether the existing analyses cover the whole compositional spectrum originally present - the two analysed profiles are indeed quite different, the lavas from profile 91 and $94 \mathrm{a}$ having $\mathrm{Mg}$ ratios below and above 0.50 respectively (fig. 72). The characterisation of this formation is thus necessarily vague. All analysed rocks are main basalts of low-Ti, med-Ti and high-Ti type (Table 19). There are no clear compositional sub-groups (fig. 72), but since profile 91 is stratigraphically higher than profile $94 \mathrm{a}$, the difference between the two profiles may express an upwards evolution towards more differentiated compositions.

The Igtertiva Formation apparently includes differentiated alkaline (hawaiitic) components, as read from the chemical composition of crystals in a (completely hydrated) tuff layer; see chapter on mineralogy.

Representative analyses are given in Table 4.

Eruption sites. The coastal dyke swarm cuts through the Skranterne Formation, but was not observed cutting the Igtertivâ Formation. Geochemically the dykes are similar to the lavas of the Igtertivã Formation (see lat$\mathrm{er}$ ), and we therefore infer that these lavas were fed by the coastal dykes. The confinement of the source for the ash layer in profile 91 to within $10 \mathrm{~km}$ from Kap Dalton is in accordance with this. 
Boundaries. The lower boundary of the formation has not been established due to the faulting in the area. The upper boundary is marked by a conglomerate bed at the base of the overlying Eocene Kap Dalton Formation of marine sediments.

\section{Kap Dalton Formation}

The sediments overlying the basalts in the Kap Dalton area were named the Kap Dalton Series by Wager (1935). Hassan (1953) described similar sediments overlying the basalts in the Kap Brewster area. The sediments were renamed the Kap Dalton Formation by Birkenmajer (1972). Their biostratigraphical age is the $W$. varielongituda zone of the Ypresian (Soper et al., 1976). The sediments overlie the basalts unconformably and basal conglomerates are well developed.

In the Kap Dalton area the basal conglomerate is $2 \mathrm{~m}$ thick and consists of well rounded pebbles of igneous rocks. These were described by Wager (1935) and are particularly interesting because they consist of alkaline igneous rocks of a variety of types: malignite, tinguaite, monchiquite, kersantite, soda-trachyte, trachy-andesite, trachy-basalt, leucite-nephelinite and nephelineleucitite are the names given by Wager. The occurrence of this strongly alkaline pebble association so completely detached from the alkaline rocks in the surrounding areas (Kangerdlugssuaq. Găseland, northern Jameson Land) suggests that a late phase of alkaline activity may indeed have been very extensive,

In the Savoia Halvø area the basal conglomerate overlies deeply weathered basalt. Locally, erosion has cut deep into the underlying Skranterne Formation, so that all of this formation except one lava flow is removed in profile 121 (Kamelryggen). In this place the basal conglomerate is $50 \mathrm{~m}$ thick, stratified (fig, 31) and with pebbles of feldspar-phyric basalts similar to those in the Skranterne Formation. A few pebbles of apparent Rømer Fjord Formation basalt suggest that erosion may have gone even deeper (Watt \& Watt, 1983). Eight kilometres further east on Savoia Halvø the basal conglomerate is $2 \mathrm{~m}$ thick and overlies lavas of the uppermost Skrænterne Formation, showing that the deep erosion has been local.

\section{Kap Brewster Formation}

Sediments of probably Miocene age overlie the basalts at one small locality in the Kap Brewster area. They were named the Kap Brewster series by Hassan (1953) and Kap Brewster Formation by Birkenmajer (1972). They consist of breccia, conglomerate and sandstone of dominantly basaltic material, and are older than some of the faulting in the area.

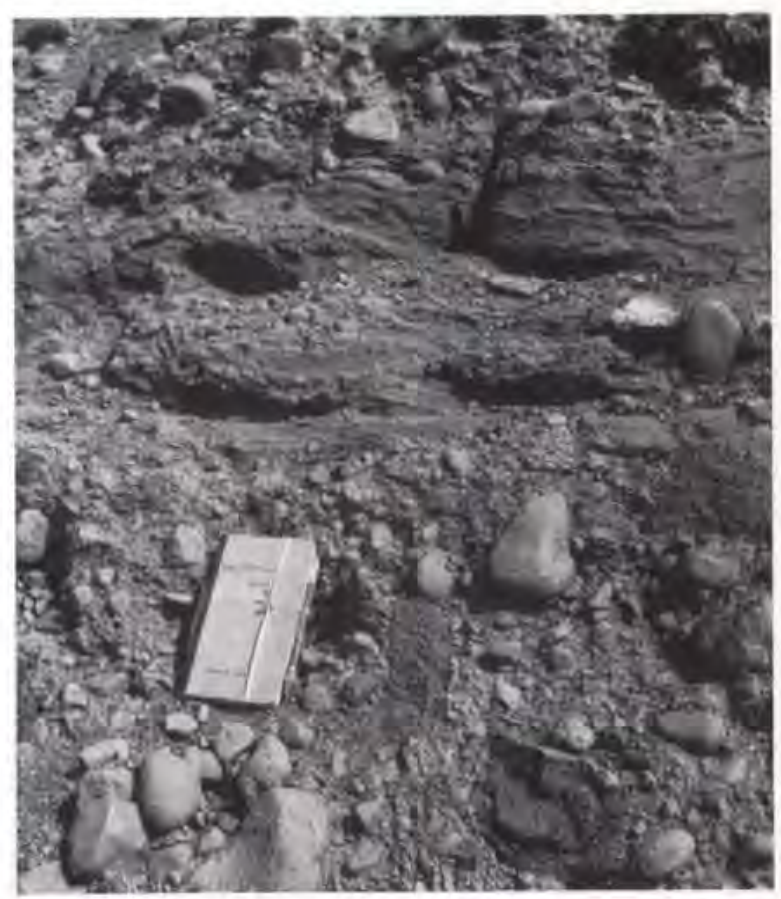

Fig. 31. Kap Dalton Formation conglomerate at Savoia Halvø. The pebbles are entirely of basalt fragments, some characteristic of the Rømer Fjord and Skrænterne Formations.

\section{Dykes}

A simplified compilation of observed dykes is shown in fig. 32. Many observations were made by aerial reconnaissance, and there are only a limited number of ground observations and samples. The dykes come in two natural groups, respectively dykes from the 'inland' regions and dykes from the swarm along the Blosseville Kyst.

\section{Inland dykes (46 analyses)}

Inland dykes $0.5-10 \mathrm{~m}$ wide occur in a broad, loose 'swarm' on Milne Land and Jameson Land, Găseland, and south of Gåsefjord and inner Scoresby Sund. They cut through basement and Mesozoic sediments, and through the basalt formations present, mostly Magga Dan, Milne Land and lower Geikie Plateau Formations. They become less frequent with height in the Geikie Plateau Formation, but no case of a dyke feeding a lava has been observed. Both tholeitic and alkaline dykes are found. Representative analyses are given in Table 5 .

The directions of the tholeiitic dykes are rather variable, but there is a general tendency that in the west, around Vindblæsdal, the dykes trend mostly NE, then swing towards east on Gáseland and Milne Land, and 


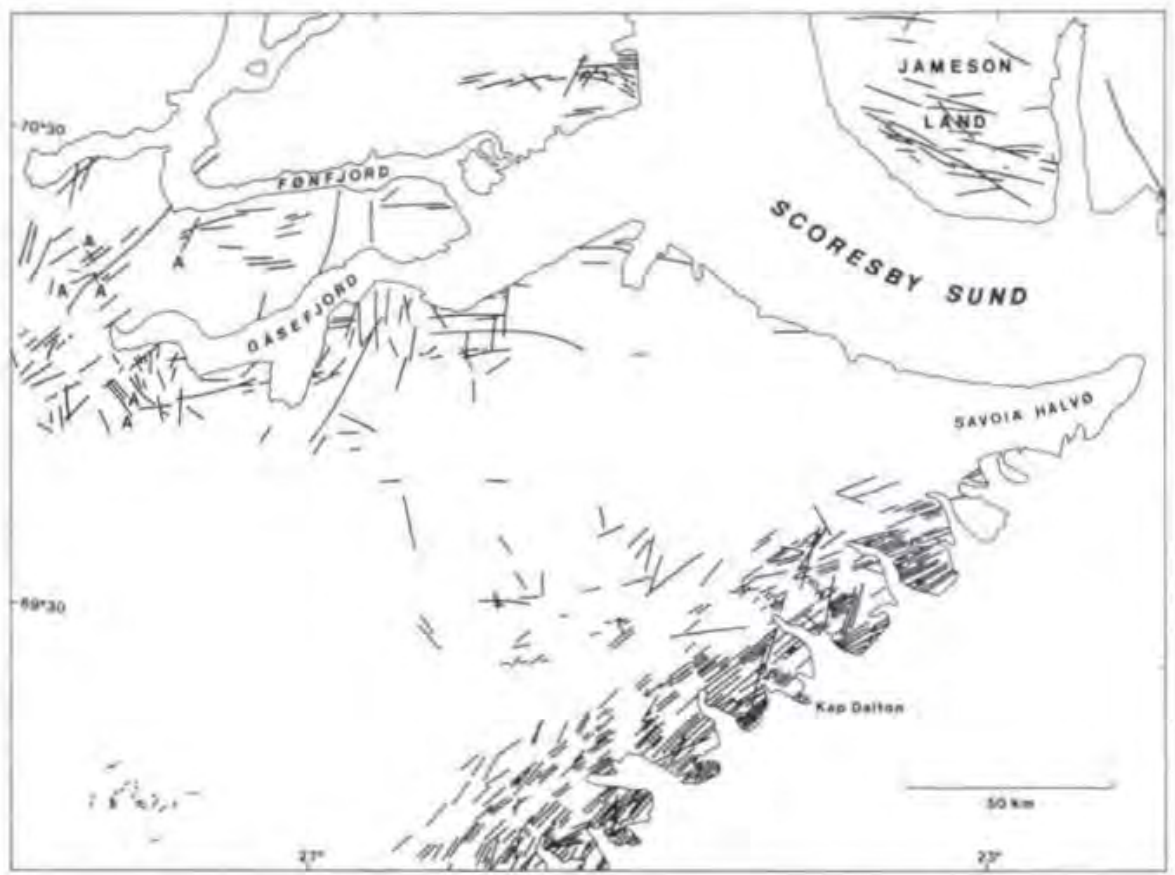

Fig. 32. Tertiary dyke distribution in the Scoresby Sund region. Outside the basalt area the dykes are taken from published 1:100 000 maps. A $=$ alkaline dykes.

swing further towards ESE in the east in Jameson Land (fig. 32). South of Gåsefjord several directions are present, but cross-cutting relations are few. A $160^{\circ}$ trending generation is a late feature. The youngest dykes appear to be two east trending titano-tholeite dykes of which one can be followed over nearly $50 \mathrm{~km}$ into the Geikie Plateau, cutting the Rømer Fjord Formation.

The tholeiitic dykes belong to the main basalt types (Table 19). They are either feeders to some of the known lava successions or they represent a magmatic activity that is younger than any of these. While we cannot dismiss the last possibility completely, we believe that the majority of these dykes are Geikie Plateau Formation feeders. Their composition is very similar to that of the Geikic Plateau Formation lavas in Milne Land and Gàseland (cf. figs 72 and 73).

The three samples of titano-tholeiite dykes are very similar and two $(98609,98679)$ probably derive from one long dyke. They have a transitional alkaline character like some of the titano-tholeiites from the Rømer Fjord Formation. The dykes could perhaps be feeders to lavas from this formation, but they are more extreme in composition than any of the known titano-tholeiites from the Rømer Fjord Formation. Moreover, a dyke with similar extreme composition (215638, see below) occurs among the coastal dykes and cuts the upper unit of the Skranterne Formation. These dykes are very much akin to a generation of ferro-tholeiitic dykes on Disko, West Greenland, where they represent the youngest recorded magmatic episode (Pedersen, 1977).
We believe that the titano-tholeiite dykes in Scoresby Sund represent a similar later episode.

A few alkaline dykes cut basement and lavas up to lower Geikie Plateau Formation level and are upwards unconstrained in age. They may be contemporary with the nephelinite tuff of the Rømer Fjord Formation, or they may be younger than all the basalts in the area and represent a late alkaline phase similar to the lavas overlying the plateau basalts in the Kangerdlugssuaq region (Prinsen af Wales Bjerge, Anwar, 1955). Chemically. they are alkali basalts, alkali trachyte, and strongly undersaturated nephelinitic types (alnöite and monchiquite) very similar to the nephelinitic lavas from the nunataks at $74^{\circ} \mathrm{N}$ (Brooks et al. 1979) and to the lavas at Prinsen af Wales Bjerge (Anwar, 1955).

The three alkali basaltic dykes known all occur in western Gãseland and have the same NE trend as the tholeiitic dykes in the area. Two alnöites in western Gaseland and two monchiquites and one alkali trachyte from south of Gåsefjord all have SE trends of $122-133^{\circ}$, perpendicular to the tholeiites, and appear situated in one continuous $\mathrm{SE}$ trending zone of $50 \mathrm{~km}$ length, running through Vindblasdal and the bottom of Gasefjord.

In the area between the inland and coastal areas dykes are sparse and appear in several directions. Dykes trending $160^{\circ}$ are also here late.

\section{Coastal dykes (50 analyses)}

A marked feature of the coastal region along the 
Table 5. Representative compositions of dykes

\begin{tabular}{|c|c|c|c|c|c|c|c|c|c|}
\hline \multirow{2}{*}{$\begin{array}{l}\text { Region } \\
\text { GGU No. } \\
\text { Type }\end{array}$} & \multicolumn{4}{|c|}{ Inland dykes } & \multicolumn{5}{|c|}{ Coastal dykes } \\
\hline & $\begin{array}{l}96930 \\
\text { low- } \mathrm{Ti}\end{array}$ & $\begin{array}{l}96812 \\
\text { med-Ti }\end{array}$ & $\begin{array}{l}167115 \\
\text { high- } \mathrm{Ti}\end{array}$ & $\begin{array}{l}98890 \\
\text { Ti-thol }\end{array}$ & $\begin{array}{l}167106 \\
\text { alkali } \\
\text { basalt }\end{array}$ & $\begin{array}{l}215507 \\
\text { low-Ti }\end{array}$ & $\begin{array}{l}215535 \\
\text { med- } \\
\text { high-Ti }\end{array}$ & $\begin{array}{c}98341 \\
\text { med- } \\
\text { high-Ti }\end{array}$ & $\begin{array}{c}215577 \\
\text { alkali-rich } \\
\text { basalt }\end{array}$ \\
\hline $\mathrm{SiO}_{2}$ & 49.15 & 49.12 & 48.93 & 47.75 & 45.18 & 49.09 & 49.24 & 49.84 & 50.21 \\
\hline $\mathrm{TiO}_{2}$ & 2.12 & 2.31 & 2.97 & 4.51 & 5.15 & 1.76 & 3.05 & 2.66 & 2.44 \\
\hline $\mathrm{Al}_{2} \mathrm{O}_{3}$ & 14.07 & 14.10 & 13.56 & 12.35 & 14.37 & 14.74 & 12.98 & 13.44 & 13.23 \\
\hline $\mathrm{Fe}_{2} \mathrm{O}_{3}$ & 1.62 & 1.64 & 1.80 & 2.08 & 1.85 & 1.57 & 1.93 & 1.96 & 1.84 \\
\hline $\mathrm{FeO}$ & 10.83 & 10.99 & 12.01 & 13.87 & 12.29 & 10.48 & 12.91 & 13.03 & 12.26 \\
\hline $\mathrm{MnO}$ & 0.19 & 0.19 & 0.20 & 0.25 & 0.19 & 0.21 & 0.23 & 0.20 & 0.22 \\
\hline $\mathrm{MgO}$ & 7.17 & 6.96 & 6.36 & 5.61 & 5.58 & 7.10 & 5.51 & 4.86 & 5.69 \\
\hline $\mathrm{CaO}$ & 12.05 & 11.96 & 11.09 & 9.86 & 10.30 & 12.38 & 10.47 & 10.41 & 9.53 \\
\hline $\mathrm{Na}_{2} \mathrm{O}$ & 2.35 & 2.29 & 2.41 & 2.41 & 3.38 & 2.26 & 2.74 & 2.79 & 3.75 \\
\hline $\mathrm{K}_{2} \mathrm{O}$ & 0.28 & 0.22 & 0.38 & 0.79 & 0.75 & 0.26 & 0.59 & 0.50 & 0.57 \\
\hline $\mathrm{P}_{2} \mathrm{O}_{5}$ & 0.18 & 0.22 & 0.28 & 0.52 & 0.96 & 0.17 & 0.35 & 0.32 & 0.26 \\
\hline $\mathrm{Mg}$ ratio & 0.514 & 0.530 & 0.486 & 0.419 & 0.448 & 0.547 & 0.433 & 0.400 & 0.453 \\
\hline $\mathrm{FeO}^{*}$ & 12.29 & 12.47 & 13.63 & 15.74 & 13.96 & 11.89 & 14.65 & 14.79 & 13.92 \\
\hline \multicolumn{10}{|c|}{ CIPW norm } \\
\hline $\mathrm{Q}$ & & & & 0.44 & & & & 0.53 & \\
\hline or & 1.65 & 1.30 & 2.25 & 4.67 & 4.43 & 1.54 & 3.49 & 2.95 & 3.37 \\
\hline$a b$ & 19.88 & 19.38 & 20.39 & 20.39 & 25.72 & 19.12 & 23.18 & 23.60 & 31.73 \\
\hline an & 27.01 & 27.54 & 25.06 & 20.55 & 21.82 & 29.30 & 21.37 & 22.67 & 17.58 \\
\hline ne & & & & & 1.56 & & & & \\
\hline di & 26.00 & 25.01 & 23.28 & 20.79 & 18.98 & 25.53 & 23.59 & 22.55 & 23.32 \\
\hline hy & 13.74 & 17.10 & 19.49 & 20.38 & & 12.95 & 17.59 & 19.06 & 5.22 \\
\hline ol & 4.91 & 2.39 & 0.62 & & 12.80 & 5.56 & 1.37 & & 10.87 \\
\hline $\mathrm{mt}$ & 2.35 & 2.38 & 2.61 & 3.02 & 2.68 & 2.28 & 2.80 & 2.84 & 2.67 \\
\hline il & 4.03 & 4.39 & 5.64 & 8.57 & 9.78 & 3.34 & 5.79 & 5.05 & 4.63 \\
\hline ap & 0.42 & 0.51 & 0.65 & 1.20 & 2.22 & 0.39 & 0.81 & 0.74 & 0.60 \\
\hline
\end{tabular}

All analyses have had the oxidation ratio adjusted to $\mathrm{Fe}_{2} \mathrm{O}_{3} / \mathrm{FeO}=0.15$ and have been recalculated to $100 \%$ on a volatile-free basis. The original analyses are in appendix 2 and trace element analyses in appendix 3 .

Note the difference between the Ti-rich Si-undersaturated alkali basalt 167106 from Gasseland and the alkali-rich hypersthene normative basalt 215577 from the Blosseville Kyst.

98890: $\mathrm{MnO}$ was not analysed in this sample. The value given here is estimated by comparison with a similar dyke (215638).

The various chemical types are defined in Table 19.

Blosseville Kyst is the swarm of dykes parallel to the coast up to $30 \mathrm{~km}$ inland. The coastal dykes have been largely investigated from aerial reconnaissance (Watt, 1975), and to the south of Kap Dalton there are no ground observations. While many individual dykes may be overlooked and their detailed directions inaccurate, the general representation of the swarm in fig. 32 should be correct.

The orientation and width of the coastal dyke swarm varies from south to north. At Søkongen Bugt $\left(68^{\circ} \mathrm{N}\right)$ the swarm is narrow, but north thereof it rapidly widens so that at $69^{\circ} \mathrm{N}$ it has attained its full width of $30 \mathrm{~km}$ (fig. 32 ). The swarm is weakly arcuate, trending $30^{\circ}$ in the south, $40^{\circ}$ in the middle between Barclay Bugt and Kap
Dalton, and $60-65^{\circ}$ in Henry Land and Turner $\emptyset$, so that north-east of Turner $\emptyset$ the swarm swings out to sea. Manby Halvø is so badly exposed that any possible dykes are covered by drift. At Steward $\emptyset$ and Savoia Halvø there are no dykes.

The dykes are generally $5-25 \mathrm{~m}$ wide, and individual dykes are only continuous over a few kilometres. In addition to the swarm that closely follows the coast smaller dyke groups and single dykes have other trends. In the southern part of the area there are dykes trending $150-170^{\circ}$ and $90^{\circ}$, the latter being cut by the first. At one locality at Bartholin Bræ a $90^{\circ}$ dyke of approximately $30 \mathrm{~m}$ thickness at glacier level appears to thin and die out upwards. Two dykes on Henry Land have an 


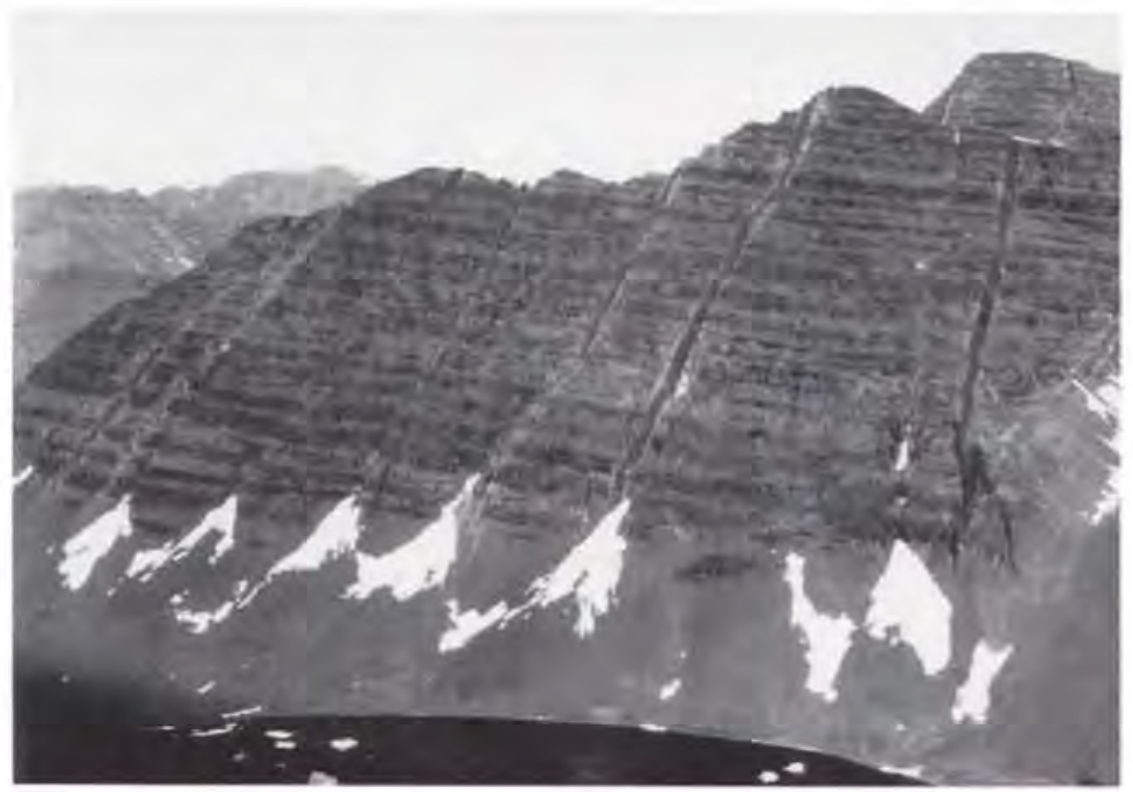

Fig. 33. Coast parallel dykes cutting the Skræenterne Formation on the Blosseville Kyst. North side of d'Aunay Bugt $\left(69^{\circ} \mathrm{N}\right.$. $\left.25^{\circ} 30^{\prime} \mathrm{W}\right)$. orientation of $120^{\circ}$, a direction not otherwise recognised on that part of the coast. These dykes could mark the edges of the tilted blocks associated with the block faulting in the area.

The dyke 'density' reaches a maximum of $15-20 \%$ at the outer coast between Kap Barclay and Henry Land. Inland from the coast the dyke 'density' decreases slowly, and at Bartholin Bræ there is about one dyke per kilometre $(\leq 1 \%)$.

The dykes cut all the basalt formations except the youngest (Igtertivã Formation). The majority of the dykes were intruded perpendicular to the lava flows, and where blocks have been tilted due to faulting the dykes are with few exceptions also tilted (fig. 33). The main swarm is thus older than the block faulting. The time difference between dyking and faulting is probably small, because the fault scarps in the area are largely parallel to the dyke swarm (Watt, 1975), so that the same tensional stress system appears responsible for both dyking and faulting. Occasional single dykes and groups of dykes around Barclay Bugt and d'Aunay Bugt have dips differing from those of the main group by $15^{\circ}$.
The coastal dykes are tholeitic basalts of the main basalt types with no clear division into sub-groups (Table 5). A few dykes are of mildly alkaline character (fig. 73). They may not all be contemporaneous, but we regard the major part of them as feeders for the Igtertivâ Formation. Various geochemical features of the two groups are identical, primarily the $\mathrm{TiO}_{2} / \mathrm{P}_{2} \mathrm{O}_{5}$ ratios which are different from all other basalt formations and dykes (cf. fig. 79), and the occasional occurrence in both groups of a mildly alkaline, differentiated (hawaiitic) component. Dykes with very low $\mathrm{TiO}_{2}$ contents (1.5-1.9\%) have no counterparts in the Igtertivâ Formation, but that may be due to our scant knowledge of this formation.

One titano-tholeiite dyke (215638) from the upper Skrænterne Formation level has a $\mathrm{TiO}_{2} / \mathrm{P}_{2} \mathrm{O}_{5}$ ratio similar to the main lavas and inland dykes. This dyke is compositionally almost as extreme (high $\mathrm{TiO}_{2}$ and $\mathrm{FeO}$, low $\mathrm{MgO}$ ) as the late titano-tholeiite dykes from the inland area (see above) and probably belongs to this association. 


\section{General features}

\section{Tectonics}

The general structure of the region south of Scoresby Sund appears from Plate 1. Over the greater part of the area west of an approximately $30 \mathrm{~km}$ wide coastal strip the basalts are essentially flat-lying and unfaulted with a weak regional dip $1 / 2-1^{\circ} \mathrm{SE}$. In contrast along the Atlantic coast there is a $10-30 \mathrm{~km}$ wide zone of block faulting extending from Kap Brewster in the NE to Kap Dalton in the SW. The tectonic pattern here is very different from that of the coastal zone further south towards Kangerdlugssuaq, where Wager \& Deer (1938) described a gradual coastal flexure. This was later reinterpreted as a system of antithetic faults (Nielsen \& Brooks, 1981).

\section{Inland region}

Within the largely undisturbed inland area sections across Gãsefjord (Plate 1, sections 4 \& 5) show that a NE-SW trending fault appears to be situated in outer Gassefjord with downthrows to the SE of $200-400 \mathrm{~m}$. This could be a southerly continuation or offshoot of the main boundary fault between the gneiss highland and the sedimentary basin that runs through eastern Milne Land in a SSW direction (cf. Geological map of Greenland 1:100 000, Kap Leslie). An extension of the fault may continue into inner Gåsefjord, but as shown in section 6 there is no discernable vertical displacement. However, there is a slight difference in dip of the basalt flows on the two sides of the fjord. If the interpretation of the fault along Gasefjord is correct it indicates that there must have been at least minor movement along the boundary fault also in Tertiary time. There is no sign of a more direct SSW continuation of the boundary fault south of Scoresby Sund with the possible exception of a weakness zone along the major glacier of Sydbræ with no discernable displacement.

\section{Coastal zone}

In the coastal region between Kap Brewster and Kap Dalton an up to $40 \mathrm{~km}$ wide zone of faulting extends along the Atlantic coast with a general trend of $40^{\circ}$. In a zone close to the unfaulted inland area the downthrows are small and the inclination of the basalts almost unaltered. In an intermediate zone, starting approximately at the heads of the fjords, the basalts generally dip inland up to $10^{\circ}$ and may be broken up into smaller blocks. In the outermost zone the basalts are tilted seawards up to $50^{\circ}$ in a series of block faults which tend to follow an en echelon pattern sidestepping to the SE.

The fault planes are normally at right angles to the lava flows as are the dykes. The faulting seems to reach a maximum magnitude in the Kap Dalton and the Kap Brewster areas. These two areas, important to the understanding of both structure and stratigraphy, are discussed separately below. Only in these two areas is the main fault exposed, which caused the foundering of the interjacent coastal region. The two areas are also the keys to the interpretation of the stratigraphic relationship between the lavas and the overlying sediments which form a termination of the volcanic activity in the region.

As indicated above the tectonic pattern changes markedly south of Kap Dalton where the coastal zone has the appearance of a steadily dipping mass.

Kap Dalton area. At Kap Dalton the main fault is exposed 5-7 km west of the point of the peninsula where it forms a marked easterly facing escarpment. It can be followed north-eastwards across the promontory to the north of the Kap Dalton peninsula, trending approx. $40^{\circ}$. Apart from local fault drag (fig. 34 ) causing upturning of the adjacent lavas to dips of up to $40^{\circ}$, the succession to the west of the main fault is almost flatlying with a north-westerly dip of $3^{\circ}$ (fig. 30). To the east of the main fault lavas of the Igtertivâ Formation are downthrown in a $3-5 \mathrm{~km}$ wide graben to the level of the upper part of the Geikie Plateau Formation indicating a displacement in excess of $1500 \mathrm{~m}$. The lavas in the graben show a north-westerly dip of $5-10^{\circ}$, steepest in the south-eastern area, and are further broken into smaller blocks after the deposition of the overlying sediments. The graben is bounded towards the SE by a fault through the peninsula $2 \mathrm{~km}$ from the point, with downthrows to the NW. The lavas on the outer part of the peninsula, flanking the graben, have north-westerly dips of $15-20^{\circ}$ and belong to the upper unit of the Skrænterne Formation (profile 11, Plate 2). The relative downthrow of the graben at the SE boundary fault may thus only be a few hundred metres, but the bounding block to the SE is itself downfaulted around $1400 \mathrm{~m}$ relative to the mainland.

The faults on both sides of the graben are accompanied by crush zones up to $500 \mathrm{~m}$ in width with carbonate mineralisation along the fault planes.

Swarms of dykes cut the lavas on both sides of the graben, but are conspicuously absent from the graben itself. With an approximate trend of $70^{\circ}$ a number of 
Fig. 34. Drag fold in the graben 8 $\mathrm{km}$ to the north of Kap Dalton, looking south. In the left background is seen the central graben with lavas of the Igtertivâ Formation overlain by sediments of the Kap Dalton Formation (cf. fig. 30).

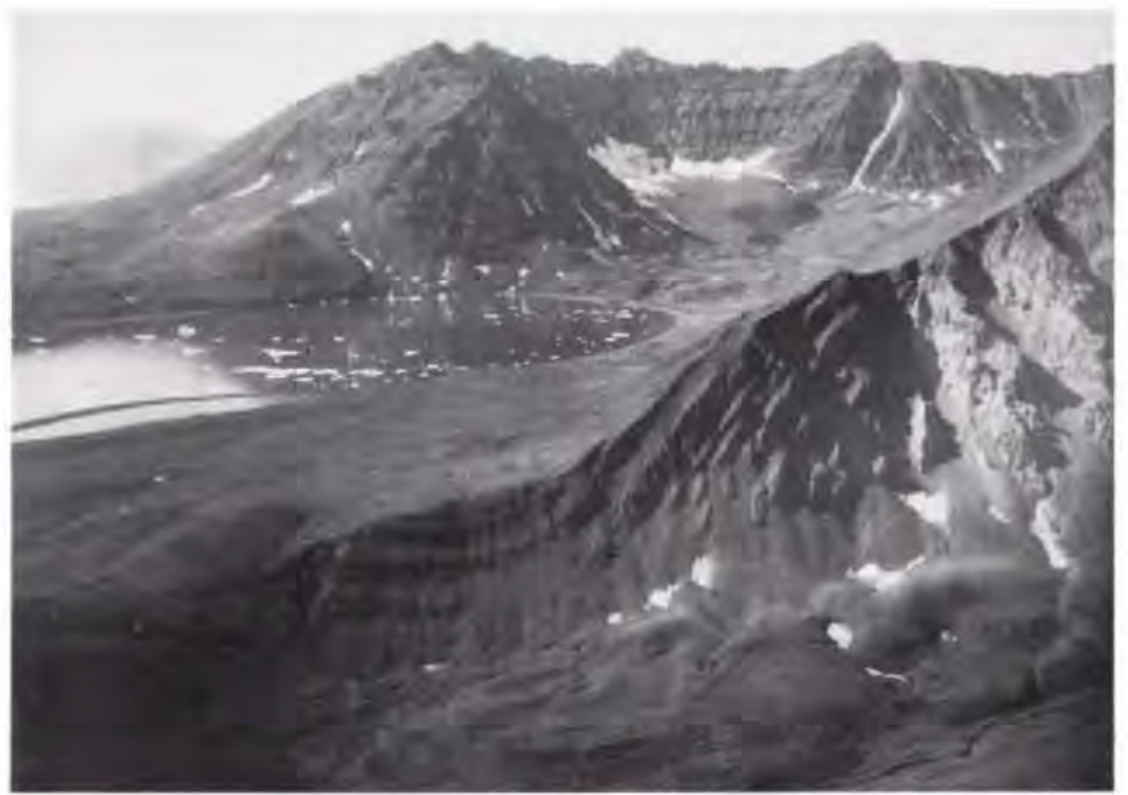

dykes were seen to be cut off by the main fault at an angle of $20-30^{\circ}$, indicating that at least the majority were intruded prior to the faulting.

Kap Brewster and Savoia Halvo. The peninsula of Savoia Halvø is crossed from NE to SW by a major fault zone, which has been studied in some detail. The fault is frequently made up of groups of faults forming wedgeshaped blocks. At its northern end where there is a considerable displacement along a single fault plane a mylonite has developed. Here short sequences of the uppermost lavas overlain by sediments of the Miocene Kap Brewster Formation are brought down to the level of the Milne Land Formation implying a displacement in excess of $1500 \mathrm{~m}$. Only $5 \mathrm{~km}$ further to the SW displacements are reduced to $600-700 \mathrm{~m}$.

West of the main fault only scattered minor faults occur and the lava flows here have a general westerly or south-westerly dip of $34^{\circ}$. A $75 \mathrm{~m}$ thick sequence of poorly exposed Upper Cretaceous mudstone underlies basalts of the Milne Land Formation immediately west of the main fault at its northern end. The contact is not exposed.

East of the main fault the basalts are faulted into blocks with dips generally varying between 10 and $30^{\circ} \mathrm{SE}$, the headland of Kap Brewster itself forming a single block with a shallower dip to the $\mathrm{E}$ of $5^{\circ}$, but steepening to about $30^{\circ}$ near the main fault.

It is believed that the major fault across Savoia Halvø may reflect renewed movement on the eastern side of the sedimentary basin to the north. A somewhat attenuated lava succession east of the fault line indicates that the contemporary subsidence, which must have accompanied the volcanic activity in the area as a whole, did not affect the point of Kap Brewster to the same degree, possibly owing to an influence from the southern extension of the basement on Liverpool Land. The same influence may be called upon to explain the occurrence of pre-basaltic sediments and lavas of the Milne Land Formation west of the main fault, and the south-westerly dip of the lavas there.

The magmatic activity was followed by rapid uplift and subsequent foundering of the coastal zone, The marked shore line produced by the fault scarps lent itself to rapid erosion and deposition of the upper Eocene Kap Dalton Formation.

The Kap Brewster Formation represents a repeat of the process after renewed activity on the same fault (Birkenmajer, 1972).

\section{Zeolite zones}

During the field work it was investigated whether zeolite zones like those described by Walker (1960) from eastern Iceland were recognisable in the Scoresby Sund basalt pile, and this was found to be the case although the zones are not equally well defined in all areas.

Zeolites and other secondary minerals are common in the basalts. They occur in almond-shaped cavities in the massive parts of a flow, in pipe vesicles at the base of flows, in abundance in the brecciated upper part of a flow and occasionally on joint planes. They are frequent 
in hyaloclastic deposits. The minerals are either massive or form large, well-shaped crystals where there are open spaces allowing growth. Chabazite (several habits), analcime, calcite (both as Iceland spar and dog-tooth spar), heulandite and stilbite frequently have well-developed crystal forms easily recognisable with the eye or hand lens. The following list gives the secondary minerals that have been recognised during the field work in the area, with an estimate of their frequency. The field identifications were later supplemented with refractive indices measurements and a few $\mathrm{X}$-ray determinations.

\begin{tabular}{|c|c|c|c|}
\hline Zeolites & & Non-zeolites & \\
\hline analcime & a & apophyllite & 0 \\
\hline chabazite & va & aragonite & $\mathrm{r}$ \\
\hline heulandite & va & calcite & a \\
\hline levyne & c & celadonite & c \\
\hline mesolite/scolecite & va & chalcedony/opal & va \\
\hline mordenite & c & quartz & va \\
\hline phillipsitc & r & & \\
\hline stilbitc & va & & \\
\hline thomsonite & $\mathrm{a}$ & & \\
\hline
\end{tabular}

No attempt has been made to divide the mesolite/ scolecite group in the field.

The lavas in Scoresby Sund have a dominance of quartz normative flows in the lower part (Magga Dan, Milne Land and lower Geikie Plateau Formations) while the middle and upper part (most of Geikie Plateau, Rømer Fjord, Skrænterne and Igtertivâ Formations) are almost exclusively olivine normative. The secondary mineral assemblages in the quartz and olivine normative sequences show differences corresponding to Walker's (1960) distinction between 'tholeiites' and 'olivine basalts' in eastern Iceland. The quartz normative flows contain dominantly secondary silica minerals, but in contrast to Iceland there are also critical zeolite minerals as chabazite, thomsonite and analcime present, probably because the quartz normative lavas, apart from somewhat higher silica contents, do not show gross compositional differences from the olivine normative lavas. The presence of these zeolites have allowed the zeolite zones established in the olivine normative sequence to be tentatively extended over the whole basalt area.

In the lower, quartz normative, part of the sequence dominating the inland areas chalcedony and quartz are the common secondary minerals. Concentric zones of chalcedony or chalcedony and quartz are common in the vesicles, and mushroom-shaped forms are characteristic in certain places. Water level agate is known in one locality on Milne Land. Calcite is a common associate, and aragonite appears to replace calcite in the higher levels. Chabazite, thomsonite and analcime are subordinate.

Zeolites dominate the secondary mineral assemblage of the middle and upper, olivine normative, part of the succession. Chalcedony and quartz occur sporadically, and calcite is frequent in some profiles. A zeolite zonation similar to that established by Walker (1960) on eastern Iceland is evident. In the lower parts of the succession many species of zeolite are present, and the number of species decreases with height. An abundance of mesolite-scolecite characterises the lower part of the succession, corresponding to Walker's mesolite-scolecite zone. Thereafter follows an analcime zone with often large well-formed crystals of analcime. The lower boundary of the analcime zone is not well marked, while its upper boundary is better defined by the disappearance of analcime and the dominance of chabazite, marking the beginning of Walker's chabazite-thomsonite zone. In this zone chabazite is frequently accompanied by discrete cushions of thomsonite. Levyne is also a characteristic mineral of this upper zone, while stilbite and scolecite may occur exceptionally. Zeolites are present up to the top of the sequence, but the intensity of zeolitisation is small at the top, and there are many empty vesicles. The top thus just reaches the zeolitefree zone of Walker (1960).

The zeolite zones are approximately horizontal and thus cut through the formation boundaries. At the Gejkie Plateau, where the zones are best delineated, the mesolite-scolecite zone is minimum $700 \mathrm{~m}$ thick and reaches from sea level to $700-800 \mathrm{~m}$ a.s.l. The analcime zone is $100-200 \mathrm{~m}$ thick with the upper boundary around $900 \mathrm{~m}$ a.s.l., and the chabazite-thomsonite zone is $1000 \mathrm{~m}$ thick, covering the level from $900 \mathrm{~m}$ to the plateau top at $1900 \mathrm{~m}$ a.s.l. This is the height of the boundary towards the zeolite-free zone that is missing. In terms of formations, the Geikie Plateau Formation around the Geikie Plateau is thus mainly in the mesolite-scolecite-analcime zone, while the Skranterne Formation is mostly in the chabazite-thomsonite zone. The boundary at $900 \mathrm{~m}$ cuts the Rømer Fjord Formation around Borgvig (Plate 1). At the Blosseville Kyst the picture is obscured due to the intense faulting and dyking.

The zone boundaries are much less marked in the quariz normative basalts in the inner fjord region. The Magga Dan and Milne Land Formation lavas around Gassefjord have scolecite and appear to be in the mesolite-scolecite zone. Analcime occurs very scattered up to $1100 \mathrm{~m}$ in Gåseland and $1300 \mathrm{~m}$ in Milne Land. A definite analcime zone is not present. Almost all the 
basalts on Gåseland and Milne Land are in the chabazite-thomsonite zone, including the whole Geikie Plateau Formation and most of the Milne Land Formation (Plate 1).

The near horizontal zeolite zones indicate that the zeolitisation took place after the main tilting of the lava sequence, and that the event had a regional character. On the other hand, the zeolitisation took place before the erosion planed the sequence down to its present level. If the Skrænterne Formation ever reached northwest of Gasefjord it must have been in a rapidly thinning wedge, leaving all of the Geikie Plateau Formation there in the chabazite-thomsonite zone.

Remnants of a local area with hydrothermal activity are found at the bottom of Gasefjord, where profile 87 shows intense zeolitisation and hematitisation.

At the Blosseville Kyst there are at present warm springs $\left(40-60^{\circ} \mathrm{C}\right)$ at Rømer Fjord and Henry Land. These springs are local aquifers in the faulted terrain and are not formed by hydrothermal activity at an increased geothermal gradient.

Temperatures for the zeolite zones on Iceland have been established by Kristmannsdóttir \& Tómasson (1978) and Pálmason et al. (1979), and extended to low-temperature areas by Kristmannsdóttir (1982). Using these data it is possible to calculate the geothermal gradient at the Geikie Plateau during the zeolitisation of the basalts. Two points are fixed on the geotherm; the top of the chabazite zone at $1900 \mathrm{~m}$ and $30^{\circ} \mathrm{C}$, and the bottom of the chabazite zone at $900 \mathrm{~m}$ and $70^{\circ} \mathrm{C}$. This gives a geothermal gradient of $40^{\circ} \mathrm{C} / \mathrm{km}$. Assuming a linear gradient this places the top of the laumontite zone at $110^{\circ} \mathrm{C} 100 \mathrm{~m}$ below sea level. Further, assumption of a warm temperate climate with $15^{\circ} \mathrm{C}$ as mean annual temperature places the top of the lava pile at $2275 \mathrm{~m}$.
This means that a little less than $400 \mathrm{~m}$ of lavas have been lost by erosion. If the geothermal gradient was not linear this figure decreases, perhaps to around $200 \mathrm{~m}$. The lost lavas are mainly of the Skrænterne Formation; and the three units of this formation probably originally extended further to the north-west. It is also possible that there was an independent overlying sequence of alkaline lavas in the inland areas, as known from Prinsen af Wales Bjerge (Anwar, 1955). Possible feeder dykes are present around the bottom of Gásefjord.

The calculation of the geothermal gradient is subject to some uncertainties, the largest of which is the temperature at which zeolites stop forming. A maximum gradient is obtained by setting the top of the laumontite zone at $110^{\circ} \mathrm{C}$ as high as possible, i.e. at $0 \mathrm{~m}$. This gives a maximum gradient of $44^{\circ} \mathrm{C} / \mathrm{km}$ and a missing lava sequence of $240 \mathrm{~m}$ for a linear gradient. A possible minimum gradient is obtained by using a temperature of $40^{\circ} \mathrm{C}$ for the cessation of zeolite formation. This gives a minimum geothermal gradient of $30^{\circ} \mathrm{C} / \mathrm{km}$ and a missing lava sequence of $830 \mathrm{~m}$ which seems excessive. The calculated gradient of $40^{\circ} \mathrm{C} / \mathrm{km}$ is considered the most realistic

\section{Lava volumes}

\section{Calculated volumes of the basalt formations}

Volumes for the successive lava formations have been calculated for the area north of the line A-D in fig. 35, and results are shown in Table 6. Because thicknesses vary, each formation was divided into a number of sectors whose volumes were calculated independently and summed up. The average thicknesses in Table 6 were calculated as total volume/total area.

Table 6. Volumes of the successive basalt formations

\begin{tabular}{|c|c|c|c|c|c|c|}
\hline & \multicolumn{2}{|c|}{$\begin{array}{l}\text { Calculated north of } \\
\text { line } A-D\end{array}$} & $\begin{array}{l}\text { th of } \\
\text { average } \\
\text { thickness m }\end{array}$ & \multicolumn{2}{|c|}{$\begin{array}{l}\text { Estimated between } \\
\text { line } A-D \text { and } 69^{\circ} \mathrm{N}\end{array}$} & $\begin{array}{l}69^{\circ} \mathrm{N} \\
\quad \text { volume } \\
\mathrm{km}^{3}\end{array}$ \\
\hline lgtertivâ Fm & $2500 ?$ & $500 ?$ & $200 ?$ & $2000 ?$ & $200 ?$ & $400 ?$ \\
\hline Skranterne Fm & 13700 & 8300 & 600 & 18000 & $700-1000$ & $12000-18000$ \\
\hline Rømer Fjord Fm & 14000 & 1850 & 130 & 11000 & $100-200$ & $1000-2000$ \\
\hline Geikie Plateau Fm & 22900 & 20500 & 900 & 17000 & $600-900$ & $10000-15000$ \\
\hline Miine Land Fm & 23000 & 4600 & 200 & - & - & \\
\hline Magga Dan Fm & 5100 & 650 & 130 & - & - & \\
\hline total & - & 36400 & 2160 & - & $1600-2200$ & $23000-35000$ \\
\hline
\end{tabular}

Average thicknesses calculated as total calculated volume/total area. For further explanation and discussion see text. 


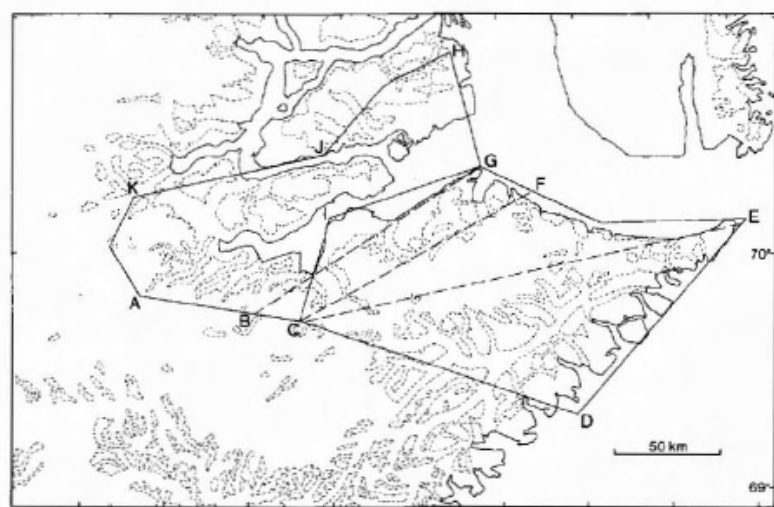

Fig. 35. Areal divisions used for volume calculations. See text for explanation.

Magga Dan Formation: The area considered is that between the original north-western limit given on fig. 35 , and a line between points $\mathrm{B}$ and $\mathrm{G}$ on the figure. Thicknesses vary from $40 \mathrm{~m}$ in the inner sector on Gåseland, through $80 \mathrm{~m}$ to $200 \mathrm{~m}$ in the outer sector $\mathrm{S}$ and $\mathrm{E}$ of Gåsefjord. If the formation continues below sea level to the east, considerable additional volumes exist: shifting the SE limit from line $\mathrm{BG}$ to line $\mathrm{CF}$ in fig. 35 adds $560 \mathrm{~km}^{3}\left(2800 \mathrm{~km}^{2} \times 0.2 \mathrm{~km}\right)$ to the formation, i.e. almost a doubling of the volume. If the formation extends to Savoia Halvø, only a fraction of it is known.

Milne Land Formation: The area considered is that between the original north-western limit, approximated by line HJK in fig. 35, and line CE to the south-east. This limitation is a compromise: a known minimum volume of $3100 \mathrm{~km}^{3}$ is obtained by using line CF as the south-east limit, but if on the other hand the formation extends below the entire eastern area (to line DE) with $200 \mathrm{~m}$ thickness, the total volume is $5500 \mathrm{~km}^{3}$.

Geikie Plateau Formation: The whole area delimited in fig. 35 was used. Thicknesses increase from $400 \mathrm{~m}$ in the north-west to $1000 \mathrm{~m}$ south-east of line A-G.
Rømer Fjord Formation: Area CDEGI was used. Thicknesses increase from $50 \mathrm{~m}$ in the west to $200 \mathrm{~m}$ in the east.

Skrænterne Formation: Area CDEGI was used. Thicknesses increase from $100 \mathrm{~m}$ in the west to $800 \mathrm{~m}$ in the east.

Igtertivâ Formation: The area was calculated as a 30 $\mathrm{km}$ broad and $85 \mathrm{~km}$ long strip along the Atlantic coast. The thickness of $200 \mathrm{~m}$ is a guess, and the resulting volume is very uncertain.

Estimated volumes. For the area between line A-D in fig. 35 and $69^{\circ} \mathrm{N}$ we have tentatively estimated the volumes for the formations known to be present there; but because thicknesses are so unconstrained the figures in Table 6 are rounded and given as ranges.

\section{Volumes of the various basalt types}

For the area north of line A-D in fig. 35 the detailed subdivisions of the basalts have allowed calculation of the volumes of the various basalt types. The figures are presented as percentages in Table 7. Note the similar evolution with time in the two main volcanic episodes: $\mathrm{Mg}$-rich basalts occur in the lower, heterogeneous formations, while low-Ti basalts only occur in the upper part of the thick monotonous formations. The medium-Ti and high-Ti basalts are calculated together because they are not distinguishable as units in the second episode. The high-Si basalts are calculated with the main basalts. Estimated percentages of high-Si basalts are $20 \%$ in Magga Dan, $6 \%$ in Milne Land and $1 \%$ in each of the Geikie Plateau and Skrænterne Formations. The volume figures for the Igtertivâ Formation are tentative because of the limited data.

\section{Volumes of individual lava flows}

Data on the volumes of individual lava flows come from the Milne Land and Skrænterne Formations. In

Table 7. Volume percentages of the various basalt types

\begin{tabular}{|c|c|c|c|c|c|c|c|c|}
\hline \multirow{2}{*}{\multicolumn{2}{|c|}{ Episode Formation }} & \multicolumn{4}{|c|}{ Mg-rich basalts } & \multicolumn{3}{|c|}{ Main basalts } \\
\hline & & Mikis & MORB & ol-thol & Hjørnedal & low-Ti & m-h-Ti & Ti-thol \\
\hline 3 & Igtertivâ Fm & & & & & $30 ?$ & $70 ?$ & \\
\hline \multirow{3}{*}{2} & Skrænterne Fm & & & & & 36 & 63 & 1 \\
\hline & Rømer Fjord Fm & & 0.3 & 53 & & & 16 & 31 \\
\hline & Geikie Plateau Fm & $\operatorname{tr}$ & & & & 15 & 83 & 2 \\
\hline \multirow[t]{3}{*}{1} & Milne Land Fm & 3 & & & 9 & & 72 & 16 \\
\hline & Magga Dan Fm & & & & & & 100 & \\
\hline & Percent of total & 0.3 & 0.01 & 3 & 0.8 & 17 & 74 & 5 \\
\hline
\end{tabular}


Table 8. Volumes of individual lava flows

\begin{tabular}{|c|c|c|c|c|}
\hline Formation & Flow position/name & area $\mathrm{km}^{2}$ & thickness $\mathrm{m}$ & volume $\mathrm{km}^{3}$ \\
\hline Skrænterne, upper unit & & 140 & 15 & 2.1 \\
\hline " & & 250 & 20 & 5.0 \\
\hline$"$ & & 85 & 50 & 4.3 \\
\hline Skrænterne, middle unit & $\begin{array}{l}\text { profile } 44, \\
1594-1628 \mathrm{~m}\end{array}$ & 700 & 30 & 21 \\
\hline " & $\begin{array}{l}\text { profile } 44, \\
1576-1594 \mathrm{~m}\end{array}$ & 600 & 30 & 18 \\
\hline " & $\begin{array}{l}\text { profile } 44, \\
1557-1576 \mathrm{~m}\end{array}$ & 3000 & 20 & 60 \\
\hline$"$ & $\begin{array}{l}\text { average of } 4 \text { flows } \\
1426-1557 \mathrm{~m}\end{array}$ & 2800 & 30 & 84 \\
\hline " & $\begin{array}{l}\text { profile } 44, \\
1392-1426 \mathrm{~m}\end{array}$ & 600 & 30 & 18 \\
\hline " & $\begin{array}{l}\text { profile } 44 \text {, compound } \\
\text { sequence } 1358-1392 \mathrm{~m}\end{array}$ & 2600 & 30 & 78 \\
\hline Milne Land & upper Ti-tholeiite & 7700 & 25 & 192 \\
\hline " & Hjørnedal marker & 11400 & 25 & 285 \\
\hline$"$ & Mikis type flow & 4850 & 20 & 97 \\
\hline$"$ & lower Ti-tholeiite & 6750 & 45 & 304 \\
\hline
\end{tabular}

The flows are arranged in stratigraphic succession.

The lava flows from the Skranterne Formation were only followed in the northern and eastern part of the Geikie Plateau. Several of the flows probably extend further south, and the volumes given are minimum volumes. The compound sequence consists of many thin flow units.

The upper and lower Ti-tholeiite horizons have not been followed in the field, and their identity as single large flows is inferred. The Hjørnedal marker horizon is one flow except in a small area where there are two flows.

the Milne Land formation four large lava flows are petrographically and chemically distinct and have been recognised in a number of profiles. Their areal extents are shown in fig. 13, and calculated extents and volumes are given in Table 8. All four flows drop below sea level to the $\mathrm{SE}$, and to obtain comparable figures the areas were all delimited to the SE by the line CF in fig. 35 . The flows may continue beyond this line, so that the flows are even larger than calculated.

The upper and lower titano-tholeiite horizons have not been followed in the field, and their identity as single large flows is inferred. The Hjørnedal marker horizon is one flow except in a small area where there are two flows.

Another type of data on flow volumes was obtained by airborne reconnaissance on the northern and eastern Geikie Plateau, where visually characteristic flows or flow groups in the Skrænterne Formation have been followed over an area of around $3000 \mathrm{~km}^{2}$. Many of the flows must also be present further south, and the volumes given in Table 8 are thus minimum volumes. The five upper flows have their northern limit in the area.

The volumes set out in Table 8 span a very wide range, from 2 to $300 \mathrm{~km}^{3}$. We believe, however, that the large volumes of the flows in the Milne Land Formation are exceptional (see section on magma chambers). The data for the Skrænterne Formation lead us to estimate that 'typical' plateau lava flows are $15-30 \mathrm{~m}$ thick and cover $500-4000 \mathrm{~km}^{2}$ with volumes of $10-60 \mathrm{~km}^{3}$. Both smaller and larger flows occur occasionally. The Hjørnedal marker flow and the Mikis type flow are special cases dealt with later.

\section{Productivity}

In the area north of the line AD in fig. 35 the total amount of magma produced can be estimated under certain assumptions. It is assumed that the Magga Dan, Milne Land and Geikie Plateau Formations, which all had eruption sites in the inland regions, are largely preserved in their original extent. Their combined volume from Table 6 , col. 2 , is thus close to $26000 \mathrm{~km}^{3}$. These three formations constitute the lower sequence, or first eruptive episode (see later). The Rømer Fjord and Skrænterne Formations constitute the upper sequence, or second eruptive episode (see later), and 
while the Rømer Fjord Formation may be assumed to be largely preserved (close to $2000 \mathrm{~km}^{3}$ ) this is not the case for the Skrænterne Formation. Firstly, around 200 $m$ of lavas have been planed off the top. Secondly, if the lavas of this formation were originally disposed symmetrically about the eruption sites (inferred to have been situated south-east of the present Atlantic coast), then more than half the originally produced lava volume has been split off from the continent and disappeared. Using a thickness of $800 \mathrm{~m}$ instead of the $600 \mathrm{~m}$ in Table 6 , and a somewhat arbitrary factor of 2.3 to correct for the missing parts, the original lava volume of the Skrænterne Formation is calculated as close to $25000 \mathrm{~km}^{3}$. The combined volume for the upper sequence is thus $27000 \mathrm{~m}^{3}$, much the same as for the lower sequence.

Assuming a time span of three million years for the production of the whole lava pile gives a productivity of $0.018 \mathrm{~km}^{3}$ per year. The lengths of the productive rift systems are around $150 \mathrm{~km}$ for the inland areas of the first episode, and $120 \mathrm{~km}$ for the coastal areas of the second episode. This gives production figures of respectively 173 and $225 \mathrm{~km}^{3}$ per $\mathrm{km}$ rift length for the first and second episode, or $1.15 \times 10^{-4}$ to $1.5 \times 10^{-4} \mathrm{~km}^{3}$ per $\mathrm{km}$ rift per year.

In the area between line $\mathrm{AD}$ and $69^{\circ} \mathrm{N}$ volume estimates and definition of rift lengths are much more uncertain. Average figures and an assumed correction factor of 2.3 for the missing part of the Skranterne Formation give a total volume of about $48000 \mathrm{~km}^{3}$. For an 80 $\mathrm{km}$ long rift the productivity for three million years is $2.0 \times 10^{-4} \mathrm{~km}^{3}$ per kilometer rift per year.

Between $69^{\circ} \mathrm{N}$ and Kangerdlugssuaq there are $c$. $20000 \mathrm{~km}^{2}$ of basalts with an estimated average thickness of $3 \mathrm{~km}$, giving a volume of $60000 \mathrm{~km}^{3}$. If a similar amount of material (a guess) has been chopped off at the coast, the total production was $120000 \mathrm{~km}^{3}$. For a $200 \mathrm{~km}$ long rift the productivity for three million years is $2.0 \times 10^{-4} \mathrm{~km}^{3}$ per kilometer rift per year.

Nielsen \& Brooks (1981) calculated very similar production rates for the East Greenland basalts. Comparable values are also found in Iceland, where productivities are in the range $0.6 \times 10^{-4}$ to $2.5 \times 10^{-4} \mathrm{~km}^{3} / \mathrm{km}^{2}$ rift/year, decreasing from the centre towards the north and south (Jakobsson, 1972; Pálmason, 1983).

The total lava production in central East Greenland may thus be estimated at $53000+48000+120000 \sim$ $220000 \mathrm{~km}^{3}$. If lavas also covered Jameson Land, which is very probable, an additional $100 \times 100 \times 1=10000$ $\mathrm{km}^{3}$ may be added to this figure.

\section{Correlation south of $69^{\circ} \mathrm{N}$}

Due to the inaccessibility of the country around $69^{\circ} \mathrm{N}$, correlation between the Scoresby Sund and Kangerdlugssuaq regions is not well established. The lower basalt sequence (Magga Dan, Milne Land and Geikie Plateau Formations) in Scoresby Sund is not exposed south of Knighton Fjord, and airborne reconnaissance along the Blosseville Kyst shows that the Rømer Fjord Formation drops below sea level south of Barclay Bugt. Reconnaissance in 1986 showed that the top of the formation reappears, probably upfaulted, at Søkongen Bugt $\left(68^{\circ} 44^{\prime} \mathrm{N}\right)$, and the formation is infersed to lie just slightly below sea level along the $90 \mathrm{~km}$ long stretch of the Blosseville Kyst between these two locations. The overlying Skrænterne Formation is thus almost fully exposed.

The Skranterne Formation appears to constitute the main part or all of the exposed plateau basalts south of $69^{\circ} \mathrm{N}$. It becomes both thicker and more extensive towards the south: in the northern areas, the middle unit of this formation thins rapidly inland and only reaches $110 \mathrm{~km}$ inland from the coast (Plate 2). But further to the south-west, profile 77 (Gronau Nunatakker, see fig. 2) located about $140 \mathrm{~km}$ from the Atlantic coast consists of minimum $75 \mathrm{~m}$ of middle Skrænterne lavas. Field reconnaissance in 1986 showed that the lavas exposed at $3566 \mathrm{~m}$ near the top of Gunbjørn Fjeld $60 \mathrm{~km}$ south of Gronau Nunatakker are of typical Skrænterne appearance. The formation can be recognised along the Blosseville Kyst southwards to Grivel Bugt and Wiedemann Fjord around $68^{\circ} 30^{\prime} \mathrm{N}$, but in the vicinity around Nansen Fjord the lavas become atypical, often aphyric, and the correlation uncertain. The lavas may have originated from another eruptive centre, but may still be contemporaneous with the Skranterne Formation and included in it. Chemical analyses of plateau basalts from Nansen Fjord (Brooks et al., 1976 and unpublished data) are consistent with an interpretation as the Skrænterne Formation when plotted in diagrams like those of figs 72,77 and 78 . The same is true for the oldest dyke generation of the coastal dyke swarm in the Kangerdlugssuaq region, the pre-flexural thol-1 dykes, which have been interpreted as feeders for the plateau basalts (Nielsen, 1978). In conclusion, we regard the upper basalt sequence in the Scoresby Sund region (Rømer Fjord and Skrænterne Formations) as equivalent to the plateau basalts overlying the Lower Basalts in the Kangerdlugssuaq region. 
We tentatively correlate the lower basalt sequence in the Scoresby Sund region with the almost $2 \mathrm{~km}$ thick succession of Lower Basalts in the Kangerdlugssuaq region: the Vandfaldsdalen, Mikis and Hængefjeldet Formations described by Nielsen et al. (1981). The correlation is chronological and not lithological: the lithologies of the two lava sequences are quite distinctly different, and they were produced by different volcanic systems. The lower basalt sequence in the Scoresby Sund region was erupted largely from the Gassefjord region, while the source of the lower basalts in the
Kangerdlugssuaq region was south and east of the present coast (Nielsen et al., 1981). The correlation is supported by the occurrence in the Milne Land and Geikie Plateau Formations of two flows of Mikis type lava, similar to the lavas of the Mikis Formation. In the north this magma type does not appear to have had a separate plumbing system, and the magma had probably migrated laterally from large storage chambers of this magma type in the Kangerdlugssuaq area (see section on origin of magma types). 


\section{PART 2. PETROLOGY}

\section{Petrography}

\section{General}

All the lavas and most of the dykes are tholeiitic basalts, and their petrography and mineralogy is relatively uniform. Phenocryst minerals comprise olivine, chromite, plagioclase and augite, and in one case orthopyroxene, while groundmass minerals include olivine, plagioclase, augite, pigeonite, titanomagnetite and ilmenite. Apatite, orthopyroxene, rutile and pseudobrookite have also been identified. As secondary minerals occur zeolites, various clay minerals, carbonates and quartz/agate. Uncommon xenoliths are of basement gneisses, sandstone and gabbroic cumulates.

The petrographic variation in relation to the various basalt types is subtle, and only the highly-porphyritic Hjørnedal marker flow and the olivine-phyric Mikis type basalt are easily distinguishable petrographically. Table 9 lists modal analyses of representative samples of the major basalt types. The rocks in the table were chosen to be phenocryst-poor, of about equal grain size, chemically analysed and microprobed (excepting 98881). The Hjørnedal marker is excluded because it contrasts to the others in being heavily porphyritic, and the high-Si basalts are excluded because they are petrographically very variable. From this table the systematic mineralogical differences between the basalt types are apparent: olivine decreases from more than $10 \%$ in the Mikis type basalt to $1-2 \%$ in the titano-tholeites, while in the same sequence the amount of FeTi oxides increases from around $2.5 \%$ to almost $7 \%$. The amount of plagioclase is relatively constant, and so is the clinopy-

Table 9. Modal compositions of representative aphyric/phenocryst-poor samples from various basalt types

\begin{tabular}{|c|c|c|c|c|c|c|c|c|}
\hline $\begin{array}{l}\text { GGU No. } \\
\text { Chemical type }\end{array}$ & $\begin{array}{l}98593 \\
\text { Mikis }\end{array}$ & $\begin{array}{c}98550 \\
\text { MORB }\end{array}$ & $\begin{array}{l}98871 \\
\text { ol-thol }\end{array}$ & $\begin{array}{c}98536 \\
\mathrm{I}-\mathrm{Ti}\end{array}$ & $\begin{array}{l}98489 \\
\mathrm{~m}-\mathrm{Ti}\end{array}$ & $\begin{array}{c}98516 \\
h-t i\end{array}$ & $\begin{array}{c}98572 \\
\text { Ti-th }\end{array}$ & $\begin{array}{c}98881 \\
\text { Ti-th }\end{array}$ \\
\hline Olivine, fresh & 0.3 & 4.1 & 8.4 & 3.1 & 0.6 & 1.3 & 0.0 & 0.0 \\
\hline Olivine, altered & 10.7 & 5.7 & 1.5 & 4.3 & 4.1 & 2.2 & 1.0 & 2.0 \\
\hline Plagioclase, phenocrysts & 0.0 & $<0.2$ & 0.0 & 0.6 & 3.6 & 0.5 & 1.6 & 0.4 \\
\hline Plagioclase, groundmass & 44.9 & 44.1 & 41.1 & 51.1 & 51.1 & 50.2 & 52.6 & 47.3 \\
\hline Plagioclase, altered & 1.9 & 5.3 & 8.2 & 0.0 & 0.0 & 0.0 & 0.0 & 0.0 \\
\hline Clinopyroxene, phenocrysts & 0.0 & 0.0 & 0.0 & 0.0 & $<0.2$ & $<0.2$ & 0.0 & 0.0 \\
\hline Clinopyroxene, groundmass & 31.1 & 27.9 & 25.3 & 32.1 & 28.9 & 30.8 & 34.6 & 36.3 \\
\hline Fe-Ti oxides & 2.6 & 2.4 & 2.9 & 3.4 & 5.0 & 4.9 & 6.5 & 6.8 \\
\hline Chromite & $<0.2$ & $<0.2$ & $<0.2$ & 0.0 & 0.0 & 0.0 & 0.0 & 0.0 \\
\hline Interstitial 'glass' (clay) & 7.6 & 4.8 & 1.2 & 4.2 & 4.7 & 5.7 & 3.7 & 7.1 \\
\hline Mesostasis & 0.0 & 0.7 & 1.7 & 1.2 & 2.0 & 4.2 & 0.0 & 0.0 \\
\hline Zeolite (interstitial) & $<0.2$ & 4.9 & 9.7 & 0.0 & 0.0 & 0.0 & 0.0 & 0.0 \\
\hline Carbonate (interstitial) & 0.8 & 0.0 & 0.0 & 0.0 & 0.0 & 0.0 & $<0.2$ & 0.0 \\
\hline Vesicle filling (clay) & 0.0 & 0.0 & 0.0 & $<0.2$ & 0.0 & 0.2 & 0.0 & 0.1 \\
\hline Rock $\mathrm{Mg} /\left(\mathrm{Mg}+\mathrm{Fe}^{2+}\right)$ & 0.648 & 0.628 & 0.608 & 0.527 & 0.503 & 0.480 & 0.480 & 0.425 \\
\hline Rock $\mathrm{TiO}_{2}$ wt $\%$ & 2.39 & 1.30 & 2.26 & 2.18 & 2.64 & 3.14 & 3.61 & 3.80 \\
\hline Oxidal. stage, Fe-Ti oxides & $\mathrm{C} 5, \mathrm{R} 3-7$ & $7 \mathrm{C} 2-4, \mathrm{R} 1-2$ & C $3-4$, R2-3 & $\mathrm{C} 3-4, \mathrm{R} 1-4$ & $\mathrm{C} 1, \mathrm{R} 1$ & $C I, R 1$ & $C_{1}, \mathrm{RI}$ & $\mathrm{Cl}, \mathrm{RI}$ \\
\hline
\end{tabular}

For the definition of chemical types see Table 19.

Polished thin sections were counted in a combination of reflected and transmitted light to avoid overestimation of the opaque and mafic phases and ensure correct mineral identification.

Approx, 1600 points were counted in each section, giving a 'lower limit of detection' of around $0.2 \%$ (van der Plas \& Tobi, 1965).

Oxidation stages of the Fe-Ti oxides after Haggerty (1976). 
roxene, although the titano-tholeiites seem to have more pyroxene than the other basalts. All samples contain notable amounts of interstitial 'glass' (now altered to smectite), and almost all samples contain some mesostasis, i.e. extremely fine-grained polymineralic pockets. Similarly, Peck et al. (1966) found a constant amount of $8 \%$ glass below the solidus in basalts from a Hawaiian lava lake.

For petrographical classification purposes the modal differences between the 'neighbouring' groups in Table 9 are too small to be of routine diagnostic value, and the differences are often masked by differences in grain size, texture and phenocryst content. Many titano-tholeiites may be recognised by their large oxide contents. Note, however, that the $\mathrm{TiO}_{2}$-rich Mikis type basalt and the $\mathrm{TiO}_{2}$-poor $\mathrm{MORB}$ type basalts, whose dominant oxides are ilmenite and titanomagnetite respectively, have nearly equal modal amounts of oxides.

Table 9 also gives an impression of the general alteration state of the lavas.

\section{Phenocrysts}

The lavas were divided in the field into alternating aphyric and porphyritic formations (fig. 3). However, many of the lavas from the 'aphyric' formations do contain sparse phenocrysts, and only few lavas are apparently completely aphyric. Moreover, all the glassy rocks encountered contain phenocrysts/microphenocrysts in abundance. Thus, in principle, all the lavas are more or less porphyritic, i.e. they were at or below their liquidus temperature at the time of extrusion.

The phenocryst association olivine + chromite occurs in the Mg-rich basalts, i.e. the Mikis type basalt and the MORB type basalts and olivine tholeites of the Rømer Fjord Formation. The main basalts contain either olivine + plagioclase or olivine + plagioclase + augite as phenocryst association. The division into $\mathrm{Mg}$-rich basalts and main basalts thus corresponds to the division between olivine tholeiites and plagioclase tholeiites by Shido et al. (1971). Some glassy pillow breccias from the Magga Dan Formation and the Hjørnedal marker flow in the Milne Land Formation contain olivine + chromite + plagioclase + augite, and one very silica-rich basalt (98788) from the Magga Dan Formation contains olivine + chromite + orthopyroxene + augite, with plagioclase only occurring as microliths. It is notable that olivine is a phenocryst phase in all basalts including the most iron and titanium-rich ones, while magnetite and ilmenite were never encountered as phenocrysts. The phenocryst associations are summarised in Table 20 in combination with a later discussion of phase relations and temperatures.
The amount of phenocrysts varies from one formation to the next (fig. 36). The lavas in the 'aphyric' Magga Dan and Geikie Plateau Formations contain $0-7 \%$ by volume of phenocrysts, and usually below $2 \%$, while the lavas of the 'porphyritic' Milne Land and Skrænterne Formations contain $0-15 \%$ phenocrysts, usually below $10 \%$. Plagioclase is volumetrically by far the most important phenocryst phase, amounts up to $10 \%$ being quite normal, while the combined amounts of olivine and pyroxene phenocrysts usually do not exceed $1 \%$. The Hjørnedal marker flow with up to $23 \%$ phenocrysts is exceptional.

Lavas with accumulations of phenocrysts are only found in very few instances, and most of these are clearly out of range of the plots in fig. 36. A few examples were found in the porphyritic Milne Land and Skrænterne Formations and in the basalts of the 'big feldspar divide' in the Rømer Fjord Formation. From variation diagrams (figs 76,77 ) it appears that at least some samples of the very phenocryst-rich Hjørnedal marker flow have accumulated some feldspar.

There is a complicated relation between lava composition and phenocryst content. For instance, the low-Ti lavas from the Geikie Plateau Formation have less than $1 \%$ phenocrysts while the chemically similar lavas from the middle unit of the Skrænterne Formation have $4-15 \%$ phenocrysts. There does, however, seem to be a general tendency that both the least and the most fractionated lavas are phenocryst-poor, while the phenocryst-rich lavas are confined to intermediate fractionation states with $\mathrm{Mg}$ ratios of $0.56-0.44$. (The Hjørnedal marker is a notable exception.) Within this intermediate fractionation interval lavas may or may not be porphyritic. At a Mg-ratio of 0.50 almost all lavas have some phenocrysts - a 'bell-shaped' distribution is evident for the Geikie Plateau Formation in fig. 36.

\section{Groundmass}

The lava samples are usually from the lower, massive parts of the lava flows and do not normally contain vesicles and vesicle fillings.

Ubiquitous groundmass mineral phases are plagioclase, augite, titanomagnetite and ilmenite. Groundmass olivine is found in most of the fresh samples but is not identifiable in the more altered samples. Pigeonite was identified in 12 out of 22 microprobed samples. The occurrence of groundmass olivine and pigeonite seems to be independent of the bulk composition of the lavas, and the two minerals occur together in several samples. Orthopyroxene was found in the groundmass of one sample together with magnetite in a fine-grained reaction rim resulting from high-temperature oxidation of 

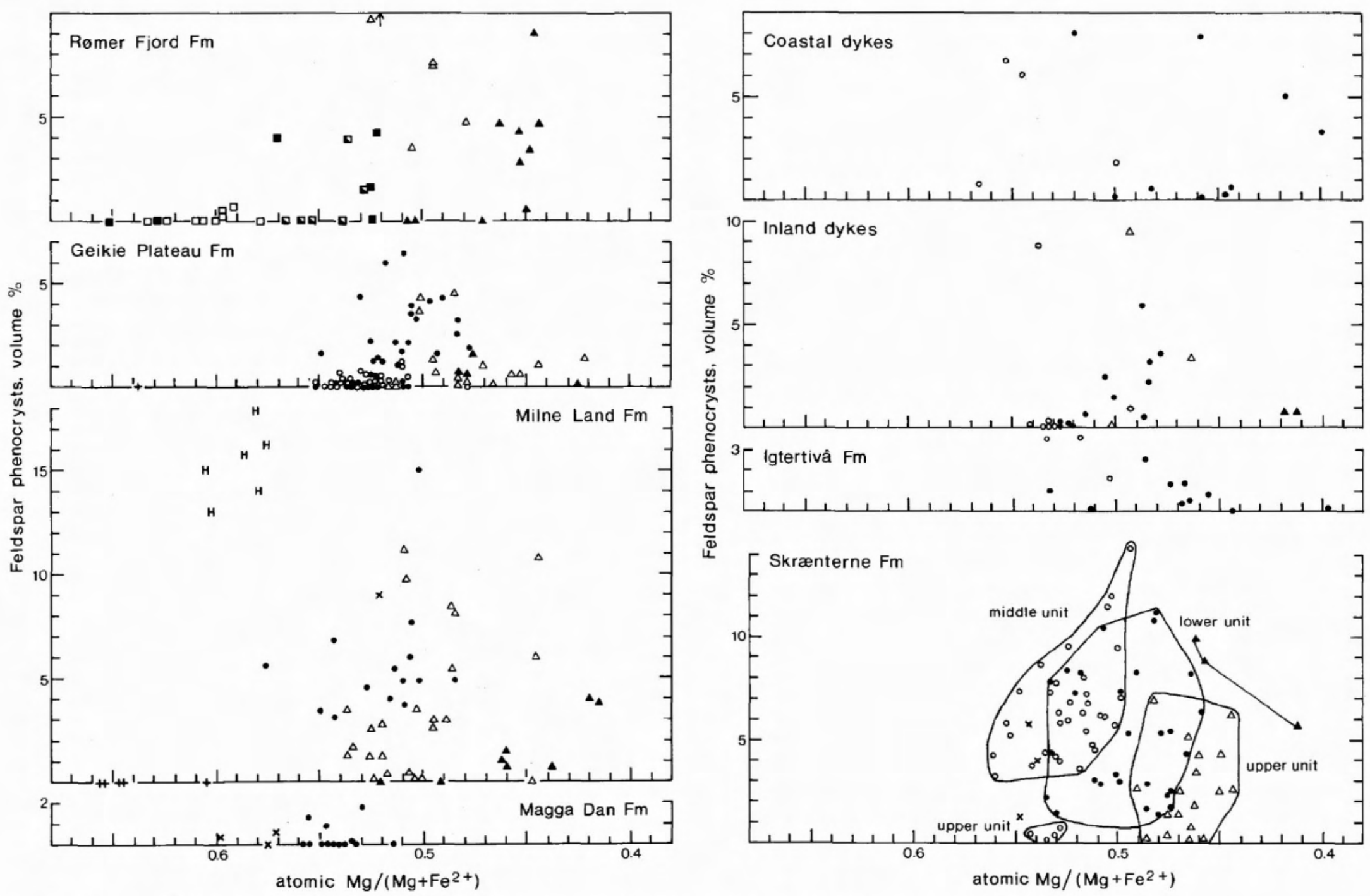

Fig. 36. The amount of feldspar phenocrysts plotted against fractionation stage ( $\mathrm{Mg}$ ratio) in the various basalt formations and chemical types. The feldspar was measured by counting on a millimetre-grid placed over the thin sections, viewed under low magnification in a stereo microscope.

Symbols for the various chemical types as in fig. 68 except for the Skrænterne Formation, where the symbols designate the sub-units as indicated. 
olivine. Rutile and pseudobrookite occur in a few very oxidised samples as high-temperature breakdown products of titanomagnetite and ilmenite. Tiny needlets of apatite were identified with the microprobe in the mesostasis of five samples. All the basalts originally contained a few percentages of interstitial glass (Table 9), now represented by yellow-brown smectite. Microcrystalline mesostasis is present in many rocks (Table 9), and in some of the high-silica basalts the mesostasis contains needlets of a $\mathrm{SiO}_{2}$-polymorph.

The dominating groundmass texture is intergranular, sometimes grading to subophitic. Most of the compound lavas of the Rømer Fjord Formation are, however, strongly ophitic, and this is in very good accordance with the systematic distribution of Icelandic basaltic lavas with different textures in the alkali/silica diagram found by Jakobsson $(1979$, p 71). Occasional ophitic lavas do occur in the other formations, and one such lava in the Geikie Plateau Formation can be used as a short-distance petrographic marker horizon. A pilotaxitic texture, with near-parallel alignment of the groundmass feldspars, is found in a couple of titano-tholeiite samples, and hyalo-ophitic and intersertal textures occur in the partly crystalline pillow lavas.

Segregation pockets occur in a few rocks, notably in the microprobed 98554 discussed later. This sample contains around $10 \%$ of $2-10$ millimetre-sized rounded or lobate patches considerably more coarse-grained than the basalt matrix (fig. 37). The mineralogy of these patches is the same as that in the basalt matrix except that no olivine is present.

Fine-scale globular structures with tiny (up to $5 \mathrm{mi}$ crons) semi-opaque spheres in clear feldspathic matrix are found in a few high-Si rocks. The structures are considered evidence for late-stage liquid immiscibility as described by Philpotts $(1978,1982)$.

Most lava samples are vesicle-free and therefore do not normally contain zeolites except in the Rømer Fjord Formation. The samples are never completely fresh and invariably contain some yellow to dark brown or green microcrystalline clayey material. This occurs in groundmass interstices (altered glass or mesostasis), as alteration products of olivine, as vesicle fillings, and sometimes in small veins. Table 9 gives the modal amount of alteration products and the oxidation state of the $\mathrm{Fe}-\mathrm{Ti}$ oxides in representative samples from the various basalt types. The more $\mathrm{Mg}$-rich basalts are evidently more prone to alteration than the more evolved types.

\section{Mikis type basalt}

This Mg-rich basalt type (Table 19) is inconspicuous in the field but is easily recognisable in thin section (fig.

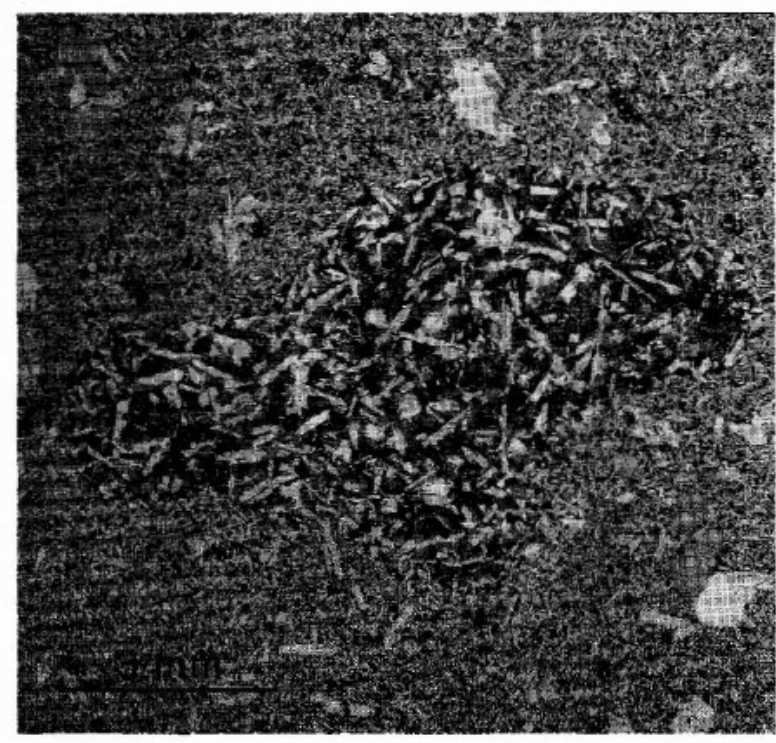

Fig. 37. Thin section of coarse-grained segregation pocket in high-Ti basalt (GGU 98554). Microprobed sample, see figs 46, 52 and 54. Note phenocrysts of olivine (upper centre), feldspar and augite in the fine-grained rock. Plane polarised light.

38). It contains $1-3 \%$ olivine phenocrysts up to $1 \mathrm{~mm}$ large, with frequent inclusions of small chromite octahedra. A pillow breccia facies of this rock contains fresh, pale brown glass with around $7 \%$ olivine phenocrysts with chromite, and abundant microliths of plagioclase and pyroxene. The groundmass of the crystallised rock has an intergranular texture with plagioclase, olivine, augite, pigeonite and Fe-Ti oxides of which platy ilmenite grains are prominent. Interstitial green clayey material or zeolite amount to several per cent (Table 9).

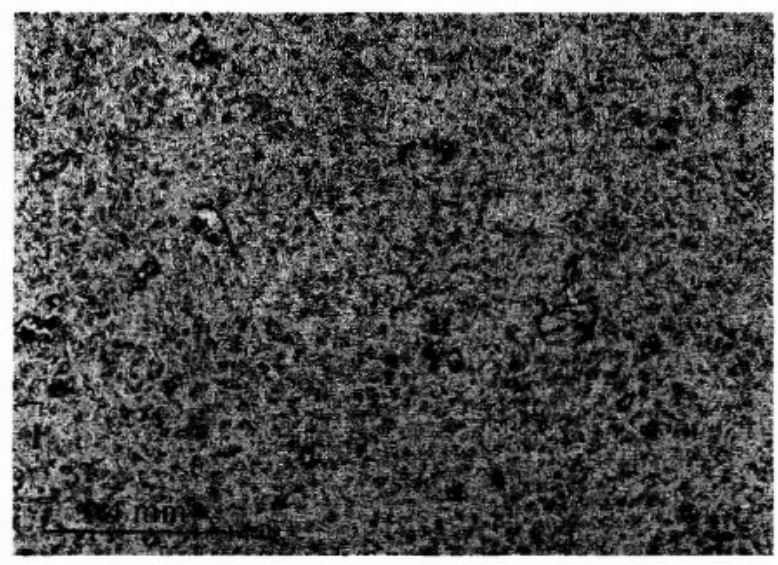

Fig. 38. Thin section of Mikis type basalt with olivine microphenocrysts marginally altered to semi-opaque oxides. GGU 98593. Plane polarised light. 


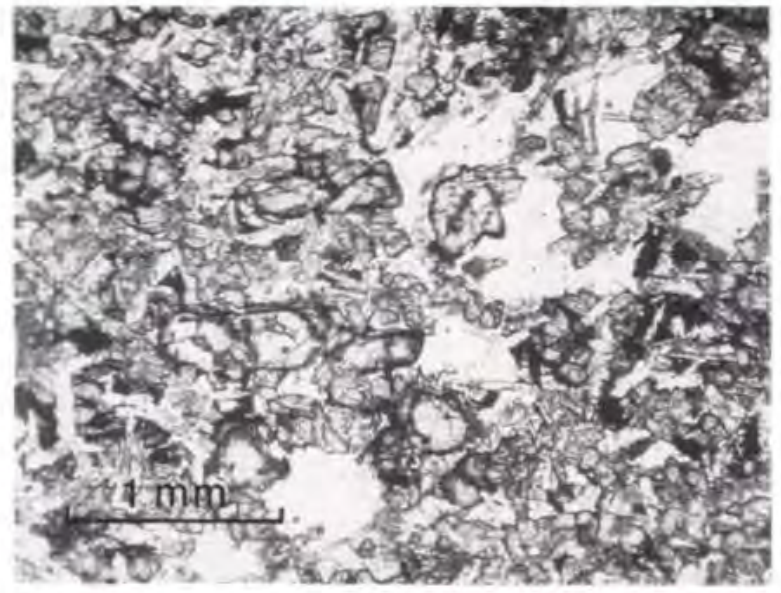

Fig. 39. Thin section of olivine tholente (GGU 98871). The relatively coarse-grained rock is rich in olivine crystals (high relief) with small chromite octahedra. The light interstitial patches consist of various zeolites. Plane polarised light.

\section{MORB type basalt and olivine tholeiite}

These basalt types (Table 19) constitute the MORB type unit and the lower and upper compound units of the Rømer Fjord Formation. They are petrographically very similar. In hand sample the rocks are aphyric or with few small feldspar phenocrysts. In thin section (fig. 39 ) are seen relatively large amounts of olivine, up to $10 \%$, of subhedral to euhedral shape and with many inclusions of small chromite octahedra. The major part of the olivine crystals are of groundmass size. The groundmass is relatively coarse grained $(0.5-1 \mathrm{~mm})$ and with dominantly ophitic texture. Pigeonite was found in one of the three microprobed samples (98550). Zeolites occur abundantly and fill out large interstitial areas. Vesicles are also filled out with zeolites and sometimes calcite. The olivine tholeiites from some of the coastal sections contain only minor amounts of zeolites and are invariably heavily altered, with abundant clay. The zeolite-rich samples are usually rather well preserved, although both plagioclase and augite may by marginally zeolitised.

The MORB-type unit includes sparsely feldsparphyric, chromite-free lavas with subophitic to intergranular, coarse-grained texture. These have a more differentiated character, evident in the chemical composition (lower $\mathrm{Mg}$ ratio, fig. 72). Likewise, the olivine tholeittes of the upper compound unit are more differentiated than those in the lower compound unit (fig. 72). The upper compound unit contains very little chromite and is sometimes sparsely feldsparphyric (fig. 36). Apart from this it conforms to the descriptions given above.

\section{Hjørnedal marker flow}

This basalt flow is characterised by its high total phenocryst content (18-23\%), very characteristic platy olivine phenocrysts and a relatively high content of large augite phenocrysts (fig. 40).

Plagioclase phenocrysts in broad laths up to $5 \mathrm{~mm}$ long constitute $13-18 \%$ of the lava. They show complicated zoning patterns with core-and-rim zoning and oscillatory zoning as described in the feldspar section below. Olivine phenocrysts amount to $2-5 \%$ and occur in two forms: (a) large platy crystals, in thin section 1-5 $\mathrm{mm}$ 'long' and 0.2-0.4 mm thin, and (b) equant olivine

Fig. 40. Thin section of Hjornedal marker flow (GGU 96882). Among the numerous phenocrysts are seen olivine in equant crystals (lower left) and platy crystals (upper left, centre, lower right): feldspar with and without inclusion-filled cores (the crystal in the upper centre is also shown in fig. 50a); and augites sometimes with inclusion zones near the rims (e.g. lower centre), as also shown in fig. 53. Plane polarised light.

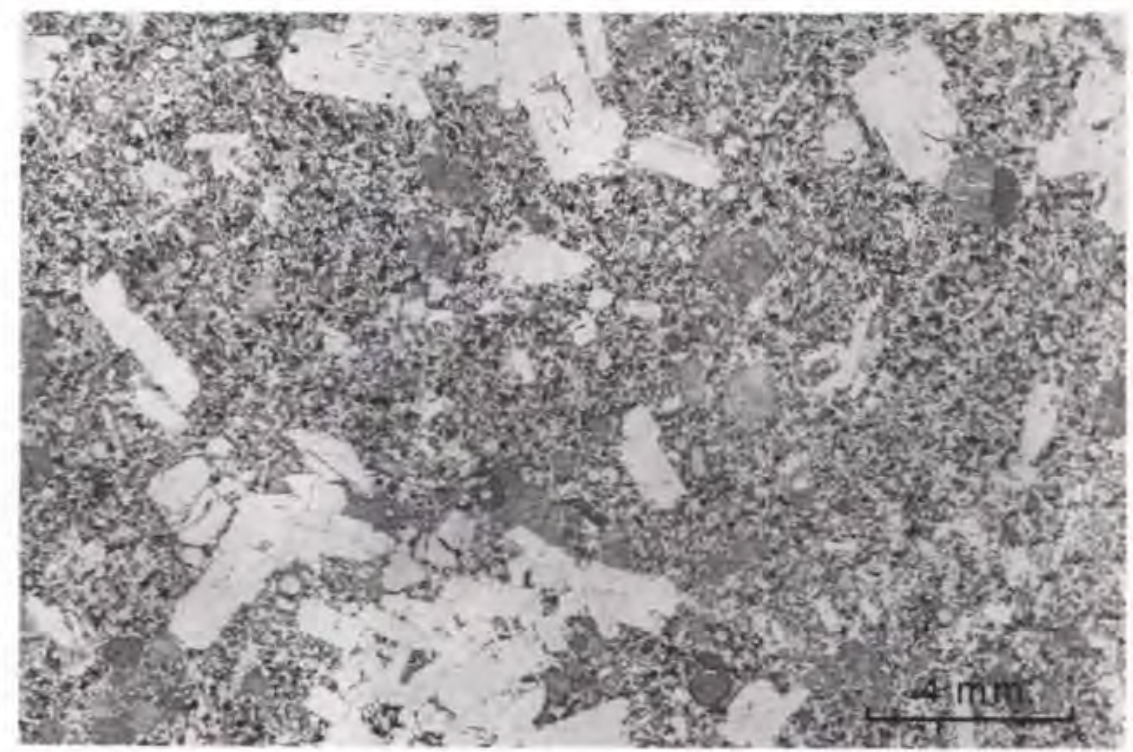


crystals up to $2 \mathrm{~mm}$ large, often less. The two forms occur side by side (fig. 40). The platy crystals appear corroded, in contrast to the equant ones. Scattered chromite octahedra occur in both types of olivine and have also been found in a few augite phenocrysts. Augite phenocrysts amount to $2-4 \%$ and many are unusually large, up to $2 \mathrm{~mm}$ in size. Some of these show evidence of two-stage growth, with concentric inclusion zones near the rims (fig. 53). The smaller ones form glomerocrysts as in the main basalts.

The groundmass of this flow is moderately fine grained and with intergranular texture. Brown mesostasis speckled with tiny oxide crystals and light crisscross needlets occur abundantly in all samples. Pigeonite was only found in reaction rims on olivine.

\section{Main basalts}

The four types of main basalt (low- Ti, med-Ti, high- $\mathrm{Ti}$ basalt and titano-tholeiite) are very similar petrographically and are described together. Their systematic modal differences are outlined in Table 9. They have phenocrysts of plagioclase, olivine and sometimes augite in amounts varying from 0 to $15 \%$, with plagioclase as the by far most abundant phase.

The plagioclase phenocrysts occur as single crystals or in aggregates of several individuals. These aggregates range in appearance from tight clusters of near-parallel crystals to loose clusters of randomly orientated crystals. Several clusters contain also phenocrysts of olivine, and sometimes subhedral augite, giving the cluster a gabbroic appearance. Judged from the zoning pattern in the plagioclases many of these crystals have been clustered together for some time during growth, but their outer parts, towards the groundmass, are euhedral and show that the clusters were suspended in a liquid while they grew. The plagioclase zoning patterns are described in the section on the feldspars.

The olivine phenocrysts are subhedral to euhedral and often inconspicuous because of their small size, barely larger than the groundmass. They are often heavily altered.

Augite phenocrysts are most frequently seen in the more porphyritic lavas, but there are differences between the individual formations, as set out below. Single augite phenocrysts are usually subhedral and relatively small, especially in the three lower formations. Augite phenocrysts often form tight rounded clusters of several anhedral individuals. Superficially, these glomerocrysts have the appearance of xenocrysts, but their composition is identical with that of single augite phenocrysts in the same rock. Moreover, similar clusters of microphenocrysts are found in glassy rocks, and we believe they are cognate.

The groundmasses are mostly fine grained with intergranular texture, but there are large and unsystematic variations in both grain size and texture. Segregation pockets were described in the general section.

In the following the characteristics of the main basalts from the successive formations and dykes are pointed out.

Magga Dan Formation. The crystalline lavas have only scarce and small phenocrysts in a fine-grained groundmass. In general, the lavas of this formation contain more glass and mesostasis than those from the later formations. Some lavas are only partly crystalline, with an intersertal texture, and in these rocks microphenocrysts of olivine, plagioclase and augite may be discerned. These phases are clearly seen in the glassy rocks of the pillow breccias. Rare small chromite crystals have been found enclosed in olivine in the basalts of this formation.

Milne Land Formation. The main basalts contain up to $10 \%$ of plagioclase phenocrysts (fig. 36). The phenocrysts generally form 2-10 mm long rather slender laths occurring singly or in loose aggregates (fig. 41). Olivine and augite together amount to up to $1 \%$. The olivine phenocrysts are in all studied samples completely altered; they are never seen to contain chromite. Approximately half of the lavas contain augite phenocrysts, mainly those with high phenocryst contents, i.e. the medium-Ti type lavas (fig. 36), while augite phenocrysts were not found in the titano-tholeiite types. The augite crystals usually form glomerocrysts.

The groundmasses are very variable in both grain size ( $<0.1 \mathrm{~mm}$ to $0.8 \mathrm{~mm}$ ) and texture, even within the same lava flow sampled in different profiles.

Geikie Plateau Formation. Phenocrysts in this formation are sparse and are mostly found in the medium-Ti unit. They consist of a few single plagioclase laths, traces of more or less altered olivine and, in approximately one third of porphyritic samples, a few small augite phenocrysts. Chromite has been found in one sample (98575) in an unusually large olivine crystal, possibly a xenocryst. The groundmasses are generally fine grained, with intergranular texture, although coarse ophitic flows do occur. Pigeonite is present in around half of the microprobed samples.

Rømer Fjord Formation. In the 'big feldspar basalts' feldspar phenocrysts constitute $3-10 \%$ of the rock and form laths which are usually around $0.5 \mathrm{~cm}$ long but 
Fig. 41. Thin section of typical basalt from the Milne Land Formation, with plagioclase phenocrysts of single laths or in loose aggregates. No other phenocrysts are visible in this picture. GGU 98599. high-Ti basalt. Plane polarised light.

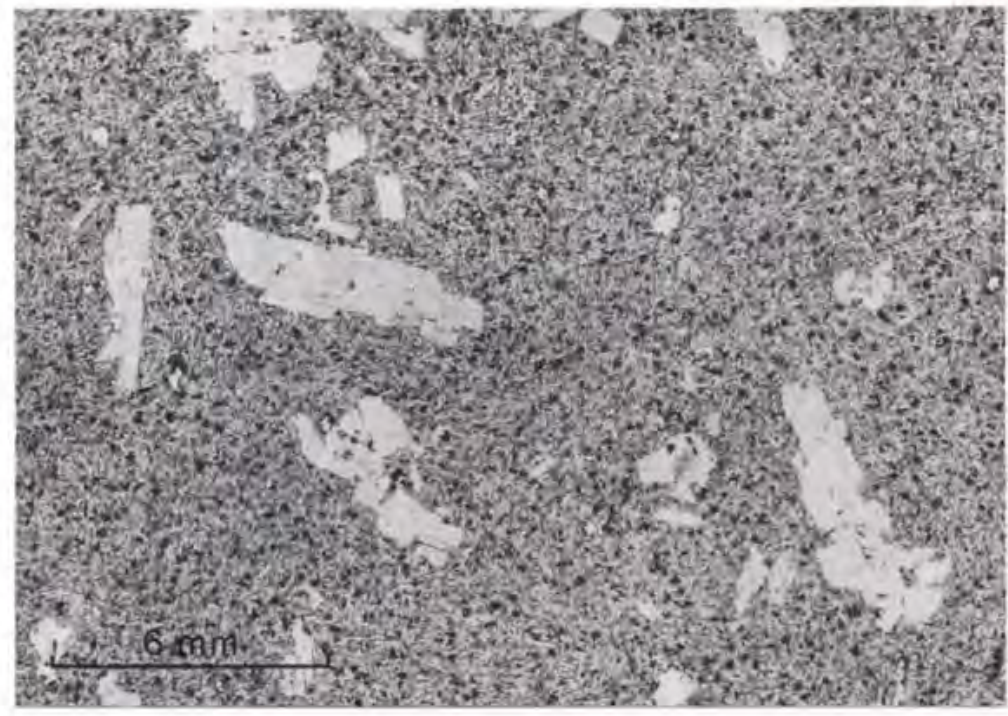

may sometimes be as large as 1-2 cm. They tend to occur in stellate aggregates (fig. 42). Olivine phenocrysts are often completely altered, and augite phenocrysts are rare. The groundmass is usually relatively coarse grained $(0.5-1 \mathrm{~mm})$ and with intergranular to subophitic texture. Yellow-brown interstitial 'glass' (recrystallised) is widespread, and many of the rocks are rather poorly preserved, with no fresh olivine. The amount of zeolite is small.

In the type area around Rømer Fjord the formation contains at the base a sequence of titano-tholeiites. chemically similar to the big feldspar basalts, but with no or few feldspar phenocrysts. Petrographically, these are similar to the groundmass of the big feldspar basalts.

Skranterne Formation. This formation consists of rather monotonous feldsparphyric basalts. The rocks contain typically $2-10 \%$ plagioclase phenocrysts forming small stout broad laths which usually occur in compact clusters of several individuals (fig. 43). The differences in phenocryst content between the three units of the formation (fig. 36) are not noticeable by cursory inspection of thin sections. Scattered small olivine phenocrysts occur in almost all samples. Phenocrysts/microphenocrysts of augite are present in around two thirds of the samples, amounting to $0.5-1 \%$. Groundmasses are usually fine grained and intergranular, but coarser subophitic and ophitic types do occur. Pigeonite occurs in many samples.

In the upper part of the formation the amount and size of the feldspar phenocrysts decrease, while the number of augite microphenocrysts increases.

Fig. 42. Thin section of 'big feldspar busalt' with a stellate aggregate of plagioclase laths. Note olivine phenocrysts between the laths. The section also shows sieve-textured plagioclase crystals and a small augite phenocryst (upper centre). GGU 215532, medium-high-Ti basalt, Rømer Fjord Formation. Plane polarised light.

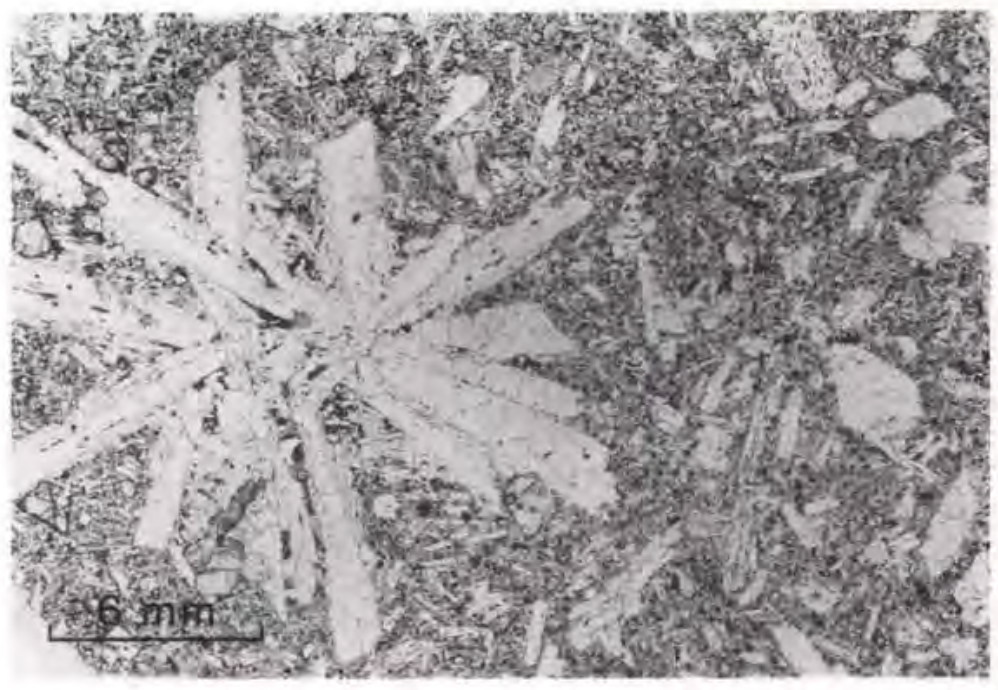




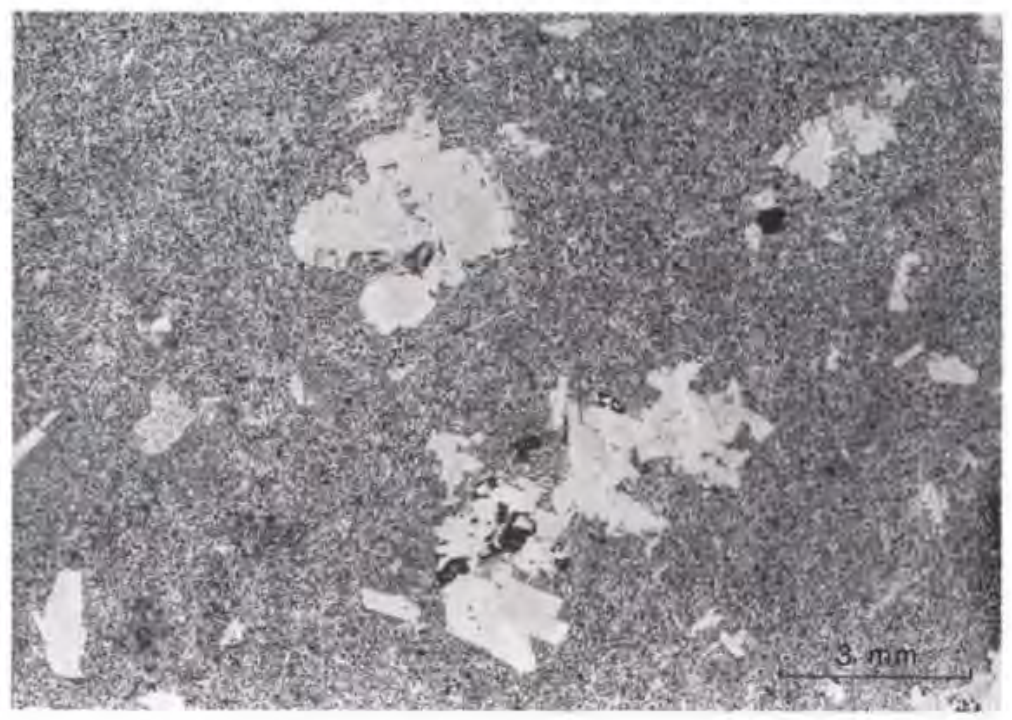

Fig. 43. Thin section of typical basalt from the Skranterne Formation with clusters of small stout plagioclase crystals. Note also a sieve-textured plagioclase crystal (left middle) and heavily altered olivine phenocrysts (mostly black). Augite phenocrysts are present but are inconspicuous on the photograph. GGU 98553, medium-high-Ti basalt. Plane polarised light.

Igtertiva Formation. These lavas have only $0-4 \%$ feldspar phenocrysts of small size (1-2 mm). The lavas are characteristic by containing numerous augite microphenocrysts (fig. 44) together with a few larger augite phenocrysts, amounting to around $2 \%$. The few olivine grains are always completely altered. The groundmasses are fine grained, with intergranular texture.

Tholeitic inland dykes. These are usually sparsely porphyritic with $0-4 \%$ phenocrysts, although a couple of samples have around $11 \%$ total phenocrysts (fig. 36). Glassy chilled contacts tend to have a high content of microphenocrysts (olivine + plagioclase + augite, estimated at $10-20 \%$ ) which in a holocrystalline sample would be recorded as groundmass. The crystalline

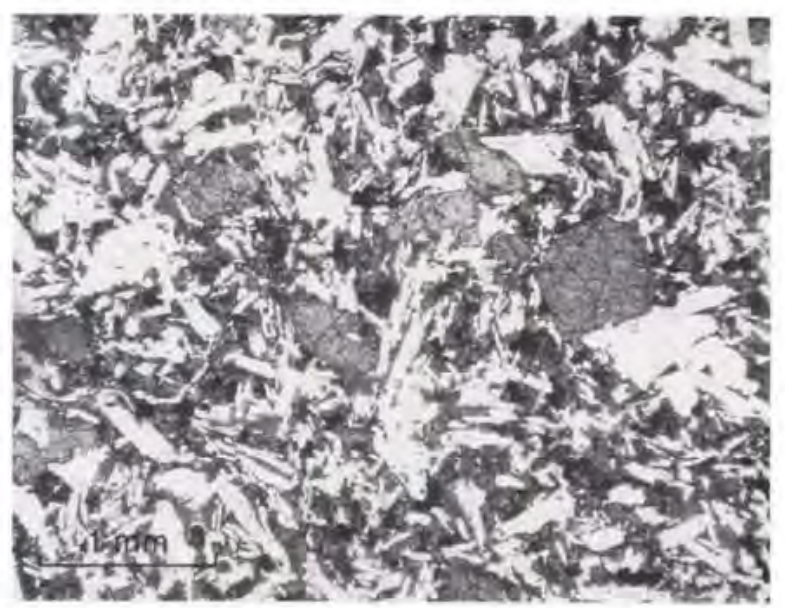

Fig. 44. Thin section of a basalt from the Igtertiva Formation, showing augite microphenocrysts of various sizes. GGU 116348. Plane polarised light. groundmasses vary from fine grained intergranular to coarse grained ophitic (doleritic). These dykes are petrographically quite similar to the lavas of the Geikie Plateau Formation, and they do not resemble the lavas from the Skrænterne and Rømer Fjord Formations.

Tholeitic dykes along the Blosseville Kyst. These dykes are in general more coarse grained than the normal lavas and the dykes in the inland region, and their texture is doleritic, mostly subophitic. Probably due to this many dykes appear aphyric. Phenocrysts of plagioclase amount to $0-2 \%$, and less coarse-grained samples also have evident phenocrysts of olivine and augite in small amounts. In a few cases the amount of phenocrysts goes up to $8-9 \%$ (fig. 36). Samples from chilled contacts have a high content of microphenocrystic olivine, plagioclase and augite, estimated at $10-15 \%$. Approximately half of the samples contain fresh olivine. This contrasts with the lavas of the Skranterne Formation which hosts most of these dykes, and where the olivine almost always is completely broken down. There are no clear petrographic distinctions between the various chemical types of dykes. The two hawaiite dykes encountered are not petrographically distinct from the basalts.

\section{High-Si basalts}

This is a very heterogeneous rock group. Where the high-Si basalt appears to be a just slightly modified main basalt type, as in the Milne Land and Skranterne Formations, its petrography is similar to the main basalts.

The high-Si basalts of the Magga Dan Formation are in some cases crystalline rocks rich in mesostasis with 


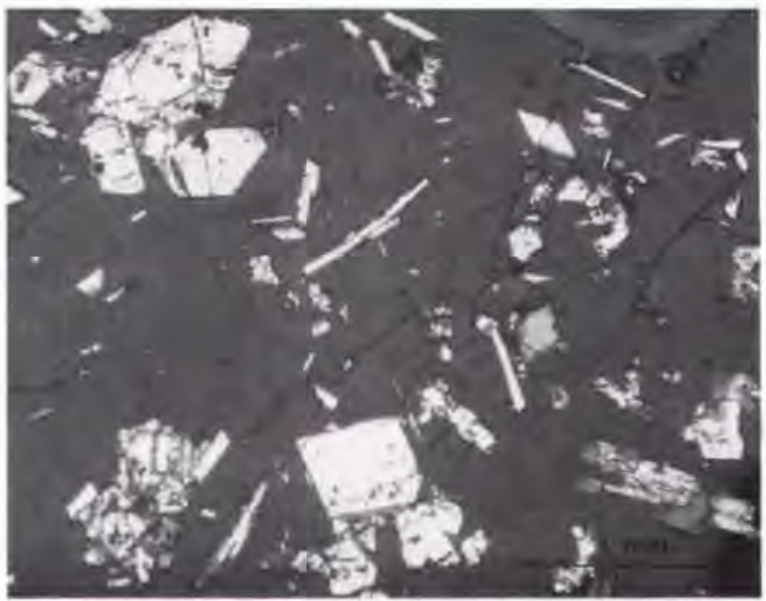

Fig. 45. Thin section of a glassy high-Si basalt. The fresh, homogeneous glass matrix has phenocrysts of euhedral olivine with black chromite inclusions, small slender plagioclase laths, and small clusters of rounded augite crystals (lower left and lower right). Part of a vesicle is seen in the upper right side. GGU 96928. Magga Dan Formation. Partly crossed polars.

small needlets of a $\mathrm{SiO}_{2}$-polymorph, and sometimes with fine-scale globular structures indicating late-stage liquid immiscibility. In other cases they are glassy pillow breccias (fig. 45) with microphenocrysts of olivine, plagioclase and augite, with small chromite octahedra in many olivines, and sometimes also in the fresh yellow glass. One silica-rich pillow breccia sample ( 98788 ) contains phenocrysts of olivine with chromite, and microphenocrysts of orthopyroxene and pigeonite, both mantled by augite, and augite crystals, in a dark aphanitic groundmass with feldspar microliths, and with sparse remains of fresh yellow glass.

\section{Alkaline rocks}

\section{Tuffs in the Rømer Fjord Formation}

The $12 \mathrm{~m}$ thick tuff layer in profile IV (Sydbra) is polymict. In thin section well-rounded up to $1 \mathrm{~mm}$ large lithic fragments are seen of various rock types of alkali basaltic and nephelinitic character, and crystal fragments of colourless and green clinopyroxene, brown kaersutitic amphibole, phlogopite, apatite and perovskite, cemented by carbonate material.

The scattered alkaline fragments from a tuff horizon in profile 117 (Pyramiden) are up to $0.5 \mathrm{~mm}$ large, rounded, lithic fragments very similar to those from profile IV. One $0.2 \mathrm{~mm}$ large fragment of a grass-green alkali pyroxene has also been found.
Petrographically these fragments show great similarities to some of the lamprophyre dykes in western Gáseland, $100 \mathrm{~km}$ WNW of Sydbræ, (see below), and also to some of the nephelinitic lavas from the nunataks $450 \mathrm{~km}$ to the north, described by Brooks et al. (1979).

\section{Tuff in the Igtertiva Formation}

The $7 \mathrm{~m}$ thick pyroclastic horizon at the bottom of profile 91 is polymict. The chemical composition of crystal fragments allow an alkali basaltic and a differentiated alkaline (hawaiitic?) component to be discerned (see chapter on mineralogy). The last-named component is the one causing the eruption, but the glass enclosing the phenocrysts is completely hydrated. Most lithic fragments and a few crystal fragments are of normal tholeiitic basalt.

\section{Alkaline dykes}

The alkaline basaltic dykes encountered in the western part of Gasseland are petrographically distinctive. In addition to the common minerals in basalt they contain abundant apatite and small to considerable amounts of interstitial nepheline, analcime and brown amphibole and biotite. They contain less than $1 \%$ of feldspar phenocrysts, augite phenocrysts are not seen, and in all samples olivine is completely altered. The groundmasses are medium to coarse grained, subophitic to ophitic. Four lamprophyre dykes found in the western part of Gâseland and south of the bottom of Gásefjord belong to two distinct types. The two dykes in Gáseland are alnöites after Rock (1977), with phenocrysts of phlogopite, olivine, clinopyroxene and melilite in a groundmass of prismatic clinopyroxene crystals, equant titanomagnetite and perovskite crystals, phlogopite, and of various zeolites and feldspathoids, Thomsonite, phillipsite, Ba-phillipsite, pectolite and sodalite have been identified. The two dykes south of Gãsefjord are monchiquites after Rock (1977), with phenocrysts of prismatic clinopyroxene, titanomagnetite and biotite with a matrix of light minerals where nepheline, sodalite and $\mathrm{K}$-feldspar have been identified. An alkali trachyte dyke occurs south of the bottom of Găsefjord. This dyke carries phenocrysts of alkali feldspar, brown biotite and apatite in a fine-grained groundmass of alkali feldspar and acicular green aegirine-augite. Obvious xenocrysts are brown amphibole marginally lined by biotite, and colourless or green spongy clinopyroxene. The dyke contains rounded colourless inclusions which consist of a mixture of calcite and a microcrystalline nearly isotropic substance interpreted as hydrated glass. This substance also occurs in the fine-grained groundmass; it 
is a hydrous alumino-silicate very poor in basic cations, and this is possibly the cause of the quartz and corundum-normative character of the chemical analysis of this rock (see later). Other parts of this dyke have a much more mafic character and are clearly silica under- saturated, with abundant interstitial feldspathoids. $\mathrm{Ha}$ waiitic dykes occur in a few instances in the swarm along the Blosseville Kyst. They are only very mildly alkaline, and petrographically they are similar to the tholeiitic dykes of the same swarm.

\section{Mineralogy}

The ehemical composition of the minerals was investigated in selected samples of 35 lavas and pyroclastics and 12 dykes, covering all the chemical types found among the tholeiites and mildly alkaline rocks.

The major part of the microprobe analyses was made with a TPD microprobe at the Research School of Earth Sciences, Canberra, and supplemented with analyses made with a Jeol 533 Superprobe at the Institute of Mineralogy, University of Copenhagen. The analyses were made with an energy-dispersive analytical system, and the procedure applied is as described by Reed \& Ware (1975). The results from the two microprobe laboratories are concordant.

The following sections on the individual minerals are concerned with the tholeitic rocks only. Data on the mineralogy of the few mildly alkaline rocks form a separate section at the end of the chapter. Data on the mineralogy of the strongly alkaline rocks (lamprophyres) are not included.

\section{Olivine}

Olivine, or pseudomorphs after olivine, is present in all types of basalt investigated, from the least to the most evolved. In any rock the olivine crystals usually show a range in size, from obvious phenocrysts through microphenocrysts to groundmass-size olivine. In relatively coarse-grained rocks all the olivine may be of 'groundmass' size. The olivine crystals, especially the larger ones, are subhedral to euhedral, equant rhombshaped or somewhat elongated. The Hjørnedal marker flow contains platy olivine (fig. 40). The glassy rocks (fig. 45) have euhedral olivine phenocrysts with frequent glass inclusions, sometimes grading into skeletal 'hopper' olivines, signalling greater cooling rate and degree of supercooling in the glassy rocks than in the crystalline lavas (Donaldson, 1976). 'Glass' inclusions are infrequent in the olivines from the crystalline lavas.

Visibly xenocrystic olivine, i.e. dusty, spotted, resorbed grains enclosed in either clear olivine or pyroxene, is found in MORB-type basalt and some olivine tholeiites.
Many olivine crystals appear somewhat corroded and are surrounded by a reaction rim of pigeonite, and even euhedral olivines may have such a magmatic reaction rim. Near-solidus oxidation of olivine, as described by Haggerty (1976a), has occurred in a few samples where the olivines are either marginally or completely decomposed to a fine-grained, symplectic intergrowth of magnetite and Ca-poor pyroxene, mostly pigeonite, but also hypersthene. Low-temperature alteration (deuteric or weathering) of olivine is widespread, and often the olivine crystals are completely pseudomorphosed by brown or green masses of clay minerals. Carbonate may also replace olivine. Only very few samples, mostly glassy ones, contain completely unaltered olivine.

Chemical compositions. The microprobe analyses show that there is a wide range of olivine compositions present in most samples. There is usually a good correlation between crystal size and composition, such that the largest olivine crystals are the most $\mathrm{Mg}$-rich and the smallest olivine crystals are the most Fe-rich. Many crystals tend to be slightly zoned, the rims having $1-3 \%$ Fo less than the centres.

The chemical composition of the olivines in the investigated tholeiitic rocks is compiled in fig. 46 which also shows the calculated equilibrium olivine compositions. There is a fairly good correlation between most measured olivine phenocrysts and calculated olivine compositions, but there are also cases of evident discrepancy.

Olivine more magnesian than the calculated equilibrium olivine may have two explanations. Either it is xenocrystic, or the magma had a greater oxidation ratio than the $\mathrm{Fe}_{2} \mathrm{O}_{3} / \mathrm{FeO}=0.15$ used in the calculation of the olivine which is then too iron-rich. However, the discrepancy of $5 \%$ forsterite in the rock 98788 demands a magma oxidation ratio of 1.0 for the calculated olivine to attain the composition of the measured, and there are no signs in the rock that it was so oxidised. It is concluded that most excessively forsterite-rich olivines are xenocrysts. In fig. 46 there are at least five examples of too $\mathrm{Mg}$-rich olivines. The two $\mathrm{Mg}$-rich analyses from 


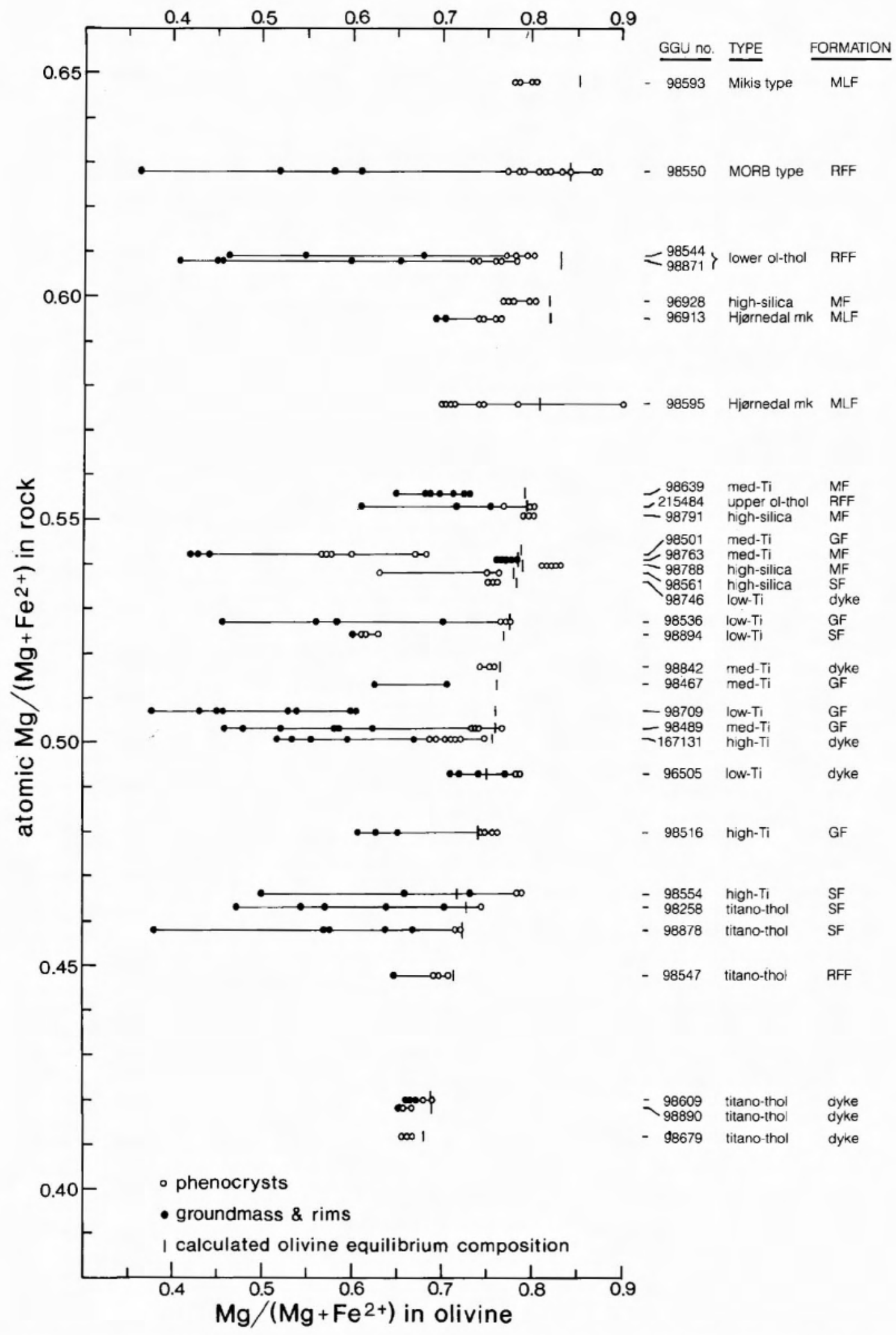

Fig. 46. Olivine compositional ranges in individual tholeiitic rocks, plotted against the $\mathrm{Mg}$ ratios of the rocks. One point represents at least one analysis. The olivine equilibrium compositions are calculated after the method of Ford et al. (1983). 
sample 98550 are both from visibly xenocrystic olivines. The analysed olivine of $\mathrm{Fo}_{\mathrm{y}_{0}}$-composition in 98595 is in no way visibly different from the other equant olivine crystals in this Hjørnedal marker sample, but a xenocryst it must be. The olivine phenocrysts in samples 98788, 96505 and 98554 are also too $\mathrm{Mg}$-rich to be equilibrium olivines.

Olivine less magnesian than the calculated equilibrium olivine may have three explanations. It is either xenocrystic, re-equilibrated or, for small discrepancies, a calculation effect brought about by using the bulk rock composition instead of glass as the liquid in equilibrium with the olivine. The effect of this is to raise the forsterite content in the calculated olivine by $2-5 \%$ (as discussed in the later section on glassy rocks and illustrated in Table 18). This may explain the slight discrepancy between some calculated and measured olivine phenocrysts. Larger discrepancies may be due to re-equilibration of the olivine. This effect has been demonstrated by e.g. Moore \& Evans (1967) who showed that olivine phenocrysts suspended in a lava lake are extensively re-equilibrated during groundmass crystallisation and subsolidus cooling at $800-1000^{\circ} \mathrm{C}$. It is possible that the relatively large range in olivine phenocryst centre compositions in some rocks, e.g. 98550 and 98595 , signal incipient re-equilibration. Significantly, in the $\mathrm{Hjør-}$ nedal marker (sample 98595) the platy olivine phenocrysts, whose relatively large surface/interior ratios make them more susceptible to alteration, are more iron-rich $\left(\mathrm{Fo}_{70-72}\right)$ than the equant olivines $\left(\mathrm{Fo}_{74-79}\right) . \mathrm{Mg}$ poor olivine phenocrysts $\left(\mathrm{Fo}_{57-68}\right)$, grossly out of equilibrium with the bulk rock, are found in samples 98501, 98894 and 98561 . These olivine crystals have no xenocrystic appearance and are normally zoned; they are either xenocrysts, or they are completely re-equilibrated during cooling of the lava.

The extent to which the groundmass olivines are reequilibrated remains unknown, but the good correlation noted above between crystal size and composition indicates that they may be so. Moore \& Evans (1967) found lava lake olivines as iron-rich as $\mathrm{Fo}_{45}$, in good accordance with the data in fig. 46.

In conclusion, most analysed olivine phenocrysts have near-equilibrium compositions, possibly slightly modified by later re-equilibration.

Minor elements. Manganese in the analysed olivines varies from below detection limit $(0.2 \% \mathrm{MnO})$ in the most $\mathrm{Mg}$-rich olivines to a maximum of $0.75 \% \mathrm{MnO}$ in the most $\mathrm{Mg}$-poor olivines. The co-variation of $\mathrm{Fe}$ and $\mathrm{Mn}$ is regular as found by Simkin \& Smith (1970), and the manganese contents are at the same level as found by these authors for a variety of rock types.
Calcium in the olivines lies in the range $0.1-0.5 \%$ $\mathrm{CaO}$, the same as found by Simkin \& Smith (1970) for olivines from extrusive rocks. There is no systematic variation in the $\mathrm{Ca}$ content of the olivines.

Nickel is barely above detection limit $(0.2 \% \mathrm{NiO})$ in the most $\mathrm{Mg}$-rich olivines and is below detection limit in most of the analysed olivines. The indicated range in $\mathrm{Ni}$ contents is thus probably like that found by Simkin \& Smith (1970).

\section{Chromite}

Early-formed chromite is found as small $(<0,04 \mathrm{~mm})$ opaque to semi-transparent octahedral crystals enclosed in olivine or, rarely, in augite or in glassy groundmass. Chromite is frequent in the Mg-rich basalt types (Mikis type, MORB type, olivine tholeiite and Hjørnedal marker) and also in the high-silica glassy rocks of the Magga Dan Formation. It is sporadically seen in a few main basalts from the Magga Dan Formation. During the probe work two occurrences of chromite in olivine from the main basalts from the Geikie Plateau and Skrænterne Formations were found (98575 and 98894), one of these (98575) in an unusually large $(1.5 \mathrm{~mm})$ olivine pseudomorph. In general, however, the main basalts do not carry chromite. Tiny chromite-like oxide crystals enclosed in olivine or augite phenocrysts are sporadically found in a few of the titano-tholeiites; these are chromian titanomagnetites and are also plotted in the chromite diagrams (fig. 47). Chromite thus occurs in lavas with $\mathrm{Mg}$ ratios above 0.56 and $\mathrm{Cr}$ contents above $350 \mathrm{ppm}$ (fig. 80); lavas with $\mathrm{Mg}$ ratios in the interval $0.56-0.45$ have no early-formed spinel, while lavas with $\mathrm{Mg}$ ratios less than 0.45 may have early-formed chromian titanomagnetite.

Similar discontinuous spinel series have been found in other rock suites: Sigurdsson \& Schilling (1976) found that chromite in Mid-Atlantic Ridge basalts is restricted to lavas with $\mathrm{Mg}$ ratios above 0.60 and $\mathrm{Cr}$ contents above $350 \mathrm{ppm}$, while Thy (1983) found that chromite occurs in Icelandic basaltic glasses with $\mathrm{Mg}$ ratios above 0.50 and titanomagnetite in glasses with $\mathrm{Mg}$ ratios below 0.43 . These limits for the no-spinel field are similar to those for the Scoresby Sund basalts. Experimental data have likewise delineated a no-spinel field in basalts with low oxygen fugacities (less than $10^{-9}$, Hill \& Roeder, 1974).

The orthopyroxene-bearing high-silica lava 98788 , with a $\mathrm{Mg}$ ratio of 0.540 , carries frequent chromite. This rock, which shows several features of mineral disequilibrium, has a very high $\mathrm{Cr}$ content, $922 \mathrm{ppm}$, which is far above the saturation value of $350 \mathrm{ppm} \mathrm{Cr}$ found by Sigurdsson \& Schilling (1976) and Maurel \& Maurel 
(1982a). This saturation value also applies to the Scoresby Sund basalts, and sample 98788 appears to have accumulated chromite.

The chromite crystals are normally euhedral to somewhat rounded. Zoning is not seen. A few grains in the Mikis type sample, in a hollowness in an olivine crystal, show fine-scale exsolution and are rimmed by titanian chromite. The 'dusty' olivine xenocrysts in the MORBtype 98550 have corroded and irregular chromite grains, and part of the 'dust' consists of around 1 micron small chromite blebs, especially frequent in diffuse zones around the larger chromite grains.
Chemical compositions. Selected analyses of chromites are presented in Table 10, and all analyses are plotted in fig. 47. These chromites are magnesium-poor and ironrich compared to those from Icelandic glassy basalts (Thy, 1983) and ocean floor basalts (e.g. Sigurdsson \& Schilling, 1976; Bryan et al., 1981). They have similar $\mathrm{Mg} /\left(\mathrm{Mg}+\mathrm{Fe}^{2+}\right)$ ratios to the chromites from the picrites in Kangerdlugssuaq (Nielsen et al., 1981) but have lower $\mathrm{Cr} /(\mathrm{Cr}+\mathrm{Al})$ ratios than most of these, probably because this ratio is far lower in the basalts than in the picrites. The chromites from the Scoresby Sund basalts are broadly similar to chromites from Hawaiian basalts

Table 10. Microprobe analyses of chromites and chromian titanomagnetite

\begin{tabular}{|c|c|c|c|c|c|c|c|c|c|}
\hline$w t \%$ & 1 & 2 & 3 & 4 & 5 & 6 & 7 & 8 & 9 \\
\hline $\mathrm{TiO}_{2}$ & 2.62 & 3.68 & 0.69 & 2.98 & 2.20 & 5.29 & 1.81 & 1.25 & 17.79 \\
\hline $\mathrm{Al}_{2} \mathrm{O}_{3}$ & 14.38 & 16.15 & 26.17 & 18.93 & 14.97 & 18.16 & 12.61 & 8.00 & 9.60 \\
\hline $\mathrm{V}_{2} \mathrm{O}_{3}$ & na & 0.64 & 0.16 & 0.52 & 0.53 & na & 0.46 & na & na \\
\hline $\mathrm{Cr}_{2} \mathrm{O}_{3}$ & 42.33 & 36.80 & 32.94 & 35.58 & 33.33 & 28.20 & 42.06 & 23.06 & 6.94 \\
\hline $\mathrm{Fe}_{2} \mathrm{O}_{3}$ & 9.07 & 10.00 & 9.60 & 8.80 & 15.27 & 11.57 & 10.01 & 33.94 & 18.26 \\
\hline $\mathrm{FeO}$ & 20.88 & 22.04 & 18.54 & 26.40 & 29.21 & 27.44 & 27.34 & 30.16 & 42.87 \\
\hline $\mathrm{MnO}$ & 0.22 & 0.28 & 0.22 & 0.45 & 0.40 & 0.31 & 0.42 & 0.42 & 0.32 \\
\hline \multirow[t]{2}{*}{$\mathrm{MgO}$} & 10.01 & 10.03 & 11.72 & 7.22 & 4.36 & 7.35 & 5.06 & 1.95 & 3.96 \\
\hline & 99.51 & 99.62 & 100.04 & 100.88 & 100.27 & 98.32 & 99.86 & 98.78 & 99.74 \\
\hline \multicolumn{10}{|c|}{ cations based on 24 cations and 32 oxygens } \\
\hline $\mathrm{Ti}$ & 0.515 & 0.718 & 0.127 & 0.579 & 0.447 & 1.054 & 0.370 & 0.273 & 3.736 \\
\hline Al & 4.433 & 4.938 & 7.562 & 5.763 & 4.768 & 5.674 & 4.045 & 2.739 & 3.160 \\
\hline$v$ & - & 0.132 & 0.032 & 0.108 & 0.115 & - & 0.099 & - & - \\
\hline $\mathrm{Cr}$ & 8.751 & 7.544 & 6.381 & 7.262 & $7+117$ & 5.909 & 9.047 & 5.295 & 1.532 \\
\hline $\mathrm{Fe}^{t+}$ & 1.786 & 1.951 & 1.771 & 1.710 & 3.105 & 2.308 & 2.068 & 7.419 & 3.836 \\
\hline $\mathrm{Fe}^{2+}$ & 4.565 & 4.780 & 3.801 & 5.702 & 6.600 & 6.082 & 6.222 & 7.326 & 10.012 \\
\hline $\mathrm{Mn}$ & 0.049 & 0.062 & 0.046 & 0.098 & 0.092 & 0.070 & 0.097 & 0.103 & 0.076 \\
\hline $\mathrm{Mg}$ & 3.901 & 3.877 & 4.281 & 2.779 & 1.756 & 2.903 & 2.052 & 0.844 & 1.648 \\
\hline $\mathrm{Mg} /\left(\mathrm{Mg}+\mathrm{Fe}^{2+}\right)$ & 0.461 & 0.448 & 0.530 & 0.328 & 0.210 & 0.323 & 0.248 & 0.103 & 0.141 \\
\hline $\mathrm{Cr} /(\mathrm{Cr}+\mathrm{Al})$ & 0.664 & 0.604 & 0.458 & 0.558 & 0.599 & 0.510 & 0.690 & 0.660 & 0.330 \\
\hline $\mathrm{Fe}^{3+} /\left(\mathrm{Fe}^{\mathrm{i}-}+\mathrm{Cr}+\mathrm{Al}\right)$ & 0.119 & 0.135 & 0.113 & 0.116 & 0.207 & 0.166 & 0.136 & 0.480 & 0.450 \\
\hline $\mathrm{Ti} /(\mathrm{Ti}+\mathrm{Cr}+\mathrm{Al})$ & 0.038 & 0.054 & 0.009 & 0.043 & 0.036 & 0.083 & 0.027 & 0.033 & 0.443 \\
\hline
\end{tabular}

Energy-dispersive analyses, Small amounts $(0.1-0.5 \%)$ of $\mathrm{SiO}_{2}$ and $\mathrm{CaO}$ disregarded.

$\mathrm{V}_{2} \mathrm{O}_{3}$ semiquantitative only. $\mathrm{na}=$ not analysed. $\mathrm{Fe}_{2} \mathrm{O}_{3}$ calculated from stoichiometry assumption.

I Chromite in olivine, $\mathrm{Fo}_{80.5}$. High-silica basalt, GGU 96928, Magga Dan Formation.

2 Chromite in olivine pseudomorph. Med -Ti rype basalt, GGU 98763, Magga Dan Formation.

3 Chromite in olivine $\mathrm{FO}_{83}$. MORB type basalt, GGU 98550, Rømer Fjord Formation.

4 Chromite in large olivine $\mathrm{Fo}_{17,3}$. Olivine tholeiite, GGU 98544, lower compound unit, Rømer Fjord Formation.

5 Chromite in rim of small olivine $\mathrm{Fo}_{55,0}$. Olivine tholeiite, GGU 98544, lower compound unit, Rømer Fjord Formation.

6 Chromite in small olivine $\mathrm{Fo}_{71,7}$. Olivine tholeite, GGU 215484, upper compound unit, Rømer Fjord Formation.

7 Re-equilibrated chromite in olivine $\mathrm{Fo}_{80.0}$. Mikis type basalt, GGU 98593, Milne Land Formation.

8 Re-equilibrated chromite in olivine $\mathrm{Fo}_{61}$. Low-Ti type basalt, GGU 98894, Skraenterne Formation.

9 Chromian titanomagnetite in olivine $\mathrm{Fo}_{70.9}$. Titano-tholeiite, GGU 98547, Rømer Fjord Formation. 


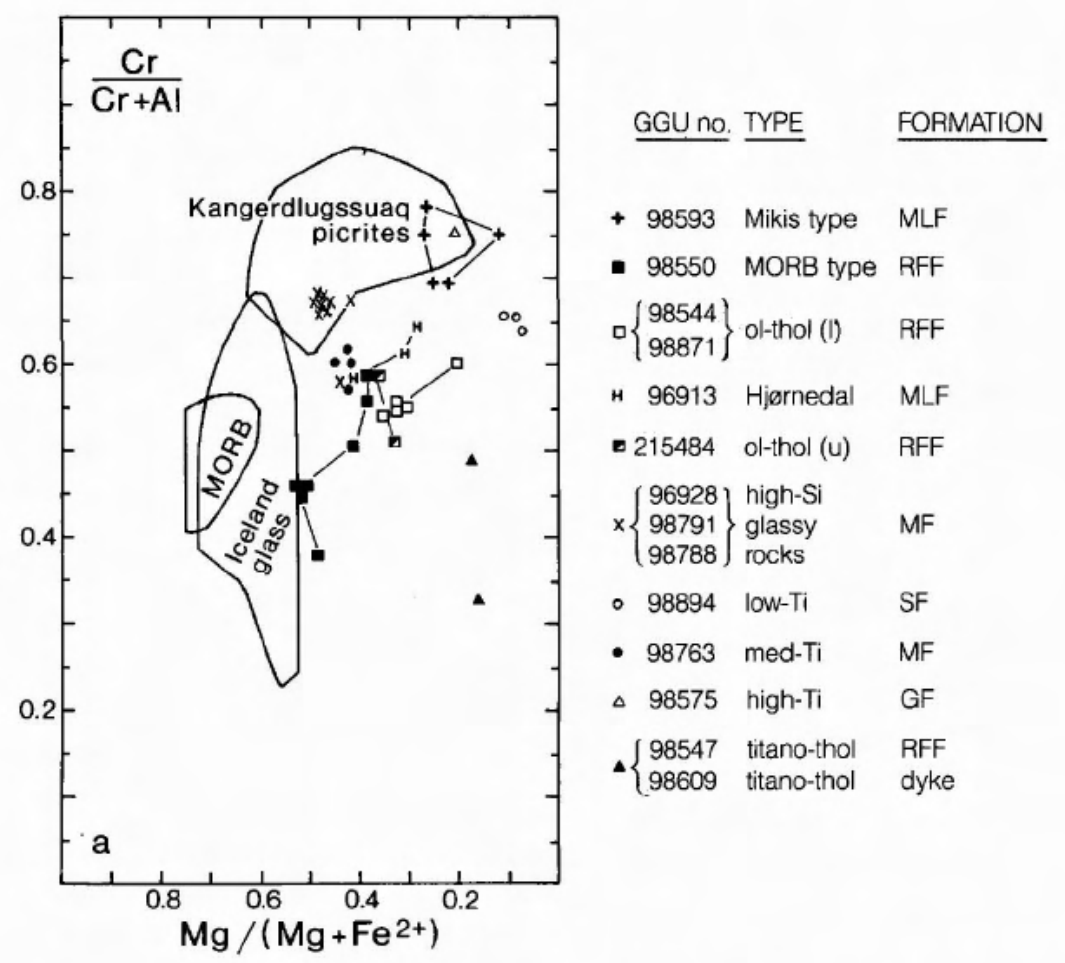

Fig. 47. Compositions of the analysed chromites plotted on three faces of the spinel prism. Lines are inserted to support the recognition of analyses from one rock type, i.e. the lines do not connect analyses from single zoned grains. The two analyses from the titano-tholeiites are chromiferous titanomagnetites, not chromites. See text for discussion.

Data from Kangerdlugssuaq picrites from Nielsen et al. (1981), for Icelandic glasses from Thy (1983) and Mäkipää (1978) and for MORB glasses from Sigurdsson \& Schilling (1976).
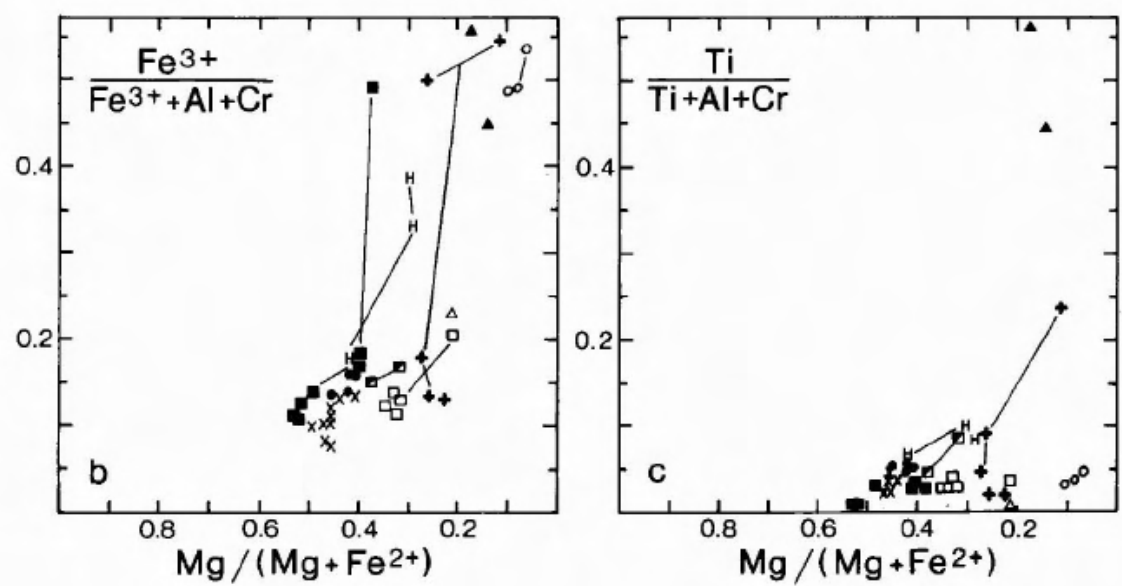

(Evans \& Moore, 1968; Evans \& Wright, 1972; Beeson, 1976).

Primary chromite has high contents of $\mathrm{Cr}_{2} \mathrm{O}_{3}, \mathrm{Al}_{2} \mathrm{O}_{3}$ and $\mathrm{MgO}$ but tends, by reaction with late liquids or by subsolidus re-equilibration, to become enriched in $\mathrm{FeO}$, $\mathrm{Fe}_{2} \mathrm{O}_{3}$ and $\mathrm{TiO}_{2}$ (Haggerty, 1976b). Examples of such $\mathrm{Fe}_{2} \mathrm{O}_{3}$ - and $\mathrm{TiO}_{2}$-enriched compositions are clearly seen in fig. $47 \mathrm{~b} \& \mathrm{c}$, although most analysed crystals seem not to be affected. The two chromian titanomagnetites from the titanotholeiites have primary high $\mathrm{TiO}_{2}$ contents. The contents of both $\mathrm{Cr}_{2} \mathrm{O}_{3}$ and $\mathrm{Al}_{2} \mathrm{O}_{3}$ decrease during re-equilibration, and thus the $\mathrm{Cr} /(\mathrm{Cr}+\mathrm{Al})$ ratio may behave variably. In fig. 47a it usually increases with re-equilibration.

The phenocrysts that enclose the small chromite crystals protect them to a certain degree from later reactions. Pyroxene protects very well while olivine does not, and both olivine and enclosed chromite may exchange $\mathrm{MgO}$ and $\mathrm{FeO}$ with the surroundings (Roeder \& Campbell, 1985). This has often happened in plutonic rocks, while chromites and olivines from rapidly chilled glassy rocks usually have retained their primary compositions (e.g. discussion in Thompson, 1973). A comparison of the $\mathrm{Mg}$ ratios in coexisting chromites and oli- 
Fig. 48. $\mathrm{Mg} /\left(\mathrm{Mg}+\mathrm{Fe}^{2+}\right)$ ratios in coexisting olivines and spinels. Only data for olivine crystals with included spinel are plotted except for the three points in parenthesis. For these three points two are combinations of spinel (included in augite) and another olivine crystal, and one (98575) is a combination of spinel and the calculated olivine composition since all olivine in this sample is altered. Symbols as in fig. 47.

Data for Snake River basalt from Thompson (1973), for Icelandic glasses from Thy (1983) and Mäkipää (1978), for MORB glasses from Sigurdsson \& Schilling (1976), for Kilauea basalts from Evans \& Wright (1972) and for Stillwater from Jackson (1969).

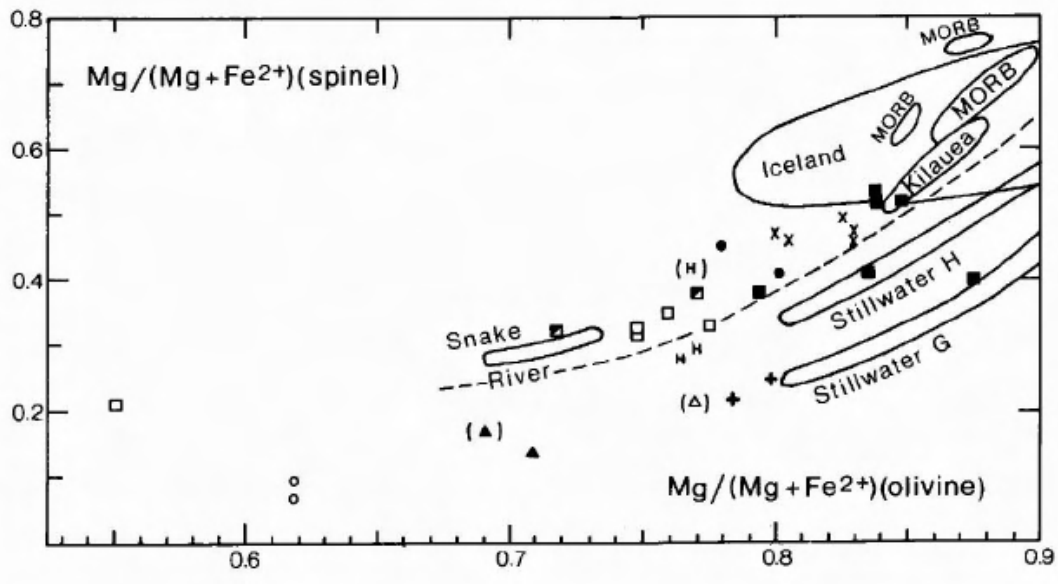

vines, as given in fig. 48, may indicate whether the minerals have re-equilibrated. Primary, unaltered olivine and chromite from Iceland, mid-ocean ridges, $\mathrm{Ki}$ lauea and Snake River form a consistent trend in this diagram, while re-equilibrated minerals like those from Stillwater plot below the primary trend. It appears from fig. 48 that many mineral pairs from the Scoresby Sund basalts are unaltered including, as expected, those from the glassy rocks. On the other hand it is also clear that some pairs are re-equilibrated, notably all from the Mikis type basalt and two or three MORB type pairs. The samples with re-equilibrated mineral pairs 98593 (Mikis type) and 98894 (low-Ti type) were also in the section on olivine pointed out as having re-equilibrated olivines. Conclusions about the mineral pairs from the two titano-tholeiites are more difficult because the chromian titanomagnetites are so different from the chro- mites. Their position in fig. 48 may indicate that they are re-equilibrated. In general, chromites with $\mathrm{Mg}$ ratios below 0.3 are considered possibly re-equilibrated.

Fig. 47a shows that there are significant differences in $\mathrm{Cr} /(\mathrm{Cr}+\mathrm{Al})$ ratios of the unaltered chromites from the various rock types. The differences are a consequence of increasing $\mathrm{Cr}$ partition coefficients with decreasing temperature, concomitantly with decreasing $\mathrm{Cr}$ contents and constant $\mathrm{Al}$ contents in the liquid. Using the $\mathrm{Cr}$ partition data of Maurel \& Maurel (1982a) it is possible to reproduce by calculation the measured $\mathrm{Cr}_{2} \mathrm{O}_{3}$ contents in the chromites, as shown in Table 11. Considering the roughness of the calculations the data reproduce quite well. The Hjørnedal chromite and the Skrænterne Formation chromite, which are also from fig. 48 indicated to be re-equilibrated, seem to have lost $\mathrm{Cr}$, while the re-equilibrated Mikis type chromite has

Table 11. Comparison of calculated and measured $\mathrm{Cr}_{2} \mathrm{O}_{3}$ contents in chromite

\begin{tabular}{lccccc}
\hline Type & $\mathrm{T}^{\circ} \mathrm{C}$ & $\mathrm{Cr}$ ppm & $\mathrm{Cr}_{\mathrm{cm}} / \mathrm{Cr}_{\text {liq }}$ & $\begin{array}{c}\text { chromite } \\
\mathrm{Cr}_{2} \mathrm{O}_{3} \text { (calc) }\end{array}$ & $\begin{array}{c}\text { chromite } \\
\mathrm{Cr}_{2} \mathrm{O}_{3} \text { (meas) }\end{array}$ \\
\hline Mikis & 1280 & 750 & 400 & 43.8 & 42.8 \\
olivine thol. & 1230 & 500 & 500 & 36.5 & 35.6 \\
MORB & 1210 & 400 & 600 & 35.1 & 32.9 \\
Hjørnedal & 1210 & 450 & 600 & 39.5 & 33.5 \\
high-Si, MF & 1190 & 390 & 800 & 45.6 & 44.0 \\
med-Ti, MF & 1190 & 340 & 800 & 39.8 & 37.9 \\
low-Ti, SF & 1190 & 250 & 800 & 29.2 & 23.0 \\
\hline
\end{tabular}

The data are constructed from different samples.

Temperatures estimated from fig.69.

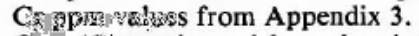

$\mathrm{Cr}, \mathrm{Cr}_{\mathrm{i}}$, trimated from data in Maurel \& Maurel (1982a, fig. 4).

Ctrentite thaspositions measured by microprobe. 
not. Roeder \& Campbell (1985) found several examples of unchanged $\mathrm{Cr} /(\mathrm{Cr}+\mathrm{Al})$ ratios during re-equilibration.

Maurel \& Maurel (1982b) found an empirical relation between $\mathrm{Fe}^{2+} / \mathrm{Fe}^{3+}$ in chromite and in coexisting liquid. Given the unaltered composition of a chromite, the $\mathrm{Fe}^{2+} / \mathrm{Fe}^{3+}$ ratio for the coexisting liquid can be calculated from their eq. 2. This was done for the glasses and crystalline rocks with unchanged chromites, resulting in oxidation ratios wt. $\% \mathrm{Fe}_{2} \mathrm{O}_{3} / \mathrm{FeO}=0.10-0.17$, corresponding rather well with the ratio of 0.15 used for recalculation of all the rock analyses (see chapter on geochemistry). Given the $\mathrm{Fe}^{2+} / \mathrm{Fe}^{3+}$ ratio of the liquid and its temperature (calculated from olivine/liquid equilibria as described later), the oxygen fugacity can be calculated after the method of Sack et al. (1980). The results from this calculation are plotted in fig. 61 in combination with the results from the Fe-Ti oxides and discussed in the Fe-Ti oxide section.

\section{Plagioclase}

Plagioclase is absent as phenocryst phase in the $\mathrm{Mg}$ rich Mikis type basalt, MORB type basalt and olivine tholeiite. Sparse plagioclase phenocrysts occur in some of the more evolved lavas of MORB type and olivine tholeiite. Plagioclase phenocrysts occur in abundance in the Hjørnedal marker flow and in the porphyritic main basalts of all four types. The mineral is a ubiquitous and abundant groundmass phase in all types of basalt (Table 9).

All the plagioclase crystals are compositionally zoned. The groundmass crystals are normally zoned, and usually with no sharp internal contacts. The phenocrysts, however, show several patterns of zoning, some of these very complex, bearing evidence of a complex series of events in the magma before it was finally extruded at the surface. Three distinct morphological parts of the feldspar phenocrysts may be discerned: cores (not always present), mantles and whole crystals (in case no core is present), and rims (always present). These are described separately below, and compositional profiles through selected phenocrysts are shown in fig. 49.

Cores. The cores are of two main types: (a) show slight continuous normal zoning (fig. 49, 98561), and (b) are inhomogeneous, with two or more resorbed zones with varying An content; the outermost zone often has the highest An content (fig. 49, 98547). Both types of cores are often filled with dark brown inclusions (presumably of altered glass) partially bounded by crystallographic planes; the feldspar immediately adjacent to these inclusions tends to have a lower An content than
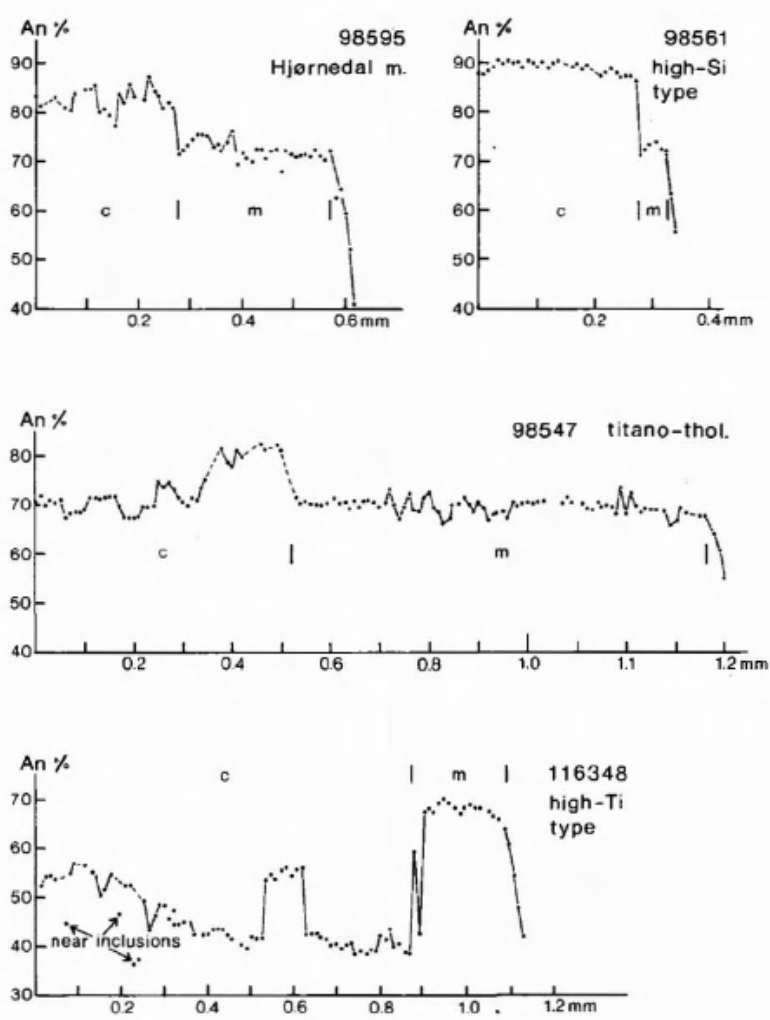

Fig. 49. Compositional profiles across complexly zoned plagioclase phenocrysts. The profiles were obtained by step-scanning with the microprobe, measuring the $\mathrm{Ca}$ and $\mathrm{Na}$ intensities. The $\mathrm{Ca}$ intensities were then converted to $\mathrm{An} \%$ by calibration on fully analysed points in the crystals. $c=$ centres, $m=$ mantles. Rims are self-evident.

the rest of the core, giving the core feldspar a mottled appearance (fig. 50a and fig. 49, 116348). The cores are more or less resorbed and sharply bounded by the mantle; the compositional break between the two parts is usually a drop in An content of 10-15\% An from core to mantle, but cores with lower An content than the mantle also occur (fig. 49, 116348).

Mantles and crystals without cores are also of two types any of which may rim any of the two types of core: (a) Strongly oscillatory zoned plagioclase in which the oscillation patterns vary from fine-scale $(2-10 \mu \mathrm{m})$ with euhedral contacts (fig. 50a) to more coarse-scale (10-30 $\mu \mathrm{m})$ very complicated patterns with signs of repeated resorption (fig. 50b). An oscillation usually covers a difference of less than $4 \%$ An. (b) Plagioclase which is apparently largely homogeneous or which only shows faint traces of oscillatory zoning. Some of these mantles or crystals may in fact be of type (a) because the differences in extinction angles by which the zoning is identified under the microscope are not visible in all crystallographic directions. 

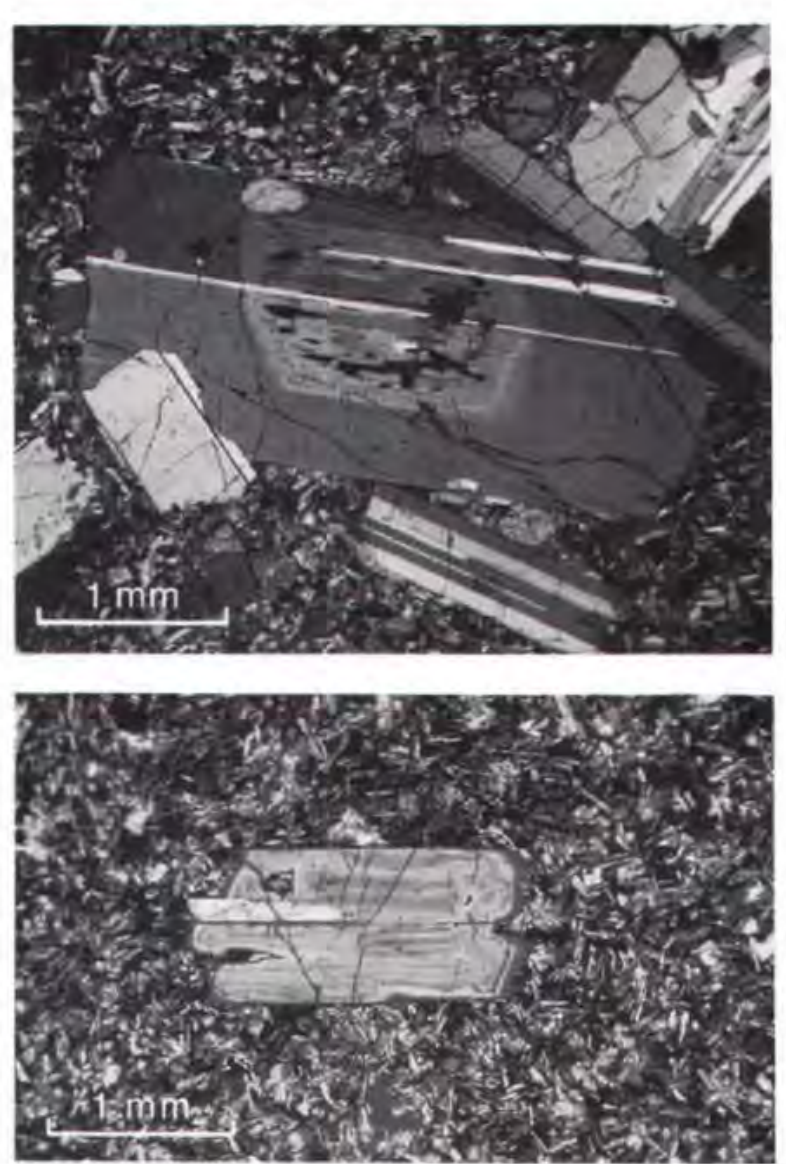

Fig. $50 \mathrm{a}$. Complex zoned plagioclase phenocryst from the Hjørnedal marker flow. GGU 96882 , crossed polars. An inclusion-rich core is surrounded by a broad finely oscillatory zoned margin, and a narrow normally zoned rim. A compositional profile through a similar crystal is shown in fig. 49 (98595) . b. Plagioclase phenocryst in GGU 98639 (Magga Dan Formation), showing a complicated zoning pattern with signs of repeated resorption. Crossed polars.

Both type (a) and (b) mantles and crystals may have brown 'glass' inclusions, although not frequently.

Rims. The narrow outer rims are always normally zoned and correspond in composition to the groundmass plagioclase. The border between the interior and the rim is usually sharp, euhedral, but may be gradational or slightly resorbed.

Combination of the two types of mantle with and without the two types of cores lead to, in principle, six types of feldspar phenocryst zoning, and these occur in all the formations and in all the chemical types which are feldsparphyric. There is no preference for any of the phenocryst types to any of the chemical groups of rocks. Neither is there any connection between phenocryst size and type of zoning. Any single sample, however, tends to have one phenocryst type as the dominant, but two or three types with or without 'glass' inclusions may occur beside each other. Crystals in one aggregate cluster are usually of the same type.

Plagioclase phenocrysts with similar complicated zoning have been described from Bouvetöya (Imsland $e t$ al., 1977), Iceland (Mäkipää, 1978) and the Mid-Atlantic ridge (e.g. Kuo \& Kirkpatrick, 1982). Kuo \& Kirkpatrick related the zoning pattern to pre-eruptive events in the magma chamber involving repeated magma injection and mixing. The cores should thus have formed from the primitive liquid during the injection into the magma chamber; supercooling of this liquid led to skeletal crystallisation and incorporation of the numerous 'glass' inclusions so frequently seen in the cores. The mantles crystallised during convection and repeated mixing of the two magmas (oscillatory zoned) and during differentiation after the mixing was completed (normally zoned). The rims formed during and after the transport of the magma to the surface. The plagioclases in the Scoresby Sund basalts may be similarly interpreted, as discussed later in the section 'Magma mixing and open magma chambers'.

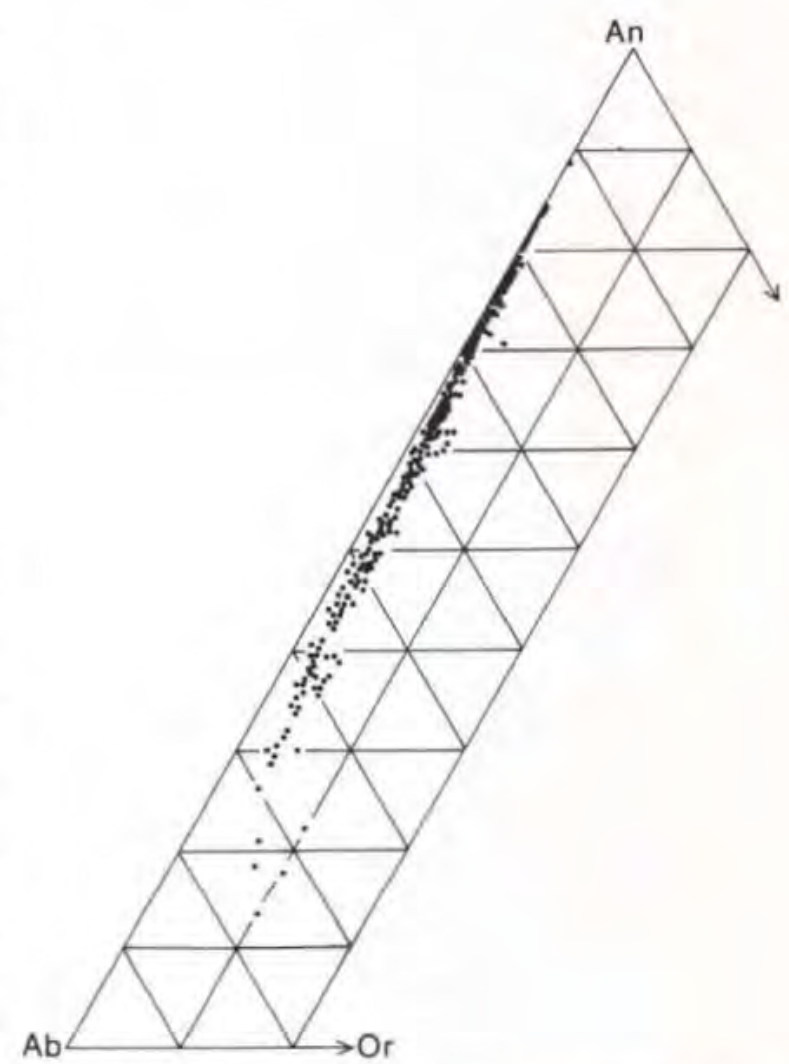

Fig. 51, Compilative plot of feldspar analyses from the tholeiitic lavas and dykes. Ab-An-Or mol per cent. 


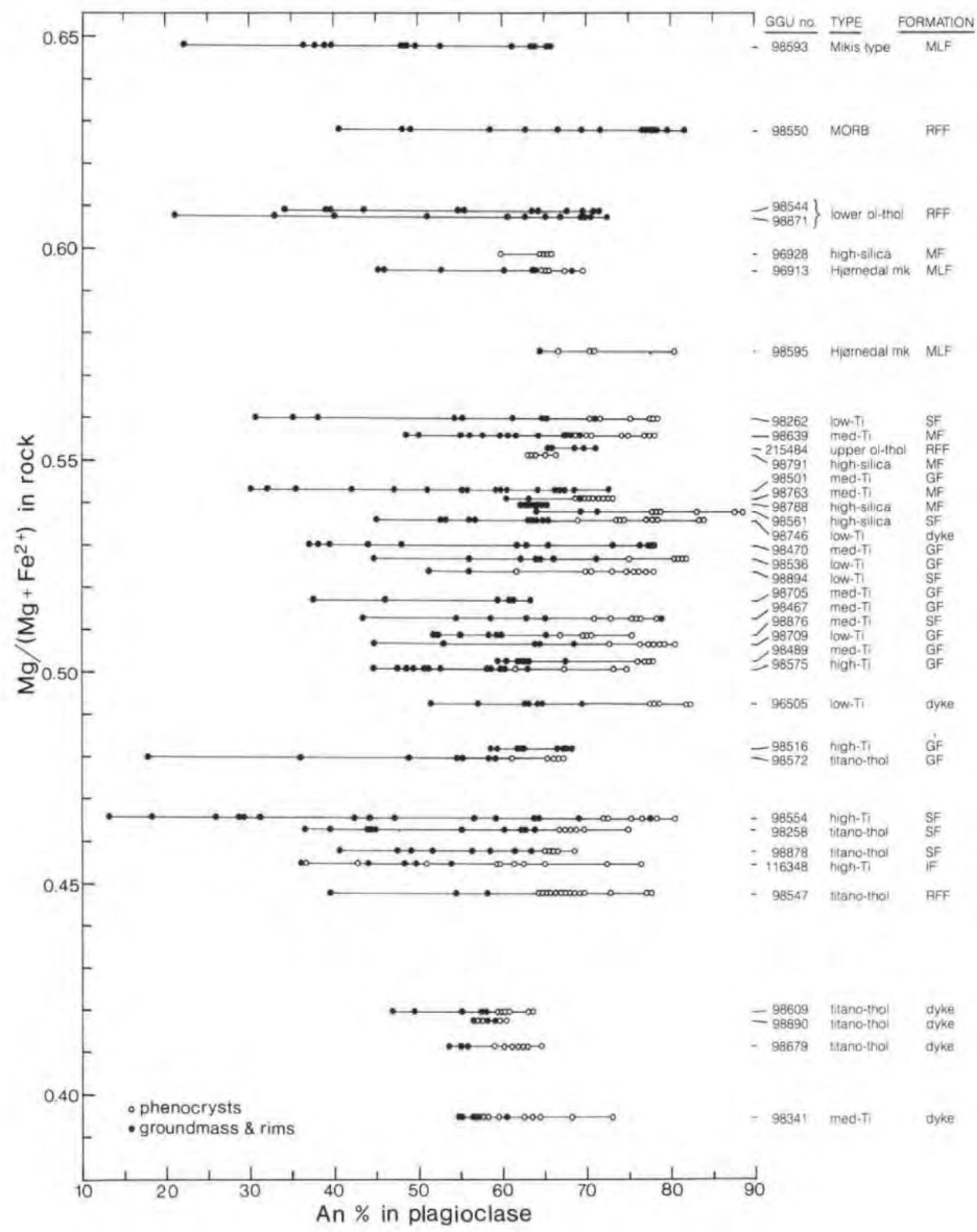

Fig. 52. Feldspar compositional ranges in individual tholeiitic rocks. plotted against the $\mathrm{Mg}$ ratios of the rocks. A point represents af least one analysis; see text for discussion. 
Chemical compositions. The chemical composition of the plagioclases in the investigated tholeiitic rocks is compiled in a triangular diagram (fig. 51), and in fig. 52 the plagioclase compositions are plotted against the $\mathrm{Mg}$ ratio of the rocks. The complete range of feldspar compositions encountered is $\mathrm{An}_{88.3} \mathrm{Ab}_{11,7} \mathrm{Or}_{0}$ to $\mathrm{An}_{13,2^{-}}$ $\mathrm{Ab}_{76,7} \mathrm{Or}_{10.1}$. Fig. 52 shows that there is no simple correlation between the differentiation state (the $\mathrm{Mg}$ ratios) of the basalts and the composition of the plagioclase phenocrysts, although there is a general tendency for the titano-tholeiites to have the more An-poor phenocrysts. The correlation improves if some An-rich cores and marginal zones, obviously not in equilibrium with the main magma, are disregarded, e.g. in 98561, 96505,98341 . Unusually low An contents are found in plagioclase from the high-silica rocks of the Magga Dan Formation $\left(A n_{60-6 b_{0}}\right)$, as may be expected from a relatively more polymerised Si-enriched magma. However, the high-silica lava 98561 from the Skranterne Formation has, on the contrary, unusually An-rich plagioclase (up to $\mathrm{An}_{88}$ ). This may be xenocrystic. Low-An plagioclase obviously not in equilibrium with the magma is found in a phenocryst core in 116348 (figs 49 and 52). Even when these exceptions are disregarded the correlation between the differentiation state of the basalt and the composition of the plagioclase phenocrysts is not good. Calculated equilibrium plagioclases show no connection to the measured plagioclases (see section on glassy rocks) and have not been plotted in fig. 52. The only generalisation that can be obtained from fig. 52 is that the bulk of the main basalts appear to have equilibrium plagioclase of composition $\mathrm{An}_{70-30}$. while the titano-tholeiites are more evolved, with equilibrium plagioclase of composition $\mathrm{An}_{60-70}$.

The composition of the groundmass plagioclases is, as expected, strongly dependent on the crystallisation history of the basalts. The quenched glassy rocks have very narrow feldspar compositional intervals $(98788,98791)$. and at the other extreme is seen a basalt with coarsegrained segregation pockets in which the feldspar has fractionated as far as to $\mathrm{An}_{132}$ (98554). The 'average normal' basalt has groundmass feldspar of composition $\mathrm{An}_{\mathbf{s}_{2}-70}$.

Minor elements. Potassium contents increase regularly with the sodium contents of the plagioclases, from below detection limit (i.e, $0.1 \% \mathrm{~K}_{2} \mathrm{O}$ ) in many phenocrysts to $1.67 \% \mathrm{~K}_{2} \mathrm{O}(10 \% \mathrm{Or})$ in a feldspar in a segregation pocket. The cumulative feldspar triangular diagram (fig. 51) shows that most analyses fall on a narrow band of $\mathrm{K}$-enrichment, and only in late-stage plagioclase with less than $\mathrm{An}_{80}$ individual $\mathrm{K}$-enrichment trends are clearly evident.
For magnesium, the detection limit is $0.2 \% \mathrm{MgO}$, and most analyses show $<0.2-0.4 \% \mathrm{MgO}$ in both phenocryst and groundmass plagioclase. These values are not accurate enough for calculation of $\mathrm{Mg} / \mathrm{Mg}+\mathrm{Fe}$ ratios in the feldspars.

The iron contents are significantly above the detection limit of $0.2 \% \mathrm{FeO}$. The plagioclase phenocrysts have relatively constant contents of $0.5-0.8 \% \mathrm{FeO}$, while in the groundmass plagioclases the iron contents are higher and increase with increasing sodium contents to $1.5 \% \mathrm{FeO}$. There are no evident differences between the lava types.

\section{Pyroxenes}

Augite is absent as phenocryst phase in the Mg-rich Mikis type basalt, MORB type basalt and olivine tholeiite. The Hjørnedal marker flow contains abundant large augite phenocrysts. Augite appears to be on the liquidus in all four main basalt types, but only around half of the porphyritic samples actually carry augite phenocrysts.

The augite phenocrysts show signs of slight compositional zoning in changes of extinction position and darkening of colour towards the rims. Oscillatory zoning is sometimes seen. In some crystals inclusion zones are found near the rims; these are especially frequent in the Hjørnedal marker flow (fig. 53), Visibly xenocrystic augite has been noted in a few cases where brown 'dusty' augite is found as centres in clear, colourless grains. Their xenocrystic nature is confirmed by their composition, as described below.

The groundmass augite varies in form from discrete equant grains in intergranular samples to large ragged

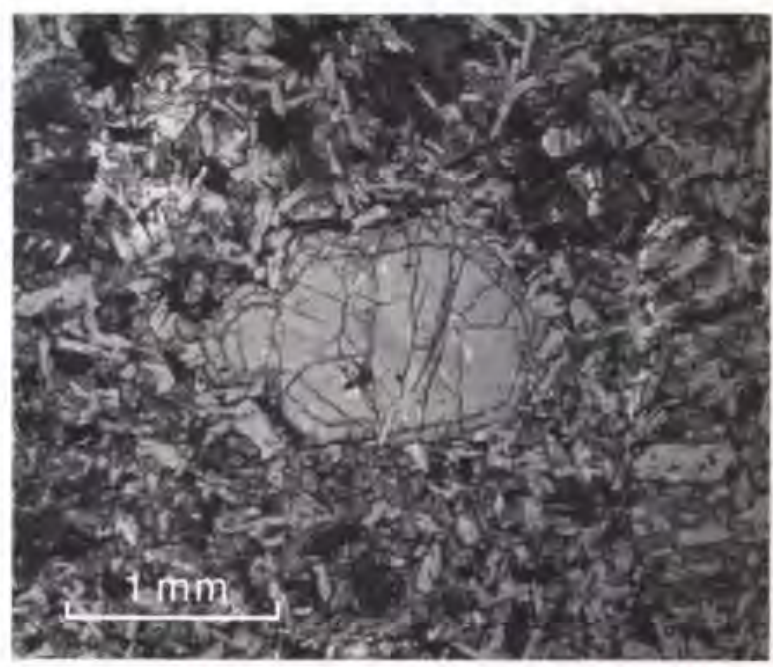

Fig. 53. Augite phenocryst with inclusion zone near the rim. GGU 98595, Hjørnedal marker flow. Plane polarised light. 

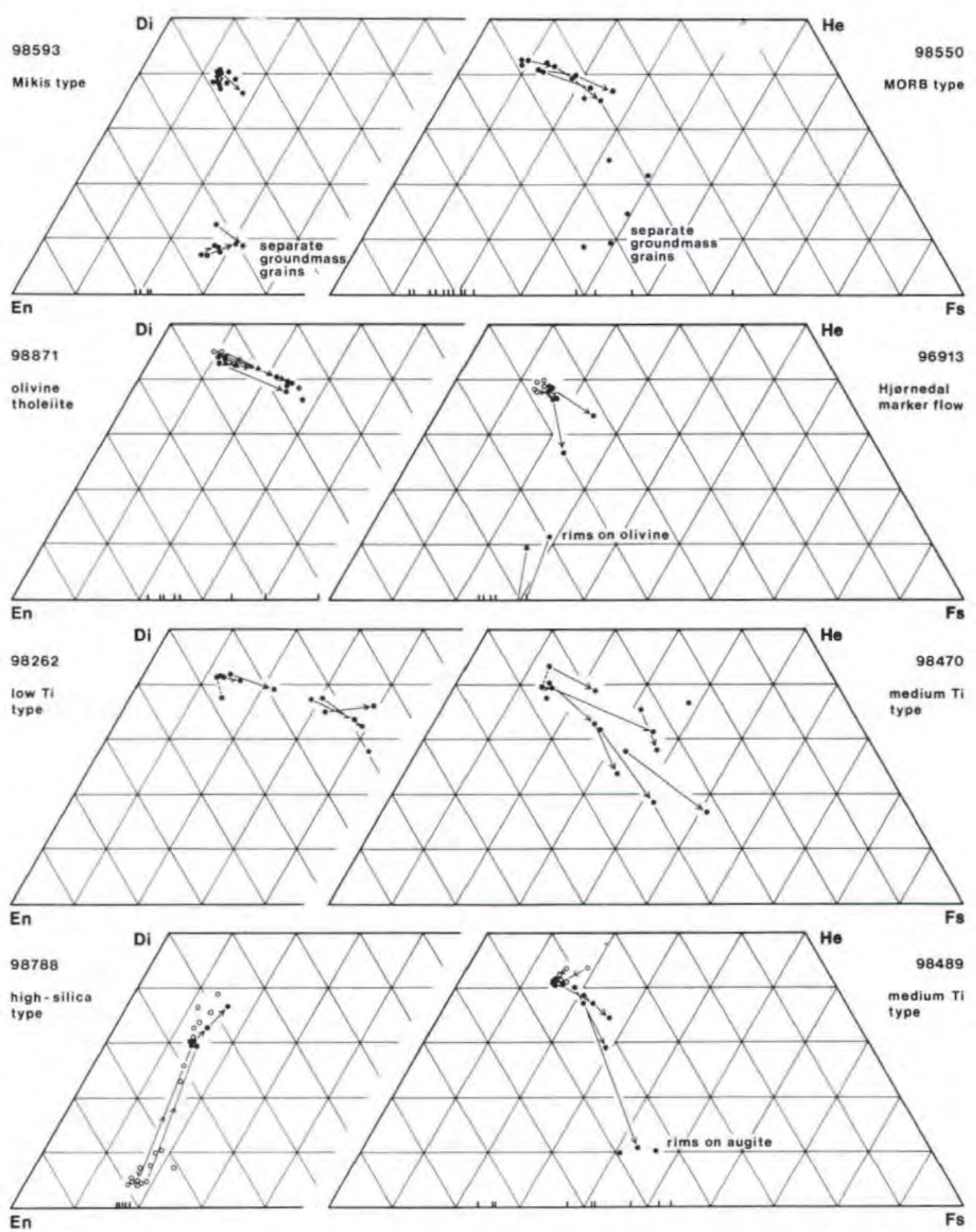

Fig. 54. Pyroxene compositions in representative tholeïtic rocks. Open circles: phenocrysts. Closed circles: rims and groundmass grains. Ringed dots in 98554: pyroxenes in segregation pockets. Arrows connect analyses from the same grain in direction from core to margin. Broken lines connect equivalent points in different sectors of sector zoned grains. Vertical bars at the base line 
crystals in the less frequent ophitic samples. The colour of the augite varies from greenish in the more $\mathrm{Mg}$-rich samples through neutral in most of the samples to distinctly brownish in the Ti-rich samples. Many grains have lighter coloured cores grading into darker rims, indicating that they are compositionally zoned. Hourglass zoning patterns are commonly found.

Pigeonite is difficult to discern from augite optically, and time has not allowed the detailed optical investigations necessary to check for this mineral in all rock samples. Pigeonite is found in half of the microprobed samples, but mostly in very subordinate amounts. It occurs as separate groundmass grains, as rims on augite and as rims on olivine. In all but one case it appears to be a late-stage crystallisation product, the exception being the high-silica lava 98788 .

Orthopyroxene phenocrysts, mantled by augite, occur in the above-mentioned high-silica lava 98788 . Apart from this, orthopyroxene has only been identified in one lava in a largely pigeonitic high-temperature breakdown product of olivine.
Chemical compositions. The compositional variation of the pyroxenes in the tholeiitic rocks is illustrated by the selected pyroxene quadrilaterals in fig. 54 and representative analyses are given in Table 12. The majorelement composition of the clinopyroxenes in many ways parallels that of the olivines: there is, with certain exceptions, a correlation between bulk rock composition and the composition of the most magnesian clinopyroxene, which changes gradually from approximately $\mathrm{En}_{48} \mathrm{Fs}_{9} \mathrm{Wo}_{43}$ in the MORB type basalt to approximately $\mathrm{En}_{45} \mathrm{Fs}_{15} \mathrm{Wo}_{40}$ in the titano-tholeiites. The exceptions are the same rocks as some of those which do not conform to the olivine correlation in fig. 46: the Mikis type basalt has both olivines and clinopyroxenes which are more iron-rich than the bulk rock $\mathrm{Mg}$ ratio indicates they should be, and the high-Ti type 98554 analogously has both olivines and clinopyroxenes which are more magnesium-rich than they should be.

The pyroxenes in the high-silica basalt 98788 contrast markedly to those in the normal rocks: the augite is much more $\mathrm{Ca}$ poor than normally, and the rock has

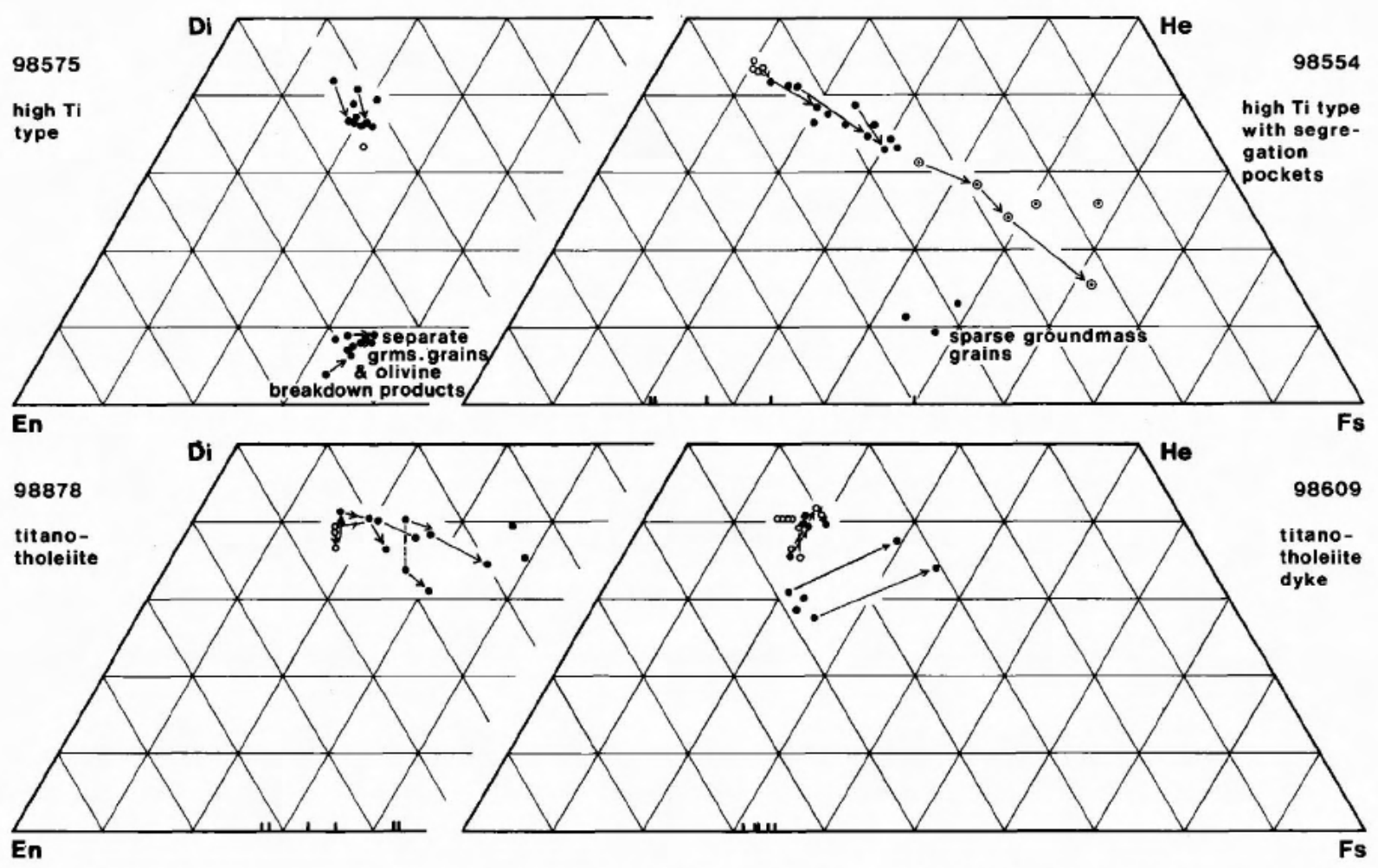

indicate compositions of analysed olivines from the rock. The rocks are arranged with $\mathrm{Mg}$ ratios decreasing from upper left to lower right. 


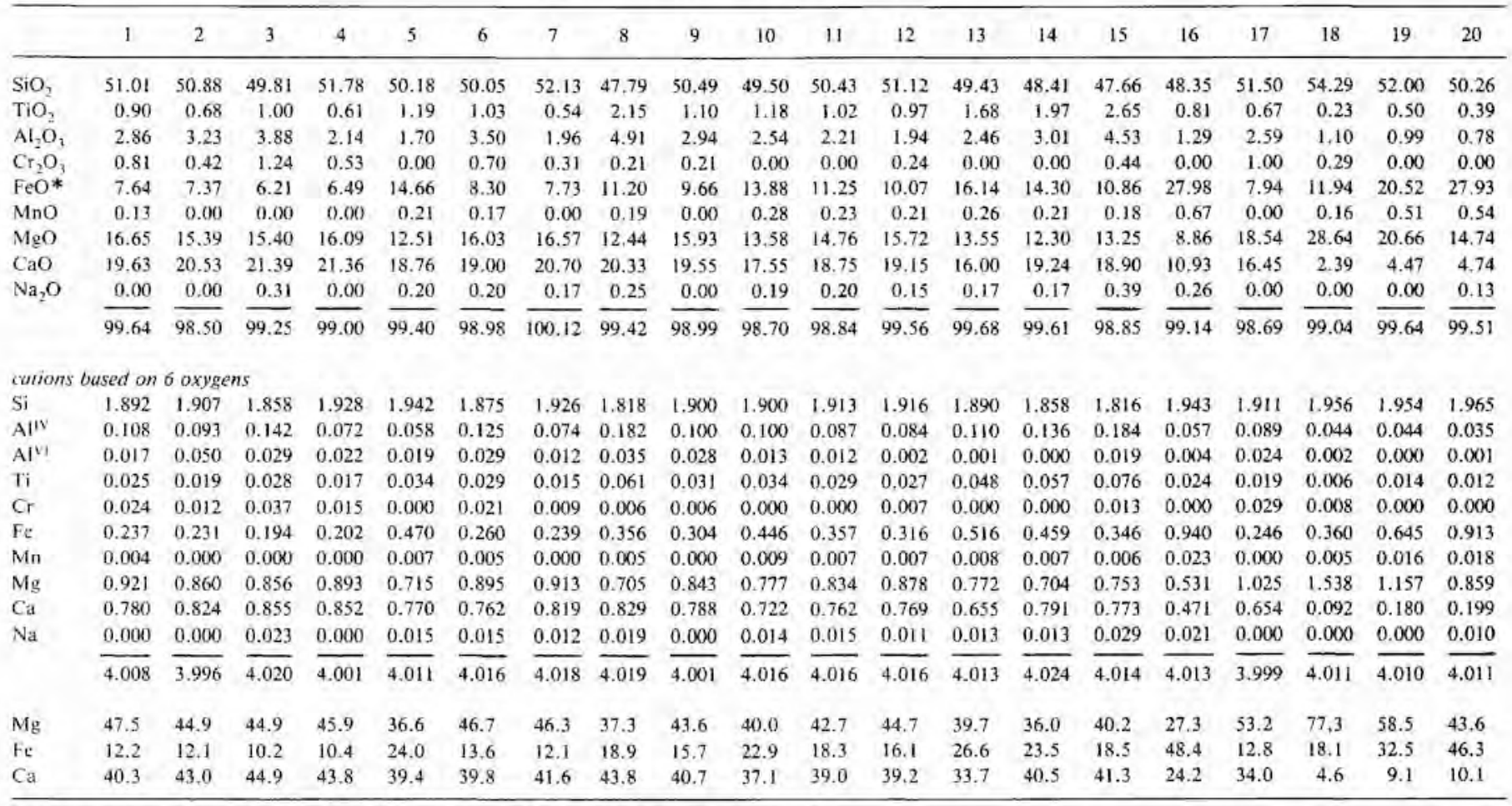

1 Augite, centre of groundmass grain. Mikis type basalt, GGU 98593, Milne Land Formation.

2 Augite, brown xenocrystic grain. Olivine tholeite, GGU 98871, Romer Fjord Formation.

3 Augite, clear rim immediately adjacent to previous xenocrystic grain.

4 Augite, centre of clear groundmass grain. Olivine tholeiite, GGU 98871

5 Augite, rim on previous grain.

6 Augite phenocryst. Hjørnedal marker flow, GGU 96913, Milne Land Formation.

Augite, centre of groundmass grain. Low-Ti basalt, GGU 98262, Skrzenterne Formation.

8 Augite, centre of microphenocryst

10 Augite, outer rim on previous grain.

11 Augite, centre of groundmass grain. High-Ti basalt, GGU 98575. Geikie Plateau Formation.

12 Augie, centre of grounce

13 Augite, light sector of sector-zoned groundmass grain. Titano-tholeite, GGU 98878.

14 Augite, brown sector of sector-zoned groundmass grain. As previous.

15 Augite, Ti-rich outer part of phenocryst. Titano-tholeiite, GGU 98609 , dyke.

16 Subcalcic ferroaugite in segregation pocket. High-Ti basalt, GGU 98554 , Skranterne Formation.

17 Augite microphenocryst. High-Si basalt, GGU 98788, Magga Dan Formation.

18 Orhopyroxene microphenocryst. As previous.

19 Pigeonite, centre of groundmass grain. High-Ti basalt, GGU 98575, Geikie Plateau Formation.

20 Pigeonite, rim on augite. Med-Ti basalt, GGU 98489, Geikie Plateau Formation. 
bronzite phenocrysts. Both features are a result of the high silica activity in this, supposedly crustally contaminated magma.

The individual pyroxene crystallisation trends in fig. 54 illustrate the effect of cooling rate: the quicklycooled, aphanitic 98788 has a short, steep augite trend indicative of metastable crystallisation (Smith \& Lindsley, 1971a), while the gabbroic 98470 has a prolonged trend parallel to the equilibrium crystallisation trend of the Skaergaard augites. Segregation pockets in 98554 (fig. 37) is an extreme example of internal differentiation. The short pyroxene trends in 98593 and 98575 are probably due to high-temperature re-equilibration, as also indicated by the iron-rich and high-temperature altered olivines and oxidised oxides in these rocks.

The effect of sector zoning is seen in the pyroxene trend of 98470 as a scattering effect, because there is a difference of 3-6 Wo\% between the parallel zoning trends of the dark $\mathrm{Al}+\mathrm{Ti}$-enriched sectors (high Wo) and the lighter sectors (low Wo) in a single crystal (Table 12). The effect is present to a lesser degree in some of the other diagrams too $(98262,98878)$.

All microprobe analyses of pyroxenes from the tholeiitic rocks, excepting the strongly contaminated basalts, are compiled in fig. 55. The pyroxene compositional variation found by Fawcett et al. (1973) for the Scoresby Sund basalts is encompassed by the variation seen in fig. 55 and is nearly the same. With the inherent data scatter due to metastable crystallisation, sector zoning and other effects, the pyroxene compositions define a broad trend tending to close in a diffuse trace of a solvus crest. The area encompassed by the analyses in fig. 55 defines a typical tholeiitic pyroxene composi- tional range similar to the ranges found in tholeiitic basalts from Hawaii (Fodor et al., 1975), Iceland (Mäkipää 1978; Sigurdsson et al., 1978) and the Columbia River Plateau (Smith \& Lindsley, 1971b). Pyroxenes from ocean floor basalts include more iron-poor compositions, down to $\mathrm{Fs}_{6}$ (e.g. Bence et al., 1975, Le Roex \& Dick, 1981). Compared with the pyroxenes in the lower lavas in the Kangerdlugssuaq district (Nielsen et al., 1981) the picrites contain more iron-poor $\left(\mathrm{Fs}_{8-15}\right)$ and Ca-rich $\left(\mathrm{Wo}_{40-45}\right)$ pyroxenes than the majority of the plateau basalts.

Xenocrystic pyroxene. Petrographically xenocrystic augite occurs in a few samples, of which 98871 is shown in figs $54,57 \& 58$. 'Dusty' rounded cores show normal zoning from $\mathrm{Fs}_{12}$ to $\mathrm{Fs}_{19}$ and are sharply rimmed by clear inclusion-free augite with normal zoning from $\mathrm{Fs}_{10}$ to $\mathrm{Fs}_{25}$, thus repeating the composition of the core. The xenocrysts and especially the contact zones of the two generations tend to have increased $\mathrm{TiO}_{2}$ and $\mathrm{Al}_{2} \mathrm{O}_{3}$ contents (Table 12). Some other rocks, e.g. 98489 (figs 54, 57 and 58) have augite phenocrysts that are not visibly xenocrystic but show reverse zoning and have higher contents of $\mathrm{TiO}_{2}, \mathrm{Al}_{2} \mathrm{O}_{3}$ and $\mathrm{CaO}$ (higher $\mathrm{Wo} \%$ in fig. 54) than other augite phenocrysts. These pyroxene cores are interpreted as analogues of the core and rim zoned plagioclase phenocrysts, indicative of mixing of different batches of magma.

Al and Ti in pyroxenes. A compilative plot of $\mathrm{Al}_{2} \mathrm{O}_{3} v$. $\mathrm{TiO}_{2}$ in the analysed tholeiitic clinopyroxenes is shown in fig. 56. In almost all the analyses Ti can be accounted for by the substitution $(\mathrm{Mg}, \mathrm{Fe})^{\mathrm{VI}}+2 \mathrm{Si}^{\mathrm{IV}}=\mathrm{Ti}^{\mathrm{VI}}+$

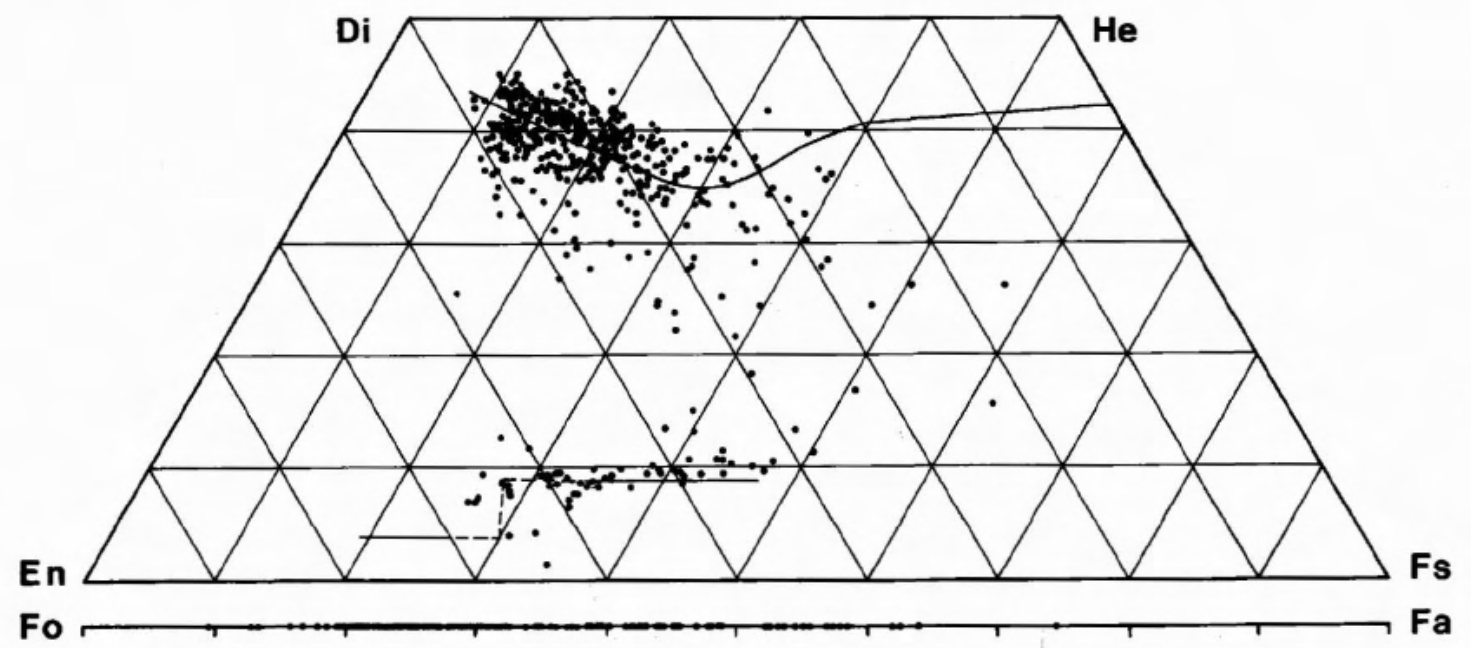

Fig. 55. Compilative plot of pyroxene and olivine analyses from the tholeiitic rocks, excepting the strongly contaminated rocks. The Skaergaard pyroxene trend (Brown \& Vincent, 1963) is inserted for comparison. 


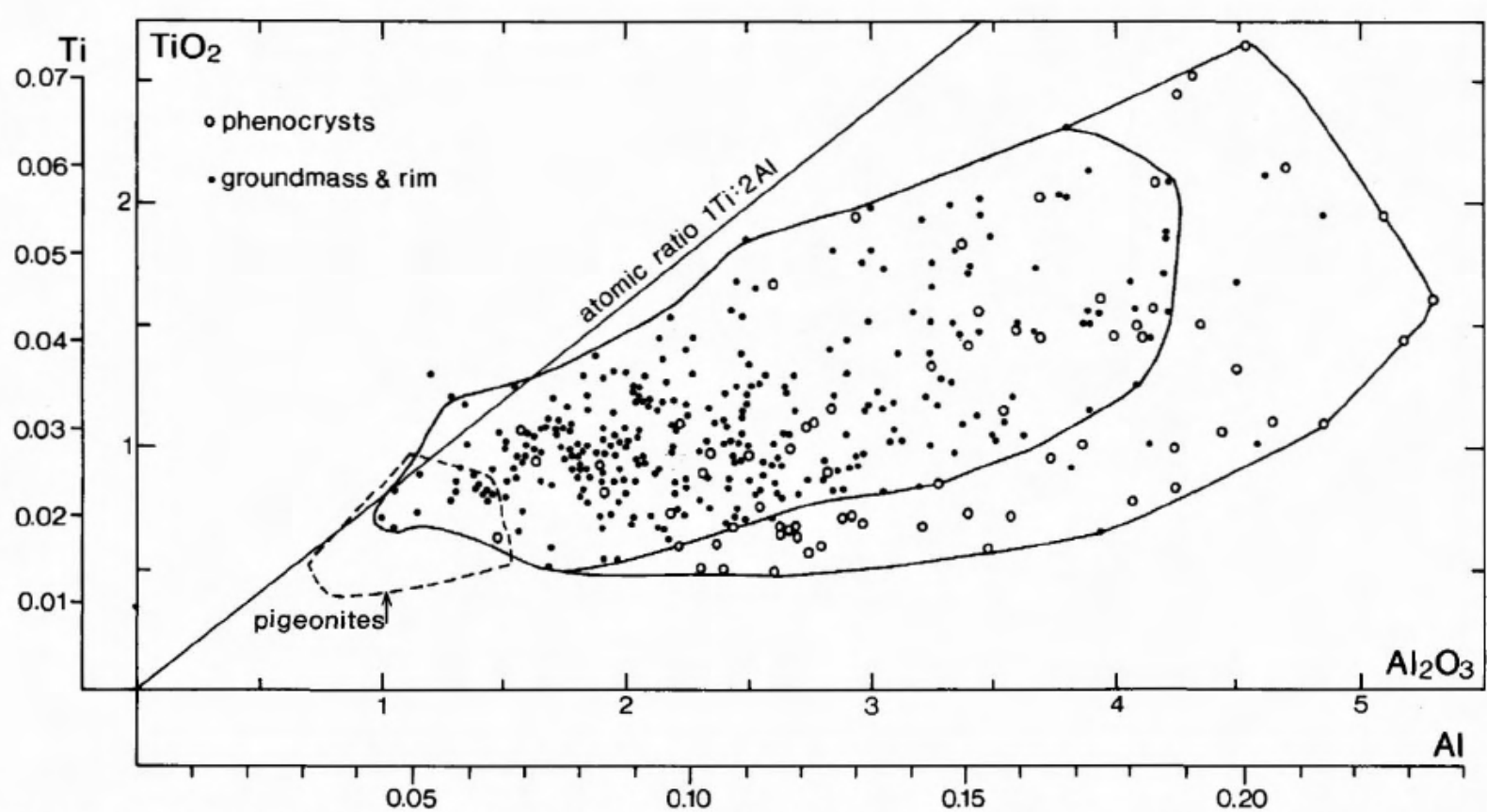

Fig. 56. Correlation between $\mathrm{TiO}_{2}$ and $\mathrm{Al}_{2} \mathrm{O}_{3}$ (wt.\%) in analysed augites. The auxiliary axes give approximate $\mathrm{Ti}$ and $\mathrm{Al}$ in atoms per 6 oxygens. Contours surround the whole augite field (excepting one doubtful analysis with $2 \mathrm{Ti}>\mathrm{Al}$ ) and the more contracted field of groundmass and rim augite.

$2 \mathrm{Al}^{\mathrm{IV}}$, and there is excess $\mathrm{Al}$ available for other substitutions, mainly $(\mathrm{Mg}, \mathrm{Fe})^{\mathrm{Vl}}+\mathrm{Si}^{\mathrm{IV}}=\mathrm{Al}^{\mathrm{VI}}+\mathrm{Al}^{\mathrm{IV}}$ and

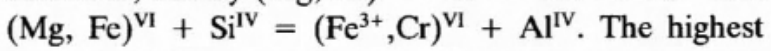
contents of these two 'tschermakitic' pyroxene components, visualised as deviations from the 1Ti: $2 \mathrm{Al}$ line in fig. 56, are found in phenocrysts, probably as an effect of the higher crystallisation temperature of these.

The behaviour of $\mathrm{TiO}_{2}$ and $\mathrm{Al}_{2} \mathrm{O}_{3}$ with proceeding crystallisation, expressed as the $\mathrm{Fs} \%$ in the augite, is shown for selected representative rocks in figs 57 and 58. In all rocks, except $98609, \mathrm{TiO}_{2}$ in the augite increases with proceeding crystallisation to a maximum around $\mathrm{Fs}_{20-25}$ and then declines again. The maximum is simply explained as an effect of the onset of crystallisation of Fe-Ti oxides which deplete the rest magma in $\mathrm{TiO}_{2}$. The behaviour of the titano-tholeiite dyke 98609 in fig. 57 is erratic; its augite phenocrysts show complicated oscillatory and sector zoning and may not all be cognate, and its Fe-Ti oxides (mainly ilmenite) are petrographically very late, which may explain the increasing $\mathrm{TiO}_{2}$ in the groundmass augite.

The behaviour of $\mathrm{Al}_{2} \mathrm{O}_{3}$ in the augite closely matches that of $\mathrm{TiO}_{2}$ (fig. 58), especially in the more differentiated rocks, confirming that the major part of the $\mathrm{Al}_{2} \mathrm{O}_{3}$ occurs in coupled substitution with $\mathrm{TiO}_{2}$. In the least differentiated rocks ( 98550 and 98871 ) the earlyformed augites have relatively low contents of $\mathrm{TiO}_{2}$ but not of $\mathrm{Al}_{2} \mathrm{O}_{3}$, conveying greater contents of 'tschermakitic' pyroxene components. This is probably an effect of higher crystallisation temperatures of the least differentiated rocks; Herzberg \& Chapman (1976) showed that the solubility of the 'tschermakite' component in clinopyroxene in a spinel lherzolite assemblage increases with increasing temperature and shows little dependence on pressure. The petrographically xenocrystic augites in 98871 and 98489 do not have abnormally high 'tschermakite' contents.

In several cases maximum $\mathrm{Al}_{2} \mathrm{O}_{3}$ and $\mathrm{TiO}_{2}$ contents in augites are found in zones adjacent to a major compositional break in a crystal, e.g. 98871, 98489 and 98609. This, as well as the sector zoning in $\mathrm{Al}$ and $\mathrm{Ti}$, indicates that crystallisation kinetics also influences the $\mathrm{Al}_{2} \mathrm{O}_{3}$ and $\mathrm{TiO}_{2}$ contents.

Similar augite trends, with decreasing $\mathrm{Al}$ and variable or decreasing $\mathrm{Ti}$ with crystallisation, have been described from Hawaiian tholeiites (Fodor et al., 1975), ocean floor basalts (Bence et al., 1975) and the differentiated tholeiitic lavas of Thingmuli, Iceland (Carmichael, 1967). Compared with pyroxene composition compilations like those of Schweitzer et al. (1978) and Leterrier et al. (1982) the range in Al contents in fig. 56 is perfectly normal for anorogenic tholeiites, while the Ti contents are slightly high $(0.01-0.075$ compared with $0.00-0.055$ of Leterrier et al., 1982). 


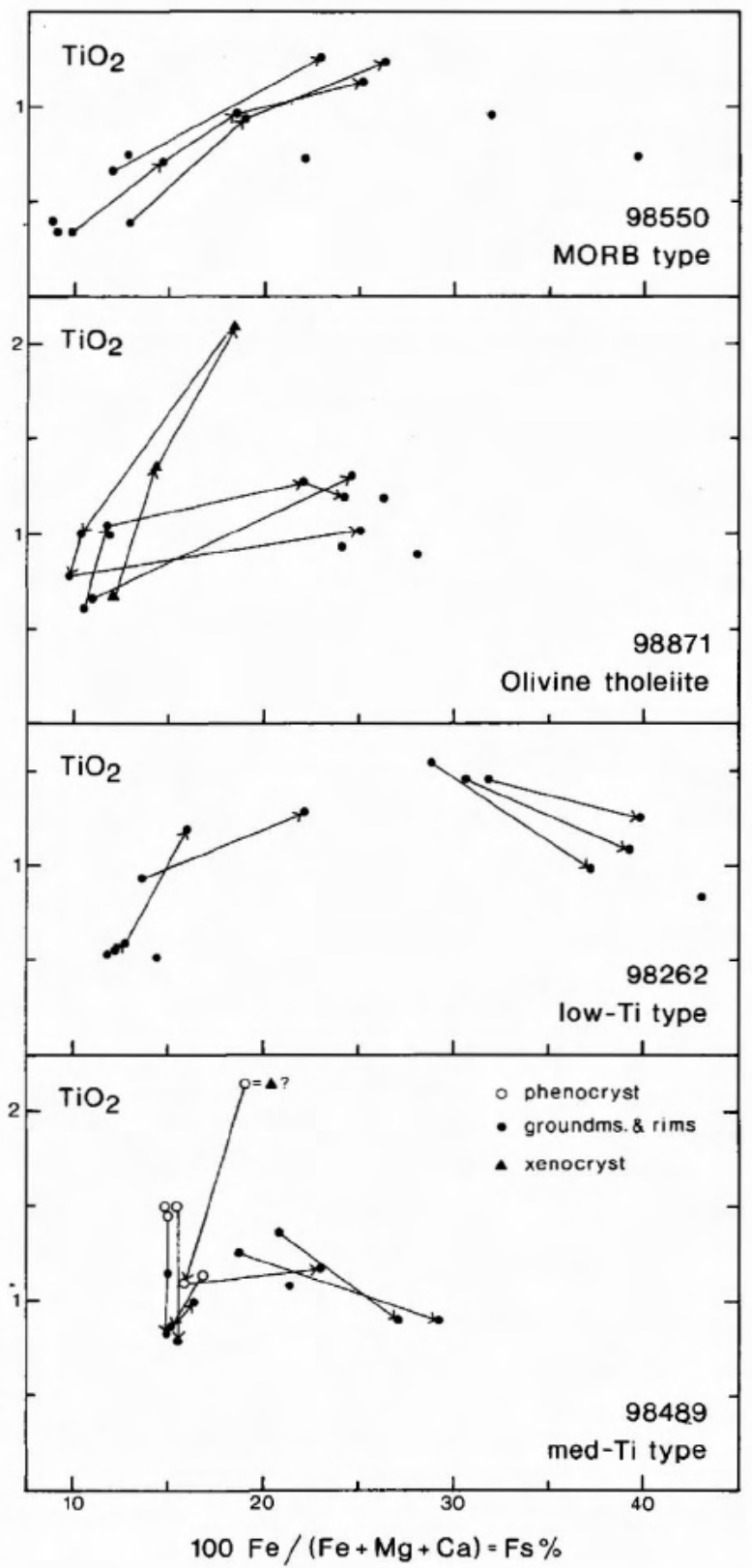

The pigeonites have $\mathrm{TiO}_{2}$ contents of $0.4-1.0 \%$ and $\mathrm{Al}_{2} \mathrm{O}_{3}$ contents of $0.7-1.5 \%$ and thus partly overlap the augite field in fig. 56 . They show no systematic core-torim variation. The orthopyroxenes have only $0-0.25 \%$ $\mathrm{TiO}_{2}$ and the same $\mathrm{Al}_{2} \mathrm{O}_{3}$ content as the pigeonites.

As already apparent from fig. 57 there is a correlation between the $\mathrm{TiO}_{2}$ contents of the magma and of the augite first crystallising from it, be it of phenocryst or groundmass habit. This correlation is illustrated for the analysed tholeiitic rocks in fig. 59. Because $\mathrm{TiO}_{2}$ in the augite increases during the first crystallisation, the up-

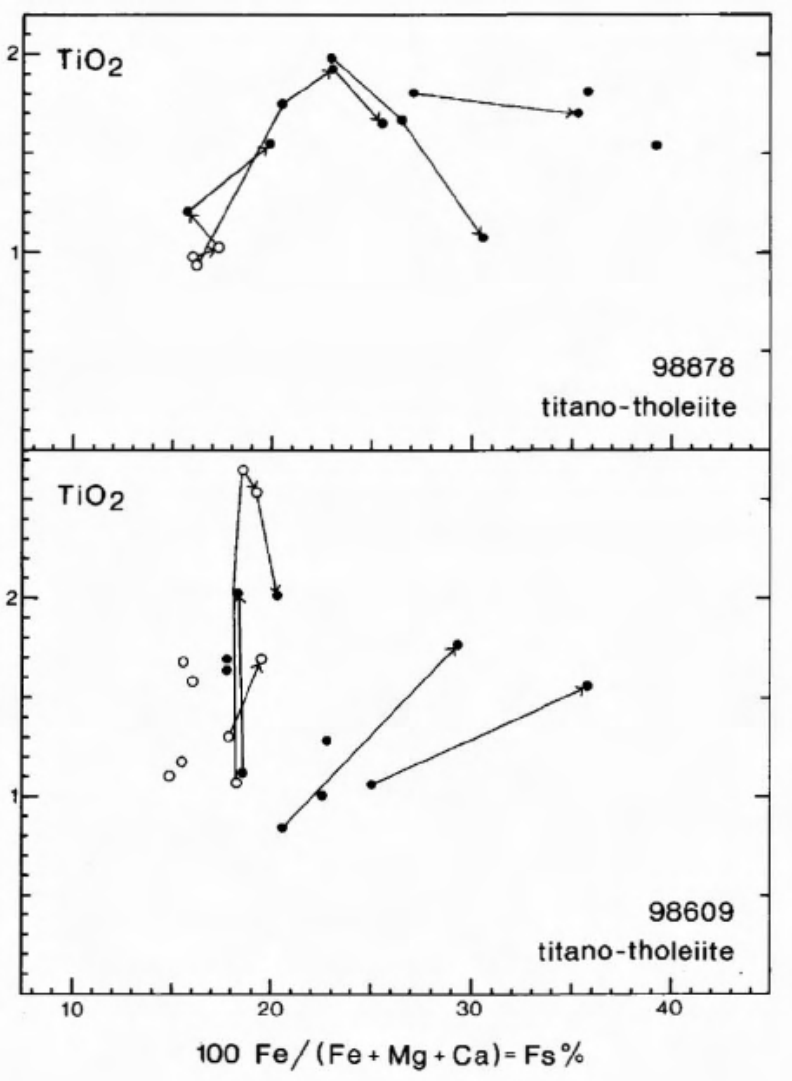

Fig. 57. Correlation between $\mathrm{TiO}_{2}$ and iron enrichment in augites from selected rocks, partly the same as in fig. 54 . The rocks are arranged with $\mathrm{Mg}$ ratios decreasing and $\mathrm{TiO}_{2}$ contents increasing from top to bottom and from left to right. Arrows connect analyses from the same grain in direction from core to rim.

per limits of the $\mathrm{TiO}_{2}$ values of the 'early formed' augite are not always well defined. Unusually Ti-rich augite centres in five rocks are shown by broken lines in fig. 59. From this figure approximate partition coefficients $\left(\mathrm{TiO}_{2}\right)_{\text {augite }} /\left(\mathrm{TiO}_{2}\right)_{\text {liq }}$ may be derived, preferably from the better defined lower limits of $\mathrm{TiO}_{2}$. The value of this coefficient rises from 0.25 to 0.33 with $\mathrm{TiO}_{2}$ in the rock increasing from $1.3 \%$ to $3 \%$ whereafter it stays approximately constant. These partition coefficients are used for fractionation calculations. 


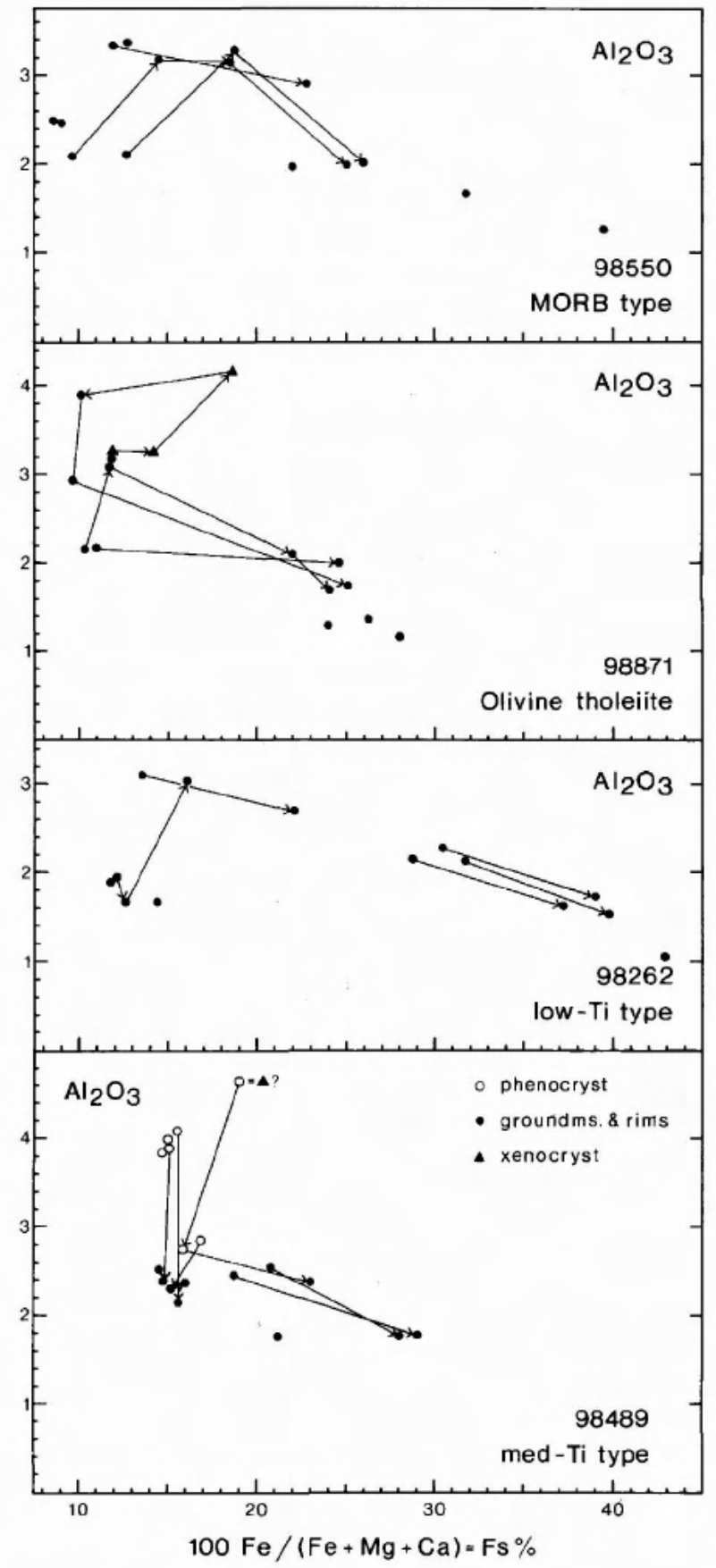

Other elements in pyroxenes. When recalculated on a basis of 6 oxygens per formula unit most augites show a cation excess of up to 0.020 , indicating that $\mathrm{Fe}^{3+}$ is usually present in amounts of up to 0.060 atoms per formula unit, corresponding to up to $2.0 \mathrm{wt} \% \mathrm{Fe}_{2} \mathrm{O}_{3}$. $\mathrm{Na}_{2} \mathrm{O}$ ranges between 0.0 and $0.3 \mathrm{wt} \%$, and because the analyses were made with an energy dispersive system the uncertainty of the $\mathrm{Na}_{2} \mathrm{O}$ determination is relatively

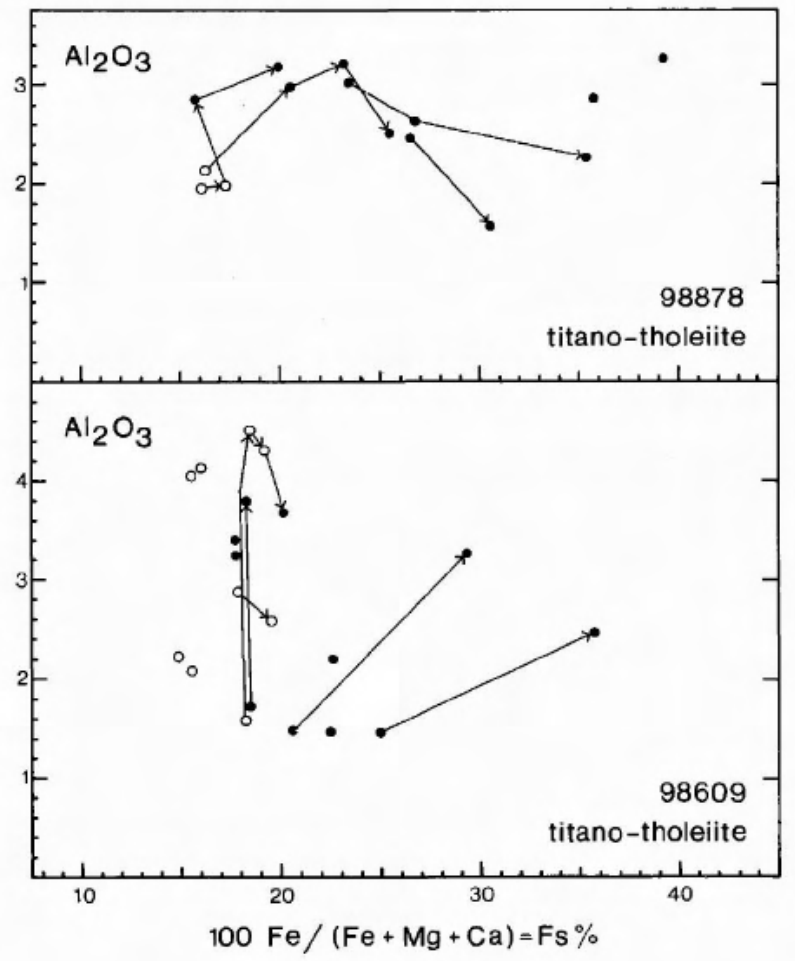

Fig. 58. Correlation between $\mathrm{Al}_{2} \mathrm{O}_{3}$ and iron enrichment in augites from selected rocks, partly the same as in fig. 54 . The rocks are arranged with $\mathrm{Mg}$ ratios decreasing from top to bottom and from left to right. Arrows connect analyses from the same grain in direction from core to rim.

large. Because of the uncertainty of both the $\mathrm{Fe}^{3+}$ and $\mathrm{Na}$ figures no attemps to assign these cations to specific substitutions in the augites have been made.

The chromium content in the augites is shown in fig. 60 . There is a clear inverse correlation between the iron and chromium contents of these pyroxenes, as also found in pyroxenes from several other basalt groups (Papike \& White, 1979; Basaltic Volcanism Study Pro- 
Fig. 59. Correlation between $\mathrm{TiO}_{2}$ in the bulk rock and $\mathrm{TiO}_{2}$ in early-formed augite, phenocrystic or groundmass if no phenocrysts are present. The range in $\mathrm{TiO}_{2}$ contents in the early augite is shown by a vertical bar, and in five rocks the broken lines indicate unusually $\mathrm{Ti}$-rich augite centres of unresolved origin. Sample 98554 at $2.8 \% \mathrm{TiO}_{2}$ is abnormal in this diagram as in several others.

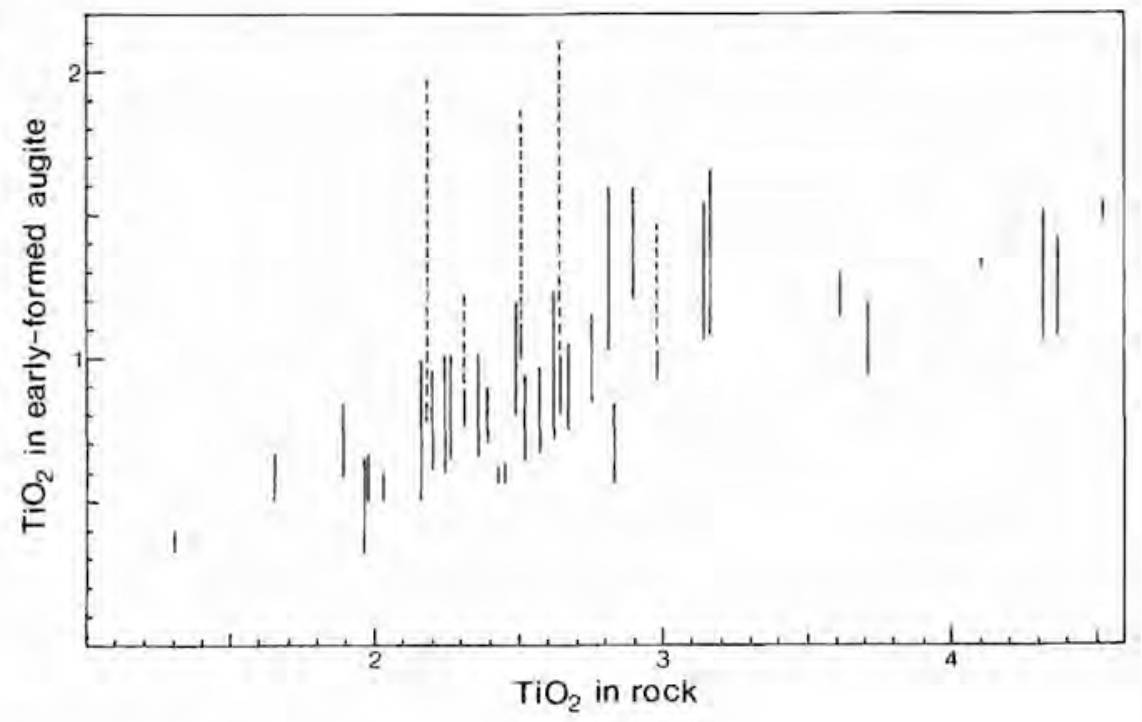

ject, 1981). The Scoresby Sund overall trend is very similar to those of Keweenawan and Hawaiian basalts (Papike \& White, 1979, Fodor et al., 1975). The subgroups in the data set are shown separately on fig. $60 \mathrm{~b}-\mathrm{d}$. The 'normal' trend for the main basalts is defined in fig. 60d. (Excepted from this trend is the Magga Dan Formation (fig. 60c), a high-Si lava, and 98554 which is anomalous in several respects, see sections on olivine and plagioclase.) The Mg-rich basalts, fig. $60 \mathrm{~b}$, have augites with the same or just slightly higher $\mathrm{Cr}_{2} \mathrm{O}_{3}$ contents as the main basalts, despite the fact that the $\mathrm{Mg}$-rich basalts contain much more chromium than the main basalts (fig. 80 ). This may be because the pyroxenes in the $\mathrm{Mg}$-rich basalts crystallised after chromite had depleted the liquid in chromium or, rather, because the $\mathrm{Mg}$-rich basalts crystallised at higher temperatures than the main basalts (see fig. 69). Partition coefficients $\mathrm{Cr}_{\text {augrt }} / \mathrm{Cr}_{\text {Hiq }}$ are inferred to increase with decreasing temperatures (Irvine, 1975) thereby counteracting the effect of decreasing $\mathrm{Cr}_{\mathrm{riq}}$ during magma evolution. The Hjørnedal marker flow was intermediate in both temperature and $\mathrm{Cr}$ contents, and its augite phenocrysts have the same $\mathrm{Cr}$ contents as the other basalts. A mantle on an augite xenocryst in olivine tholeiite 98871 (figs 57,58 and 60 ) is strongly enriched in $\mathrm{Cr}$, indicating that the equilibrium partitioning was disturbed during the event of mixing of the xenocryst into the final magma.

The augites in the high-Si basalts and some Magga Dan Formation basalts have in many cases higher $\mathrm{Cr}$ contents than other augites. These rocks contain as much $\mathrm{Cr}$ as the Mg-rich basalts (fig. 80 ), but the partition coefficients $\mathrm{Cr}_{\text {sugite }} / \mathrm{Cr}_{\text {hiq }}$ were probably greater because the high-Si magmas were more polymerised (Irvine, 1975).

\section{Fe-Ti oxides}

Titanomagnetite and ilmenite are ubiquitous phases in the crystalline lavas but are not found in any of the glassy or aphanitic rocks. They are always groundmass phases and range from small euhedral crystals to large poikiloblastic grains, the most frequent type being subhedral grains with a few silicate inclusions. In the most rapidly chilled rocks the $\mathrm{Fe}-\mathrm{Ti}$ oxides have skeletal development, with thin, bladed ilmenites and cruciform titanomagnetites.

The amount of Fe-Ti oxides in a rock is directly and systematically related to its $\mathrm{TiO}_{2}$ content and ranges from $2.4 \%$ (modal) in the most $\mathrm{TiO}_{2}$-poor to $6.8 \%$ (modal) in the most $\mathrm{TiO}_{2}$-rich of the point-counted samples (Table 9). In almost all rocks titanomagnetite and ilmenite occur in approximately equal amounts, but in a few cases one oxide strongly predominates. This is also illustrated in Table 9, where the Mikis type basalt with $2.39 \% \mathrm{TiO}_{2}$ and the MORB type basalt with $1.30 \%$ $\mathrm{TiO}_{2}$ have equal modal amounts of oxides due to the predominance of ilmenite in the Mikis type and of titanomagnetite in the MORB type basalt.

When classified according to the oxidation states of Haggerty (1976a) around half of the samples have completely unaltered oxides (stages $\mathrm{Cl}$ and R1), although many titanomagnetite grains contain composite or sandwich-type ilmenite inclusions. Most of the other half of the samples are moderately to strongly oxidised (up to stages $\mathrm{C} 5$ and $\mathrm{R} 7$ ) with extensive replacement of ilmenite by rutile, hematite and pseudobrookite. The pointcounted representative sample set conforms to this distribution (Table 9). Watkins \& Haggerty (1967) found generally high oxidation stages of the oxides across 

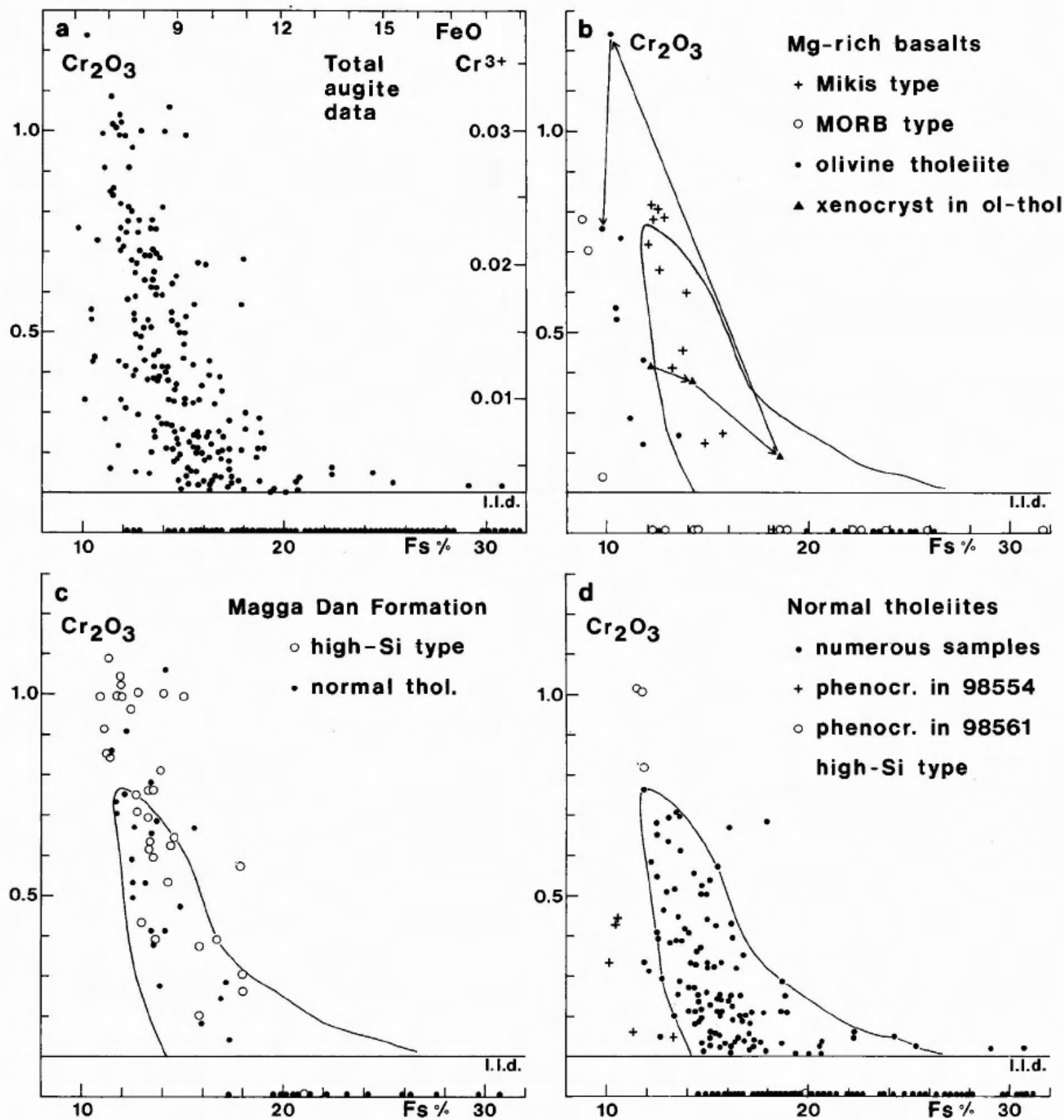

Fig. 60. $\mathrm{Cr}_{2} \mathrm{O}_{3}(\mathrm{wt} \%)$ in augite $v$. iron enrichment expressed as $\mathrm{Fs} \%$, i.e. $100 \mathrm{Fe} /(\mathrm{Fe}+\mathrm{Mg}+\mathrm{Ca})$ in augite. In (a) auxiliary axes of approximate atomic $\mathrm{Cr}^{3+}$ (per 6 oxygens) and wt $\% \mathrm{FeO}$ are also shown. l.l.d = lower limit of detection $=0.1 \% \mathrm{Cr}_{2} \mathrm{O}_{3}$, below which the computer simply writes 0.00 . The contours in diagrams (b) and (c) are the 'normal' augite trend from diagram (d).

some Icelandic lava flows, especially in the centre of the flow, and Jensen (1979) produced analogous oxidation profiles for lavas from the Faeroe Islands. Two of the Faeroe lavas have low oxidation stages (C1-C3) in the lower 2-3 metres. The good preservation state of the oxides in the Scoresby Sund lava samples may be a result of the sampling technique, most samples being collected in the lower massive part of the flow, 1-2 metres above the base.

Temperatures and oxygen fugacities for seemingly coexisting pairs of analysed homogeneous titanomagnetite and ilmenite were deduced from the graphs of Spencer \& Lindsley (1981), and the results are shown in fig. 61 in combination with results obtained from chromite 
Fig. 61. Temperatures and oxygen fugacities. Left part of the diagram: temperatures and oxygen fugacities derived from coexisting titanomagnetite-ilmenite pairs (after Spencer \& Lindsley, 1981). Right part of the diagram: hightemperature oxygen fugacities for lavas with unaltered chromite phenocrysts, calculated from data of Maurel \& Maurel (1982b) and Sack et al. (1980). The synthetic buffer curves are hematite-magnetite (HM), nickel-nickel oxide (NNO), fayalite-magnetite-quartz (FMQ) and magnetite-wüstite (MW). See discussion in text.
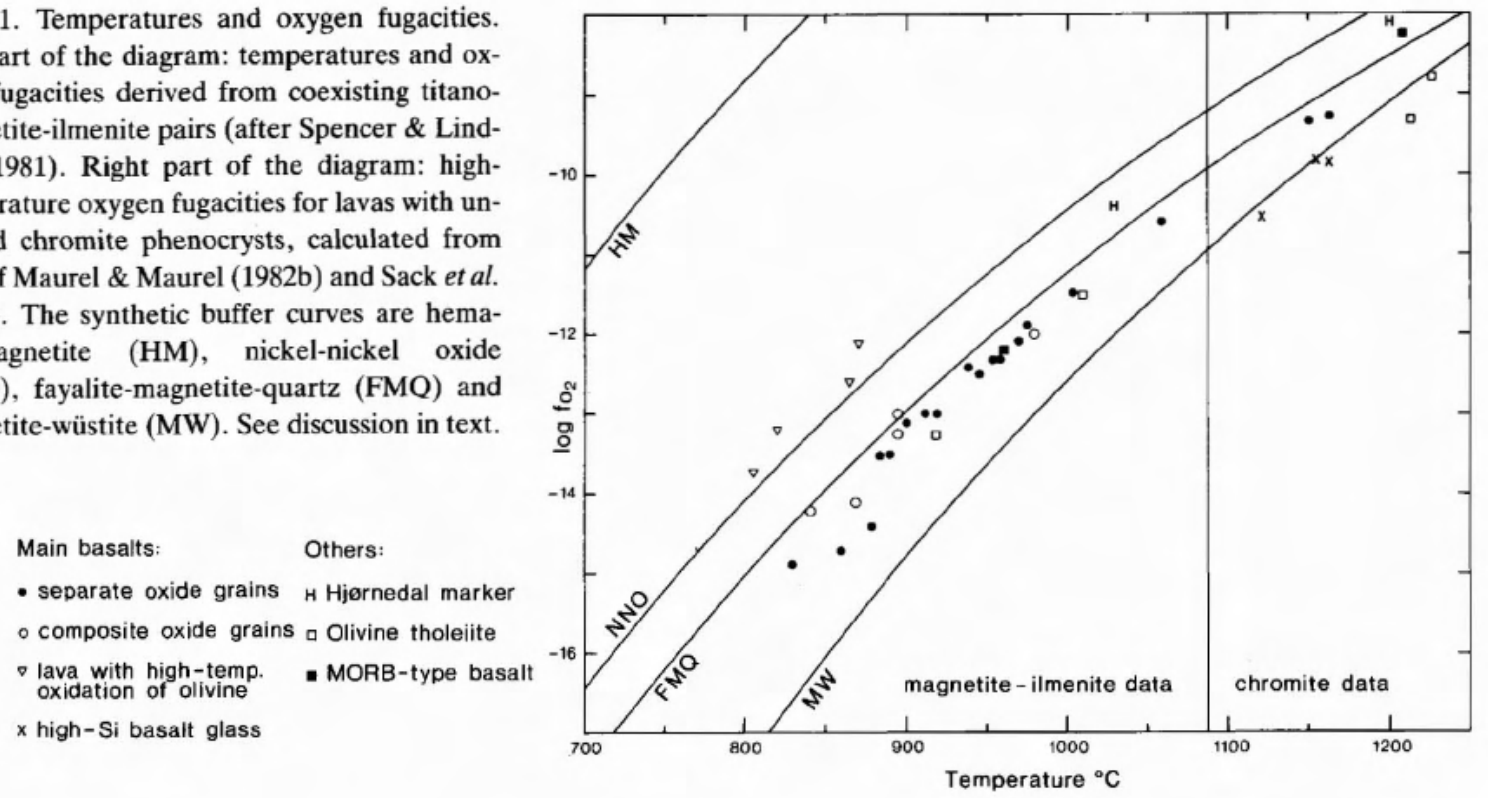

as described in the chromite section. Where the two data sets can be compared they are concordant, placing the main basalts just below the FMQ buffer curve and the Hjørnedal magma between the FMQ and NNO curves. The $\mathrm{Mg}$-rich basalts show rather scattered results, and the high-Si basalt glasses appear to be formed at relatively low oxygen fugacities around the MW buffer curve. The contamination process which is considered led to the formation of the high-Si basalts may have involved a slight reduction of the magma.

The chromite data are liquidus temperature data while the majority of the Fe-Ti oxide pairs have equilibrated in the temperature interval $800-1000^{\circ} \mathrm{C}$, i.e. around and below the solidus which is estimated to be near $1000^{\circ} \mathrm{C}$ (Peck et al., 1966 , found $980^{\circ} \mathrm{C}$ for a similar basalt from Kilauea). All the analysed main basalt lavas except one none-the-less conform to a single, buffered cooling path showing that the systems even at this stage were internally buffered, and that the volatile phase did not exert any significant control. The position of the cooling path just below the synthetic FMQ buffer curve is compatible with cooling paths from other basic extrusive rocks, notably Thingmuli, Iceland (Carmichael, 1967) and Picture Gorge basalt, USA (Lindsley \& Haggerty, 1971). Other examples are summarised by Haggerty (1976b).

The composite oxide grains consist of titanomagnetite with subhedral ilmenite crystals either marginally or in the centre; these were considered by Buddington \& Lindsley (1964) to be formed by oxidation exsolution, but Haggerty (1976a) argued that they could be primary intergrowths, partly from the lack of other signs of oxidation in these grains. The data in fig. 61 show that some of the composite grains equilibrated under slightly higher $f_{\mathrm{O}}$, than the discrete grains, i.e. there may be at least some secondary oxidation associated with their formation.

The main basalt sample (98575) which does not conform to the common cooling path shows signs of hightemperature oxidation of the olivines which are completely pseudomorphed by a vermicular aggregate of Ca-poor pyroxene and titanomagnetite (see section on olivine) while the pyroxenes are re-equilibrated (fig. $54)$. This is in accordance with the high oxygen fugacities measured for four oxide pairs in this sample (fig. 61 ), and it is possibly connected with the fact that this particular sample was taken in the middle of the lava flow and not, as usual, just above the base. The sample does still seem to be internally buffered. The Hjørnedal marker sample with high $f_{\mathrm{O}_{2}}$ similarly shows incipient high-temperature oxidation of the olivine.

The content of minor elements in the Fe-Ti oxides is rather constant, and independent of the bulk rock composition. The titanomagnetites contain $1-3 \% \quad \mathrm{Al}_{2} \mathrm{O}_{3}$, $0.5-2.0 \% \mathrm{MgO}, 0.3-0.8 \% \mathrm{MnO}$ and trace amounts of $\mathrm{CaO}$. Most analyses show $0.5-1.3 \% \mathrm{~V}_{2} \mathrm{O}_{3}$, and a few analyses show trace amounts of $\mathrm{Cr}_{2} \mathrm{O}_{3}$. Two examples of chromiferous titanomagnetite are discussed in the previous section. The ilmenites contain $0.1-0.4 \% \mathrm{Al}_{2} \mathrm{O}_{3}$, $0.5-4.0 \% \mathrm{MgO}, 0.3-0.6 \% \mathrm{MnO}$ and trace amounts of $\mathrm{CaO}$; some also contain up to $0.5 \% \mathrm{~V}_{2} \mathrm{O}_{3}$. These element distributions are typical for basaltic $\mathrm{Fe}-\mathrm{Ti}$ oxides. 
Table 13. Broad beam microprobe analyses of fine-grained mesostasis

\begin{tabular}{|c|c|c|c|c|c|c|}
\hline & 1 & 2 & 3 & 4 & 5 & 6 \\
\hline $\mathrm{SiO}_{2}$ & 50.18 & 49.78 & 50.58 & 53.92 & 67.85 & 65.05 \\
\hline $\mathrm{TiO}_{2}$ & 3.08 & 1.18 & 1.79 & 0.82 & 1.26 & 0.52 \\
\hline $\mathrm{Al}_{2} \mathrm{O}_{3}$ & 13.21 & 13,43 & 13.87 & 13.91 & 12.95 & 13.17 \\
\hline $\mathrm{FeO}$ & 14.94 & 11.48 & 11.97 & 9.27 & 3.98 & 5.59 \\
\hline $\mathrm{MnO}$ & 0.16 & 0.00 & 0.22 & 0.00 & 0.13 & 0.00 \\
\hline $\mathrm{MgO}$ & 4.30 & 4.81 & 1.27 & 3.50 & 1.65 & 1.78 \\
\hline $\mathrm{CaO}$ & 9.66 & 5.92 & 9.13 & 4.12 & 5.37 & 2.54 \\
\hline $\mathrm{Na}_{2} \mathrm{O}$ & 2.90 & 4.86 & 3.17 & 5.29 & 4.06 & 4.92 \\
\hline $\mathrm{K}_{2} \mathrm{O}$ & 0.41 & 0.49 & 0.37 & 1.63 & 0.38 & 2.37 \\
\hline \multirow[t]{2}{*}{$\mathrm{P}_{3} \mathrm{O}_{5}$} & 0.11 & 1.52 & 1.49 & 2.32 & 0.94 & 0.77 \\
\hline & 98.95 & 93.47 & 93.86 & 94.95 & 98.57 & 96.71 \\
\hline $\mathrm{Mg} / \mathrm{Mg}+\mathrm{Fe}^{2-\dagger}$ & 0.368 & 0.459 & 0.177 & 0.433 & 0.456 & 0.392 \\
\hline \multicolumn{7}{|c|}{$\mathrm{CIPW}$ norms, calculated with $\mathrm{Fe}_{2} \mathrm{O}_{3} / \mathrm{FeO}$ adjusted to 0.15} \\
\hline C & & & & 1.20 & & \\
\hline$Q$ & 2.34 & & 9.21 & 3.29 & 30.52 & 18.13 \\
\hline or & 2.42 & 2.89 & 2.18 & 9.62 & 2.24 & 13.99 \\
\hline$a b$ & 24.50 & 41.05 & 26.77 & 44.71 & 34.33 & 41.46 \\
\hline an & 21.78 & 13.36 & 22.48 & 6.12 & 15.98 & 6.85 \\
\hline di & 21.34 & 5.04 & 11.29 & & 3.73 & 0.61 \\
\hline hy & 17.67 & 18.54 & 12.78 & 21.32 & 6.42 & 11.69 \\
\hline of & & 4.63 & & & & \\
\hline$m t$ & 2.86 & 2.20 & 2.29 & 1.77 & 0.76 & 1.07 \\
\hline il & 5.84 & 2.24 & 3.39 & 1.56 & 2.39 & 0.99 \\
\hline ap & 0.25 & 3.52 & 3.45 & 5.37 & 2.18 & 1.78 \\
\hline
\end{tabular}

\footnotetext{
; Iron adjusted to $\mathrm{Fe}_{2} \mathrm{O}_{3} / \mathrm{FeO}=0.15$, probably a minimum value

1 'Basalt' mesostasis, med - Ti basalt, GGU 98763, Magga Dan Formation.

2 'Tholeitic andesite' mesostasis, low-Ti basalt, GGU 98262, Skrænterne Formation.

3 'Andesite' mesostasis, titano-tholeite, GGU 98878, Skrænterne Formation.

4 'Dacite' mesostasis, med -Ti basalt, GGU 98470, Geikie Plateau Formation.

5 'Dacite' mesostasis, Hjørnedal marker, GGU 96913, Milne Land Formation.

6 'Dacite-rhyolite' mesostasis, high-Ti basalt, GGU 98554, Skrænterne Formation.

All 'names' given according to the classification of Irvine \& Baragar (1971).
}

\section{Residual products}

The ultimate crystallisation products mostly consist of glass which is now in more or less advanced states of decomposition, ranging from palagonitisation with hydration and alkali loss to complete conversion to clay minerals. As illustrated by Table 9 most rocks contain $1-7 \%$ 'glass', and additionally they contain up to $4 \%$ mesostasis which is a very fine-grained polycrystalline aggregate with tiny oxide speckles and occasional apatite needlets. The fine-grained, polycrystalline mesostasis represents relatively unmodified late-stage liquids. Broad beam analyses of some of these are presented in Table 13. The late-stage products may be characterised as tholeiitic andesite-dacite-rhyolite rather like the differentiated rocks ('icelandites' etc.) from the Thingmuli central volcano, Iceland (Carmichael, 1964). They do not, however, conform to a single trend as the rocks of Thingmuli. The residual products from the titano-tholeiites are very iron-rich and magnesium-poor, and those from the Hjørnedal marker are very silica-rich and alkali-poor.

\section{Secondary minerals}

The mineral chemistry study of the basalts was centred on the primary phases, and the samples selected for microprobe analysis were chosen to be poor in second- 
ary minerals. The study of the secondary minerals is therefore far from complete, and the notes given below on zeolites, clay minerals and carbonates are cursory.

Zeolites. Zeolites are commonly found in the upper scoriaceous parts of the lava flows, as described in the section on zeolite zonation. The basalt samples collected for rock and mineral chemistry come from the lower, massive parts of the lava flows and normally do not contain zeolites. It is difficult or impossible to identify zeolites by chemical analysis alone, because several zeolites have near-identical chemical formulae and sometimes the only difference lies in the water content. Zeolites are very unstable under electron bombardment, and microprobe analyses tend to give too high figures. The identity of some of the zeolites presented in Table 14 is therefore only suggested.

Most of the żeolite analyses performed are from the $\mathrm{Mg}$-rich lavas of the Rømer Fjord Formation. In these lavas zeolites fill out large and extensive interstitial ar- eas. As identified by crystal optics and microprobe the most common zeolites in these rocks are clear, massive aggregates of chabazite, stilbite or scolecite, while lesser amounts of radiating fibrous aggregates of thomsonite and phillipsite also occur. Microprobe analyses of these phases are presented in Table 14.

Clay minerals. Clay minerals are present in most basalt samples. Amygdales in vesicular basalt may be lined with or completely filled out with clay minerals, and many massive basalt samples contain interstitial clay material produced by alteration of interstitial glass. Olivine is in many cases partly or completely altered to clay. In the field several occurrences of 'chlorophaeite' were noted, with the characteristic colour change upon exposure from bright lustrous olive-green to dull black. described by e.g. Campbell \& Lunn (1925). Grass-green 'celadonite' occurs in some vesicular samples.

The microprobed samples are massive, and the interstitial clay minerals and the clays replacing olivine

Table 14. Microprobe analyses of interstitial zeolites

\begin{tabular}{|c|c|c|c|c|c|c|}
\hline & 1 & 2 & 3 & 4 & 5 & 6 \\
\hline $\mathrm{SiO}_{2}$ & 46.08 & 39.35 & 55.75 & 56.15 & 51.00 & 46.72 \\
\hline $\mathrm{Al}_{2} \mathrm{O}_{3}$ & 24.68 & 29.04 & 18.66 & 19.11 & 22.08 & 24.19 \\
\hline $\mathrm{FeO}$ & 0.00 & 0.00 & 0.14 & 0.23 & 0.00 & 0.00 \\
\hline $\mathrm{MgO}$ & 0.15 & 0.00 & 0.18 & 0.34 & 0.16 & 0.08 \\
\hline $\mathrm{CaO}$ & 10.76 & 12.73 & 9.01 & 7.70 & 11.62 & 7.77 \\
\hline $\mathrm{Na}_{2} \mathrm{O}$ & 1.95 & 3.70 & 0.48 & 0.00 & 0.23 & 1.46 \\
\hline \multirow[t]{2}{*}{$\mathrm{K}_{2} \mathrm{O}$} & 0.98 & 0.00 & 0.85 & 3.82 & 0.09 & 5.96 \\
\hline & 84.59 & 84.82 & 85,07 & 87,35 & 85.18 & 86.18 \\
\hline \multicolumn{7}{|c|}{ culions based on 72 oxygens water-free } \\
\hline $\mathrm{Si}$ & 22.108 & 19.237 & 25.806 & 25.672 & 23.842 & 22.444 \\
\hline Al & 13.959 & 16.737 & 10.183 & 10.300 & 12.169 & 13.700 \\
\hline $\mathrm{Fc}$ & - & - & 0.054 & 0.088 & - & - \\
\hline $\mathrm{Mg}$ & 0.107 & $\cdot$ & 0.124 & 0.232 & 0.111 & 0.057 \\
\hline $\mathrm{Ca}$ & 5.531 & 6.668 & 4.469 & 3.772 & 5.821 & 3.999 \\
\hline $\mathrm{Na}$ & 1.814 & 3.507 & 0.431 & - & 0.208 & 1.360 \\
\hline \multirow[t]{2}{*}{ K } & 0.600 & - & 0.502 & 2.228 & 0.054 & 3.653 \\
\hline & 44.120 & 46.149 & 41.569 & 42.292 & 42.205 & 45.213 \\
\hline $\mathrm{Si}+\mathrm{Al}$ & 36.067 & 35.974 & 35.989 & 35.972 & 36.011 & 36.144 \\
\hline
\end{tabular}

I Massive, blocky anhedral zeolite with scolecite-like composition, MORB type basalt, GGU 98550, Rømer Fjord Formation.

2 Thomsonite, aggregate of radiating, fibrous crystals. GGU 98550.

3 Stilbite, clear interstitial aggregates of large anhedral crystals. Olivine tholeiite, GGU 98871, Rømer Fjord Formation.

4 Potassic stilbite, round 'bleb' in centre of previous crystal.

5 Clear massive zeolite with chabazite-like composition, GGU 98871.

6 Phillipsite, radiating crystals growing marginally on a scolecite-filled vug. High-Ti basalt, GGU 98501. Geikie Plateau Formation. 
Table 15. Microprobe analyses of clay minerals and carbonates

\begin{tabular}{|c|c|c|c|c|c|c|c|c|c|}
\hline & 1 & 2 & 3 & 4 & 5 & 6 & & 7 & 8 \\
\hline $\mathrm{SiO}_{2}$ & 37.87 & 43.35 & 19.09 & 49.48 & 42.28 & 54.27 & $\mathrm{FeO}$ & 9.96 & 50.95 \\
\hline $\mathrm{TiO}_{2}$ & 0.00 & 0.00 & 0.00 & 0.00 & 0.10 & 0.40 & $\mathrm{MnO}$ & 0.00 & 1.02 \\
\hline $\mathrm{Al}_{2} \mathrm{O}_{3}$ & 8.94 & 5,78 & 2.84 & 7.23 & 5.17 & 17.46 & $\mathrm{MgO}$ & 40.48 & 2.10 \\
\hline $\mathrm{Fe}_{2} \mathrm{O}_{3} \dagger$ & 17.53 & 13.15 & 55.12 & 16.21 & 29.84 & 4.65 & $\mathrm{CaO}$ & 0.31 & 5.99 \\
\hline $\mathrm{MnO}$ & 0.00 & 0.00 & 0.55 & 0.00 & 0.34 & 0.00 & $\mathrm{CO}_{2}$ calc. & 50.53 & 38.83 \\
\hline $\mathrm{MgO}$ & 21.57 & 17.60 & 4.77 & 12.24 & 11.60 & 5.17 & & $\overline{101.28}$ & $\overline{98.89}$ \\
\hline $\mathrm{CaO}$ & 0.51 & 1.51 & 1.01 & 1.50 & 2.99 & 1.65 & & & \\
\hline $\mathrm{Na}_{2} \mathrm{O}$ & 0.00 & 0.42 & 0.35 & 0.43 & 0.25 & 0.59 & & & \\
\hline \multirow[t]{3}{*}{$\mathrm{K}, \mathrm{O}$} & 0.11 & 0.89 & 0.00 & 1.21 & 0.55 & 1.81 & & & \\
\hline & 86.53 & 82.70 & 83.73 & 88.30 & 93.12 & 86.00 & & & \\
\hline & \multicolumn{6}{|c|}{ cations based on 22 oxygens water-free } & \multicolumn{3}{|c|}{ atomic percentages } \\
\hline $\mathrm{Si}$ & 5.782 & 6.784 & 3.671 & 7.205 & 6.246 & 7.631 & $\mathrm{Fe}$ & 12.07 & 80.36 \\
\hline $\mathrm{Ti}$ & - & - & - & - & 0.011 & 0.042 & $\mathrm{Mn}$ & 0.00 & 1.63 \\
\hline Al & 1.609 & 1.066 & 0.644 & 1.241 & 0.900 & 2.894 & $\mathrm{Mg}$ & 87.46 & 5.90 \\
\hline $\mathrm{Fe}^{1}$. & 2.014 & 1.549 & 7.976 & 1.776 & 3.318 & 0.492 & $\mathrm{Ca}$ & 0.47 & 12.11 \\
\hline $\mathrm{Mn}$ & - & - & 0.090 & - & 0.043 & $=$ & & & \\
\hline $\mathrm{Mg}$ & 4.908 & 4.105 & 1.367 & 2.656 & 2.554 & 1.083 & & & \\
\hline $\mathrm{Ca}$ & 0.083 & 0.253 & 0.208 & 0.234 & 0.473 & 0.249 & & & \\
\hline $\mathrm{Na}$ & - & 0.127 & 0.130 & 0.121 & 0.072 & 0.161 & & & \\
\hline \multirow[t]{2}{*}{ K } & 0.021 & 0.178 & - & 0.225 & 0.104 & 0,325 & & & \\
\hline & $\overline{4.417}$ & $\overline{14.061}$ & $\overline{14.085}$ & $\overline{13.459}$ & $\overline{13.721}$ & $\overline{12.877}$ & & & \\
\hline
\end{tabular}

\footnotetext{
$†$ All iron quoted as $\mathrm{Fe}_{2} \mathrm{O}_{3}$.

I Brownish green clay, olivine pseudomorph. Mikis type basalt, GGU 98593, Milne Land Formation.

2 Light yellow centre of olivine pseudomorph. Med -Ti type basalt, GGU 98575, Geikie Plateau Formaion.

3 Clear dark-brown hydrated iron oxide silicate; rim on olivine pseudomorph of previous analysis. GGU 98575.

4 Yellow interstitial devitrified glass. GGU 98575.

5 Clear brown interstitial devitrified glass. Low-Ti type basalt, GGU 98536. Geikie Plateau Formation.

6 Brown lining on zeolite-filled vesicle. Titano-tholeite, GGU 98878, Skrænterne Formation.

7 Radiating carbonate filling vesicle. Glassy high-silica basalt, GGU 98788, Magga Dan Formation.

8 Massive carbonate filling vesicle. Pillow lava, GGU 98788, Magga Dan Formation.
}

are seen in the microscope as transparent yellowish or sometimes greenish or brownish aggregates. 'Glass' inclusions in phenocrystic olivine or plagioclase now consist of orange-brown to dirty green fibrous clay minerals, sometimes associated with dark brown masses of amorphous ?iron silicate hydrate. The microprobe analyses (Table 15) show that the clays compositionally are smectites, i.e. Fe and $\mathrm{Mg}$-rich, $\mathrm{Al}$-poor clays with rather variable compositions. These alteration products are similar to those analysed by Böhlke et al. (1980) from ocean floor basalts.

Carbonate, Like the zeolites, carbonate is not a common constituent of the normal massive basalt samples, although it is widespread in the brecciated flow tops. A few microprobed basalt samples contain sparse calcite interstitially or after olivine, while the high-silica pyro- clastic breccias in the Magga Dan Formation contain vesicle fillings of carbonates which are members of the siderite-magnesite $\left(\mathrm{Fe}_{2} \mathrm{CO}_{3}-\mathrm{Mg}_{2} \mathrm{CO}_{3}\right)$ solid solution series. These are compositionally very variable, even within one vesicle, and range from $\mathrm{Ca}_{12} \mathrm{Mg}_{6} \mathrm{Fe}_{\mathrm{s} 2}$ to $\mathrm{Ca}_{0} \mathrm{Mg}_{88} \mathrm{Fe}_{12}$ (Table 15).

\section{Minerals in alkaline rocks}

Fig. 62 shows features of the feldspar and pyroxene compositions of the alkali basaltic and hawaiitic rocks. The alkali basalt dyke from Gåseland (96921) contains labradorite feldspar laths rimmed by oligoclase and alkali feldspar, and its brown-tinted augites are distinctly more calcic than the augites from the tholeiites. 


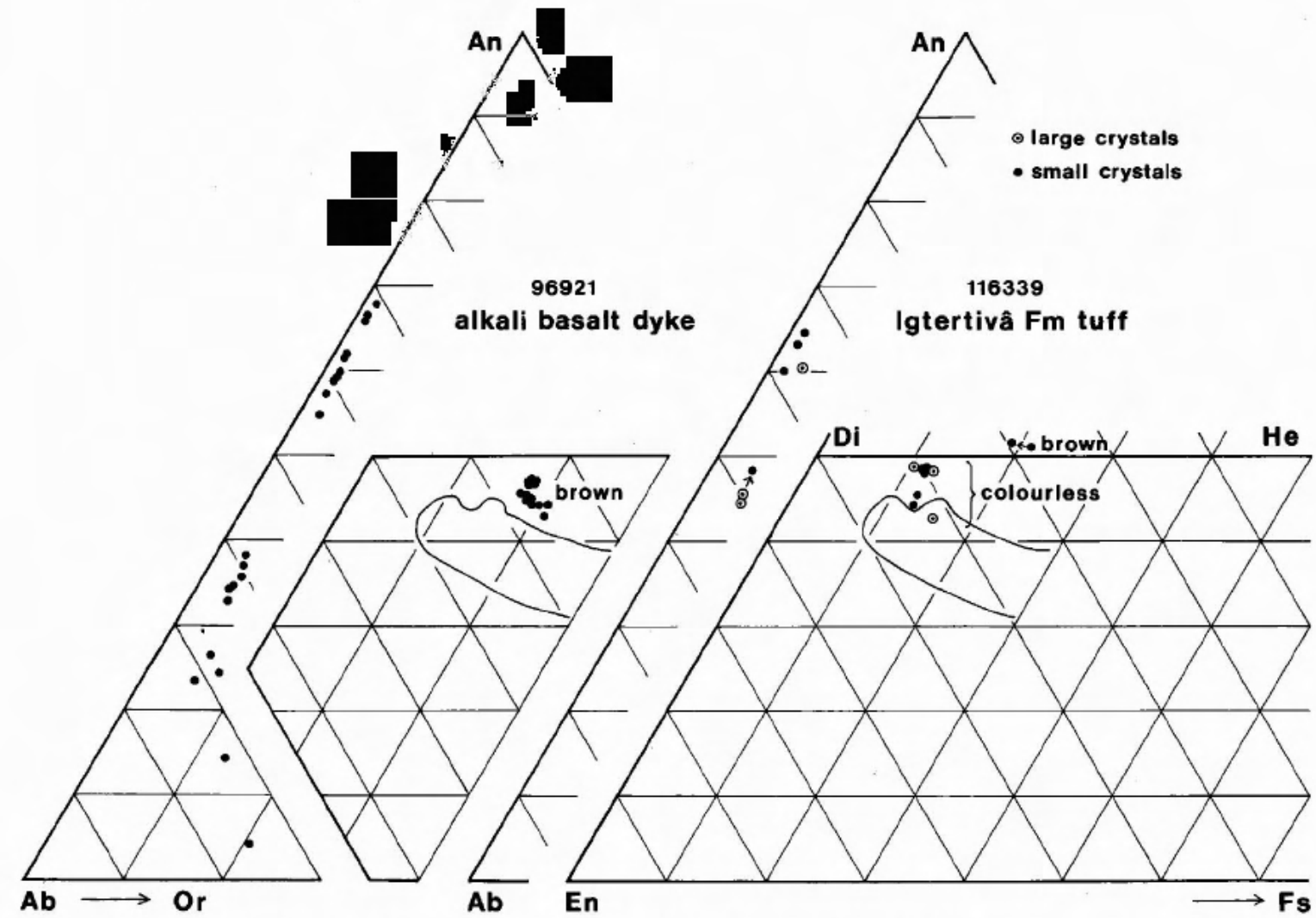

Fig. 62. Composition of plagioclase and augite in two alkaline rocks. The compositional field of the pyroxene in the tholeiitic rocks is shown for comparison (cf. fig. 55). The colours of the pyroxenes are indicated on the diagram. The tuff is polymict; see text for discussion.

The Igtertivâ Formation tuff sample is evidently polymict and contains at least two plagioclase populations and three clinopyroxene populations. Colourless tholeiitic clinopyroxene $\left(\mathrm{Wo}_{43}\right)$, and perhaps also some of the labradorite feldspar, comes from a 'normal' tholeiitic magma. Colourless calcic clinopyroxene $\left(\mathrm{Wo}_{48.49}\right)$ and most of the labradorite $\left(\mathrm{An}_{60-65}\right)$ feldspar probably belong to an alkali basaltic magma, and brown, strongly calcic clinopyroxene $\left(\mathrm{Wo}_{51-52}\right)$ and potassium-rich andesine $\left(\mathrm{An}_{4448}, \mathrm{Or}_{5}\right)$, together with brown amphibole (not analysed) are from a differentiated alkaline magma. The glass matrix is completely altered and consists of analcime.

As seen from fig. 63 the augites from the alkaline rocks reach considerably higher $\mathrm{Al}_{2} \mathrm{O}_{3}$ and $\mathrm{TiO}_{2}$ contents than the augites from the tholeiites.

\section{Glassy rocks and geothermometry}

Rocks with well-preserved glass are only found in pillow breccias and in chilled dyke selvages. These rocks are all porphyritic, with $3-10 \%$ of phenocrysts and mi- crophenocrysts in pale yellow-brown clear glass. In the fragmentary rocks many glass fragments are altered along their margins to stronger coloured brown to dark brown birefringent palagonite.

In eight rocks the glass was analysed with the electron microprobe. Five to thirteen points per sample were analysed with the electron beam defocussed, and the average analyses are presented in Table 16. The glasses are in general homogeneous; only $\mathrm{Na}_{2} \mathrm{O}$ may be slightly variable. For five of these rocks there are also bulk chemical analyses given in the appendix. Relative to the bulk rocks the glasses are depleted in $\mathrm{MgO}$ and enriched in $\mathrm{Na}_{2} \mathrm{O}$ and $\mathrm{TiO}_{2}$, while $\mathrm{SiO}_{2}, \mathrm{CaO}$ and $\mathrm{K}_{2} \mathrm{O}$ are approximately the same. The high-silica basalt glasses are depleted in $\mathrm{FeO}$ and enriched in $\mathrm{Al}_{2} \mathrm{O}_{3}$ while the opposite is true for the 'normal' basalt glasses. The differences between glass and bulk rock are, however, not very large, and the glasses all classify as basalt according to Irvine \& Baragar (1971).

All the analysed glassy rocks contain fresh phenocrysts of olivine and plagioclase, and for these it is possible to apply the olivine-liquid and the plagioclase- 


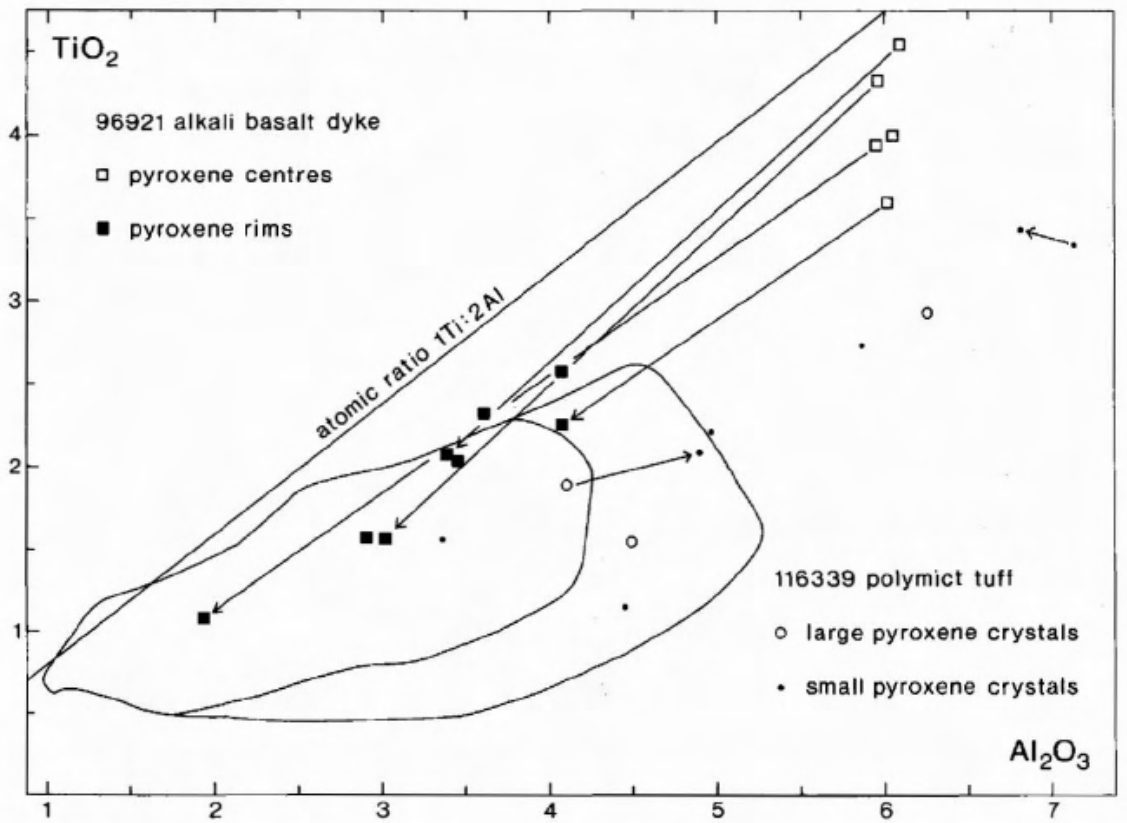

Fig. 63. Correlation between $\mathrm{TiO}_{2}$ and $\mathrm{Al}_{2} \mathrm{O}_{3}$ (wt.\%) in augites from two alkaline rocks. The compositional field of the pyroxenes in the tholeiitic rocks is shown for comparison (cf. fig. 56).

liquid geothermometers, and for those rocks that also contain chromite the olivine-spinel geothermometer may be applied. When the compositions of some crystal centres are discarded, the olivine and plagioclase in equilibrium with the glass are known with uncertainties of $0-2 \%$ Fo and $2-5 \%$ An respectively. This, in turn, gives rise to differences of up to $7^{\circ} \mathrm{C}$ for the olivine temperatures and up to $12^{\circ} \mathrm{C}$ for the plagioclase temperatures. These differences are insignificant compared with the uncertainties inherent in the thermometres themselves.

Table 17 shows the equilibration temperatures calculated with various methods, as indicated. The olivineliquid geothermometer exists in different formulations of which I have used the original by Roeder \& Emslie (1970) and a modified version by Ford et al. (1983). The youngest version takes into account the influence of the chemical composition of the liquid on the Mg-Fe partitioning. The two sets of results in Table 17 are both reasonable except for 98788 in which the olivine cannot be in equilibrium with the liquid (see Table 18). The two methods give similar results for the high-Si rocks, while for the 'normal' basalts the Roeder - Emslie temperatures are $30-50^{\circ}$ higher than the Ford et al. temperatures. However, the Ford et al. temperature set shows very consistent variations with $\mathrm{Mg}$ ratio of the sample (excepting the disequilibrium sample 98788) which is geologically realistic. The plagioclase-liquid temperatures are almost constant, which is suspect. The plagioclase temperatures are sensitive to the water pressure and are considered less reliable than the olivine temper- atures. The olivine-spinel equilibration temperatures are very low and most probably record the sub-solidus temperatures at which olivine and spinel were closed to re-equilibration (Lehmann, 1983).

In conclusion, the Ford et al. (1983) temperatures in Table $\mathbf{1 7}$ are considered to be the best approximations to magmatic temperatures.

\section{Calculation of equilibrium phenocryst compositions and liquidus temperatures}

The experimental work of Roeder \& Emslie (1970) on olivine-liquid equilibria showed that the $\mathrm{FeO} / \mathrm{MgO}$ distribution between olivine and liquid is independent of temperature and pressure with an equilibrium distribution coefficient $(\mathrm{FeO} / \mathrm{MgO})_{\mathrm{o} !} /(\mathrm{FeO} / \mathrm{MgO})_{\text {liq }}$ of 0.30 . For an analysed rock (liquid) the $X_{\mathrm{FeO}} / X_{\mathrm{MgO}}$ is known, and the composition of olivine in equilibrium with the liquid may be calculated. Ford et al. (1983) elaborated the method to encompass simultaneous calculation of olivine composition and equilibration temperature from bulk rock analyses (assuming that the liquid is olivine saturated), by guessing a temperature and then solving the thermometer equation for the olivine composition. When the temperature guess is correct the calculated olivine is stoichiometric. The olivine compositions and 'equilibration' temperatures in Table 18, cols. b and d were calculated in this way.

The data in Table 18 show that the calculated equilibrium olivines for both bulk rocks and glasses are in good accordance with the measured phenocryst compositions 
Table 16. Microprobe analyses of glasses from the Scoresby Sund basalts

\begin{tabular}{|c|c|c|c|c|c|c|c|c|}
\hline GGU No. & 98791 & 96928 & 98788 & 98842 & 215830 & 98514 & 215692 & 98890 \\
\hline $\mathrm{SiO}_{2}$ & 53.21 & 53.16 & 54.31 & 48.64 & 47.50 & 48.25 & 47.86 & 46.85 \\
\hline $\mathrm{TiO}_{2}$ & 1.86 & 2.19 & 1.72 & 2.72 & 3.61 & 3.66 & 3.79 & 5.09 \\
\hline $\mathrm{Al}_{2} \mathrm{O}_{3}$ & 13.95 & 13.78 & 14.45 & 13.06 & 12.59 & 12.07 & 11.70 & 11.80 \\
\hline $\mathrm{Cr}_{2} \mathrm{O}_{3}$ & 0.03 & 0.02 & 0.04 & 0.00 & 0.06 & na & na & na \\
\hline $\mathrm{FeO}^{*}$ & 10.00 & 10.34 & 9.25 & 13.32 & 13.45 & 14,95 & 15.69 & 16.43 \\
\hline $\mathrm{MnO}$ & 0.06 & 0.00 & 0.04 & 0.18 & 0.18 & 0.30 & 0.20 & 0.17 \\
\hline $\mathrm{MgO}$ & 6.10 & 5.51 & 4.83 & 6.28 & 6.00 & 5.51 & 5.01 & 4.83 \\
\hline $\mathrm{CaO}$ & 9.72 & 9.12 & 9.79 & 10.37 & 11.11 & 10.96 & 10.12 & 9.36 \\
\hline $\mathrm{Na}, \mathrm{O}$ & 2.87 & 2.92 & 2.72 & 2.82 & 2.66 & 2.62 & 2.80 & 2.79 \\
\hline $\mathrm{K}, \mathrm{O}$ & 0.77 & 0.99 & 0.80 & 0.40 & 0.43 & 0.39 & 0.54 & 0.95 \\
\hline \multirow[t]{2}{*}{$\mathrm{P}_{2} \mathrm{O}_{5}$} & 0.17 & 0.21 & 0.16 & na & na & 0.28 & 0.39 & na \\
\hline & 98.74 & 98.24 & 98.11 & 97.79 & 97.59 & 98.99 & 98.10 & 98.27 \\
\hline $\mathrm{Mg} /\left(\mathrm{Mg}+\mathrm{Fe}^{2} \cdot\right)$ & 0.552 & 0.519 & 0.514 & 0.488 & 0.474 & 0.427 & 0.392 & 0.373 \\
\hline \multicolumn{9}{|l|}{ CIPW norms } \\
\hline $\mathrm{Q}$ & 3.83 & 4.58 & 7.49 & & & & & \\
\hline or & 4.55 & 5.84 & 4.72 & 2.36 & 2.54 & 2.30 & 3.18 & 5.60 \\
\hline$a b$ & 24.26 & 24.68 & 23.00 & 23.82 & 22.47 & 22.13 & 23.64 & 23.55 \\
\hline an & 22.88 & 21,54 & 24.83 & 21.76 & 21.10 & 19.98 & 17.72 & 16.83 \\
\hline di & 19.86 & 18.35 & 18.69 & 24.50 & 28.04 & 27.06 & 24.98 & 24.68 \\
\hline hy & 17.53 & 16.63 & 13.96 & 12.81 & 9.21 & 16.69 & 16.94 & 10.53 \\
\hline ol & & & & 4.84 & 4.76 & 0.40 & 0.54 & 4.28 \\
\hline $\mathrm{mi}$ & 1.91 & 1.98 & 1.77 & 2.55 & 2.57 & 2.86 & 3.00 & 3.14 \\
\hline i) & 3.53 & 4.15 & 3.26 & 5,16 & 6.84 & 6.94 & 7.18 & 9.65 \\
\hline ap & 0.39 & 0.49 & 0.37 & & & 0.65 & 0.90 & \\
\hline $\mathrm{An} \%$ & 47.06 & 45.14 & 50.44 & 46.26 & 46.96 & 45.98 & 41.40 & 40.24 \\
\hline
\end{tabular}

$\mathrm{Mg}$ ratios and norms calculated with $\mathrm{Fe}_{2} \mathrm{O}_{3} / \mathrm{FeO}=0.15$.

98791 High-Si basalt glass, pillow breccia, Magga Dan Formation.

96928 High-Si basalt glass, pillow brecia, Magga Dan Formation. Bulk rock analysis in appendix, first row.

98788 High-Si basalt glass with orthopyroxene phenocrysts, pillow breccia, Magga Dan Formation. Bulk rock analysis in appendix.

98842 Med-Ti basalt glass, dyke from Gåseland. Bulk rock analysis in appendix.

215830 Titano-tholeiite glass, big feldspar basalt. Rømer Fjord Formation.

98514 Titano-tholeiite glass, pillow breccia, lower part of Geikie Plateau Formation. Analysis of same lava in appendix, profile 52,98516 .

215692 Titano-tholeiite glass, pillow breccia, lower part of Skræenterne Formation.

98890 Titano-tholeiite glass, late dyke south of Scoresby Sund. Bulk rock analysis in appendix.

except for sample 98788 in which the olivine is obviously too magnesian. The equilibrium olivine compositions calculated from the bulk rock analyses of the microprobed samples are plotted in fig. 46.

The composition of plagioclase crystallising at known temperature and low pressure from a dry melt of known composition may be calculated after the method of Drake (1976). Results of this calculation, compared with measured phenocryst compositions, are shown in Table 18. The concordance between calculated and measured compositions is not always good; in the $\mathrm{Si}$ rich rocks $(98791,96928$ and 98788$)$ the calculated pla- gioclase compositions fall completely out of the range of measured compositions, and the same is the case for the titano-tholeiite sample 98890 . The discrepancy is largest for the bulk rock-based calculated plagioclases, these being too An-rich by $6-14 \%$ An. The same impression was gained by comparing calculated and measured plagioclases for the microprobed samples, and the calculated plagioclases are therefore not shown in the plagioclase diagram (fig. 52). The identification of plagioclase xenocrysts therefore relies on textural and analytical evidence, and this is mostly adequate.

The composition of pyroxene crystallising from a 
Table 17. Geothermometry of the glassy rocks

\begin{tabular}{|c|c|c|c|c|c|c|c|c|}
\hline \multirow[b]{2}{*}{ GGU No. } & \multirow[b]{2}{*}{$\begin{array}{l}\text { Glass } \\
\text { Mg ratio }\end{array}$} & \multicolumn{3}{|c|}{$\begin{array}{c}\text { Olivine-liquid } \\
\text { equilibrium }\end{array}$} & \multicolumn{2}{|c|}{$\begin{array}{l}\text { Plagioclase-liquid } \\
\text { equilibrium }\end{array}$} & \multicolumn{2}{|c|}{$\begin{array}{c}\text { Olivine-spinel } \\
\text { equilibrium }\end{array}$} \\
\hline & & $\begin{array}{c}\text { Olivine } \\
\text { Fo\% }\end{array}$ & $T^{\circ} \mathrm{C}^{\mathrm{b}}$ & $T^{\circ} \mathrm{C}^{\mathrm{c}}$ & $\begin{array}{c}\text { Plagioclase } \\
\text { An\% }\end{array}$ & $T^{\circ} \mathrm{C}^{0}$ & $\begin{array}{c}\text { Spinel } \\
\text { Mg ratio }\end{array}$ & $T^{\circ} \mathrm{C}^{\mathrm{e}}$ \\
\hline 98791 & 0.552 & 80.0 & 1159 & 1155 & 65.0 & 1170 & 0.464 & 1096 \\
\hline 96928 & 0,519 & 77.6 & 1145 & 1144 & 65.0 & 1166 & 0,461 & 1078 \\
\hline 98788 & 0.514 & 81.5 & 1105 & 1190 & 62.7 & 1169 & 0.470 & 962 \\
\hline 98842 & 0.488 & 75.6 & 1183 & 1154 & 69.3 & 1180 & - & - \\
\hline 215830 & 0.474 & 75.3 & 1178 & 1142 & 71.7 & 1181 & - & - \\
\hline 98514 & 0.427 & 70.7 & 1170 & 1124 & 65.3 & 1177 & - & - \\
\hline 215692 & 0.393 & 68.2 & 1160 & 1112 & 61.6 & 1178 & - & - \\
\hline 98890 & 0.373 & 65.4 & 1158 & 1112 & 56.3 & 1178 & - & - \\
\hline
\end{tabular}

a Glass $\mathrm{Mg}$ ratios calculated assuming $\mathrm{Fe}_{2} \mathrm{O}_{3} / \mathrm{FeO}=0.15$.

b Temperature calculated after Roeder \& Emslie (1970), $T_{\text {MR }}$.

c Temperature calculated after Ford et al, (1983), $T_{\mathrm{Mg}}$.

d Temperature calculated after Kudo \& Weill (1970), with modifications by Mathez (1973), $p_{\mathrm{H}_{2} \mathrm{O}}=1 \mathrm{~atm}$.

e Temperature calculated after Roeder et al. (1979).

known melt may also be calculated (Nielsen \& Drake, 1979). The uncertainty inherent in this calculation is, however, larger than the generally expected differences between equilibrium and xenocrystic pyroxene, and augite xenocrysts have only been identified when they are optically or chemically distinct from the normal augite in a sample.

The olivine equilibration temperatures calculated for the glasses are consistently around $10^{\circ}$ higher than the 'measured' temperatures. This is an effect of the calculation method of Ford et al. (1983). The temperatures calculated for the bulk rocks are higher by up to $60^{\circ}$ than the calculated glass temperatures. This difference represents a real cooling interval from the olivine liquidus intersection down to the quenching of the glass. The actual extrusion temperature must lie in this interval. The Ford et al. (1983) bulk rock temperatures were used in constructing the temperature-composition diagram (fig. 69) for the total basalt suite. Compared to temperatures calculated from the Roeder \& Emslie (1970) equation, the Ford et al. (1983) temperatures are $10-20^{\circ}$ lower in the $\mathrm{Mg}$-rich end and $30-40^{\circ}$ lower in the Fe-rich end of the compositional spectrum.

Table 18. Comparison of calculated and measured temperatures and phenocryst compositions in glassy rocks and corresponding bulk rocks

\begin{tabular}{ccccccccc}
\hline \multirow{2}{*}{ GGU No } & & & \multicolumn{2}{c}{ Olivine } & \multicolumn{2}{c}{ Plagioclase } \\
\hline 98791 & glass & 0.552 & 1166 & 1155 & 79.0 & $79.4-80.0$ & 72.9 & $63.4-66.2$ \\
96928 & glass & 0.519 & 1153 & 1144 & 76.6 & $77.1-80.5$ & 71.1 & $59.7-65.8$ \\
& bulk & 0.599 & 1212 & - & 81.9 & & 78.1 & \\
98788 & glass & 0.514 & 1121 & 1090 & 75.9 & $81.5-83.2$ & 71.5 & $61.9-65.4$ \\
& bulk & 0.540 & 1162 & - & 77.4 & & 74.6 & \\
98842 & glass & 0.488 & 1164 & 1154 & 74.8 & $74.2-75.8$ & 71.5 & $63.7-75.0$ \\
& bulk & 0.517 & 1165 & - & 76.6 & & 77.3 & \\
215830 & glass & 0.474 & 1149 & 1142 & 74.0 & $75.3-78.3$ & 70.7 & $65.0-76.5$ \\
& bulk & 0.498 & 1160 & & 75.8 & & 76.5 & \\
98514 & glass & 0.427 & 1132 & 1124 & 69.4 & $70.7-75.5$ & 67.7 & $64.2-69.3$ \\
98516 & bulk & 0.480 & 1151 & - & 74.0 & & 75.3 & \\
215692 & glass & 0.392 & 1125 & 1112 & 66.1 & $67.6-71.1$ & 64.0 & $61.6-76.8$ \\
98890 & glass & 0.373 & 1122 & 1112 & 64.9 & $65.2-66.7$ & 64.9 & $56.3-60.6$ \\
& bulk & 0.419 & 1138 & - & 68.7 & & 71.7 & \\
\hline
\end{tabular}

a $\mathrm{Mg}$ ratios ratios calculated assuming $\mathrm{Fe}_{2} \mathrm{O}_{3} / \mathrm{FeO}=0.15$.

b Temperatures calculated from glass/bulk rock analysis by the method of Ford et al. (1983), $\mathcal{T}_{\text {sur: }}$.

c Temperatures calculcated from glass-olivine thermometry after Ford et al. (1983), $T_{\mathrm{Mg}}$ (Table 17).

d Equilibrium olivine composition calculated from glass/bulk rock analysis by the method of Ford $e t a l$. (1983), $P=1 \mathrm{~atm}$.

e Olivine phenocryst compositions as measured with the microprobe.

f Equilibrium plagioclase composition calculated from glass/bulk rock analysis by the method of Drake (1976), with $T=T_{\text {calc }}$.

g Plagioclase phenocryst composition as measured with the microprobe. 


\section{Geochemistry}

The basalts were analysed for major elements in the chemical laboratory of GGU by a combination of XRF and wet chemical methods. $\mathrm{SiO}_{2}, \mathrm{TiO}_{2}, \mathrm{Al}_{2} \mathrm{O}_{3}, \mathrm{Fe}_{2} \mathrm{O}_{3}$, $\mathrm{MnO}, \mathrm{MgO}, \mathrm{CaO}, \mathrm{K}_{2} \mathrm{O}$ and $\mathrm{P}_{2} \mathrm{O}_{5}$ were determined by $\mathrm{XRF}$ analysis of fused glass discs, with sodium tetraborate as a flux, and synthetic monoelement standards, with ensuing matrix correction as described by Sørensen (1975). $\mathrm{Na}_{2} \mathrm{O}$ (and in the older analyses also $\mathrm{MgO}$ ) was determined by atomic absorption spectrometry and $\mathrm{FeO}$ by titration. The loss on ignition was corrected for oxygen uptake due to oxidation of iron. All analyses are reported in appendix 2 . The analyses are of high and uniform quality, a necessary prerequisite for dealing with the variations in this basalt succession. The analyses were made during the years $1977-83$, and even within this time span small-scale geological variations, such as the differences in $\mathrm{TiO}_{2}$ content in the Geikie Plateau Formation north and south of Gåsefjord (fig. 72a \& b), were convincingly reproduced. It is therefore certain that the main cause of the data scatter in the variation diagrams is geological, not analytical.

Analyses for trace elements were carried out by XRF at the Institute of Petrology, University of Copenhagen, by J. C. Bailey, and at Grant Institute of Geology, University of Edinburgh, by J. G. Fitton. Overlap samples show that the accordance between the two data sets is good except for the rare earths. The REE data are therefore excluded from the data tables (appendix 3), but used in constructing the spider diagrams presented.

Reconnaissance analyses for $\mathrm{Sr}$ isotopes have been carried out on 10 selected samples. They were analysed by $O$. Larsen at the Institute of Petrology, University of Copenhagen. The data are presented in Table 21.

\section{Effects of alteration, and recalculation of analyses}

Before discussing the chemical composition of the Scoresby Sund basalt magmas it is necessary to consider the chemical changes brought about by the low-temperature zeolite facies metamorphism of the lavas. As appears from the data in fig. 64 , the lavas are both hydrated and oxidised, usually with water contents of $0.5-3.0 \mathrm{wt} \%$ and oxidation ratios $\left(\mathrm{wt} \% \mathrm{Fe}_{2} \mathrm{O}_{3} / \mathrm{FeO}\right)$ of $0.2-1.2$. These values are similar to those reported for Tertiary basalts from Iceland (e.g. Floyd \& Fuge, 1982) and from Britain (e.g. Thompson, 1982). In contrast, fresh basaltic glasses from the ocean floor have water contents below 0.5\% (Moore, 1970; Moore \& Schilling, 1973 ) and oxidation ratios of $0.1-0.3$ (Miyashiro et al., 1969). To overcome these effects, all analyses were recalculated to $100 \%$ on a volatile-free basis before the

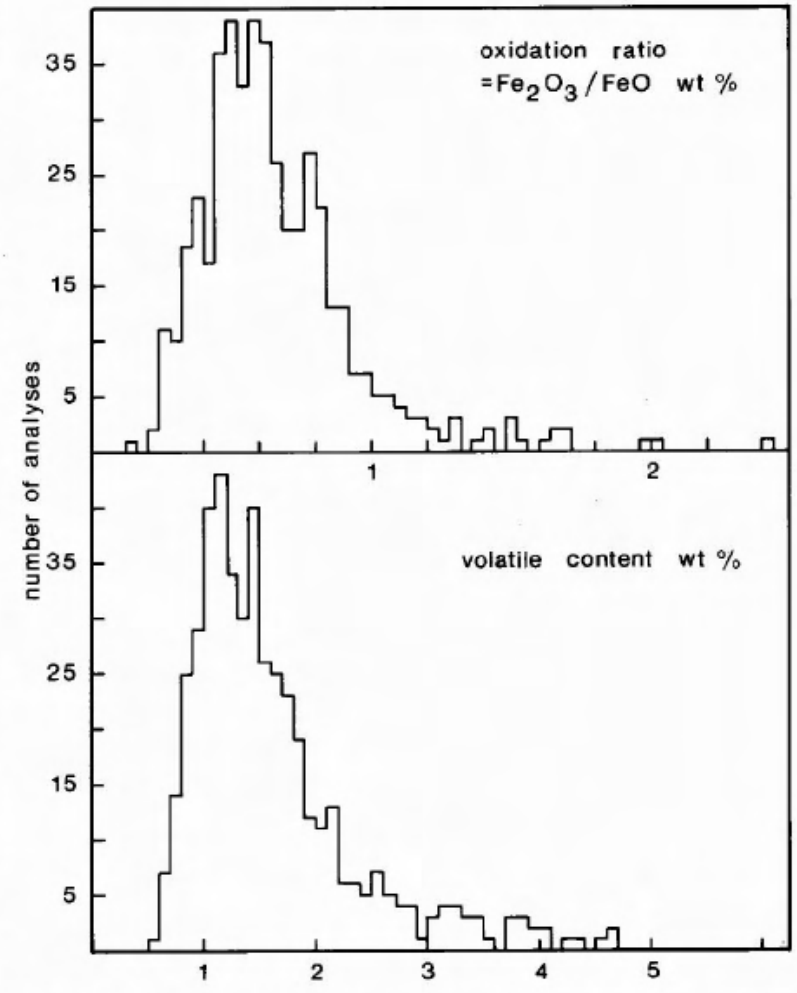

Fig. 64. Histograms of oxidation ratios and volatile contents in the Scoresby Sund basalts. Because in almost all cases $\mathrm{CO}_{2} \leq$ $0.1 \%$, the volatile content is almost exclusively $\mathrm{H}_{2} \mathrm{O}^{+}$.

The histograms are for the total data set. There are no major differences between the individual formations and dykes except that the lavas of the Rømer Fjord Formation are more hydrated (zeolitised) than the others. The samples with above 3\% volatiles are mostly from this formation; these are not, however, particularly oxidised, so that the two 'tails' towards high values in the two diagrams are not due to the same samples.

oxides were plotted in the various diagrams, and the norms and the $\mathrm{Mg}$ ratios were calculated with the oxidation ratios adjusted to 0.15 , as suggested by Brooks (1976), to approximate the original magmatic compositions.

Elements known to be mobile during zeolite facies metamorphism are $\mathrm{Si}, \mathrm{Mg}$ and alkalies, while $\mathrm{Fe}, \mathrm{Al}$, $\mathrm{Mn}, \mathrm{Ti}$ and $\mathrm{P}$ are relatively stable (Wood $e t$ al., 1976). In the Scoresby Sund basalt samples, loss of $\mathrm{Si}$ and $\mathrm{Mg}$ has not been observed with certainty, while loss of $\mathrm{Na}$ is seen in a few strongly hydrated samples (fig. 73). $\mathrm{K}$ is extensively redistributed, as shown for the most homogeneous of the formations, the Geikie Plateau Formation, in a $\mathrm{K}_{2} \mathrm{O} / \mathrm{P}_{2} \mathrm{O}_{5}$ plot (fig. 65) which should be compared with the $\mathrm{TiO}_{2} / \mathrm{P}_{2} \mathrm{O}_{5}$ plot in fig. 79 . In contrast to 


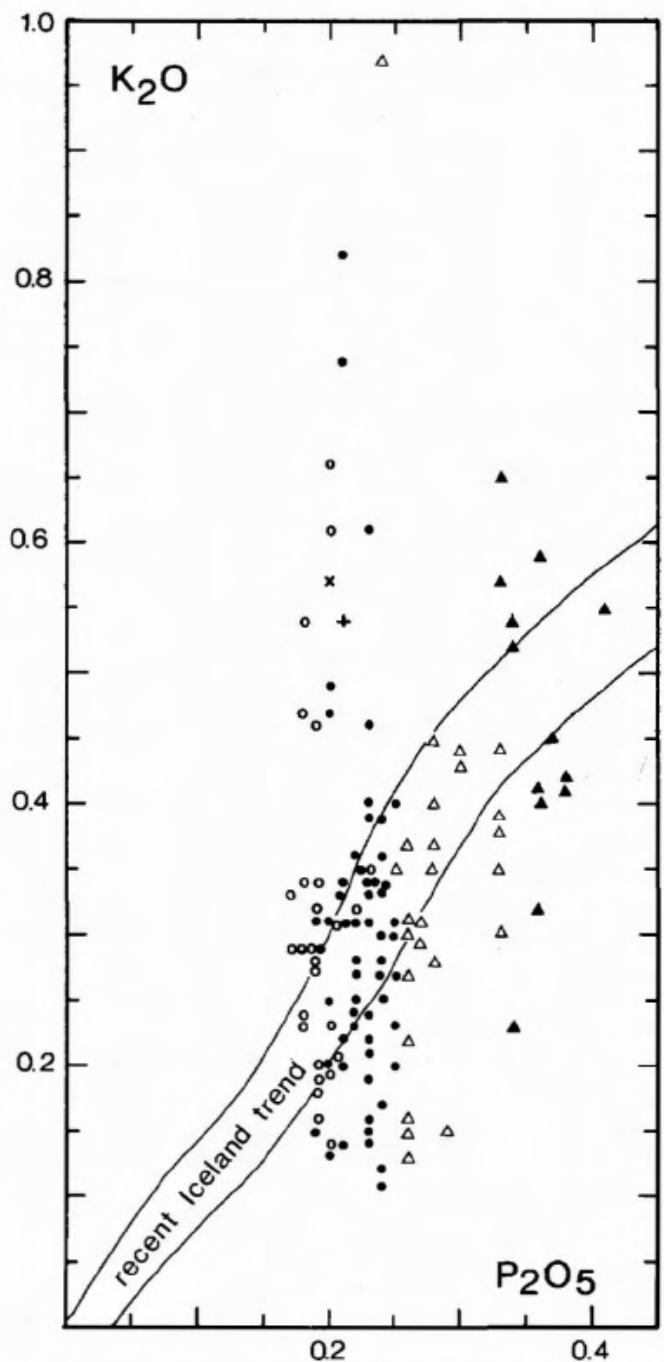

Fig. 65. $\mathrm{K}_{2} \mathrm{O} v \cdot \mathrm{P}_{2} \mathrm{O}_{5}$ (wt \% oxide) for samples from the Geikie Plateau Formation. These two relatively incompatible elements should ideally correlate closely and form a trend like the inserted one for recent tholeiites from Iceland (data from Jakobsson et al., 1978; Jakobsson, 1979). The large data scatter is due to redistribution of $\mathrm{K}_{2} \mathrm{O}$, not $\mathrm{P}_{2} \mathrm{O}_{5}$, compare fig. 79. $\mathrm{K}_{2} \mathrm{O}$ in the leached samples does not go below $0.1 \%$ because approximately this amount of $\mathrm{K}_{2} \mathrm{O}$ resides in the plagioclase $(50 \%$ plagioclase with $0.2 \% \mathrm{~K}_{2} \mathrm{O}$ on average) and is not available for leaching. The leachable $\mathrm{K}_{2} \mathrm{O}$ resides in mesostasis and in terstitial glass. Symbols as in fig. 68 .

$\mathrm{K}, \mathrm{Ti}$ and $\mathrm{P}$ are clearly unaffected by the alteration. From fig. 65 it can, however, be concluded that the original $\mathrm{K}$ contents in the lavas were fairly similar to those in recent Icelandic lavas. $\mathrm{Rb}$ is similarly redistributed, and the $\mathrm{K} / \mathrm{Rb}$ ratios vary erratically between 200 and 2000 .

With the above reservations, the analyses are in the following considered to closely approximate the original composition of magma plus crystals.

\section{Effects of crystal accumulation}

Lavas which show chemical signs of having accumulated phenocrysts are rare, and only plagioclase accumulation has been detected. Plagioclase accumulative lavas have abnormally high $\mathrm{Al}_{2} \mathrm{O}_{3}$ contents which is best seen in the $\mathrm{Al}_{2} \mathrm{O}_{3}-\mathrm{CaO}$ plots in fig. 77. All lavas with more than $15.5 \% \mathrm{Al}_{2} \mathrm{O}_{3}$ are clearly outliers in this figure and are considered to be plagioclase accumulative; these (11 samples) are all highly porphyritic. They are not plotted in the normative diagrams (figs 74 and 75) where they are obviously displaced towards higher contents of normative plagioclase. In other diagrams, such as figs 73 and 76 , they line up with their 'normal' equivalents.

A few other lavas, e.g. one in the Magga Dan Formation, with higher $\mathrm{Al}_{2} \mathrm{O}_{3}$ contents than usual for the group, may also be slightly plagioclase accumulative.

As discussed in the section on simple oxide variation diagrams, the chemical variation within the highly porphyritic Hjørnedal marker flow, with $13-18 \%$ plagioclase phenocrysts (fig. 36), can only be explained if the most differentiated samples have accumulated around $5 \%$ plagioclase relative to the least differentiated ones.

With these exceptions, the analyses are considered to represent magma compositions.

\section{General classification and divisions}

As the main parameter for characterising the compositional variation of the basalts the $\mathrm{Mg}$ ratio, atomic $\mathrm{Mg} /\left(\mathrm{Mg}+\mathrm{Fe}^{2+}\right)$ is used. A number of other variation parameters are frequently used, and to facilitate comparison with other types of plot fig. 66 was constructed. The variation diagrams presented here are necessarily of selected character, but the publication in appendices 2 and 3 of the complete set of analyses should amend for this and enable the reader to produce any desired plot.

The analysed lava samples are all tholeiitic basalts according to the chemical classification of Irvine \& $\mathrm{Ba}$ ragar (1971). $\mathrm{Mg}$ ratios range from 0.65 to 0.39 , and there are no picrites and no rocks as differentiated as tholeiitic andesite. This is also true according to the more recent IUGS classification system based on the alkali-silica diagram (Le Bas et al., 1986) excepting a few high-Si basalts discussed below. All the basalts are thus evolved types, and there are no primary magmas which should have $\mathrm{Mg}$ ratios in excess of 0.7 (Hanson \& Langmuir, 1978; Bender et al., 1978). According to the classification of Wood (1978), the Scoresby Sund basalts 
Fig. 66. Comparison chart for various widely used variation parameters. While the lower axis (weight $\mathrm{MgO}$ ) is necessarily only approximate, being independent of $\mathrm{FeO}$, the three ratios are uniquely correlated. Useful conversion factors are, for $\mathrm{Fe}_{2} \mathrm{O}_{3}$ / $\mathrm{FeO}$, adjusted to 0.15 : if weight $\mathrm{FeO}^{*} /\left(\mathrm{FeO}^{*}+\mathrm{MgO}\right)=\mathrm{a}$, and weight $\mathrm{FeO}^{*} / \mathrm{MgO}=\mathrm{b}$, then $\mathrm{Mg}$ ratio $=1 /(1+0.4944 \times \mathrm{a} /(1-\mathrm{a}))$ $=1 /(1+0.4944 \mathrm{~b})$.
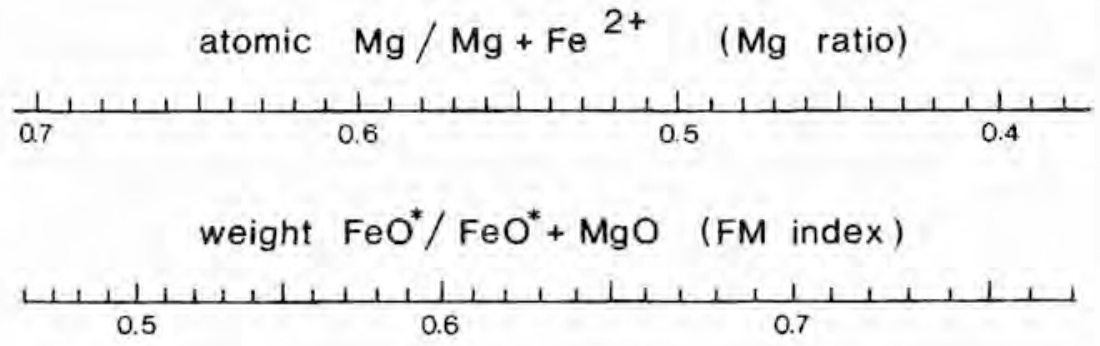

weight $\mathrm{FeO}^{*} / \mathrm{MgO}$

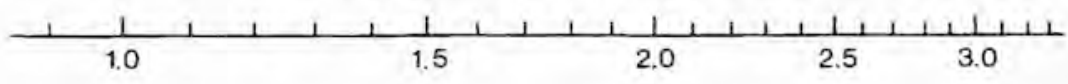

approximate weight $\mathrm{MgO}$
98
7 divide about equally into high magnesia basalts and low magnesia basalts, the division (at FM index $=65, \mathrm{Mg}$ ratio $=0.52$ ) cutting right through the natural chemical groupings set out below. Only four samples classify as ferrobasalts (FM $>74, \mathrm{Mg}$ ratio $\leq 0.415)$.

From variation diagrams as those in fig. 72 it is clear that the lavas come in some natural chemical groups. The main part of the basalts have $\mathrm{Mg}$ ratios less than 0.57 , and these are called the 'main basalts'. A few specific lavas or lava units have $\mathrm{Mg}$ ratios above 0.57 and are called the 'Mg-rich basalts'. Within both groups, sub-groups are distinct, and these are summarised in Table 19 and discussed below.

The division between $\mathrm{Mg}$-rich basalts and 'main basalts' is approximately coincident with Jakobsson et al.'s (1978) distinction at $\mathrm{FeO}^{*} / \mathrm{MgO}=1.4(\mathrm{Mg}$ ratio $=0.59)$ between olivine tholeiites erupted from shield volcanoes and fissure-erupted tholeiites on the Reykjanes Peninsula. As described in the stratigraphy chapter there is evidence that some of the Mg-rich basalts in the Scoresby Sund region form lava shields (the upper and lower compound units of the Rømer Fjord Formation), and the coincidence appears to be significant.

\section{Main basalts}

The main basalts with $\mathrm{Mg}$ ratios less than 0.57 constitute $96 \%$ of the total lava volume (Table 7). They are divided into four types based on their $\mathrm{TiO}_{2}$ contents. The basis for the division is the feature that appears from fig. 72, and is illustrated in histograms in fig. 67, that certain values of $\mathrm{TiO}_{2}$, viz. $2.25 \%, 2.8 \%$ and $3.5 \%$, are seldom or never attained, and that these values are the same in the different formations. Thus low-Ti basalts have $\mathrm{TiO}_{2}$ contents below $2.25 \%$ but somewhat depending on the $\mathrm{Mg}$ ratio (see e.g. fig. 72 partial diagram b; this tends to blur the histograms in fig. 67), medium-Ti basalts have $\mathrm{TiO}_{2}$ contents between $2.25 \%$ and $2.79 \%$, high-Ti basalts have $\mathrm{TiO}_{2}$ contents between $2.80 \%$ and $3.49 \%$ and titano-tholeiites have $\mathrm{TiO}_{2}$ contents of $3.50 \%$ or greater. The term 'titano-tholeiite' has been coined to convey the Ti-rich, yet non-alkaline nature of this basalt type. They are not ferrobasalts in the sense of Wood (1978) and Flower et al. (1982).

The division of the main basalts into four groups is most evident in the lower basalt sequence (Magga Dan, Milne Land and Geikie Plateau Formations). In the upper sequence (Rømer Fjord and Skrænterne Formations) and in the Igtertivâ Formation the minimum at $2.8 \% \mathrm{TiO}_{2}$ is not present, and consequently the medium- $\mathrm{Ti}$ and high- $\mathrm{Ti}$ basalts are combined as mediumhigh-Ti basalts. In the Skrænterne and Igtertivâ Formations there is an indication of a natural group limit at $3.0 \% \mathrm{TiO}_{2}$ (fig. 72), and this limit was used in figs 24,29 and plate 2 to indicate the relatively few lavas with $3.0-3.5 \% \mathrm{TiO}_{2}$. The distribution pattern of the inland dykes is similar to that of the Geikie Plateau Formation. That of the coastal dykes shows no significant minima between $1.5 \%$ and $3.2 \% \mathrm{TiO}_{2}$; but to facilitate comparison with the basalt formations a low-Ti group is somewhat arbitrarily distinguished for the coastal dykes (fig. 72).

\section{Mg-rich basalts}

The Mg-rich basalts are either single lava flows or, in 
Table 19. Compositional divisions of the Scoresby Sund basalts

\begin{tabular}{|c|c|c|c|c|c|c|c|c|c|}
\hline \multirow{3}{*}{$\overline{M g-r i c h ~ b a s a l t s}$} & \multirow[b]{2}{*}{$\mathrm{TiO}_{2}$} & \multirow[b]{2}{*}{$\mathrm{Mg} /\left(\mathrm{Mg}+\mathrm{Fe}^{2+}\right)$} & \multirow[b]{2}{*}{ MF } & \multirow{2}{*}{ MLF } & \multicolumn{3}{|c|}{ Occurrence } & \multirow[b]{2}{*}{ IF } & \multirow[b]{2}{*}{ Remarks } \\
\hline & & & & & GF & RFF & $\mathrm{SF}$ & & \\
\hline & & & & & & & & & \\
\hline Mikis type & $2.30-2.70$ & $>0.60$ & & $x$ & $x$ & & & & Two single flows \\
\hline olivine thol. & $2.00-2.40$ & $>0.57$ & & & & $x$ & & & Lower compound unit \\
\hline MORB type & $<1.85$ & variable & & & & $x$ & & & MORB type unit \\
\hline Hjørnedal mark. & $2.20-2.60$ & $0.57-0.61$ & & $x$ & & & & & One large flow \\
\hline \multicolumn{10}{|l|}{ Main basalts } \\
\hline titano-thol. & $\geqslant 3.50$ & & & $x$ & $x$ & $x$ & $x$ & & \\
\hline high-Ti type & $2.80-3.50$ & $<0.57$ & & $x$ & $x$ & $x$ & $x$ & $x$ & \\
\hline med-Ti type & $2.25-2.80$ & & $x$ & $x$ & $\times$ & & $x$ & $x$ & \\
\hline low-Ti type & $1.75-2.32$ & & & & $x$ & & $x$ & $x$ & \\
\hline high-Si type & $\mathrm{SiO}_{2}$ & $>51 \%$ & $x$ & $x$ & $x$ & & $x$ & & Occ. flows \& hyaloclastites \\
\hline
\end{tabular}

the Rømer Fjord Formation, groups of compound lava flows. They only constitute $4 \%$ of the total lava volume (Table 7).

The Mikis type lavas (one in the Milne Land Formation and one in the Geikie Plateau Formation) have the highest $\mathrm{MgO}$ contents and $\mathrm{Mg}$ ratios of all the investi- gated basalts, and relative to the $\mathrm{Mg}$ ratios they are unusually rich in $\mathrm{TiO}_{2}, \mathrm{P}_{2} \mathrm{O}_{5}$ and alkalies. These characteristics are similar to those of the dominant lava type in the Mikis Formation in the Lower Basalts at Kangerdlugssuaq (Brooks et al., 1976; Nielsen et al., 1981), hence the name.
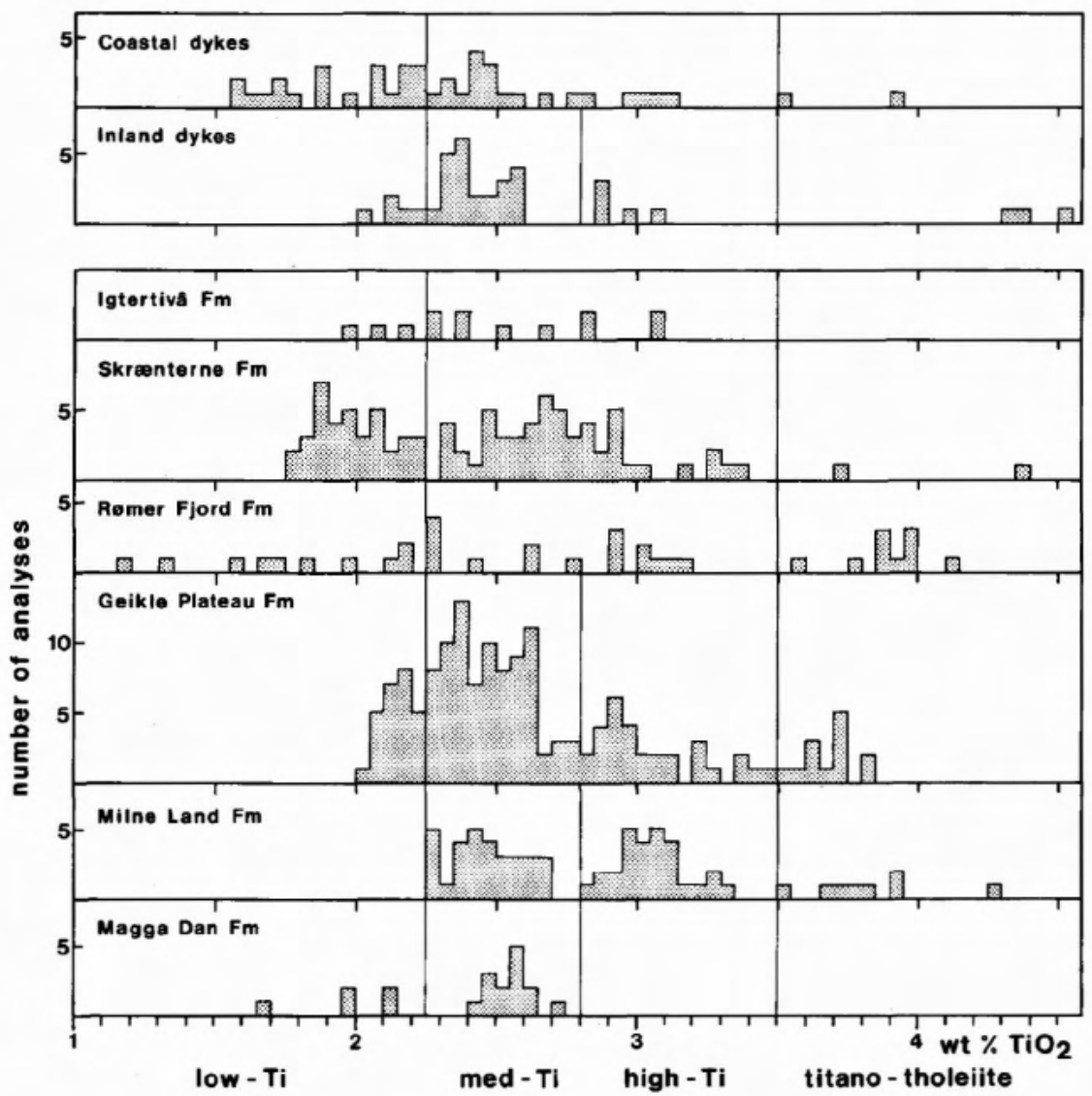

Fig. 67. $\mathrm{TiO}_{2}$ distribution in the successive lava formations and in the dykes. The frequency minima around $2.25,2.80$ and $3.50 \%$ $\mathrm{TiO}_{2}$ according to which the lavas were sub-divided are shown with vertical lines. The minimum at $2.80 \% \mathrm{TiO}_{2}$ only applies to the lower sequence (Magga Dan, Milne Land and Geikie Plateau Formations) and the inland dykes. Note the similarity in distribution pattern between the Geikie Plateau Formation and the inland dykes which supposedly fed this formation. The figure shows a gradual shift towards lower $\mathrm{TiO}_{2}$ values with time and gives an approximately correct impression of the volume relations. 
The olivine tholeiites of the Rømer Fjord Formation have lower $\mathrm{Mg}$ ratios than the Mikis type lavas. Relative to their $\mathrm{Mg}$ ratios they have high contents of $\mathrm{TiO}_{2}$ and $\mathrm{P}_{2} \mathrm{O}_{5}$. The lavas in the lower compound unit are the typical olivine tholeiites, while those in the upper compound unit have $\mathrm{Mg}$ ratios below 0.57 and classify strictly speaking as main basalts of med-high-Ti type. They have, however, higher $\mathrm{Mg}$ ratios than any other main basalts with similar $\mathrm{TiO}_{2}$ contents (fig. 72 ), and their chemical as well as their petrographic character indicate that they are differentiated olivine tholeiites.

The MORB type lavas of the Rømer Fjord Formation are, in strong contrast to the olivine tholeiites, unusually low in $\mathrm{TiO}_{2}, \mathrm{P}_{2} \mathrm{O}_{5}$ and alkalies. In this they resemble ocean floor basalts (MORB). These few lavas span a considerable range in $\mathrm{Mg}$ ratios (fig. 72).

The Hjørnedal marker is a single voluminous flow in the Milne Land Formation with a composition that is distinct from all other flows. In the $\mathrm{TiO}_{2}-\mathrm{Mg}$ ratio plot (fig. 72) it overlaps with the olivine tholeiites but, in contrast, the $\mathrm{Hjørnedal} \mathrm{marker} \mathrm{is} \mathrm{relatively} \mathrm{high} \mathrm{in} \mathrm{SiO}_{2}$ (c. $50 \%$, compare the plots in fig. 73 ) and is usually quartz normative, while the olivine tholeiites have up to $15 \%$ normative olivine. The Hjørnedal marker flow should thus not be termed an olivine tholeite. This lava flow shows lateral compositional variation. Samples from the eastern profiles have the lowest $\mathrm{Mg}$ ratio and are quartz normative, while the samples from the two western profiles 71 and 72 have the highest $\mathrm{Mg}$ ratios and are olivine normative. The lava may have been erupted from a zoned magma chamber. It is later shown to be a mixture of main basalt and Mikis type basalt.

\section{High-Si basalts}

Lavas with unusually high $\mathrm{SiO}_{2}$ contents are found in most formations. These lavas are easily noticed in the alkali/silica diagram (fig. 73). Six lavas have more than $52 \% \mathrm{SiO}_{2}$ and thereby plot in the basaltic andesite field in the alkali-silica classification diagram of Le Bas et al. (1986). However, the rocks in question do not show other geochemical evidence of being more fractionated than the other basalts; they are definitely not andesitic, and they are here included with the other high-Si basalts. $\mathrm{A} \mathrm{SiO}_{2}$ value above $51 \%(50.5 \%$ for the Skranterne Formation because of flow correlation) was used to assign samples to this group. It is not a homogeneous group but may include lavas of any of the other types in Table 19 with sufficiently high $\mathrm{SiO}_{2}$ contents, possibly due to crustal contamination (increased ${ }^{87} \mathrm{Sr} /{ }^{86} \mathrm{Sr}$ ratios, Table 21). In many cases, the composition of a high-Si sample still clearly indicates to which type it originally belonged, and only for the high-Si lavas from the Magga Dan Formation and the singular high-Si lava from the Geikie Plateau Formation is there any doubt about the original chemical affiliation. The high-Si basalts from these two formations have high $\mathrm{Mg}$ ratios and were possibly inherently different and less evolved than the 'normal' basalts.

Throughout this bulletin it has been attempted to use a consistent set of symbols for the various chemical types. The keys to these symbols are given in fig. 68 . The inevitable exceptions to the system are noted as such in the appropriate figure captions.

\begin{tabular}{|c|c|c|c|}
\hline & Lithology & Lithology & Chronology \\
\hline IF & Igtertivä Formation & & third episode \\
\hline $\begin{array}{l}\text { SF } \\
\text { RFF }\end{array}$ & $\begin{array}{l}\text { Skrænterne Formation } \\
\text { Rømer Fjord Formation }\end{array}$ & upper basalt sequence & second episode \\
\hline $\begin{array}{l}\text { GF } \\
\text { MLF } \\
\text { MF }\end{array}$ & $\begin{array}{l}\text { Geikie Plateau Formation } \\
\text { Milne Land Formation } \\
\text { Magga Dan Formation }\end{array}$ & lower basalt sequence & first episode \\
\hline
\end{tabular}

Fig. 68. Formation codes, lithological and chronological divisions, and key symbols for the various chemical types of the Scoresby Sund basalts. This notation is used throughout the work except where otherwise stated. The chemical types are described in the text.

\section{Key symbols}

lower basalt sequence
* titano-tholeiite
$\Delta$ high-Ti type
- med-Ti type
o low-Ti type
$\times$ high-Si basalt
$\otimes$ high-Si basalt with
orthopyroxene phenocrysts
H Hjørnedal marker
+ Mikis type

upper basalt sequence

$\Delta$ titano-tholeiite

$\triangle$ RFF high-Ti type

- SF upper unit lmed-high

- SF lower unit Ti type

- low-Ti type

* high-Si basalt

- RFF MORB type

- RFF upper compound unit

- RFF lower compound unit 


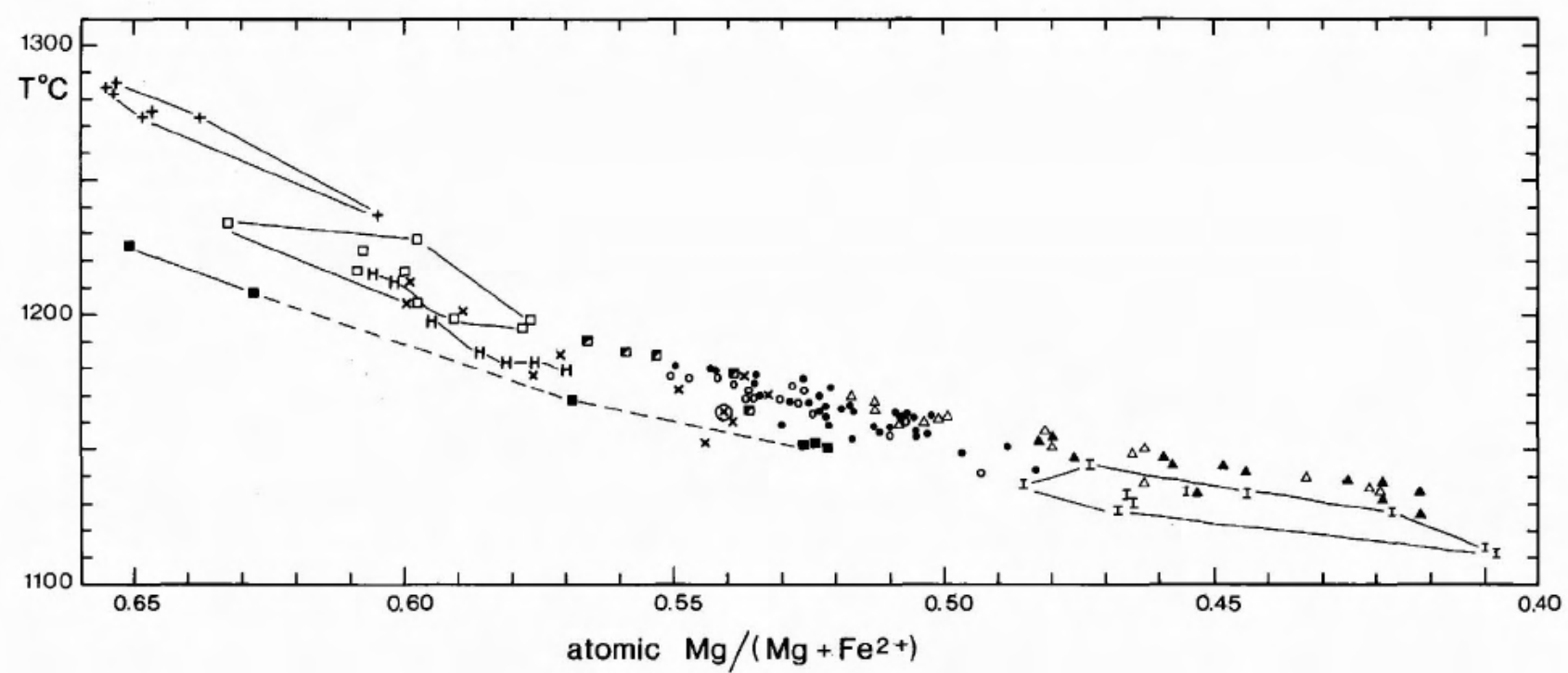

Fig. 69. Olivine saturation temperatures for magmas calculated from whole-rock analyses after the method of Ford et al. (1983). The temperatures are taken to approximate to extrusion temperatures. Symbols as in fig. 68 except for $I=$ Igtertivâ Formation basalts.

\section{General properties of the magmas}

In the following calculations of temperatures and densities all available data for the less common magma types were used, and for the main basalts the data for the Geikie Plateau Formation in profiles 48, 52, 55, 59 and 76 were used which, due to their tight clustering in fig. 72 sub-diagram $b$, are believed to be the most unambiguous magma representatives. The most iron-rich part of the suite is, however, supplemented with other selected analyses to give better coverage.

\section{Temperatures}

Temperatures based on mineral-glass and mineralbulk rock relations in microprobed samples were calculated in an earlier section (Tables 17-18). Based solely on bulk rock analyses (and assuming olivine saturation) temperatures have also been calculated for the total basalt suite, following Ford et al. (1983), as shown in fig. 69. Comparisons to the mineral thermometers are included in Table 18.

The $\mathrm{Mg}$-rich basalts have temperatures in the range

Table 20. Phenocryst associations and corresponding calculated magma temperatures in the Scoresby Sund basalts

\begin{tabular}{|c|c|c|}
\hline Phenocrysts & Lava type & $\begin{array}{c}\text { Calculated } \\
\text { temperatures }{ }^{\circ} \mathrm{C}\end{array}$ \\
\hline $\mathrm{ol}+\mathrm{crm}$ & $\begin{array}{l}\text { Mikis type basalt } \\
\text { MORB type basalt, Mg ratio }>0.57 \\
\text { RFF lower compound unit } \\
\text { RFF upper compound unit }\end{array}$ & $\begin{array}{l}1285-1237 \\
1225-1208 \\
1234-1195 \\
1191-1178\end{array}$ \\
\hline $\begin{array}{l}\mathrm{ol}+\mathrm{crm}+\mathrm{pl}+\mathrm{cpx} \\
\mathrm{ol}+\mathrm{crm}+\mathrm{pl}+\mathrm{cpx}+\mathrm{opx}\end{array}$ & $\begin{array}{l}\text { Hjørnedal type } \\
\text { High-Si basalts, } \mathrm{Mg} \text { ratio }>0.57 \\
\text { One high-Si basalt, } \mathrm{Mg} \text { ratio }=0.54\end{array}$ & $\begin{array}{c}1215-1179 \\
1212-1185 \\
1162\end{array}$ \\
\hline $\begin{array}{l}\mathrm{ol}+\mathrm{pl} \\
\mathrm{ol}+\mathrm{pl}+\mathrm{cpx}\end{array}$ & $\begin{array}{l}\text { Main basalts, all } \mathrm{TiO}_{2} \text { groups } \\
\text { MORB types, } \mathrm{Mg} \text { ratio }<0.57 \\
\text { High-Si basalts, } \mathrm{Mg} \text { ratio }<0.57\end{array}$ & $1181-1111$ \\
\hline
\end{tabular}

The calculated temperatures are olivine saturation temperatures calculated from the whole-rock analyses after the method of Ford et al. (1983). 


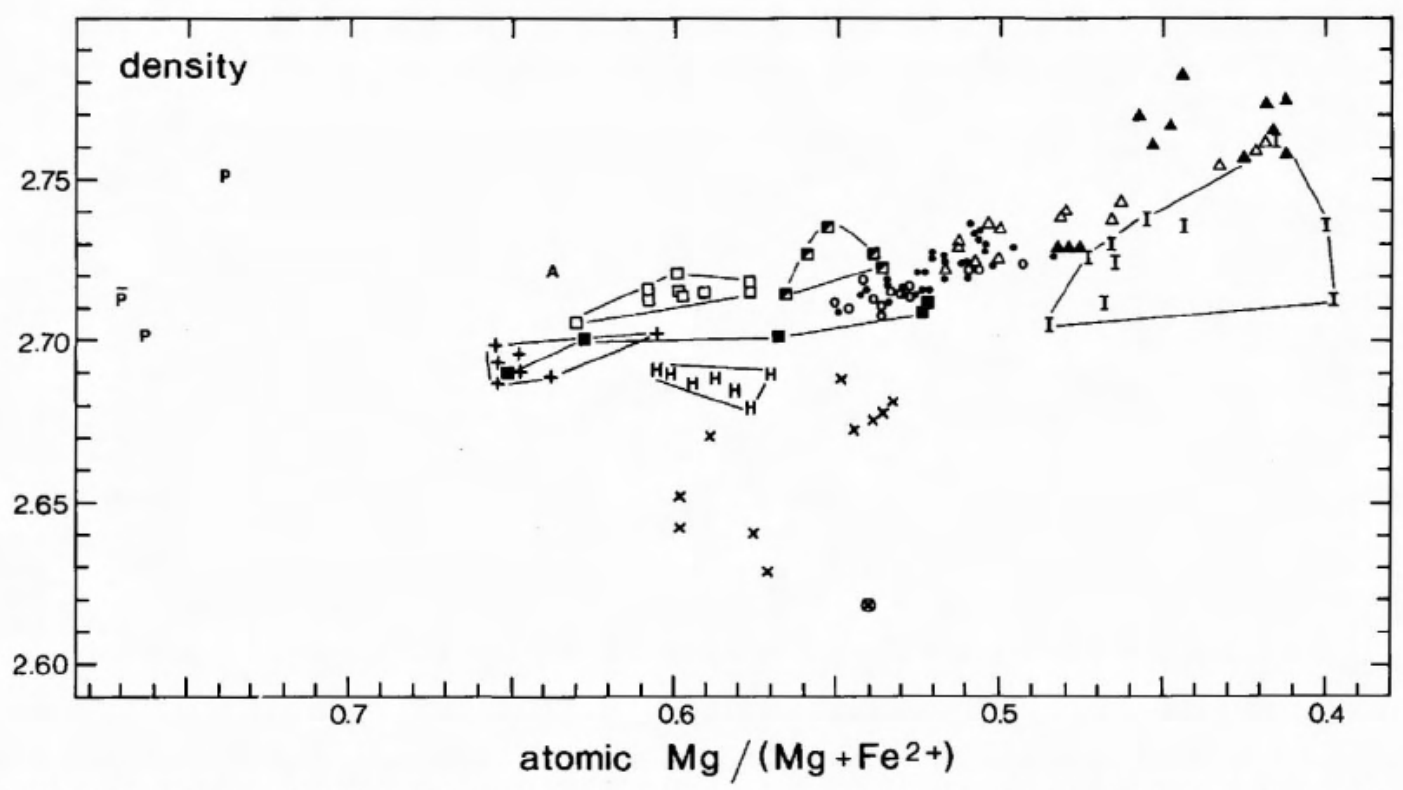

Fig. 70. Calculated densities (dry) for the Scoresby Sund basalts. Symbols as in fig. 68 except for I = Igtertivâ Formation basalts. Data from Kangerdlugssuaq lavas from Nielsen et al. (1981). $\mathrm{P}=$ picrite, $\overline{\mathrm{P}}=$ average picrite, $\mathrm{A}=$ ankaramite.

$1286^{\circ}$ to $1180^{\circ} \mathrm{C}$, and there are significant differences between the various types, the Mikis type magma having the highest and the MORB type the lowest temperatures for equal $\mathrm{Mg}$ ratios.

The main basalts have temperatures in the range $c$. $1180^{\circ}-1110^{\circ} \mathrm{C}$. For these, there is an indication that, like the Mg-rich basalts, basalts with higher $\mathrm{TiO}_{2}$ contents have higher temperatures at equal $\mathrm{Mg}$ ratios. However, change of the iron oxidation ratio from 0.15 to 0.25 will increase the $\mathrm{Mg}$ ratio by $0.015-0.020$ and decrease the calculated temperature by $4-5^{\circ}$. If the more $\mathrm{TiO}_{2}$-rich magmas were also more oxidised, as is quite likely, the temperature differences at equal $\mathrm{Mg}$ ratios will tend to be eliminated for the main basalts but not for the Mgrich basalts.

In conclusion, the more 'enriched' Mg-rich basalts (Mikis type) are hotter than the more 'depleted' (MORB types) at equal $\mathrm{Mg}$ ratios, while a possible similar effect in the main basalts is obscured by the uncertainty about the oxidation states of the magmas.

\section{Phase relations}

The various phenocryst associations in the basalts are summarised in Table 20. Generally, the magmas which crystallised above $1180^{\circ} \mathrm{C}$ have olivine + chromite on the liquidus, with the notable exception of the Hjørnedal type and some high-Si basalts. Below $1180^{\circ} \mathrm{C}$ liquidus phases are olivine + plagioclase or olivine + plagioclase + augite (see section on petrography).
There is no measurable temperature difference between the incoming of plagioclase and augite. As shown in the following sections the whole suite of 'main basalts' which crystallised below $1180^{\circ} \mathrm{C}$ shows chemical evidence of extensive low-pressure fractionation of olivine + plagioclase + augite, no matter whether augite phenocrysts are present or not, or whether the rocks are apparently aphyric, as are many basalts of the Geikie Plateau Formation.

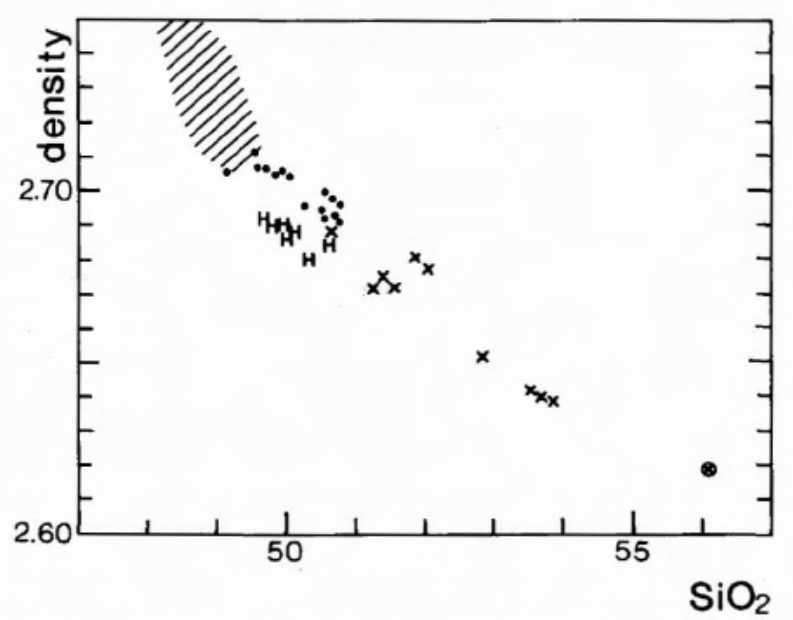

Fig. 71. Calculated densities (dry) $v$. the silica content of selected lavas. Symbols as in fig. 68 except that dots = Magga Dan Formation lavas, and ruled area $=$ field of Geikie Plateau Formation lavas. 

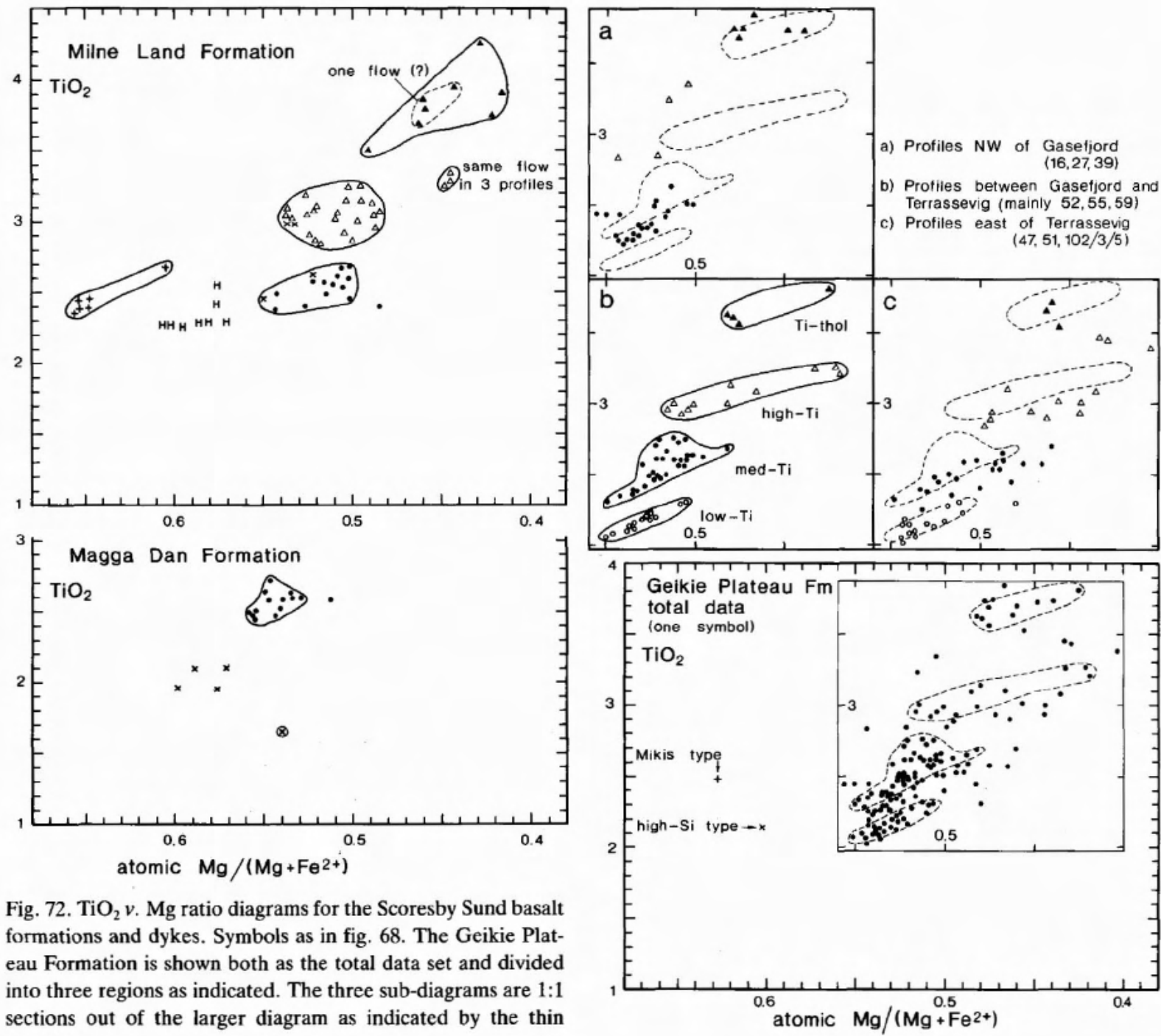

\section{Densities}

Densities were calculated after the method of Bottinga et al. (1982), using the temperatures calculated as discussed in the preceding section. The results are shown in fig. 70. Sparks et al. (1980) and Sparks \& Huppert (1984) showed that basaltic magma suites usually attain a density minimum around a $\mathrm{Mg}$ ratio of 0.65 to 0.60 , and magmas with $\mathrm{Mg}$ ratios higher than that of the minimum density are very often not erupted at the surface. This also appears to be the case for the Scoresby Sund lavas. The Mikis type basalts probably represent the density minimum, although this is not well defined owing to the scarcity of more primitive lava compositions. The picrites from Kangerdlugssuaq plotted in fig. 70 (Nielsen et al., 1981) give quite scattered densities, but they are higher than those of the Mikis

type basalts. In the right part of the figure densities increase with fractionation, i.e. increasing iron content. The values of $2.69 \mathrm{~g} / \mathrm{cm}^{3}$ for the minimum and around 2.77 for the most iron-rich basalts are similar to those calculated for basaltic glasses from Iceland (Sparks et al., 1980).

The calculated densities for the high-Si basalts and the Hjørnedal marker are lower than for the normal basalts. There is a well-defined inverse correlation between the silica content and the density of the basalts (fig. 71). Thus, if a magma in a crustal magma chamber reacted with the side-wall, the contaminated magma would collect below the roof of the magma chamber and shield the underlying magma from further contamination. It would also be the first and easiest magma to erupt at the surface. The Hjørnedal magma, being a 

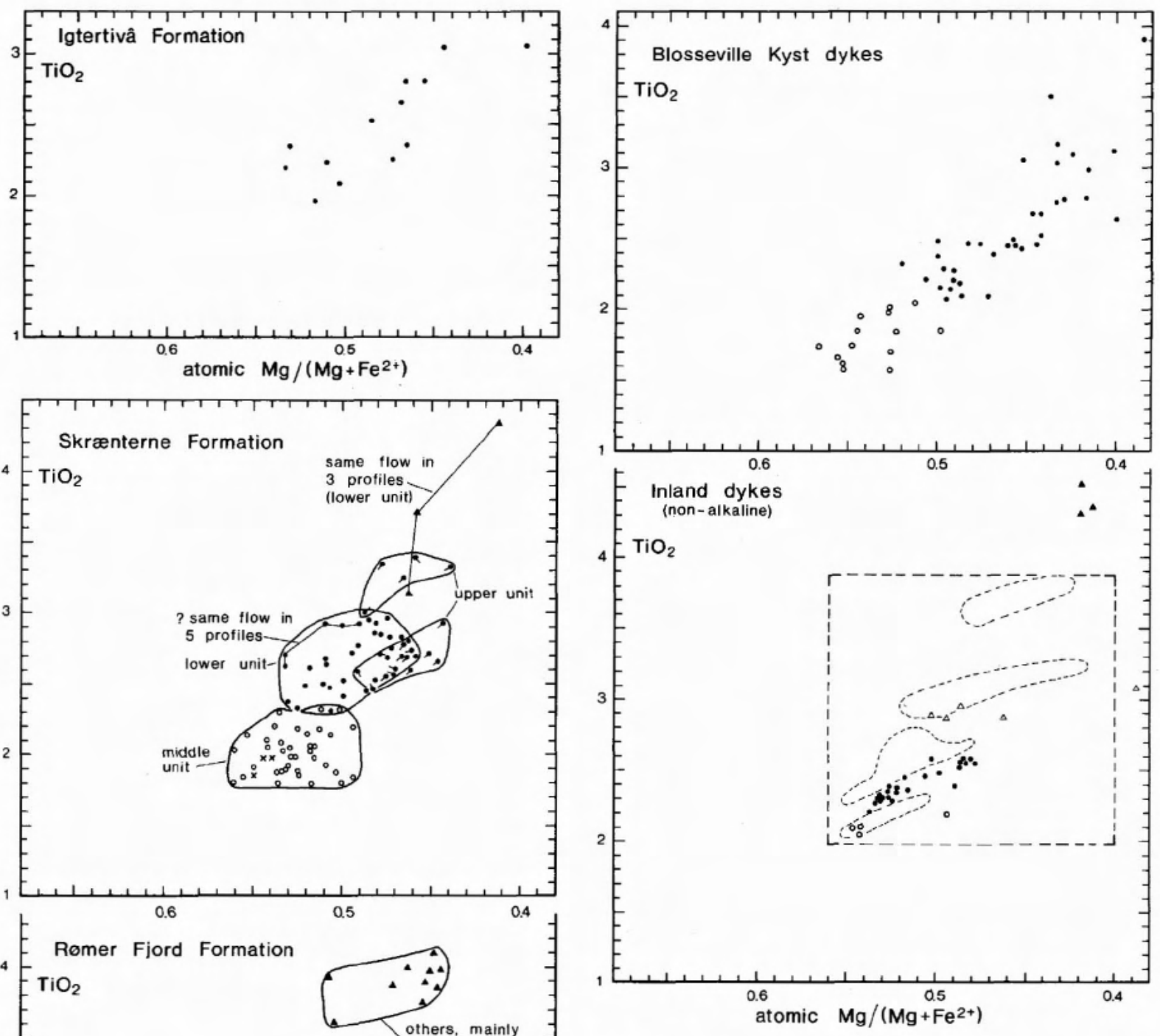

Fig. 72 cont.

frame. The contours of the distribution pattern for subset $b$ are repeated with dashed lines on the other diagrams for the Geikie Plateau Formation and on that for the inland dykes.

Fig. 70 shows that the various basalt types have somemixture of main basalt and Mikis type basalt, would likewise collect below the roof (see later section on magma mixing). what varying density 'levels' relative to the $\mathrm{Mg}$ ratio. This is primarily caused by differences in silica contents. 
The olivine tholeites of the Rømer Fjord Formation are thus relatively dense. The titano-tholeites with density $>2.75$ are all relatively silica-poor rocks with $\mathrm{SiO}_{2}$ contents of $47-48 \%$, from the upper Geikie Plateau and Rømer Fjord Formations. In contrast, the less dense Igtertivâ Formation lavas have $\mathrm{SiO}_{2}$ contents of $49-50 \%$ (see fig. 73).

In conclusion, the density pattern in fig. 70 is expected and explicable. Though the density differences are small, they are crucial for the fluid dynamic behaviour of the magmas during intrusion, mixing and eruption, as discussed by Sparks et al. (1980) and Sparks \& Huppert (1984).

\section{Discussion of major elements}

\section{Compositional variations within the basalt pile and dykes}

Each basalt formation has a compositional pattern that is characteristic and different from those of the other formations. In several cases, the compositional pattern within a formation can be used to establish a relatively detailed stratigraphy, as earlier described. This section is concerned with the overall variation pattern within the basalt pile and dykes.

Variation diagrams of $\mathrm{TiO}_{2} v . \mathrm{Mg}$ ratio are shown in fig. 72. From these diagrams the division of the basalts into the various chemical types is clearly apparent. The groupings are especially clear in the Milne Land and Rømer Fjord Formations, while the picture for the Geikie Plateau Formation is diffuse when all data are plotted in one diagram. This is because the Geikie Plateau Formation shows lateral compositional variation, with $\mathrm{Mg}$ ratios decreasing from the inland areas towards the Atlantic coast to the SE. This is demonstrated in the sub-diagrams a, b, c of fig. 72 from the Geikie Plateau Formation. Diagram b shows four very well-defined clusters corresponding to the four successive units of main basalt in this formation (Plate 2).

The Skranterne Formation shows no lateral variation. A characteristic feature of the Skrænterne Formation in all types of geochemical diagrams is that the analyses plot in larger, 'looser' clusters than those from the two other uniform formations, the Magga Dan and Geikie Plateau Formations, which form relatively small, tight clusters. This is ascribed to the porphyritic nature of the Skrænterne Formation, although definite signs of crystal accumulation have only been found in a few samples. The Geikie Plateau Formation forms the clearest magmatic evolution trends.

Lateral compositional variation is found in the Rømer Fjord Formation where the lavas, especially the two compound units, become increasingly olivine normative towards the south-east, i.e. towards the Blosseville Kyst.

The vertical variations through the basalt pile are considerably more conspicuous than the lateral variations, and some variations are repeated through the two major sequences or volcanic episodes. $\mathrm{Mg}$-rich tholeiites are only present in the lower part of each sequence (Milne Land and Rømer Fjord Formation), and even within the main basalts there is a systematic decrease in $\mathrm{Mg}$ ratio through each sequence. For similar $\mathrm{TiO}_{2}$ contents the main basalts of the Magga Dan and Milne Land Formations have relatively higher $\mathrm{Mg}$ ratios than the overlying Geikie Plateau Formation (fig. 72), and the same feature is apparent for the main basalts of the Rømer Fjord Formation in relation to the overlying Skrænterne Formation (fig. 72). The lavas of the Skrænterne Formation have the lowest $\mathrm{Mg}$ ratios for similar $\mathrm{TiO}_{2}$ contents in the two major sequences, while the lavas from the Igtertivâ Formation have similarly low Mg ratios.

Another feature varying with stratigraphic height is the $\mathrm{TiO}_{2}$ concentration which decreases with height in each of the two major sequences and ends with a reversal to higher values (Plate 2). Low-Ti basalts only occur near the top of each sequence. Further, the histograms in fig. 67 show that up through the whole lava pile the $\mathrm{TiO}_{2}$ distribution is gradually displaced towards lower values of $\mathrm{TiO}_{2}$. The histograms represent the number of analysed samples, but they do give an approximately correct impression of the volume relationships (cf. Table 7), and thus it is seen that with time $\mathrm{TiO}_{2}$-poor lavas become increasingly important; a trend which seems to have continued into the coastal dyke swarm.

In some aspects, the two major volcanic sequences are different. As shown in the combined profile, fig. 3, the normative character of the lavas changes gradually from quartz normative in the lower part of the succession to olivine normative in the middle and upper parts. Thus, the first volcanic sequence started with quartz normative products and only developed olivine normative products in its upper part, while the lavas of the second sequence are almost exclusively olivine normative. The 'reversals' at the end of both sequences developed a near-saturated character.

The development in normative character up through the succession is directly related to the silica content of the lavas, as shown in the alkali/silica diagrams in fig. 73. The silica content is maximum, around $50 \%$, in the Magga Dan Formation lavas and decreases to a minimum, around $48 \%$, in the Rømer Fjord Formation, followed by an increase to about $49 \%$ in the Skrænterne 


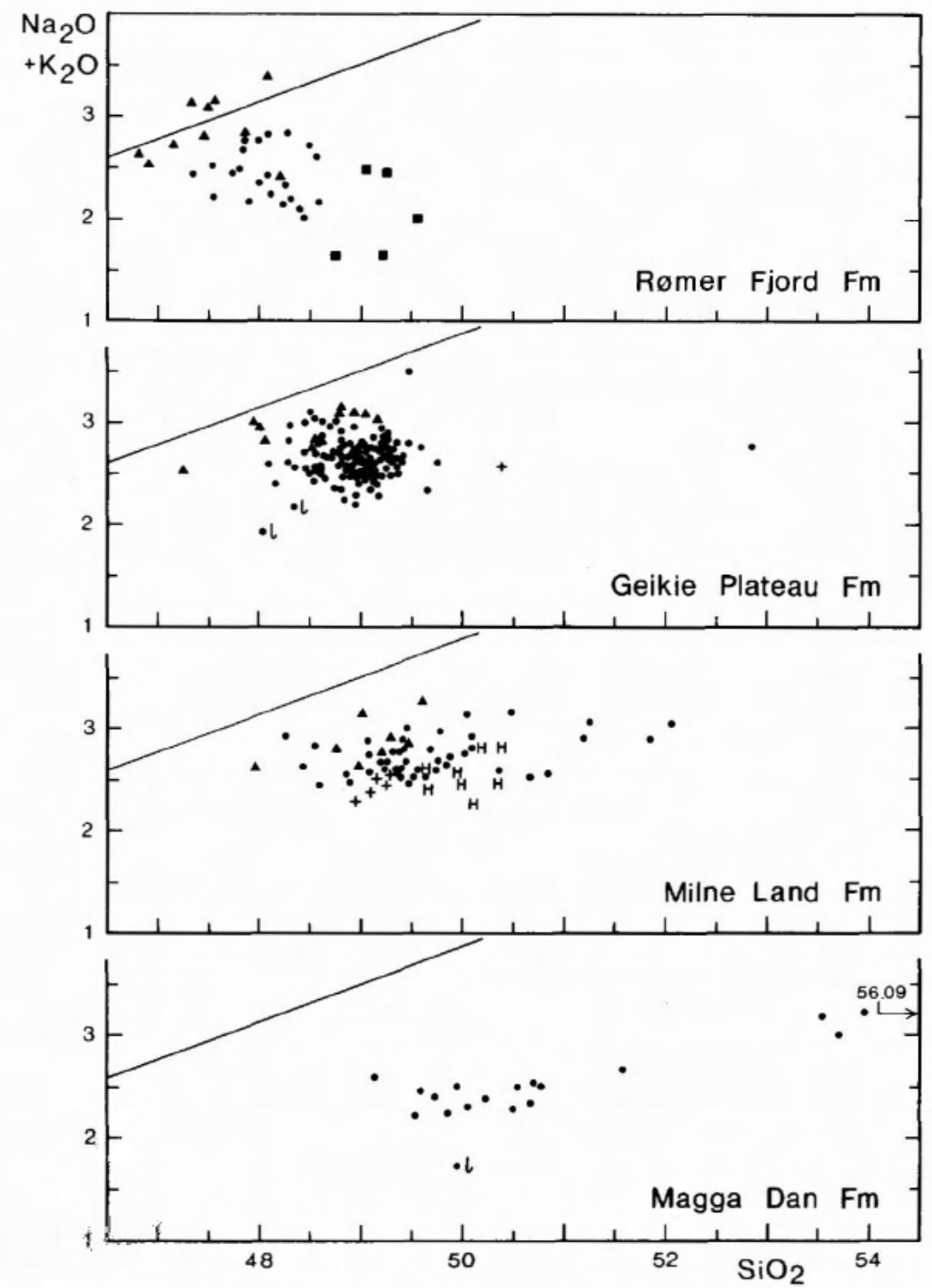

Fig 73. Aikali-silica diagrams for the basalt formations and dykes. Symbols: Squares $=$ MORB type; triangles $=$ titano-tholeiites $;$ crosses $=$ Mikis type $; \mathrm{H}=$ Hjørnedal marker , dots $=$ all other basalts; $1=$ indicates leached samples.

Full line $=$ Hawaiian division line of Macdonald \& Katsura (1964). Dashed line = alkaline/

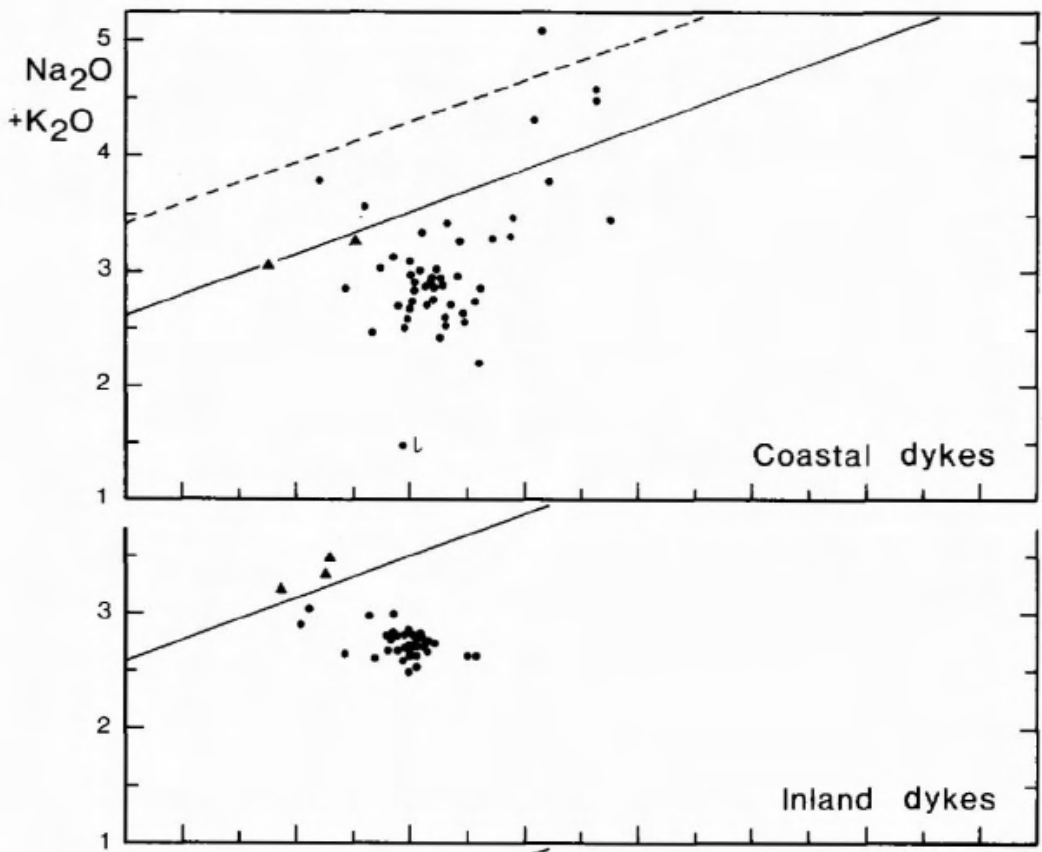

tholetitic division line of Irvine \& Baragar (1971). 


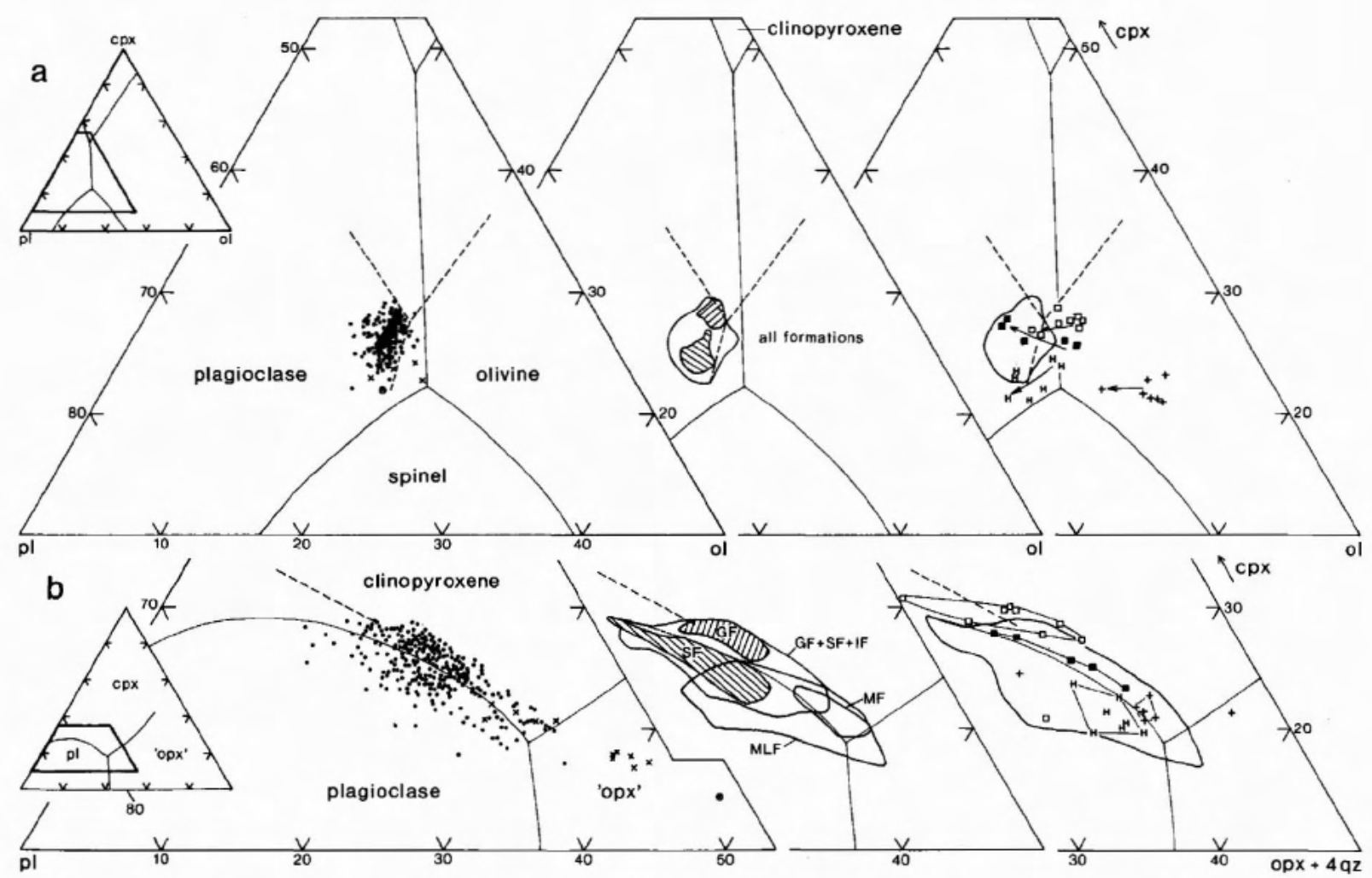

Fig. 74. Scoresby Sund basalt analyses plotted into the system $o l-p l-c p x-q z$. The cation normative projections used are those of Irvine $(1970,1979)$. Phase boundaries as follows: Full lines: $1 \mathrm{~atm}$ melting relations in Hawaiian basalts. $\boldsymbol{a}$ from Osborn \& Tait (1952); $b, c, d$ from Irvine $(1970,1979) ; d$ redrawn after Morse (1980, p. 236).

and Igtertivâ Formations. The differences persist for lavas of all differentiation states, and thus there are two kinds of titano-tholeiites: relatively high-silica, quartz normative ones in the lower part of the succession (lower Geikie Plateau Formation and downwards) and relatively low-silica, mostly olivine normative ones in the upper part of the succession (upper Geikie Plateau Formation and upwards). The higher silica contents of the lower basalts are ascribed to contamination of the magmas with continental crust, as discussed later.

The dykes are also shown in the geochemical plots (figs 72 and 73). The similarities between the inland dykes and the Geikie Plateau Formation lavas, which we believe were fed by these dykes, is obvious. The inland dykes cluster tightly in the same way as the Geikie Plateau Formation lavas, and two dykes with low $\mathrm{Mg}$ ratios are the easternmost samples, indicating the same sort of regional difference as was found in the Geikie Plateau Formation. The coastal dykes and the
Broken lines in all diagrams are based on 1 atm melting relations in ocean-floor tholeiites (Walker et al., 1979) recalculated into the present projection by Pedersen (1985b) from where the lines are redrawn.

Left diagram: Main basalts, all data. Crosses designate high-Si basalts, and a ringed cross is the high-Si basalt with orthopyroxene phenocrysts.

Igtertivâ Formation lavas are likewise similar. Note that the alkaline coastal dykes all except one plot below the alkaline/tholeiitic division line of Irvine \& Baragar (1971) (fig. 73) and thus are only very mildly alkaline.

\section{Phase diagrams}

In fig. 74 the Scoresby Sund basalt analyses are plotted in the normative phase diagrams used by Irvine $(1970,1979)$. In general, the basalts conform to lowpressure cotectic $o l-p l-c p x$ compositions, in accordance with their modes, and apparently fit better to the ocean floor tholeiite cotectic curves than to the Hawaiian curves.

The Mg-rich basalt types each plot in individual areas and show evidence of olivine fractionation in accordance with their phenocryst mineralogy. Except for the Mikis type, they seem to approach closely to the olivineplagioclase cotectic. The Hjørnedal marker is multiply 


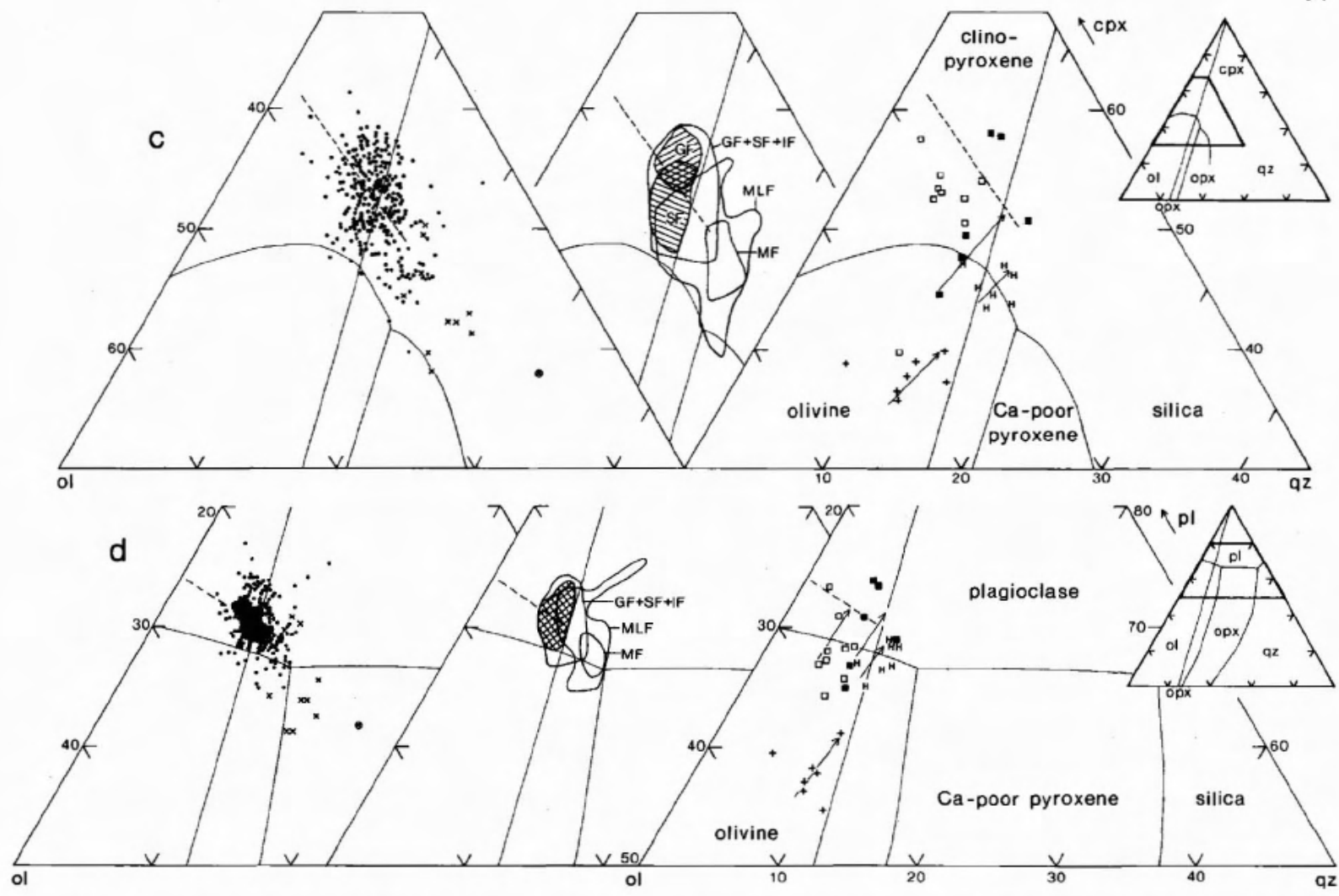

Middle diagram: Main basalts, all data contoured. The two low-Ti units in the upper part of each of Geikie Plateau and Skrænterne Formations plot in two more or less well-separated fields (hatched areas) while the medium-Ti, high-Ti and titanotholeiites plot in the same general area (contoured). In the diagrams where the degree of silica saturation is seen (b, c, d), the various formations plot in only partly overlapping fields in accordance with their differences in silica saturation.

saturated (Table 20) but has an unusual bulk composition with indication of plagioclase accumulation (fig. 74a).

The main basalts cluster rather tightly around the ol-pl-cpx cotectic in fig. 74a, while the clusters are more elongate in fig. 74b-d. There are no systematic variations in $\mathrm{Mg}$ ratio along these trend-like clusters, and they are not fractionation trends. What the plots show are the varying degrees of silica saturation, and the clusters are therefore most elongate in the most oblique projection (b) and least elongate in the projection from quartz (a). The degree of silica saturation is independent of the fractionation state, and all four $\mathrm{TiO}_{2}$ related main basalt types plot within the same general area. However, the two low-Ti basalt units from the upper part of each of the Geikie Plateau and Skrænterne Formations plot within more restricted areas and show some particular differences. They are equally silica undersaturated (fig. 74b-d) and have equal ollpl ratios (a,
Right diagram: Mg-rich basalts. Symbols as in fig. 68. Contour $=$ field of main basalts. Arrows point in the direction of decreasing $\mathrm{Mg}$ ratio within a group, corresponding to increasing differentiation. If there are no arrows there are no systematic trends in $\mathrm{Mg}$ ratios (e.g. b).

d) but the Skrænterne low-Ti lavas have higher $p l / c p x$ ratios than the Geikie Plateau ones $(a, b)$.

The same feature is seen in the weight-normative diagram ol-pl-(cpx+opx) (fig. 75). Within the main basalts, the two low-Ti units fall in separate fields while the other main basalt groups plot within the same broad field. The Mg-rich basalts plot in parallel, elongate fields. Ocean floor basalts plot in similar parallel narrow fields reminiscent of cotectic lines (Bryan \& Dick, 1982; Fisk et al., 1982; Schilling et al., 1983). The various oceanic basalt groups show differences in several major elements, while the only major difference between the two low-Ti units in Scoresby Sund seems to be that the Skrænterne low-Ti unit has around $1 \% \mathrm{Al}_{2} \mathrm{O}_{3}$ more than the Geikie Plateau low-Ti unit (fig. 77). Only in some cases is this compensated for by a lower $\mathrm{FeO}^{*}$ in the Skrænterne unit (fig. 76); generally, the compensation seems to be distributed over all the other elements and is thus not noticeable. 
Lateral shifts in the position of the pseudo-cotectic in fig. 75 have been argued by the above cited authors to be due to compositional differences between those parts of the mantle from which the primary liquids formed. For the Scoresby Sund basalts this would imply at least four distinct types of mantle, which is considered very unlikely. During magma equilibration, compositional effects may shift the position of the ol-pl-px cotectic (Biggar, 1983), and so may pressure differences (Presnall et al., 1979). However, the two Mg-rich magma types in fig. 75 are not three-phase cotectic and need not be constrained by the position of the cotectic. There seems to be a compositional effect, because the sequence Mikis-type basalt - Rømer Fjord Formation olivine tholeiite - main basalt, with increasing $p l / p x$ ratio, corresponds to a sequence with decreasing $\mathrm{Mg}$ ratio for the same $\mathrm{TiO}_{2}$ contents (figs 72 and 89). This is the opposite of what should be expected from experimental $o l$-pl-px data (Biggar, 1983). The pressure influence is difficult to evaluate in this diagram because $c p x$ and $o p x$ are combined, and no conclusions are drawn regarding the significance of the separate pseudo-cotectic trends in fig. 75. A probable pressure effect appears from the ol-di-hy-qz diagram in fig. 88 .

\section{Simple oxide variation diagrams}

Simple oxide-oxide plots also illustrate both intraand inter-formational variations. Alkali-silica diagrams are already given in fig. 73 . The $\mathrm{FeO}^{*}-\mathrm{MgO}$ plots of the main basalts of the successive formations in fig. 76 show the partly overlapping $\mathrm{TiO}_{2}$ groups, with higher $\mathrm{TiO}_{2}$ contents expectedly corresponding to higher $\mathrm{FeO}^{*}$ and lower $\mathrm{MgO}$. (The upper Skrænterne Formation, though, generally does not have higher $\mathrm{TiO}_{2}$ contents than the lower, despite the difference in $\mathrm{FeO}^{*}$.) The Geikie Plateau Formation shows the tightest clustering and the clearest trends in this as well as in many other diagrams. The high-Si basalts fall off the main trend owing to low $\mathrm{FeO}^{*}$ contents and in some cases high $\mathrm{MgO}$ contents.

The right part of fig. 76 shows the Mg-rich basalts in the same diagram. In contrast to the main basalts, the Mg-rich basalt trends appear to be dominated by olivine fractionation, in agreement with the modes and the normative plots (fig. 74). An exception is the Hjørnedal marker, the trend of which can only be produced if there was accumulation of plagioclase accompanying the apparent fractionation. This is consistent with the Hjørnedal trends in figs 74 and 77 , and is conceivable in view of the highly porphyritic character of this particular lava flow (13-18\% modal plagioclase phenocrysts, fig. 36).

Fig. 77 shows $\mathrm{Al}_{2} \mathrm{O}_{3}-\mathrm{CaO}$ plots of the successive formations, with the Mg-rich basalts plotted in the formations in which they occur. The various $\mathrm{TiO}_{2}$ groups again show partly overlapping trends with decreasing $\mathrm{CaO}$ and $\mathrm{Al}_{2} \mathrm{O}_{3}$ and slightly decreasing $\mathrm{CaO} / \mathrm{Al}_{2} \mathrm{O}_{3}$ ra-

- Skrænterne Fm, low-Ti unit

- Geikie Plateau Fm, low-Ti unit

Other main basalts

+ Mikis type basalt

- Rømer Fjord Fm, lower comp. unit

pl

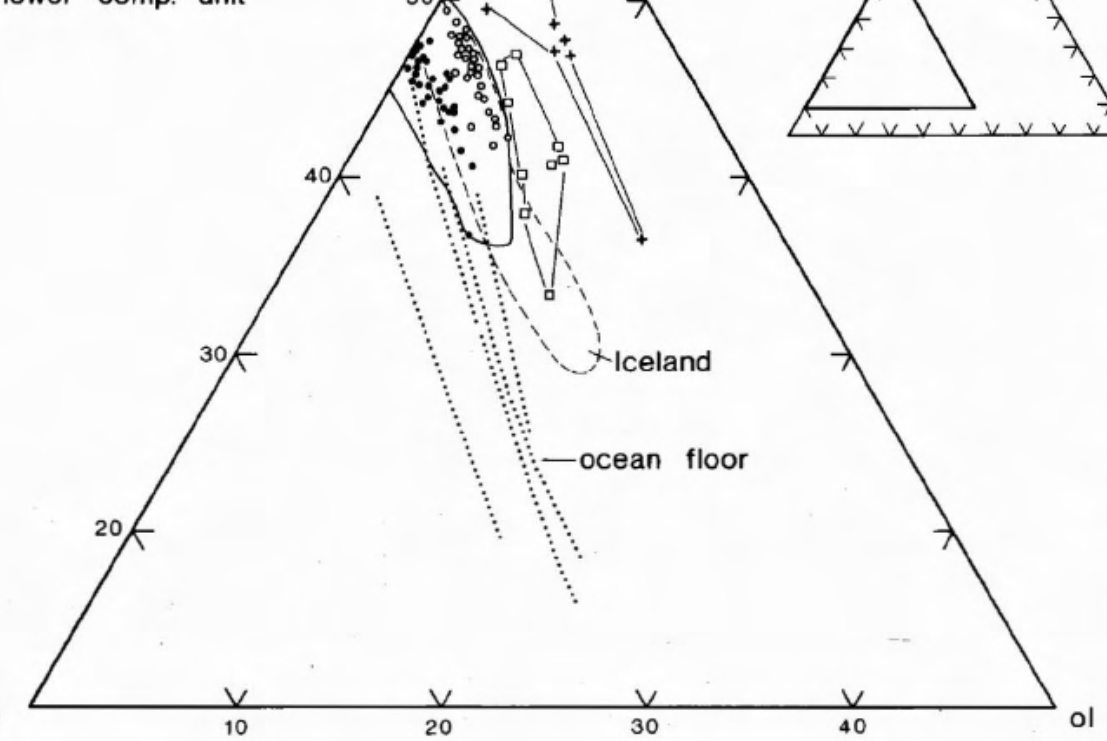

Fig. 75. Scoresby Sund basalt analyses plotted in the weight normative triangle $p l-o l-p x$. Data for Iceland from Schilling et al. (1983). Data for ocean floor basalts from Bryan \& Dick (1982).

Only olivine normative basalts plot in this diagram. The elongate trends are reminiscent of cotectic lines, but there is no or only a weak correlation between the fractionation states $(\mathrm{Mg}$ ratios) and the amounts of normative olivine in the Scoresby Sund lavas. 

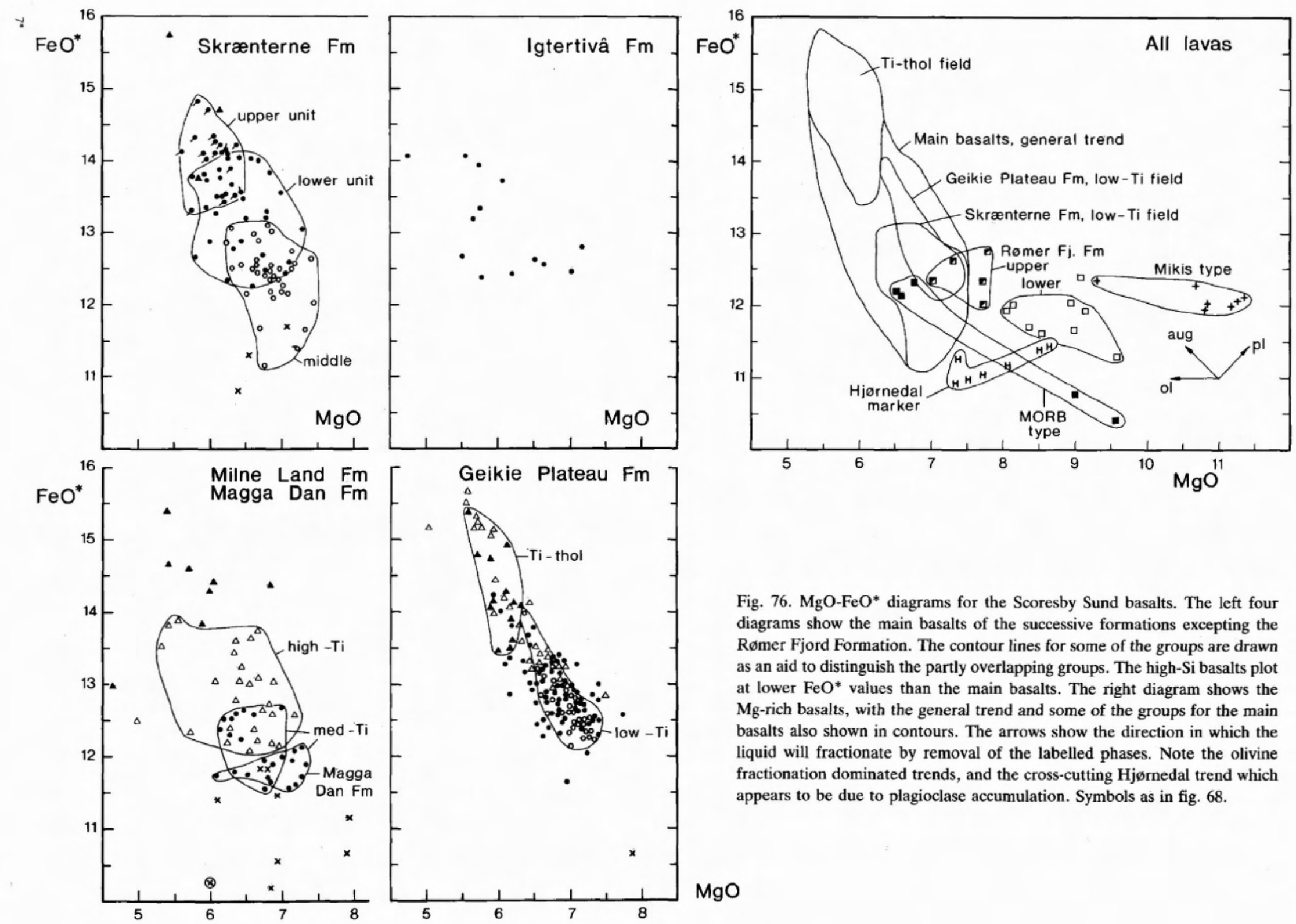

Fig. 76. MgO-FeO* diagrams for the Scoresby Sund basalts. The left four diagrams show the main basalts of the successive formations excepting the Rømer Fjord Formation. The contour lines for some of the groups are drawn as an aid to distinguish the partly overlapping groups. The high-Si basalts plot at lower $\mathrm{FeO}^{*}$ values than the main basalts. The right diagram shows the $\mathrm{Mg}$-rich basalts, with the general trend and some of the groups for the main basalts also shown in contours. The arrows show the direction in which the liquid will fractionate by removal of the labelled phases. Note the olivine fractionation dominated trends, and the cross-cutting Hjørnedal trend which appears to be due to plagioclase accumulation. Symbols as in fig. 68 . 

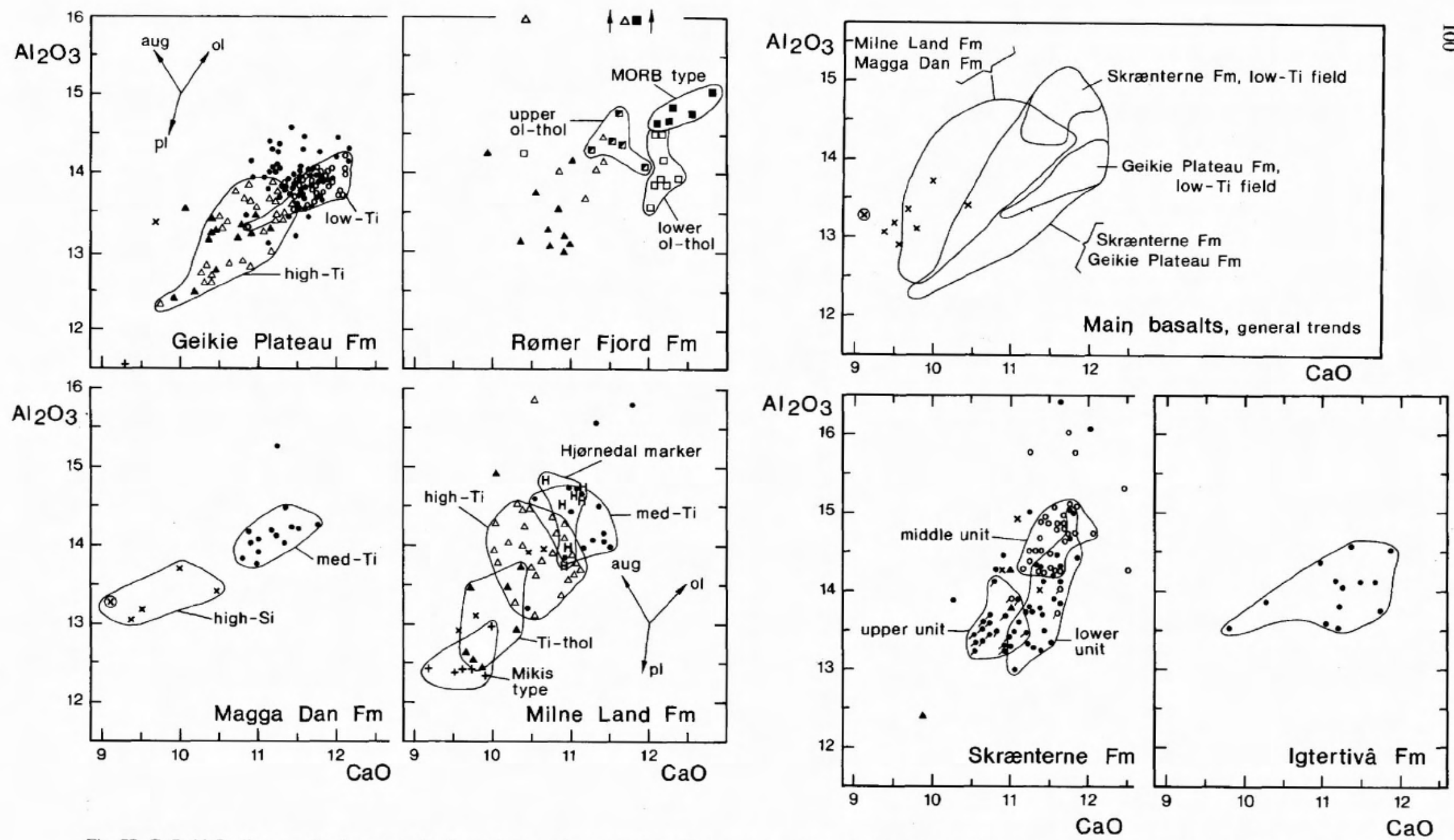

Fig. 77. $\mathrm{CaO}-\mathrm{Al}_{2} \mathrm{O}_{3}$ diagrams for the successive formations, and a comparison of the main basalt trends. The contour lines for some of the groups are drawn as an aid to distinguish the partly overlapping groups. The arrows show the direction in which the liquid will fractionate by removal of the labelled phases. $\mathrm{All}$ rocks with more than $15.5 \% \mathrm{Al} \mathrm{O}_{3}$ are considered to be plagioclase cumulative.

Note the difference in $\mathrm{Al}_{2} \mathrm{O}_{3}$ between the low-Ti lavas from the Geikie Plateau and Skrænterne Formations. Note also the difference in the general trends between the two lowest formations (Magga Dan and Milne Land) on the one hand and the later formations on the other. This is discussed in the text. The practically vertical Hjørnedal trend can be produced by adding $5 \%$ plagioclase $\left(32 \% \mathrm{Al}_{2} \mathrm{O}_{3}\right)$ to the most $\mathrm{Al}$-poor sample which is also the least fractionated.

Symbols as in fig. 68 . 
Fig. 78. Variation in $\mathrm{CaO} / \mathrm{Al}_{2} \mathrm{O}_{3}$ ratios with fractionation state for the Mg-rich lavas and the low- $\mathrm{Ti}$ group lavas of the main basalts. Feldspar cumulative rocks are not plotted. The arrows show the direction in which the liquid will fractionate by removal of the labelled phases. Clinopyroxene is the only phase that can produce a decrease in $\mathrm{CaO} / \mathrm{Al}_{2} \mathrm{O}_{3}$ with fractionation. From other diagrams it appears that the Hjørnedal trend is due to plagioclase accumulation.

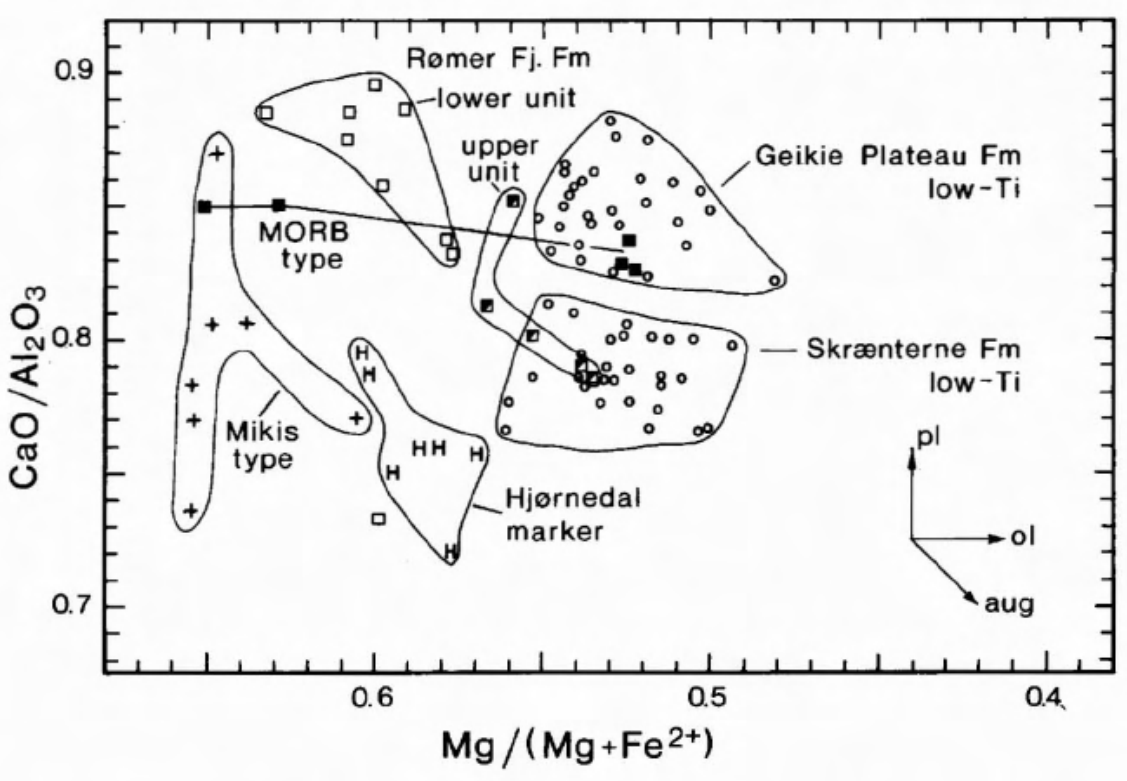

tios with increasing fractionation state. The decrease in $\mathrm{CaO} / \mathrm{Al}_{2} \mathrm{O}_{3}$ is indicative of augite fractionation because augite is the only possible fractionating mineral which would have this effect. For the Hjørnedal marker, the most fractionated samples (with the lowest $\mathrm{Mg}$ ratios) have the highest $\mathrm{Al}_{2} \mathrm{O}_{3}$ contents, indicating plagioclase accumulation accompanying the apparent fractionation of mafic phases. Among the Mg-rich basalts, the three groups of compound flows from the Rømer Fjord Formation are highly calcic. The high-Si basalts have distinctly lower $\mathrm{CaO}$ and the same or lower $\mathrm{Al}_{2} \mathrm{O}_{3}$ than their normal counterparts. This is explicable in terms of assimilation of crustal material: the crustal rocks most probably had $\mathrm{Al}_{2} \mathrm{O}_{3}$ contents of the same size as those of the basalts while the $\mathrm{CaO}$ contents were much lower in the crustal rocks. It is also possible that $\mathrm{CaO}$ was selectively extracted from the basalt magma due to precipitation of basic plagioclase at the contacts to the crustal rocks (Metson \& Switzer, 1966).

The compilative diagram in fig. 77 shows that the general $\mathrm{CaO}-\mathrm{Al}_{2} \mathrm{O}_{3}$ trend for the two lowest formations (Magga Dan and Milne Land) is displaced towards lower $\mathrm{CaO}$ contents relative to the trend for the later basalt formations. This is reminiscent of the displacement of the high-Si basalts and may indicate that the two lowest formations are overall contaminated with crustal material. The compositional difference in $\mathrm{Al}_{2} \mathrm{O}_{3}$ between the two low-Ti groups of main basalt earlier noted is clearly seen.

Fig. 78 shows the variation in $\mathrm{CaO} / \mathrm{Al}_{2} \mathrm{O}_{3}$ ratio with fractionation state (Mg ratio) for some clearly distinguished lava groups. The lower compound unit of the Rømer Fjord Formation, and less clearly also the upper compound unit, show decreasing $\mathrm{CaO} / \mathrm{Al}_{2} \mathrm{O}_{3}$ ratio with increasing fractionation. Because these magmas do not appear to have fractionated augite at low pressure (Table 20), this may be an indication of a high-pressure stage of clinopyroxene fractionation. The $\mathrm{CaO}$ and $\mathrm{Al}_{2} \mathrm{O}_{3}$-poor Mikis type basalt does not show a consistent trend in this ratio. The Hjørnedal trend is steep and is controlled more by plagioclase accumulation than by augite fractionation, as evident from figs 76 and 77 . The two low-Ti main basalt units are so loosely clustered that an augite fractionation trend is barely discernable. The completely separated fields for the low-Ti basalts from the Geikie Plateau and Skrænterne Formations may be used to assign low-Ti basalts (and only these) of uncertain stratigraphic position to either of these formations.

The $\mathrm{TiO}_{2}-\mathrm{P}_{2} \mathrm{O}_{5}$ diagrams (fig. 79) show very tightly correlated trends. Most high-Si basalts have apparently lost $\mathrm{TiO}_{2}$ or gained $\mathrm{P}_{2} \mathrm{O}_{5}$, and a couple of other outliers are flow tops which have apparently gained $\mathrm{P}_{2} \mathrm{O}_{5}$. All the lavas except the Igtertivâ Formation lie on the same trend which also includes the inland tholeiitic dykes. The trend is almost rectilinear, but compared with similar and more primitive magmas from the Reykjanes Ridge (Jakobsson et al., 1978) it is more probable that the trend is curved or kinked and passes through the origin, as indicated. The $\mathrm{TiO}_{2} / \mathrm{P}_{2} \mathrm{O}_{5}$ ratios are thus not constant during the formation of the lavas; the ratio varies from 16 to 9.5 , and decreases with fractionation, indicating that $\mathrm{P}_{2} \mathrm{O}_{5}$ is more incompatible than $\mathrm{TiO}_{2}$. A similar feature is seen in the Reykjanes Ridge basalts (Jakobsson et al., 1978).

The Igtertivâ Formation lavas and the Blosseville 

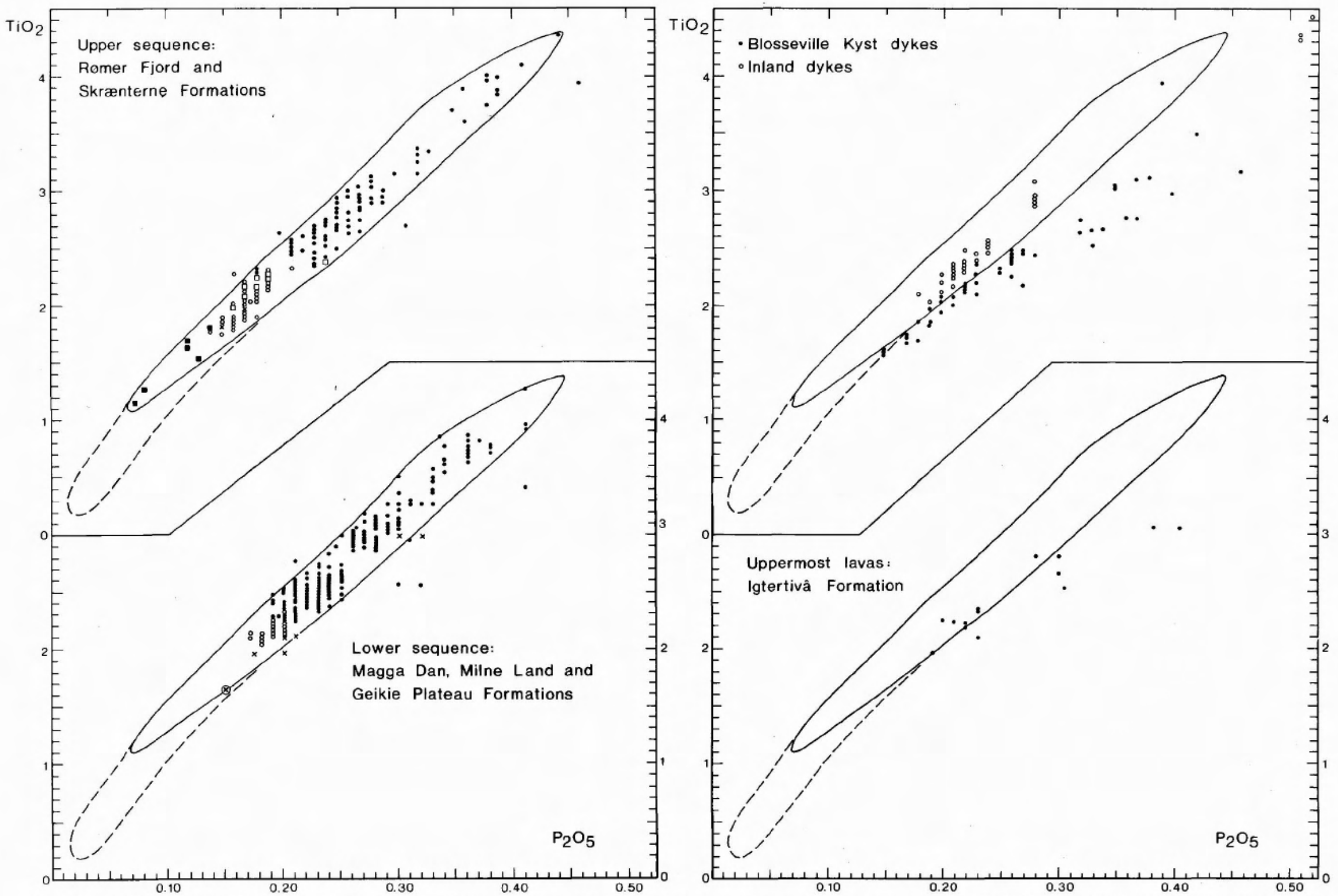

Fig. 79. $\mathrm{TiO}_{2}-\mathrm{P}_{2} \mathrm{O}_{5}$ diagrams for lavas and tholeiitic dykes. Only selected chemical groups have been distinguished in the symbols, viz. the MORB type and the lower compound unit in the Rømer Fjord Formation, the high-Si basalts, and the low-Ti group of the main basalts. Note that the main basalt group divisions according to $\mathrm{TiO}_{2}$ are distinguishable, with relatively open spaces around $2.2-2.3 \%, 2.8 \%$ (lower sequence and inland dykes only) and $3.5 \% \mathrm{TiO}_{2}$. The Mikis type and $\mathrm{Hj} ø$ rnedal marker of the lower sequence plot within the dense med-Ti type cluster at $2.25-2.75 \% \mathrm{TiO}_{2}$.

The contoured trend is the same in all diagrams and is based on both upper and lower sequence lavas. The prolongation of the trend towards the origin (broken contour) is based on data from the Reykjanes Ridge (Jakobsson et al., 1978). Note the deviating trends for the Igtertivâ Formation lavas and the Blosseville Kyst dykes, discussed in the text. 
Kyst dykes have $\mathrm{TiO}_{2}-\mathrm{P}_{2} \mathrm{O}_{5}$ trends which are mutually identical and deviate from the trend of the other lavas and inland dykes. This supports the suggestion that the Igtertivâ Formation lavas were fed by dykes of the coastal swarm. This trend has a lesser slope, $\mathrm{TiO}_{2} / \mathrm{P}_{2} \mathrm{O}_{5}$ ratios between 10.6 and 7.0, and overlaps with the main basalt trend in the low-(Ti, P) end of the diagram. At $\mathrm{TiO}_{2}$ contents above c. $2.6 \%$, however, the two trends are completely separated.
The Igtertivâ Formation also differs from the earlier basalt formations in several trace element ratios. The implications of this are discussed further in the petrogenesis chapter.

\section{Trace elements}

Trace elements were analysed in selected representative lavas from all types and formations, and throughout
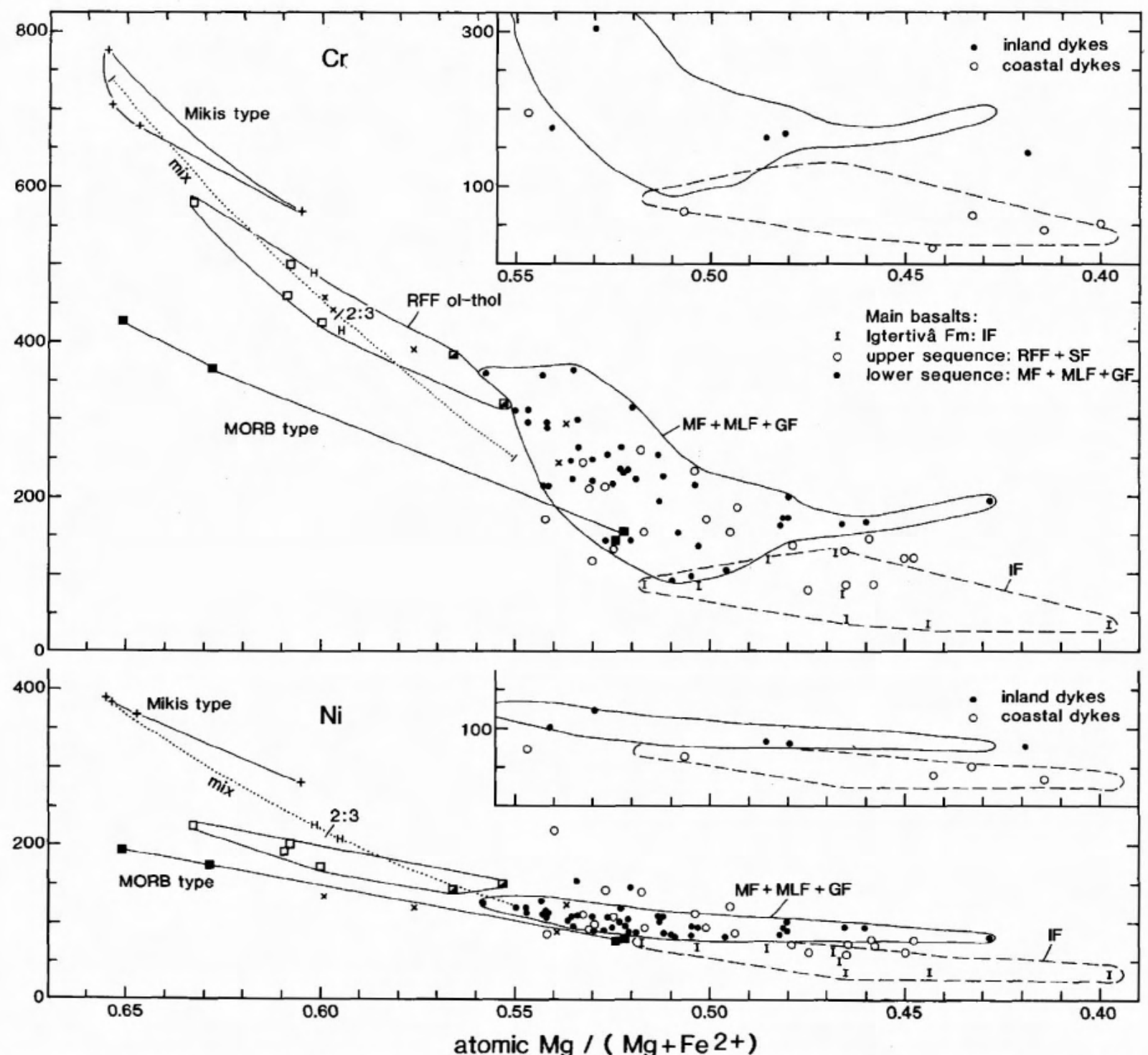

Fig. 80. $\mathrm{Cr}$ and $\mathrm{Ni}$ in the Scoresby Sund basalts and dykes. Symbols as in fig. 68 except for the main basalts and dykes, for which the symbols are indicated on the $\mathrm{Cr}$ diagram. The data points for the lower sequence (Magga Dan, Milne Land and Geikie Plateau Formations) are surrounded by a contour, and those for the Igtertivâ Formation by a broken contour. These contours are repeated in the inserted dyke diagrams.

The stippled line labelled 'mix' is a mixing curve for Mikis type basalt $(\mathrm{Mg}$ ratio $=0.654, \mathrm{Cr}=740 \mathrm{ppm}, \mathrm{Ni}=390 \mathrm{ppm})$ and main basalt $(\mathrm{Mg}$ ratio $=0.550, \mathrm{Cr}=250 \mathrm{ppm}, \mathrm{Ni}=120 \mathrm{ppm})$. Such a mixture in the ratio $2: 3$ is close to the composition of the Hjørnedal marker flow (H). 
the geochemically very coherent section of the Geikie Plateau Formation in profile 52. All the data are presented in appendix 3 except the less precise REE data. Variation diagrams are given in figs 80-82.

$\mathrm{Cr}$ and $\mathrm{Ni}$. These elements are strongly partitioned into chromite, olivine and clinopyroxene, and decrease with increasing degree of fractionation (fig. 80). The $\mathrm{Mg}$-rich basalts form three parallel trends of which the Mikis type is the more 'enriched' and the MORB type is the more 'depleted'. The Hjørnedal marker flow is in a later chapter interpreted as a 2:3 mixture of Mikis type basalt and main basalt, and the mixing curves for $\mathrm{Cr}$ and $\mathrm{Ni}$ are shown in fig. 80.

The main basalts of the lower and upper sequences show a five-fold range in $\mathrm{Cr}$ values (77-365 ppm) and a three-fold range in Ni values (57-155 ppm). The larger range for $\mathrm{C}_{r}$ than for $\mathrm{Ni}$ results from higher bulk partition coefficients for $\mathrm{Cr}$ than for $\mathrm{Ni}$. As shown in a later chapter, quantitative calculations of fractionation, mixing and tapping in an open magma chamber reproduce very well the measured $\mathrm{Cr}$ and $\mathrm{Ni}$ contents of the main basalts in profile 52 (Geikie Plateau Formation, fig. 91).

The basalts of the Igtertivâ Formation have generally
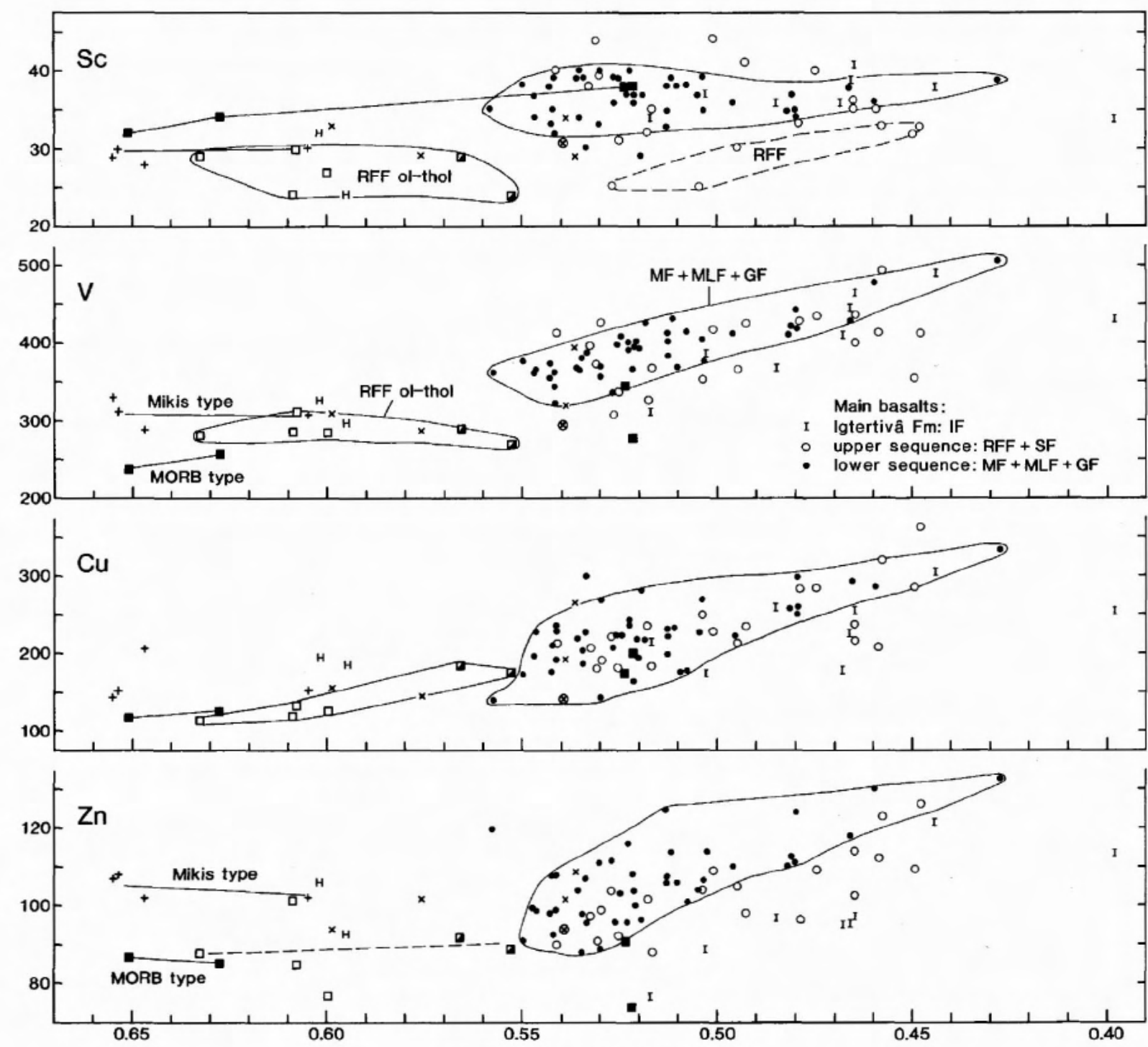

atomic $\mathrm{Mg} /\left(\mathrm{Mg}+\mathrm{Fe}^{2+}\right)$

Fig. 81. Sc, V, Cu and $\mathrm{Zn}$ in the Scoresby Sund basalts. Symbols as in fig. 68 except for the main basalts for which the symbols are indicated on the $\mathrm{V}$ diagram. Data for the $\mathrm{Mg}$-rich basalt types are joined by lines or contours. The contour around the main basalts is for the data of the lower sequence. The data for the upper sequence and the Igtertiva Formation overlap those of the lower but the upper sequence shows generally more scattered results than the lower. The dyke data similarly overlap and are not plotted. 

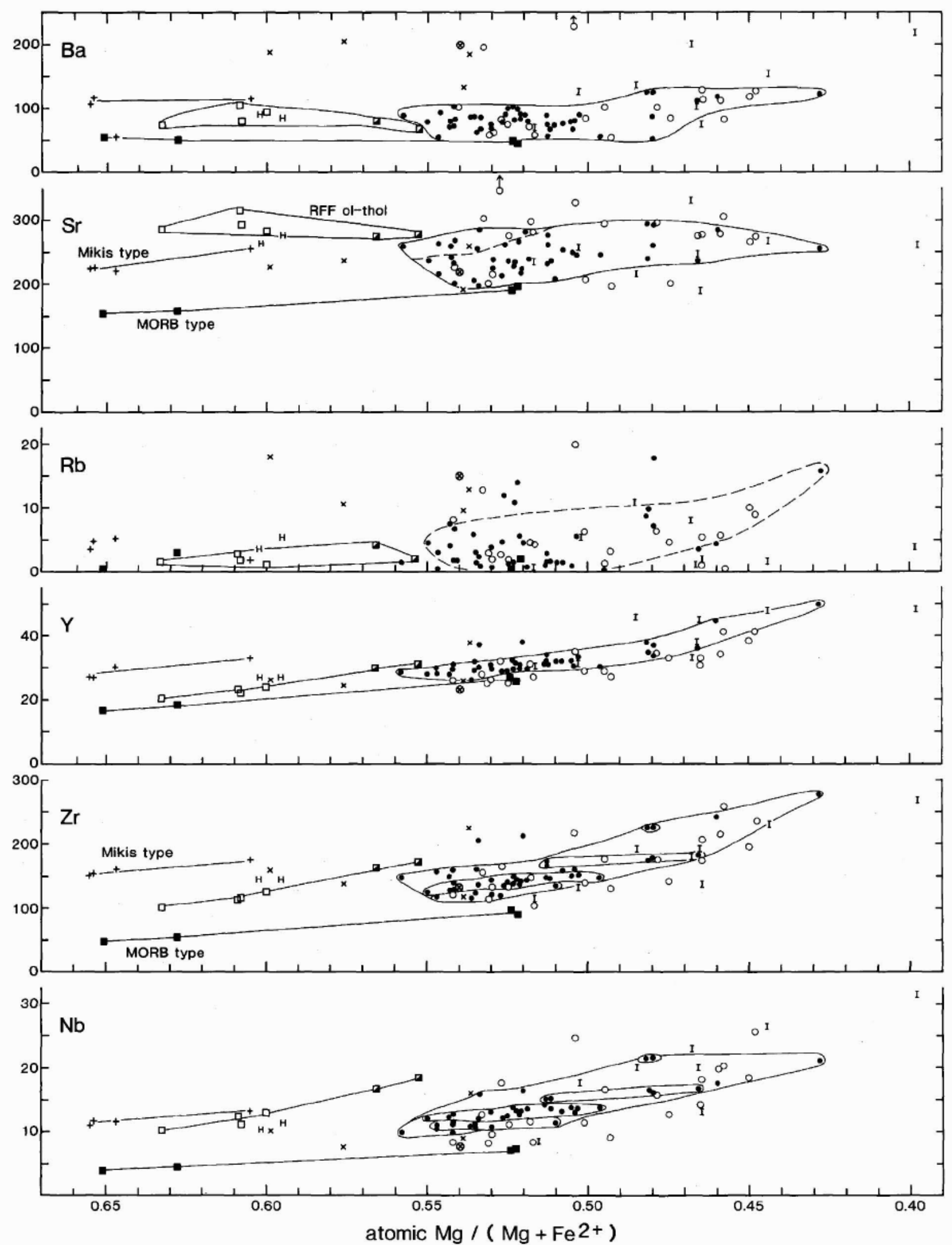

Fig. 82. $\mathrm{Ba}, \mathrm{Sr}, \mathrm{Rb}, \mathrm{Y}, \mathrm{Zr}$ and $\mathrm{Nb}$ in the Scoresby Sund basalts. For explanation see fig. 81. The sub-trends indicated for $\mathrm{Zr}$ and $\mathrm{Nb}$ in the main basalts are the low-Ti, medium-Ti, high-Ti and titano-tholeiite units of the Geikie Plateau Formation. 
lower $\mathrm{Cr}$ and $\mathrm{Ni}$ contents than the earlier basalts. There is virtually no overlap in $\mathrm{Cr}$ and $\mathrm{Ni}$ between the lower sequence and the Igtertivâ Formation (fig. 80), and this feature is also seen in the inland and coastal dykes which are interpreted to have fed the two sequences respectively. Those samples of the upper sequence that overlap into the Igtertiva Formation field are from the upper unit in the Skrænterne Formation, i.e. they are those closest in age to the Igtertivâ Formation.

The basalts of the Magga Dan Formation have the highest $\mathrm{Cr}$ contents (313-365 ppm) of the main basalts, and there seems to be a development through the whole lava sequence toward generally lower $\mathrm{Cr}$ contents with time. No such feature is seen for $\mathrm{Ni}$.

$S c, V, C u$ and $\mathrm{Zn}$. Sc maintains relatively constant levels within the various basalt groups, while $\mathrm{V}, \mathrm{Cu}$ and $\mathrm{Zn}$ increase with fractionation (fig. 81). Within the main basalts (lower sequence) these elements vary by factors of $1.2,1.5,2.4$ and 1.5 respectively. $\mathrm{Sc}$ and $\mathrm{V}$ are incorporated in clinopyroxene, and $\mathrm{Zn}$ probably in olivine, while $\mathrm{Cu}$ appears to be strongly incompatible. The basalts of the Igtertivâ Formation and partly of the Skrænterne Formation tend to have relatively low contents of $\mathrm{V}, \mathrm{Cu}$, and especially $\mathrm{Zn}$.

The Mg-rich basalts show parallel trends in fig. 81 , with the Mikis type being relatively rich in $\mathrm{V}, \mathrm{Cu}$ and $\mathrm{Zn}$. Sc is one of the few trace elements that is not enriched in the Mikis type basalt.

The lowest $\mathrm{Sc}$ contents are found in the olivine tholeiites and the main basalts of the Rømer Fjord Formation. This suggests that clinopyroxene fractionation started at an earlier stage in these basalts than in the others, perhaps at high pressure. Cpx is not petrographically phenocrystic. Clinopyroxene fractionation in the Rømer Fjord Formation is also indicated by the decrease in $\mathrm{CaO} / \mathrm{Al}_{2} \mathrm{O}_{3}$ with fractionation (fig. 78) and the direction of the fractionation trend in the ol-cpx-pl diagram fig. 74a. In contrast, the MORB type basalt from the same formation shows no signs of early clinopyroxene fractionation.

The Sc diagram also indicates that the main basalts of the Rømer Fiord Formation may be more closely related to the olivine tholeiites from the same formation than to the main basalts of the other formations. This is substantiated by the $\mathrm{Zr} / \mathrm{Nb}$ ratios described below.

$\mathrm{Ti} / \mathrm{V}$ ratios have been used to characterise rocks of various tectonic settings (Shervais, 1982). The Scoresby Sund basalts have $\mathrm{Ti} / \mathrm{V}$ in the range $30-60$, and usually $35-50$. These values are intermediate between those of MORB (20-50) and Hawaii (40-60).

$B a, S r, R b, Y, Z r, N b$. Ba and $\mathrm{Sr}$ are moderately incompatible when feldspar is not fractionated. $\mathrm{Ba}$ is preferentially incorporated in alkali feldspar, and $\mathrm{Sr}$ in plagioclase. In the Scoresby Sund basalts both elements are nearly constant during fractionation (fig. 82), also in the Mg-rich basalts. The $\mathrm{Mg}$-rich basalts form three parallel trends with different levels of $\mathrm{Ba}$ and $\mathrm{Sr}$, the Mikis type being the richest in $\mathrm{Ba}$ and the olivine tholeiites richest in $\mathrm{Sr}$. The Igtertivâ Formation and the dykes have $\mathrm{Ba}$ and $\mathrm{Sr}$ contents similar to the other basalts. The high-Si rocks are without exception distinctly enriched in $\mathrm{Ba}$ (around two times 'normal' contents).

$\mathrm{Rb}, \mathrm{Y}, \mathrm{Zr}$ and $\mathrm{Nb}$ are all incompatible and show increasing concentrations with fractionation (fig, 82). $\mathrm{Rb}$ is extensively redistributed in the lavas, and the primary fractionation trend in fig. 82 is inferred. However, it is clear that all the high-Si rocks are enriched in $\mathrm{Rb}$ by two to three times 'normal' contents. Rb (and $\mathrm{K}$ ) in the dykes appear to be much less redistributed than in the lavas.

$\mathrm{Y}, \mathrm{Zr}$ and $\mathrm{Nb}$ are not easily redistributed, and these elements have been extensively used in discussions of tectonic setting and petrogenesis. The Scoresby Sund basalts show significant variability with respect to these elements.

The Mg-rich basalts form parallel trends with different levels of $\mathrm{Y}, \mathrm{Zr}$ and $\mathrm{Nb}$, the Mikis type always with the higher level and the MORB type with the lower.

The geochemically coherent suite of the Geikie Plateau Formation (mainly from profile 52 ) shows different levels of $\mathrm{Zr}$ and $\mathrm{Nb}$, independent of the $\mathrm{Mg}$ ratio (fig. 82 ), corresponding to the four $\mathrm{TiO}_{2}$-based chemical groups (fig. 72). Y shows the same tendency but less clearly, due to analytical uncertainty. In this suite the $\mathrm{Zr}$ range is $118-226 \mathrm{ppm}(92 \%)$, the $\mathrm{Nb}$ range is $10.5-21.5$ $\mathrm{ppm}=105 \%$, and the $\mathrm{Y}$ range is $26-38 \mathrm{ppm}=46 \% . \mathrm{Y}$ is thus distinctly less incompatible than $\mathrm{Zr}$ and $\mathrm{Nb}$ and is probably incorporated into augite like $\mathrm{TiO}_{2}$ (the corresponding $\mathrm{TiO}_{2}$ range is $2.08-3.62 \mathrm{wt} \%=74 \%$ ). $\mathrm{Zr} / \mathrm{Y}$ and $\mathrm{Nb} / \mathrm{Y}$ ratios will therefore increase during fractionation within one suite of rocks, while $\mathrm{Zr} / \mathrm{Nb}$ ratios will be very nearly constant.

Fig. 83 shows a plot of $\mathrm{Zr} v$. Nb for the lavas. The various formations are separated in some very clear groups, and there is a systematic development towards lower $\mathrm{Zr} / \mathrm{Nb}$ ratios with time from the Magga Dan to the Rømer Fjord Formation. The high-Si basalts plot in the trend of the formations they belong to, except the two most Si-rich ones from the Magga Dan Formation which are evidently displaced in the direction of the basement that contaminated them (see later). It is notable that the trend for the Milne Land Formation includes both the Mikis type and the main basalts, and consequently also the Hjørnedal marker which is con- 

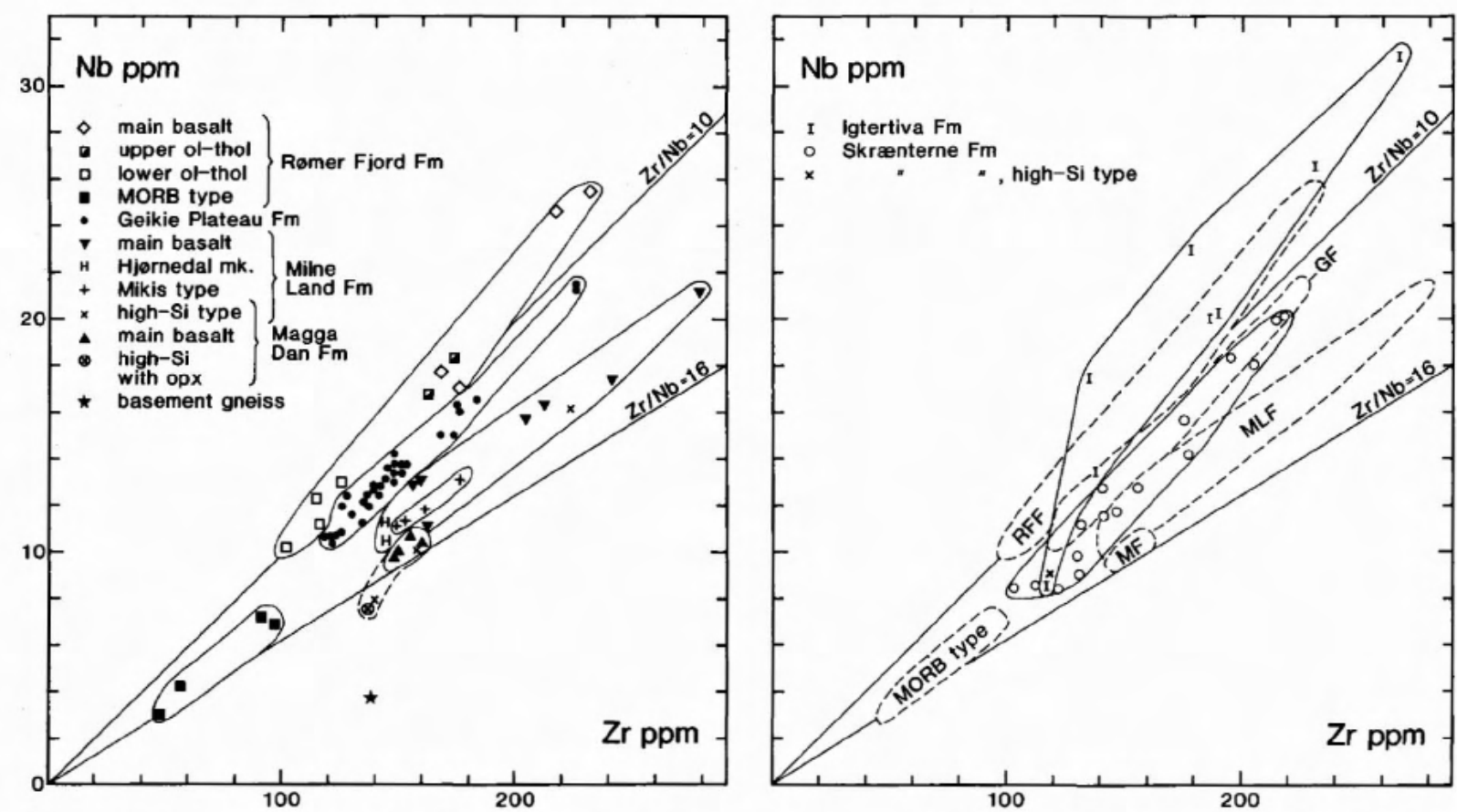

Fig. 83. $\mathrm{Nb} v . \mathrm{Zr}$ in the Scoresby Sund lavas. The individual trends for the formations in the left diagram are repeated with broken lines in the right diagram. The line with $\mathrm{Zr} / \mathrm{Nb}=16$ separates $\mathrm{N}-\mathrm{MORB}$ (below the line) from enriched MORB (above the line) (Le Roex, 1987).

sidered a mixture of these two. The trend for the Rømer Fjord Formation includes both the olivine tholeiites and the main basalts, which makes it most likely that the main basalts of this formation (high-Ti basalts and titano-tholeiites) were derived from the olivine tholeiites. This fits well with the absence of less differentiated main basalts in this formation (fig. 72).

The MORB type basalts have $\mathrm{Zr} / \mathrm{Nb}$ ratios distinctly higher than the other rocks of the Rømer Fjord Formation. The MORB trend in fig. 83 on the other hand lines up well with the trend for the Skrænterne Formation. The MORB type basalts occur at the top of the Rømer Fjord Formation (Plate 2) but are geochemically more akin to the overlying Skrænterne Formation, to which the type may perhaps be parental.

The trend for the Skrænterne Formation in fig. 83 overlaps with those for the Geikie Plateau and Milne Land Formations and is, like in many other diagrams, rather loose. The trend for the Igtertivâ Formation is well separated from it, having $\mathrm{Zr} / \mathrm{Nb}$ ratios generally below 10 like the Rømer Fjord Formation. The inland and coastal dykes are likewise well separated (fig. 84).

The $\mathrm{Zr}-\mathrm{Nb}-\mathrm{Y}$ relations are further discussed in the chapter on petrogenesis.

Multi-element diagrams. Fig. 85 shows 'spidergrams' for the various Scoresby Sund basalt types, excepting

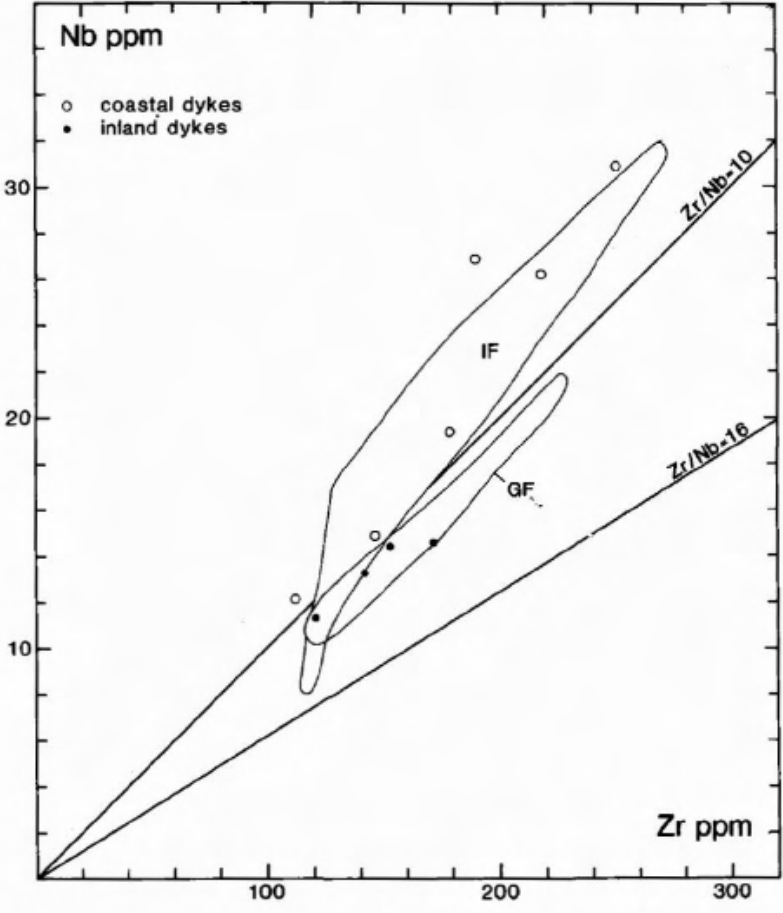

Fig. 84. $\mathrm{Nb} v . \mathrm{Zr}$ in the Scoresby Sund dykes. The trends of the Geikie Plateau and Igtertivâ Formations, which are believed to have been fed by the inland dykes and coastal dykes respectively, are drawn for comparison. A titano-tholeiite dyke from the inland region is an independent, late magma type. 


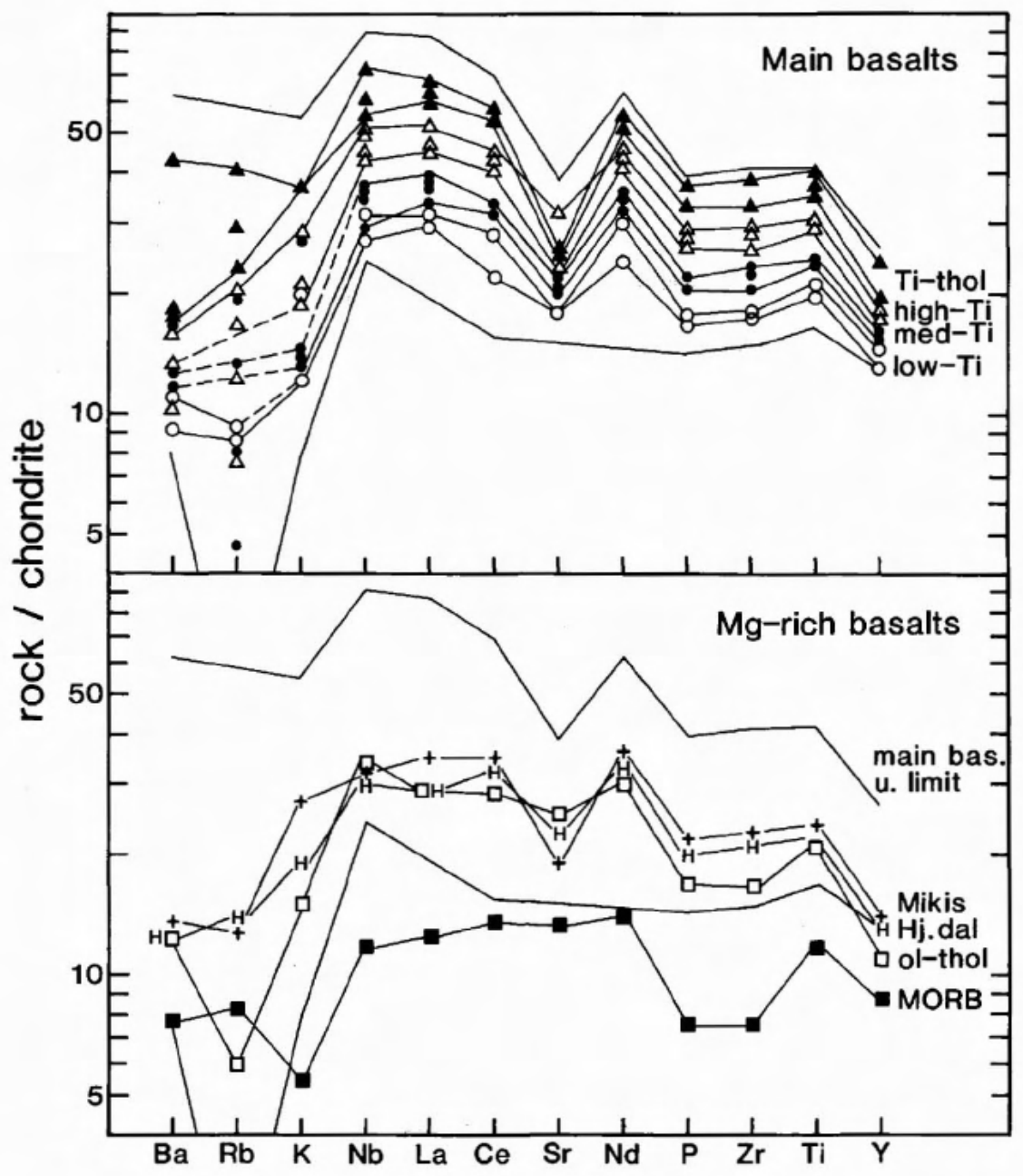

Fig. 85. Spidergrams for the incompatible elements and $\mathrm{Sr}$ in the Scoresby Sund basalts. Normalisation factors from Thompson (1982). Symbols for the various chemical groups as in fig. 68 . The data points for the Mg-rich basalts are averages of 2-4 very similar rocks, while the many analyses of the main basalts are reduced to averages of the four $\mathrm{TiO}_{2}$-based sub-groups within each basalt formation. In the main basalt diagram lines connect maximum and minimum values for each group. The lines for $\mathrm{Ba}, \mathrm{Rb}$ and $\mathrm{K}$ are tentative because these elements have been redistributed, especially $\mathrm{Rb}$ which has often been partially lost. Lines without symbols are upper and lower limits of the data for the main basalts, shown in both diagrams.

Spectra for the high-Si basalts are not included. They are shown in fig. 92 . the high-Si basalts discussed later. The irregularities in the $\mathrm{Ba}-\mathrm{Rb}-\mathrm{K}$ segments due to secondary processes are evident. Apart from this, the spectra for all formations and all basalt types have basically similar shapes, with the Sr trough deepening in the more evolved lavas because of plagioclase fractionation. The spectra have shapes characteristic of ocean-island basalts, and they would be classified as 'initial rifting tholeiites' by Pearce et al. (1975) and Holm (1985), and as 'continental basalts that resemble ocean island basalts' by Thompson $e t$ al. (1984). No signs of crustal contamination are apparent.

Of the Mg-rich basalts the olivine tholeiites, the Mikis type basalts and the Hjørnedal marker, despite their less-evolved character, have incompatible element contents similar to those of the main basalts (medium-Ti type). The MORB-type basalt has low contents of these elements, and the Nb-Nd segment of the spidergram slopes upward to the right as in the MOR-basalts.

\section{Strontium isotopes}

Reconnaissance $\mathrm{Sr}$ isotope analyses were carried out on ten samples and the results are given in Table 21. The analyses were aimed at establishing a 'normal' $\mathrm{Sr}$ isotopic level for the main basalts, and identification of any deviations from this level in the various basalt types, particularly the Si-rich ones.

The three main basalts from the Geikie Plateau Formation have identical ${ }^{87} \mathrm{Sr} /{ }^{86} \mathrm{Sr}$ ratios of 0.7034 , and the same ratio is found in an olivine tholeiite from the Rømer Fjord Formation. For the Skrænterne Formation, Holm (1988) gives ${ }^{87} \mathrm{Sr}{ }^{86} \mathrm{Sr}$ ratios of $0.7032-0.7044$ (2 samples) while Holm (1988) and Carter et al. (1979) give ${ }^{87} \mathrm{Sr} /{ }^{86} \mathrm{Sr}$ ratios of $0.7032-0.7036$ (9 samples) for lavas of unknown stratigraphic position from Nansen Fjord, Wiedemann Fjord and Scoresby Sund. These are all probably from the Skrænterne Formation which thus 
Table $21 .{ }^{87} \mathrm{Sr} /{ }^{86} \mathrm{Sr}$ and $\mathrm{Rb} / \mathrm{Sr}$ ratios in the Scoresby Sund basalts

\begin{tabular}{lllll}
\hline GGU No. & Formation & Basalt type & $\mathrm{Rb} / \mathrm{Sr}$ & ${ }^{87 \mathrm{Sr} /{ }^{66} \mathrm{Sr}}$ \\
\hline 98536 & Geikie Plateau & low-Ti & 0.0205 & 0.7034 \\
98489 & - & med-Ti & 0.0220 & 0.7035 \\
98511 & Ti-tholeite & 0.0301 & 0.7034 \\
98544 & Rømer Fjord & Mg-rich basalt & 0.0084 & 0.7034 \\
98641 & Magga Dan & med-Ti & 0.0137 & 0.7037 \\
98549 & Rømer Fjord & MORB & 0.0055 & 0.7038 \\
96882 & Milne Land & Hjørnedal & 0.0133 & 0.7039 \\
96487 & Milne Land & Mikis & 0.0111 & 0.7045 \\
98561 & Skrænterne & high-Si & 0.0423 & 0.7057 \\
98761 & Magga Dan & high-Si & 0.0360 & 0.7079 \\
\hline
\end{tabular}

$\mathrm{Rb} / \mathrm{Sr}$ ratios measured by XRF at Geologisk Centralinstitut, University of Copenhagen, analyst J. C. Bailey.

${ }^{87} \mathrm{Sr} /{ }^{80} \mathrm{Sr}$ ratios measured at Geologisk Centralinstitut, University of Copenhagen, analyst $\mathrm{O}$.

Larsen. The standard deviation is 1 on the fourth decimal place, while an age correction of $50 \mathrm{Ma}$ only affects the fifth decimal place. The ratios are therefore given as measured.

does not appear to be significantly different from the Geikie Plateau Formation. Similar St isotope values were found in lower Tertiary basalts from the lower plateau lava series of Hold with Hope (Upton et al., 1984), the Faeroes and West Greenland (Carter et al., 1979).

Slightly higher isotope ratios are found in a Magga Dan Formation lava, in a MORB type lava, and in the Hjørnedal marker flow $(0.7037-0.7039)$. The Magga Dan Formation lava is thought to be slightly contaminated with continental crustal material, as discussed later. The Hjørnedal marker flow is a mixture of main basalt and Mikis type basalt (see section on magma mixing).

Holm (1988) found an ${ }^{87} \mathrm{Sr} /{ }^{86} \mathrm{Sr}$ ratio of 0.7037 for two lavas from the Igtertivâ Formation, which may thus have slightly higher $\mathrm{Sr}$ isotope ratios than the earlier main basalts.

The Mikis type basalt has a Sr isotope ratio of 0.7045 , clearly higher than the above-mentioned basalts. Similar basalts from the Lower Basalts in the Kangerdlugssuaq region have similarly higher Sr isotope ratios (Carter et al., 1979; Holm, 1988). This basalt type may include material from another reservoir.

The two high-Si lavas, with 51.4 and $53.7 \% \mathrm{SiO}_{2}$, have ${ }^{87} \mathrm{Sr} /{ }^{86} \mathrm{Sr}$ ratios of 0.7057 and 0.7079 respectively. These results lend support to the contention that the high-Si lavas were contaminated by continental crustal material.

There are no data for the nephelinite tuff in the Rømer Fjord Formation. However, nephelinites from the Gardiner Complex, Kangerdlugssuaq, have initial
Sr isotope ratios around 0.7037 (Nielsen \& Buchardt, 1985 ), and nephelinites from the nunatak zone at $74^{\circ} \mathrm{N}$ have initial ratios around 0.7040 (Brooks et al., 1979).

The $\mathrm{Sr}$ isotopes are discussed in the chapter on petrogenesis.

\section{Comparison with other basalt areas}

The East Greenland plateau basalts are tholeiites rich in iron and titanium ('FeTi basalts' of Brooks \& Jakobsson, 1974) and relatively rich in a number of incompatible trace elements. Large volumes of such tholeiites occur in two different tectonic environments; in oceanic islands like Iceland, Hawaii and Galapagos, and in areas with continental flood basalts like East Greenland, Deccan, Ethiopia, the Columbia River Plateau and the Parana and Karoo Basins. It has been argued that the mantle source of the basalts in both tectonic settings is indeed the same, and that the continental basalts are in most cases contaminated with continental crustal material (Thompson et al., 1983; Anderson, 1985; Campbell, 1985). Holm (1985) distinguished two major types of continental flood basalts: true intracontinent basalts, and plate-margin continental basalts. The last category has 'oceanic' character and is discriminated from the 'true' continental basalts in $\mathrm{TiO}_{2}$ $\mathrm{K}_{2} \mathrm{O}-\mathrm{P}_{2} \mathrm{O}_{5}$ (Pearce et al., 1975) and $\mathrm{TiO}_{2}$-Nb-Th diagrams (Holm, 1985). In this division, the rather siliceous and potassic, Ti- and Fe-poor Columbia River, Parana and Karoo basalts are 'true' continental, while the K-poor FeTi basalts from Deccan, Ethiopia and East Greenland are plate-margin continental. (Data 


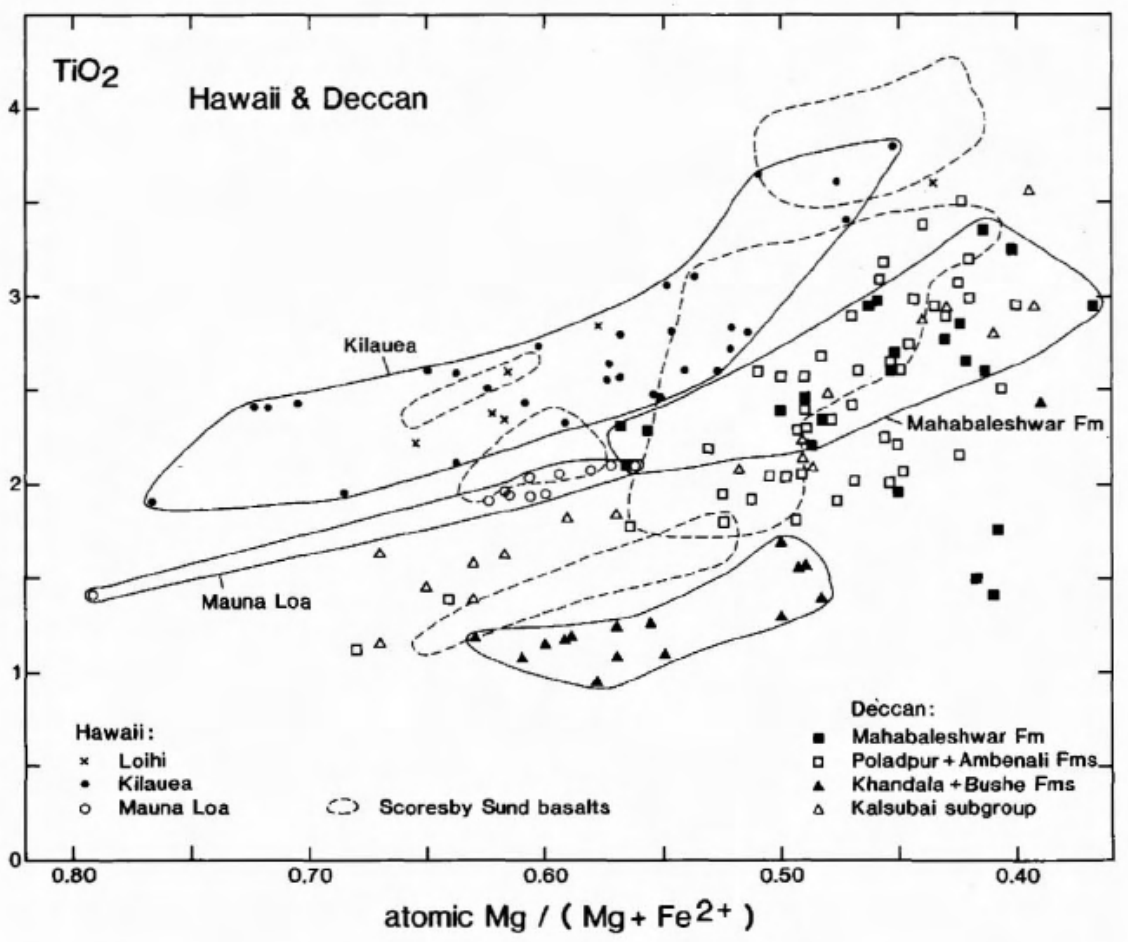

Fig. 86. $\mathrm{TiO}_{2} v$. Mg ratio diagram for tholeiites from Hawaii (Mauna Loa, Kilauea and Loihi) and Deccan. Scoresby Sund basalt contours inserted for comparison. Data for Hawaii from Macdonald \& Katsura (1964; tholeiites from other volcanoes fall within the Kilauea-Mauna Loa area), Basaltic Volcanism Study Project (1981), Easton \& Garcia (1981), Moore (1983) and Frey \& Clague (1983). Data for Deccan from Najafi et al. (1981), Cox \& Hawkesworth (1985) and Beane et al. (1986).

from sources in Pearce et al., 1975; Basaltic Volcanism Study Project, 1981; Holm, 1985; and for Parana basalts Bellieni et al., 1984.) The compositional difference between the two types of continental flood basalts may be rooted in varying degrees of reaction with the continental crust (Thompson et al., 1983). The tholeiites of the Deccan Peninsula are those continental basalts that show the closest similarity to the East Greenland basalts. East Greenland and Deccan tholeiites are similar not only in chemical composition but also in approximate age and tectonic setting, being formed in the process of initiation of continental splitting. In such a setting the influence of the continent is minimal, and the 'oceanic' character of the magma most apparent. However, both in Deccan (Cox \& Hawkesworth, 1985) and in East Grecnland, the magmas did not escape contamination within the continental crust.

Compared to the tholeiites of the oceanic islands of Iceland, Hawaii, Galapagos and Reunion, the Scoresby Sund basalts show the closest similarity to Iceland, as discussed in the last chapter. The tholeiites from Hawaii have higher $\mathrm{SiO}_{2}$ and $\mathrm{Sr}$, and lower $\mathrm{FeO}$ and $\mathrm{V}$ (Basaltic Volcanism Study Project, 1981; Leeman et al., 1980); those from Galapagos have slightly higher $\mathrm{K}_{2} \mathrm{O}$ and $\mathrm{Al}_{2} \mathrm{O}_{3}$ (McBirney \& Williams, 1969), while those from Reunion have considerably higher $\mathrm{K}_{2} \mathrm{O}$, Rb, Ba, Sr and $\mathrm{Nb}$ (Upton \& Wadsworth, 1972; Fisk et al., 1988).

Figs 86-87 show compilations of data for tholeiites from Deccan and Hawaii in some of the geochemical diagrams also used for the Scoresby Sund basalts, and later for the North Atlantic province. Deccan and Ha-

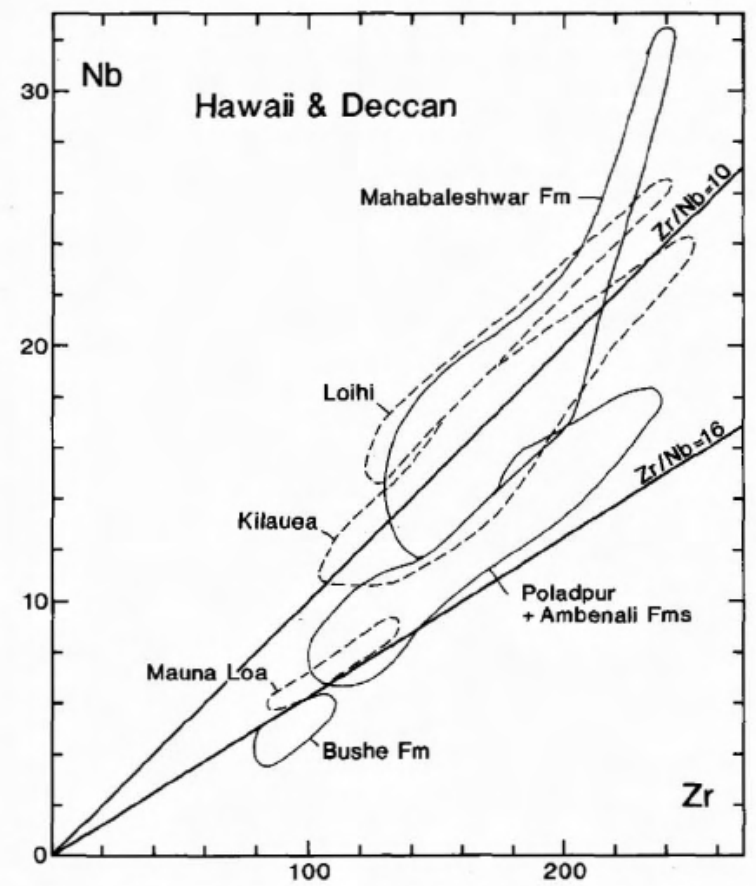

Fig. 87. $\mathrm{Nb} v . \mathrm{Zr}$ diagram for tholeiites from Hawaii and Deccan. Data for Hawaii from Basaltic Volcanism Study Project (1981), Easton \& Garcia (1981) and Frey \& Clague (1983). Data for Deccan from Najafi et al. (1981) and Cox \& Hawkesworth (1985). 
waii plot in almost completely separate areas of the $\mathrm{TiO}_{2}-\mathrm{Mg}$ ratio diagram (fig. 86), and Deccan and Scoresby Sund coincide roughly although the Deccan basalts tend to have lower $\mathrm{Mg}$ ratios. It is notable that all the tholeiites from Hawaii are very $\mathrm{TiO}_{2}$ rich, and that Kilauea actually produces a magma like the Mikis type magma in Scoresby Sund. Kilauea and Mauna Loa on Hawaii, and some of the individual lava formations on Deccan, plot in separate fields in the $\mathrm{TiO}_{2}-\mathrm{Mg}$ ratio diagram, and there are corresponding separations in the
$\mathrm{Nb}-\mathrm{Zr}$ diagram (fig. 87). For Deccan and Hawaii lavas with high $\mathrm{TiO}_{2}$ contents (for a given $\mathrm{Mg}$ ratio) have higher $\mathrm{Nb}$, slightly higher $\mathrm{Zr}$, and lower $\mathrm{Zr} / \mathrm{Nb}$. The Scoresby Sund basalts partly conform to this pattern (fig. 83), but the Mikis type magma has higher $\mathrm{Zr} / \mathrm{Nb}$ than expected from its $\mathrm{TiO}_{2}$ contents, and the Igtertivâ Formation has lower $\mathrm{Z}_{\mathrm{r}} / \mathrm{Nb}$ than expected. All Deccan basalts and most Hawaiian basalts have $\mathrm{TiO}_{2} / \mathrm{P}_{2} \mathrm{O}_{5}$ similar to the major part of the Scoresby Sund basalts.

\section{Petrogenesis}

The Scoresby Sund basalts include several magma types, all of which except one are within the tholeiite spectrum. The Mg-rich basalt types comprise the Mikis type basalt, the Hjornedal type, the MORB type olivine tholeiite, and the 'enriched' Rømer Fjord Formation olivine tholeitite type. The 'main basalts' come in four distinct groups (fig. 72). In addition, there are some high-Si basalts and a strongly alkaline nephelinitic type. None of the tholeiitic magma types are primary, and various post-generational processes have contributed to the compositional spectrum encountered. It will be concluded that the nephelinite, the Mikis type, the MORB type, the Rømer Fjord Formation olivine tholeite and one or more parental 'main basalts' were independently generated in the mantle. The Hjørnedal type is a mixture of Mikis type and main basalt, the four main basalt groups result from processes in open magma chambers, and the high-Si basalts are contaminated with continental crust.

The post-generational processes took place in magma chambers within and below the continental crust, and these chambers and the processes therein must be considered before addressing the generation processes in the mantle.

\section{Magma chambers}

Once generated in the mantle the primary magma(s) will tend to collect at the mantle-crust boundary because of the density contrast there (e.g. Cox, 1980). In a tensional environment, like East Greenland in the stage of initiation of rifting and sea floor spreading, magmas may also proceed into the crust and form magma chambers there, and eventually erupt at the surface. The continental crust in this part of East Greenland has an estimated thickness of $25-30 \mathrm{~km}$ (H. C. Larsen, personal communication, 1985). The magma in a magma chamber at the crust-mantle boundary would thus be under a pressure of at least $7 \mathrm{kbar}$, but the magmas that erupted at the surface have equilibrated to lower pressure conditions. Low-pressure equilibration was shown in the discussion of the phase relations in fig. 74. Cox (1980) argued that it may be difficult to detect the differences between fractionation at 1 bar and at higher pressures up to around $10 \mathrm{kbar}$, because plagioclase is stable throughout this interval. However, the phase relations do change, and this is illustrated in the phase diagram in fig. 88 used by Thompson $(1982,1987)$. The main basalts plot close to the 1 atm ol-pl-px cotectic but are systematically displaced toward lower cpx values. This is probably a pressure effect (Presnall et al., 1979). It is difficult to quantify, but following Thompson (1987) pressures up to around $3.5 \mathrm{~kb}$, i.e. around $13 \mathrm{~km}$ depth, are indicated. The Mikis type magma is even more displaced, and higher pressures for this may be indicated. It is concluded that most of the magmas finally equilibrated at a high level, and there must have been magma chambers within the crust.

\section{Shape and size of magma chambers and volcanic systems}

Magma chambers in rift zones are generally assumed to be elongated parallel to the rift, and parallel to the dominating dyke swarms. Some of the Columbia River basalt flows were erupted from vent systems around 100 $\mathrm{km}$ long and less than $15 \mathrm{~km}$ broad (Swanson et al., 1975). In contrast, feeder dykes for the Deccan basalts occur over a broad area and have random orientations (Beane et al., 1986). The dykes which from geochemical similarities are believed to have fed the Geikie Plateau Formation lavas occur in a rather loose and ill-defined swarm in the inner fjord region, around $200 \mathrm{~km}$ long and $60 \mathrm{~km}$ broad (fig. 32). The dense dyke swarm along the Blosseville Kyst, which fed the Igtertivâ Formation lavas, is around $200 \mathrm{~km}$ long and $30 \mathrm{~km}$ broad (fig. 32; 


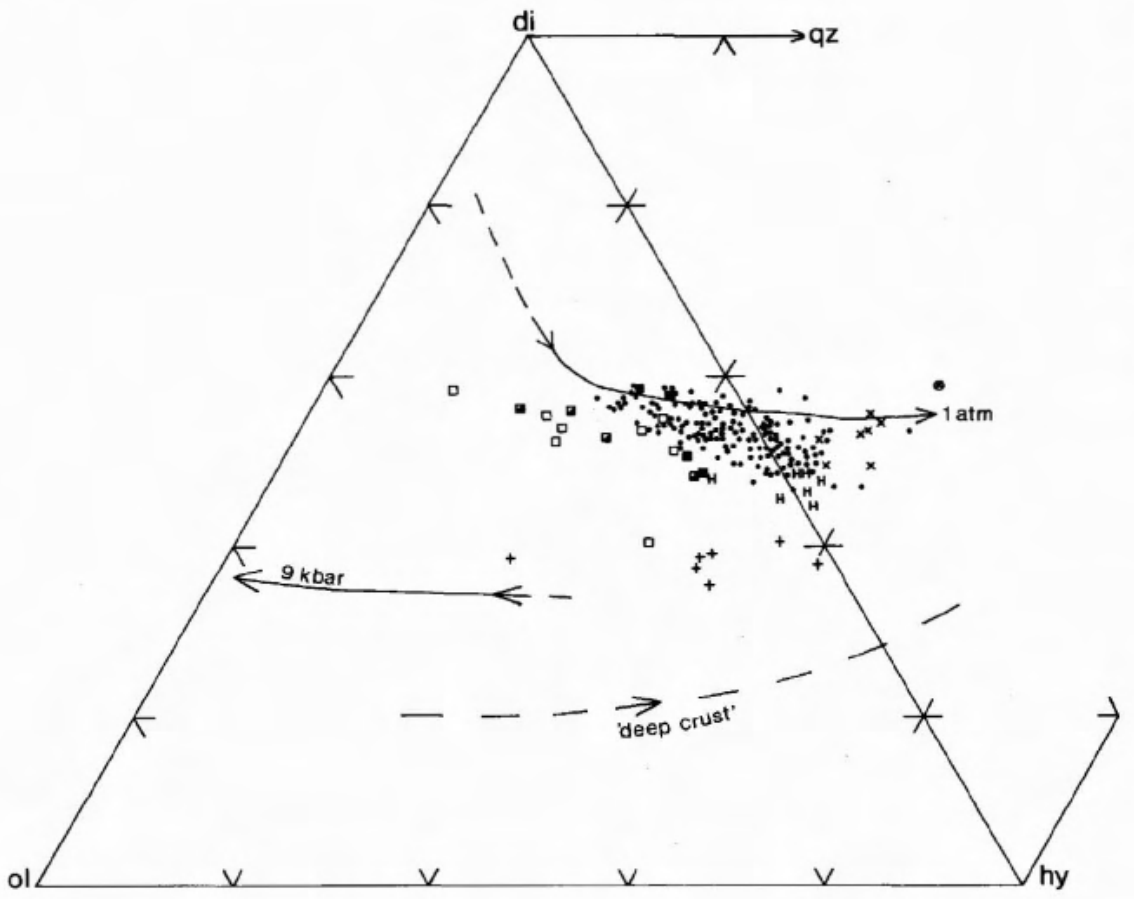

Fig. 88. Scoresby Sund basalts plotted in the weight normative triangles ol-di-hy and di-hy-qz. Symbols as in fig. 68, except for filled circles $=$ all main basalt types. Curves with arrows are the ol + plag + px + liquid cotectic curves at the indicated pressures. They are taken from Thompson (1982).

Watt, 1975). It is difficult to estimate the size of the underlying magma chamber from such data because magma may flow laterally in the conduit for many kilometres. The shape of the chamber may be either silllike, equidimensional or dyke-like; most authors seem to prefer sill-like chambers in such a tectonic setting (e.g. Cox, 1980; Basaltic Volcanism Study Project, 1981).

O'Hara \& Mathews (1981) have argued that the mass fraction of a magma chamber that is erupted at one time is below 1\%, and Gudmundsson (1987) calculated a normal maximum of $0.5 \%$ even when taking overpressure due to crustal bending into account. A 'typical' Scoresby Sund lava flow was earlier estimated to cover $1000-4000 \mathrm{~km}^{2}$ with a volume of $20-60 \mathrm{~km}^{3}$ (section on volumes; Larsen \& Watt, 1985), which necessitates magma chambers of up to $12000 \mathrm{~km}^{3}$ in volume. This may seem large, but such a chamber can easily be accommodated within the area of the dyke swarms, e.g. as a sill-like ellipsoid with axes of $150 \times 30 \times 5 \mathrm{~km}$, located at $10-15 \mathrm{~km}$ depth.

The largest known flows with volumes of around 300 $\mathrm{km}^{3}$ (Table 8 ) are possibly special cases where larger fractions (up to $2.5 \%$ ) of the chambers were erupted.

The figures given above may seem large but are of the same magnitude as in other continental flood basalt areas. The largest known lava flow in the Columbia River basalt has a volume of $700 \mathrm{~km}^{3}$ (Hooper, 1984), implicating very large magma chambers. However, comparing the Scoresby Sund volcanism with its modern equivalent in Iceland the differences in scale are striking. In Iceland, the dyke and fissure swarms of the neovolcanic zone are 20-100 km long and 4-20 km broad, and individual lava volumes are usually less than $1 \mathrm{~km}^{3}$, occasionally a few cubic kilometres (Jakobsson et al., 1978; Saemundsson, 1978; Jakobsson, 1979). The largest neovolcanic systems and lavas occur in the nonspreading Eastern Volcanic Zone (Jakobsson, 1979). The Tertiary lavas in Iceland are generally larger and may be of several cubic kilometre's volume (A. Gudmundsson, personal communication, 1988). The scale differences between Scoresby Sund and Iceland must be caused by the different tectonic settings of the regions. The calculated magma productivity is the same for the two regions (see section on volumes), and the eruption frequency has obviously been much lower in Scoresby Sund than in Iceland. Following Gudmundsson (1986) this can be explained as an effect of different aspect ratios of the magma chambers. Magma chambers in actively spreading rift zones are confined to the rift and have large height/width ratios, leading to high eruption rates, while sill-shaped magma chambers like those inferred for Scoresby Sund and similar non-spreading regions have low height/width ratios leading to low eruption rates. If the magma productivity is high in a nonspreading region, very voluminous magma chambers may develop. 


\section{Temporal development of magma chambers and eruption sites}

During the time of the extrusion of the Magga Dan Formation, when magma chambers were first established, they were probably small and very irregular. The known activity was situated inland, with local eruption sites on the Găseland highland, and others in the lowland around Gassefjord. The eastern and south-eastern extent of the formation is not delimited, and there may have been activity further than known in these directions.

When the Milne Land Formation lavas were extruded, the magma chambers had merged to larger, coherent units, and the first very voluminous flows were erupted. Eruption sites are not known, but from lava flow distributions (fig. 13) they appear to have been concentrated in the Gassefjord area. As for the preceding formation the eastern and south-eastern extents are not delimited, and there may have been further activity in these directions.

For the Geikie Plateau Formation lavas the eruption sites known at present are situated in the inland regions around Găsefjord, but there may be others concealed towards the east and south-east. The question arises, whether the extensive basalts of this formation were all filtered through the same magma chamber, or whether there were several magma chambers. The possibility that each of the successive units of the Geikie Plateau Formation were erupted from different volcanic systems is rendered unlikely by the fact that dykes of all compositional types (except titano-tholeiites) occur intermingled in the broad, loose feeder 'swarm'. The width of this swarm ( $60 \mathrm{~km}$ or more) indicates that magmas were available over wide areas, and the compositional differences between the north-western, central, and southeastern parts of the Geikie Plateau Formation lavas indicate that the magma had lateral compositional variations. The question of one or more magma chambers may not be very relevant if the plumbing system had developed into a complex and extensive system of more or less interconnected magma pools, sills and dykes with eruption sites scattered over large areas. Irrespective of any interconnections the processes that controlled the composition of the lavas would be the same all over and lead to a similar compositional development throughout the formation. At the end of the formation the volcanic activity waned and the magma chambers died.

In the second magmatic episode the sites of activity had moved south-east of Gasefjord. The episode started with the Rømer Fjord Formation, with relatively small volumes of four distinct magma types erupted from several discrete sites. The nephelinite(s) formed from one (or more?) central volcano(es), the known one situated near Sydbre. The lower and upper compound units of 'enriched' olivine tholeiites form two shieldlike structures centred respectively in the central and eastern part of the Geikie Plateau, where their eruption sites are inferred to be. The MORB type olivine tholeiites presumably originated in one event and possibly in one volcanic system situated along a $100 \mathrm{~km}$ long NE-SW line on the north-western Geikie Plateau. It is noticeable that the nephelinitic volcano was situated very close (within $10-20 \mathrm{~km}$ ) to the MORB volcanic system; however, the volcano was extinct when the MORB type lavas formed. The few thick flows of strongly differentiated 'big feldspar basalt' appear to be quite extensive; their eruption sites are guessed to be at the Blosseville Kyst. The thick sequence of titanotholeiites near the Blosseville Kyst appears to be of local origin. In all, the Rømer Fjord Formation appears to be formed from at least six separate, relatively small, volcanic systems scattered on the Geikie Plateau and east of it. Independently generated (and fractionated) magmas are thus feasible for this formation.

At the time of the Skrænterne Formation only 'main basalt' magma was extruded. Because no eruption sites are known, and because the formation contracts towards the Blosseville Kyst with time, the main eruption sites are inferred to have been situated to the east of the present coast line. The flows in this formation are voluminous and extensive, and the crustal reservoirs must have been large. We envisage, as for the Geikie Plateau Formation, a complex system of more of less interconnected magma pools, sills and dykes. If the crustal tension was larger than during the first episode, the magma chambers would have been concentrated into a narrower zone.

The feeder system for the uppermost lava formation, the Igtertivâ Formation, was the dense dyke swarm at the Blosseville Kyst, and the centre of activity for this, third, volcanic episode had thus moved to the west relative to the second episode. The few preserved lavas are relatively thin and were probably never widespread. It is possible that most of the magma produced stayed in the dilating crust as the numerous dykes. The magma was just as low-pressure equilibrated as the preceding magma, and there is the usual need for a crustal magma reservoir. In this episode it is evident that the tension was increased and the zone of dyking contracted, and in the end the crust collapsed in a system of faulted blocks downthrown to the east. 


\section{Processes in the magma chambers}

\section{Crystal fractionation}

It is immediately clear from variation diagrams such as the $\mathrm{TiO}_{2}-\mathrm{Mg}$ ratio diagrams in figs 72 and 89 that, although fractional crystallisation may be an important process, simple crystal fractionation from a common parent magma cannot generate the compositional spread encountered in the Scoresby Sund basalts. In order to delineate how much of the compositional variation can be ascribed to fractional crystallisation quantitative calculations for the various basalt types were performed.

For the four types of main basalt, data from the Geikie Plateau Formation were used because these form tight well-defined trends in contrast to the looser groups in the other formations. Olivine, plagioclase and augite are liquidus phases available for fractionation within the main basalts. Petrographically, the Geikie Plateau Formation lavas are aphyric or contain very sparse phenocrysts (mostly $<1 \%$, fig. 36 ) of olivine and plagioclase and only in very few instances augite. 'Missing' phenocrysts of clinopyroxene, despite obvious geochemical signs of clinopyroxene fractionation, is a common problem of basalt genesis (e.g. Rhodes \& Dungan, 1979; Basaltic Volcanism Study Project, 1981). The aphyric lavas of the Geikie Plateau Formation present the apparent problem of three missing phenocryst phases. This is not, however, regarded as a real problem, because compositionally similar lavas from the Skrænterne Formation contain all three phenocryst phases in abundance. It must therefore be concluded that, whether aphyric or porphyritic, the lavas are similarly fractionated, and there must have been an intratelluric phenocryst 'filter'.

One may speculate two explanations for the differences between the aphyric and porphyritic lavas. Either, the 'filter' acted more effectively on the Geikie Plateau Formation lavas than on those from the Skrænterne Formation (perhaps as an effect of physical differences between the two sets of plumbing systems), or the fractionating phases were similarly removed from both formations. In the last case the phenocrysts present do not represent the fractionated phases. Such a case has been argued by Sparks et al. (1984) who suggest that magmas fractionate by plating of crystals on to the walls of the magma chambers, and that the crystals formed within the magma did not participate in the fractionation process. In this case it may be dubious to use just

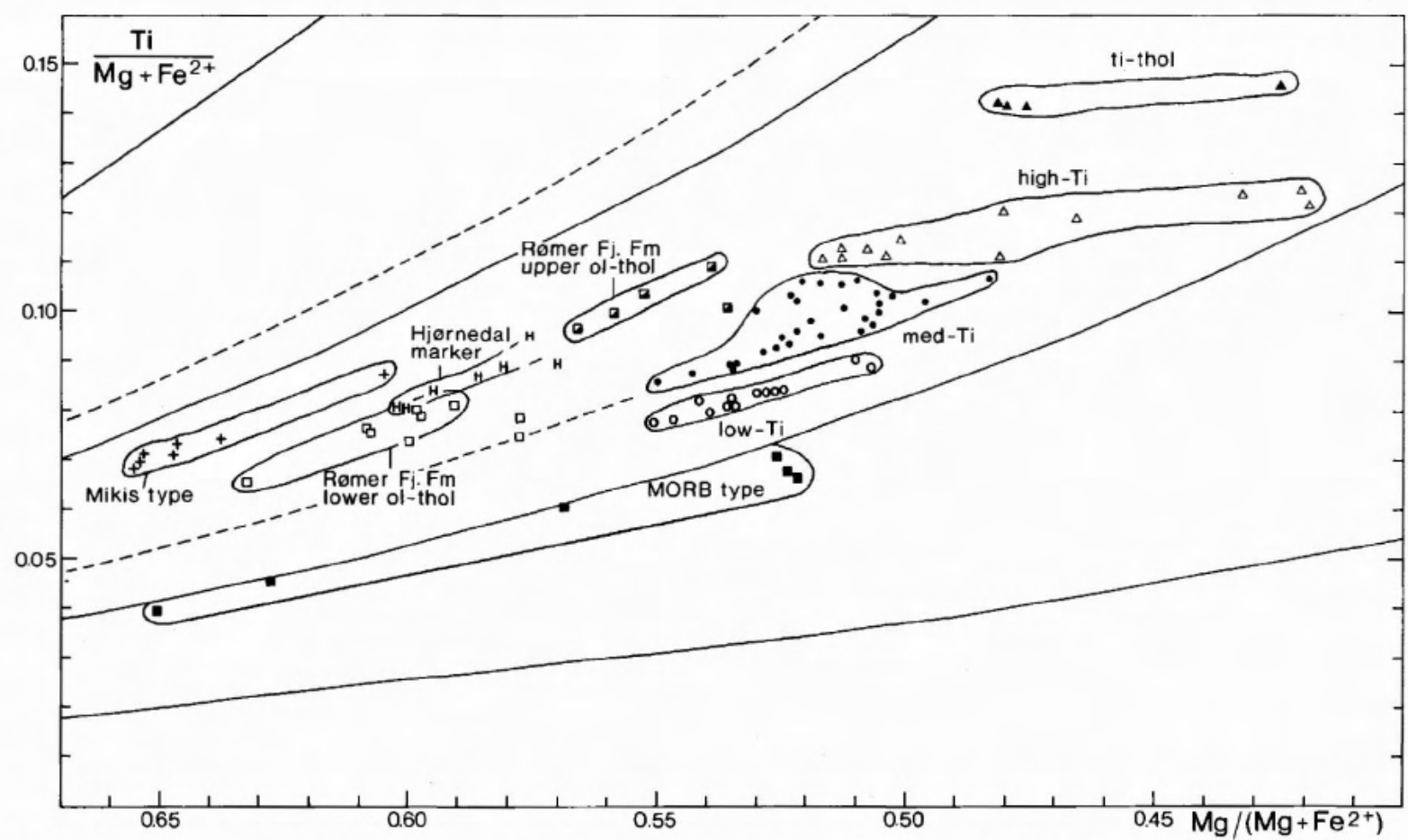

Fig. 89. Fractionation diagram (after Irvine, 1979) showing the trends defined by the Mg-rich basalt types, and the well-defined main basalt trends from the Geikie Plateau Formation (fig. 72 partial diagram b, c). The two Ti-richest of these are obviously not caused by crystal fractionation. Symbols as in fig. 68. The dashed lines are the picritic (upper) and tholeiitic (lower) trends of the Lower Basalts from Kangerdlugssuaq (Brooks \& Nielsen, 1982a), inserted for comparison. 
Table 22. Results of fractionation calculations on Geikie Plateau Formation lavas

\begin{tabular}{|c|c|c|c|c|c|c|c|c|}
\hline Model & 1 & 2 & 3 & 4 & 5 & 6 & 7 & 8 \\
\hline Mother & 98535 & 98483 & 98513 & 98511 & 98483 & 98578 & 98361 & 98513 \\
\hline Daughter & 98709 & 98578 & 98880 & 98881 & 98513 & 98880 & 98376 & 98881 \\
\hline \multicolumn{9}{|l|}{ residuals: } \\
\hline $\mathrm{SiO}_{2}$ & 0.04 & -0.03 & -0.05 & -0.21 & -0.10 & -0.14 & -0.02 & 0.08 \\
\hline $\mathrm{TiO}_{2}$ & -0.02 & 0.01 & -0.39 & -0.38 & 0.35 & 0.04 & 0.06 & -0.07 \\
\hline $\mathrm{Al}_{2} \mathrm{O}_{3}$ & -0.02 & 0.02 & 0.03 & 0.18 & 0.08 & 0.11 & 0.02 & -0.07 \\
\hline $\mathrm{FeO}^{*}$ & -0.04 & 0.03 & 0.16 & 0.40 & 0.03 & 0.19 & 0.01 & -0.09 \\
\hline $\mathrm{MgO}$ & -0.02 & 0.01 & -0.04 & -0.03 & 0.08 & 0.05 & 0.01 & -0.03 \\
\hline $\mathrm{MnO}$ & -0.01 & -0.01 & 0.02 & 0.03 & -0.02 & 0.02 & -0.01 & 0.02 \\
\hline $\mathrm{CaO}$ & -0.06 & 0.04 & 0.08 & 0.34 & 0.15 & 0.23 & 0.02 & -0.13 \\
\hline $\mathrm{Na}_{2} \mathrm{O}$ & -0.05 & 0.03 & 0.00 & 0.03 & 0.01 & -0.04 & -0.08 & -0.04 \\
\hline $\mathrm{K}_{2} \mathrm{O}$ & 0.00 & 0.00 & 0.05 & -0.01 & -0.01 & 0.04 & -0.01 & 0.04 \\
\hline $\mathrm{P}_{2} \mathrm{O}_{5}$ & 0.00 & 0.02 & -0.01 & -0.03 & 0.04 & 0.02 & 0.00 & 0.01 \\
\hline$\Sigma r^{2}$ & 0.011 & 0.005 & 0.190 & 0.502 & 0.166 & 0.132 & 0.011 & 0.047 \\
\hline accepted & + & + & - & - & - & - & + & $(+)$ \\
\hline \multicolumn{9}{|c|}{ fractionate and daughter: } \\
\hline olivine & $1.8 \%$ & $3.4 \%$ & $3.0 \%$ & $1.7 \%$ & $1.6^{0 / 0}$ & $1.0 \%$ & $0.6 \%$ & $3.3 \%$ \\
\hline plagioclase & $6.0 \%$ & $5.5 \%$ & $11.4 \%$ & $9.0 \%$ & $5.1 \%$ & $10.4 \%$ & $9.0 \%$ & $13.3 \%$ \\
\hline augite & $4.5 \%$ & $3.9 \%$ & $9.4 \%$ & $5.7 \%$ & $3.2 \%$ & $7.8 \%$ & $8.7 \%$ & $10.4 \%$ \\
\hline daughter & $87.6 \%$ & $87.3 \%$ & $76.2 \%$ & $83.7 \%$ & $90.2 \%$ & $80.9 \%$ & $81.7 \%$ & $72.9 \%$ \\
\hline
\end{tabular}

Model 1: The low-Ti trend

Model 2: The med-Ti trend

Model 3: The high-Ti trend

Model 4: The titano-tholeiite trend

In samples 98355,98578 and $98511 \mathrm{~K}_{2} \mathrm{O}$ was

adjusted to an estimated value for unaltered material.
Between-irends-fractionation:

5: primitive med-Ti to primitive high-Ti

6: differentiated med-Ti to differentiated high-Ti

7: The same, 2 samples from profile 47

8: primitive high-Ti to differentiated titano-tholeite these crystals to model the fractionation process, but on the other hand they could not have been very different from the crystals formed along the walls. It was noted during the calculations that small changes in the composition of the fractionated minerals only had small effects on the result.

The model calculations were made using the least squares mixing program of Wright \& Doherty (1970). Mineral compositions were taken from microprobe analyses of minerals from the appropriate lava types. Selected models are shown in Table 22. It is seen that both the low-Ti trend and the medium-Ti trend of the Geikie Plateau Formation lavas (fig. 89) can be produced, from left to right, by fractionation of around $13 \%$ crystals of olivine, plagioclase and augite. But neither the high- $\mathrm{Ti}$ or the titano-tholeiite trends give satisfactory solutions; the error lies mainly on $\mathrm{TiO}_{2}$ : both trends are too 'flat'. Introduction of ilmenite and/or titanomagnetite does not improve the results because the residuals for $\mathrm{FeO}^{*}$ and $\mathrm{TiO}_{2}$ have opposite signs. Cross-trend fractionation between the relatively primitive compositions (left side) is not successful either (model 5): these trends are too 'steep' with respect to $\mathrm{TiO}_{2}$. Cross-trend fractionation between relatively differentiated samples give mixed results (models 6 and 7): even if $\mathrm{TiO}_{2}$ is approximately correct the other major elements may not fit the model (model 6). Cross-irend fractionation as in model 8 appears to be possible; in this model only the $\mathrm{CaO}$ residual is above $0.1 \%$, the suggested level of acceptance (Wright, 1974).

In conclusion, it is possible to produce the low-Ti trend and the medium-Ti trend (although not the hump on the back' of this, fig. 89) by fractional crystallisation of, in both cases, around $6 \%$ plagioclase, $4 \%$ augite and $2-3 \%$ olivine. The high- $\mathrm{Ti}$ and titano-tholeiite trends cannot have formed by crystal fractionation within the group. It is possible to produce the most iron-rich high-Ti and titano-tholeiite lavas by crystal fractionation from some less differentiated compositions in the trend below. But it is not possible to produce the $\mathrm{Mg}$-rich (left end) of any of the trends by fractionation from a parent in the trend below. These magmas are excessively en- 
riched in $\mathrm{TiO}_{2}$ compared to what is required for a model assuming petrogenetic relationship by crystal fractionation. The data for $\mathrm{Zr}$ (appendix 3, fig. 82) show the same thing: the low- $\mathrm{Ti}$ and medium-Ti trends are well explained by the crystal fractionation models 1 and 2 in Table 22, but the other trends are not. Open magma chamber processes have already been advocated as a possible solution to this problem (Larsen \& Watt, 1985) and this is elaborated below. The open magma chamber solution permits the main basalts to be generated from one parent magma type, to which the low-Ti basalts are those closest in composition.

Fig. 89 shows that of the four $\mathrm{Mg}$-rich basalt types the only possible candidate for a parent magma to the main basalts is the MORB type basalt, and even this is not possible without assuming one 'jump' more in the position of the trend. The compositional trend of the MORB type basalts themselves appears to be controlled by crystal fractionation, but the data on this liquid type are too sparse to allow calculations, because the process must be performed in steps to allow the incoming of plagioclase and compositional changes in the olivine.

The compositional trends of the other Mg-rich basalt types also appear from fig. 89 to be controlled by crystal fractionation. Quantitative calculations, however, do not give completely satisfactory results. The Mikis type trend can largely be explained by fractionation of, from left to right, $5 \%$ olivine of composition $\mathrm{Fo}_{90}$, even though the iron residual is rather high $(0.25$; this can also be read from fig. 76), and there is also a $\mathrm{Zr}$ residual. Calculations on the trend of 'enriched' olivine tholeiites give poor solutions for several major elements when olivine alone is fractionated. Fractionation of augite has already been inferred from $\mathrm{MgO}-\mathrm{FeO}$ and $\mathrm{MgO}-\mathrm{CaO} / \mathrm{Al}_{2} \mathrm{O}_{3}$ relations and the low $\mathrm{Sc}$ contents (figs $76,78,81$ ), and incorporation of augite improves the calculated solutions although, like the Mikis type trend, the iron residuals especially are still high (around 0.4 ). A few samples from the two 'enriched' olivine tholeiite trends also plot outside the trends, and it must be concluded that, even though crystal fractionation probably has been important in generating the trends, other processes have also been at work. These lavas are rich in zeolites, and their compositions may after all not be unchanged by the zeolitisation. It can also be concluded from fig. 89 that the two groups of 'enriched' olivine tholeiites (the lower and upper compound units of the Rømer Fjord Formation) may be related through fractionation from a common parent magma type.

The last $\mathrm{Mg}$-rich magma type, the Hjørnedal type, has already been shown to have within-type variation caused by plagioclase accumulation in the more 'fractionated' (i.e. Mg-poor) samples (figs 76-78). Quantita- tive calculations show that the well-defined three-quarters of the Hjørnedal variation trend in fig. 89 can be produced by fractionation from the most primitive composition present of $2.5 \%$ olivine and $1.5 \%$ augite, and addition of $3 \%$ plagioclase. The trend is, however, possibly partly a pseudo-trend caused by mixing, as discussed in the next section.

In conclusion, crystal fractionation was an important process in producing the within-type variations shown as trends in fig. 89. It fails, however, to explain the high- $\mathrm{Ti}$ and titano-tholeiite trends and the genetic relations between the trends. These are considered below.

\section{Magma mixing and open magma chambers}

O'Hara (1977) drew attention to the fact that most volcanic systems are open systems that undergo repeated tappings and fillings, and this concept has won general acceptance as geological common sense.

In a process of repeated mixing of differentiating magma in the chamber with batches of more primitive magma, the magmas may be kept apart by density differences and only mix when the new magma batch is sufficiently fractionated (Sparks et al., 1980). Even then, such magma mixing should lead to local disequilibrium between crystals and melt which would be detectable in the crystals when erupted. The Scoresby Sund basalts display numerous examples of complexly zoned phenocrysts, and phenocrysts in disequilibrium with the magma. Especially the zoned plagioclase crystals are significant (fig. 49), and also petrographically and compositionally xenocrystic olivine (fig. 46) and augite (fig. 53) have been found in a number of samples. Very similar features in lavas from the Mid-Atlantic Ridge and other places have been interpreted in terms of refilling and mixing of magmas (e,g. Rhodes $e t$ al., 1979; Kuo \& Kirkpatrick, 1982; Stakes et al., 1984). There is thus good petrographic evidence for mixing processes in the Scoresby Sund magmas, notably in the Hjørnedal type, the olivine tholeiites and the main basalts.

O'Hara \& Mathews (1981) developed quantitatively the processes that take place in such periodically refilled, periodically tapped and continuously fractionated magma chambers. They showed how minor and trace elements were 'decoupled' from the major elements, and that both compatible and incompatible elements were enriched in the magma relative to their concentration during simple crystal fractionation processes. Just such 'excessive' enrichment of an incompatible element, $\mathrm{TiO}_{2}$, is a central problem of the main basalts in Scoresby Sund.

The variation within the main basalts was earlier in- 
terpreted (Larsen \& Watt, 1985) as caused by open magma chamber processes acting on one magma type. Supporting evidence for this is the observation from the well-defined magma evolution trends of the Geikie Plateau Formation that, within any one lava profile, every lava flow has a composition that is to a certain degree dependent on the composition of the preceding lava flow. Given one lava flow, the composition of the next flow is determined within certain limits, as shown by the flow-to-flow variation for $\mathrm{TiO}_{2}$ in profile 52 (fig. 91). All profiles through the Geikie Plateau Formation show this relation. The stratigraphic variation within the Geikie Plateau Formation was thus explained as the combined result of chamber replenishment, crystallisation and eruption. At the start of the formation large magma chambers were filled with relatively fractionated magma. The rate of replenishment increased during the Geikie Plateau Formation time and shortened the residence time of the magma in the chamber, so that successively erupted magmas became less fractionated. When finally the magma supply waned and the magma chamber 'died' (fig. 3) the 'reverse' unit was formed. The overall differentiation trend in fig. 91 is steeper than any of the four individual main basalt trends, and within it individual fractionation and replenishment trends are evident at several levels.

The same explanation applies to the stratigraphic variation in the Skrænterne Formation. In this formation,

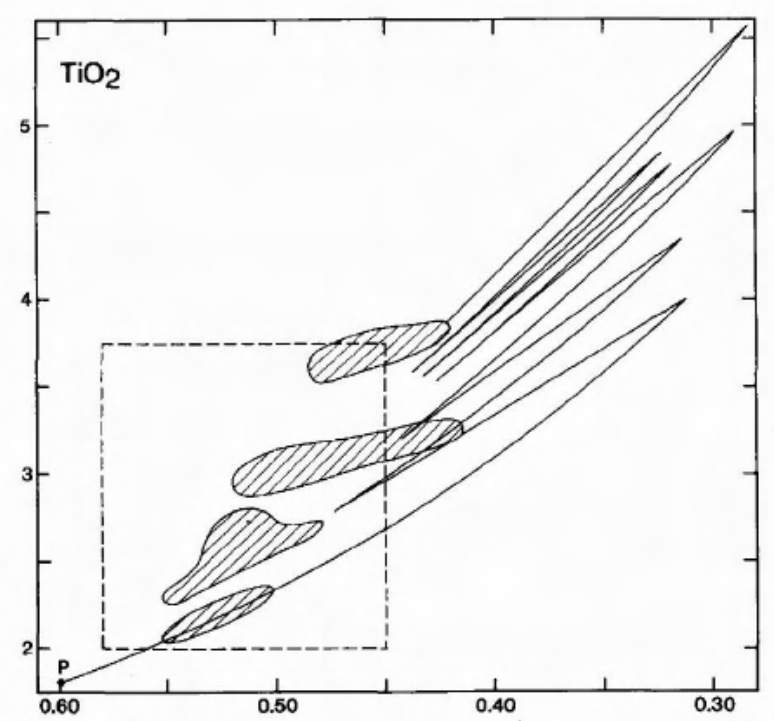

Fig. 90. Repeated fractionation and mixing events can produce 'excessive' enrichment of both incompatible and compatible elements. As starting composition was chosen a 'primitive' composition $(\mathrm{P})$ with $\mathrm{FeO}=11.80 \%, \mathrm{MgO}=8.80 \%, \mathrm{TiO}_{2}=$ $1.80 \%$ and $\mathrm{Cr}=400 \mathrm{ppm}$. Bulk partition coefficients were calculated from the mixing model no. 1 in Table 22: $\mathrm{D}(\mathrm{FeO})=$ $0.44, \mathrm{D}(\mathrm{MgO})=1.76, \mathrm{D}\left(\mathrm{TiO}_{2}\right)=0.13 . \mathrm{D}(\mathrm{Cr})$ was put at a however, the trends and correlations such as shown in fig. 91 are much looser than for the Geikie Plateau Formation. This difference between the two formations is a recurrent feature and is thought to reflect the phenocrystic nature of the Skrænterne Formation lavas.

Cox (1988) has noted that an 'excessive' enrichment in incompatible elements in open magma chambers will only be noticeable after many repeated fractionation and mixing cycles, and this may not be likely for an ordinary basalt sequence. Arrival at a 'steady-state' composition demands very many cycles, and steady states are normally not obtained. The very fact that there are systematic compositional developments in the Scoresby Sund basalt sequence testifies that a steady state was not attained.

The ability of an open system to produce 'excessive' element enrichment has been tested by quantitative calculations of repeated fractionation and mixing events, following O'Hara \& Mathews (1981). The calculations were performed for the moderately and strongly incompatible elements $\mathrm{TiO}_{2}$ and $\mathrm{Zr}$, and the compatible elements $\mathrm{Cr}$ and $\mathrm{Ni}$. As the results for $\mathrm{TiO}_{2}$ and $\mathrm{Zr}$, and $\mathrm{Cr}$ and $\mathrm{Ni}$, are very similar, only $\mathrm{TiO}_{2}$ and $\mathrm{Cr}$ are shown in figs 90 and 91 . A hypothetical primitive magma with a $\mathrm{Mg}$ ratio of $0.60, \mathrm{TiO}_{2}=1.80, \mathrm{Zr}=100 \mathrm{ppm}, \mathrm{Cr}=400$ $\mathrm{ppm}$ and $\mathrm{Ni}=160 \mathrm{ppm}$ was chosen as a starting point. The calculations (fig. 90) show that the element enrichment in question can be produced in relatively few

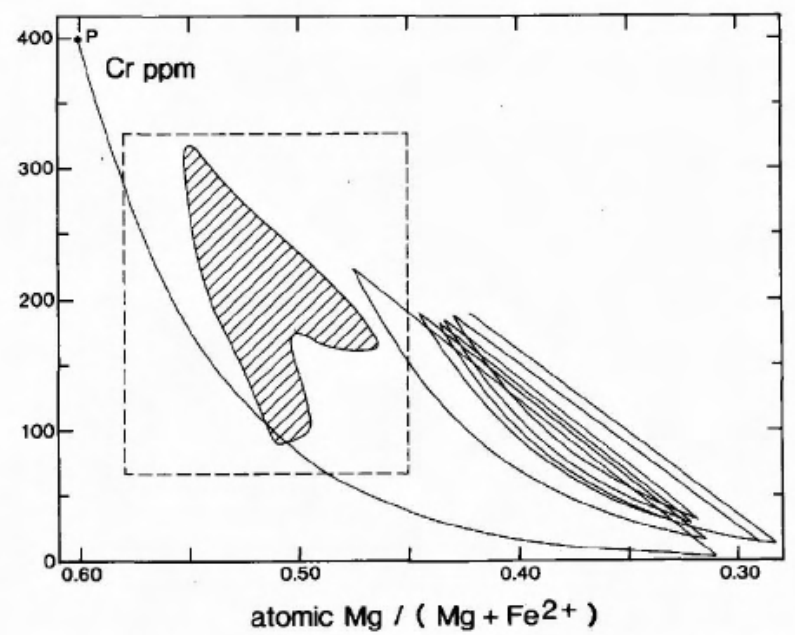

constant value of 6.0 which is a compromise between the changing conditions of chromite and augite fractionation. Six calculated cycles of fractionation and mixing are shown. The degree of fractionation ( $\mathrm{x}$ ), of tapping (y) and of refilling (z) were put at $x=0.3-0.6, y=0, z=0.5$. Less extreme fractionation demand a higher number of cycles to obtain the same effect.

The ruled areas enclose the data points for profile 52 , shown in fig. 91; the outlines of fig. 91 are shown as broken lines. 

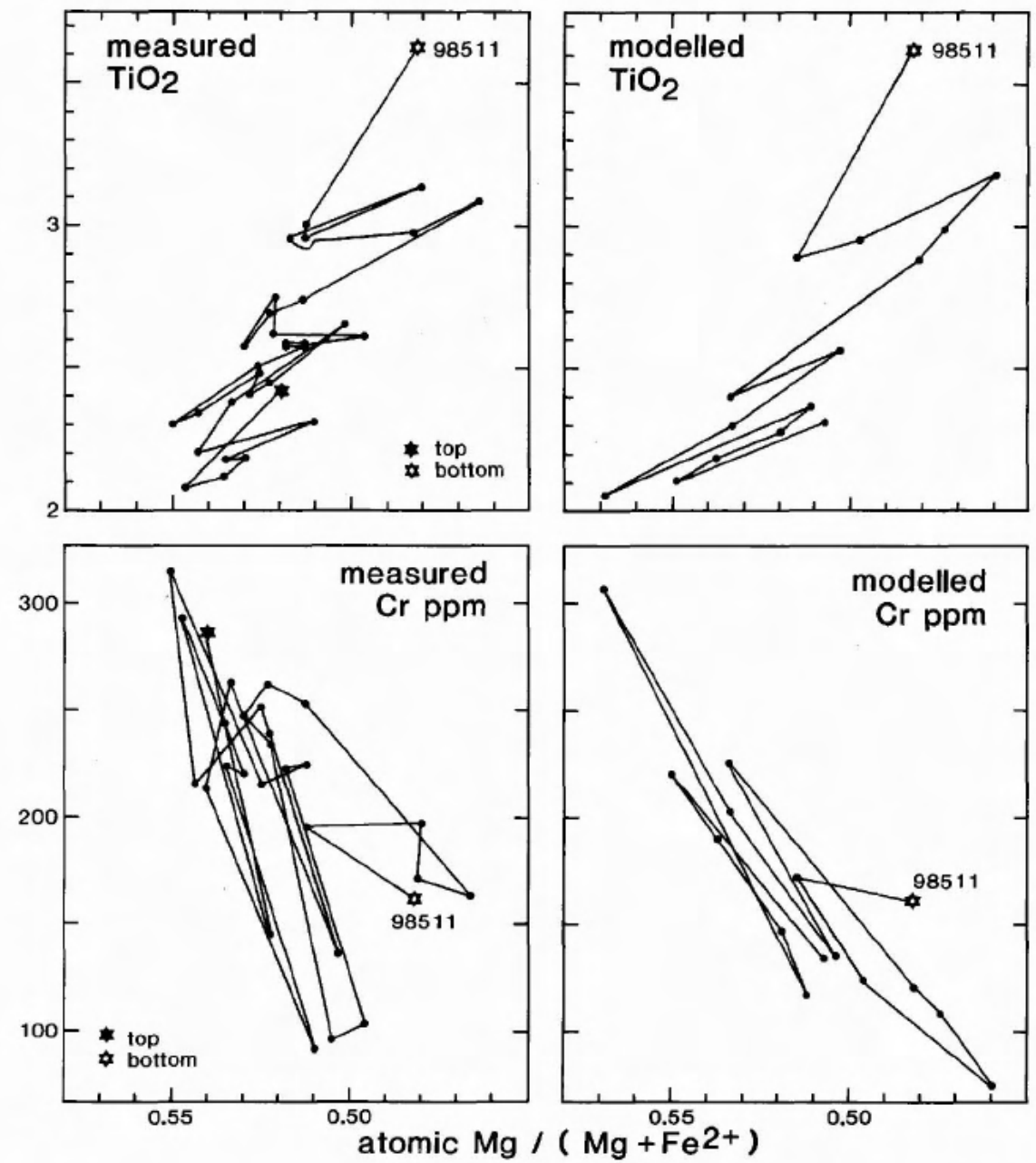

Fig. 91. Flow-to flow development in a single profile in the Geikie Plateau Formation. Left: Profile 52 as measured. Right: numerical simulation of $\mathrm{TiO}_{2}$ and $\mathrm{C}_{r}$ in profile 52. As starting composition was taken the lowest flow, GGU 98511. The parameters were varied so that $\mathrm{x}=$ $0.03-0.20, y=0.02-0.25$ and $z=$ $0.1-1.0$. The 'lavas were erupted' following one cycle of mixing with primitive magma ( $P$, fig. 90) and subsequent fractionation. Large displacements downwards are due to combinations of little fractionation and large refilling of primitive magma. The modelling was optimized for the $\mathrm{TiO}_{2}$ data. While the calculated $\mathrm{Cr}$ values are in the correct range and faithfully reproduce the very large relative variations, the connecting lines have somewhat different slopes. This may be due to the oversimplification of a constant bulk $\mathrm{Cr}$ partition coefficient. fractionation and mixing cycles, provided that the degree of fractionation is considerable, the amount of tapping is small or zero, and the amount of refilling is around half the chamber volume. The fractionated liquids in the calculated model are rather extreme, but similar element enrichment can be produced with less extreme fractionation and a greater number of cycles. If gabbro assimilation (auto-contamination) is allowed for, the incompatible elements will be further enriched.

Conditions of considerable refilling and little or no tapping mean that the magma chamber must expand. This, together with considerable fractionation, is most likely to occur in the beginning of a magmatic episode when magma chambers are developing. Strongly fractionated lavas, although not as extreme as those calculated, do constitute relatively large proportions of the lower parts (Milne Land and Rømer Fjord Formations) of the two volcanic episodes in Scoresby Sund (Table 7). Remarkably, a basaltic glass almost as extreme as the calculated fractionated compositions was reported from the Reykjanes Ridge by Melson \& O'Hearn (1986) (5.43\% $\mathrm{TiO}_{2}, \mathrm{Mg}$ ratio 0.348 ).

The Geikic Plateau Formation would then have started with huge magma chambers filled with Ti-enriched fractionated magma. Starting with this magma it is possible by mixing and fractionation calculations to simulate numerically the development up-sequence of this formation (fig. 91). The effect is obtained by allowing tapping and letting the refilling rate in most cycles dominate over the fractionation rate, so that successively less fractionated magmas result. The parameters of the model were within the limits given in fig. 91, and they were not chosen at random but to produce a trend in principle, although not in detail, similar to the $\mathrm{TiO}_{2}$ trend observed. The fact that the lavas come in four distinct $\mathrm{TiO}_{2}$ groups may result from certain combinations of the parameters being more likely than others.

With a $\mathrm{Zr}$ bulk partition coefficient of zero, the model very accurately reproduces the development of $\mathrm{Zr}$ in profile $52(226-118 \mathrm{ppm})$. For $\mathrm{Ni}$, the calculated 
variation (78-139 ppm, estimated bulk partition coefficient $=2.8$ ) compares well with the measured variation of $81-120 \mathrm{ppm}$.

In conclusion, the quantitative calculations support the suggestion by Larsen \& Watt (1985) that the main basalts may have originated from one parent magma by processes in open magma chambers. However, additional processes are not excluded. The $\mathrm{Zr} / \mathrm{Nb}$ ratios clearly indicate that the high-Ti basalts and titano-tholeiites from the Rømer Fjord Formation were derived from the olivine tholeiites in that formation. The main basalts as a group thus do have more than one parent magma.

\section{Origin of the Hjørnedal marker flow}

The Hjørnedal marker flow is the only $\mathrm{Mg}$-rich basalt type that is multiply saturated with olivine, feldspar and augite (Table 20); moreover it contains chromite. Its feldspar phenocrysts show very complicated zoning patterns, and a very $\mathrm{Mg}$-rich olivine crystal $\left(\mathrm{Fo}_{q_{0}}\right)$ has been found in it. Least-square calculations like those performed for testing crystal fractionation showed that the most $\mathrm{Mg}$-rich Hjørnedal type composition can be explained as a mixture of around two parts of the most primitive Mikis type basalt with around three parts of main basalt from the medium-Ti group. The best fits were obtained when olivine, plagioclase and an oxide were allowed to fractionate $\left(\Sigma r^{2}<0.005\right)$. Several possible main basalt parents were tested, and plagioclase (up to $3 \%$ ) consistently had to be added to the mixture, and iron oxide (c. $1 \%)$ subtracted. The need for subtracting an iron oxide also appears from the $\mathrm{FeO}^{*}-\mathrm{MgO}$ diagram (fig. 76): the Hjørnedal magma has very low iron contents relative to both parents. Plagioclase addition was minimised when a high-Al basalt from the Milne Land Formation was used as parent. It is concluded that the mixing process is feasible, but that the actual main basalt magma composition is probably not present as a lava. Calculated backwards it has lower $\mathrm{FeO}^{*}($ c. $11 \%)$ and higher $\mathrm{CaO}(c, 12 \%)$ than most lavas but is all the same reasonable.

In the mixing calculations the more $\mathrm{Mg}$-poor and the more $\mathrm{Mg}$-rich Hjørnedal compositions require different main basalt parents to give good solutions. This can also be read from the $\mathrm{Al}_{2} \mathrm{O}_{3}$ - $\mathrm{CaO}$ diagram (fig. 77) where the Mikis type, Mg-rich Hjørnedal and Mg-poor $\mathrm{Hj} ø$ nedal compositions do not fall on a single line. This could be because the Mg-poor Hjornedal magma is fractionated from the $\mathrm{Mg}$-rich one, as discussed in the previous section, or because the main basalt was compositionally variable. The last explanation is considered the most probable because the fractionation solution involves addition of plagioclase, and the Hjømedal $\mathrm{FeO}^{*}-\mathrm{MgO}$ trend in fig. 76 looks more like a mixing line. However, an overprint of fractionation may well be present.

The trace element data are consistent with a mixing process. $\mathrm{Ni}$ and $\mathrm{Cr}$ are around four times higher in the Mikis type basalt than in the main basalts, and a 2:3 mixture of these compositions has the same $\mathrm{Ni}$ and $\mathrm{Cr}$ contents as the Hjørnedal marker, as shown in fig. 80 . The incompatible trace elements are insensitive to the mixing process because their concentrations are nearly the same in the two end members.

A mixing process also explains the $\mathrm{Sr}$ isotope ratio of 0.7039 for the Hjørnedal marker (Table 21). The Mikis type and the main basalt type have ${ }^{87} \mathrm{Sr} /{ }^{86} \mathrm{Sr}$ ratios of 0.7045 and 0.7034 respectively, and similar $\mathrm{Sr}$ contents, and a $2: 3$ mixture of these two types gives an ${ }^{87} \mathrm{Sr} /{ }^{86} \mathrm{Sr}$ ratio of 0.7038 .

An origin of the Hjørnedal magma type by the mixing of Mikis type and medium-Ti type magma is geologically feasible, too. The Mikis type lava flow in the Milne Land Formation is a single flow of minimum 95 $\mathrm{km}^{3}$ volume intercalated with main basalts of medium-Ti and high-Ti type. The Hjørnedal marker flow is of minimum $285 \mathrm{~km}^{3}$ volume and followed the Mikis type flow with none or one or two main basalt flows between (Plate 1). The Mikis type magma, from wherever it came, apparently entered the existing large magma chamber in which the main basalts were fractionated. If around $200 \mathrm{~km}^{3}$ Mikis type magma arrived, the half part was erupted directly, probably owing to its low density (fig. 70). Around $100 \mathrm{~km}^{3}$ stayed in the chamber and mixed in the top of it with medium-Ti magma in the proportion $2: 3$. This gave around $250 \mathrm{~km}^{3}$ Hjørnedal type magma which was then erupted in one event with an unusually high fraction of tapped magma, probably again because of its low density.

At the eruption of the Hjørnedal marker flow the magma chamber was effectively swept clean of this magma type, and the main basalts continued their development. Only in one profile (72) is there an indication that the next lava flow contains remains of the Hjørnedal magma (sample 98841). Profile 72 is probably close to the extrusion site for the Hjørnedal flow. The lateral compositional variation in the Hjørnedal flow (cf. section on major elements) suggests that the magma chamber was zoned, either vertically or laterally; the main basalt participating in the mixing was also inhomogeneous, and the zoning may be inherited. The copious development of phenocrysts in the Hjørnedal magma may be explained as resulting from the mixing process, the Mikis type magma being forced towards the cotectic. 


\section{Crustal contamination}

Basalts erupted onto a continent have been stored below and in the continental crust and have passed through the crust on their way to the surface. The degree to which the chemical and isotopic composition of such basalts have been influenced by the continental crust has been a matter of much controversy. Some workers have contended that large amounts of crustal contamination have occurred in most or all continental flood basalts, while other workers have argued that the compositional characteristics of these basalts are attained through their generation in an enriched, subcontinental mantle. The controversy has concerned areas as Antarctica (e.g. Faure et al., 1974; Kyle, 1980), the Columbia River group (e.g. McDougall, 1976; Carlson et al., 1981; Carlson, 1984; Church, 1985), the British Tertiary igneous province (e.g. Thompson et al., 1982, 1983; Weaver \& Tarney, 1983), the Karoo basalts (Cox, 1983) and the Deccan traps (Mahoney et al., 1982; Cox \& Hawkesworth, 1985). The trouble arises from the fact that the two processes lead to similar results and thus are very hard to distinguish. In recent years a sort of consensus has developed that both processes probably are at work, but the question to what degree is still a matter of debate.

In some basalt provinces, like the Antarctic, all the basalts have high initial ${ }^{87} \mathrm{Sr} /{ }^{86} \mathrm{Sr}$ ratios which have none the less been ascribed to the mantle source (Kyle, 1980). In general, however, single lavas showing increased $\mathrm{Sr}$ isotope ratios relative to the surrounding co-magmatic lavas may be inferred to be contaminated by crustal material. On the other hand, contamination with lower crustal granulite facies rocks containing very little $\mathrm{Rb}$ and consequently with low ${ }^{87} \mathrm{Sr}{ }^{86} \mathrm{Sr}$ ratios may not leave any imprint on the $\mathrm{Sr}$ isotopic signature of the lavas. Data for several isotope systems are usually necessary.

Two features of the Scoresby Sund basalts require discussion in this context: firstly, the sporadic occurrence of high-Si, high- ${ }^{-87} \mathrm{Sr} /{ }^{86} \mathrm{Sr}$ lavas and, secondly, the systematic compositional change (decrease) in silica saturation up through the lava pile.

High-Si basalts. Lavas with unusually high silica contents for the region occur in several instances in the two lower formations (Magga Dan and Milne Land Formations); one has been found in the Geikie Plateau Formation, and one or two flows occur in the Skrænterne Formation (fig. 73). Some of these lavas are otherwise compositionally similar to the other lavas of the unit in which they occur (Milne Land and Skrænterne Formation, fig. 72), while others (in the Magga Dan and
Geikie Plateau Formations) are compositionally quite distinct from all the other lavas. They are lower in $\mathrm{TiO}_{2}$ and have higher $\mathrm{Mg}$ ratios (fig. 72), partly because of lower iron contents though some samples also have high $\mathrm{MgO}$ (fig. 76), and they are low in $\mathrm{CaO}$ and sometimes in $\mathrm{Al}_{2} \mathrm{O}_{3}$ (fig. 77). Except for the high $\mathrm{MgO}$, such compositional features would be expected to result from contamination of a basalt of one of the main types with siliceous crustal material. Sr isotopic data for two high-Si basalts show ${ }^{87} \mathrm{Sr} /{ }^{86} \mathrm{Sr}$ ratios considerably higher than normal $(0.7057$ and 0.7079 against the normal 0.7034 , Table 21) in accordance with the theory that the high-Si basalts include a crustal component. Silicic basalts showing similar geochemical features also occur in the plateau basalts of West Greenland (Pedersen, 1985; Pedersen \& Pedersen, 1987) and on the Faeroe Islands (Hald \& Wågstein, 1983), and have been similarly interpreted.

The Precambrian/Caledonian basement in East Greenland is heterogeneous and comprises various units with different isotopic characteristics. The best candidate for a contaminant to the lavas would be Archaean gneisses, such as the Trrskeldal banded gneisses with $30-100 \mathrm{ppm} \mathrm{Rb}, 100-300 \mathrm{ppm} \mathrm{Sr}{ }^{87} \mathrm{Sr}^{86} \mathrm{Sr}=0.72$ 0.75 , and $\mathrm{SiO}_{2}=65-75 \%$ (Rex et al., 1977 and unpublished $\mathrm{Rb}$ and $\mathrm{Sr}$ data (D. Rex) and chemical analyses). Simple calculations set out in Table 23 show that the two high-Si lavas may be produced by bulk contamination of basalt with respectively $10 \%$ and $20 \%$ of such Archaean material. The calculations show that crustal contamination is a feasible explanation for the compositional features of the high-Si basalts. The process was, however, probably not as simple as bulk contamination (mixing), because basalt contamination by continental crusi is likely to be selective. Assimilation of partially molten crust is much more likely than bulk assimilation (Patchett, 1980), and diffusion rates for various elements are variable (Watson, 1982). Watson (1982) showed that the major elements of the crust most likely to be assimilated into basaltic magma are $\mathrm{SiO}_{2}$ and $\mathrm{K}_{2} \mathrm{O}$, and in accordance with this all high-Si lavas have also increased $\mathrm{K}_{2} \mathrm{O}$ contents $(0.39-0.87 \%$ against the normal values of $0.2-$ $0.4 \%)$.

The trace element data are consistent with the idea of crustal contamination of the high-Si basalts. Fig. 92 shows spidergrams for five high-Si basalts and a possible contaminant. Crustal contamination of a sample will show up as increased contents of $\mathrm{Rb}, \mathrm{Ba}$ and $\mathrm{K}$, and as troughs in the spidergram for $\mathrm{Nb}, \mathrm{P}$ and $\mathrm{Ti}$ (Thompson et al., 1984, also evident from the spectrum of the analysed gneiss sample). The high-Si basalts all have increased $\mathrm{Ba}, \mathrm{Rb}$ and $\mathrm{K}$ and have lost the $\mathrm{Nb}$ and $\mathrm{Ti}$ peaks, while $\mathrm{P}$ is almost unaffected (compare with the 
Table 23. Results of calculations of bulk contamination of a Scoresby Sund basalt with Archaean basement

\begin{tabular}{|c|c|c|c|c|c|c|c|}
\hline GGU No. & $\begin{array}{c}\text { contaminant } \\
133158\end{array}$ & $\begin{array}{l}\text { basalt } \\
98489\end{array}$ & $\begin{array}{c}10 \% \mathrm{ctm} \\
\mathrm{a}\end{array}$ & $\begin{array}{c}10 \% \mathrm{ctm} \\
\mathrm{b}\end{array}$ & 98561 & $\begin{array}{c}20 \% \mathrm{ctm} \\
\mathrm{c}\end{array}$ & 98761 \\
\hline $\mathrm{SiO}_{2}$ & 73.07 & 48.95 & 51.36 & 51.58 & 51.40 & 53.77 & 53.70 \\
\hline $\mathrm{TiO}_{2}$ & 0.20 & 2.64 & 2.40 & 2.00 & 1.98 & 2.15 & 1.95 \\
\hline $\mathrm{Al}_{2} \mathrm{O}_{3}$ & 13.87 & 14.04 & 14.02 & 14.40 & 14.23 & 14.01 & 13.69 \\
\hline $\mathrm{FeO} *$ & 2.08 & 12.99 & 11.90 & 11.98 & 11.30 & 10.81 & 10.18 \\
\hline $\mathrm{MnO}$ & 0.03 & 0.21 & 0.19 & 0.18 & 0.18 & 0.17 & 0.16 \\
\hline $\mathrm{MgO}$ & 1.11 & 6.46 & 5.93 & 6.10 & 6.52 & 5.39 & 6.84 \\
\hline $\mathrm{CaO}$ & 3.39 & 11.21 & 10.43 & 10.71 & 10.92 & 9,65 & 10.01 \\
\hline $\mathrm{Na}_{2} \mathrm{O}$ & 3.90 & 2.40 & 2.55 & 2.41 & 2.49 & 2.70 & 2.55 \\
\hline $\mathrm{K}_{2} \mathrm{O}$ & 1.07 & 0.34 & 0.41 & 0.22 & 0.43 & 0.49 & 0.45 \\
\hline $\mathrm{P}_{2} \mathrm{O}_{5}$ & 0.06 & 0.23 & 0.21 & 0.18 & 0.17 & 0.20 & 0.17 \\
\hline${ }^{87} \mathrm{Sr} /{ }^{86} \mathrm{Sr}$ & 0.7225 & 0.7034 & 0.7057 & - & 0.7057 & 0.7082 & 0.7079 \\
\hline $\mathrm{Cr}$ & 36 & 136 & 126 & 172 & 244 & 116 & 390 \\
\hline $\mathrm{Ni}$ & 16 & 96 & 88 & 80 & 88 & 80 & 119 \\
\hline Sc & 3.9 & 33 & 30 & 37 & 34 & 27 & 29 \\
\hline V & 38 & 374 & 340 & 385 & 325 & 307 & 287 \\
\hline $\mathrm{Cu}$ & 48 & 259 & 238 & 215 & 195 & 217 & 145 \\
\hline $\mathrm{Zn}$ & 28 & 114 & 105 & 91 & 102 & 97 & 102 \\
\hline $\mathrm{Ba}$ & 291 & 88 & 108 & 78 & 131 & 129 & 203 \\
\hline $\mathrm{Sr}$ & 279 & 216 & 222 & 205 & 191 & 229 & 238 \\
\hline $\mathrm{Rb}$ & 32 & 5.5 & 8.2 & 6.5 & 9.4 & 10.8 & 10.5 \\
\hline $\mathrm{Y}$ & 6.4 & 33 & 30 & 25 & 26 & 28 & 24 \\
\hline $\mathrm{Zr}$ & 138 & 152 & 150 & 132 & 118 & 149 & 138 \\
\hline $\mathrm{Nb}$ & 3.7 & 13.3 & 12.3 & 8.5 & 9.1 & 11.4 & 7.7 \\
\hline
\end{tabular}

133158: Tærskeldal banded gneiss. Major elements by GGU's geochemical laboratory; trace elements by J. C. Bailey, and ${ }^{87} \mathrm{Sr} /{ }^{86} \mathrm{Sr}$ from Rex et al. (1977). Age c. $2500 \mathrm{Ma}$.

98489: Med-Ti type basalt from the Geikie Plateau Formation. Isotopic data from Table 21.

a: Calculated mixture of $10 \% 133158+90 \% 98489$. Compare with sample 98561 .

b: Calculated mixture of $10 \% 133158+90 \%$ 215629, low-Ti basalt from the Skrænterne Formation. Compare with sample 98561 .

98561: High-Si lava from the low-Ti unit in the Skrænterne Formation.

c: Calculated mixture of $20 \% 133158+80 \% 98489$. Compare with sample 98761 .

98761: High-Si lava from the Magga Dan Formation.

ctm: contamination.

uncontaminated basalt spectra in fig. 85). In the $\mathrm{Zr} v$. $\mathrm{Nb}$ diagram (fig. 83) and in the $\mathrm{Zr} / \mathrm{Y} v . \mathrm{Zr} / \mathrm{Nb}$ diagram (fig. 93) the high-Si rocks are also displaced towards the crustal values.

There are some discrepancies between the calculated and the real contaminated basalts in Table 23 (col. 3 and 5). However, high-Si sample 98561 is from the low-Ti unit in the Skrænterne Formation, and if a normal basalt from this unit is used as parent all major elements and most trace elements fit the bulk mixing model very well (Table 23, col. 4 and 5). In contrast, the high-Si lavas of the Magga Dan Formation have consistently too high $\mathrm{MgO}$ and $\mathrm{Cr}$ contents to be bulk mixtures of any of the known components, and any selective contamination only makes the discrepancy worse because $\mathrm{MgO}$ and $\mathrm{Cr}$ are refractive. It is suggested that these high-Si magmas were derived from magmas that were more primitive than the known erupted lavas. These magmas were relatively hot and would thereby have larger capacities of melting their surroundings (Huppert \& Sparks, 1985) and thus produce the high degree of contamination $(20 \%)$ indicated for these rocks. In comparison, Thompson et al. (1982) found that major element constraints indicated $5-10 \%$ crustal contaminant in the Preshal Mhor basalt on Skye while incompatible element constraints indicated $15-20 \%$ of contaminant, and concluded that the contaminant was an incompatibleelement-enriched crustal melt. For the high-Si Scoresby Sund basalts there is no discrepancy between major and trace element indications of crustal involvement, but because both parent basalt and contaminant in the lower sequence are rather ill constrained, this is not 


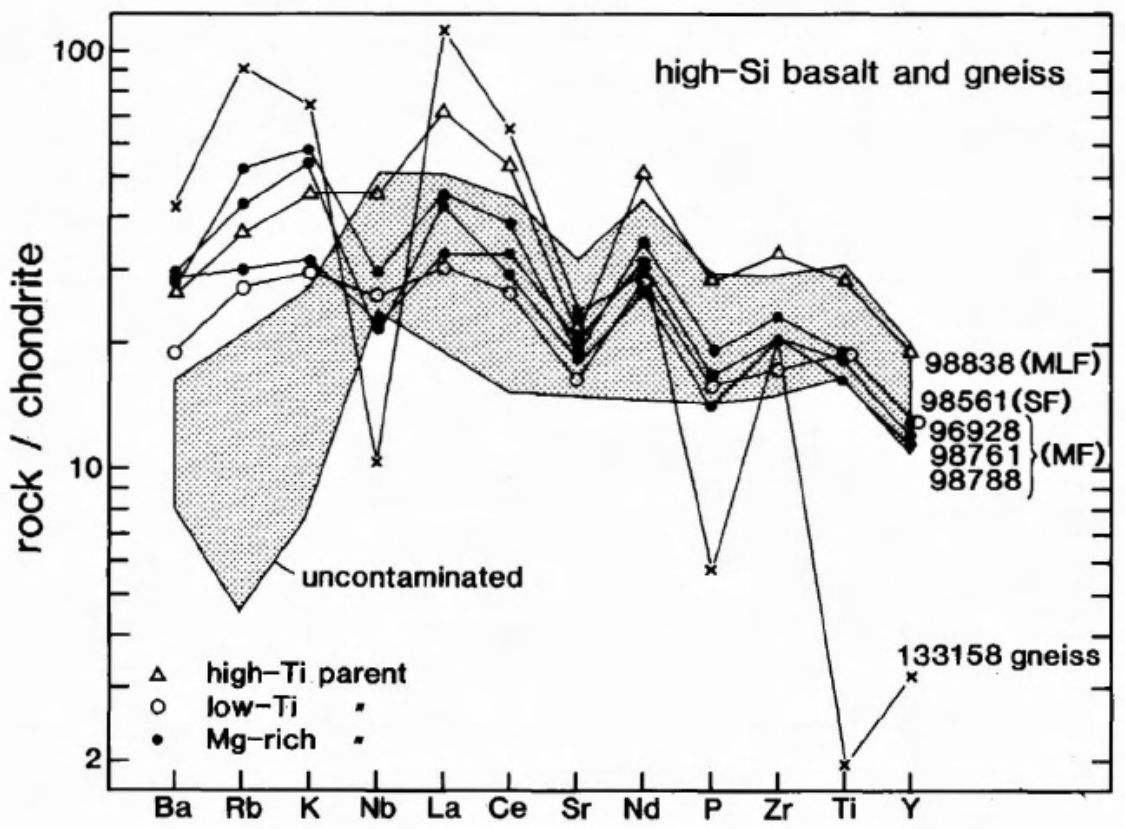

Fig. 92. Spidergrams for high-Si basalts and a selected gneiss sample from East Greenland. Element normalisation factors after Thompson (1982). The stippled area shows the range of uncontaminated possible parents (from fig. 85). Increased $\mathrm{Ba}, \mathrm{Rb}$ and $\mathrm{K}$ in the high-Si basalts are evident. conclusive evidence for bulk contamination. The calculated $\mathrm{Ba}$ contents in Table 23 are all low, and $\mathrm{Ba}$ at least may have been selectively incorporated in the high-Si magmas.

Variation of silica saturation with height. There is a systematic compositional decrease in silica saturation of the basalts up through the lava pile (fig. 3). This is caused by differences in the silica content, which decreases from an average of $50 \%$ in the Magga Dan Formation, through $49.5 \%$ in the Milne Land Formation to $49 \%$ in the Geikie Plateau Formation (fig. 73), while the other elements are very much the same. The feature is explicable in either of two ways: as a result of primary processes in the mantle, with melting at higher levels producing more siliceous magmas (e.g. Green \& Ringwood, 1967), or as a result of a secondary process, viz. contamination with crustal material in open magma chambers, as previously advocated (Larsen \& Watt, 1985). The primary process is considered to be an unlikely explanation because melting at various depths should produce differences not only in the silica contents but also in many other elements (e.g. Presnall et al., 1979), and this is not seen. On the other hand the decreasing $\mathrm{Si}$ contents are understandable in terms of the theory that the basalts are contaminated with continental crust. Low degrees of contamination, e.g. $2-4 \%$, with the same Archaean crustal material as used above (Table 23) lead to increases in $\mathrm{SiO}_{2}$ with $0.5-1.0 \%$ and in the ${ }^{87} \mathrm{Sr} /{ }^{36} \mathrm{Sr}$ ratio with $0.0003-0.0008$ while other elements suffer only imperceptible changes. These fig- ures are in the range of those in question: a lava from the Magga Dan Formation with $50.70 \% \mathrm{SiO}_{2}$ has a $\mathrm{Sr}$ isotope ratio of 0.7037 against the 'normal' level of 0.7034 (Table 21). The geological distribution of the quartz normative lavas is also understandable in a contamination context: the earlier magmas were more likely to come into direct contact with the basement rocks than the later magmas that were injected into already existing, gabbro-lined magma chambers. Thus, contamination was strongest in the beginning and affected mostly the Magga Dan and Milne Land Formations. The $\mathrm{Zr}-\mathrm{Nb}$ relations (fig. 83), with a sudden change in $\mathrm{Zr} / \mathrm{Nb}$ from the Milne Land to the Geikie Plateau Formation, indicate that there could not have been much magma surviving in the chambers from the one formation and mixing into the next. The Geikie Plateau Formation apparently established its own magma chambers, and the quartz normative lavas in the lower part of this formation show that there may have been some initial contamination that gradually wore off with time. The second basalt sequence was not contaminated. It may be that congealed magma chambers from earlier formations were present in the crust over large areas, including the south-eastern tracts, so that the later magmas came more into contact with gabbros than with the siliceous basement rocks.

Contamination and magma chambers. The two types of contamination discussed above: the accidental high-Si basalt and the overall silica variation with height, are related to the existence of magma chambers. The mag- 
nesian high-Si basalts in the Magga Dan Formation have not been filtered through a magma chamber. They were injected into the crust as relatively primitive magmas which melted more crust the hotter they were (Huppert \& Sparks, 1985). These were the pioneers that established the magma chambers in the crust, and most of them crystallised in the process and never erupted (Patchett, 1980). In the new magma chambers sidewall assimilation continued until the chambers were lined with gabbro; at the same time the magma chambers were repeatedly filled, fractionated and tapped, so that the effect of the contamination gradually wore off. Thus, the overall silica variation with height is produced in the large crustal magma chambers. The few high-Si lavas produced after the magma chambers were established are contaminated on the way from the crustal magma chamber to the surface and still clearly reflect the composition of the magma in the chamber (the high-Si basalts of the Milne Land and Skrænterne Formations, fig. 72). Only the magnesian high-Si basalt in the Geikie Plateau Formation may have emerged from deeper levels without being filtered through a large magma chamber.

The most siliceous of the high-Si basalts is sample 98788 from the Magga Dan Formation. This sample contains orthopyroxene phenocrysts (see section on petrography), and estimated from its silica content ( $56 \%$ ) it contains around $30 \%$ contaminant. For reasons given above it should be expected to be very magnesian, but as seen from fig. 72 it is not. However, it contains very magnesian olivine $\left(\mathrm{Fo}_{81.5-83.2}\right.$, fig. 46) which formed in equilibrium with a liquid with a $\mathrm{Mg}$ ratio comparable to those of the other high-Si basalts (around 0.60). The interpretation of the data is that a highly magnesian, strongly contaminated magma batch stayed in an incipient magma chamber in the crust and equilibrated and fractionated there before it continued to the surface. This explains its orthopyroxene phenocrysts and relatively fractionated character.

\section{Processes in the mantle}

Discussions on basalt genesis have been concerned with the question of how many mantle reservoir types there are, and which magmas are primary. For the North Atlantic region, one model invokes only one mantle type and one primary magma with other magma types being ascribed to processes in the crust (Oskarsson et al., 1982, 1985); other models invoke only one mantle type from which several magma types arise due to differences in depth and mechanism and degree of partial melting (e.g. (Langmuir et al., 1977; Thompson et al., 1980). Many models invoke two types of mantle, depleted and undepleted or enriched (e.g. Schilling, 1973; Tatsumoto, 1978; Brooks \& Nielsen, 1982a); the depleted mantle may form a layer lying above or below the undepleted, or the undepleted may occur as plumes and veins within the depleted mantle. A third mantle component is the subcontinental lithosphere the character of which is uncertain, but which may consist of secondarily enriched depleted mantlc. If so, meiting products of this may be very difficult to distinguish from products of a primordial undepleted mantle.

In the tectonic framework in which the East Greenland basalts formed all three mantle types have to be considered. This section evaluates the involvement of such mantle types in the genesis of the Scoresby Sund basalts, with evidence from the $\mathrm{Sr}$ isotopes and the minor and trace elements. In the final chapter this is combined into the tectonic framework of the whole North Atlantic region with the Iceland hot spot and mantle plume.

\section{Sr isotopes}

The mantle that produces the typical normal midocean-ridge basalts (MORB) has a ${ }^{87} \mathrm{Sr} /{ }^{186} \mathrm{Sr}$ ratio around 0.7024-0.7030 (Basaltic Volcanism Study Project, 1981). The oceanic island basalts (OIB) have very variable $\mathrm{Sr}$ isotope ratios, but those that are compositionally akin to the Scoresby Sund basalts (Iceland, Hawaii, Galapagos) have ratios in the range 0.7029-0.7039. Their mantle source is thus still depleted relative to the bulk earth (undepleted) value of 0.7047 , but less so than the MORB-generating mantle, and in all three cases a hot spot/mantle plume is involved. For Hawaii, three mantle components have been postulated (Staudigel $e t$ al., 1984), a depleted (MORB) mantle, a mantle plume, and oceanic lithosphere. In the North Atlantic, Carter el al. (1979) found ${ }^{87} \mathrm{Sr} /{ }^{86} \mathrm{Sr}$ ratios of $0.7030-0.7041$ for Lower Tertiary basalts from East and West Greenland and the Faeroes, and noted the similarity in source isotopes to the Recent Icelandic basalts $(0.7029$ 0.7035 ). Hemond et al. (1988) estimated $a^{87} \mathrm{Sr}{ }^{86} \mathrm{Sr}$ ratio of 0.70305 for the present Iceland mantle plume, and ascribed the higher ratios in many rocks to crustal recycling and hydrothermal alteration.

For the Scoresby Sund basalts the ${ }^{87} \mathrm{Sr} r^{86} \mathrm{Sr}$ isotope ratios presented earlier are as follows (leaving out the results that are considered due to post-generational processes like crustal contamination and magma mixing). Geikie Plateau Formation, main basalts: 0.7034; Rømer Fjord Formation, olivine tholeite: 0.7034; Rømer Fjord Formation, MORB type basalt: 0.7038; presumed Skranterne Formation, main basalts: 0.7032 0.7036 (Carter et al., 1979; Holm, 1988); Igtertivâ For- 
mation, main basalts: 0.7037 (Holm, 1988); nephelinites from various places: 0.7037-0.7040 (Nielsen \& Buchardt, 1985; Brooks et al., 1979); Mikis type basalt (Milne Land Formation): 0.7045.

The Mikis type basalt, if uncontaminated, thus either originated in an undepleted or in a secondarily enriched depleted mantle. All the other magma types have originated in more or less depleted mantle. A depleted mantle with ${ }^{87} \mathrm{Sr} /{ }^{86} \mathrm{Sr}=0.7034$ gave rise to most of the basalts. The higher ${ }^{87} \mathrm{Sr}{ }^{86} \mathrm{Sr}$ level of $0.7037-0.7040$ in magmas as different as the MORB type basalts, the nephelinites, and the main basalts of the Igtertivâ Formation, may be due to production from another mantle type or to addition of another component, with more ${ }^{87} \mathrm{Sr}$, of either mantle or crustal origin, perhaps introduced by secondary processes.

\section{Minor and trace elements}

The Mg-rich basalt types have different contents of a number of elements, despite near-similar degrees of evolution (Mg ratios, figs 80-82). The Mikis type basalt is relatively enriched in a large number of both compatible and incompatible elements, the olivine tholeiites are intermediate, and the MORB-type basalt is relatively depleted in almost all minor and trace elements. Such features can be produced by varying degrees and depths of melting of the same mantle, but the Mikis type basalt is so enriched that an alkali basalt parent should be expected. It is possible to argue that the Mikis type basalt is a crustally contaminated alkali basalt, but that means that the near-parallelism of the incompatible-element spectra in fig. 85 is spurious. The large amounts of similar 'enriched tholeiite' that also occur in Kangerdlugssuaq and the Faeroes (figs 95 and 100) make spurious contamination unlikely. It is more likely that the Mikis type basalt either originated by melting of an undepleted or secondarily enriched mantle, or, alternatively, originated in the same mantle as the other basalts, and received an addition from an enriched mantle. The addition would have been a silicate melt rich in $\mathrm{Ti}$ and $\mathrm{Fe}$, as opposed to a metasomatic fluid which mainly carries K (Menzies et al., 1987a). An addition of Fe would explain the high contents of $\mathrm{Cr}$ and $\mathrm{Ni}$ relative to the $\mathrm{Mg}$ ratio in this basalt type and can also be inferred from the $\mathrm{FeO}^{*}$ - $\mathrm{MgO}$ diagram (fig. 76).

Fig. 83 shows some very clear differences in $\mathrm{Zr} / \mathrm{Nb}$ ratios between the individual basalt formations. Similar variations, but with a much larger range, have been found in lavas from the Southwest Indian Ridge (Le Roex et al., 1983). They were interpreted in terms of mixing of a normal depleted N-MORB mantle component with high $\mathrm{Zr} / \mathrm{Nb}(\sim 60)$ and low $\mathrm{Zr} / \mathrm{Y}(\sim 3)$ and an

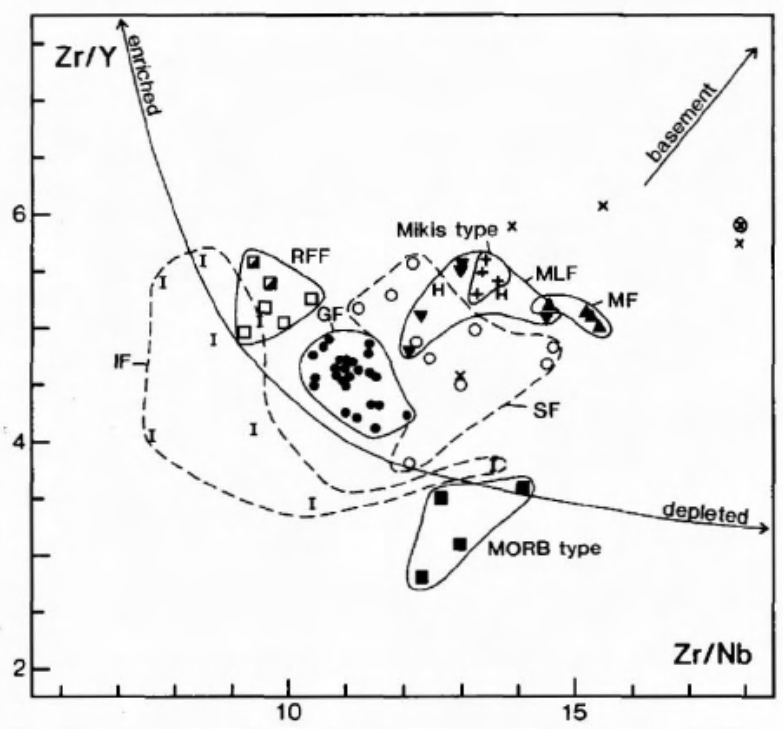

Fig. 93. $\mathrm{Zr} / \mathrm{Y} v . \mathrm{Zr} / \mathrm{Nb}$ in the Scoresby Sund lavas. Symbols as in figs 83 and 84 . The $\mathrm{Zr} / \mathrm{Nb}$ ratio is nearly constant during fractionation, while the $\mathrm{Zr} / \mathrm{Y}$ ratio increases somewhat. Therefore, lavas with $\mathrm{Mg}$ ratios below 0.50 have not been plotted except for the Igtertivâ Formation where almost all the lavas have $\mathrm{Mg}$ ratios less than 0.50 .

The mixing curve between an enriched and a depleted end member is taken from Le Roex et al. (1983). The arrow labelled 'basement' points to the data for basement sample 133158 (appendix 3).

enriched mantle plume component with low $\mathrm{Zr} / \mathrm{Nb}(\sim$ $7)$ and high $\mathrm{Zr} / \mathrm{Y}(\sim 8)$. The Scoresby Sund basalts, with $\mathrm{Zr} / \mathrm{Nb}=7.6-15.4$, and $\mathrm{Zr} / \mathrm{Y}=2.8-5.6$ classify as transitional in this scheme, also the MORB-type basalt. Le Roex et al. (1983) constructed a mixing hyperbola between a depleted and an enriched component. This is shown in the mixing diagram, fig. 93, with the Scoresby Sund basalt data. Though a North Atlantic mixing curve may have a different position, it is clear that the Rømer Fjord olivine tholeiites, the Geikie Plateau Formation and the MORB type basalts may be produced by such a mixing process. Alternatively, the rather subtle differences between these three groups may be produced by different degrees of melting of the same mantle, because in a melting process with clinopyroxene and/or garnet as a residual phase the bulk partition coefficients vary in the sequence $\mathrm{Y}>\mathrm{Zr}>\mathrm{Nb}$. The Rømer Fjord olivine tholeiites would thus have been produced by the smallest, and the MORB type basalts by the largest degrees of melting. This explanation fits with the similar $\mathrm{Sr}$ isotope ratios of the Rømer Fjord olivine tholeiites and the Geikie Plateau Formation, while the slightly higher isotope ratio for the MORB type basalt does not 
imply any higher amounts of a depleted component. The explanation also fits with the near-equal $\mathrm{TiO}_{2} / \mathrm{P}_{2} \mathrm{O}_{5}$ ratios of the three groups, the ratio being slightly higher in the MORB-type basalt (Ti less incompatible than P).

The position of the Skrænterne Formation in fig. 93 indicates that its parent magma may bave been produced by larger degrees of melting than the parent magma of the Geikie Plateau Formation. A similar degree of melting as for the MORB type basalt is indicated, and considering that $\mathrm{Zr} / \mathrm{Y}$ ratios may increase during fractionation (cpx), it is possible that a MORB type basalt is parental to the Skrænterne Formation. The other incompatible element data (figs 72, 79, 82, 83) and $\mathrm{Sr}$ isotopes neither invalidate nor support this possibility, which is left open.

Neither mixing of two mantle types nor varying degrees of melting can produce the spread of the Magga Dan, Milne Land and Igtertivâ Formations across the mixing curve in fig. 93. Crustal contamination is a possible explanation for the Magga Dan and Milne Land Formations, but the $2-4 \%$ basement contamination earlier inferred for these formations will only shift a point in fig. 93 very slightly, unless the contamination is selective. It is also notable that the Mikis type basalt in fig. 93 plots among the other basalts of the Milne Land Formation, and it is possible that the main basalts of this formation like the Mikis type basalt contain contributions from a mantle component that was less depleted but had relatively high $\mathrm{Zr} / \mathrm{Nb}$ ratio.

The Igtertivâ Formation and coastal dykes have low $\mathrm{Zr} / \mathrm{Nb}$ ratios $(<10$, figs 83 and 84$)$. They have also lower $\mathrm{TiO}_{2} / \mathrm{P}_{2} \mathrm{O}_{5}$ ratios than all the other basalts (fig.
79). Such coupled variations in $\mathrm{Zr} / \mathrm{Nb}$ and $\mathrm{TiO}_{2} / \mathrm{P}_{2} \mathrm{O}_{5}$ are common in the North Atlantic region (Table 24). Besides in the Igtertivâ Formation, low $\mathrm{Zr} / \mathrm{Nb}$ and low $\mathrm{TiO}_{2} / \mathrm{P}_{2} \mathrm{O}_{5}$ occur in the Upper Plateau Lava Series of northern East Greenland (figs 98 and 99 ) and in most Tertiary and Recent basalts from Iceland (fig. 105 and 106). High $\mathrm{Zr} / \mathrm{Nb}$ and high $\mathrm{TiO}_{2} / \mathrm{P}_{2} \mathrm{O}_{5}$ occur in most Scoresby Sund basalts (figs 79 and 83), in the Lower Plateau Lava Series of northern East Greenland (figs 98 and 99), in the Faeroes (figs 101 and 102), in the lower lava group of the Miocene lavas in Reydarfjördur, Iceland (figs 105 and 106), and possibly in the Skagi basalts in Iceland too. It is difficult to ascribe these differences to mixing between relatively enriched (in $\mathrm{P}_{2} \mathrm{O}_{5}$ and $\mathrm{Nb}$ ) and depleted mantle materials because both alkali basalts, E-type MORB and N-type MORB have low $\mathrm{TiO}_{2} / \mathrm{P}_{2} \mathrm{O}_{5}$ ratios (Table 24).

High $\mathrm{TiO}_{2} / \mathrm{P}_{2} \mathrm{O}_{5}$ ratio trends as in the Scoresby Sund basalts are not common. Outside the North Atlantic they occur in the Deccan basalts and in the Hawaiian tholeiites (Table 24). In all cases the basalts seem to be erupted through relatively thick crust in an oceanic island or continental margin setting with no plate spreading. The Icelandic lavas with high $\mathrm{TiO}_{2} / \mathrm{P}_{2} \mathrm{O}_{5}$ ratios (Skagi and Reydarfjördur lower series) may also be interpreted as having passed through thicker and colder crust than usual, because this will happen in a spreading environment when the rift jumps to a new position. The Skagi zone is a short-lived rift zone, and also the Reydarfjördur lower lavas possibly formed in a newly started rift zone. They are of anomaly 5 age (Bleil et al., 1982), a time when there were several rift jumps in

Table 24. Summary of $\mathrm{TiO}_{2} / \mathrm{P}_{2} \mathrm{O}_{5}$ and $\mathrm{Zr} / \mathrm{Nb}$ variations in oceanic and plate-margin continental basalts

\begin{tabular}{|c|c|c|c|}
\hline & $\mathrm{Zr} / \mathrm{Nb}<10$ & $\mathrm{Zr} / \mathrm{Nb}=10-16$ & $\mathrm{Zr} / \mathrm{Nb}>16$ \\
\hline $\begin{array}{l}\text { low } \\
\mathrm{TiO}_{2} / \mathrm{P}_{2} \mathrm{O} \\
\text { trend }\end{array}$ & $\begin{array}{l}\text { Scoresby Sund: Igtertivã Fm } \\
\text { NE Greenland: UPLS } \\
\text { Iceland: most basalts } \\
\text { Alkali basalts } \\
\text { E-MORB; some T-MORB }\end{array}$ & $\begin{array}{l}\text { Iceland: scattered data } \\
\text { T-MORB }\end{array}$ & N-MORB \\
\hline $\begin{array}{l}\text { high } \\
\mathrm{TiO}_{2} / \mathrm{P}_{2} \mathrm{O}_{5} \\
\text { trend }\end{array}$ & $\begin{array}{l}\text { Scoresby Sund: Rømer Fjord Fm } \\
\text { Iceland: partly Reydarfjördur } \\
\text { lower lava group } \\
\text { Hawaii: Loihi; partly Kilauea } \\
\text { Deccan: partly Mahabaleshwar Fm }\end{array}$ & $\begin{array}{l}\text { Scoresby Sund: most basalts } \\
\text { NE Greenland: LPLS } \\
\text { Faeroe Islands: all basalts } \\
\text { Iceland: Reydarfjördur } \\
\text { lower lava group; Skagi zone? } \\
\text { Hawaii: Kilauea; Mauna Loa } \\
\text { Deccan: most basalts }\end{array}$ & Primitive N-MORB \\
\hline
\end{tabular}

The 'low' and 'high' $\mathrm{TiO}_{2} / \mathrm{P}_{2} \mathrm{O}_{5}$ trends are relative to the trend for most of the Scoresby Sund basalts which is defined as 'high' (fig. 79). No figures can be given for the division because the ratio changes by differentiation within a group. 
Iceland (Helgason, 1985). Most high- $\mathrm{TiO}_{2} / \mathrm{P}_{2} \mathrm{O}_{5}$ groups have $\mathrm{Zr} / \mathrm{Nb}=10-16$. Notable exceptions are the Rømer Fjord olivine tholeiites and the Loihi seamount in Hawaii, both with low $\mathrm{Zr} / \mathrm{Nb}$ of $7.5-10$ (figs 83 and 87 ); both groups initiate a new volcanic cycle.

Low $\mathrm{TiO}_{2} / \mathrm{P}_{2} \mathrm{O}_{5}$ ratio trends as in the Igtertivâ Formation are widespread. They occur in all alkali basalts, in tholeiites from the mid-oceanic ridges including Iceland's spreading zones, and in 'true' continental basalts like the Columbia River basalts (Hooper, 1982) and the Parana (Bellieni et al., 1984) and Karoo (Cox, 1983) basalts. Obviously, several processes may lead to these low $\mathrm{TiO}_{2} / \mathrm{P}_{2} \mathrm{O}_{5}$ ratios. It is important that the ratio is not constant during magmatic evolution, so that post-generational processes may be decisive. In the MOR basalts the low $\mathrm{TiO}_{2} / \mathrm{P}_{2} \mathrm{O}_{5}$ ratios seem to be connected with the crustal accretion process. In these rocks $\mathrm{Zr} / \mathrm{Nb}$ ratios vary widely, but such that rocks with relatively high $\mathrm{TiO}_{2} / \mathrm{P}_{2} \mathrm{O}_{9}$ ratios generally also have relatively high $\mathrm{Zr} / \mathrm{Nb}$ ratios. Most primitive N-MORB rocks actually have high $\mathrm{TiO}_{2} / \mathrm{P}_{2} \mathrm{O}_{5}$ ratios (e.g. Le Roex et al., 1981). It is thus still possible to explain the $\mathrm{TiO}_{2} / \mathrm{P}_{2} \mathrm{O}_{5}$ and $\mathrm{Zr} / \mathrm{Nb}$ varations in Table 24 in terms of mixing of depleted and enriched components, with the MOR basalts containing imprints of post-generational processes in spreading ridge systems (viz. crustal recycling). Some of the other basalt groups may be similarly imprinted.

In the Scoresby Sund basalts, the Igtertivâ Formation and the coastal dyke swarm may have a parent like the preceding Skrænterne Formation. The low $\mathrm{TiO}_{2} / \mathrm{P}_{2} \mathrm{O}_{5}$ and $\mathrm{Zr} / \mathrm{Nb}$ ratios may either be explained by assuming addition of some less-depleted ( $\mathrm{Nb}$ and $\mathrm{P}$ richer) mantle material (mixing curve in fig. 93 displaced toward the lover left) or taken as a signal that the rifting and crustal collapse eventually led to the production of oceanic crust. The first explanation, with the parallel mantle mixing curves, necessitates at least three different components. In support of the second possibility is the fact that the oceanic magnetic anomaly $24 \mathrm{~N}$ can be followed from the shelf and onto land in the crustal strip that houses the coastal dyke swarm in the area $(\mathrm{H}$. C. Larsen, 1988 and personal communication), indicating that this crustal strip is oceanic in character. The two possibilities may be reconciled if the 'less depleted' component involved is not mantle but recycled oceanic crust.

\section{Petrogenetic scheme}

Based on the foregoing discussion the following petrogenetic scenario can now be drawn up.

A moderately depleted mantle with ${ }^{87} \mathrm{Sr} /{ }^{36} \mathrm{Sr}$ around 0.7034 is the main source for the Scoresby Sund basalts. In the following this is called the North Atlantic mantle because it must have been very widespread in the North Atlantic region at the time of opening (Carter et al., 1979).

The first volcanic episode started in the inland regions around Gåsefjord. Mg-rich basalts were produced but became contaminated with crustal material and were usually not erupted. The erupted main basalts of the Magga Dan and Milne Land Formations were probably produced from the North Atlantic mantle, but they also contain up to $4 \%$ of continental crust, besides an imprint from some material with high $\mathrm{Zr} / \mathrm{Nb}$ and high $\mathrm{Zr} / \mathrm{Y}$ ratios.

The Mikis type basalt is envisaged as a mixture of primitive magma produced from the North Atlantic mantle and a substantial proportion of partial melt rich in $\mathrm{Fe}, \mathrm{Ti}$ and other incompatible elements and ${ }^{87} \mathrm{Sr}$ produced from a undepleted or secondarily enriched mantle which is tentatively identified as the subcontinental lithosphere. The Mikis type basalt is one of the major basalt types in the Lower Basalt formations in the Kangerdlugssuaq area $200 \mathrm{~km}$ south of Scoresby Sund (Nielsen et al., 1981). In the Scoresby Sund region this basalt type is represented by only two flows in the lower part of the sequence and constitutes only $0.2 \%$ of the total erupted volume. The Lower Basalts in Kangerdlugssuaq and the basalts of the first volcanic cycle in Scoresby Sund are considered equivalent in time (chapter on General Features). All the Mikis type magma was probably generated by one 'event' in the mantle below the Kangerdlugssuaq region and stored there. The environment at the time was tensional, with deep cracks proceeding from the successfully rifted continental margin south of Kangerdlugssuaq towards the NNE through solid continental crust (Larsen \& Watt, 1985). In this environment it is easily conceivable that a small fraction of the Mikis type magma migrated some $200 \mathrm{~km}$ towards the NNE at subcrustal or crustal levels. It never established its own storage system in the north but invaded an existing magma chamber filled with local main basalt magma, and partly mixed with it, as earlier discussed. The Mikis type magma was apparently only generated in the first volcanic episode.

The Geikie Plateau Formation resulted from a new melting event in the North Atlantic mantle, producing main basalt magma with a $\mathrm{Zr} / \mathrm{Nb}$ ratio distinct from the two earlier formations. The magmas were only slightly, or not at all, contaminated with continental crust.

In the second volcanic episode eruption sites moved to the south-east where new rifting was taking place. The Rømer Fjord Formation that initiated the episode consists of several magma types erupted from scattered eruption sites. The connection between the magma types may be qualitatively envisaged in terms of a ther- 
mal anomaly in the North Atlantic mantle, centred under the new rifting region south-east of the present coastline. In the central part of the anomaly large degrees of melting produced primary magma of the main basalt type that was erupted in the succeeding Skrænterne Formation. Further inland smaller degrees of melting at deeper levels produced the primary magma for the moderate volumes of 'enriched' olivine tholeiites which were erupted there, and which evolved to the high-Ti basalts and titano-tholeiites in the Rømer Fjord Formation. Furthest away from the thermal anomaly small degrees of melting at still deeper levels produced the small amount of nephelinite magma erupted there, perhaps with some addition of ${ }^{87} \mathrm{Sr}$-enriched material.

The MORB type basalt in the top of the Rømer Fjord Formation was erupted in small volume (estimated 5 $\mathrm{km}^{3}$ ) in an inland area (Plate 1) and was probably produced in one event. In an earlier discussion it was noted that it may represent the primitive magma for the main basalts of the Skrænterne Formation, but its location far from the centre of the thermal anomaly does not corroborate this. The magma may have travelled a long distance from the production site in the SE, but it is also probable that this magma type is the result of a singular event; the magma could have been produced by local melting of ultramafic cumulates or residua at depth. The strong depletion of the MORB type basalt in incompatible elements is in contrast to its highish $\mathrm{Sr}$ isotope ratio of 0.7038 . The MORB type basalt was erupted in the same area as earlier the nephelinite (Plate 2) and may have originated in the cumulates or residua after the formation of the nephelinite.

The basalts of the Skranterne Formation were produced in the centre of the thermal anomaly in the North Atlantic mantle. One or two specific lava flows were contaminated by continental crust on their way from the magma chamber to the surface.

In the third volcanic episode the basalts of the Igtertivã Formation were generated in the North Atlantic mantle. They also contain a less-depleted component with low $\mathrm{TiO}_{2} / \mathrm{P}_{2} \mathrm{O}_{5}$ and low $\mathrm{Zr} / \mathrm{Nb}$, different from the 'enriched' component in the first episode and possibly of recycled basalt.

\section{The North Atlantic Tertiary igneous province}

\section{East Greenland in relation to continental break-up}

The break-up of the North Atlantic continent in late Paleocene time was accompanied by intense volcanism along the rifted continental margins of Greenland and north-western Europe. Basalts extruded around the time of opening now occur in central East Greenland, northern East Greenland and the British Isles, and on the mostly submerged continental fragments of the Rockall Plateau, the Faeroe Plateau, the Jan Mayen Ridge and the Vøring Plateau, besides in West Greenland where the basalts are related to opening in the Labrador Sea. Successively younger volcanics form thick seaward-dipping sequences around the continentto-ocean transition zones and build up the oceanic crust in the North Atlantic region. The volcanic activity has continued along the Mid-Atlantic Ridge to the present time, i.e. over a time span of 55-60 million years.

The opening history of the North Atlantic is clear in the general features if not in details (Talwani \& Eldholm, 1977; Nunns, 1983; Larsen, 1988). The various parts of the North Atlantic are shown in fig. 94 in their pre-drift and in their present configurations. The initial line of opening was situated close to the present coast of East Greenland except in the region between Kangerdlugssuaq and Hold With Hope, where it had a large deflection to the east (Larsen, 1988), see fig 94, thus dividing the line into three segments. Spreading along the northern and southern segments (the present Mohns and Reykjanes ridges) has been simple and continuous throughout the period until present, while spreading along the middle segment has been very complex, with repeated shifts in the position of the spreading axis, likewise throughout the period. The middle segment is the one that gave rise to the basalts in central East Greenland and that later has given rise to Iceland and the Kolbeinsey-Jan Mayen spreading axis.

The opening along the initial axis apparently started between geomagnetic anomaly 25 and 24 , and the oldest sea-floor magnetic anomaly identified is $24 \mathrm{R}$. Spreading started in the south and progressed towards the north with a rate of around $1 \mathrm{~m} /$ year (Larsen, 1988). The middle segment must have been in a state of considerable tension, and rifting accompanied by volcanism could have extended from the southern spreading segment northwards into the continental crust of the middle segment. Although no signs of proper rifting, with formation of faults, are present, the eruption sites for the lower basalt sequence in the Scoresby Sund region are almost colinear with the northern and southern initial spreading segments (figs 32 and 94) (the 'initial magmatic lineament' of Nielsen, 1987). Thus, the tectonic episodes leading to the formation of the Scoresby 


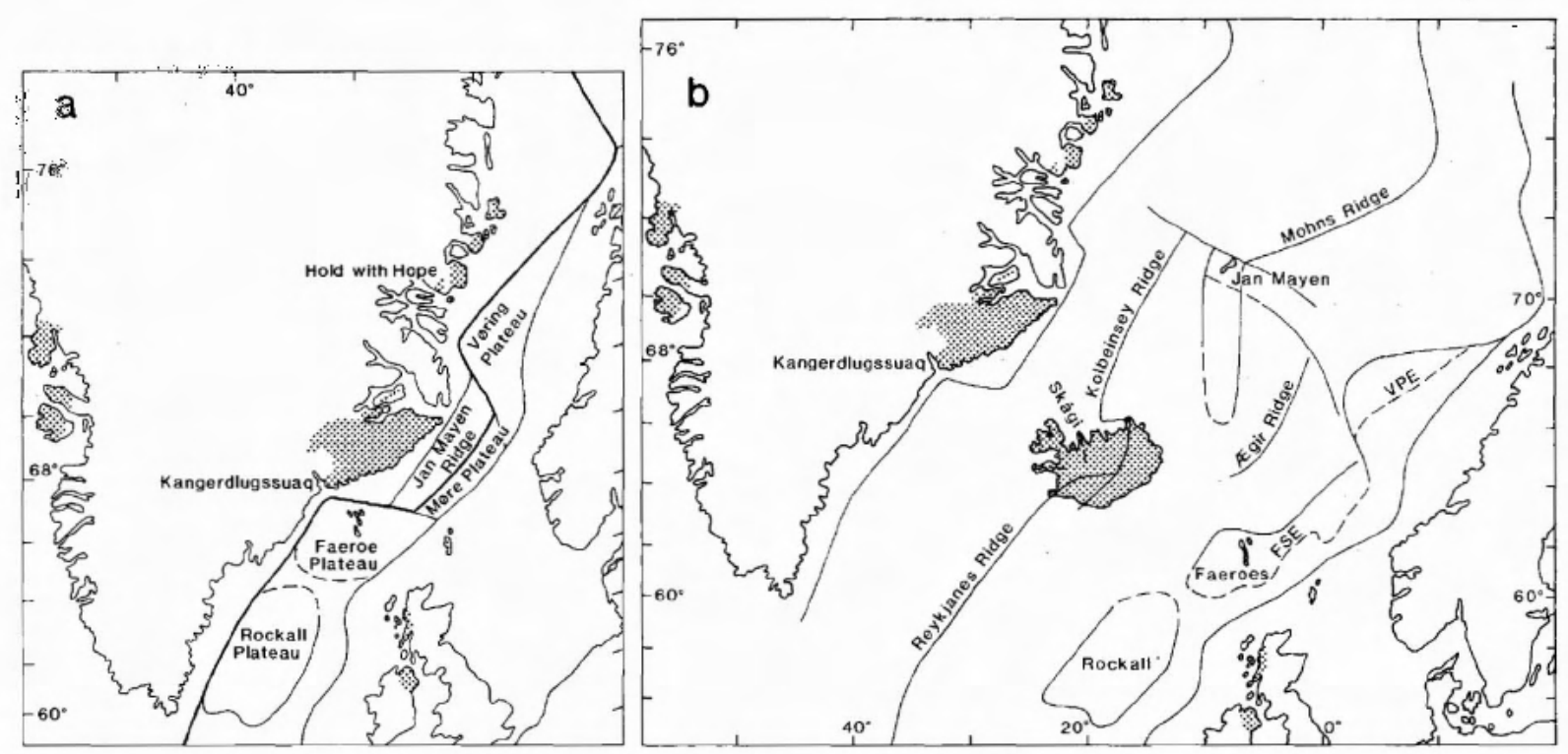

Fig. 94. Geography of the North Atlantic region before spreading started in anomaly 24 time (a) and at present (b), based on references given in the text. The initial line of opening is shown as a heavy line in a. The volcanic areas are shaded. VPE Vøring Plateau Escarpment; FSE Faeroe-Shetland Escarpment.

Sund basalts may be seen as repeated attempts to shortcut the eastern deflection in the middle segment and unite the southern and northern spreading segments into a linear feature (Larsen \& Watt, 1985). The two episodes leading to the formation of the two regional basalt sequences both failed; the crust held and the magmatism waned and died. In the third episode rifting, faulting and intense dyke intrusion took place in a narrow zone near the present Atlantic coast; this episode was successful in so far as the crust started to collapse and a narrow strip of crust with a magnetic signature like oceanic crust and of anomaly $24 \mathrm{~N}$ age was produced. According to Larsen (1988) the event was only short-lived and gave rise to the East Greenland extinct axis. only much later, in the early Miocene (anomaly 6 time), the northward propagating Reykjanes-Kolbeinsey ridge finally cut through the basalts and split off a continental fragment from East Greenland. This fragment now forms the base of the Jan Mayen Ridge (Talwani \& Eldholm, 1977), and it must contain the eastern part of the second basalt sequence (Rømer Fjord and Skrænterne Formations).

\section{North Atlantic regions}

\section{Mantle configuration}

The configuration of the mantle in the North Atlantic region is an important aspect of any petrogenetic model. There is good evidence and unanimous agree- ment that a hotspot is presently situated beneath Iceland; there is less agreement as to whether this thermal anomaly is also a material anomaly, with extra material being added by a more or less deeply rooted mantle plume. Recent geophysical data may be taken as support for the mantle plume hypothesis (Bott, 1988), and such a hypothesis explains many features of the North Atlantic igneous province (e.g. White, 1988). Even accepting the mantle plume hypothesis, the chemical character of the material in the plume is conjectural: Schilling (1973) suggested that the plume consists of enriched (or undepleted) mantle, while Hemond et al. (1988) inferred that the plume consists of mantle that is isotopically only slightly less depleted than MORB-generating mantle. In either case there are at least three mantle components as discussed in the petrogenesis chapter: a depleted asthenosphere component, a more or less enriched plume component, and a lithospheric, possibly enriched component. Open to discussion are questions such as which magmas originated in which mantle types; the nature of the widespread, moderately depleted 'North Atlantic mantle' mentioned in the previous chapter; and whether distant parts of the province like West Greenland and the British Isles are also influenced by the plume.

Another important aspect is the evolution with time, especially during the break-up process. Did the mantle plume exist before spreading started, where was it, and what are the relations between the plume and the break-up process? Has the plume changed character with time? 
All these questions have been discussed at length in numerous papers. The picture that has most recently emerged of the break-up is that the plates are pulled apart while mantle passively wells up to fill the created gap. The hot mantle plume may have influenced the course of the break-up line and the location of the volumetrically most productive areas by 'active' upwelling superimposed on the passive (White et al., 1987; Mutter et al., 1988).

Vink (1984) and White (1988) both argued that the mantle plume existed before spreading started, and Vink (1984) placed it at the start beneath eastern central Greenland. Other authors are not clear on this point. At some time, however, all agree that it was situated beneath the Kangerdlugssuaq area which shows many signs of having been a high temperature area. From there it 'moved east' beneath new-formed oceanic crust and is now situated beneath Iceland. White (1988) and Bott (1988) both argue that the plume material spreads out in and mixes with the asthenosphere, and that the plume material may be present in a region of $2000 \mathrm{~km}$ diameter. This is relevant for the question of the North Atlantic mantle.

Various models for the derivation of the basalt types in the North Atlantic were mentioned in the previous chapter (section on mantle materials). The tholeitic basalts may, by their degree of enrichment in some elements, be considered in relation to the three schematic trends shown in fig. 95 for $\mathrm{TiO}_{2}$ : an enriched 'picrite-ankaramite' trend, an intermediate 'tholeiite' trend and a depleted N-MORB trend. While the $\mathrm{N}$ MORB trend in all models arises from a strongly depleted mantle (asthenosphere), it is debatable whether e.g. the mantle plume gives rise to the enriched trend, and the intermediate trend may be a mixing feature, or the plume gives rise to the intermediate trend, and the enriched trend arises in an enriched subcontinental lithosphere or contains an addition from it.

The development of the North Atlantic igneous province in time and space may shed some light on these questions, and in the following the various parts of the province are reviewed and compared in selected geochemical diagrams.

\section{Central East Greenland}

The Scoresby Sund basalts are continuous with the basalts of the Kangerdlugssuaq region. In this region $c$. $2 \mathrm{~km}$ of tuffs, hyaloclastites and lavas constitute the Lower Basalts of Nielsen et al. (1981), inferred to have sources slightly south of the present coast. They are all apparently reversely magnetised (Nielsen et al., 1981). They are overlain by an estimated $5 \mathrm{~km}$ of subaerial
Fig. 95. $\mathrm{TiO}_{2}-\mathrm{Mg}$ ratio diagram for tholeiitic lavas from the Kangerdlugssuaq region, with Scoresby Sund data contours shown for comparison. Data sources: Nielsen et al. (1981), Brooks \& Nielsen (1982), Fawcett et al. (1982), Gill et al. (1988), Holm (1988), and unpublished analyses from T. F. D. Nielsen. The trends for the picrite-ankaramite series (pic) and the tholeiite series (th) are from Brooks \& Nielsen (1982a). The N-MORB trend is drawn after data in Basaltic Volcanism Study Project (1981).

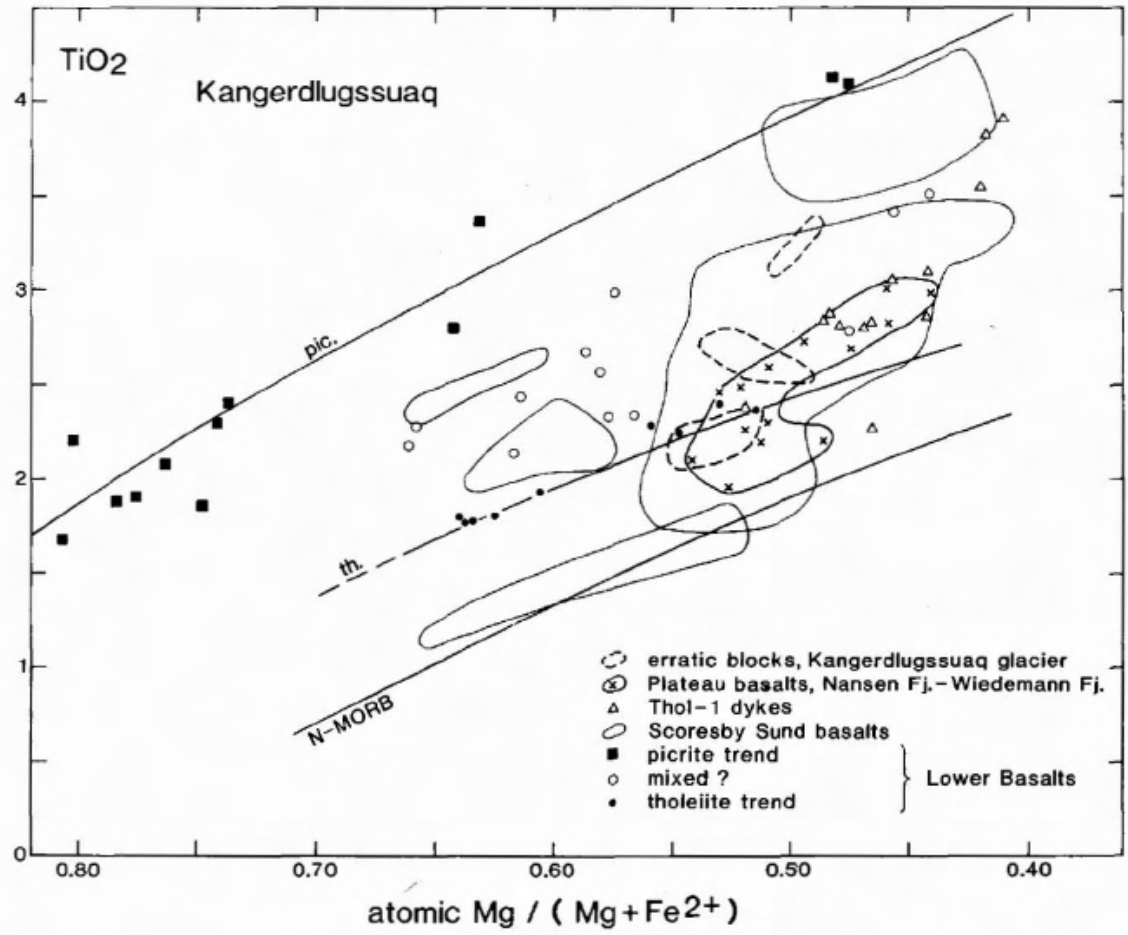




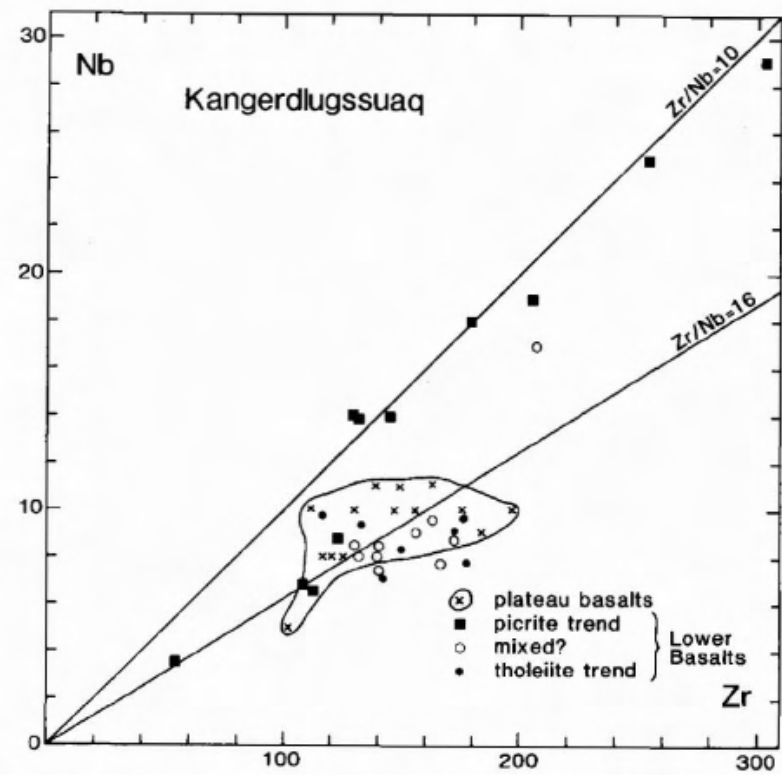

Fig. 96. $\mathrm{Nb}-\mathrm{Zr}$ diagram for tholeiitic lavas from the Kangerdlugssuaq region. Data sources: Gill et al. (1988), Holm (1988), and unpublished analyses from T. F. D. Nielsen. Compare with the Scoresby Sund data in fig. 83.

plateau basalts (Wager, 1947; Nielsen \& Brooks, 1981) (Irminger Formation of Soper et al., 1976), which may have been fed by the coast-parallel tholeiitic dyke swarm THOL-1 (Nielsen, 1978). Then followed gabbro intrusions, among these the Skaergaard intrusion dated at $55 \mathrm{Ma}$ (Brooks \& Gleadow, 1976). Shortly afterwards the coastal zone collapsed in a great flexure (Wager, 1934), later re-interpreted as a series of closely-spaced antithetic faults (Nielsen \& Brooks, 1981). Later magmatism (dyke swarms, salic intrusions and inland lavas) is of alkaline character and will not be treated here. These magmas have recently been reviewed by Nielsen (1987).

Geochemically, the Lower Basalts are complex (fig. 95). They are all tholeiitic but may be divided into two series, the lavas of which are intercalated. A 'picriteankaramite' series comprises rocks enriched in incompatible elements (but not alkaline), and a 'tholeiite' series comprises rocks low in incompatible elements (Brooks \& Nielsen, 1982a), see figs 95 and 96. The two series were considered derived respectively from undepleted and depleted mantle. Rocks with character intermediate between the two trends (Mikis type basalt of Gill et al., 1988) were considered as mixtures between the two kinds of magma, although Gill et al. (1988) made allowance for some of the fractionated tholeiites to obtain 'excessive' enrichment of incompatible elements by open magma chamber processes.
Comparing the Lower Basalts with the Scoresby Sund basalts it is seen that the picrite-ankaramite trend is not represented in the Scoresby Sund region, a 'mixed trend' is represented by the two Mikis type lavas from the lower basalt sequence, and the tholeiite trend corresponds roughly to the medium- $\mathrm{Ti}$ trend of the main basalts. There are no low-Ti type or MORB type basalts in the Lower Basalts. If the Lower Basalts are timeequivalent to the lower basalt sequence in the north, as was suggested in the chapter on General Features, they were definitely produced in separate regions. The Lower Basalts have rather scattered $\mathrm{TiO}_{2} / \mathrm{P}_{2} \mathrm{O}_{5}$ ratios but largely similar to those of the Scoresby Sund basalts. The few $\mathrm{Nb}$ analyses indicate that $\mathrm{Zr} / \mathrm{Nb}$ ratios are usually greater than 10 (fig. 96). Individual $\mathrm{Zr} / \mathrm{Nb}$ ratios for the picrite-ankaramite series and the other series are evident, reminiscent of the individual trends for the Scoresby Sund basalts (fig. 83), and the $\mathrm{Zr} / \mathrm{Nb}$ ratios of the Mikis type basalts in Kangerdlugssuaq and Scoresby Sund are similar. The Lower Basalts have variable initial ${ }^{87} \mathrm{Sr} /{ }^{86} \mathrm{Sr}$ ratios of $0.7031-0.7073$ (both series), decreasing with time to less than 0.7043 (Holm, 1988). Both Gill et al. (1988) and Holm (1988) interpreted the geochemical variations within the Lower Basalts as caused by mixing between OIB-source mantle material and enriched lithospheric mantle beneath the continental crust in the first stage of continental break-up.

Analytical data on the plateau basalts from the Irminger Formation (Brooks et al., 1976) and on erratic blocks from the inland region (presumably from high in the sequence, Fawcett et al., 1982) show that these are indistinguishable from the Scoresby Sund basalts (figs 95 and 96). The $\mathrm{CaO} / \mathrm{Al}_{2} \mathrm{O}_{3}$ ratios of the low-Ti basalts are in all cases except one less than 0.82 which puts these basalts on line with the Skrænterne Formation further north, and contrasts them with the Geikie Plateau Formation (cf. figs 77 and 78). The Irminger Formation was also correlated with the Skrænterne Formation in the chapter on General Features.

The pre-flexure coast-parallel THOL-1 dyke swarm (Nielsen, 1978) may have fed the Irminger Formation according to the major elements (fig. 95). A suite of tholeiitic dykes from Fladø south of Kangerdlugssuaq can be divided into a picrite-ankaramite series and a tholeiite series, like the Lower Basalts (Gill et al., 1988). However, the Fladø dykes are more strongly enriched in some incompatible elements, particularly $\mathrm{Nb}$, than any of the corresponding known lavas in the region.

\section{Northern East Greenland}

The lava areas in northern East Greenland are best 
Fig. 97. $\mathrm{TiO}_{2}-\mathrm{Mg}$ ratio diagram for tholeiitic lavas from northern East Greenland, Vøring Plateau and Jan Mayen Ridge, with Scoresby Sund data contours shown for comparison. WF Wollaston Forland, $\mathrm{B} \emptyset$ Bontekoe $\emptyset$. Data sources: Greenland: NoeNygaard \& Pedersen (1983 and unpublished data), Hald (1978), Upton et al. (1984). Vøring Plateau and Jan Mayen Ridge: Kharin (1976), Raschka \& Eckhardt (1976), Ridley et al. (1976), Leg 104 Shipboard Scientific Party (1987), Viereck et al. (1988). Pic: the picrite-ankaramite trend from the Lower Basalts in Kangerdlugssuaq (Brooks \& Nielsen, 1982a).

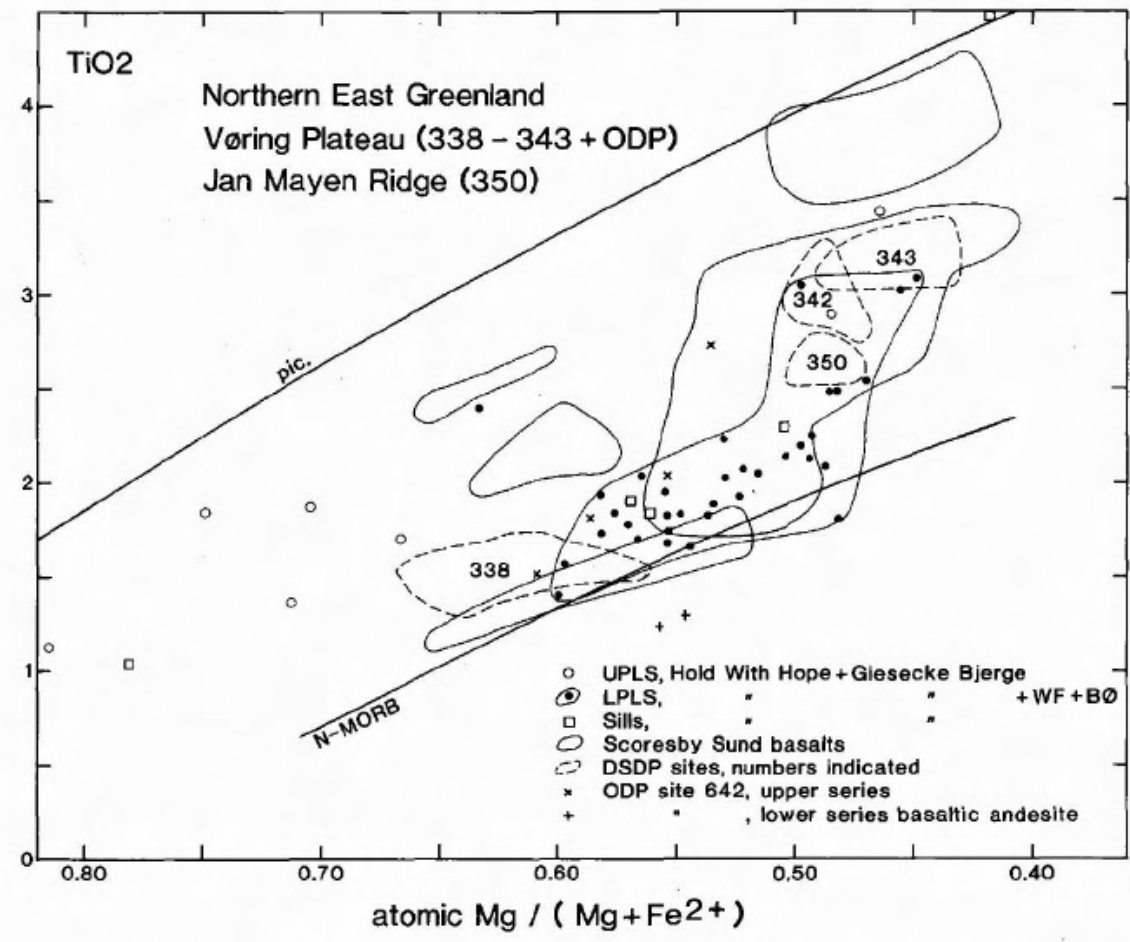

with which they may be equivalent, or they may be younger than both lava series (Hald, 1978; Upton et al., 1984).

On a group of nunataks at $74^{\circ} \mathrm{N}$ occurs a series of strongly alkaline Tertiary lavas (Brooks et al., 1979).

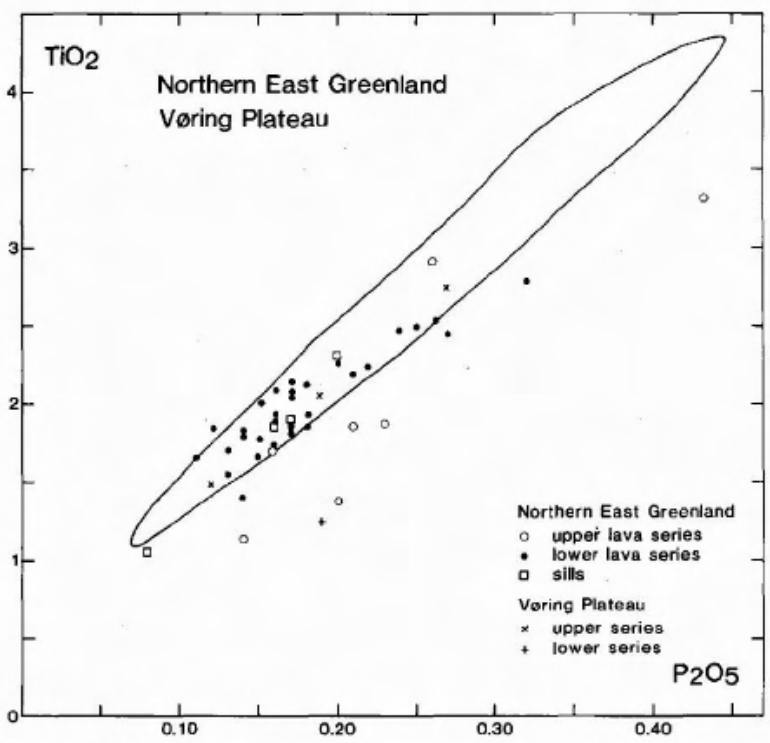

Fig. 98. $\mathrm{TiO}_{2}-\mathrm{P}_{2} \mathrm{O}_{5}$ diagram for tholeiitic lavas from northern East Greenland and Vøring Plateau, with Scoresby Sund data contours shown for comparison. Data sources: Noe-Nygaard \& Pedersen (1974, 1983), Hald (1978), Upton et al. (1984), Viereck et al. (1988).
Abundant sills in the pre-Tertiary sediments below the basalts are mainly similar to the lower lava series incompatible-element-enriched, often alkaline basalts.

The lower lava series (LPLS) has geochemical characteristics very much like the Scoresby Sund basalts: high $\mathrm{TiO}_{2} / \mathrm{P}_{2} \mathrm{O}_{5}$, high $\mathrm{Zr} / \mathrm{Nb}$ and initial $\mathrm{Sr}$ isotope ratios of 0.7031-0.7036 (op.cit); (figs 97-99). Their $\mathrm{TiO}_{2}$-contents correspond mostly to the low-Ti group, and they have similar incompatible element contents (Upton et al., 1984). Similar lavas are present on Wollaston Forland (Upton et al., 1984) and on Bontekoe $\varnothing$ (Noe-Nygaard $\&$ Pedersen, 1983). The lower lava series appears to have been erupted from fissures east of the present coast, and all the lavas are reversely magnetised (Hald, 1978; Upton et al., 1984).

The upper lava series (UPLS) in contrast displays low $\mathrm{TiO}_{2} / \mathrm{P}_{2} \mathrm{O}_{5}$, low $\mathrm{Zr} / \mathrm{Nb}$ and initial $\mathrm{Sr}$ isotope ratios of up to 0.7080 . The lavas appear to form local lava shields, and they are mostly normally magnetised (Hald, 1978; Upton et al., 1984). The magmas were interpreted by Upton et al. (1984) to have interacted with enriched lithospheric mantle, while Nielsen (1987) suggested that they are extreme open-system differentiates from the preceding tholeiite magmas. 


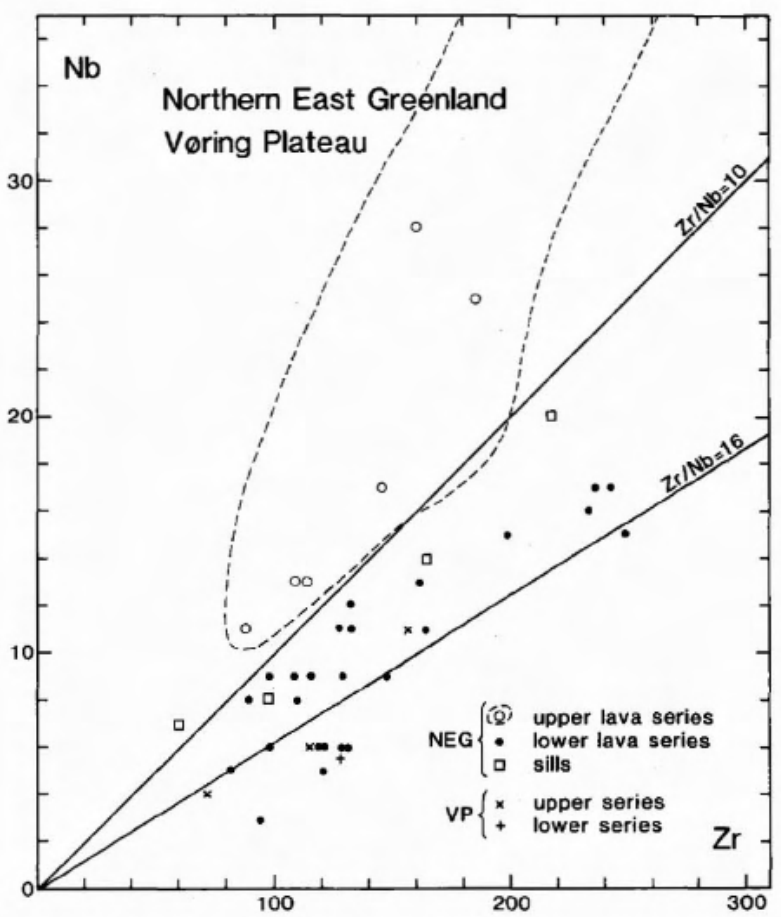

Fig. 99. $\mathrm{Nb}-\mathrm{Zr}$ diagram for tholeiitic lavas from northern East Greenland and Vøring Plateau. Data sources: Noe-Nygaard \& Pedersen (1974), Upton et al. (1984), Viereck et al. (1988). Compare with the Scoresby Sund data in fig. 83.

They are included in the review of Nielsen (1987) and are not considered in the present context.

\section{Vøring Plateau}

The Vøring Plateau is part of the North-West European continental margin and is conjugate to the northern East Greenland margin north of Kong Oscar Fjord (fig. 94). Its SE part is the Vøring Basin, a postCaledonian sedimentary basin, and its NW parts is the uplifted Vøring Marginal High. The NW margin is a thick sequence of seaward-dipping reflectors where the oldest oceanic anomaly identified is anomaly 24 (Talwani \& Eldholm, 1977). Below the dipping reflector sequence lies a sequence of K-rich basalts and siliceous peraluminous andesites that are strongly contaminated with continental crustal material (Leg 104 Shipboard Scientific Party, 1987; Viereck et al., 1988).

Volcanic rocks have been recovered from the area by DSDP leg 38 and ODP leg 104 (Kharin, 1976; Raschka \& Eckhardt, 1976; Ridley et al., 1976; Schilling, 1976; Leg 104 Shipboard Scientific Party, 1987; Viereck et al., 1988). The rocks from sites 338 and 342 are situated on top of the Vøring Marginal High and may be the oldest; hole 642 penetrated the dipping reflector sequence ('upper series') and bottomed in the crustally contaminated sequence ('lower series') which Skogseid \& Eldholm (1987) interpreted to have formed during the earliest phase of rifting. Site 343 is situated in ocean floor of anomaly 23 age (Mutter $e t$ al., 1982).

There is no obvious connection between the structural setting and the geochemistry of the basalts (fig. 97). Those from sites 338 and 342 could be conjugate to those in northern East Greenland but are not particularly similar, although the site 338 basalts do show resemblances to the LPLS in their Ti-poor nature and nearly flat REE spectra (Schilling, 1976). In site 642 the upper series is similar to site 338 , while the younger ocean floor in site 343 is Ti-rich and LRRE-enriched strongly fractionated basalt. This may perhaps be accounted for by thick crust due to the rift jump that occurred in the area around anomaly 23 time (Skogseid \& Eldholm, 1987), similar to the rift jump effect in Iceland discussed in the section on Petrogenesis.

The few reliable data on $\mathrm{Ti}, \mathrm{P}, \mathrm{Nb}$ and $\mathrm{Zr}$ (Viereck et al., 1988) indicate clear similarities between the upper series in site 642 and the LPLS in northern East Greenland.

\section{Jan Mayen Ridge}

The supposed continental fragment of the Jan Mayen Ridge was originally situated along East Greenland from north of Kangerdlugssuaq to northern Liverpool Land (fig. 94; Talwani \& Eldholm, 1977; Larsen, 1980, 1988) and was split off from East Greenland in Oligocene-Miocene time (anomaly 12-6). Some of the 'missing' parts of the central East Greenland basalts, particularly the eastern part of the Skrænterne Formation, must be situated on the $c .75 \mathrm{~km}$ wide continental part of the Jan Mayen Ridge. The ridge has a prominent reflector horizon $(\mathrm{O})$ ascribed to an unconformity related to the opening of the Norwegian-Greenland Sea. The nature of the rocks below reflector $\mathrm{O}$ is debated (Myhre et al., 1984; Gudlaugsson et al., 1988), but they may be volcanic. They have not been reached by drilling. Gudlaugsson et al. (1988, p. 87) suggested that "an equivalent of the $\mathrm{E}$ Greenland plateau basalts may underlie the seaward-dipping reflectors and cover the southern part of the ridge". This is in accordance with the present author's view.

DSDP leg 38 drilled four sites on the Jan Mayen Ridge. Site 350 at the southern extension of the Jan Mayen Ridge bottomed in fresh Eocene basalt of Tirich, LREE-enriched, fractionated character (fig. 97), quite similar to the Scoresby Sund basalts. Unfortunately, the exact nature of this part of the ridge is not 
clear, and the basalt cannot be related to any of the reflectors further to the north.

Sites 346, 347 and 349 showed thick terrigeneous marine sediments of Eocene - early Oligocene age (Talwani et al., 1976), i.e. deposited after the basalts but before the Jan Mayen Ridge was split off from East Greenland. Contemporary thick sediments formed on the East Greenland shelf east of the Blosseville Kyst escarpment (Larsen, 1984, 1989). Together with the early Eocene shoreline-facies sediments above the Igtertivâ Formation in the graben at Kap Dalton and at Kap Brewster (Kap Dalton Formation), this indicates that the crustal collapse during the formation of the East Greenland extinct axis at anomaly $24 \mathrm{~N}$ time left the part of the continent east of the axis in general submerged.

The island of Jan Mayen at the northernmost end of the Jan Mayen Ridge is a presently active volcano that produces a potassic, alkaline rock suite ranging from ankaramites through alkali basalts to trachytes (Imsland, 1984). The volcanism has been ascribed to a hotspot (Vogt, 1974), but Imsland (1984) adopted the model developed for off-rift alkaline volcanism in Iceland, and ascribed the volcanism to an extension of the hot thermal regime of the Mohns Ridge southward across the Jan Mayen fracture zone and into older, thicker crust, possibly of oceanic character, below the Jan Mayen island (cf. fig. 94).

\section{Faeroes Basalt Plateau}

The plateau of the Faeroe Islands and surrounding banks is probably situated on a microcontinent (Bott $e t$ al., 1974; Gariepy et al., 1983; Hald \& Waagstein, 1983). Its likely pre-drift position is very close to East Greenland around and south of Kangerdlugssuaq (fig. 94), and its north-western margin toward Iceland and Greenland is a sequence of seaward-dipping reflectors (Smythe, 1983). The plateau is covered with a thick sequence of basalts which crop out in the Faeroe Islands and have been dredged from the banks. On the islands the basalts are divided into a lower, a middle, and an upper series (Noe-Nygaard \& Rasmussen, 1968; Rasmussen \& Noe-Nygaard, 1970). The known sequence is around $5.5 \mathrm{~km}$ thick, and all basalts are extruded subaerially.

The lower basalt series consists of tholeiitic basalts with $\mathrm{Mg}$ ratios of $0.56-0.38$ and $\mathrm{TiO}_{2}=1.5-3.8 \%$ (Hald \& Waagstein, 1984). They have LREE-enriched REE spectra (Schilling \& Noe-Nygaard, 1974; Gariepy et al., 1983), but low $\mathrm{K}_{2} \mathrm{O}$ contents and $\mathrm{Zr} / \mathrm{Nb}>10$. They are thus very similar to the Scoresby Sund main basalts (figs 100-102). The possibility that these basalts are coeval is, however, rejected from palaeomagnetic evidence given below.

The middle basalt series followed after slight erosion of the surface and deposition of a coal-bearing horizon.
Fig. 100. $\mathrm{TiO}_{2}-\mathrm{Mg}$ ratio diagram for lavas from the Faeroe Islands, with Scoresby Sund data contours shown for comparison. Data sources: Hald \& Waagstein (1984), Waagstein \& Hald (1984), Waagstein (1988). The NMORB trend is drawn after data in Basaltic Volcanism Study Project (1981).

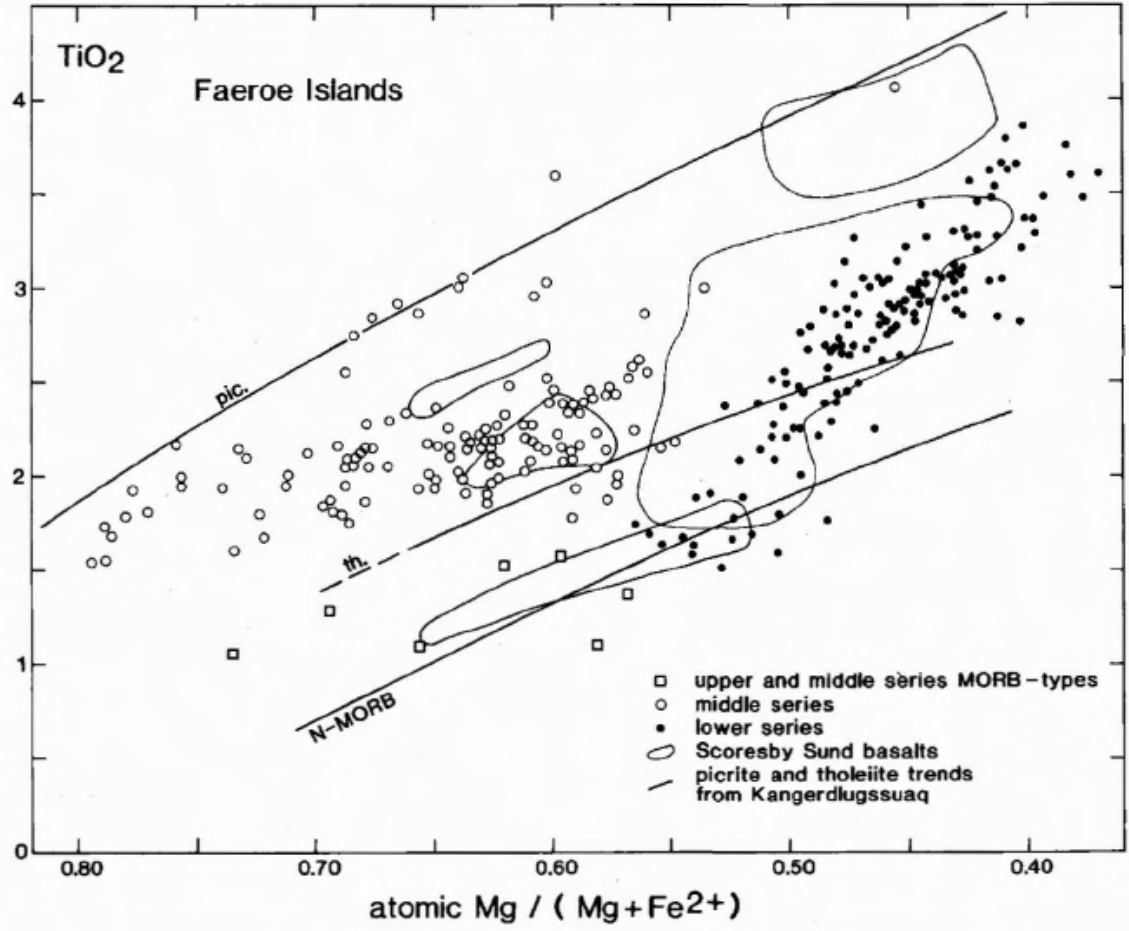




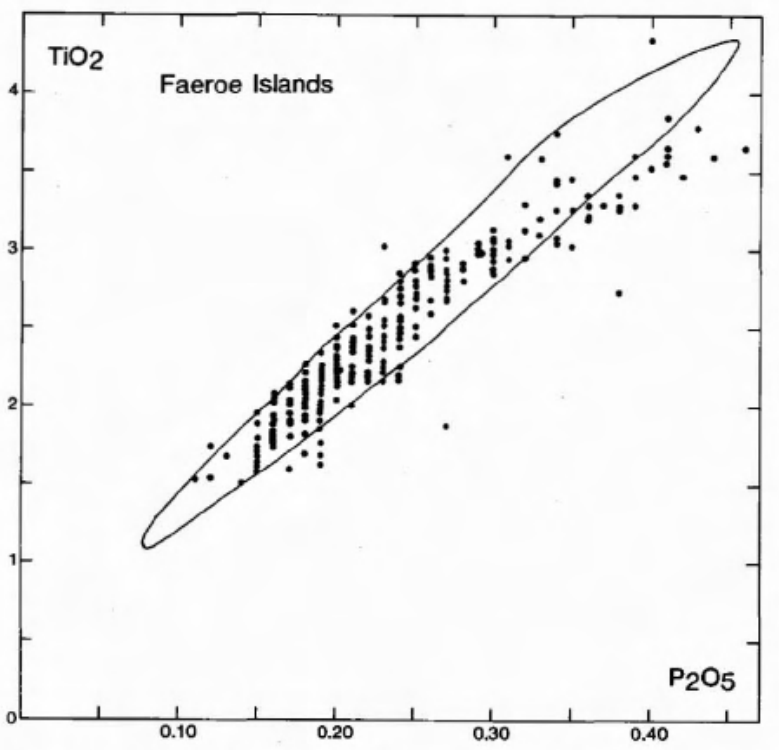

Fig. 101. $\mathrm{TiO}_{2}-\mathrm{P}_{2} \mathrm{O}_{5}$ ratio for lavas from the Faeroe Islands, with Scoresby Sund data contours shown for comparison. There is complete overlap between samples from all series. Data sources as in fig. 100.

The volcanism started with tuffs and agglomerates followed by lavas (Rasmussen \& Noe-Nygaard, 1970). The middle series is compositionally variable, but nearly all rocks share a distinct geochemical signature (Waagstein \& Hald, 1984). They are Mg-rich tholeiites enriched in incompatible elements and with LREE-enriched REE

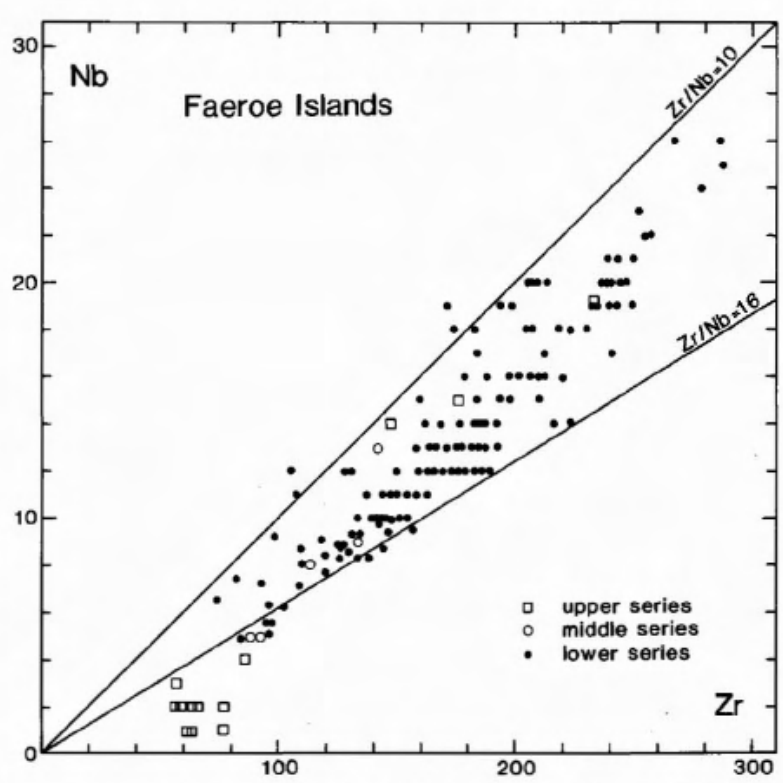

Fig. 102. $\mathrm{Nb}-\mathrm{Zr}$ diagram for lavas from the Faeroe Islands. Data sources: Waagstein \& Hald (1984), Gariepy et al. (1983). Compare with the Scoresby Sund data in fig. 83 . spectra (Schilling \& Noe-Nygaard, 1974; Gariepy et al., 1983). They have low $\mathrm{K}_{2} \mathrm{O}$-contents and are not alka line, and they have the same element ratios as the lower series (figs 101-102). Waagstein \& Hald (1984) noted their similarity to the Lower Basalts in the Kangerdlugssuaq region, and this also appears from fig. 100. Similar basalts are not known from other parts of the North Atlantic Tertiary igneous province, and both sequences are referred to chron $24 \mathrm{R}$ (see below). This together with the close pre-drift position of the Faeroes and Kangerdlugssuaq (fig. 94) suggests that the two sequences are indeed coeval. The implications of this is discussed later.

The upper basalt series on the Faeroes is dominated by depleted MORB-type basalts, although less depleted basalts also occur (Schilling \& Noe-Nygaard, 1974; Bollingberg et al., 1975; Gariepy et al., 1983; Waagstein, 1988). These authors agree that the source characteristics of the MORB-type basalts are different from that of the earlier basalts, but interpretations vary from expiring mantle blobs to change from continental to oceanic lithospheric regime.

Palaeomagnetically, most authors refer the lower basalt series to chron 25 and 26 , and the reversely magnetised middle and upper basalt series to chron 24R (Smythe et al., 1983; Andersen, 1988; Waagstein, 1988; Tarling et al., 1988). This view is adopted here, although Abrahamsen et al. (1984) referred the basalts to chron 24-22.

\section{Rockall Plateau}

The Rockall Plateau microcontinent (reviewed by Roberts et al., 1984) is believed to have separated from Europe by oceanic spreading in the Rockall Trough in the late Cretaceous. In the early Tertiary oceanic spreading started along the Reykjanes Ridge and separated the Rockall Plateau from its conjugate margin in southern East Greenland (fig. 94). Both margins show symmetrically developed seaward-dipping reflector sequences (Larsen \& Jakobsdóttir, 1988), the oldest magnetic anomaly identified is number $24 \mathrm{R}$, and spreading has been continuous until present.

DSDP leg 81 recovered basalts from both the top of the plateau and from various parts of the dipping reflector sequence at the NW margin. All the basalts are more or less depleted tholeiites with N-MORB affinity (Joron et al., 1984; Richardson et al., 1984; Merriman et al., 1988). These authors concluded that the trace element ratios, especially the $\mathrm{Zr} / \mathrm{Nb}$ ratios of $16-33$, set these basalts in distinct contrast to the basalts of Iceland, the Faeroes and Greenland. They are, however, similar to the N-MOR basalts from the equivalent parts 
of the Mid-Atlantic Ridge (Schilling et al., 1983). Richardson et al. (1984) concluded that this part of the spreading system is beyond the influence of the Iceland mantle plume, and that the N-MORB magma was available from very early on in the splitting process.

A commercial well in the Rockall Trough penetrated slightly enriched olivine tholeiites and bottomed in a sequence of peraluminous dacites with a large component of continental crust (Morton et al., 1988).

\section{The British Isles}

The British Tertiary igneous province is situated on continental crust some $400-600 \mathrm{~km}$ from the continental margin to the NW. The magmatic products are very diverse and include basic and differentiated lavas and dykes, and a number of central intrusions of ultramafic rocks, gabbros and granites. Crustal contamination is considered to be important in both lavas and intrusions (e.g. Moorbath \& Thompson, 1980; Dickin, 1981).

The basic lavas are divided into a number of types, reviewed by Thompson (1982). The volumetrically dominant 'plateau magma type' is an alkaline or transitional basalt, while the 'non-porphyritic central type' is tholeiitic but with low iron and $\mathrm{TiO}_{2}$ contents, rather different from the FeTi-basalts of Greenland, Iceland, the Faeroes and the Vøring Plateau. The Preshal Mhor magma type, occurring in the upper lavas and late dykes, is a strongly depleted high-Ca magma which is quite similar to the MORB-type basalt in the Rømer Fjord Formation in Scoresby Sund. It is considered produced by further melting of a lherzolitic residuum (Thompson et al., 1980), analogous to one of the possibilities for the genesis of the MORB-type basalt in Scoresby Sund.

The main part of the British basic magmas are strikingly different from those of other parts of the North Atlantic. The different tectonic settings may have contributed to this, but the main cause seems to be different mantle materials. The British plateau magma type has very low contents of incompatible elements compared to other alkaline-transitional basalts, and this has been ascribed to previous melt extraction in the Permian (e.g. Morrison et al., 1980). Both these authors and Menzies et al. (1987b) conclude that the upper mantle under Britain was different and isolated from the upper mantle system which gave rise to other parts of the North Atlantic igneous province.

\section{West Greenland}

The West Greenland early Tertiary lava region (fig. 94) has a structure that may be considered a mirror image of the East Greenland region: both are situated on the edge of the continent, with major eruption sites along the now collapsed outer coast, from where the lavas spilled over a Mesozoic sedimentary basin and lapped onto the Precambrian basement of the continen-
Fig. 103. $\mathrm{TiO}_{2}-\mathrm{Mg}$ ratio diagram for lavas from West Greenland, with Scoresby Sund data contours shown for comparison. Data sources: Clarke (1970), Clarke \& Pedersen (1976), Clarke et al. (1983), Pedersen (1985a,b), and unpublished GGU analyses from the Maligât Formation on Disko.

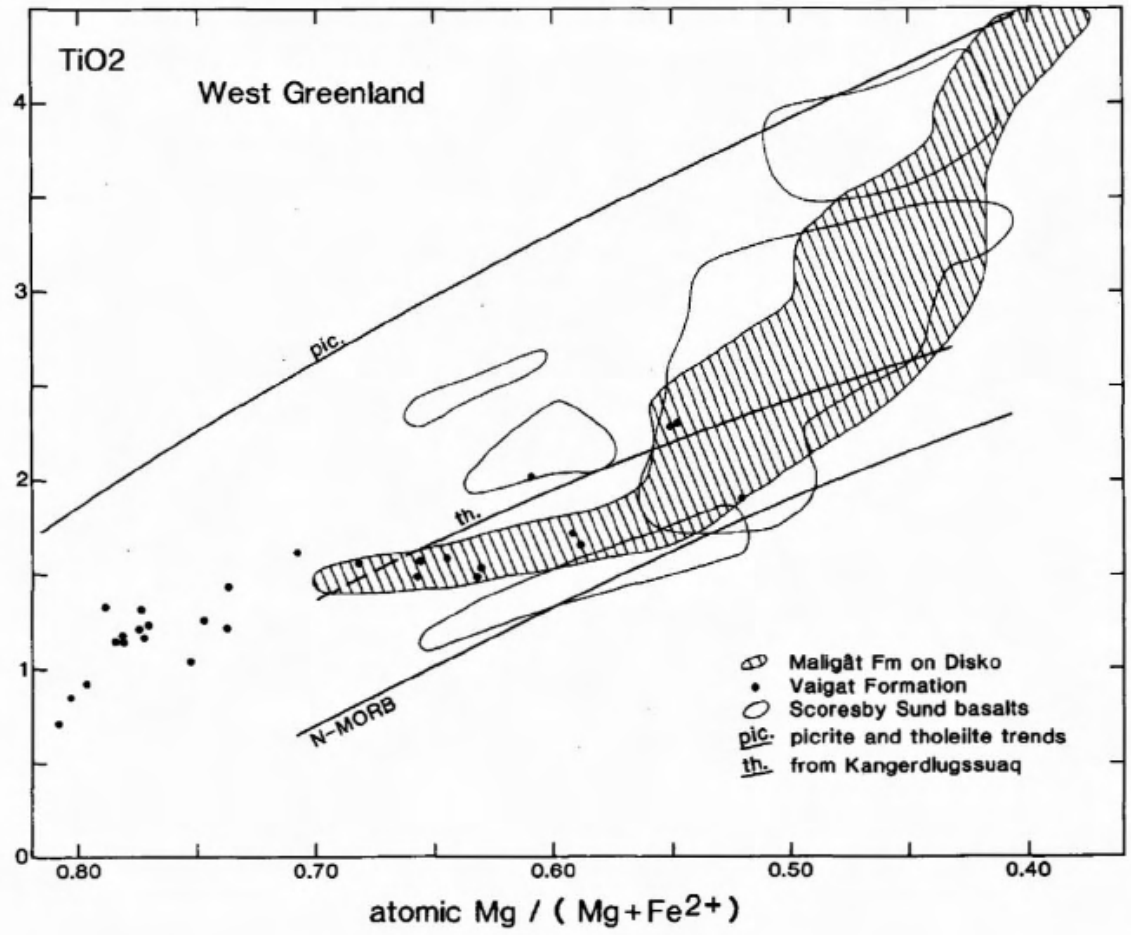


tal interior. As in East Greenland the volcanism started with $\mathrm{Mg}$-rich picritic lavas with intercalated basalts (the Vaigat Formation), switched to evolved, mostly feldsparphyric tholeiitic basalts (the Maligât Formation), and ended with a variety of magmatic products some of which are alkaline (e.g. Clarke \& Pedersen, 1976).

The picrites of East and West Greenland are, however, quite different. While the picrites in East Greenland are subordinate in volume and enriched in incompatible elements, as earlier noted (fig. 95), those in West Greenland constitute a very considerable volume of the volcanics and have low concentrations of incompatible elements (e.g. Clarke, 1970; Pedersen, 1985a,b), fig. 103. They have ${ }^{87} \mathrm{Sr}{ }^{86} \mathrm{Sr}$ ratios in the range 0.7029 0.7035 (Holm et al., 1988) similar to the North Atlantic mantle. They conform to the tholeiitic trend from Kangerdlugssuaq and are possible parental liquids for the evolved basalts, in contrast to the picrites in Kangerdlugssuaq.

The evolved tholeiitic basalts in West Greenland and Scoresby Sund are very similar (fig. 103). As in the Scoresby Sund basalts it is not possible to derive the Ti-rich basalts in West Greenland from the less differentiated basalts by simple fractionation of the observed phenocrysts. The open system fractionation and mixing processes appealed to for East Greenland may also apply to West Greenland. The process of mixing between the 'tholeiite' and enriched 'picrite-ankaramite' lineages suggested for the Lower Basalts in Kangerdlugssuaq (Brooks \& Nielsen, 1982a) is unlikely for West Greenland because no enriched lineage appears to be present.

\section{Iceland}

Iceland is an emerged part of the Mid-Atlantic Ridge, built up of volcanic rocks of Miocene to Recent age. There are thus no rocks of an age comparable to the East Greenland basalts, but none the less there are rocks very similar in composition to them.

Iceland possesses a complicated pattern of rift zones (fig. 94). At present there is a central rift zone where active 'subaerial sea-floor spreading' takes place, and a western and an eastern rift zone with no active spreading; but there have been several rift jumps in the past (e.g. Helgason, 1985). The rocks of the central rift zone range from primitive $\mathrm{N}$-MORB type olivine tholeiites through evolved, more or less Fe-Ti-rich tholeiites to highly silicic rocks (e.g. Imsland, 1983), while the rocks of the non-spreading rift zones range from tholeiites to transitional and alkaline rocks (e.g. Jakobsson, 1979). Some selected rocks are shown in figs 104-106.

A comparison of the Scoresby Sund basalts with Icelandic lavas at similar fractionation stage shows major element similarities between the MORB type basalt in Scoresby Sund and the evolved tholeiites of the Reyk-

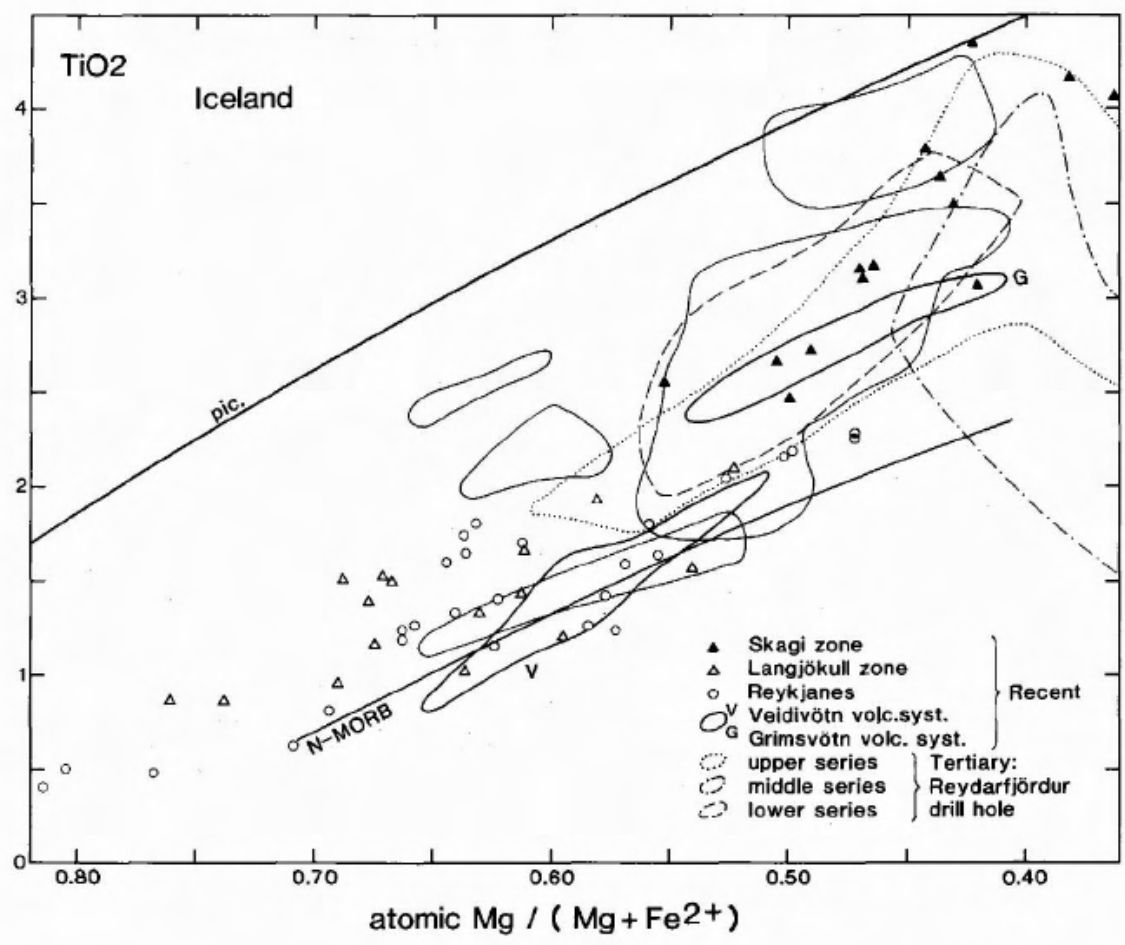

Fig. 104. $\mathrm{TiO}_{2}-\mathrm{Mg}$ ratio for selected tholeiitic lavas from Iceland, with Scoresby Sund data contours shown for comparison (light contours). Data sources: Sigurdsson et al. (1978), Jakobsson et al. (1978), Jakobsson (1979), Flower et al. (1982). 


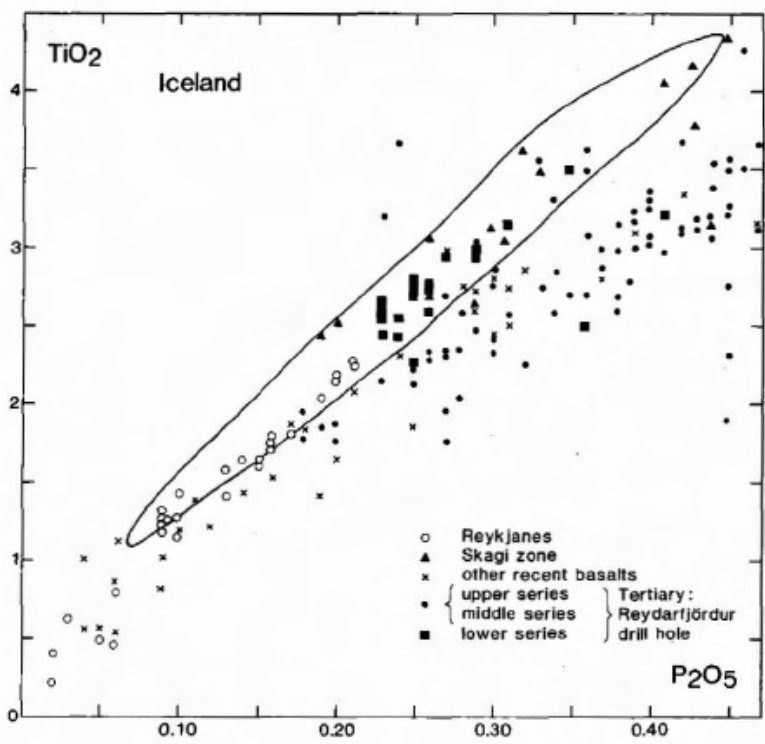

Fig. 105. $\mathrm{TiO}_{2}-\mathrm{P}_{2} \mathrm{O}_{5}$ diagram for selected tholeiitic lavas from Iceland, with Scoresby Sund data contours shown for comparison. Data sources: Sigurdsson et al. (1978), Jakobsson et al. (1978), Wood et al. (1979), Flower et al. (1982).

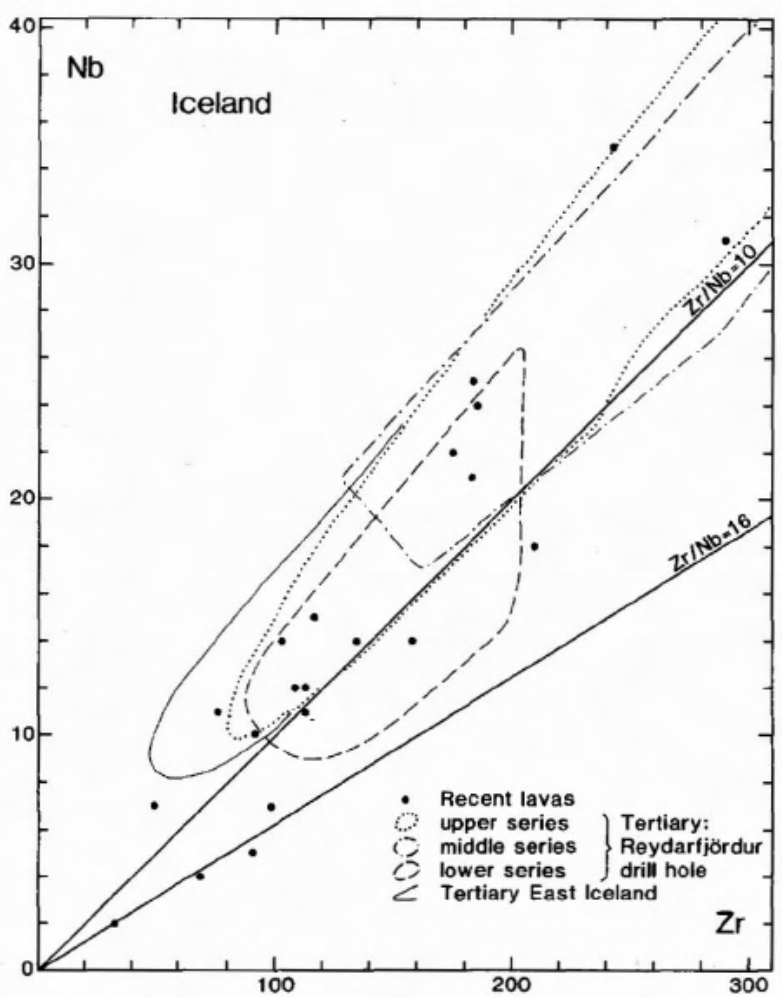

Fig. 106. $\mathrm{Nb}-\mathrm{Zr}$ diagram for tholeiitic lavas from Iceland. Data sources: Wood (1978), Wood et al. (1979), Gibson et al. (1982). Compare with the Scoresby Sund data in fig. 83. janes Peninsula (Jakobsson et al., 1978) and the Veidivötn volcanic system (Jakobsson, 1979). The main basalts in Scoresby Sund are similar to the Grimsvötn volcanic system (Jakobsson, 1979), to basalts from the Skagi zone (Sigurdsson et al., 1978), and to the Miocene basalts from eastern Iceland (Thingmuli, Carmichael, 1964; Reydarfjördur, Flower et al., 1982). Considering the minor and trace elements, however, most of the Icelandic rocks have $\mathrm{TiO}_{2} / \mathrm{P}_{2} \mathrm{O}_{5}$ and $\mathrm{Zr} / \mathrm{Nb}$ ratios corresponding to the Igtertivâ Formation and different from the bulk of the basalts in Scoresby Sund (compare figs 105-106 with figs 79 and 83). only the lower lava group in the Reydarfjördur drill hole (Gibson et al., 1982) and the Skagi zone basalts have $\mathrm{TiO}_{2} / \mathrm{P}_{2} \mathrm{O}_{5}$ ratios similar to the major part of the Scoresby Sund basalts, and the lower lava group has correspondingly many lavas with $\mathrm{Zr} / \mathrm{Nb}>10$ (fig. 106). No $\mathrm{Nb}$ and $\mathrm{Zr}$ data are available for the Skagi basalts. These differences were discussed in the chapter on Petrogenesis, where they were associated with differences in tectonic setting, the Scoresby Sund basalts (except the Igtertivâ Formation) being produced in a non-spreading setting and most of the Icelandic basalts being produced in a spreading setting with addition of a component of recycled oceanic crust.

\section{Mid-Atlantic Ridge}

The lavas erupted along the Mid-Atlantic Ridge are not uniform N-MOR basalts but vary from $\mathrm{N}$-type through transitional (T-type) to plume-type (E-type) enriched basalts (Schilling \& Sigurdsson, 1979; Sigurdsson, 1981; Schilling et al., 1983; Schilling, 1986; Melson \& O'Hearn, 1986). A whole row of hotspots/mantle plumes have been postulated along the Mid-Atlantic Ridge at $2^{\circ} \mathrm{N}, 15^{\circ} \mathrm{N}, 35^{\circ} \mathrm{N}, 38.5^{\circ} \mathrm{N}$ (Azores), $45^{\circ} \mathrm{N}, 65^{\circ} \mathrm{N}$ (Iceland) and $72^{\circ} \mathrm{N}$ (Jan Mayen). The degree of enrichment of incompatible elements varies between the individual enriched areas, that of the Azores being strong and that of Iceland moderate. The enriched basalts have geochemical ratios like the Igtertivâ Formation, and only rocks from some normal segments, and from DSDP site 409 south of Iceland, have $\mathrm{Zr} / \mathrm{Nb}>10$ (Wood et al., 1979).

The enriched ridge segments are relatively shallow and presumably have a thicker crust. This feature may however be interpreted both in terms of a mantle plume model and a crustal/lithospheric remelting model.

The Reykjanes Ridge south of Iceland is transitional south to $61^{\circ} \mathrm{N}$, gradually becoming normal. This has been interpreted as southward-directed flow from the Iceland mantle plume (e.g. Schilling et al., 1983). On the other hand, Kolbeinsey Ridge north of Iceland is of uniform normal type and shows no influence from Ice- 
land despite coming very close (fig. 94). This is remarkable, considering that the East Greenland basalts were produced earlier at the same latitude albeit not by the present ridge. The character of a ridge segment at a given latitude can apparently change with time, perhaps in connection with a rift jump.

\section{Discussion}

\section{Regional correlation}

Excepting the isolated areas of the British Isles and West Greenland, it should be possible to make some correlations between the Paleocene-Eocene basalt areas in the North Atlantic. The Rockall and Vøring Plateaux are difficult to line up with the other areas because of the limited data available. For northern East Greenland, the Scoresby Sund region, the Kangerdlugssuaq region and the Faeroes a crude correlation scheme is shown in Table 25.

The position of the Faeroe Islands basalts on the magneto-stratigraphic time scale is crucial. If the solution suggested by most authors (cited in the section on the Faeroe Islands) and also shown in Table 25 is correct, then the lower series is the oldest known and was erupted before spreading started in the region. The solution places the middle series of the Faeroe Islands in the lower part of chron $24 \mathrm{R}$ besides the Lower Basalts in Kangerdlugssuaq. These two lava series also share a unique enriched geochemistry (figs 95 and 100), and both contain tuffs at the bottom. Their pre-drift positions are very close (fig. 94), and it is suggested that the two series were formed in the same event. The correlation is extended north to the lower basalt sequence in the Scoresby Sund region due to the (sparse) occurrence of similar enriched magmas there. A correlation to northern East Greenland is not possible.

The Rømer Fjord and Skrænterne Formations are correlated with the Irminger Formation on geological grounds, and a more detailed correlation between these formations may be possible in the future. The upper series on the Faeroe Islands is approximately contemporary with these formations and has a distinctly different, MORB-like geochemical character. It was produced after the continents had split apart, possibly in association with the generation of new oceanic crust between Kangerdlugssuaq and the Faeroe Islands.

The lavas in northern East Greenland cannot be placed with certainty on the magneto-stratigraphic time scale, but they are assumed to be associated to the continental break-up (Upton et al., 1984). They are therefore placed in chron 24 in Table 25, although other ages cannot be dismissed.

The Igtertivâ Formation is placed in chron $24 \mathrm{~N}$ due to its apparent positive magnetisation (field measurements; Larsen \& Watt, 1985). In the Kangerdlugssuaq area the higher levels of the plateau basalts and the capping alkaline lavas have not been palaeomagnetically investigated, and the possibility that the sequence ranges into chron $24 \mathrm{~N}$ is open.

\section{The occurrence of primitive and evolved basalts}

Primitive basalts, with $\mathrm{Mg}$ ratios of 0.7 and higher (picrites), occur in continental areas in West Greenland, Kangerdlugssuaq and the Faeroe Islands, and in an oceanic environment in Iceland. In Iceland they are associated with crustal accretion in the central rift zone,

Table 25. Tentative correlation scheme for parts of the North Atlantic in the early Tertiary

\begin{tabular}{|c|c|c|c|c|}
\hline $\begin{array}{l}\text { Northern East } \\
\text { Greenland }\end{array}$ & Scoresby Sund & Kangerdlugssuaq & $\begin{array}{l}\text { Faeroe } \\
\text { Islands }\end{array}$ & Chron, \\
\hline $\begin{array}{l}\text { Upper } \\
\text { series }\end{array}$ & Igtertivâ Fm & $\begin{array}{l}\text { Alkaline } \\
\text { lavas? }\end{array}$ & & $24 \mathrm{~N}$ \\
\hline \multirow[t]{2}{*}{ Lower series } & $\begin{array}{l}\text { Skrænterne Fm } \\
\text { Rømer Fjord Fm }\end{array}$ & Irminger $\mathrm{Fm}$ & $\begin{array}{l}\text { Upper } \\
\text { series }\end{array}$ & \multirow{2}{*}{$24 \mathrm{R}$} \\
\hline & $\begin{array}{l}\text { Geikie Plateau Fm } \\
\text { Milne Land Fm } \\
\text { Magga Dan Fm }\end{array}$ & $\begin{array}{l}\text { Hængefjeld Fm } \\
\text { Mikis Fm } \\
\text { Vandfaldsdal Fm }\end{array}$ & $\begin{array}{l}\text { Middle } \\
\text { series }\end{array}$ & \\
\hline & & & $\begin{array}{l}\text { Lower } \\
\text { series }\end{array}$ & $\begin{array}{l}25 \mathrm{~N} \\
25 \mathrm{R} \\
26 \mathrm{~N} \\
26 \mathrm{R}\end{array}$ \\
\hline
\end{tabular}


and they may have been continuously erupted at the spreading centre since the spreading started. On the continent, they have in any one area only been erupted in one limited time period, not necessarily at the start of volcanism, but in all cases apparently at the start of continental rupture. In this situation, the density filter that normally prevents primitive magmas from reaching the surface does not seem to exist. The situation may depend on the upwelling of mantle material to sufficiently high levels beneath the surface.

Evolved tholeiitic basalts, with $\mathrm{Mg}$ ratios commonly between 0.6 and 0.4 , with relatively high contents of $\mathrm{Fe}$ and $\mathrm{Ti}$, and moderate contents of incompatible elements, occur in most areas of the North Atlantic, viz. central and northern East Greenland, the Vøring Plateau, the Faeroe Islands, West Greenland, Iceland and the Mid-Atlantic Ridge. They have been erupted throughout the time from Paleocene to Recent and in all tectonic settings. However, most magmas on the continental parts have higher $\mathrm{TiO}_{2} / \mathrm{P}_{2} \mathrm{O}_{5}$ and $\mathrm{Zr} / \mathrm{Nb}$ ratios than most magmas on the oceanic parts. The author has ascribed this feature to different post-generational processes due to different tectonic settings, but other explanations may be possible.

\section{Petrogenetic models for the North Atlantic igneous province}

Considered in relation to the three schematic trends in e.g. fig. 95, the preceding review shows that magmas belonging to the enriched 'picrite-ankaramite' trend were only erupted in Kangerdlugssuaq and the Faeroe Islands, and only in the same limited time period as the picrites there. Magmas broadly clustering around the intermediate 'tholeiite' trend are common in both space and time, while magmas approaching N-MORB in composition are rare except at the Mid-Atlantic Ridge (including Iceland's central rift zone) and the Rockall Plateau.

The question of which magmas came from which mantle type is difficult to address because the the composition of the supposed mantle plume is not known, and any amount of mixing between the mantle materials or their melts is possible. Some possible simplified scenarios can be sketched.

1) The mantle plume is only slightly or not at all different from N-MORB generating mantle. The most unmodified magmas are erupted in Iceland's central rift zone, but the bulk of the magmas undergo post-generational enrichment processes in the lithosphere. This is the model of Oskarsson et al., $(1982,1985)$ the mechanism of which depends on crustal accretion in a spreading zone. It has to be postulated that similar enrichment processes can occur under non-spreading conditions, resulting in very similar basalts except for $\mathrm{TiO}_{2} / \mathrm{P}_{2} \mathrm{O}_{5}$ and $\mathrm{Zr} / \mathrm{Nb}$ ratios. The most enriched magmas may include a component of enriched subcontinental lithosphere.

2) The mantle plume is considerably enriched and has given rise to the 'picrite-ankaramite' trend, while depleted asthenospheric mantle has given rise to the 'tholeiite' trend. This is like the model of Brooks \& Nielsen (1982a), It was modified by Gill et al. (1988) and Holm (1988) so that the 'picrite-ankaramite' series also includes a component of enriched lithospheric mantle. Since the mantle plume has been situated in the Kangerdlugssuaq area this model explains the confinement of the enriched basalts to Kangerdlugssuaq and the Faeroes. But it has to postulate, either a filter mechanism that prevents enriched magmas from the plume to erupt in Iceland today, or that the plume has changed composition with time. It also offers no explanation for the difference between the less-depleted North Atlantic mantle and the N-MORB generating mantle.

3) The mantle plume is the one that gives rise to the intermediate 'tholeiite' trend. This is in essence the model of Schilling (1973). It explains the 'North Atlantic mantle' simply as the plume material. A consequence of this model is that all the North Atlantic igneous areas except Great Britain, the Rockall Plateau and the Mid-Atlantic Ridge south of $61^{\circ} \mathrm{N}$ are plume influenced. The plume must have been present before the spreading started, and the plume material has either mushroomed out within the asthenosphere in a region with more than $1000 \mathrm{~km}$ diameter (White, 1988), or has been channelled such distances (Vink, 1984). The enriched magmas in the Kangerdlugssuaq-Faeroes area may still be explained as containing a component of enriched lithospheric mantle, melted due to the extra heat provided by the centre of the plume (the 'jet' of Gill et al., 1988). This model explains the scarcity of N-MORBs in the Tertiary parts, but not their relatively frequent occurrence at present along the Mid-Atlantic Ridge including Iceland, unless it is postulated that the plume has changed composition with time.

The real situation may contain elements from all three scenarios. Given that both scenarios 2 and 3 operate with an enriched lithospheric component in the most enriched basalts, they may easily be reconciled into one scenario with a mantle plume component with an unspecified degree of enrichment and an N-MORB producing asthenopheric component. The whole spectrum between the two may be produced by mixing of mantles or magmas and also by the post-generational processes envisaged for scenario 1 . This petrogenetic frame is only very general, but it must be concluded that it is at 
present not possible to pinpoint more specific scenarios because many of the variables are not sufficiently constrained. In particular, the composition and dynamics of the mantle plume and its possible evolution with time are relevant and should be addressed in the future. Any model has to be tested against the geological record, and collection of data to complete this record, as has been done for the Scoresby Sund basalts in this work, is necessary for testing future models.

\section{Concluding remarks}

The North Atlantic igneous province contains a record of plate lectonic processes, crustal formation and the life of a hotspot/mantle plume during nearly 60 million years. The volcanic products from the initial phase of continental break-up are of special significance because they record the processes in a stage of marked disequilibrium in crust and mantle. The Scoresby Sund basalts provide a particularly well-exposed and complete section through the products from the initial phase, and the present study has, by combining stratigraphic and geochemical methods, demonstrated the evolution of the igneous activity in space and time that took place during continental break-up and initiation of sea-floor spreading. The knowledge of this evolution contributes to the understanding of the underlying processes in mantle and crust.

\section{Acknowledgements}

The establishing of the detailed stratigraphy and the systematic geochemical variations would not have been possible without the high quality of the geochemical analyses performed by I. Sørensen, J. Kystol and the staff at GGU's chemical laboratory. Special thanks go to J. C. Bailey for most of the trace element analyses. J. G. Fitton is thanked for additional trace element analyses, and $\mathrm{O}$. Larsen for the $\mathrm{Sr}$ isotope analyses. N. G. Ware and J. G. Rønsbo are thanked for heip with the microprobe work. Research School of Earth Sciences, Canberra, and the Danish Natural Science Research Council provided laboratory facilities outside GGU. C. H. Emeleus and N. J. Soper contributed to the field work at Kap Brewster and along the Blosseville Kyst. The work has benefited from numerous discussions with $\mathrm{H}$. C. Larsen, A. K. Pedersen and T. F. D. Nielsen; the latter is also thanked for unpublished analyses from the Kangerdlugssuaq area.

\section{References}

Abrahamsen, N., Schönharting, G., \& Heinesen, M. 1984: Palaeomagnetism of the Vestmanna core and magnetic age and evolution of the Faeroe Islands. In Berthelsen, O., Noe-Nygaard, A. \& Rasmussen, J. (edit.) The deep drilling project $1980-81$ in the Faeroe Islands. Ann. Soc. Sci. Faeroensis 1984, 93-108.

Andersen, M. S. 1988: Late Cretaceous and early Tertiary extension and volcanism around the Facroe Islands. In Morton, A. C. \& Parson, L. M. (edit.) Early Tertiary volcanism and the opening of the NE Atlantic, Spec. Publ. geol. Soc. 39, 115-122.

Anderson, D. L. 1985: Hotspot magmas can form by fractionation and contamination of mid-ocean ridge basalts. Nature, Lond, 318, 145-149.

Anwar, Y. M. 1955: Geological investigations in East Greenland. Part V. The petrography of the Prinsen af Wales Bjerge lavas. Meddr Gronland 135(1), 31 pp.

Bailey, J. C. \& Noe-Nygaard, A. 1976: Chemistry of Miocene plume tholeiites from northwest lceland. Lithos 9, 185-201.

Basaltic Volcanism Study Project 1981: Basaltic volcanism on the terrestrial planets. New York: Pergamon Press. $1286 \mathrm{pp}$.

Bay, E. 1895: Geologi In Ryder,C. Den østgrønlandske Expedition, udført i Aarene 1891-92 under Ledelse af C. Ryder. Meddr Gronland 19, 145-187.

Beane, J. E., Turner, C. A. Hooper, P, R, Subbarao, K. V. \& Walsh. J. N. 1986: Stratigraphy, composition and form of the Deccan basalts, Western Ghats, India. Bull. volcan. 48 , $61-83$
Beckinsale, R. D., Brooks, C. K. \& Rex, D. C. 1970: K-Ar ages for the Tertiary of East Greenland. Bull. geol. Soc. Denmark 20, 27-37.

Beeson, M. H. 1976: Petrology, mineralogy, and geochemistry of the East Molokai volcanic series, Hawaii. U.S. geol. Surv, Prof. Pap. 961, 53 pp.

Bellieni, G., Chiaramonti, P. C., Marques, L. S., Melfi, A. J., Piccirillo, E. M., Nardy, A. J. R. \& Roisenberg, A. 1984: High- and low- $\mathrm{TiO}_{2}$ flood basalts from the Parana plateau (Brazil): petrology and geochemical aspects bearing on their mantle origin. Neues Jahrbuch Miner, Abh. 150, 273-306.

Bence, A. E., Papike, J. J. \& Ayuso, R. A. 1975: Petrology of submarine basalts from the central Caribbean: DSDP leg 15. J. geophys. Res. 80, 4775-4804.

Bender, J. F., Hodges, F. N. \& Bence, A. E. 1978: Petrogenesis of basalts from the project FAMOUS area: experimental study from 0 to 15 bars. Earth planet. Sci. Lett. 41, 277-302.

Berggren, W. A., Kent, D. V. \& Flynn, J. J. 1985: Jurassic to Paleogene: Part 2. Paleogene geochronology and chronostratigraphy. In Snelling, N. J. (edit.) The chronology of the geological record. Mem, Geol. Soc. 10, 141-195.

Birkenmajer. K. 1972: Report of investigations of Tertiary sediments at Kap Brewster, Scoresby Sund, East Greenland. Rapp. Gronlands geol. Unders. 48, 85-91.

Bleil, V., Hall, J. H., Johnson, H. P, Levi, S. \& Schönharting, G. 1982: The natural magnetization of a 3-kilometer section of Icelandic crust. J. geophys. Res. 87, B8, 6569-6589. 
Bøggild, O. B. 1909: The minerals from the basalt of EastGreenland. Meddr Gronland 28, 97-129.

Böhlke, J. K., Honnorez, J. \& Honnorez-Guerstein, B.-M. 1980: Alteration of basalts from site 396 B, DSDP: petrographic and mineralogic studies. Contr. Miner. Petrol. 73, 341-364.

Bott, M. H. P., Sunderland, J., Smith, P. J., Casten, U. \& Saxov, S. 1974: Evidence for continental crust beneath the Faeroe Islands. Nature, Lond. 248, 202-204.

Bott, M. H. P. 1988: A new look at the causes and consequences of the Icelandic hot-spot. In Morton, A. C. \& Parson, L. M. (edit.) Early Tertiary volcanism and the opening of the NE Atlantic. Spec. Publ. geol. Soc. 39, 15-23.

Bottinga, Y., Weill, D. \& Richet, P. 1982: Density calculations for silicate liquids. I. Revised method for aluminosilicate compositions. Geochim. cosmochim. Acta 46, 909-919.

Brooks, C. K. 1973: Tertiary of Greenland - a volcanic and plutonic record of continental break-up. Mem. Amer. Ass. Petrol. Geol. 19, 150-160.

Brooks, C. K. 1976. The $\mathrm{Fe}_{2} \mathrm{O}_{3} / \mathrm{FeO}$ ratio of basalt analyses: an appeal for a standardized procedure. Bull. geol. Soc. Denmark 25, 117-120.

Brooks, C. K. \& Gleadow, A. J. W. 1977: A fission-track age for the Skaergaard intrusion and the age of the East Greenland basalts. Geology 5, 539-540.

Brooks, C. K. \& Jakobsson, S. P. 1974: Petrochemistry of the volcanic rocks of the North Atlantic Ridge system. In Kristjansson, L. (edit.) Geodynamics of Iceland and the North Atlantic area. 139-154. Dordrecht: D. Reidel.

Brooks, C. K. \& Nielsen, T. F. D. 1982a: The E Greenland continental margin: a transition between oceanic and continental magmatism. J. geol. Soc. Lond. 139, 265-275.

Brooks, C. K. \& Nielsen, T. F. D. 1982b: The Phancrozoic development of the Kangerdlugssuaq area, East Greenland. Meddr Grønland, Geosci. 9, 30 pp.

Brooks, C. K., Nielsen, T. F. D. \& Petersen, T. S. 1976: The Blosseville Coast basalts of East Greenland: their occurrence, composition and temporal variation. Contr. Miner. Petrol. 58, 279-292.

Brooks, C. K., Pedersen, A. K. \& Rex, D. C. 1979: The petrology and age of alkaline mafic lavas from the nunatak zone of central East Greenland. Bull. Gronlands geol. Unders. 133, $28 \mathrm{pp}$.

Brown, G. M. \& Vincent, E. A. 1963: Pyroxenes from the late stages of fractionation of the Skaergaard intrusion, East Greenland. J. Petrology 4, 175-197.

Bryan, W. B. \& Dick, H. J. B. 1982: Contrasted abyssal basalt liquidus trends: evidence for mantle major element heterogeneity, Earth planet. Sci. Lett. 58, 15-26.

Bryan,W. B., Thompson, G. \& Ludden, J. N. 1981: Compositional variation in normal MORB from $22^{\circ}-25^{\circ} \mathrm{N}$ : Mid-Atlantic ridge and Kane fracture zone. J. geophys. Res. 86, 11815-11836.

Buddington, A. F. \& Lindsley, D. H. 1964: Iron-titanium oxide minerals and synthetic equivalents. J. Petrology 5, 310-357.

Butler, R. F. \& Coney, P. J. 1981: A revised magnetic polarity time scale for the Paleocene and early Eocene and implica- tions for Pacific plate motion. Geophys. Res. Lett. 8, 301304.

Callomon, J. H. \& Birkelund, T. 1980: The Jurassic transgression and the mid-late Jurassic succession in Milne Land, central East Greenland. Geol. Mag. 117, 211-227.

Campbell, I. H 1985: The difference between oceanic and continental tholeiites: a fluid dynamic explanation. Conir. Miner. Petrol. 91, 37-43.

Campbell, R. \& Lunn, J. W. 1925: Chlorophaeite in the dolerites (tholeiites) of Dalmahoy and Kaimes Hills, Edinburgh. Mineralog. Mag. 20, 435-440.

Carlson, R. W. 1984: Isotopic constraints on Columbia River flood basalt genesis and the nature of the subcontinental mantle. Geochim. cosmochim. Acta 48, 2357-2372.

Carison, R. W., Lugmair, G. W. \& Macdougall, J. D. 1981: Columbia River volcanism: the question of mantle heterogeneity or crustal contamination. Geochim. cosmochim. Acta 45, 2483-2499.

Carmichael, I. S. E. 1964: The petrology of Thingmuli, a Tertiary volcano in eastern Iceland. J. Petrology 5, 435-460.

Carmichael, 1. S. E. 1967: The mineralogy of Thingmuli, a Tertiary volcano in eastern Iceland. Amer. Miner. 52, 18151841.

Carter, S. R., Evensen, N. M., Hamilton, P. J. \& O'Nions, R. K. 1979: Basalt magma sources during the opening of the North Atlantic. Nature, Land. 281, 28-30.

Christic, D. M. \& Sinton, J. M. 1981: Evolution of abyssal lavas along propagating segments of the Galapagos spreading center. Earih planel. Sci. Lett. 56, 321-335.

Church, S. E. 1985: Genetic interpretation of lead-isotopic data from the Columbia River Basalt group, Oregon, Washington, and Idaho. Bull. geol. Soc. Amer. 96, 676-690.

Clague D. A., Frey, F. A., Thompson, G. \& Rindge, S. 1981: Minor and trace element chemistry of volcanic rocks dredged from the Galapagos spreading center: role of crystal fractionation and mantle heterogeneity. J. geophys. Res. 86, B10, 9469-9482.

Clarke, D. B. 1970; The Tertiary basalts of Baffin Bay: possible primary magma from the mantle. Contr. Miner. Petrol. 25, 203-224.

Clarke, D. B. \& Pedersen, A. K. 1976: Tertiary volcanic province of West Greenland. In Escher, A. \& Watt, W. S. (edit.) Geology of Greenland, 364-385. Copenhagen: Geol. Surv. Greenland.

Clarke, D. B., Muecke, G. K. \& Pe-Piper, G, 1983: The lamprophyres of Ubekendt Ejland, West Greenland: products of renewed partial melting or extreme differentiation. Contr. Miner. Petr. 83, 117-127.

Cox, K. G. 1980: A model for flood basalt volcanism. $J$. Petrology 21, 629-650.

Cox, K. G. 1983: The Karoo Province of southern Africa: origin of trace element enrichment patterns. In Hawkesworth, C. J. \& Norry, M. J. (edit.) Continental basalts and mantle xenoliths, 139-157. Cheshire: Shiva Pub. Ltd.

Cox, K. G. 1988: Numerical modelling of a randomized RTF magma chamber: a comparison with continental flood basalt sequences. J. Petrology 29, 681-697.

Cox, K. G. \& Hawkesworth, C. J. 1985: Geochemical stratig- 
raphy of the Deccan Traps at Mahabaleshwar, Western Ghats, India, with implications for open system magmatic processes. J. Petrology 26, 355-377.

Curry, D. \& Odin, G. S. 1982: Dating of the Palacogene. In Odin, G. S. (edit.) Numerical dating in stratigraphy, 607630. John Wiley.

Deer, W. A. 1976: Tertiary igneous rocks between Scoresby Sund and Kap Gustav Holm, East Greenland. In Escher, A. \& Watt, W. S. (edit.) Geology of Greenland, 404-429. Copenhagen: Geol. Surv. Greenland.

Dickin, A. 1981: Isotope geochemistry of Tertiary igneous rocks from the Isle of Skye, N. W. Scotland. J. Petrology 22, 155-189.

Donaldson, C. H. 1976: An experimental investigation of olivine morphology. Contr. Miner. Petrol. 57, 187-213.

Drake, M. J. 1976: Plagioclase-melt equilibria. Geochim. cosmochim. Acta 40, 457-465.

Easton, R. M. \& Garcia, M. O. 1980: Petrology of the Hilina Formation, Kilauea Volcano, Hawaii. Bull. Volcanol. 43, 657-674.

Evans, B. W. \& Moore, J, G, 1968; Mineralogy as a function of depth in the prehistoric Makaopuhi tholeiitic lava lake, Hawaii. Contr. Miner. Petrol. 17, 85-115.

Evans, B. W. \& Wright, T. L. 1972: Composition of liquidus chromite from the 1959 (Kilauea Iki) and 1965 (Makaopuhi) eruptions of Kilauca volcano, Hawaii. Amer. Miner. 57, 217-230.

Faller, A. M. 1975: Palaeomagnetism of the oldest Tertiary basalts in the Kangerdlugssuaq area of East Greenland. Bull. geol. Soc, Denmark 24, 173-178.

Faure, G., Bowman, J. R., Elliott, D. H. \& Jones, L. M. 1974: Strontium isotope composition and petrogenesis of the Kirkpatrick Basalt, Queen Alexandra Range, Antarctica. Contr. Miner. Pecrol, 48, 153-169.

Fawcett, J. J., Brooks, C. K. \& Rucklidge, J. C. 1973: Chemical petrology of Tertiary flood basalts from the Scoresby Sund area. Meddr Grønland 195(6), $54 \mathrm{pp}$.

Fawcett, J. J., Gittins, J., Rucklidge, J. C. \& Brooks, C. K. 1982: Petrology of Tertiary lavas from the western Kangerdiugssuaq area, East Greenland. Mineralog. Mag. 45, 211218.

Fisk, M. R., Bence, A. E. \& Schilling, J.-G. 1982: Major element chemistry of Galapagos Rift Zone magmas and their phenocrysts. Earth planet. Sci. Lett. 61, 171-189

Fisk, M. R., Upton, B. G. J., Ford, C. E. \& White, W. M. 1988: Geochemical and experimental study of the genesis of magmas of Reunion Island, Indian Ocean. J. geophys. Res. 93, B5, 4933-4950.

Flower, M. F. J., Pritchard, R. G., Brem, G., Cann, J. R., Delaney, J., Emmerman, R., Gibson, I. L., Oakley, P. J., Robinson, P. T. \& Schmincke, H.-U. 1982: Chemical stratigraphy, Iceland Research Drilling Project Reydarfjordur, Eastern Iceland. J. geophys. Res. 87, B8, 6489-6510.

Floyd, P. A. \& Fuge, R. 1982: Primary and secondary alkali and halogen element distribution in Iceland Research Drilling Project basalts. J. geophys. Res. 87, B8, 6477-6488.

Fodor, R. V., Keil, K. \& Bunch, T. E. 1975: Contributions to the mineralogy of Hawaiian rocks. IV. Pyroxenes in rocks from Haleakala and West Maui volcanoes, Maui, Hawaii. Contr. Miner. Petrol. 50, 173-195.

Ford, C. E., Russell, D. G., Craven, J. A. \& Fisk, M. R. 1983: Olivine-liquid equilibria: temperature, pressure and compo. sition dependence of the crystal/liquid cation partition coefficients for $\mathrm{Mg}, \mathrm{Fe}^{2+}, \mathrm{Ca}$ and $\mathrm{Mn}$. J. Petrology 24, 256-265,

Frey, F. A. \& Clague, D. A. 1983: Geochemistry of diverse basalt types from Loihi Seamount, Hawaii: petrogenetic implications. Earth planet. Sci. Lett. 66, 337-355.

Gariepy, C., Ludden, J \& Brooks, C, 1983: Isotopic and trace element constraints on the genesis of the Faeroe lava pile. Earth planet. Sci. Lelt. 63, 257-272.

Gibson, I. L., Kirkpatrick, R. J., Emmerman, R., Schmincke, H.-U., Pritchard, G., Oakley, P., Thorpe, R. S. \& Marriner, G. F. 1982: The trace clement composition of the lavas and dikes from a $3-\mathrm{km}$ vertical section through the lava pile of Eastern Iceland. J. geophys. Res. 87, B8, 6532-6546.

Gill, R. C. O., Nielsen, T. F. D., Brooks, C. K. \& Ingram, G. A. 1988: Tertiary volcanism in the Kangerdlugssuaq region, E Greenland; trace-element geochemistry of the Lower Basalts and tholejitic dyke swarms. In Morton, A. C. \& Parson. L. M. (edit.) Early Tertiary volcanism and the opening of the N E Atlantic. Spec. Publ. geol. Soc. 39, 161-179.

Green, D. H. \& Ringwood, A. E. 1967: The genesis of basaltic magmas. Contr. Miner. Petrol. 15, 103-190.

Grønlie, G., Chapman, M. \& Talwani, M. 1979: Jan Mayen Ridge and Iceland Plateau: origin and cvolution. Norsk Polarinst. Ser. 170, 25-47.

Gudlaugsson, S. T., Gunnarsson, K., Sand, M. \& Skogseid, J. 1988: Tectonic and volcanic events at the Jan Mayen Ridge microcontinent. In Morton, A. C. \& Parson, L. M. (edit.) Early Tertiary volcanism and the opening of the NE Atlantic. Spec. Publ, geol. Soc. 39, 85-93.

Gudmundsson, A. 1986: Possible effect of aspect ratios of magma chambers on eruption frequency. Geology 14, 991994.

Gudmundsson, A. 1987: Lateral magma flow, caldera collapse, and a mechanism of large eruptions in Iceland. J. volcanol. geotherm. Res. 34, 65-78.

Haggerty, S, E. 1976a: Oxidation of opaque mineral oxides in basalts. In Rumble, D. (edit.) Reviews in mineralogy, 3. Oxide minerals, $\mathrm{Hg} 1-\mathrm{Hg} 100$. Washington: Mineralogical Society of America.

Haggerty, S. E. 1976b: Opaque mineral oxides in terrestrial igneous rocks. In Rumble, D. (edit.) Reviews in mineralogy 3. Oxide minerals, $\mathrm{Hg} 101-\mathrm{Hg} 300$. Mineralogical Society of America.

Hailwood, E. A. 1977: Configuration of the geomagnetic field in early Tertiary times. J. geol. Soc. Lond. 133, 23-36.

Hailwood, E. A., Tarling, D. H., Mitchell, J. G. \& Løvlie, R 1973: Preliminary observations on the palaeomagnetism and radiometric ages of the Tertiary basalt sequence of Scoresby Sund, East Greenland. Rapp. Gronlands geol. Unders. 58, 43-47.

Hald, N. 1978: Tertiary igneous activity at Giesecke Bjerge, northern East Greenland, Bull, geol. Soc. Denmark 27, 109 115.

Hald, N. \& Waagstein, R. 1983: Silicic basalts from the Faeroe 
Islands: evidence of crustal contamination. In Bott, M. H. P., Saxov, S., Talwani, M. \& Thiede, J. (edit.) Structure and development of the Greenland-Scotland Ridge, 343-349. Plenum Publishing Co.

Hald, N. \& Waagstein, R. 1984: Lithology and chemistry of a $2-\mathrm{km}$ sequence of Lower Tertiary tholeiitic lavas drilled on Suduroy, Faeroe Island (Lopra-1). In Berthelsen, O., NoeNygaard, A. \& Rasmussen, J. (edit.) The deep drilling project $1980-81$ in the Faeroe Islands. Ann. Soc. Sci. Faeroensis $1984,15-38$.

Haller, J. 1970: Tectonic map of East Greenland (1:500,000). An account of tectonism, plutonism, and volcanism in East Greenland. Meddr Gronland 171(5), $286 \mathrm{pp}$,

Hanson, G. N. \& Langmuir, C. H. 1978: Modelling of major elements in mantle-melt systems using trace element approaches. Geochim. cosmochim. Acta 42, 725-741.

Hansen, K. 1985: Fission track determinations of vertical movements in the crust caused by continental rifting: a fission track age study of the Scoresby Sund area. Method and results. Unpublished lic. scient. thesis, University of Copenhagen. $119 \mathrm{pp}$.

Hartz, N. 1902: Beretning om Skibsexpeditionen til Grønlands $\emptyset$ stkyst. For Tidsrummet fra d. 18. Juli til d. 12. September 1900. Meddr Gronland 27, 153-181.

Hassan, M. Y. 1953: Tertiary faunas from Kap Brewster, East Greenland. Meddr Grønland 111(5), 42 pp.

Helgason, J. 1985: Shifts of the plate boundary in Iceland: some aspects of Tertiary volcanism. J. geophys. Res. 90, B12, 10084-10092.

Hemond, C., Condomines, M., Fourcade, S., Allegre, C. J., Oskarsson, N. \& Javoy, M. 1988: Thorium, strontium and oxygen isotopic geochemistry in recent tholeiites from Iceland: crustal influence on mantle-derived magmas. Earth planet. Sci. Lett. 87, 273-285.

Henriksen, N. 1986: Descriptive text to 1:500 000 sheet 12 Scoresby Sund, 27 pp. Copenhagen: Geol. Surv. Greenland.

Herzberg, C. T. \& Chapman, N. A. 1976: Clinopyroxene geothermometry of spinel-lherzolite. Amer. Miner. 61, 626637.

Hill, R. \& Roeder, P. 1974: The crystallization of spinel from basaltic liquid as a function of oxygen fugacity. J. Geol. 82, 709-729.

Holm, P. E. 1985: The geochemical fingerprints of different tectonomagmatic enrichments using hygromagmatophile element abundances of tholeiitic basalts and basaltic andesites. Chem. Geol. 51, 303-323.

Holm P, M. 1988: Nd, $\mathrm{Sr}$ and $\mathrm{Pb}$ isotope geochemistry of the Lower Lavas, E Greenland Tertiary Igneous Province. In Morton, A. C. \& Parson, L. M. (edit.) Early Tertiary volcanism and the opening of the N E Atlantic. Spec. Publ. geol. Soc. 39, 181-195.

Holm, P. M., Gill, R. C. O., Pedersen, A. K., Larsen, J. G., Hald, N.. Nielsen, T. F. D. \& Thirlwall, M. F. 1988: Tertiary picrites of West Greenland: petrogenetic implications of trace element \& $\mathrm{Sr}-\mathrm{Nd}$ isotope geochemistry. Chem. Geol. 70, 49 only.

Holmes, A. 1918: The basaltic rocks of the arctic region Mineralog. Mag. 18, 180-223.
Hooper, P.R. 1982: The Columbia River basalts. Science 215, 1463-1468.

Hooper, P.R. 1984: Physical and chemical constraints on the evolution of the Columbia River basalt. Geology 12, 495499.

Huppert, H. E. \& Sparks, R. S. J. 1985: Cooling and contamination of mafic and ultramafic magmas during ascent through continental crust. Earth planet. Sci. Lett. 74, 371386.

Imsland, P. 1983: Iceland and the ocean floor. Comparison of chemical characteristics of the magmatic rocks and some volcanic features. Contr. Miner. Petrol. 83, 31-37.

Imsland, P. 1984: Petrology, mineralogy and evolution of the Jan Mayen magma system. Visindafelag Islendinga 43, 332 pp.

Imsland, P., Larsen, J. G., Prestvik, T. \& Sigmond, E. M. 1977: The geology and petrology of Bouvetøya, south Atlantic Ocean. Lithos 10, 213-234.

Irvine, T. N. 1970: Crystallization sequences in the Muskox intrusion and other layered intrusions. 1. Olivine-pyroxeneplagioclase relations. Spec. Publ. geol. Soc. S.Afr. 1, 441476.

Irvine, T. N. 1975: Crystallization sequences in the Muskox intrusion and other layered intrusions - Il. Origin of chromitite layers and similar deposits of other magmatic ores. Geochim. cosmochim. Acta 39, 991-1020.

Irvine, T. N. 1979: Rocks whose composition is determined by crustal accumulation and sorting. In Yoder, H. S., Jr. (edit.) The evolution of the igneous rocks. Fiftieth anniversary perspectives. 245-306. Princeton University Press.

Irvine, T. N. \& Barager, W. R. A. 1971: A guide to the chemical classification of the common volcanic rocks. Can. J. Earth Sci. 8, 523-548.

Jackson, E. D. 1969: Chemical variation in coexisting chromite and olivine in chromitite zones of the Stillwater Complex. Econ. Geol. Monogr. 4, 41-71.

Jakobsson, S. P. 1972: Chemistry and distribution pattern of Recent basaltic rocks in Iceland. Lithos 5, 365-386.

Jakobsson, S. P. 1979: Petrology of Recent basalts of the eastern volcanic zone, Iceland. Acta Nanur. Islandica 26, 1-103.

Jakobsson, S. P., Jonsson, J. \& Shido, F. 1978: Petrology of the western Reykjanes Peninsula, Iceland. J. Petrology 19, 669. 705.

Jensen, Aa. 1979: Mineralogical and geochemical variations across three basaltic lava flows from the Faeroe Islands. Bull. geol. Soc. Denmark 28, 95-114.

Joron, J. L., Bougault, H., Maury, R. C., Bohn, M. \& Desprairies, A. 1984: Strongly depleted tholeiites from the Rockall Plateau Margin, North Atlantic: geochemistry and mineralogy. Initial Rep. Deep Sea Drilling Project 81, 783794.

Kharin, G. N. 1976: The petrology of magmatic rocks, DSDP leg 38. Ininal Rep. Deep Sea Drilling Projecr 38, 685-715.

Kristmannsdóttir, H. 1982: Alteration in the IRDP drill hole compared with other drill holes in Iceland. I. geophys. Res. 87, B8, 6525-6531

Kristmannsdottir, H. \& Tómasson, J. 1978: Zeolite zones in 
geothermal areas in Iceland, In Sand, L. B. \& Mumpton, F, A. (edit.) Natural zeolites. Occurrence, properties, use. 297284. New York, Oxford: Pergamon Press.

Kudo, A. M. \& Weill, D. F. 1970: An igneous plagioclase thermometer. Contr. Miner. Petrol. 25, 52-65.

Kuo, L.-C. \& Kirkpatrick, R. J. 1982: Pre-eruption history of phyric basalts from DSDP legs 45 and 46: evidence from morphology and zoning patterns in plagioclase. Contr. Miner. Petrol. 79, 13-27.

Kyle, P. R. 1980: Development of heterogeneities in the subcontinental mantle: evidence from the Ferrar Group, Antarctica. Contr. Miner. Petrol. 73, 89-104.

Langmuir, C. H., Bender, J. F., Bence, A. E. \& Hanson, G. N. 1977: Petrogenesis of basalts from the FAMOUS area: Mid-Atlantic Ridge. Earth planet. Sci. Lett. 36, 133-156.

Larsen, B. 1980: A marine geophysical survey of the continental shelf of East Greenland $60^{\circ} \mathrm{N}-71^{\circ} \mathrm{N}$, Project 'DANA 79', preliminary report. Unpublished report, Grønlands geol. Unders., $30 \mathrm{pp}$.

Larsen, H. C. 1978: Offshore continuation of East Greenland dyke swarm and North Atlantic Ocean formation. Nature 274, 220-223.

Larsen, H. C. 1980: Geological perspectives of the East Greenland continental margin. Bull. geol. Soc. Denmark 29, 77101.

Larsen, H. C. 1984: Geology of the East Greenland shelf. In Norwegian Petroleum Society (edit.) Perroleum geology of the North European margin, 329-339.

Larsen, H. C. 1985: Petroleum geological assessment of the East Greenland shelf. Project NAD - East Greenland. Final report (No.8). Unpublished report Grønlands geol. Unders. 79 pp. \& appendices.

Larsen, H. C. 1988: A multiple and propagating rift model for the NE Atlantic. In Morton, A. C. \& Parson, L. M. (edit.) Early Tertiary volcanism and the opening of the NE Atlantic. Spec. Publ. geol. Soc. 39, 157-158.

Larsen, H. C. 1989: The East Greenland shelf. In Grantz, A., Johnson, L. \& Sweeney, J. F. (edit.) The Arctic Ocean region, $x x-x x$. The geology of North America, L. Boulder, Colorado: Geological Society of America.

Larsen, H. C. \& Jakobsdóttir, S. 1988: Distribution, crustal properties and significance of seawards-dipping sub-basement reflectors off E Greenland. In Morton, A. C. \& Parson, L. M. (edit.) Early Tertiary volcanism and the opening of the NE Atlantic. Spec. Publ. geol. Soc. 39, 95-114.

Larsen, L. M. \& Watt, W. S. 1985: Episodic volcanism during break-up of the North Atlantic: evidence from the East Greenland plateau basalts. Earth planet. Sci. Lett. 73, 105116.

Le Bas, M. J., Le Maitre, R. W., Streckeisen, A. \& Zanettin, B. 1986: A chemical classification of volcanic rocks based on the total alkali-silica diagram. J. Petrology 27, 745-750.

Leeman, W. P., Budahn, J. R., Gerlach, D. C., Smith, D. R. \& Powell, B. N. 1980: Origin of Hawaiian tholeites: trace element constraints. Amer. J. Sci. 280-A, 794-819.

Lehmann, J. 1983: Diffusion between olivine and spinel: application to geothermometry. Earth planet. Sci. Lett. 64, 123138.
Leg 104 Shipboard Scientific Party 1987: Site 642: Norwegian Sea. Proc. Ocean Drilling Program 104A, 53-453.

Le Roex, A. P. 1987: Source regions of mid-ocean-ridge basalts: evidence for enrichment processes. In Menzies, M. A. \& Hawkesworth, C. J. (edit.) Mantle metasomatism, 389422. London: Academic Press.

Le Roex, A. P. \& Dick, H. J. B. 1981: Petrography and geochemistry of basaltic rocks from the Conrad fracture zone on the America-Antarctica ridge. Earth planet. Sci. Lett. 54, 117-138.

Le Roex, A. P., Dick, H. J. B., Erlank, A. J., Reid, A. M. Frey, F. A. \& Hart, S. R. 1983: Geochemistry, mineralogy and petrogenesis of lavas erupted along the Southwest Indian Ridge between the Bouvet triple junction and 11 degrees east, J. Petrology 24, 267-318.

Leterrier, J., Maury, R. C, Thonon, P., Girard, D. \& Marchal, M. 1982: Clinopyroxene composition as a method of identification of the magmatic affinities of paleo-volcanic series. Earth planet. Sci. Lett. 59, 139-154.

Lindsley, D. H. \& Haggerty, S. E. 1971: Phase relations of Fe-Ti oxides and aenigmatite; oxygen fugacity of the pegmatoid zones. Yb. Carnegie Instn Wash. 69, 278-284.

McBirney, A. R. \& Williams, H. 1969: Geology and petrology of the Galapagos Islands. Mem. geol. Soc. Amer. 118, 197 pp.

Macdonald, G. A. \& Katsura, T. 1964: Chemical composition of Hawaiian lavas. J. Petrology 5, 82-133.

McDougall, 1. 1976: Geochemistry and origin of basalt of the Columbia River Group, Oregon and Washington. Bull. geol. Soc. Amer. 87, 777-792.

Mahoney, J., Macdougall, J. D., Lugmair, G. W., Murali, A. V., Sankar Das, M. \& Gopalan, K. 1982: Origin of the Deccan Trap flows at Mahabaleshwar inferred from Nd and Sr isotopic and chemical evidence. Earth planet. Sci. Lett. 60, 47-60.

Măkipää, H. 1978: Petrological relations in some Icelandic basaltic hyaloclastites. Bull. geol. Soc. Finland 50, 91-112.

Mathez, E. A. 1973: Refinement of the Kudo-Weill plagioclase thermometer and its application to basaltic rocks. Contr. Miner. Petrol. 41, 61-72.

Maurel, C. \& Maurel, P. 1982a: Étude expérimentale de la solubilité du chrome dans les bains silicatés basiques et de sa distribution entre liquide et minéraux coexistants: conditions d'existance du spinelle chromifere. Bull. Minéral 105, 640647.

Maurel, C. \& Maurel, P. 1982b: Étude expérimentale de l'equilibre $\mathrm{Fe}^{2+}-\mathrm{Fe}^{3+}$ dans les spinelles chromifères et les liquides silicatés basiques coexistants, à $1 \mathrm{~atm}$. C.r. hebd. Séanc. Acad. Sci. Paris 295, Sér. 2, 209-212.

Melson, W. G. \& O'Hearn, T. 1986: 'Zero-age' variations in the composition of abyssal volcanic rocks along the axial zone of the Mid-Atlantic Ridge. In Vogt, P. R. \& Tucholke, B. E. (edit.) The geology of North America, M, The western North Atlantic region, 117-136. Geological Society America.

Melson, W. G. \& Switzer, G. 1966: Plagioclase-spinel-graphite xenoliths in metallic iron-bearing basalts, Disko Island, Greenland. Amer. Miner. 51, 664-676.

Menzies, M., Rogers, N., Tindle, A. \& Hawkesworth, C. 
1987a: Metasomatic and enrichment processes in lithospheric peridotites, an effect of asthenospheric-lithospheric interaction. In Menzies, M. A. \& Hawkesworth, C. J. (edit.) Mantle metasomatism, 313-361. London: Academic Press.

Menzies, M. A., Halliday, A. N., Palacz, Z., Hunter, R. H., Upton, B. G. J., Aspden, P. \& Hawkesworth, C. J. 1987b: Evidence from mantle xenoliths for an enriched lithospheric keel under the Outer Hebrides. Nature, Lond. 325, 4447.

Merriman, R. J., Taylor, P. N. \& Morton, A. C. 1988: Petrochemistry and isotope geochemistry of early Palacocene basalts forming the dipping reflector sequences SW of Rockall Plateau, NE Atlantic. In Morton, A. C. \& Parson, L. M. (edit.) Early Tertiary volcanism and the opening of the NE Atlantic. Spec. Publ. geol. Soc. 39, 123-134.

Miyashiro, A.. Shido, F. \& Ewing, M. 1969: Diversity and origin of abyssal tholeinte from the Mid-Atlantic Ridge neat $24^{\circ}$ and $30^{\circ}$ north latitude. Contr. Miner. Petrol. 23, 38-52.

Moorbath, S. \& Thompson, R. N. 1980: Strontium isotope geochemistry and petrogenesis of the Early Tertiary lava pile of the Isle of Skye, Scotland, and other basic rocks of the British Tertiary Province: an example of magma-crust interaction. J. Petrology 21, 295-321.

Moore, J. G. 1970: Water content of basalt erupted on the ocean floor. Contr. Miner. Petrol. 28, 272-279.

Moore, J. G. \& Evans, B, E. 1967: The role of olivine in the crystallization of the prehistoric Makaopuhi tholeiitic lava lake, Hawaii. Contr. Miner. Petrol. 15, 202-223.

Moore, J. G. \& Schilling, J.-G, 1973: Vesicles, water, and sulfur in Reykjanes Ridge basalts. Contr. Miner. Petrol. 41, 105-118.

Moore, R. B. 1983: Distribution of differentiated tholeiitic basalts on the lower east rift zone of Kilauea Volcano, Hawaii: a possible guide to geochemical exploration. Geology 11, 136-140.

Morgan, W, J. 1983: Hotspot tracks and the early rifting of the Atlantic. Tectonophysics 94, 123-139.

Morrison, M. A., Thompson, R. N., Gibson, I. L. \& Marriner, G. F. 1980: Lateral chemical heterogeneity in the Paleocene upper mantle beneath the Scottish Hebrides. Phil. Trans. $R$. Soc. Lond. A297, 229-244.

Morse, S. A. 1980: Basalts and phase diagrams. New York: Springer Verlag.

Morton, A. C., Dixon, J. E., Fitton, J. G., Macintyre, R. M., Smythe, D.K. \& Taylor, P. N. 1988: Early Tertiary volcanic rocks in well 163/6-1A, Rockall Trough. In Morton, A. C. \& Parson, L. M. (edit.) Early Tertiary volcanism and the opening of the NE Atlantic. Spec. Publ, geol. Soc. 39, 293-308.

Mussett, A. E. 1980: British Tertiary Igneous Province probably not associated with East Greenland lavas. Nature, Lond. 284, 376-377.

Mutter, J. C., Talwani, M. \& Stoffa, P. L. 1982: Origin of seaward-dipping reflectors in oceanic crust off the Norwegian margin by 'subaerial sea-floor spreading'. Geology 10, 353-357.

Mutter, J. C., Buck, W. R. \& Zehnder, C. M. 1988: Convective partial melting 1. A model for the formation of thick basaltic sequences during the initiation of spreading. $J$. geophys. Res. 93, B2, 1031-1048.
Myhre, A. M., Eldholm, O. \& Sundvor, E. 1984: The Jan Mayen Ridge: present status. Polar Res. 2, 47-59.

Najafi, S. J., Cox, K. G. \& Sukheswala, R. N. 1981: Geology and geochemistry of the basalt flows (Deccan Traps) of the Mahad-Mahabaleshwar section, Bombay, India. Mem. geol. Soc. India 3, 300-315.

Nielsen, R. L. \& Drake, M. J. 1979: Pyroxene-melt equilibria. Geochim. cosmochim. Acta 43, 1259-1272.

Nielsen, T. F. D. 1978: The Tertiary dike swarm of the Kangerdlugssuaq area, East Greenland. Contr. Miner. Petrol. 67, 63-78.

Nielsen, T. F. D. 1987: Tertiary alkaline magmatism in East Greenland: a review. In Fitton, J. G. \& Upton, B. G. J. (edit.) Alkaline igneous rocks. Spec. Publ. geol. Soc. 30, 489-515.

Nielsen, T. F. D. \& Brooks, C. K. 1981: The E Greenland rifted continental margin: an examination of the coastal flexure, J. geol, Soc. Lond. 138, 559-568.

Nielsen, T. F. D. \& Buchardt, B. 1985: Sr-C-O isotopes in nephelinitic rocks and carbonatites, Gardiner Complex, Tertiary of east Greenland. Chem. Geol. 53, 207-217.

Nielsen, T. F. D., Soper, N. J., Brooks, C. K., Faller, A. M., Higgins, A. C. \& Matthews, D. W. 1981: The pre-basaltic sediments and the Lower Basalts at Kangerdlugssuaq, East Greenland, their stratigraphy, lithology, palaeomagnetism and petrology. Meddr Gronland Geosci. 6, 25 pp.

Noe-Nygaard, A. 1974: Cenozoic to Recent volcanism in and around the North Atlantic basin. In Nairn, A. E. M. \& Stehli, F, G, (edit.) The ocean basins and margins, 2, 391443. New York \& London: Plcnum Press.

Noe-Nygaard, A. 1976: Tertiary igneous rocks between Shannon and Scoresby Sund, East Greenland. In Escher, A. \& Watt, W. S. (edit.) Geology of Greenland, 386-402. Copenhagen: Geological Survey of Greenland.

Noe-Nygaard, A. \& Pedersen, A. K. 1974: Progressive chemical variation in a tholeitic lava sequence at Kap Stosch, northern East Greenland. Bull. geol. Soc. Denmark 23, $175-$ 190.

Noe-Nygaard, A. \& Pedersen, A. K. 1983: Tertiary volcanic rocks from Bontekoe $\emptyset$, East Greenland. Rapp. Grenlands geol. Unders. 116, 13 pp.

Noe-Nygaard, A. \& Rasmussen, J. 1968: Petrology of a 3000 metre sequence of basaltic lavas in the Faeroe Islands. Lithos 1, 286-304.

Nordenskjöld, O. 1907: On the geology and physical geography of East-Greenland. Meddr Gronland 28, 151-284.

Nunns, A. G. 1983: Plate tectonic evolution of the GreenlandScotland Ridge and surrounding regions. In Bott, M. H. P. et al. (edit.) Structure and development of the Greenland-Scotland Ridge, 11-30. New York: Plenum.

Odin, G. S. \& Curry, D. 1985: The Palaeogene time-scale: radiometric dating versus magnetostratigraphic approach. $J$. geol. Soc. London 142, 1179-1188.

Odin, G. S. \& Mitchell, J. G. 1983: Dating of the PalaeoceneEocene Blosseville Group basalts, Scoresby Sund, East Greenland: a review. Newsletter. Stratigr. 12, 112-121.

O'Hara, M. J. 1977: Geochemical evolution during fractional crystallisation of a periodically refilled magma chamber. $\mathrm{Na}$ ture, Lond. 266, 503-507. 
O'Hara, M. J. \& Mathews, R. E. 1981: Geochemical evolution in an advancing, periodically replenished, periodically tapped, continuously fractionated magma chamber. J. geol. Soc. Lond. 138, 237-277.

Osborn, E. F. \& Tait, D. B. 1952: The system diopside-forsterite-anorthite. Amer. J. Sci. Bowen Vol. 413-433.

Oskarsson, N., Sigvaldason, G. E. \& Steinthorsson, S. 1982; A dynamic model of rift zone petrogenesis and the regional petrology of Iceland. J. Petrology 23, 28-74.

Oskarsson, N., Steinthorsson, S. \& Sigvaldason, G. E. 1985: Iceland geochemical anomaly: origin, volcanotectonics, chemical fractionation and isoiope evolution of the crust. $J$. geophys. Res. 90, B12, 10011-10025.

Pálmason, G. 1983: oral communication 1983. Lecture 03/14, IUGG 28th General Assembly, Hamburg.

Pálmason, G., Arnórsson, S., Fridleifsson, I. B., Kristmannsdottir, H., Saemundsson, K., Stefansson, V. Steingrimsson, B., Tómasson, J. \& Kristjánsson, L. 1979: The Iceland crust: evidence from drillhole data on structure and processes. In Talwani, M., Harrison, C.G. \& Hayes, D. E. (edit.) Deep Drilling Results in the Atlantic Ocean: Ocean crust. Amer. geophys. Un. Maurice Ewing Ser. 2, 43-65.

Papike, J. J. \& White, C. 1979: Pyroxenes from planetary basalts: characterization of 'other' than quadrilateral components. Geophys. Res. Lett. 6, 913-916.

Patchett, P. J, 1980: Thermal effects of basalts on continental crust, and likely mechanisms of crustal contamination in magmas. Nature, Lond. 283, 559-561.

Pearce, T. H., Gorman, B. E. \& Birkett, T. C. 1975: The $\mathrm{TiO}_{2}-\mathrm{K}_{2} \mathrm{O}-\mathrm{P}_{2} \mathrm{O}_{5}$ diagram: a method of discriminating between oceanic and non-oceanic basalt. Earth planet. Sci. Lett. 24, 419-426.

Peck, D. L.. Wright, T. L. \& Moore, J. G. 1966: Crystallization of tholeiitic basalts in Alae lava lake, Hawaii. Bull. volcan. 29, 629-656.

Pedersen, A. K. 1977: Dyke intrusions along the south coast of Disko. Rapp. Gronlands geol. Unders. 81, 57-67.

Pedersen, A. K. 1985a: Lithostratigraphy of the Tertiary Vaigat Formation on Disko, central West Greenland. Rapp. Gronlands geol. Unders. 124, $30 \mathrm{pp}$.

Pedersen, A. K. 1985b: Reaction between picrite magma and continental crust: early Tertiary silicic basalts and magnesian andesites from Disko, West Greenland. Bull. Gronlands geol. Unders. 152, $126 \mathrm{pp}$.

Pedersen, A. K. \& Pedersen, S. 1987: Sr isotope chemistry of contaminated Tertiary volcanic rocks from Disko, central West Greenland. Bull, geol. Soc. Denmark 36, 315-336.

Philpotts, A. R. 1978: Textural evidence for liquid immiscibility in tholeiites. Mineralog. Mag. 42, 417-425.

Philpotts, A. R. 1982: Compositions of immiscible liquids in volcanic rocks. Contr. Miner. Petrol. 80, 201-218.

Plas, L. v. d. \& Tobi, A. C. 1965: A chart for judging the reliability of point counting results. Amer. J. Sci, 263, 87-90.

Presnall, D. C., Dixon, I. R., O'Donnell, T. H. \& Dixon, S. A. 1979: Generation of mid-ocean ridge tholeiites, J. Petrology 20, 3-35.

Raschka, H. \& Eckhardt, F.-J. 1976: Geochemistry of basalts from the Norwegian-Greenland Sea, leg 38, DSDP. Initial Rep. Deep Sea Drilling Project 38, 719-730.
Rasmussen, J. \& Noe-Nygaard, A. 1070: Geology of the Faeroe Islands. Danmarks geol. Unders. (I)25, $142 \mathrm{pp}$.

Ravn, J. P. J. 1933: New investigations of the Tertiary at Cape Dalton, East Greenland. Meddr Gronland 105(1), 15 pp.

Reed, S. J. B. \& Ware, N. G. 1975: Quantitative electron microprobe analysis of silicates using energy-dispersive $\mathrm{X}$ ray spectrometry. J. Petrology 16, 499-519.

Rex, D. C., Gledhill, A. R. \& Higgins, A. K. 1977: Precambrian $\mathrm{Rb}-\mathrm{Sr}$ isochron ages from the crystalline complexes of inner Forsblads Fjord, East Greenland fold belt. Rapp. Gronlands geol. Unders. 85, 122-126.

Rhodes, J. M. \& Dungan, M. A. 1979: The evolution of ocean-floor basaitic magmas. In Talwani, M., Harrison, C. G. \& Hayes, D. E. (edit.) Deep drilling results in the Atlantic Ocean: ocean crust. Amer. geophys. Un. Maurice Ewing Ser. 2, 262-272.

Rhodes, J. M., Dungan, M. A., Blanchard, D. P. \& Long, P. E. 1979: Magma mixing at mid-ocean ridges: evidence from basalts drilled near $22^{\circ} \mathrm{N}$ on the mid-Atlantic ridge. Tectonophysics 55, 3561 .

Richardson, C., Oakley, P. J. \& Cann, J. R. 1984: Trace and major element geochemistry of basalts from leg 81. Initial Rep. Deep Sea Drilling Project 81, 795-806.

Ridley, W. I., Perfit, M. R. \& Adams, M.-L. 1976: Petrology of basalts from Decp Sea Drilling Project, leg 38. Initial Rep. Deep Sea Drilling Project 38, 731-739.

Roberts, D. G., Backman, J, Morton, A. C., Murray, J. W. \& Keene, J. B. 1984: Evolution of volcanic rifted margins: synthesis of leg 81 results on the west margin of Rockall Plateau. Initial Rep. Deep Sea Drilling Project 81, 883-911.

Rock, N. M. S. 1977: The nature and origin of Jamprophyres: some definitions, distinctions, and derivations. Earth-Sci. Rev. 13, 123-169.

Roeder, P. L. \& Campbell, I. H. 1985: The effect of postcumulus reactions on composition of chrome-spinels from the Jimberlana intrusion. J. Petrology 26, 763-786.

Roeder. P. L. \& Emslie, R, F. 1970: Olivine-liquid equilibrium. Contr. Miner. Petrol. 29, 275-289.

Roeder, P. L., Campbell, I. H. \& Jamieson, H. E. 1979: A re-evaluation of the olivine-spinel geothermometer. Contr. Miner. Petrol. 68, 325-334.

Sack, R. O., Carmichael. 1. S. E., Rivers, M. \& Ghioso, M. S. 1980: Ferric-ferrous equilibria in natural silicate liquids at 1 bar. Contr. Miner. Petrol. 75, 369-376.

Saemundsson, K. 1978: Fissure swarms and central volcanoes of the neovolcanic zones in Iceland. Geol. J. Spec. Iss. 10, $415-432$.

Schilling, J.-G. 1973; Iceland mantle plume: geochemical study of Reykjanes Ridge. Nature, Lond. 242, 565-571.

Schilling, J.-G, 1976: Rare-earth, Sc, Cr, Fe, Co and Na abundances in DSDP leg 38 basement basaits: some additional evidence on the evolution of the Thulean Volcanic Province. Initial Rep. Deep Sea Drilling Project 38, 741-750.

Schilling, J.-G. 1986: Geochemical and isotopic variation along the Mid-Atlantic Ridge axis from $79^{\circ} \mathrm{N}$ to $0^{\circ} \mathrm{N}$. In Vogt, P. R. \& Tucholke, B. E. (edit.) The geology of North America, $M$. The western North Atlantic region, 137-156. Geological Society America. 
Schilling, J.-G. \& Noc-Nygaard, A. 1974: Faroe-Iceland plume: rare-earth evidence, Earth planet. Sci. Lett. 24, 1-14.

Schilling, J.-G.\& Sigurdsson, H. 1979: Thermal minima along the axis of the Mid-Atlantic Ridge. Nature, Lond. 282, 370375.

Schilling, J.-G., Zajac, M., Evans, R., Johnston, T., White, W., Devine, J. D. \& Kingsley. R. 1983: Petrologic and geochemical variations along the Mid-Atlantic ridge from $29^{\circ} \mathrm{N}$ to $73^{\circ} \mathrm{N}$. Amer. J. Sci. $283,510-586$.

Schweitzer, E. L., Papike, J. J. \& Bence, A. E. 1978: Clinopyroxenes from deep sea basalts: a statistical study. Geophys. Res. Lell. 5, 573576.

Scoresby, W. 1823: Journal of a voyage to the northern whalefishery: including researches and discoveries on the eastern coast of West Greenland, made in the summer of 1822, in the ship Baffin of Liverpool. 472 pp. Edinburgh: Constable.

Shervais,J. W. 1982: Ti-V plots and the petrogenesis of modern and ophiolitic lavas. Earth planet. Sci. Lett. 59, 101-118.

Shido, F., Miyastiiro, A. \& Ewing, M. 1971: Crystallization of abyssal tholeiites. Contr. Miner. Petrol. 31, 251-266.

Sigurdsson, H. J. 1981: First-order major element variation in basalt glasses from the Mid-Atlantic Ridge: $29^{\circ} \mathrm{N}$ to $73^{\circ} \mathrm{N}, J$. geophys. Res. 86, B10, 9483-9502.

Sigurdsson, H. \& Schilling, J.-G. 1976: Spinels in Mid-Atlantic Ridge basalts: chemistry and occurrence. Earth planet. Sci. Lett. 29, 7-20.

Sigurdsson. H. Schilling, J.-G. \& Meyer, P. S. 1978: Skagi and Langjökull volcanic zones in Iceland: 1. Petrology and structure. J. geophys. Res. 83, 3971-3982.

Simkin, T. \& Smith, J. V. 1970; Minor element distribution in olivine. J. Geol. 78, 304-325.

Skogseid. J. \& Eldholm, O. 1987: Early Cenozoic crust at the Norwegian continental margin and the conjugate Jan Mayen Ridge. J. geophys. Res. 92, B11, 11471.11491.

Smith, D. \& Lindsley, D. H. 1971a: Stable and metastable augite crystallization trends in a single basalt flow. Amer. Miner. 56, 225-233.

Smith, D. \& Lindsley, D. H. 1971b: Chemical variations in pyroxene and olivine from Picture Gorge basalt. $\mathrm{Yb}$. Carnegie Instn Wash. 69, 269-274.

Smythe, D. K. 1983: Faeroe-Shetland Escarpment and continental margin north of the Faeroes, In Bott, M. H. P., Saxov, S., Talwani, M. \& Thiede, J. (edit.) Structure and development of the Greenland-Scolland Ridge, 77-90. New York: Plenum Press.

Smythe, D. K., Chalmers, J. A., Skuce, A. G., Dobinson, A. \& Mould, A. S. 1983: Early opening history of the North Atlantic-I. Structure and origin of the Faeroe-Shetland escarpment. Geophys. J. R. astr. Soc. 72, 373-398.

Soper, N. J. \& Costa, L. I. 1976: Palynological evidence for the age of Tertiary basalts and post-basaltic sediments at Kap Dalton, central East Greenland. Rapp. Gronlands geol. Unders. 80, 123-127.

Soper, N. J., Downie, C., Higgins, A. C. \& Costa, L. I. 1976a: Biostratigraphic ages of Tertiary basalts on the east Greenland continental margin and their relationshio to plate separation in the northeast Atlantic. Earth planet. Sci. Lett. 32, 149-157.
Soper, N. J., Higgins, A. C., Downie, C., Matthews, D. W. \& Brown, P. E, 1976b: Late Cretaceous - carly Tertiary stratigraphy of the Kangerdlugssuaq area, east Greenland, and the age of opening of the north-east Atlantic. J. geol. Soc. Lond. 132, 85-104.

Sørensen, I. 1975: X-ray fluorescence spectrometry at GGU. Rapp. Gronlands geol. Unders. 75, 16-18.

Sparks, R, S. J. \& Huppert, H. E. 1984: Density changes during the fractional crystallization of basaltic magmas: fluid dynamic implications. Contr. Miner. Petrol. 85, 300-309.

Sparks, R. S. J., Meyer, P. \& Sigurdsson, H. 1980: Density variation amongst mid-ocean ridge basalts: implications for magma mixing and the scarcity of primitive lavas. Earth planet. Sci. Lett. 46, 419-430.

Sparks, R. S. J., Wilson, L. \& Sigurdsson, H. 1981: The pyroclastic deposits of the 1875 eruption of Askja, Iceland. Phil. Trans. R. Soc. Lond. A 299, 241-273.

Sparks, R. S. J., Huppert, H. E. \& Turner, J. S. 1984: The fluid dynamics of evolving magma chambers. Phil. Trans. $R$. Soc. Lond. A310, $511-534$.

Spencer, K. J. \& Lindsley, D. H. 1981: A solution model for coexisting iron-titanium oxides. Amer. Miner. 66, 1189 1201.

Stakes, D. S., Shervais, J. W. \& Hopson, C. A. 1984: The volcanic-tectonic cycle of the FAMOUS and AMAR valleys, Mid-Atlantic Ridge $\left(36^{\circ} 47^{\prime} \mathrm{N}\right)$ : evidence from basalt glass and phenocryst compositional variations for a steady state magma chamber beneath the valley midsections, AMAR 3 . J. geophys. Res. 89, B8, 6995-7028.

Staudigel, H., Zindler, A., Hart, S. R., Leslie, T., Chen, C. Y. \& Clague, D. 1984: The isotope systematics of a juvenile intraplate volcano: $\mathrm{Pb}, \mathrm{Nd}$ and $\mathrm{Sr}$ isotope ratios of basalts from the Loihi Seamount, Hawaii. Earth planet. Sci. Lert. 69, 13-29.

Sun, S. S., Nesbitt, R. W. \& Sharaskin, A. Y. 1979: Geochemical characteristics of mid-ocean ridge basalts. Earth planet. Sci. Lett. 44, 119-138.

Surlyk. F., Clemmensen, L. B. \& Larsen, H. C. 1981: PostPaleozoic evolution of the East Greenland continental margin. Mem. Can. Soc. Petrol. Geol. 7, 611-645.

Swanson. D. A., Wright, T. L. \& Helz, R. T. 1975: Linear vent systems and estimated rates of magma production and eruption for the Yakima basalt on the Columbia Plateau. Amer. J. Sci. 275, 877-905.

Talwani, M. \& Eldholm, O. 1977: Evolution of the Norwegian-Greenland Sea. Bull. geol. Soc. Amer. 88, 969-999.

Talwani, M. et al. 1976: Sites 346, 347, and 349. Initial Rep. Deep Sea Drilling Project 38, 521-594.

Talwani, M., Mutter, J. \& Eldholm, O. 1981: The initiation of opening of the Norwegian Sea. Oceanologica Acta 4, Supp., 23-30.

Tarling, D. H. 1967: The palaeomagnetic properties of some Tertiary lavas from East Greenland. Earth planet. Sci. Lett. 3, 81-88.

Tarling, D. H. \& Mitchell, J. G. 1976: Revised Cenozoic polarity time scale. Geology 4, 133-136.

Tarling, D. D., Hailwood, E. A. \& Lovlie, R. 1988: A palacomagnetic study of lower Tertiary lavas in E. Greenland and 
comparison with other lower Tertiary observations in the northern Atlantic. In Morton, A. C. \& Parson, L. M. (edit.) Early Tertiary volcanism and the opening of the NE Atlantic. Spec, Publ. geol. Soc. 39, 215-224.

Tatsumoto, M. 1978: Isotopic composition of lead in oceanic basalt and its implication to mantle evolution. Earth planet. Sci. Lett. 38, 63-87.

Terry, R. D. \& Chilingar, G. V. 1955: Summary of 'Concerning some additional aids in studying sedimentary formations' by M. S. Shvetsov. J. sedim. Petrol. 25, 229-234.

Thompson, R. N. 1973: Titanium chromite and chromian titanomagnetite from a Snake River Plain basalt, a terrestrial analogue to lunar spinels. Amer. Miner. 58, 826-830.

Thompson, R. N. 1982: Magmatism of the British Tertiary Volcanic Province. Scott. J. Geol. 18, 49-107.

Thompson, R. N. 1987: Phase-equilibria constraints on the genesis and magmatic evolution of oceanic basalts. EarthSci. Rev. 24, 161-210.

Thompson, R. N., Gibson, I. L., Marriner, G. F., Mattey, D. P. \& Morrison, M. A. 1980: Trace-element evidence of multistage mantle fusion and polybaric fractional crystallization in the Palaeocene lavas of Skye, NW Scotland. J. Petrology 21, 265-293.

Thompson, R. N., Dickin, A. P., Gibson, I. L. \& Morrison, M. A. 1982: Elemental fingerprints of isotopic contamination of Hebridean Palaeocene mantle-derived magmas by Archaean sial. Contr. Miner. Petrol. 79, 159-168.

Thompson, R. N., Morrison, M. A., Dickin, A. P. \& Hendry, G. L. 1983: Continental flood basalts ... Arachnids rule OK? In Hawkesworth, C. J. \& Norry, M. J. (edit.) Continental basalts and mantle xenoliths, 158-185. Cheshire: Shiva Publ. Ltd.

Thompson, R. N., Morrison, M. A., Hendry, G. L. \& Parry, S. J. 1984: An assessment of the relative roles of crust and mantle in magma genesis: an elemental approach. Phil. Trans. R. Soc. Lond. A310, 549-590.

Thy, P. 1983: Spinel minerals in transitional and alkali bașaltic glass from Iceland. Contr. Miner. Perrol. 83, 141-149.

Upton, B. G. J. \& Wadsworth, W. J. 1972: Aspects of magmatic evolution of Reunion Island. Phil. Trans. R. Soc. Lond. A, 271, 105-130.

Upton, B. G. J., Emeleus, C. H. \& Hald, N, 1980: Tertiary volcanism in northern $\mathrm{E}$ Greenland: Gauss Halvø amd Hold with Hope. J. geol. Soc. Lond. 137, 491-508.

Upton, B. G. J., Emeleus, C. H. \& Beckinsale, R. D. 1984: Petrology of the northern East Greenland Tertiary flood basalts: evidence from Hold with Hope and Wollaston Forland. J. Petrology 25, 151-184.

Viereck, L, G., Taylor, P. N., Parson, L. M., Morton, A. C., Hertogen, J., Gibson, I. L. \& the ODP Leg 104 Scientific Party 1988: Origin of the Palaeogene Voring Plateau Volcanique sequence, In Morton, A. C. \& Parson, L. M. (edit.) Early Tertiary volcanism and the opening of the NE Atlantic. Spec. Publ. geol. Soc. 39, 69-83.

Vink, G. E. 1984: A hotspot model for Iceland and the Vøring Plateau. J. geophys. Res. 89, B12, 9949-9959.

Vogt, P. R. 1974: The Iceland phenomenon: imprints of a hot spot on the ocean crust, and implications for flow below the plates. In Kristjansson, L. (edit.) Geodynamics of Iceland and the North Atlantic area, 105-126. Dordrecht: D. Reidel Publ. Comp.

Waagstein, R. 1988: Structure, composition and age of the Facroe basalt plateau. In Morton, A. C. \& Parson, L. M. (edit.) Early Tertiary volcanism and the opening of the NE Atlantic. Spec. Publ. geol. Soc. 39, 225-238.

Waagstein, R. \& Hald, N. 1984: Structure and petrography of a $660 \mathrm{~m}$ lava sequence from the Vestmanna-1 drill hole, lower and middle basalt series, Faeroe Islands. In Berthelsen, $\mathrm{O}$., Noe-Nygaard, A. \& Rasmussen, J. (edit.) The deep drilling project $1980-81$ in the Faeroe Islands. Ann. Soc. Sci. Faeroensis $1984,39-70$.

Wager, L. R. 1934: Geological investigations in East Greenland. Part I. General geology from Angmagsalik to Kap Dalton. Meddr Gronland 105(2) $46 \mathrm{pp}$.

Wager, L. R. 1935: Geological investigations in East Greenland, Part II: geology of Kap Dalton. Meddr Gronland 105 (3), $32 \mathrm{pp}$.

Wager, L. R. 1935: Geological investigations in East Greenland. Part II: Geology of Kap Dalton. Meddr Gronland 105(3), $32 \mathrm{pp}$. Grønland 134(5), $64 \mathrm{pp}$.

Walker, D., Shibata, T. \& Delong, S. E. 1979: Abyssal tholeiites from the oceanographer Fracture zone II. Phase equilibria and mixing. Contr. Miner. Petrol. 70, 111-125.

Walker, G. P. L. 1960; Zeolite zones and dike distribution in relation to the structure of the basalts of eastern Iceland. $J$. Geol. 68, 515-528.

Watkins, N. D. \& Haggerty, S. E. 1967: Primary oxidation variation and petrogenesis in a single lava. Contr. Miner. Petrol. 15, 251-271.

Watson, E. B. 1982: Basalt contamination by continental crust: some experiments and models. Contr. Miner. Petrol. 80, 73-87.

Watt, M. 1975: Photo-reconnaissance of the Blossevilie Kyst between Steward $\varnothing$ and Søkongens Bugt, central East Greenland. Rapp. Gronlands geol. Unders. 75, 91-95.

Watt, W. S. 1969: The Tertiary basalts of Scoresby Sund, a preliminary report. Rapp. Gronlands geol Unders. 21, 36-40.

Watt, W. S. \& Watt, M. 1971: Preliminary report of the mapping of the basalts of parts of Milne Land and Găseland. Rapp. Grønlands geol. Unders. 37, 42-50.

Watt, W. S. \& Watt, M. 1973: Preliminary report on the mapping of the basalts of the inner part of Scoresby Sund. Rapp. Gronlands geol. Unders. 58, 37-42.

Watt, W. S. \& Watt, M. 1979: Mapping of Tertiary basalts on the northern Blosseville Kyst, East Greenland. Rapp. Gronlands geol. Unders. 95, 85-86.

Watt, S. \& Watt, M. 1983: Stratigraphy of the basalts of Savoia Halvø, central East Greenland. Rapp. Grønlands geol. Unders. 115, 83-88.

Watt, W. S. \& Wrang, P. 1984: Migrated hydrocarbons in basalt on the south side of Scoresby Sund. Rapp. Grønlands geol. Unders. 120, 84-85.

Watt, W. S., Emeleus, C. H. \& Watt, M. 1972: Preliminary report on the basalts of Volquart Boons Kyst, East Greenland. Rapp. Gronlands geol. Unders. 48, 75-83. 
Watt, W. S., Soper, N. J. \& Watt, M. 1976: Reconnaissance mapping of the northern Blosseville Kyst between Kap Brewster and Kap Dalton, central East Greenland. Rapp. Grønlands geol. Unders. 80, 120-122.

Watt, W. S., Larsen, L. M. \& Watt, M. 1986: Volcanic history of the Lower Tertiary plateau basalts in the Scoresby Sund region, East Greenland. Rapp. Gronlands geol. Unders. 128, 147-156.

Weaver, B. L. \& Tarney, J. 1983: Chemistry of the sub-continental mantle: inferences from Archaean and Proterozoic dykes and continental flood basalts. In Hawkesworth, C. J. \& Norry, M. J. (edit.) Continental basalts and mantle xenoliths, 209-229. Cheshire: Shiva Publ. Ltd.

Wenk, E. 1961: On the crystalline basement and the basal part of the pre-Cambrian Eleonore Bay group in the southwestem part of Scoresby Sund. Meddr Gronland 168(1), 54 pp.

White, R. S. 1988: A hot-spot model for early Tertiary volcanism in the N Atlantic. In Morton, A. C. \& Parson, L. M. (edit.) Early Tertiary volcanism and the opening of the NE Atlantic. Spec. Publ. geol. Soc. 39, 3-13.

White, R. S., Spence, G. D., Fowler, S. R., Mckenzie, D. P., Westbrook, G. K. \& Bowen, A. N. 1987: Magmatism at rifted continental margins. Nature, Lond. 330, 439-444.
Wood, D. A. 1978: Major and trace element variations in the Tertiary lavas of eastern Iceland and their significance with respect to the Iceland geochemical anomaly. J. Petrology 19, $393-436$.

Wood, D. A. 1979: Dynamic partial melting: its application to the petrogenesis of basalts erupted in Iceland, the Faeroe Islands, the Isle of Skye (Scotland) and the Troodos Massif (Cyprus). Geochim. cosmochim. Acta 43, 1031-1046.

Wood, D. A., Gibson, I. L. \& Thompson, R. N. 1976: Elemental mobility during zeolite facies metamorphism of the Tertiary basalts of Eastern Iceland. Contr. Miner. Petrol. 55, 241-254.

Wood, D. A., Joron, J.-L., Treuil, M., Norry, M. \& Tarney, J. 1979: Elemental and $\mathrm{Sr}$ isotope variations in basic lavas from Iceland and the surrounding ocean floor. Contr. Miner. Petrol. 70, 319-339.

Wright, T. L. 1974: Presentation and interpretation of chemical data for igneous rocks. Contr. Miner. Petrol. 48, 233248.

Wright, T. L. \& Doherty, P. C. 1970: A linear programming and least squares computer method for solving petrological mixing problems. Bull. geol. Soc. Amer. 81, 1995-2008. 


\section{APPENDIX 1}

Location of type profiles, reference profiles, and other profiles with analysed samples

\begin{tabular}{|c|c|c|c|c|}
\hline Profile & Map sheet & Latitude & Longitude & Name \\
\hline I & 7002 & $70.068^{\circ} \mathrm{N}$ & $26.682^{\circ} \mathrm{W}$ & basalt valley, E Gáseland \\
\hline iv & 7002 & $70.167^{\circ} \mathrm{N}$ & $26.203^{\circ} \mathrm{W}$ & Sydbra \\
\hline V & $70 \emptyset 2$ & $70.223^{\circ} \mathrm{N}$ & $26.250^{\circ} \mathrm{W}$ & outer Sydbræ \\
\hline VII & 690 & $69.858^{\circ} \mathrm{N}$ & $27.208^{\circ} \mathrm{W}$ & Levynitfjeld, W. Magga Dan Gletscher \\
\hline VIII & 7002 & $70.367^{\circ} \mathrm{N}$ & $25.407^{\circ} \mathrm{W}$ & Tanderne \\
\hline 8 & 7062 & $70.813^{\circ} \mathrm{N}$ & $25.837^{\circ} \mathrm{W}$ & NE Milne Land \\
\hline 13 & 7002 & $70.618^{\circ} \mathrm{N}$ & $26.093^{\circ} \mathrm{W}$ & S Milne Land \\
\hline 16 & 7002 & $70.325^{\circ} \mathrm{N}$ & $26.858^{\circ} \mathrm{W}$ & Knakket \\
\hline 21 & 7002 & $70.222^{\circ} \mathrm{N}$ & $25.135^{\circ} \mathrm{W}$ & Bredegletscher \\
\hline 27 & 7002 & $70.608^{\circ} \mathrm{N}$ & $26.207^{\circ} \mathrm{W}$ & S Milne Land \\
\hline 28 & 7002 & $70.608^{\circ} \mathrm{N}$ & $26.207^{\circ} \mathrm{W}$ & S Milne Land \\
\hline 37 & 7003 & $70.307^{\circ} \mathrm{N}$ & $28.437^{\circ} \mathrm{W}$ & Hjørnedal \\
\hline 38 & 7003 & $70.300^{\circ} \mathrm{N}$ & $28.063^{\circ} \mathrm{W}$ & central Gâseland \\
\hline 39 & 7003 & $70.305^{\circ} \mathrm{N}$ & $27.878^{\circ} \mathrm{W}$ & central Gâseland \\
\hline 44 & 7002 & $70.042^{\circ} \mathrm{N}$ & $24.208^{\circ} \mathrm{W}$ & Skratenterne \\
\hline 47 & 7002 & $70.252^{\circ} \mathrm{N}$ & $24.513^{\circ} \mathrm{W}$ & below Spiret \\
\hline 48 & 7002 & $70.252^{\circ} \mathrm{N}$ & $24.942^{\circ} \mathrm{W}$ & peak $1290, S$ of Terrassevig \\
\hline 51 & 7001 & $70.1^{\circ} \mathrm{N}$ & $23.52^{\circ} \mathrm{W}$ & Ostre Borggletscher \\
\hline 52 & 7002 & $70.253^{\circ} \mathrm{N}$ & $25.888^{\circ} \mathrm{W}$ & W of Tænderne \\
\hline 55 & 7002 & $70.065^{\circ} \mathrm{N}$ & $26.118^{\circ} \mathrm{W}$ & upper Sydbrae \\
\hline 59 & $70 \subseteq 2$ & $70.172^{\circ} \mathrm{N}$ & $26.993^{\circ} \mathrm{W}$ & Ravebrac \\
\hline 63 & 690 & $69.967^{\circ} \mathrm{N}$ & $28.03^{\circ} \mathrm{W}$ & $\mathrm{S}$ of Gåsefjord \\
\hline 65 & 690 & $69.948^{\circ} \mathrm{N}$ & $28.485^{\circ} \mathrm{W}$ & $\mathrm{S}$ of Gàsefjord \\
\hline 71 & 7063 & $70.167^{\circ} \mathrm{N}$ & $30.513^{\circ} \mathrm{W}$ & westernmost nunatak \\
\hline 72 & 7063 & $70.093^{\circ} \mathrm{N}$ & $29.598^{\circ} \mathrm{W}$ & western nunatak \\
\hline 74 & 7002 & $70.172^{\circ} \mathrm{N}$ & $25.257^{\circ} \mathrm{W}$ & W Brcdegletscher \\
\hline 76 & 690 & $69.88^{\circ} \mathrm{N}$ & $26.95^{\circ} \mathrm{W}$ & E Magga Dan Gletscher \\
\hline 77 & 690 & $69.47^{\circ} \mathrm{N}$ & $29.57^{\circ} \mathrm{W}$ & Gronau Nunatakker \\
\hline 78 & 690 & $69.40^{\circ} \mathrm{N}$ & $29.55^{\circ} \mathrm{W}$ & Gronau Nunatakker \\
\hline 91 & 6901 & $69.462^{\circ} \mathrm{N}$ & $24.163^{\circ} \mathrm{W}$ & below sediments at Kap Dalton \\
\hline $94 \mathrm{a}$ & 6901 & $69.414^{\circ} \mathrm{N}$ & $24.142^{\circ} \mathrm{W}$ & S side of Kap Dalton \\
\hline 102 & 6901 & $69.798^{\circ} \mathrm{N}$ & $23.870^{\circ} \mathrm{W}$ & head of Rømer Fjord \\
\hline 103 & 6901 & $69.758^{\circ} \mathrm{N}$ & $23.857^{\circ} \mathrm{W}$ & head of Romer Fjord \\
\hline 104 & $690 !$ & $69.857^{\circ} \mathrm{N}$ & $24.070^{\circ} \mathrm{W}$ & Bartholin Brze \\
\hline 105 & 6901 & $69.773^{\circ} \mathrm{N}$ & $23.905^{\circ} \mathrm{W}$ & inner Rømer Fjord \\
\hline 106 & 6901 & $69.790^{\circ} \mathrm{N}$ & $23.868^{\circ} \mathrm{W}$ & inner Rømer Fjord \\
\hline 108 & 6901 & $69.482^{\circ} \mathrm{N}$ & $24.413^{\circ} \mathrm{W}$ & Kap Dalion valley \\
\hline 114 & 6901 & $69.932^{\circ} \mathrm{N}$ & $23.313^{\circ} \mathrm{W}$ & N of Manby Halvo \\
\hline 111 & $69 \emptyset 1$ & $69,932^{\circ} \mathrm{N}$ & $24.110^{\circ} \mathrm{W}$ & Kap Dalton east of graben \\
\hline 112 & 6901 & $69.512^{\circ} \mathrm{N}$ & $24.378^{\circ} \mathrm{W}$ & head of Kap Dalton valley \\
\hline 117 & 6901 & $69.993^{\circ} \mathrm{N}$ & $23.963^{\circ} \mathrm{W}$ & Pyramiden \\
\hline 126 & 7001 & $70.130^{\circ} \mathrm{N}$ & $22.258^{\circ} \mathrm{W}$ & Sostrene, Savoia Halvo \\
\hline 129 & 7001 & $70,142^{\circ} \mathrm{N}$ & $22.197^{\circ} \mathrm{W}$ & Kastcllet, Savoia Halvo \\
\hline
\end{tabular}




\section{APPENDIX 2}

$\begin{array}{ll}\text { MF } & \text { Magga Dan Formalion } \\ \text { MLF } & \text { Milne Land Formation } \\ \text { GF } & \text { Gtikic Platesu Formation } \\ \text { Mikis } & \text { Mixis type } \\ \text { Hjarn } & \text { Hjernedal masker type } \\ \text { MORB } & \text { MORB fype } \\ \text { h-Si } & \text { high sitica } \\ & \\ \text { na } & \text { not anslysed }\end{array}$

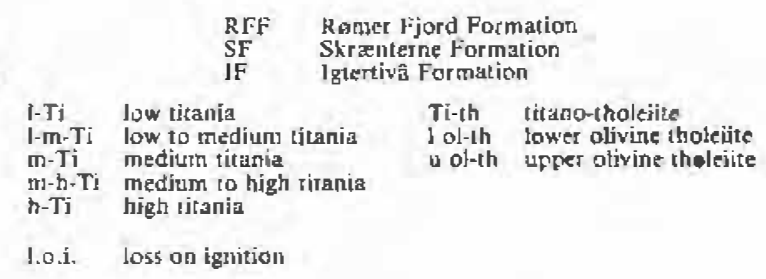

\begin{tabular}{|c|c|c|c|c|c|c|c|c|c|c|c|c|c|c|}
\hline \multirow{5}{*}{$\begin{array}{l}\text { Profiles } \\
\text { Forrtiation } \\
\text { Type } \\
\text { Height m } \\
\text { GGU No. }\end{array}$} & \multirow{2}{*}{$\frac{I}{M L F}$} & \multirow{2}{*}{$\frac{I V}{M L F}$} & \multirow{2}{*}{$\frac{\downarrow}{M L F}$} & \multirow{2}{*}{$\frac{V I I}{\text { REF }}$} & \multirow{2}{*}{$\frac{\text { FIII }}{\text { MLE }}$} & \multirow{2}{*}{$\frac{\boldsymbol{s}}{\mathrm{MLF}}$} & \multirow{2}{*}{$\frac{\delta}{M L F}$} & \multirow{2}{*}{$\frac{\text { /3 }}{\text { ML.F }}$} & \multicolumn{2}{|c|}{65 near 38} & \multicolumn{4}{|c|}{ Profile 16 - Knakket } \\
\hline & & & & & & & & & $M F$ & MF & MLF & MLF & MILF & MILF \\
\hline & Mikis & $m-T i$ & Mikiki & MORB & Mixis & $h-T i$ & Hjorn & Ti-th & $h-S i$ & $h \cdot S i$ & Mikis & Mikis & $H_{j k+1} n$ & h. Si \\
\hline & & 240 & & 1455 & & 3240 & 1270 & & 845 & 1237 & 810 & 836 & 843 & 874 \\
\hline & 96110 & 96185 & 96205 & 96272 & 96325 & 96403 & 96404 & 96455 & 98788 & 96928 & 96487 & 96484 & 960457 & 96460 \\
\hline $\mathrm{SiO}_{\mathrm{T}}$ & 4788 & $478 \mathrm{I}$ & 4805 & 4757 & 4829 & 490 & 4922 & d7 99 & 5479 & 5265 & 4798 & 4726 & 4846 & 5009 \\
\hline TiO & 260 & 255 & 238 & 152 & 239 & 306 & 225 & 386 & 161 & 193 & 231 & 232 & 223 & $24 k$ \\
\hline $\mathrm{Al}_{3} \mathrm{O}_{i}$ & 1264 & 1425 & 12.12 & 1629 & 1219 & 1368 & 1444 & 1347 & 1397 & 1283 & 12.19 & 1205 & 1424 & 1363 \\
\hline Eod, & 508 & 1064 & 3.83 & 468 & 458 & 332 & 314 & 498 & 291 & 1.45 & 398 & 292 & 534 & $\{13$ \\
\hline Fee & 7.41 & 257 & 8.28 & 673 & 756 & 919 & 804 & 982 & 743 & 920 & 826 & 906 & 613 & 750 \\
\hline $\mathrm{MnO}$ & 016 & 016 & 017 & 018 & 017 & 018 & 016 & 020 & na & $\mathrm{na}$ & 017 & 18 & ก & חан \\
\hline $\mathrm{MgO}$ & 908 & 605 & 1096 & 713 & $106]$ & 653 & 759 & 560 & 5.84 & 777 & 1112 & 10) 94 & 716 & 679 \\
\hline $\mathrm{CaO}$ & 974 & 1032 & 34 & $116 \mathrm{i}$ & 942 & 1062 & 1098 & 1020 & 888 & 9.23 & y53 & 888 & 1078 & 1027 \\
\hline $\mathrm{Na}, \mathrm{O}$ & 209 & 257 & 201 & 201 & 211 & 235 & 206 & 237 & 235 & 230 & 191 & 234 & 213 & 224 \\
\hline$k, 0$ & 033 & 061 & 043 & (1) 10 & 040 & (1) 38 & 015 & 021 & 678 & $0 \$ 2$ & 031 & 70 & 0.37 & 060 \\
\hline $\mathrm{P}$ & 026 & 027 & $\bullet 23$ & 13 & 023 & - 30 & 021 & $0 \neq 0$ & 15 & 0.20 & 023 & 023 & 021 & 023 \\
\hline I.0.i. & 185 & 173 & 188 & 212 & $\frac{1.91}{10}$ & $10 B$ & 138 & 156 & 202 & 126 & 321 & 378 & 271 & 218 \\
\hline & $\overline{9915}$ & 99.53 & 9968 & 100107 & $\overline{9986}$ & 99.59 & $\overline{9962}$ & 9976 & 4973 & 9965 & 10020 & 1666 & 9976 & 10107 \\
\hline
\end{tabular}

\begin{tabular}{|c|c|c|c|c|c|c|c|c|c|c|c|c|c|c|c|}
\hline $\begin{array}{l}\text { Fotmation } \\
\text { Type } \\
\text { Height m } \\
\text { GGL No. }\end{array}$ & $\begin{array}{r}\text { MLF } \\
H_{1}-\mathrm{Ti} \\
907 \\
96461\end{array}$ & $\begin{array}{r}\text { MLF } \\
\text { Ti-1h } \\
916 \\
96462\end{array}$ & $\begin{array}{r}\text { NII.F } \\
\text { M.Ti } \\
993 \\
96464\end{array}$ & $\begin{array}{r}\text { GFF } \\
\text { Ti-ch } \\
1036 \\
9,465\end{array}$ & $\begin{array}{r}\text { GF } \\
5 \text { irth } \\
1070 \\
96466\end{array}$ & $\begin{array}{r}G F \\
\mathrm{~h}-\mathrm{Ti} \\
1092 \\
96467\end{array}$ & $\begin{array}{r}\text { GF } \\
k 1-T i \\
1152 \\
96469\end{array}$ & $\begin{array}{r}\text { GF } \\
\mathrm{m}+\mathrm{Ti} \\
1176 \\
96470\end{array}$ & $\begin{array}{r}\text { GF } \\
\text { In-Ti } \\
1252 \\
96473\end{array}$ & $\begin{array}{r}\mathrm{GF} \\
\mathrm{m}-\mathrm{Ti} \\
1288 \\
96474\end{array}$ & $\begin{array}{r}\text { CF } \\
m-T i \\
1301 \\
96475\end{array}$ & $\begin{array}{r}\mathrm{GF} \\
\mathrm{m-Ti} \\
1320 \\
96476\end{array}$ & $\begin{array}{r}\text { Gr } \\
\text { I- } 17-17 \\
1345 \\
96477\end{array}$ & $\begin{array}{r}G F \\
1-m-\mathrm{Ti} \\
1396 \\
96479\end{array}$ & $\begin{array}{r}\mathrm{GF} \\
\mathrm{I}-\mathrm{m}-\mathrm{T} i \\
1431 \\
96480\end{array}$ \\
\hline 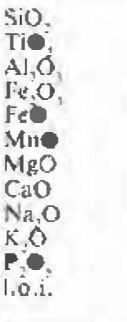 & $\begin{array}{r}4872 \\
285 \\
1379 \\
847 \\
419 \\
173 \\
551 \\
71 \\
232 \\
673 \\
027 \\
281 \\
9936\end{array}$ & $\begin{array}{r}48.44 \\
383 \\
1242 \\
415 \\
1138 \\
n a \\
529 \\
951 \\
243 \\
043 \\
039 \\
168 \\
9995\end{array}$ & $\begin{array}{r}48.66 \\
242 \\
1438 \\
473 \\
768 \\
113 \\
623 \\
1075 \\
229 \\
0.28 \\
020 \\
226 \\
99.81\end{array}$ & $\begin{array}{r}4737 \\
364 \\
1290 \\
526 \\
8.95 \\
074 \\
617 \\
1014 \\
236 \\
041 \\
037 \\
197 \\
9954\end{array}$ & $\begin{array}{r}4732 \\
362 \\
1242 \\
715 \\
786 \\
119 \\
574 \\
1020 \\
239 \\
0.39 \\
035 \\
245 \\
9989\end{array}$ & $\begin{array}{r}47.42 \\
275 \\
1366 \\
667 \\
648 \\
024 \\
732 \\
982 \\
198 \\
095 \\
0.23 \\
250 \\
10002\end{array}$ & $\begin{array}{r}4782 \\
277 \\
1358 \\
491 \\
821 \\
113 \\
678 \\
1095 \\
215 \\
027 \\
027 \\
253 \\
00124\end{array}$ & $\begin{array}{r}4803 \\
246 \\
1406 \\
505 \\
769 \\
\text { 119 } \\
663 \\
1087 \\
324 \\
0.39 \\
024 \\
210 \\
9976\end{array}$ & $\begin{array}{r}4832 \\
237 \\
1395 \\
435 \\
776 \\
n 1 \\
704 \\
1096 \\
239 \\
032 \\
023 \\
250 \\
1004\end{array}$ & $\begin{array}{r}4633 \\
232 \\
1351 \\
381 \\
855 \\
03 \\
742 \\
1042 \\
252 \\
037 \\
023 \\
433 \\
5981\end{array}$ & $\begin{array}{r}4851 \\
247 \\
1366 \\
494 \\
823 \\
119 \\
637 \\
1137 \\
243 \\
927 \\
024 \\
180 \\
00329\end{array}$ & $\begin{array}{r}4797 \\
237 \\
1360 \\
469 \\
8.33 \\
112 \\
665 \\
1143 \\
234 \\
038 \\
023 \\
174 \\
9073\end{array}$ & $\begin{array}{r}4846 \\
228 \\
1359 \\
526 \\
766 \\
713 \\
682 \\
1139 \\
236 \\
044 \\
021 \\
168 \\
10015\end{array}$ & $\begin{array}{r}4730 \\
2.25 \\
13.61 \\
525 \\
761 \\
119 \\
694 \\
1127 \\
207 \\
041 \\
021 \\
306 \\
9998\end{array}$ & $\begin{array}{r}4811 \\
226 \\
1372 \\
653 \\
661 \\
70 \\
705 \\
1135 \\
2.36 \\
0.42 \\
020 \\
1.67 \\
100.23\end{array}$ \\
\hline
\end{tabular}

Profile 21

Profile 27 and 28 - southern Milne Land

\begin{tabular}{|c|c|c|c|c|c|c|c|c|c|c|c|c|c|}
\hline $\begin{array}{l}\text { Formation } \\
\text { Type } \\
\text { Heighu in } \\
\text { GCiU No. }\end{array}$ & $\begin{array}{r}G \overline{1} \\
1-\mathrm{m}-\mathrm{Ii} \\
147 \\
96481\end{array}$ & $\begin{array}{r}G F \\
1-m-T i \\
1+75 \\
96483\end{array}$ & $\begin{array}{r}\text { RFE? } \\
\mathrm{m}-\mathrm{Ti} \\
780 \\
96550\end{array}$ & $\begin{array}{r}\text { RFT } \\
\text { h-Ti } \\
1156 \\
96562\end{array}$ & $\begin{array}{r}\text { MIf } \\
\text { Ti-Lh } \\
981 \\
96656\end{array}$ & $\begin{array}{c}\text { MIEF } \\
h-T i \\
1052 \\
9665 \%\end{array}$ & $\begin{array}{r}\text { ML.F } \\
h \cdot T i \\
1079 \\
96661\end{array}$ & $\begin{array}{r}\text { MLF } \\
\text { Hjarn } \\
1124 \\
96662\end{array}$ & $\begin{array}{r}\text { MLF } \\
h-T i \\
1154 \\
96603\end{array}$ & $\begin{array}{r}\text { MLF } \\
\text { Ti-1h } \\
1163 \\
96666\end{array}$ & $\begin{array}{r}\text { MLF } \\
M . T i \\
1174 \\
96667\end{array}$ & $\begin{array}{r}M L F \\
h \cdot T i \\
1183 \\
96668\end{array}$ & $\begin{array}{c}\mathrm{MLI} \\
\mathrm{mLi}-\mathrm{Ii} \\
1254 \\
96639\end{array}$ \\
\hline 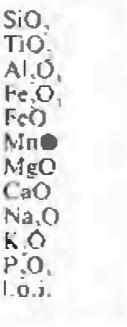 & $\begin{array}{r}4580 \\
216 \\
1411 \\
476 \\
765 \\
1924 \\
707 \\
1155 \\
152 \\
031 \\
019 \\
460 \\
99106\end{array}$ & $\begin{array}{r}4826 \\
226 \\
1355 \\
658 \\
633 \\
04 \\
664 \\
1123 \\
233 \\
041 \\
121 \\
195 \\
9975\end{array}$ & $\begin{array}{r}4760 \\
233 \\
1362 \\
400 \\
912 \\
620 \\
699 \\
1113 \\
208 \\
047 \\
622 \\
2.00 \\
9976\end{array}$ & $\begin{array}{r}4775 \\
286 \\
1387 \\
301 \\
872 \\
020 \\
602 \\
1116 \\
239 \\
135 \\
028 \\
120 \\
4966\end{array}$ & $\begin{array}{r}4854 \\
360 \\
1323 \\
349 \\
1043 \\
732 \\
579 \\
103 \\
213 \\
045 \\
0.35 \\
171 \\
9993\end{array}$ & $\begin{array}{r}4803 \\
294 \\
1368 \\
398 \\
815 \\
593 \\
674 \\
1048 \\
222 \\
924 \\
028 \\
279 \\
9953\end{array}$ & $\begin{array}{r}4834 \\
396 \\
1394 \\
191 \\
831 \\
74 \\
646 \\
1048 \\
224 \\
027 \\
029 \\
263 \\
4383\end{array}$ & $\begin{array}{r}4898 \\
223 \\
1929 \\
334 \\
768 \\
03 \\
731 \\
1085 \\
217 \\
023 \\
021 \\
257 \\
9986\end{array}$ & $\begin{array}{r}4819 \\
295 \\
1398 \\
611 \\
640 \\
513 \\
607 \\
1006 \\
237 \\
024 \\
028 \\
324 \\
9989\end{array}$ & $\begin{array}{r}4875 \\
368 \\
1466 \\
496 \\
826 \\
620 \\
455 \\
987 \\
273 \\
1149 \\
633 \\
112 \\
9960\end{array}$ & $\begin{array}{r}4895 \\
307 \\
1344 \\
674 \\
637 \\
n a \\
623 \\
983 \\
240 \\
032 \\
32 \\
219 \\
9986\end{array}$ & $\begin{array}{r}4875 \\
295 \\
1409 \\
481 \\
753 \\
119 \\
609 \\
1024 \\
242 \\
028 \\
077 \\
283 \\
\text { Dा26 }\end{array}$ & $\begin{array}{r}48.48 \\
2.39 \\
1416 \\
439 \\
810 \\
19 \\
599 \\
1110 \\
240 \\
037 \\
023 \\
210 \\
952\end{array}$ \\
\hline
\end{tabular}




\begin{tabular}{|c|c|c|c|c|c|c|c|c|c|c|c|c|c|}
\hline $\begin{array}{l}\text { Formation } \\
\text { Type } \\
\text { Height m } \\
\text { GGU No. }\end{array}$ & $\begin{array}{r}\text { MLF } \\
\text { h-Ti } \\
1301 \\
96631\end{array}$ & $\begin{array}{r}\text { MLF } \\
\text { h.Ti } \\
1328 \\
96633\end{array}$ & $\begin{array}{r}\text { MLF } \\
\text { h-Ti } \\
1350 \\
96634\end{array}$ & $\begin{array}{r}\text { GF } \\
\text { Ti-th } \\
1370 \\
96636\end{array}$ & $\begin{array}{r}\text { GF } \\
\text { Ti-th } \\
1391 \\
96637\end{array}$ & $\begin{array}{r}\text { GF } \\
\text { h-Ti } \\
1395 \\
96638\end{array}$ & $\begin{array}{r}\text { GF } \\
\text { m-Ti } \\
1502 \\
96641\end{array}$ & $\begin{array}{r}\mathrm{GF} \\
\mathrm{m}-\mathrm{Ti} \\
1560 \\
96642\end{array}$ & $\begin{array}{r}\mathrm{GF} \\
\mathrm{m}-\mathrm{Ti} \\
1625 \\
96645\end{array}$ & $\begin{array}{r}\mathrm{GF} \\
\mathrm{m}-\mathrm{Ti} \\
\mathrm{I} 638 \\
96647\end{array}$ & $\begin{array}{r}\mathrm{GF} \\
1-\mathrm{m}-\mathrm{Ti} \\
1658 \\
96649\end{array}$ & $\begin{array}{r}\text { GF } \\
\mathrm{I}-\mathrm{m}-\mathrm{Ti} \\
1678 \\
9665 \mathrm{I}\end{array}$ & $\begin{array}{r}\mathrm{GF} \\
1-\mathrm{m}-\mathrm{Ti} \\
1706 \\
96653\end{array}$ \\
\hline $\begin{array}{l}\mathrm{SiO}_{2} \\
\mathrm{TiO}_{2} \\
\mathrm{Al}_{2} \mathrm{O}_{3} \\
\mathrm{Fe}_{2} \mathrm{O}_{3} \\
\mathrm{FeO} \\
\mathrm{MnO} \\
\mathrm{MgO} \\
\mathrm{CaO} \\
\mathrm{Na}_{2} \mathrm{O} \\
\mathrm{K}_{2} \mathrm{O} \\
\mathrm{P}_{2} \mathrm{O} \\
1.0 .1\end{array}$ & $\begin{array}{r}48.68 \\
279 \\
13.65 \\
484 \\
808 \\
\text { na } \\
661 \\
1086 \\
248 \\
027 \\
028 \\
170 \\
10024\end{array}$ & $\begin{array}{r}4830 \\
280 \\
13.50 \\
430 \\
8.56 \\
\text { na } \\
665 \\
1086 \\
2.45 \\
0.26 \\
0.26 \\
1.97 \\
99.91\end{array}$ & $\begin{array}{r}4657 \\
2.95 \\
1257 \\
5.22 \\
844 \\
\mathrm{na} \\
7.07 \\
10.13 \\
2.33 \\
0.37 \\
0.29 \\
427 \\
10021\end{array}$ & $\begin{array}{r}47.12 \\
3.58 \\
12.97 \\
5.64 \\
8.36 \\
\text { na } \\
6.02 \\
10.48 \\
2.37 \\
031 \\
0.35 \\
\frac{2.29}{99.49}\end{array}$ & $\begin{array}{r}45.12 \\
3.67 \\
13.48 \\
11.15 \\
3.50 \\
0.19 \\
5.86 \\
8.86 \\
308 \\
0.62 \\
032 \\
3.71 \\
99.56\end{array}$ & $\begin{array}{r}48.57 \\
3.21 \\
1367 \\
4.43 \\
882 \\
\mathrm{na} \\
673 \\
10.62 \\
2.53 \\
039 \\
033 \\
1.27 \\
10057\end{array}$ & $\begin{array}{r}4756 \\
237 \\
1397 \\
489 \\
769 \\
\text { na } \\
7.10 \\
1095 \\
2.18 \\
033 \\
0.21 \\
246 \\
9971\end{array}$ & $\begin{array}{r}4748 \\
242 \\
13.73 \\
452 \\
7.71 \\
\text { na } \\
638 \\
1134 \\
206 \\
035 \\
023 \\
379 \\
10001\end{array}$ & $\begin{array}{r}4709 \\
2.42 \\
13.44 \\
5.95 \\
7.34 \\
\text { na } \\
6.31 \\
1122 \\
2.11 \\
0.27 \\
0.23 \\
346 \\
9984\end{array}$ & $\begin{array}{r}4764 \\
240 \\
1356 \\
484 \\
827 \\
\text { na } \\
662 \\
1144 \\
220 \\
030 \\
0.24 \\
226 \\
9977\end{array}$ & $\begin{array}{r}47.30 \\
2.19 \\
13.77 \\
4.73 \\
7.81 \\
\text { na } \\
7.09 \\
11.64 \\
2.05 \\
0.24 \\
0.20 \\
2.72 \\
99.74\end{array}$ & $\begin{array}{r}4682 \\
214 \\
1373 \\
546 \\
692 \\
\text { na } \\
686 \\
11.66 \\
191 \\
023 \\
020 \\
403 \\
9996\end{array}$ & $\begin{array}{r}4723 \\
2.27 \\
13.52 \\
425 \\
850 \\
\text { na } \\
692 \\
1108 \\
248 \\
0.25 \\
0.20 \\
307 \\
9977\end{array}$ \\
\hline
\end{tabular}

Profile 37 - Hjørnedal

Profile 38

Profile 39 - NE Gàseland (upper part)

\begin{tabular}{|c|c|c|c|c|c|c|c|c|c|c|c|c|c|}
\hline $\begin{array}{l}\text { Formation } \\
\text { Type } \\
\text { Height m } \\
\text { GGU No. }\end{array}$ & $\begin{array}{r}\mathrm{MF} \\
\mathrm{h}-\mathrm{Si} \\
1417 \\
96875\end{array}$ & $\begin{array}{r}\mathrm{MF} \\
\mathrm{h}-\mathrm{Si} \\
1482 \\
96879\end{array}$ & $\begin{array}{r}\mathrm{MLF} \\
\mathrm{h}-\mathrm{Ti} \\
1506 \\
96881\end{array}$ & $\begin{array}{r}\text { MLF } \\
\text { Hjern } \\
1525 \\
96882\end{array}$ & $\begin{array}{r}\text { MLF } \\
\text { h-Ti } \\
1570 \\
96884\end{array}$ & $\begin{array}{r}\text { MLF } \\
\text { h-Ti } \\
1614 \\
96886\end{array}$ & $\begin{array}{r}\text { MLF } \\
\mathrm{m}-\mathrm{Ti} \\
1636 \\
96887\end{array}$ & $\begin{array}{r}\text { MLF } \\
\text { Hjørn } \\
1288 \\
96913\end{array}$ & $\begin{array}{r}\text { MLF } \\
h-T i \\
1440 \\
96939\end{array}$ & $\begin{array}{r}\text { MLF } \\
h-T i \\
1445 \\
96940\end{array}$ & $\begin{array}{r}\text { GF } \\
\text { Ti-th } \\
1458 \\
96942\end{array}$ & $\begin{array}{r}\text { GF } \\
h-T i \\
1472 \\
96943\end{array}$ & $\begin{array}{r}\text { GF } \\
\text { Ti-th } \\
1512 \\
96944\end{array}$ \\
\hline $\begin{array}{l}\mathrm{SiO}_{2} \\
\mathrm{TiO}_{2} \\
\mathrm{Al}_{2} \mathrm{O}_{3} \\
\mathrm{Fe}_{2} \mathrm{O}_{3} \\
\mathrm{FeO} \\
\mathrm{MnO} \\
\mathrm{MgO} \\
\mathrm{CaO} \\
\mathrm{Na}_{3} \mathrm{O} \\
\mathrm{K}_{2} \mathrm{O} \\
\mathrm{P}_{2} \mathrm{O}_{5} \\
\text { 1.o.i. }\end{array}$ & $\begin{array}{r}53.27 \\
208 \\
13.03 \\
2.01 \\
8.60 \\
0.16 \\
683 \\
940 \\
2.32 \\
0.86 \\
0.21 \\
1.19 \\
99.96\end{array}$ & $\begin{array}{r}50.83 \\
2.08 \\
1323 \\
2.77 \\
852 \\
0.17 \\
7.82 \\
1033 \\
2.26 \\
038 \\
0.20 \\
1.18 \\
99.77\end{array}$ & $\begin{array}{r}48.05 \\
3.05 \\
14.13 \\
3.39 \\
9.38 \\
0.18 \\
7.13 \\
10.81 \\
2.27 \\
016 \\
0.30 \\
1.07 \\
99.92\end{array}$ & $\begin{array}{r}49.32 \\
2.26 \\
13.89 \\
230 \\
9.26 \\
0.17 \\
8.46 \\
10.93 \\
229 \\
0.30 \\
0.21 \\
0.69 \\
100.08\end{array}$ & $\begin{array}{r}47.52 \\
3.29 \\
1433 \\
860 \\
5.81 \\
0.20 \\
5.35 \\
10.20 \\
253 \\
0.35 \\
0.30 \\
1.13 \\
99.61\end{array}$ & $\begin{array}{r}4883 \\
304 \\
1355 \\
341 \\
1047 \\
020 \\
631 \\
1053 \\
252 \\
035 \\
029 \\
0-77 \\
10027\end{array}$ & $\begin{array}{r}4893 \\
239 \\
1399 \\
333 \\
965 \\
020 \\
697 \\
1141 \\
240 \\
017 \\
022 \\
070 \\
10036\end{array}$ & $\begin{array}{r}49.48 \\
2.24 \\
1437 \\
313 \\
8.19 \\
017 \\
7.99 \\
1078 \\
217 \\
0.24 \\
0.21 \\
101 \\
9998\end{array}$ & $\begin{array}{r}4825 \\
284 \\
13.48 \\
488 \\
847 \\
019 \\
682 \\
11.01 \\
2.34 \\
036 \\
027 \\
124 \\
10015\end{array}$ & $\begin{array}{r}4849 \\
290 \\
1340 \\
580 \\
770 \\
020 \\
660 \\
1094 \\
234 \\
028 \\
0.31 \\
092 \\
9988\end{array}$ & $\begin{array}{r}47.29 \\
3.68 \\
12.96 \\
6.20 \\
8.24 \\
0.19 \\
6.14 \\
10.58 \\
2.36 \\
0.41 \\
0.37 \\
1.44 \\
99.86\end{array}$ & $\begin{array}{r}4693 \\
327 \\
13.42 \\
402 \\
948 \\
0.19 \\
653 \\
1098 \\
198 \\
037 \\
032 \\
2.36 \\
99.85\end{array}$ & $\begin{array}{r}4837 \\
3.70 \\
1237 \\
6.29 \\
8.97 \\
0.21 \\
5.66 \\
10.08 \\
2.55 \\
0.58 \\
0.36 \\
0.78 \\
99.92\end{array}$ \\
\hline
\end{tabular}

Profile 44 - Skrcenterne

\begin{tabular}{|c|c|c|c|c|c|c|c|c|c|c|c|c|c|c|}
\hline $\begin{array}{l}\text { Formation } \\
\text { Type } \\
\text { Height m } \\
\text { GGU No. }\end{array}$ & $\begin{array}{r}G F \\
1-m-T i \\
1520 \\
96945\end{array}$ & $\begin{array}{r}\text { GF } \\
\text { I-m-Ti } \\
1546 \\
96946\end{array}$ & $\begin{array}{r}\mathrm{GF} \\
\text { 1-m-Ti } \\
1592 \\
96948\end{array}$ & $\begin{array}{r}\mathrm{GF} \\
\text { 1-m-Ti } \\
1616 \\
96950\end{array}$ & $\begin{array}{r}\mathrm{GF} \\
\mathrm{h}-\mathrm{Si} \\
1664 \\
96953\end{array}$ & $\begin{array}{r}\mathrm{GF} \\
\mathrm{m}-\mathrm{Ti} \\
1726 \\
96954\end{array}$ & $\begin{array}{r}\text { SF } \\
\text { m-h-Ti } \\
1265 \\
98287\end{array}$ & $\begin{array}{r}\mathrm{SF} \\
\mathrm{m}-\mathrm{h}-\mathrm{Ti} \\
1284 \\
98257\end{array}$ & $\begin{array}{r}\text { SF } \\
\text { Ti-th } \\
1313 \\
98258\end{array}$ & $\begin{array}{r}\mathrm{SF} \\
\mathrm{I-Ti} \\
1360 \\
98261\end{array}$ & $\begin{array}{r}\text { SF } \\
\text { I-Ti } \\
1382 \\
98262\end{array}$ & $\begin{array}{r}\mathrm{SF} \\
1-\mathrm{Ti}_{i} \\
1398 \\
98264\end{array}$ & $\begin{array}{r}\text { SF } \\
1-T i \\
1430 \\
98265\end{array}$ & $\begin{array}{r}\mathrm{SF} \\
1-\mathrm{Ti} \\
1451 \\
98266\end{array}$ \\
\hline $\begin{array}{l}\mathrm{SiO}_{2} \\
\mathrm{TiO} \\
\mathrm{Al}_{3} \mathrm{O}_{1} \\
\mathrm{Fe}_{3} \mathrm{O} \text {, } \\
\mathrm{FeO} \\
\mathrm{MnO} \\
\mathrm{MgO} \\
\mathrm{CaO} \\
\mathrm{Na}_{3} \mathrm{O} \\
\mathrm{K}_{2} \mathrm{O} \\
\mathrm{P}_{2} \mathrm{O}_{5} \\
\text { l.o.i. }\end{array}$ & $\begin{array}{r}48.50 \\
222 \\
13.58 \\
464 \\
8.22 \\
0.19 \\
708 \\
11.35 \\
210 \\
0.33 \\
0.21 \\
1.50 \\
99.92\end{array}$ & $\begin{array}{r}46.96 \\
218 \\
1374 \\
3.84 \\
893 \\
019 \\
717 \\
1178 \\
188 \\
019 \\
019 \\
287 \\
99.92\end{array}$ & $\begin{array}{r}46.74 \\
2.20 \\
13.44 \\
5.95 \\
7.18 \\
0.19 \\
7.13 \\
11.56 \\
1.89 \\
0.19 \\
0.19 \\
262 \\
99.28\end{array}$ & $\begin{array}{r}48.33 \\
231 \\
1349 \\
3.80 \\
9.25 \\
0.20 \\
6.94 \\
11.36 \\
209 \\
0.34 \\
0.22 \\
1.35 \\
99.68\end{array}$ & $\begin{array}{r}5134 \\
2.08 \\
1300 \\
271 \\
7.91 \\
0.20 \\
7.64 \\
9.41 \\
214 \\
0.55 \\
019 \\
211 \\
9928\end{array}$ & $\begin{array}{r}47.95 \\
2.57 \\
13.67 \\
429 \\
904 \\
0.19 \\
6.76 \\
1090 \\
2.28 \\
032 \\
0.24 \\
1.58 \\
99.79\end{array}$ & $\begin{array}{r}4829 \\
246 \\
1491 \\
478 \\
792 \\
028 \\
621 \\
1167 \\
239 \\
011 \\
021 \\
122 \\
10045\end{array}$ & $\begin{array}{r}4853 \\
260 \\
1422 \\
426 \\
853 \\
027 \\
6.99 \\
11.28 \\
242 \\
0.16 \\
0.21 \\
111 \\
10058\end{array}$ & $\begin{array}{r}47.68 \\
312 \\
1411 \\
432 \\
9.74 \\
0.29 \\
5.81 \\
10.89 \\
252 \\
037 \\
030 \\
100 \\
10015\end{array}$ & $\begin{array}{r}4808 \\
2.12 \\
1460 \\
5.93 \\
665 \\
025 \\
733 \\
1147 \\
220 \\
012 \\
017 \\
1.71 \\
10063\end{array}$ & $\begin{array}{r}4843 \\
200 \\
1492 \\
561 \\
644 \\
0.27 \\
723 \\
1159 \\
206 \\
009 \\
016 \\
226 \\
10106\end{array}$ & $\begin{array}{r}4919 \\
178 \\
1493 \\
539 \\
644 \\
0.25 \\
714 \\
1144 \\
218 \\
022 \\
016 \\
1.58 \\
10070\end{array}$ & $\begin{array}{r}4961 \\
190 \\
1443 \\
423 \\
8.30 \\
028 \\
681 \\
1134 \\
236 \\
024 \\
016 \\
0.95 \\
10061\end{array}$ & $\begin{array}{r}49.44 \\
188 \\
1457 \\
398 \\
8.51 \\
0.27 \\
6.81 \\
1131 \\
236 \\
0.28 \\
0.15 \\
103 \\
10059\end{array}$ \\
\hline
\end{tabular}

Profile 47 - bay on Volquart Boons Kyst below Spiret

\begin{tabular}{|c|c|c|c|c|c|c|c|c|c|c|c|c|c|c|}
\hline $\begin{array}{l}\text { Formation } \\
\text { Type } \\
\text { Height m } \\
\text { GGU No. }\end{array}$ & $\begin{array}{r}\text { SF } \\
1-\mathrm{Ti} \\
1474 \\
98269\end{array}$ & $\begin{array}{r}\text { SF } \\
\text { 1-m-Ti } \\
1542 \\
98273\end{array}$ & $\begin{array}{r}\mathrm{SF} \\
1-\mathrm{Ti} \\
1547 \\
98275\end{array}$ & $\begin{array}{r}\text { SF } \\
\text { J-Ti } \\
1578 \\
98278\end{array}$ & $\begin{array}{r}\mathrm{SF} \\
1-\mathrm{Ti} \\
1596 \\
98279\end{array}$ & $\begin{array}{r}\mathrm{SF} \\
\mathrm{m} \cdot \mathrm{h}-\mathrm{Ti} \\
1631 \\
98281\end{array}$ & $\begin{array}{r}\text { SF } \\
\text { m-h-Ti } \\
1700 \\
98283\end{array}$ & $\begin{array}{r}\text { SF } \\
\mathrm{m}-\mathrm{h}-\mathrm{Ti} \\
1795 \\
98286\end{array}$ & $\begin{array}{r}\mathrm{GF} \\
\mathrm{h}-\mathrm{Ti} \\
68 \\
98378\end{array}$ & $\begin{array}{r}\text { GF } \\
\text { Mikis } \\
135 \\
98380\end{array}$ & $\begin{array}{r}\mathrm{GF} \\
\mathrm{m}-\mathrm{Ti} \\
186 \\
98381\end{array}$ & $\begin{array}{r}\mathrm{GF} \\
\mathrm{m}-\mathrm{Ti} \\
200 \\
98382\end{array}$ & $\begin{array}{r}\mathrm{GF} \\
\mathrm{m}-\mathrm{Ti} \\
207 \\
98355\end{array}$ & $\begin{array}{r}\text { GF } \\
\mathrm{m}-\mathrm{Ti} \\
266 \\
98384\end{array}$ \\
\hline $\begin{array}{l}\mathrm{SiO}_{2} \\
\mathrm{TiO}_{3} \\
\mathrm{Al}_{2} \mathrm{O}_{3} \\
\mathrm{Fe}_{2} \mathrm{O}_{3} \\
\mathrm{FeO} \\
\mathrm{MnO} \\
\mathrm{MgO} \\
\mathrm{CaO} \\
\mathrm{Na}_{2} \mathrm{O} \\
\mathrm{K}_{2} \mathrm{O} \\
\mathrm{P}_{2} \mathrm{O}_{5} \\
\text { I.o.i. }\end{array}$ & $\begin{array}{r}49.10 \\
2.04 \\
14.17 \\
3.92 \\
854 \\
0.27 \\
7.02 \\
11.47 \\
229 \\
030 \\
017 \\
0.97 \\
10026\end{array}$ & $\begin{array}{r}47.89 \\
2.29 \\
1403 \\
4.74 \\
865 \\
0.29 \\
669 \\
11.48 \\
2.20 \\
012 \\
019 \\
151 \\
10008\end{array}$ & $\begin{array}{r}48.91 \\
1.99 \\
1434 \\
430 \\
852 \\
028 \\
679 \\
1176 \\
218 \\
008 \\
017 \\
1114 \\
10046\end{array}$ & $\begin{array}{r}4859 \\
177 \\
1471 \\
6.61 \\
619 \\
027 \\
6.94 \\
1156 \\
212 \\
0.23 \\
014 \\
106 \\
10019\end{array}$ & $\begin{array}{r}48.85 \\
2.04 \\
14.16 \\
4.93 \\
8.48 \\
028 \\
679 \\
11.08 \\
221 \\
023 \\
0.18 \\
127 \\
10050\end{array}$ & $\begin{array}{r}49.12 \\
260 \\
1339 \\
547 \\
906 \\
031 \\
591 \\
1070 \\
241 \\
035 \\
024 \\
080 \\
10036\end{array}$ & $\begin{array}{r}4957 \\
265 \\
1340 \\
536 \\
931 \\
032 \\
559 \\
1053 \\
261 \\
038 \\
023 \\
0.67 \\
10062\end{array}$ & $\begin{array}{r}4865 \\
251 \\
1319 \\
494 \\
961 \\
031 \\
629 \\
1045 \\
243 \\
037 \\
023 \\
102 \\
10000\end{array}$ & $\begin{array}{r}48.89 \\
307 \\
1329 \\
4.91 \\
901 \\
020 \\
626 \\
1041 \\
233 \\
029 \\
027 \\
107 \\
10000\end{array}$ & $\begin{array}{r}4975 \\
245 \\
1141 \\
324 \\
922 \\
018 \\
1058 \\
919 \\
199 \\
053 \\
021 \\
116 \\
99.91\end{array}$ & $\begin{array}{r}48.75 \\
229 \\
1417 \\
683 \\
521 \\
017 \\
684 \\
1141 \\
216 \\
013 \\
020 \\
172 \\
9988\end{array}$ & $\begin{array}{r}4864 \\
245 \\
1379 \\
499 \\
819 \\
019 \\
696 \\
1084 \\
241 \\
031 \\
022 \\
104 \\
10003\end{array}$ & $\begin{array}{r}4895 \\
229 \\
1420 \\
612 \\
679 \\
019 \\
686 \\
1110 \\
232 \\
025 \\
020 \\
099 \\
10026\end{array}$ & $\begin{array}{r}48.58 \\
246 \\
1409 \\
5.49 \\
735 \\
019 \\
651 \\
11.15 \\
236 \\
036 \\
022 \\
116 \\
9992\end{array}$ \\
\hline
\end{tabular}




\begin{tabular}{|c|c|c|c|c|c|c|c|c|c|c|c|c|c|c|c|}
\hline $\begin{array}{l}\text { Formation } \\
\text { Type } \\
\text { Height m } \\
\text { GGU No. }\end{array}$ & $\begin{array}{r}\mathrm{GF} \\
\mathrm{m}-\mathrm{Ti} \\
266 \\
98356\end{array}$ & $\begin{array}{r}\text { GF } \\
\mathrm{h}-\mathrm{Ti} \\
301 \\
98357\end{array}$ & $\begin{array}{r}\mathrm{GF} \\
\mathrm{h}-\mathrm{Ti} \\
403 \\
98359\end{array}$ & $\begin{array}{r}\mathrm{GF} \\
\mathrm{h}-\mathrm{Ti} \\
424 \\
98360\end{array}$ & $\begin{array}{r}\mathrm{GF} \\
\mathrm{m}-\mathrm{Ti} \\
465 \\
98361\end{array}$ & $\begin{array}{r}\mathrm{GF} \\
1-\mathrm{Ti} \\
538 \\
98362\end{array}$ & $\begin{array}{r}\mathrm{GF} \\
1-\mathrm{Ti} \\
570 \\
98363\end{array}$ & $\begin{array}{r}\mathrm{GF} \\
\mathrm{m}-\mathrm{Ti} \\
606 \\
98364\end{array}$ & $\begin{array}{r}G F \\
1 \cdot m-T_{i} \\
665 \\
98365\end{array}$ & $\begin{array}{r}\text { GF } \\
h-T i \\
728 \\
98367\end{array}$ & $\begin{array}{r}\mathrm{GF} \\
\mathrm{m} \cdot \mathrm{Ti} \\
748 \\
98368\end{array}$ & $\begin{array}{r}\text { GF } \\
\text { I-Ti } \\
762 \\
98369\end{array}$ & $\begin{array}{r}\mathrm{GF} \\
1-\mathrm{Ti} \\
798 \\
98370\end{array}$ & $\begin{array}{r}\mathrm{GF} \\
\mathrm{l-Ti} \\
822 \\
98371\end{array}$ & $\begin{array}{r}\mathrm{GF} \\
1-\mathrm{Ti} \\
860 \\
98372\end{array}$ \\
\hline 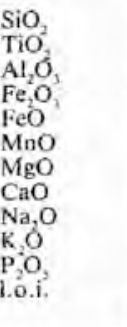 & $\begin{array}{r}4898 \\
255 \\
1392 \\
472 \\
834 \\
020 \\
646 \\
1112 \\
229 \\
031 \\
023 \\
101 \\
10013\end{array}$ & $\begin{array}{r}4800 \\
289 \\
13.42 \\
435 \\
941 \\
0.20 \\
644 \\
1133 \\
2.26 \\
015 \\
026 \\
1.22 \\
9993\end{array}$ & $\begin{array}{r}48.52 \\
285 \\
1349 \\
345 \\
1006 \\
020 \\
639 \\
1106 \\
2.28 \\
031 \\
026 \\
097 \\
9984\end{array}$ & $\begin{array}{r}4811 \\
290 \\
1337 \\
580 \\
865 \\
021 \\
613 \\
1072 \\
239 \\
027 \\
026 \\
146 \\
10027\end{array}$ & $\begin{array}{r}4839 \\
250 \\
1347 \\
548 \\
819 \\
021 \\
624 \\
11.70 \\
223 \\
015 \\
023 \\
138 \\
10017\end{array}$ & $\begin{array}{r}48.56 \\
2.15 \\
1388 \\
343 \\
902 \\
019 \\
7.12 \\
11.96 \\
2.18 \\
0.19 \\
019 \\
0.88 \\
9975\end{array}$ & $\begin{array}{r}48.22 \\
2.15 \\
1380 \\
471 \\
7.91 \\
0.19 \\
7.13 \\
11.93 \\
2.06 \\
0.20 \\
0.20 \\
1.40 \\
99.90\end{array}$ & $\begin{array}{r}4875 \\
242 \\
1351 \\
464 \\
899 \\
021 \\
609 \\
1148 \\
231 \\
023 \\
022 \\
0.92 \\
9977\end{array}$ & $\begin{array}{r}4787 \\
222 \\
1360 \\
627 \\
669 \\
019 \\
692 \\
1169 \\
199 \\
015 \\
019 \\
206 \\
9984\end{array}$ & $\begin{array}{r}47.65 \\
295 \\
1258 \\
698 \\
852 \\
023 \\
584 \\
1076 \\
234 \\
013 \\
026 \\
203 \\
10027\end{array}$ & $\begin{array}{r}4771 \\
2.49 \\
1421 \\
595 \\
7.20 \\
019 \\
605 \\
1183 \\
228 \\
0.11 \\
024 \\
163 \\
9989\end{array}$ & $\begin{array}{r}48.42 \\
212 \\
1352 \\
5.20 \\
7.77 \\
0.19 \\
694 \\
1192 \\
225 \\
018 \\
019 \\
104 \\
99.74\end{array}$ & $\begin{array}{r}4839 \\
210 \\
1350 \\
514 \\
785 \\
020 \\
690 \\
1184 \\
215 \\
027 \\
019 \\
149 \\
10002\end{array}$ & $\begin{array}{r}4860 \\
2.07 \\
1370 \\
4.93 \\
7.88 \\
0.22 \\
709 \\
1179 \\
2.25 \\
024 \\
018 \\
111 \\
10006\end{array}$ & $\begin{array}{r}48.25 \\
202 \\
1380 \\
426 \\
839 \\
019 \\
702 \\
1161 \\
210 \\
0.46 \\
0.18 \\
159 \\
99.87\end{array}$ \\
\hline
\end{tabular}

Profile 48 - peak 1290 (south of Terrassevig)

\begin{tabular}{|c|c|c|c|c|c|c|c|c|c|c|c|c|c|c|}
\hline $\begin{array}{l}\text { Formation } \\
\text { Type } \\
\text { Height m } \\
\text { GGU No. }\end{array}$ & $\begin{array}{r}\mathrm{GF} \\
\mathrm{L}-\mathrm{Ti} \\
890 \\
98373\end{array}$ & $\begin{array}{r}\mathrm{GF} \\
\mathrm{m}-\mathrm{Ti} \\
922 \\
98374\end{array}$ & $\begin{array}{r}\text { GF } \\
1-T i \\
942 \\
98375\end{array}$ & $\begin{array}{r}\text { GF } \\
\text { h-Ti } \\
1020 \\
98376\end{array}$ & $\begin{array}{r}\mathrm{GF} \\
\mathrm{1-Ti} \\
907 \\
98398\end{array}$ & $\begin{array}{r}\text { GF } \\
\mathrm{h}-\mathrm{Ti} \\
975 \\
98397\end{array}$ & $\begin{array}{r}\mathrm{GF} \\
\mathrm{h}-\mathrm{Ti} \\
1006 \\
98396\end{array}$ & $\begin{array}{r}\text { RFF } \\
\text { I ol-th } \\
1021 \\
98385\end{array}$ & $\begin{array}{r}\text { RFF } \\
1 \text { ol-th } \\
1044 \\
98387\end{array}$ & $\begin{array}{r}\text { RFF } \\
\text { Ti-th } \\
1102 \\
98388\end{array}$ & $\begin{array}{r}\text { RFF } \\
\text { u ol-th } \\
1148 \\
98391\end{array}$ & $\begin{array}{r}\text { RFF } \\
\text { MORB } \\
1194 \\
98392\end{array}$ & $\begin{array}{r}\text { RFF } \\
\text { MORB } \\
1217 \\
98393\end{array}$ & $\begin{array}{r}\mathrm{SE} \\
\mathrm{m}-\mathrm{h}-\mathrm{Ti} \\
1225 \\
98394\end{array}$ \\
\hline $\begin{array}{l}\mathrm{SiO}_{2} \\
\mathrm{TiO}_{3} \\
\mathrm{Al}_{2} \mathrm{O}_{3} \\
\mathrm{Fe}_{3} \mathrm{O}_{3} \\
\mathrm{FeO} \\
\mathrm{MnO} \\
\mathrm{MgO} \\
\mathrm{CaO} \\
\mathrm{NaO}_{2} \mathrm{O} \\
\mathrm{K}_{2} \mathrm{O} \\
\mathrm{P}_{2} \mathrm{O}_{3} \\
1.0 .1 .\end{array}$ & $\begin{array}{r}4842 \\
214 \\
1358 \\
434 \\
883 \\
020 \\
685 \\
1168 \\
216 \\
028 \\
019 \\
131 \\
9998\end{array}$ & $\begin{array}{r}4797 \\
235 \\
1371 \\
5.88 \\
724 \\
019 \\
6.98 \\
1165 \\
225 \\
027 \\
022 \\
1.26 \\
999.97\end{array}$ & $\begin{array}{r}4911 \\
212 \\
1355 \\
480 \\
764 \\
020 \\
693 \\
1159 \\
226 \\
031 \\
020 \\
127 \\
9998\end{array}$ & $\begin{array}{r}48.20 \\
3.05 \\
12.73 \\
5.34 \\
1022 \\
0.23 \\
5.72 \\
1056 \\
244 \\
040 \\
028 \\
093 \\
10010\end{array}$ & $\begin{array}{r}4905 \\
209 \\
1369 \\
422 \\
845 \\
019 \\
699 \\
1130 \\
211 \\
060 \\
020 \\
121 \\
10010\end{array}$ & $\begin{array}{r}4811 \\
317 \\
1244 \\
731 \\
884 \\
024 \\
550 \\
1027 \\
239 \\
043 \\
030 \\
123 \\
10023\end{array}$ & $\begin{array}{r}4766 \\
288 \\
1324 \\
683 \\
694 \\
023 \\
659 \\
1117 \\
221 \\
029 \\
027 \\
166 \\
9997\end{array}$ & $\begin{array}{r}4657 \\
232 \\
1378 \\
518 \\
732 \\
020 \\
880 \\
1010 \\
207 \\
028 \\
023 \\
324 \\
0009\end{array}$ & $\begin{array}{r}46.25 \\
210 \\
1342 \\
3.23 \\
8.72 \\
017 \\
863 \\
11.80 \\
1.90 \\
018 \\
017 \\
3.38 \\
99.95\end{array}$ & $\begin{array}{r}4611 \\
391 \\
1276 \\
712 \\
8.63 \\
022 \\
594 \\
1074 \\
234 \\
015 \\
038 \\
198 \\
10028\end{array}$ & $\begin{array}{r}4696 \\
256 \\
1437 \\
607 \\
650 \\
018 \\
684 \\
11.32 \\
211 \\
018 \\
025 \\
263 \\
9997\end{array}$ & $\begin{array}{r}4856 \\
169 \\
1443 \\
651 \\
608 \\
018 \\
649 \\
1209 \\
231 \\
012 \\
012 \\
164 \\
10022\end{array}$ & $\begin{array}{r}48.56 \\
1.64 \\
1471 \\
675 \\
5.94 \\
018 \\
647 \\
1217 \\
2.34 \\
0.12 \\
012 \\
1.25 \\
10025\end{array}$ & $\begin{array}{r}4830 \\
281 \\
1318 \\
495 \\
960 \\
022 \\
625 \\
1135 \\
248 \\
024 \\
025 \\
066 \\
10029\end{array}$ \\
\hline
\end{tabular}

Profile 51 - Ostre Borggletscher

Profile 52 -

\begin{tabular}{|c|c|c|c|c|c|c|c|c|c|c|c|c|c|c|}
\hline $\begin{array}{l}\text { Formation } \\
\text { Type } \\
\text { Height m } \\
\text { GGU No. }\end{array}$ & $\begin{array}{r}\text { GF } \\
\text { h-Ti } \\
225 \\
98435\end{array}$ & $\begin{array}{r}\mathrm{GF} \\
\mathrm{h}-\mathrm{Ti} \\
278 \\
98436\end{array}$ & $\begin{array}{r}\mathrm{GF} \\
\mathrm{m}-\mathrm{Ti} \\
327 \\
98437\end{array}$ & $\begin{array}{r}\text { GF } \\
\mathrm{m}-\mathrm{Ti} \\
342 \\
98438\end{array}$ & $\begin{array}{r}\mathrm{GF} \\
\mathrm{m}-\mathrm{Ti} \\
366 \\
98440\end{array}$ & $\begin{array}{r}\mathrm{GF} \\
\mathrm{m}-\mathrm{Ti} \\
383 \\
98441\end{array}$ & $\begin{array}{r}\text { GF } \\
\text { 1-Ti } \\
427 \\
98442\end{array}$ & $\begin{array}{r}\mathrm{GF} \\
1-\mathrm{Ti} \\
460 \\
98443\end{array}$ & $\begin{array}{r}\mathrm{GF} \\
\mathrm{m}-\mathrm{Ti} \\
515 \\
98444\end{array}$ & $\begin{array}{r}\mathrm{GF} \\
\mathrm{h}-\mathrm{Ti} \\
585 \\
98445\end{array}$ & $\begin{array}{r}\mathrm{GF} \\
\mathrm{h}-\mathrm{Ti} \\
588 \\
98446\end{array}$ & $\begin{array}{r}G F \\
m-T i \\
638 \\
98447\end{array}$ & $\begin{array}{r}\text { MLF } \\
\text { Ti-th } \\
158 \\
98503\end{array}$ & $\begin{array}{r}\text { MLF } \\
h-T i \\
184 \\
98505\end{array}$ \\
\hline 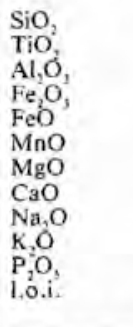 & $\begin{array}{r}4811 \\
280 \\
1338 \\
440 \\
898 \\
020 \\
638 \\
1104 \\
237 \\
022 \\
027 \\
129 \\
9944\end{array}$ & $\begin{array}{r}4788 \\
285 \\
1373 \\
520 \\
909 \\
020 \\
587 \\
1079 \\
243 \\
023 \\
028 \\
145 \\
10000\end{array}$ & $\begin{array}{r}4731 \\
2.53 \\
1365 \\
595 \\
785 \\
020 \\
635 \\
1163 \\
2.18 \\
014 \\
024 \\
200 \\
100.03\end{array}$ & $\begin{array}{r}4733 \\
260 \\
1345 \\
626 \\
788 \\
020 \\
637 \\
1162 \\
221 \\
013 \\
025 \\
179 \\
10009\end{array}$ & $\begin{array}{r}47.37 \\
2.54 \\
13.65 \\
6.27 \\
7.74 \\
0.20 \\
6.30 \\
1164 \\
2.24 \\
012 \\
024 \\
203 \\
100.34\end{array}$ & $\begin{array}{r}48.24 \\
2.44 \\
13.30 \\
584 \\
7.86 \\
0.20 \\
685 \\
1128 \\
233 \\
032 \\
023 \\
126 \\
10015\end{array}$ & $\begin{array}{r}4819 \\
2.32 \\
13.53 \\
4.79 \\
8.25 \\
0.19 \\
6.66 \\
11.86 \\
224 \\
014 \\
0.20 \\
1.42 \\
99.79\end{array}$ & $\begin{array}{r}48.65 \\
2.37 \\
13.40 \\
483 \\
8.70 \\
0.20 \\
646 \\
1137 \\
238 \\
0.32 \\
022 \\
1.05 \\
99.95\end{array}$ & $\begin{array}{r}4813 \\
267 \\
1327 \\
6238 \\
826 \\
021 \\
5.87 \\
1070 \\
2.45 \\
030 \\
0.24 \\
135 \\
99.83\end{array}$ & $\begin{array}{r}47.91 \\
3.41 \\
1254 \\
473 \\
1086 \\
0.23 \\
5.63 \\
1027 \\
267 \\
0.30 \\
033 \\
103 \\
99.91\end{array}$ & $\begin{array}{r}4797 \\
342 \\
1246 \\
527 \\
1031 \\
0.23 \\
5.69 \\
1019 \\
268 \\
038 \\
033 \\
1.12 \\
10005\end{array}$ & $\begin{array}{r}4773 \\
2.55 \\
1379 \\
628 \\
707 \\
020 \\
635 \\
1156 \\
2.38 \\
012 \\
0.24 \\
170 \\
99.97\end{array}$ & $\begin{array}{r}4867 \\
345 \\
1233 \\
477 \\
989 \\
027 \\
678 \\
9.78 \\
240 \\
034 \\
030 \\
142 \\
10040\end{array}$ & $\begin{array}{r}4721 \\
306 \\
1345 \\
603 \\
782 \\
0.31 \\
641 \\
1039 \\
240 \\
016 \\
0.28 \\
241 \\
99.93\end{array}$ \\
\hline
\end{tabular}

valley west of Tcenderne

\begin{tabular}{|c|c|c|c|c|c|c|c|c|c|c|c|c|c|c|c|}
\hline $\begin{array}{l}\text { Formation } \\
\text { Type } \\
\text { Height m } \\
\text { GGU No. }\end{array}$ & $\begin{array}{r}\text { MLF } \\
\mathrm{m}-\mathrm{Ti} \\
218 \\
98508\end{array}$ & $\begin{array}{r}\text { MLF } \\
\mathrm{m}-\mathrm{Ti} \\
280 \\
98509\end{array}$ & $\begin{array}{r}\text { MLF } \\
\mathrm{m}-\mathrm{Ti} \\
346 \\
98510\end{array}$ & $\begin{array}{r}\text { GF } \\
\text { Ti-th } \\
387 \\
98511\end{array}$ & $\begin{array}{r}\mathrm{GF} \\
\mathrm{h}-\mathrm{Ti} \\
456 \\
98512\end{array}$ & $\begin{array}{r}\mathrm{GF} \\
\mathrm{h}-\mathrm{Ti} \\
494 \\
98513\end{array}$ & $\begin{array}{r}\mathrm{GF} \\
\mathrm{h}-\mathrm{Ti} \\
513 \\
98516\end{array}$ & $\begin{array}{r}\text { GF } \\
h-T i \\
520 \\
98463\end{array}$ & $\begin{array}{r}\text { GF } \\
\text { h-Ti } \\
590 \\
98464\end{array}$ & $\begin{array}{r}\mathrm{GF} \\
\mathrm{h}-\mathrm{Ti} \\
600 \\
98465\end{array}$ & $\begin{array}{r}\mathrm{GF} \\
\mathrm{m}-\mathrm{Ti} \\
665 \\
98467\end{array}$ & $\begin{array}{r}\mathrm{GF} \\
\mathrm{m}-\mathrm{Ti} \\
673 \\
98468\end{array}$ & $\begin{array}{r}\mathrm{GF} \\
\mathrm{m}-\mathrm{Ti} \\
682 \\
98470\end{array}$ & $\begin{array}{r}\mathrm{GF} \\
\mathrm{m}-\mathrm{Ti} \\
713 \\
98471\end{array}$ & $\begin{array}{r}\mathrm{GF} \\
\mathrm{m}-\mathrm{Ti} \\
728 \\
98472\end{array}$ \\
\hline $\begin{array}{l}\mathrm{SiO}, \\
\mathrm{TiO}, \\
\mathrm{Al}, \mathrm{O}, \\
\mathrm{Fe} \mathrm{O}, \\
\mathrm{FeO} \\
\mathrm{MnO} \\
\mathrm{MgO} \\
\mathrm{CaO} \\
\mathrm{Na}, \mathrm{O} \\
\mathrm{K}, \mathrm{O} \\
\mathrm{P}, \mathrm{O}, \\
\text { l.o.i. }\end{array}$ & $\begin{array}{r}48.80 \\
2.51 \\
1368 \\
642 \\
5.63 \\
019 \\
6.16 \\
11.00 \\
244 \\
039 \\
022 \\
244 \\
9988\end{array}$ & $\begin{array}{r}4934 \\
265 \\
1371 \\
504 \\
785 \\
028 \\
627 \\
1087 \\
256 \\
039 \\
024 \\
087 \\
10007\end{array}$ & $\begin{array}{r}4897 \\
2.66 \\
1430 \\
5.81 \\
715 \\
030 \\
616 \\
1093 \\
241 \\
034 \\
023 \\
077 \\
10003\end{array}$ & $\begin{array}{r}4876 \\
359 \\
1302 \\
507 \\
878 \\
025 \\
614 \\
1026 \\
250 \\
054 \\
034 \\
089 \\
10014\end{array}$ & $\begin{array}{r}4812 \\
2.95 \\
13.20 \\
551 \\
802 \\
024 \\
675 \\
11.10 \\
228 \\
016 \\
025 \\
1.68 \\
10026\end{array}$ & $\begin{array}{r}48.13 \\
292 \\
13.30 \\
5112 \\
842 \\
024 \\
679 \\
11.10 \\
243 \\
022 \\
026 \\
113 \\
10006\end{array}$ & $\begin{array}{r}4785 \\
3.09 \\
1303 \\
6.46 \\
7.76 \\
024 \\
6.21 \\
10.93 \\
231 \\
044 \\
0.28 \\
1.41 \\
10001\end{array}$ & $\begin{array}{r}4849 \\
291 \\
1340 \\
487 \\
847 \\
024 \\
681 \\
1082 \\
231 \\
037 \\
026 \\
116 \\
10011\end{array}$ & $\begin{array}{r}48.30 \\
2.93 \\
1318 \\
5.76 \\
871 \\
0.27 \\
6.38 \\
10.46 \\
226 \\
031 \\
0.26 \\
111 \\
9993\end{array}$ & $\begin{array}{r}48.38 \\
305 \\
1309 \\
585 \\
8.68 \\
0.24 \\
602 \\
1036 \\
235 \\
036 \\
028 \\
1.11 \\
9977\end{array}$ & $\begin{array}{r}4816 \\
270 \\
1357 \\
724 \\
609 \\
024 \\
656 \\
1107 \\
221 \\
022 \\
021 \\
149 \\
9976\end{array}$ & $\begin{array}{r}4821 \\
265 \\
1376 \\
587 \\
718 \\
025 \\
674 \\
1102 \\
221 \\
022 \\
023 \\
151 \\
9985\end{array}$ & $\begin{array}{r}48.05 \\
2.51 \\
13.97 \\
636 \\
625 \\
023 \\
667 \\
1132 \\
208 \\
014 \\
022 \\
193 \\
9973\end{array}$ & $\begin{array}{r}47.77 \\
269 \\
13.68 \\
698 \\
606 \\
027 \\
663 \\
1126 \\
209 \\
020 \\
021 \\
202 \\
99.86\end{array}$ & $\begin{array}{r}47.91 \\
2.55 \\
1422 \\
462 \\
7.91 \\
024 \\
652 \\
1062 \\
199 \\
080 \\
022 \\
216 \\
9976\end{array}$ \\
\hline
\end{tabular}




\begin{tabular}{|c|c|c|c|c|c|c|c|c|c|c|c|c|c|c|c|}
\hline $\begin{array}{l}\text { Formation } \\
\text { Type } \\
\text { Height m } \\
\text { GGU No. }\end{array}$ & $\begin{array}{r}\mathrm{GF} \\
\mathrm{m}-\mathrm{Ti} \\
742 \\
98473\end{array}$ & $\begin{array}{r}\text { GF } \\
\mathrm{m}-\mathrm{Ti} \\
770 \\
98475\end{array}$ & $\begin{array}{r}\mathrm{GF} \\
\mathrm{m}-\mathrm{Ti} \\
780 \\
98476\end{array}$ & $\begin{array}{r}\mathrm{GF} \\
\mathrm{m}-\mathrm{Ti} \\
788 \\
98478\end{array}$ & $\begin{array}{r}\mathrm{GF} \\
\mathrm{m}-\mathrm{Ti} \\
800 \\
98479\end{array}$ & $\begin{array}{r}\mathrm{GF} \\
\mathrm{m}-\mathrm{Ti} \\
822 \\
98480\end{array}$ & $\begin{array}{r}\mathrm{GF} \\
\mathrm{m}-\mathrm{Ti} \\
850 \\
98481\end{array}$ & $\begin{array}{r}\mathrm{GF} \\
\mathrm{m}-\mathrm{Ti} \\
892 \\
98483\end{array}$ & $\begin{array}{r}\mathrm{GF} \\
\mathrm{m}-\mathrm{Ti} \\
920 \\
98484\end{array}$ & $\begin{array}{r}\text { GF } \\
\mathrm{m}-\mathrm{Ti} \\
964 \\
98487\end{array}$ & $\begin{array}{r}\mathrm{GF} \\
\mathrm{m}-\mathrm{Ti} \\
971 \\
98488\end{array}$ & $\begin{array}{r}\mathrm{GF} \\
\mathrm{m}-\mathrm{Ti} \\
1012 \\
98489\end{array}$ & $\begin{array}{r}\mathrm{GF} \\
\mathrm{m}-\mathrm{Ti} \\
\mathrm{I} 065 \\
98490\end{array}$ & $\begin{array}{r}\mathrm{GF} \\
1-\mathrm{Ti} \\
1092 \\
98492\end{array}$ & $\begin{array}{r}\text { GF } \\
1-\mathrm{Ti} \\
1139 \\
98493\end{array}$ \\
\hline $\begin{array}{l}\mathrm{SiO}_{2} \\
\mathrm{TiO}_{3} \\
\mathrm{Al}_{3} \mathrm{O}_{3} \\
\mathrm{Fe}_{2} \mathrm{O}_{3} \\
\mathrm{FeO} \\
\mathrm{MnO} \\
\mathrm{MgO} \\
\mathrm{CaO} \\
\mathrm{Na}_{2} \mathrm{O} \\
\mathrm{K}_{2} \mathrm{O} \\
\mathrm{P}_{2} \mathrm{O}_{3} \\
\text { l.o.i. }\end{array}$ & $\begin{array}{r}4841 \\
259 \\
1350 \\
556 \\
790 \\
025 \\
649 \\
1133 \\
221 \\
016 \\
023 \\
139 \\
10002\end{array}$ & $\begin{array}{r}4828 \\
258 \\
1328 \\
629 \\
731 \\
025 \\
655 \\
1133 \\
213 \\
017 \\
0.24 \\
1.58 \\
9999\end{array}$ & $\begin{array}{r}48.31 \\
257 \\
1343 \\
638 \\
7.17 \\
025 \\
627 \\
1146 \\
2.34 \\
015 \\
023 \\
1.57 \\
10013\end{array}$ & $\begin{array}{r}48.31 \\
256 \\
1327 \\
540 \\
792 \\
0.25 \\
682 \\
1148 \\
229 \\
019 \\
0.22 \\
117 \\
9988\end{array}$ & $\begin{array}{r}48.37 \\
2.56 \\
13.38 \\
615 \\
7.09 \\
026 \\
654 \\
11.63 \\
232 \\
019 \\
0.22 \\
129 \\
100-00\end{array}$ & $\begin{array}{r}48.36 \\
2.46 \\
1333 \\
5.74 \\
741 \\
0.26 \\
687 \\
11.39 \\
229 \\
025 \\
0.22 \\
128 \\
9986\end{array}$ & $\begin{array}{r}4838 \\
226 \\
1356 \\
537 \\
719 \\
024 \\
728 \\
1132 \\
213 \\
046 \\
020 \\
164 \\
10003\end{array}$ & $\begin{array}{r}48.18 \\
231 \\
1360 \\
4.83 \\
794 \\
025 \\
7.21 \\
1126 \\
218 \\
048 \\
020 \\
172 \\
10016\end{array}$ & $\begin{array}{r}4842 \\
245 \\
1339 \\
458 \\
858 \\
025 \\
696 \\
1075 \\
217 \\
073 \\
021 \\
143 \\
9992\end{array}$ & $\begin{array}{r}4875 \\
238 \\
1362 \\
571 \\
723 \\
027 \\
686 \\
1131 \\
235 \\
031 \\
021 \\
100 \\
10000\end{array}$ & $\begin{array}{r}48.64 \\
2.43 \\
13.62 \\
3.86 \\
918 \\
0.28 \\
6.87 \\
10.98 \\
219 \\
060 \\
0.23 \\
145 \\
10033\end{array}$ & $\begin{array}{r}48.32 \\
2.61 \\
13.86 \\
5.07 \\
8.25 \\
0.27 \\
6.41 \\
1107 \\
2.37 \\
034 \\
0.23 \\
1.16 \\
99.96\end{array}$ & $\begin{array}{r}4807 \\
235 \\
1379 \\
776 \\
543 \\
028 \\
704 \\
1159 \\
221 \\
024 \\
023 \\
141 \\
10040\end{array}$ & $\begin{array}{r}4825 \\
217 \\
1377 \\
792 \\
526 \\
027 \\
724 \\
1177 \\
231 \\
023 \\
020 \\
092 \\
10031\end{array}$ & $\begin{array}{r}4867 \\
229 \\
1383 \\
485 \\
833 \\
028 \\
654 \\
1167 \\
238 \\
020 \\
020 \\
113 \\
10037\end{array}$ \\
\hline
\end{tabular}

Profile 55 - Upper Sydbra

\begin{tabular}{|c|c|c|c|c|c|c|c|c|c|c|c|c|c|c|}
\hline $\begin{array}{l}\text { Formation } \\
\text { Type } \\
\text { Height m } \\
\text { GGU No. }\end{array}$ & $\begin{array}{r}\mathrm{GF} \\
\mathrm{J}-\mathrm{Ti} \\
1180 \\
98494\end{array}$ & $\begin{array}{r}\mathrm{GF} \\
\mathrm{J}-\mathrm{Ti} \\
1194 \\
98496\end{array}$ & $\begin{array}{r}\mathrm{GF} \\
\mathrm{J}-\mathrm{Ti} \\
1206 \\
98497\end{array}$ & $\begin{array}{r}\mathrm{GF} \\
\text { I-Ti } \\
1247 \\
98498\end{array}$ & $\begin{array}{r}\mathrm{GF} \\
\mathrm{m}-\mathrm{Ti} \\
1294 \\
98500\end{array}$ & $\begin{array}{r}\text { GF } \\
\mathrm{m}-\mathrm{Ti} \\
1309 \\
98501\end{array}$ & $\begin{array}{r}\text { GF } \\
1-T i \\
863 \\
98533\end{array}$ & $\begin{array}{r}\mathrm{GF} \\
1-\mathrm{Ti} \\
902 \\
98534\end{array}$ & $\begin{array}{r}\mathrm{GF} \\
1-\mathrm{Ti} \\
935 \\
98535\end{array}$ & $\begin{array}{r}\mathrm{GF} \\
1-\mathrm{Ti} \\
948 \\
98536\end{array}$ & $\begin{array}{r}\mathrm{GF} \\
1-\mathrm{Ti} \\
970 \\
98537\end{array}$ & $\begin{array}{r}\text { GF } \\
\text { h-Ti } \\
1058 \\
98538\end{array}$ & $\begin{array}{r}\mathrm{GF} \\
\mathrm{h}-\mathrm{Ti} \\
1130 \\
98541\end{array}$ & $\begin{array}{r}\text { RFF } \\
\text { Ti-th } \\
1162 \\
98543\end{array}$ \\
\hline $\begin{array}{l}\mathrm{SiO}_{2} \\
\mathrm{TiO} \\
\mathrm{Al}_{2} \mathrm{O}, \\
\mathrm{Fe}_{2} \mathrm{O} \\
\mathrm{FeO} \\
\mathrm{MnO} \\
\mathrm{MgO} \\
\mathrm{CaO} \\
\mathrm{Na}, \mathrm{O} \\
\mathrm{K}, \mathrm{O} \\
\mathrm{P}, \mathrm{O}, \\
\text { l.o.i. }\end{array}$ & $\begin{array}{r}4854 \\
214 \\
13.59 \\
555 \\
727 \\
028 \\
697 \\
1173 \\
228 \\
016 \\
019 \\
148 \\
10018\end{array}$ & $\begin{array}{r}4862 \\
218 \\
1355 \\
466 \\
822 \\
028 \\
691 \\
1148 \\
215 \\
045 \\
019 \\
1.82 \\
10051\end{array}$ & $\begin{array}{r}48.82 \\
2.10 \\
13.78 \\
524 \\
747 \\
0.28 \\
695 \\
1162 \\
233 \\
029 \\
017 \\
1.26 \\
10031\end{array}$ & $\begin{array}{r}4869 \\
206 \\
1392 \\
412 \\
839 \\
028 \\
722 \\
1158 \\
219 \\
033 \\
017 \\
125 \\
10020\end{array}$ & $\begin{array}{r}4794 \\
243 \\
1350 \\
459 \\
892 \\
031 \\
702 \\
1110 \\
225 \\
039 \\
023 \\
171 \\
10038\end{array}$ & $\begin{array}{r}47.96 \\
232 \\
13.84 \\
3.36 \\
9.25 \\
0.28 \\
719 \\
11.33 \\
2.22 \\
045 \\
0.23 \\
2.10 \\
10053\end{array}$ & $\begin{array}{r}4828 \\
218 \\
1367 \\
361 \\
9.36 \\
029 \\
697 \\
1129 \\
248 \\
028 \\
019 \\
182 \\
10042\end{array}$ & $\begin{array}{r}4854 \\
2.08 \\
13.75 \\
3.86 \\
8.79 \\
028 \\
708 \\
1141 \\
212 \\
0.53 \\
018 \\
1.58 \\
10020\end{array}$ & $\begin{array}{r}4861 \\
2.05 \\
1395 \\
5.79 \\
6.87 \\
028 \\
731 \\
11.81 \\
2.25 \\
023 \\
018 \\
120 \\
10053\end{array}$ & $\begin{array}{r}4903 \\
2.17 \\
1378 \\
542 \\
766 \\
028 \\
690 \\
1160 \\
241 \\
032 \\
019 \\
077 \\
100-53\end{array}$ & $\begin{array}{r}48.41 \\
218 \\
1371 \\
404 \\
896 \\
029 \\
6.92 \\
1100 \\
210 \\
065 \\
020 \\
187 \\
10033\end{array}$ & $\begin{array}{r}4838 \\
322 \\
1268 \\
479 \\
1072 \\
032 \\
567 \\
1025 \\
257 \\
044 \\
030 \\
122 \\
10056\end{array}$ & $\begin{array}{r}4890 \\
289 \\
1329 \\
435 \\
898 \\
028 \\
658 \\
1111 \\
238 \\
030 \\
026 \\
108 \\
10040\end{array}$ & $\begin{array}{r}47.45 \\
3.83 \\
13.00 \\
6.15 \\
8.59 \\
0.32 \\
5.78 \\
10.74 \\
2.18 \\
018 \\
036 \\
1.70 \\
10028\end{array}$ \\
\hline
\end{tabular}

\begin{tabular}{|c|c|c|c|c|c|c|c|c|c|c|c|c|c|c|c|}
\hline $\begin{array}{l}\text { Formation } \\
\text { Type } \\
\text { Height m } \\
\text { GGU No. }\end{array}$ & $\begin{array}{r}\text { RFF } \\
\text { I ol-th } \\
1174 \\
98544\end{array}$ & $\begin{array}{r}\text { RFF } \\
\text { I ol-1h } \\
\text { I198 } \\
98545\end{array}$ & $\begin{array}{r}\text { RFF } \\
1 \text { ol-th } \\
1207 \\
98546\end{array}$ & $\begin{array}{r}\text { RFF } \\
\text { Ti-th } \\
1218 \\
98547\end{array}$ & $\begin{array}{r}\text { RFF } \\
\text { MORB } \\
1257 \\
98549\end{array}$ & $\begin{array}{r}\text { RFF } \\
\text { MORB } \\
1270 \\
98550\end{array}$ & $\begin{array}{r}\text { RFF } \\
\text { MORB } \\
1286 \\
98551\end{array}$ & $\begin{array}{r}\text { SF } \\
\text { m-h-Ti } \\
1292 \\
98552\end{array}$ & $\begin{array}{r}\mathrm{SF} \\
\mathrm{m} \cdot \mathrm{h}-\mathrm{Ti} \\
1306 \\
98553\end{array}$ & $\begin{array}{r}\mathrm{SF} \\
\mathrm{m}-\mathrm{h}-\mathrm{Ti} \\
1354 \\
98554\end{array}$ & $\begin{array}{r}\mathrm{SF} \\
\mathrm{m}-\mathrm{h}-\mathrm{Ti} \\
1387 \\
98556\end{array}$ & $\begin{array}{r}\mathrm{SF} \\
\mathrm{m}-\mathrm{h}-\mathrm{Ti} \\
1432 \\
98557\end{array}$ & $\begin{array}{r}\text { SF } \\
\text { Ti-th } \\
1460 \\
98559\end{array}$ & $\begin{array}{r}S F \\
1-m-T i \\
1488 \\
98560\end{array}$ & $\begin{array}{r}\text { SF } \\
h-S i \\
1504 \\
9856 !\end{array}$ \\
\hline $\begin{array}{l}\mathrm{SiO}, \\
\mathrm{TiO}_{2} \\
\mathrm{Al}, \mathrm{O}, \\
\mathrm{Fe}, \mathrm{O}, \\
\mathrm{FeO} \\
\mathrm{MnO} \\
\mathrm{MgO} \\
\mathrm{CaO} \\
\mathrm{NaO} \\
\mathrm{K}, \mathrm{O} \\
\mathrm{P}, \mathrm{O} \\
1.0 .1\end{array}$ & $\begin{array}{r}4646 \\
217 \\
1327 \\
314 \\
837 \\
025 \\
863 \\
1160 \\
167 \\
026 \\
017 \\
401 \\
10000\end{array}$ & $\begin{array}{r}4683 \\
222 \\
1376 \\
342 \\
816 \\
025 \\
8.26 \\
1182 \\
181 \\
0.29 \\
0.18 \\
305 \\
100.05\end{array}$ & $\begin{array}{r}46.27 \\
219 \\
1332 \\
453 \\
709 \\
025 \\
799 \\
1183 \\
1.78 \\
022 \\
018 \\
395 \\
9960\end{array}$ & $\begin{array}{r}4643 \\
401 \\
1286 \\
633 \\
892 \\
027 \\
586 \\
1012 \\
230 \\
045 \\
039 \\
140 \\
9934\end{array}$ & $\begin{array}{r}47.97 \\
114 \\
1441 \\
437 \\
621 \\
0.22 \\
933 \\
1225 \\
1.54 \\
007 \\
007 \\
198 \\
99.56\end{array}$ & $\begin{array}{r}4705 \\
125 \\
1454 \\
420 \\
6.59 \\
0.22 \\
867 \\
1238 \\
1.50 \\
009 \\
008 \\
295 \\
99.52\end{array}$ & $\begin{array}{r}4815 \\
177 \\
1421 \\
522 \\
726 \\
025 \\
656 \\
1177 \\
185 \\
009 \\
014 \\
236 \\
9963\end{array}$ & $\begin{array}{r}4857 \\
269 \\
1365 \\
501 \\
885 \\
027 \\
605 \\
1118 \\
256 \\
033 \\
024 \\
097 \\
10037\end{array}$ & $\begin{array}{r}4850 \\
2.65 \\
1360 \\
5.95 \\
787 \\
026 \\
588 \\
1120 \\
262 \\
034 \\
025 \\
072 \\
9984\end{array}$ & $\begin{array}{r}4849 \\
280 \\
1331 \\
560 \\
856 \\
025 \\
587 \\
1090 \\
260 \\
033 \\
027 \\
123 \\
10021\end{array}$ & $\begin{array}{r}4728 \\
289 \\
1308 \\
540 \\
892 \\
027 \\
642 \\
1104 \\
234 \\
036 \\
026 \\
167 \\
9993\end{array}$ & $\begin{array}{r}4655 \\
282 \\
1343 \\
432 \\
923 \\
026 \\
677 \\
1118 \\
169 \\
023 \\
025 \\
339 \\
10012\end{array}$ & $\begin{array}{r}4676 \\
429 \\
1220 \\
582 \\
1026 \\
028 \\
536 \\
979 \\
265 \\
062 \\
044 \\
138 \\
9985\end{array}$ & $\begin{array}{r}4680 \\
224 \\
1381 \\
560 \\
7.17 \\
0.24 \\
694 \\
1215 \\
178 \\
012 \\
016 \\
288 \\
9989\end{array}$ & $\begin{array}{r}5090 \\
196 \\
1409 \\
390 \\
768 \\
023 \\
646 \\
1081 \\
247 \\
043 \\
017 \\
079 \\
9989\end{array}$ \\
\hline
\end{tabular}

Profile 59 - Ravebrie

\begin{tabular}{|c|c|c|c|c|c|c|c|c|c|c|c|c|c|c|c|}
\hline $\begin{array}{l}\text { Formation } \\
\text { Type } \\
\text { Height m } \\
\text { GGU No. }\end{array}$ & $\begin{array}{r}\mathrm{MF} \\
\mathrm{m}-\mathrm{Ti} \\
263 \\
98582\end{array}$ & $\begin{array}{r}\mathrm{MF} \\
\mathrm{m}-\mathrm{Ti} \\
269 \\
98583\end{array}$ & $\begin{array}{r}\mathrm{MF} \\
\mathrm{m}-\mathrm{Ti} \\
309 \\
98587\end{array}$ & $\begin{array}{r}\mathrm{MF} \\
\mathrm{m}-\mathrm{Ti} \\
325 \\
98588\end{array}$ & $\begin{array}{r}\mathrm{MF} \\
\mathrm{m}-\mathrm{Ti} \\
335 \\
98589\end{array}$ & $\begin{array}{r}\mathrm{MF} \\
\mathrm{m} \cdot \mathrm{Ti} \\
341 \\
98590\end{array}$ & $\begin{array}{r}\text { MLF } \\
\mathrm{h}-\mathrm{Ti} \\
396 \\
98591\end{array}$ & $\begin{array}{r}\text { ML.F } \\
\text { Ti-th } \\
425 \\
98592\end{array}$ & $\begin{array}{r}\text { MLF } \\
\text { Mikis } \\
497 \\
98593\end{array}$ & $\begin{array}{r}\text { MLF } \\
\text { h-Ti } \\
522 \\
98594\end{array}$ & $\begin{array}{r}\text { MLF } \\
\text { Hjern } \\
544 \\
98595\end{array}$ & $\begin{array}{r}\text { MLF } \\
\text { h-Si } \\
552 \\
98596\end{array}$ & $\begin{array}{r}\text { MLF } \\
\text { h-Ti } \\
575 \\
98597\end{array}$ & $\begin{array}{r}\text { MLF } \\
\text { h-Ti } \\
587 \\
98598\end{array}$ & $\begin{array}{r}\text { MLF } \\
\text { h-Ti } \\
605 \\
98599\end{array}$ \\
\hline $\begin{array}{l}\mathrm{SiO}, \\
\mathrm{TiO}_{2} \\
\mathrm{Al}, \mathrm{O} \\
\mathrm{Fe}, \mathrm{O}_{3} \\
\mathrm{FeO} \\
\mathrm{MnO} \\
\mathrm{MgO} \\
\mathrm{CaO} \\
\mathrm{Na}, \mathrm{O} \\
\mathrm{K} . \mathrm{O} \\
\mathrm{P}= \\
1.0 .1\end{array}$ & $\begin{array}{r}48.64 \\
256 \\
15.12 \\
4.32 \\
7.72 \\
024 \\
6.45 \\
1115 \\
242 \\
015 \\
024 \\
134 \\
10035\end{array}$ & $\begin{array}{r}4892 \\
261 \\
1386 \\
421 \\
816 \\
023 \\
719 \\
1122 \\
206 \\
011 \\
021 \\
153 \\
10031\end{array}$ & $\begin{array}{r}4912 \\
253 \\
1399 \\
458 \\
762 \\
023 \\
702 \\
1103 \\
211 \\
012 \\
023 \\
167 \\
10025\end{array}$ & $\begin{array}{r}4874 \\
255 \\
1397 \\
548 \\
676 \\
023 \\
663 \\
1130 \\
202 \\
0.38 \\
021 \\
182 \\
10009\end{array}$ & $\begin{array}{r}4919 \\
267 \\
1351 \\
464 \\
768 \\
023 \\
708 \\
1080 \\
212 \\
013 \\
023 \\
171 \\
9999\end{array}$ & $\begin{array}{r}4959 \\
2.46 \\
14.00 \\
4.61 \\
7.40 \\
0.22 \\
720 \\
1070 \\
220 \\
016 \\
020 \\
142 \\
100.16\end{array}$ & $\begin{array}{r}48.46 \\
321 \\
1307 \\
416 \\
978 \\
027 \\
656 \\
1013 \\
233 \\
023 \\
028 \\
147 \\
9995\end{array}$ & $\begin{array}{r}4829 \\
379 \\
1329 \\
451 \\
1002 \\
027 \\
593 \\
959 \\
218 \\
040 \\
035 \\
110 \\
9972\end{array}$ & $\begin{array}{r}47.60 \\
2.32 \\
11.96 \\
647 \\
5.75 \\
017 \\
1052 \\
963 \\
194 \\
037 \\
021 \\
\frac{275}{99.69}\end{array}$ & $\begin{array}{r}49.44 \\
2.87 \\
13.83 \\
4.86 \\
7.48 \\
0.20 \\
6.46 \\
10.25 \\
2.53 \\
059 \\
028 \\
0.83 \\
99.62\end{array}$ & $\begin{array}{r}4965 \\
239 \\
1468 \\
332 \\
782 \\
022 \\
726 \\
1058 \\
240 \\
038 \\
025 \\
125 \\
10020\end{array}$ & $\begin{array}{r}5056 \\
259 \\
13.81 \\
457 \\
712 \\
0.24 \\
6.03 \\
1054 \\
249 \\
052 \\
025 \\
093 \\
99.65\end{array}$ & $\begin{array}{r}48.18 \\
3.09 \\
1364 \\
5.35 \\
738 \\
024 \\
668 \\
992 \\
2.37 \\
015 \\
026 \\
218 \\
9944\end{array}$ & $\begin{array}{r}4853 \\
2.95 \\
1570 \\
765 \\
541 \\
019 \\
492 \\
1045 \\
255 \\
020 \\
027 \\
129 \\
100-11\end{array}$ & $\begin{array}{r}48.50 \\
2.98 \\
1396 \\
404 \\
9.15 \\
023 \\
5.97 \\
1023 \\
246 \\
039 \\
026 \\
1.10 \\
9927\end{array}$ \\
\hline
\end{tabular}




\begin{tabular}{|c|c|c|c|c|c|c|c|c|c|c|c|c|c|c|c|}
\hline $\begin{array}{l}\text { Formation } \\
\text { Type } \\
\text { Height m } \\
\text { GGU No. }\end{array}$ & $\begin{array}{r}\text { MLF } \\
\text { Ti-th } \\
649 \\
98600\end{array}$ & $\begin{array}{r}\text { MLF } \\
\mathrm{m}-\mathrm{Ti} \\
679 \\
98701\end{array}$ & $\begin{array}{r}\text { MLF } \\
\mathrm{m} \cdot \mathrm{Ti} \\
690 \\
98570\end{array}$ & $\begin{array}{r}\text { MLF } \\
\mathrm{m}-\mathrm{Ti} \\
703 \\
98571\end{array}$ & $\begin{array}{r}\text { GF } \\
T_{i-t h} \\
735 \\
98572\end{array}$ & $\begin{array}{r}\text { GF } \\
\text { Ti-1h } \\
767 \\
98573\end{array}$ & $\begin{array}{r}\mathrm{GF} \\
\mathrm{h}-\mathrm{Ti} \\
854 \\
98575\end{array}$ & $\begin{array}{r}\mathrm{GF} \\
\mathrm{m}-\mathrm{Ti} \\
926 \\
98576\end{array}$ & $\begin{array}{r}\mathrm{GF} \\
\mathrm{m}-\mathrm{Ti} \\
967 \\
98577\end{array}$ & $\begin{array}{r}\mathrm{GF} \\
\mathrm{m}-\mathrm{Ti}_{\mathrm{i}} \\
979 \\
98578\end{array}$ & $\begin{array}{r}\text { GF } \\
\mathrm{m}-\mathrm{Ti} \\
1013 \\
98579\end{array}$ & $\begin{array}{r}\text { GF } \\
\mathrm{m}-\mathrm{Ti} \\
1046 \\
98581\end{array}$ & $\begin{array}{r}\mathrm{GF} \\
\mathrm{m}-\mathrm{Ti} \\
1115 \\
98703\end{array}$ & $\begin{array}{r}\mathrm{GF} \\
\mathrm{m}-\mathrm{Ti} \\
1133 \\
98704\end{array}$ & $\begin{array}{r}\mathrm{GF} \\
\mathrm{m}-\mathrm{Ti} \\
1198 \\
98705\end{array}$ \\
\hline $\begin{array}{l}\mathrm{SiO}_{2} \\
\mathrm{TiO}_{2} \\
\mathrm{Al}_{2} \mathrm{O}_{3} \\
\mathrm{Fe}_{2} \mathrm{O}, \\
\mathrm{FeO} \\
\mathrm{MnO} \\
\mathrm{MgO} \\
\mathrm{CaO} \\
\mathrm{Na}_{2} \mathrm{O} \\
\mathrm{K}_{2} \mathrm{O} \\
\mathrm{P}_{2} \mathrm{O}_{3} \\
1.0 . i .\end{array}$ & $\begin{array}{r}4862 \\
423 \\
1246 \\
539 \\
966 \\
025 \\
538 \\
970 \\
247 \\
065 \\
041 \\
106 \\
10028\end{array}$ & $\begin{array}{r}4702 \\
229 \\
1499 \\
479 \\
680 \\
024 \\
653 \\
1092 \\
230 \\
010 \\
019 \\
310 \\
9927\end{array}$ & $\begin{array}{r}47.82 \\
2.52 \\
1438 \\
465 \\
812 \\
024 \\
648 \\
1091 \\
240 \\
011 \\
023 \\
234 \\
10020\end{array}$ & $\begin{array}{r}48.60 \\
2.56 \\
1447 \\
3.96 \\
8.53 \\
024 \\
616 \\
1091 \\
2.44 \\
020 \\
021 \\
155 \\
9983\end{array}$ & $\begin{array}{r}4829 \\
356 \\
1335 \\
433 \\
949 \\
024 \\
611 \\
9.93 \\
256 \\
051 \\
034 \\
122 \\
99.93\end{array}$ & $\begin{array}{r}4838 \\
3.50 \\
13.27 \\
4.76 \\
8.95 \\
025 \\
5.93 \\
10.28 \\
2.49 \\
056 \\
033 \\
0.98 \\
99.68\end{array}$ & $\begin{array}{r}4840 \\
296 \\
1354 \\
490 \\
874 \\
025 \\
653 \\
1074 \\
255 \\
035 \\
025 \\
071 \\
9992\end{array}$ & $\begin{array}{r}48.36 \\
268 \\
1380 \\
458 \\
8.47 \\
024 \\
647 \\
1097 \\
243 \\
027 \\
025 \\
144 \\
9996\end{array}$ & $\begin{array}{r}4795 \\
260 \\
1430 \\
5.96 \\
681 \\
024 \\
643 \\
1116 \\
229 \\
0.20 \\
024 \\
180 \\
9998\end{array}$ & $\begin{array}{r}4864 \\
264 \\
1358 \\
491 \\
866 \\
025 \\
603 \\
1116 \\
237 \\
023 \\
025 \\
148 \\
10020\end{array}$ & $\begin{array}{r}4741 \\
2.56 \\
1362 \\
588 \\
7.75 \\
024 \\
665 \\
11.19 \\
219 \\
032 \\
0.23 \\
1.65 \\
9969\end{array}$ & $\begin{array}{r}4886 \\
247 \\
1359 \\
480 \\
823 \\
024 \\
678 \\
1130 \\
232 \\
039 \\
023 \\
100 \\
10021\end{array}$ & $\begin{array}{r}4732 \\
252 \\
1348 \\
600 \\
7.72 \\
0.25 \\
673 \\
1154 \\
2.31 \\
025 \\
0.24 \\
1.30 \\
99.66\end{array}$ & $\begin{array}{r}4828 \\
235 \\
1382 \\
415 \\
892 \\
023 \\
721 \\
1104 \\
220 \\
028 \\
019 \\
153 \\
10020\end{array}$ & $\begin{array}{r}48.11 \\
2.47 \\
13.61 \\
496 \\
8.37 \\
025 \\
680 \\
11.27 \\
234 \\
033 \\
021 \\
097 \\
9969\end{array}$ \\
\hline
\end{tabular}

Profile 63 - south of Gajsefjord

\begin{tabular}{|c|c|c|c|c|c|c|c|c|c|c|c|c|c|c|}
\hline $\begin{array}{l}\text { Formation } \\
\text { Type } \\
\text { Height m } \\
\text { GGU No. }\end{array}$ & $\begin{array}{r}\mathrm{GF} \\
\mathrm{m}-\mathrm{Ti} \\
1221 \\
98706\end{array}$ & $\begin{array}{r}\mathrm{GF} \\
\mathrm{m}-\mathrm{Ti} \\
1240 \\
98707\end{array}$ & $\begin{array}{r}\mathrm{GF} \\
\mathrm{m}-\mathrm{Ti} \\
1275 \\
98708\end{array}$ & $\begin{array}{r}\mathrm{GF} \\
1-\mathrm{Ti} \\
1313 \\
98709\end{array}$ & $\begin{array}{r}\mathrm{MF} \\
\mathrm{m}-\mathrm{Ti} \\
200 \\
98638\end{array}$ & $\begin{array}{r}\mathrm{MF} \\
\mathrm{m}-\mathrm{Ti} \\
250 \\
98639\end{array}$ & $\begin{array}{r}\mathrm{MF} \\
\mathrm{m}-\mathrm{Ti} \\
316 \\
98641\end{array}$ & $\begin{array}{r}\mathrm{MF} \\
\mathrm{m}-\mathrm{Ti} \\
322 \\
98763\end{array}$ & $\begin{array}{r}\mathrm{MF} \\
\mathrm{m}-\mathrm{Ti} \\
371 \\
98754\end{array}$ & $\begin{array}{r}\mathrm{MF} \\
\mathrm{m}-\mathrm{Ti} \\
436 \\
98756\end{array}$ & $\begin{array}{r}\mathrm{MF} \\
\mathrm{m}-\mathrm{Ti} \\
457 \\
98757\end{array}$ & $\begin{array}{r}\text { MF } \\
\mathrm{m}-\mathrm{Ti} \\
469 \\
98758\end{array}$ & $\begin{array}{r}\mathrm{MF} \\
\mathrm{h}-\mathrm{Si} \\
511 \\
98761\end{array}$ & $\begin{array}{r}\text { MLF } \\
h-T i \\
543 \\
98762\end{array}$ \\
\hline $\begin{array}{l}\mathrm{SiO}_{2} \\
\mathrm{TiO}_{2} \\
\mathrm{Al}_{2} \mathrm{O}_{3} \\
\mathrm{Fe}_{2} \mathrm{O}_{3} \\
\mathrm{FeO} \\
\mathrm{MnO} \\
\mathrm{MgO} \\
\mathrm{CaO} \\
\mathrm{Na}_{2} \mathrm{O} \\
\mathrm{K}_{2} \mathrm{O} \\
\mathrm{P}_{2} \mathrm{O}_{5} \\
\text { I.o.i. }\end{array}$ & $\begin{array}{r}4795 \\
2.54 \\
13.66 \\
607 \\
7.67 \\
025 \\
6.67 \\
1120 \\
232 \\
0.20 \\
021 \\
121 \\
99.95\end{array}$ & $\begin{array}{r}4837 \\
234 \\
1364 \\
387 \\
905 \\
024 \\
713 \\
1114 \\
222 \\
031 \\
019 \\
151 \\
10001\end{array}$ & $\begin{array}{r}47.48 \\
269 \\
1386 \\
489 \\
871 \\
025 \\
664 \\
1104 \\
236 \\
021 \\
023 \\
125 \\
9961\end{array}$ & $\begin{array}{r}48.63 \\
2.28 \\
13.52 \\
4.71 \\
8.70 \\
0.27 \\
6.58 \\
11.29 \\
233 \\
031 \\
0.21 \\
1.11 \\
99.94\end{array}$ & $\begin{array}{r}49.19 \\
252 \\
1427 \\
399 \\
797 \\
028 \\
601 \\
1156 \\
224 \\
0223 \\
024 \\
141 \\
9991\end{array}$ & $\begin{array}{r}49.98 \\
244 \\
13.87 \\
283 \\
895 \\
023 \\
712 \\
1079 \\
222 \\
026 \\
020 \\
096 \\
9985\end{array}$ & $\begin{array}{r}5033 \\
245 \\
1401 \\
254 \\
930 \\
023 \\
681 \\
10.91 \\
224 \\
027 \\
019 \\
104 \\
10032\end{array}$ & $\begin{array}{r}4915 \\
249 \\
1407 \\
290 \\
923 \\
023 \\
691 \\
1131 \\
221 \\
016 \\
020 \\
109 \\
9995\end{array}$ & $\begin{array}{r}4792 \\
240 \\
1388 \\
284 \\
887 \\
023 \\
703 \\
1090 \\
146 \\
020 \\
021 \\
409 \\
10003\end{array}$ & $\begin{array}{r}49.94 \\
241 \\
1397 \\
408 \\
773 \\
022 \\
702 \\
1107 \\
208 \\
017 \\
021 \\
160 \\
10050\end{array}$ & $\begin{array}{r}5021 \\
255 \\
1378 \\
278 \\
930 \\
023 \\
683 \\
1089 \\
219 \\
013 \\
021 \\
120 \\
10030\end{array}$ & $\begin{array}{r}5040 \\
261 \\
1372 \\
299 \\
916 \\
023 \\
673 \\
1072 \\
228 \\
021 \\
024 \\
114 \\
10043\end{array}$ & $\begin{array}{r}5302 \\
193 \\
1352 \\
247 \\
783 \\
020 \\
675 \\
988 \\
252 \\
044 \\
017 \\
109 \\
9982\end{array}$ & $\begin{array}{r}48.81 \\
3.10 \\
1362 \\
415 \\
9.57 \\
024 \\
629 \\
1040 \\
2.38 \\
028 \\
028 \\
109 \\
10021\end{array}$ \\
\hline
\end{tabular}

Profile 71 - westernmost nunatak

Profile 72 - western nunatak

\begin{tabular}{|c|c|c|c|c|c|c|c|c|c|c|c|c|c|}
\hline $\begin{array}{l}\text { Formation } \\
\text { Type } \\
\text { Height m } \\
\text { GGU No. }\end{array}$ & $\begin{array}{r}\text { MLF.F } \\
\text { h-Ti } \\
1812 \\
98666\end{array}$ & $\begin{array}{r}\text { MLF } \\
\mathrm{m}-\mathrm{Ti} \\
1827 \\
98667\end{array}$ & $\begin{array}{r}\text { MLF } \\
\mathrm{m}-\mathrm{Ti} \\
1852 \\
98669\end{array}$ & $\begin{array}{r}\text { MLF } \\
\text { h-Ti } \\
1887 \\
98670\end{array}$ & $\begin{array}{r}\text { MLF } \\
\mathrm{h}-\mathrm{Ti} \\
>1914 \\
98671\end{array}$ & $\begin{array}{l}\text { MLF } \\
\text { Ti-th } \\
1624 \\
98836\end{array}$ & $\begin{array}{r}\text { MLF } \\
\text { h-Si } \\
1645 \\
98837\end{array}$ & $\begin{array}{r}\text { MLF } \\
\text { h-Si } \\
1654 \\
98838\end{array}$ & $\begin{array}{r}\text { MLF } \\
\text { h-Ti } \\
1702 \\
98839\end{array}$ & $\begin{array}{r}\text { MLF } \\
\text { Hjørn } \\
1721 \\
98840\end{array}$ & $\begin{array}{r}\text { MLF } \\
\text { Hjørn? } \\
1750 \\
98841\end{array}$ & $\begin{array}{l}\text { MLF } \\
\mathrm{m}-\mathrm{Ti} \\
1774 \\
98844\end{array}$ & $\begin{array}{r}\mathrm{MLF} \\
\mathrm{h}-\mathrm{Ti} \\
1802 \\
98845\end{array}$ \\
\hline $\begin{array}{l}\mathrm{SiO}_{2} \\
\mathrm{TiO}_{2} \\
\mathrm{Al}_{2} \mathrm{O}_{3} \\
\mathrm{Fe}_{2} \mathrm{O}_{2} \\
\mathrm{FeO} \\
\mathrm{MnO} \\
\mathrm{MgO} \\
\mathrm{CaO} \\
\mathrm{Na}_{2} \mathrm{O} \\
\mathrm{K}_{2} \mathrm{O} \\
\mathrm{P}_{2} \mathrm{O}_{3} \\
1.0 .1\end{array}$ & $\begin{array}{r}4842 \\
318 \\
1311 \\
663 \\
761 \\
020 \\
545 \\
1071 \\
228 \\
024 \\
030 \\
184 \\
\frac{1897}{99}\end{array}$ & $\begin{array}{r}49.91 \\
236 \\
15.51 \\
577 \\
5.30 \\
0.13 \\
486 \\
1158 \\
238 \\
0.16 \\
0.21 \\
146 \\
9963\end{array}$ & $\begin{array}{r}4918 \\
251 \\
1405 \\
425 \\
8.68 \\
019 \\
634 \\
1139 \\
231 \\
018 \\
023 \\
095 \\
10026\end{array}$ & $\begin{array}{r}4886 \\
288 \\
1346 \\
3.88 \\
934 \\
0.19 \\
646 \\
10.96 \\
2.24 \\
0.34 \\
0.27 \\
\frac{0.87}{9975}\end{array}$ & $\begin{array}{r}4883 \\
283 \\
1354 \\
416 \\
913 \\
019 \\
637 \\
1104 \\
220 \\
037 \\
026 \\
102 \\
9994\end{array}$ & $\begin{array}{r}4852 \\
3.77 \\
12.86 \\
4.66 \\
1012 \\
020 \\
601 \\
1028 \\
245 \\
034 \\
036 \\
103 \\
10060\end{array}$ & $\begin{array}{r}5099 \\
292 \\
1289 \\
3.33 \\
865 \\
019 \\
658 \\
963 \\
224 \\
063 \\
0.31 \\
137 \\
9973\end{array}$ & $\begin{array}{r}5154 \\
294 \\
1278 \\
288 \\
916 \\
0.17 \\
673 \\
949 \\
237 \\
065 \\
030 \\
104 \\
10005\end{array}$ & $\begin{array}{r}4886 \\
296 \\
1393 \\
449 \\
798 \\
017 \\
682 \\
1078 \\
223 \\
020 \\
029 \\
131 \\
10002\end{array}$ & $\begin{array}{r}4914 \\
225 \\
1363 \\
465 \\
710 \\
016 \\
855 \\
1084 \\
210 \\
029 \\
021 \\
106 \\
9998\end{array}$ & $\begin{array}{r}4993 \\
2.52 \\
1308 \\
4.23 \\
782 \\
017 \\
783 \\
1039 \\
228 \\
0.49 \\
0.32 \\
097 \\
10003\end{array}$ & $\begin{array}{r}49.86 \\
2.46 \\
13.83 \\
5.32 \\
675 \\
017 \\
6.75 \\
1108 \\
2.33 \\
022 \\
022 \\
103 \\
10002\end{array}$ & $\begin{array}{r}4894 \\
325 \\
1380 \\
1011 \\
421 \\
018 \\
5.27 \\
9.93 \\
254 \\
043 \\
031 \\
084 \\
9981\end{array}$ \\
\hline
\end{tabular}

Profile 74 - west Bredegletscher

Profile 76 -

\begin{tabular}{|c|c|c|c|c|c|c|c|c|c|c|c|c|c|}
\hline $\begin{array}{l}\text { Formation } \\
\text { Type } \\
\text { Height m } \\
\text { GGU No. }\end{array}$ & $\begin{array}{r}\text { MLF } \\
\text { m-Ti } \\
1879 \\
98847\end{array}$ & $\begin{array}{r}\text { MLF } \\
\text { h-Ti } \\
1921 \\
98846\end{array}$ & $\begin{array}{r}\text { RFF } \\
1 \text { ol-th } \\
1007 \\
98871\end{array}$ & $\begin{array}{l}\text { RFF } \\
h-\mathrm{Ti}_{1} \\
1070 \\
98872\end{array}$ & $\begin{array}{r}\text { RFF } \\
\mathrm{h}-\mathrm{Ti} \\
\mathrm{I} 093 \\
98873\end{array}$ & $\begin{array}{r}\mathrm{SF} \\
\mathrm{m}-\mathrm{h}-\mathrm{Ti} \\
1108 \\
98874\end{array}$ & $\begin{array}{r}\text { SF } \\
\mathrm{m}-\mathrm{h}-\mathrm{Ti} \\
1157 \\
98875\end{array}$ & $\begin{array}{r}\text { SF } \\
\mathrm{m}-\mathrm{h}-\mathrm{Ti} \\
1181 \\
98876\end{array}$ & $\begin{array}{r}\mathrm{SF} \\
\mathrm{m}-\mathrm{h}-\mathrm{Ti} \\
1262 \\
98877\end{array}$ & $\begin{array}{r}\text { SF } \\
\text { Ti-th } \\
1312 \\
98878\end{array}$ & $\begin{array}{r}\text { SF } \\
\text { b-Si } \\
1378 \\
98879\end{array}$ & $\begin{array}{r}\mathrm{GF} \\
\mathrm{h}-\mathrm{Ti} \\
1227 \\
98880\end{array}$ & $\begin{array}{r}\text { GF } \\
\text { Ti-th } \\
1250 \\
98881\end{array}$ \\
\hline $\begin{array}{l}\mathrm{SiO}_{2} \\
\mathrm{TiO}_{2} \\
\mathrm{Al}_{2} \mathrm{O}_{3} \\
\mathrm{Fe}_{3} \mathrm{O}_{1} \\
\mathrm{FeO} \\
\mathrm{MnO} \\
\mathrm{MgO} \\
\mathrm{CaO} \\
\mathrm{Na}, \mathrm{O} \\
\mathrm{Ka} \\
\mathrm{P}_{2} \mathrm{O}_{5} \\
1.0 . \mathrm{I}^{2}\end{array}$ & $\begin{array}{r}4901 \\
253 \\
1387 \\
599 \\
710 \\
019 \\
642 \\
1143 \\
233 \\
017 \\
022 \\
099 \\
10025\end{array}$ & $\begin{array}{r}48.86 \\
297 \\
1346 \\
443 \\
912 \\
0.20 \\
640 \\
10.91 \\
234 \\
031 \\
0.27 \\
0.91 \\
100-18\end{array}$ & $\begin{array}{r}4613 \\
217 \\
1301 \\
365 \\
815 \\
022 \\
877 \\
1151 \\
194 \\
020 \\
018 \\
380 \\
9973\end{array}$ & $\begin{array}{r}4761 \\
295 \\
1388 \\
557 \\
771 \\
024 \\
616 \\
1121 \\
241 \\
016 \\
026 \\
187 \\
10003\end{array}$ & $\begin{array}{r}4672 \\
305 \\
1365 \\
692 \\
694 \\
021 \\
639 \\
1059 \\
240 \\
028 \\
026 \\
\frac{228}{9969}\end{array}$ & $\begin{array}{r}4773 \\
272 \\
1403 \\
471 \\
902 \\
027 \\
6.32 \\
1066 \\
244 \\
025 \\
024 \\
141 \\
9980\end{array}$ & $\begin{array}{r}4830 \\
293 \\
1284 \\
517 \\
926 \\
027 \\
619 \\
1092 \\
255 \\
033 \\
026 \\
108 \\
10010\end{array}$ & $\begin{array}{r}4822 \\
264 \\
1333 \\
428 \\
922 \\
025 \\
671 \\
1134 \\
250 \\
027 \\
022 \\
1114 \\
100112\end{array}$ & $\begin{array}{r}4725 \\
288 \\
1300 \\
527 \\
902 \\
0227 \\
655 \\
1112 \\
240 \\
022 \\
025 \\
142 \\
9965\end{array}$ & $\begin{array}{r}4627 \\
366 \\
1366 \\
414 \\
1076 \\
027 \\
604 \\
1089 \\
244 \\
015 \\
034 \\
128 \\
9990\end{array}$ & $\begin{array}{r}5002 \\
182 \\
1383 \\
384 \\
810 \\
023 \\
697 \\
1124 \\
235 \\
033 \\
015 \\
085 \\
9973\end{array}$ & $\begin{array}{r}4821 \\
323 \\
1256 \\
533 \\
1049 \\
032 \\
549 \\
1018 \\
250 \\
044 \\
033 \\
134 \\
10042\end{array}$ & $\begin{array}{r}4852 \\
378 \\
1233 \\
510 \\
1064 \\
032 \\
556 \\
989 \\
264 \\
045 \\
037 \\
107 \\
10067\end{array}$ \\
\hline
\end{tabular}


east side of Magga Dan Gletscher

Profile 77 - Gronau Nunatakker

Profile 78 - Gronau

\begin{tabular}{|c|c|c|c|c|c|c|c|c|c|c|c|c|c|}
\hline $\begin{array}{l}\text { Formation } \\
\text { Type } \\
\text { Height m } \\
\text { GGU No. }\end{array}$ & $\begin{array}{r}\mathrm{GF} \\
\mathrm{h}-\mathrm{Ti} \\
1332 \\
98882\end{array}$ & $\begin{array}{r}\text { RFF } \\
\text { Ti-th } \\
1388 \\
98884\end{array}$ & $\begin{array}{r}\text { RFF } \\
\mathrm{h}-\mathrm{Ti} \\
1400 \\
98885\end{array}$ & $\begin{array}{r}\text { RFF } \\
\text { Ti-th } \\
1403 \\
98886\end{array}$ & $\begin{array}{r}\text { SF } \\
\text { 1-m-Ti } \\
1407 \\
98887\end{array}$ & $\begin{array}{r}\mathrm{SF} \\
\mathrm{m}-\mathrm{h}-\mathrm{Ti} \\
1433 \\
98888\end{array}$ & $\begin{array}{r}\text { SF } \\
1-\mathrm{Ti} \\
2506 \\
98891\end{array}$ & $\begin{array}{r}\mathrm{SF} \\
1-\mathrm{Ti} \\
2522 \\
98892\end{array}$ & $\begin{array}{r}\mathrm{SF} \\
1-\mathrm{Ti}_{1} \\
2535 \\
98894\end{array}$ & $\begin{array}{r}\mathrm{SF} \\
1-\mathrm{Ti} \\
2559 \\
98895\end{array}$ & $\begin{array}{r}\mathrm{SF} \\
\mathrm{l}-\mathrm{m}-\mathrm{Ti} \\
1834 \\
104104\end{array}$ & $\begin{array}{r}\mathrm{SF} \\
1-\mathrm{m}-\mathrm{Ti} \\
1840 \\
98899\end{array}$ & $\begin{array}{r}\text { SF } \\
\text { m-h-T } \\
1856 \\
98900\end{array}$ \\
\hline $\begin{array}{l}\mathrm{SiO} \\
\mathrm{TiO}_{2} \\
\mathrm{Al}_{2} \mathrm{O}, \\
\mathrm{Fe}_{2} \mathrm{O}_{3} \\
\mathrm{FeO} \\
\mathrm{MnO} \\
\mathrm{MgO} \\
\mathrm{CaO} \\
\mathrm{Na}_{2} \mathrm{O} \\
\mathrm{K}_{2} \mathrm{O} \\
\mathrm{P}_{2} \mathrm{O} \\
1.0 . i\end{array}$ & $\begin{array}{r}4804 \\
3.34 \\
13.55 \\
3.69 \\
1000 \\
0.29 \\
6.58 \\
1081 \\
2.61 \\
035 \\
033 \\
109 \\
10068\end{array}$ & $\begin{array}{r}4714 \\
385 \\
1398 \\
641 \\
665 \\
025 \\
631 \\
977 \\
267 \\
067 \\
045 \\
234 \\
10049\end{array}$ & $\begin{array}{r}4606 \\
305 \\
1544 \\
563 \\
706 \\
036 \\
657 \\
1011 \\
226 \\
016 \\
030 \\
318 \\
10018\end{array}$ & $\begin{array}{r}46.02 \\
3.92 \\
1353 \\
656 \\
857 \\
0.32 \\
6.17 \\
1036 \\
241 \\
021 \\
0.37 \\
192 \\
10036\end{array}$ & $\begin{array}{r}47.16 \\
2.25 \\
15.67 \\
506 \\
6.89 \\
025 \\
579 \\
1173 \\
238 \\
018 \\
018 \\
274 \\
10028\end{array}$ & $\begin{array}{r}47.88 \\
262 \\
1355 \\
849 \\
548 \\
029 \\
672 \\
1132 \\
243 \\
018 \\
020 \\
097 \\
10013\end{array}$ & $\begin{array}{r}4916 \\
207 \\
1433 \\
514 \\
785 \\
028 \\
692 \\
1123 \\
241 \\
029 \\
018 \\
067 \\
10053\end{array}$ & $\begin{array}{r}49.20 \\
192 \\
14.42 \\
723 \\
599 \\
028 \\
637 \\
1130 \\
235 \\
024 \\
017 \\
0.85 \\
10032\end{array}$ & $\begin{array}{r}4959 \\
1.89 \\
1446 \\
466 \\
820 \\
028 \\
675 \\
11.24 \\
235 \\
025 \\
017 \\
066 \\
10050\end{array}$ & $\begin{array}{r}4937 \\
188 \\
1485 \\
594 \\
716 \\
028 \\
626 \\
1137 \\
239 \\
019 \\
017 \\
068 \\
10054\end{array}$ & $\begin{array}{r}48.22 \\
232 \\
13.62 \\
4.18 \\
9.11 \\
021 \\
6.96 \\
1129 \\
2.22 \\
0.40 \\
0.21 \\
105 \\
99.79\end{array}$ & $\begin{array}{r}4824 \\
232 \\
1338 \\
588 \\
767 \\
021 \\
666 \\
1135 \\
221 \\
027 \\
022 \\
132 \\
9973\end{array}$ & $\begin{array}{r}4791 \\
269 \\
1242 \\
607 \\
875 \\
022 \\
586 \\
1106 \\
231 \\
019 \\
025 \\
1777 \\
9950\end{array}$ \\
\hline
\end{tabular}

Nunatakker

Profile 91 - below sediments at Kap Dalton

Profile $94 a$ - south side

\begin{tabular}{|c|c|c|c|c|c|c|c|c|c|c|c|c|c|}
\hline $\begin{array}{l}\text { Formation } \\
\text { Type } \\
\text { Height m } \\
\text { GGU No. }\end{array}$ & $\begin{array}{r}\mathrm{SF} \\
1-\mathrm{Ti} \\
1876 \\
104102\end{array}$ & $\begin{array}{r}\text { SF } \\
\mathrm{m}-\mathrm{h}-\mathrm{Ti} \\
1930 \\
104103\end{array}$ & $\begin{array}{r}\text { IF } \\
\mathrm{m}-\mathrm{h}-\mathrm{Ti} \\
12 \\
116340\end{array}$ & $\begin{array}{r}\text { IF } \\
\mathrm{m}-\mathrm{h}-\mathrm{Ti} \\
53 \\
116343\end{array}$ & $\begin{array}{r}1 F \\
\mathrm{~m}-\mathrm{h}-\mathrm{Ti} \\
84 \\
116344\end{array}$ & $\begin{array}{r}\text { IF } \\
\mathrm{m}-\mathrm{h}-\mathrm{Ti} \\
132 \\
116345\end{array}$ & $\begin{array}{r}\text { IF } \\
\mathrm{m}-\mathrm{h}-\mathrm{Ti} \\
138 \\
116346\end{array}$ & $\begin{array}{r}1 \mathrm{~F} \\
\mathrm{~m}-\mathrm{h}-\mathrm{Ti} \\
190 \\
116347\end{array}$ & $\begin{array}{r}\text { IF } \\
\mathrm{m}-\mathrm{h}-\mathrm{Ti} \\
212 \\
116348\end{array}$ & $\begin{array}{r}\text { IF } \\
\mathrm{m}-\mathrm{h}-\mathrm{Ti} \\
225 \\
116349\end{array}$ & $\begin{array}{r}\text { IF } \\
1-\mathrm{Ti} \\
57 \\
116378\end{array}$ & $\begin{array}{r}\text { IF } \\
\text { I-Ti } \\
99 \\
116379\end{array}$ & $\begin{array}{r}\mathrm{IF} \\
1-\mathrm{m}-\mathrm{Ti} \\
126 \\
116380\end{array}$ \\
\hline $\begin{array}{l}\mathrm{SiO}_{2} \\
\mathrm{TiO}_{2} \\
\mathrm{Al}_{2} \mathrm{O}_{1} \\
\mathrm{Fe}_{2} \mathrm{O}_{3} \\
\mathrm{FeO} \\
\mathrm{MnO} \\
\mathrm{MgO} \\
\mathrm{CaO} \\
\mathrm{Na}_{3} \mathrm{O} \\
\mathrm{K}_{2} \mathrm{O} \\
\mathrm{P}_{2} \mathrm{O}_{5} \\
\mathrm{Lo}_{5} .\end{array}$ & $\begin{array}{r}48.75 \\
206 \\
1360 \\
3.32 \\
912 \\
020 \\
703 \\
1139 \\
223 \\
035 \\
019 \\
124 \\
99.48\end{array}$ & $\begin{array}{r}4842 \\
283 \\
1327 \\
501 \\
931 \\
0.22 \\
5.60 \\
1098 \\
2.45 \\
0.34 \\
0.27 \\
104 \\
99.74\end{array}$ & $\begin{array}{r}4890 \\
261 \\
1393 \\
592 \\
717 \\
019 \\
543 \\
1101 \\
257 \\
060 \\
030 \\
145 \\
10008\end{array}$ & $\begin{array}{r}49.83 \\
3.01 \\
1335 \\
5.54 \\
8.89 \\
024 \\
470 \\
9.66 \\
272 \\
045 \\
041 \\
145 \\
10025\end{array}$ & $\begin{array}{r}4914 \\
249 \\
1419 \\
5.45 \\
733 \\
0.22 \\
571 \\
1083 \\
2.62 \\
0.51 \\
030 \\
150 \\
10029\end{array}$ & $\begin{array}{r}4864 \\
232 \\
1392 \\
680 \\
691 \\
025 \\
560 \\
1133 \\
256 \\
020 \\
023 \\
160 \\
10036\end{array}$ & $\begin{array}{r}48.86 \\
2.23 \\
13.34 \\
618 \\
797 \\
0.22 \\
600 \\
11.04 \\
2.46 \\
020 \\
0.20 \\
1.75 \\
10045\end{array}$ & $\begin{array}{r}4810 \\
300 \\
13.63 \\
668 \\
781 \\
029 \\
547 \\
1011 \\
267 \\
028 \\
037 \\
147 \\
9988\end{array}$ & $\begin{array}{r}48.08 \\
276 \\
13.37 \\
662 \\
774 \\
024 \\
5.66 \\
1087 \\
254 \\
0.21 \\
028 \\
1.71 \\
10008\end{array}$ & $\begin{array}{r}4816 \\
276 \\
1355 \\
747 \\
637 \\
022 \\
565 \\
1101 \\
251 \\
017 \\
029 \\
199 \\
10015\end{array}$ & $\begin{array}{r}48.60 \\
2.21 \\
1355 \\
5.70 \\
7.31 \\
0.21 \\
6.44 \\
1158 \\
249 \\
028 \\
0.21 \\
1.68 \\
10026\end{array}$ & $\begin{array}{r}48.35 \\
1.93 \\
14.31 \\
6.12 \\
6.87 \\
0.21 \\
656 \\
1171 \\
2.15 \\
0.18 \\
019 \\
1.73 \\
10031\end{array}$ & $\begin{array}{r}47.92 \\
2.30 \\
13.82 \\
493 \\
8.13 \\
0.20 \\
706 \\
11.07 \\
2.21 \\
0.33 \\
0.23 \\
1.68 \\
99.88\end{array}$ \\
\hline
\end{tabular}

of Kap Dalton

Profile 102 - Romer Fjord - Steno Gletscher (upper part)

\begin{tabular}{|c|c|c|c|c|c|c|c|c|c|c|c|c|}
\hline $\begin{array}{l}\text { Formation } \\
\text { Type } \\
\text { Height m } \\
\text { GGU No. }\end{array}$ & $\begin{array}{r}\text { IF } \\
1-\mathrm{Ti} \\
152 \\
116381\end{array}$ & $\begin{array}{r}\text { IF } \\
1-\mathrm{Ti} \\
203 \\
116382\end{array}$ & $\begin{array}{r}\mathrm{GF} \\
\mathrm{m}-\mathrm{Ti} \\
650 \\
215452\end{array}$ & $\begin{array}{r}\text { GF } \\
\text { Ti-ch } \\
676 \\
215453\end{array}$ & $\begin{array}{r}\text { GF } \\
\text { Ti-th } \\
690 \\
215454\end{array}$ & $\begin{array}{r}\text { GF } \\
\text { Ti-th } \\
741 \\
215455\end{array}$ & $\begin{array}{r}\text { RFF } \\
\text { Ti-th } \\
808 \\
215457\end{array}$ & $\begin{array}{r}\text { RFF } \\
\text { Ti-th } \\
862 \\
215458\end{array}$ & $\begin{array}{r}\text { RFF } \\
\text { Ti-th } \\
880 \\
215459\end{array}$ & $\begin{array}{r}\text { RFF } \\
1 \text { ol-th } \\
920 \\
215461\end{array}$ & $\begin{array}{r}\text { RFF } \\
1 \text { ol-th } \\
938 \\
215464\end{array}$ & $\begin{array}{r}\text { RFF } \\
\mathrm{h}-\mathrm{Ti} \\
945 \\
215465\end{array}$ \\
\hline $\begin{array}{l}\mathrm{SiO}_{2} \\
\mathrm{TiO}_{2} \\
\mathrm{Al}_{2} \mathrm{O} \\
\mathrm{Fe}_{2} \mathrm{O}_{3} \\
\mathrm{FeO} \\
\mathrm{MnO} \\
\mathrm{MgO} \\
\mathrm{CaO} \\
\mathrm{Na}_{2} \mathrm{O} \\
\mathrm{K}_{2} \mathrm{O} \\
\mathrm{P}_{2} \mathrm{O}_{5} \\
\text { l.o.i. }\end{array}$ & $\begin{array}{r}47.93 \\
2.15 \\
14.30 \\
5.39 \\
7.38 \\
0.20 \\
6.90 \\
11.15 \\
2.16 \\
0.32 \\
0.22 \\
1.76 \\
99.86\end{array}$ & $\begin{array}{r}48.95 \\
206 \\
13.96 \\
5.96 \\
6.89 \\
0.20 \\
614 \\
11.56 \\
2.49 \\
0.40 \\
0.23 \\
1.46 \\
100-30\end{array}$ & $\begin{array}{r}48.84 \\
2.54 \\
12.99 \\
498 \\
9.38 \\
022 \\
5.99 \\
1106 \\
266 \\
0.37 \\
030 \\
086 \\
10019\end{array}$ & $\begin{array}{r}4648 \\
347 \\
13.05 \\
690 \\
841 \\
023 \\
605 \\
1098 \\
224 \\
023 \\
033 \\
1.60 \\
99.97\end{array}$ & $\begin{array}{r}47.44 \\
366 \\
1312 \\
5.00 \\
9.46 \\
0.22 \\
5.88 \\
1080 \\
2.55 \\
0.41 \\
0.38 \\
0.99 \\
99.91\end{array}$ & $\begin{array}{r}47.47 \\
3.59 \\
13.35 \\
476 \\
9.52 \\
021 \\
5.89 \\
1089 \\
251 \\
041 \\
036 \\
084 \\
99.80\end{array}$ & $\begin{array}{r}4703 \\
390 \\
1288 \\
619 \\
844 \\
0.22 \\
566 \\
1080 \\
254 \\
024 \\
037 \\
184 \\
10011\end{array}$ & $\begin{array}{r}4664 \\
380 \\
1283 \\
839 \\
617 \\
019 \\
604 \\
1055 \\
259 \\
050 \\
038 \\
163 \\
9971\end{array}$ & $\begin{array}{r}4606 \\
348 \\
1290 \\
573 \\
816 \\
022 \\
669 \\
1041 \\
239 \\
060 \\
035 \\
312 \\
10011\end{array}$ & $\begin{array}{r}4623 \\
2.03 \\
1400 \\
403 \\
792 \\
017 \\
783 \\
11.73 \\
207 \\
019 \\
016 \\
3.54 \\
9990\end{array}$ & $\begin{array}{r}4664 \\
1.92 \\
1339 \\
277 \\
840 \\
017 \\
929 \\
1184 \\
188 \\
019 \\
015 \\
3.11 \\
9975\end{array}$ & $\begin{array}{r}4560 \\
2.97 \\
1316 \\
513 \\
857 \\
020 \\
728 \\
1077 \\
202 \\
030 \\
027 \\
3.87 \\
10014\end{array}$ \\
\hline
\end{tabular}

Profile 103 - head of Romer Fjord Profile 104 - Bartholin Brce

\begin{tabular}{|c|c|c|c|c|c|c|c|c|c|c|c|c|c|c|}
\hline $\begin{array}{l}\text { Formation } \\
\text { Type } \\
\text { Height m } \\
\text { GGU No. }\end{array}$ & $\begin{array}{r}\mathrm{GF} \\
\mathrm{h}-\mathrm{Ti} \\
85 \\
215475\end{array}$ & $\begin{array}{r}\mathrm{GF} \\
\mathrm{h}-\mathrm{Ti} \\
118 \\
215476\end{array}$ & $\begin{array}{r}\text { RFF } \\
\text { Ti-th } \\
670 \\
215482\end{array}$ & $\begin{array}{r}\text { RFF } \\
\text { u ol-th } \\
680 \\
215483\end{array}$ & $\begin{array}{r}\text { RFF } \\
\text { u ol-th } \\
710 \\
215484\end{array}$ & $\begin{array}{r}\mathrm{SF} \\
\mathrm{m}-\mathrm{h}-\mathrm{Ti} \\
736 \\
215485\end{array}$ & $\begin{array}{r}\mathrm{SF} \\
\mathrm{m}-\mathrm{h}-\mathrm{Ti} \\
877 \\
215486\end{array}$ & $\begin{array}{r}\text { SF } \\
m \cdot h-T i \\
908 \\
215487\end{array}$ & $\begin{array}{r}\mathrm{SF} \\
\mathrm{m}-\mathrm{h}-\mathrm{Ti} \\
938 \\
215489\end{array}$ & $\begin{array}{r}\mathrm{SF} \\
\mathrm{m}-\mathrm{h}-\mathrm{Ti} \\
965 \\
215490\end{array}$ & $\begin{array}{r}\text { SF } \\
\mathrm{m} \cdot \mathrm{h} \cdot \mathrm{Ti} \\
996 \\
215491\end{array}$ & $\begin{array}{r}\text { SF } \\
\text { m-h-Ti } \\
1018 \\
215492\end{array}$ & $\begin{array}{r}\text { SF } \\
\text { m-h-Ti } \\
1045 \\
215493\end{array}$ & $\begin{array}{r}\mathrm{SF} \\
1-\mathrm{Ti} \\
1070 \\
215494\end{array}$ \\
\hline $\begin{array}{l}\mathrm{SiO}_{2} \\
\mathrm{TiO}_{3} \\
\mathrm{Al}_{2} \mathrm{O}_{3} \\
\mathrm{Fe}_{2} \mathrm{O}_{3} \\
\mathrm{FeO} \\
\mathrm{MnO} \\
\mathrm{MgO} \\
\mathrm{CaO} \\
\mathrm{Na}_{2} \mathrm{O} \\
\mathrm{K}_{2} \mathrm{O} \\
\mathrm{P}_{2} \mathrm{O}_{5} \\
1.0 .1 .\end{array}$ & $\begin{array}{r}4745 \\
295 \\
1271 \\
671 \\
803 \\
021 \\
584 \\
1095 \\
248 \\
015 \\
028 \\
167 \\
9943\end{array}$ & $\begin{array}{r}4907 \\
3.38 \\
12.26 \\
7.19 \\
8.51 \\
0.22 \\
502 \\
966 \\
293 \\
055 \\
041 \\
085 \\
10005\end{array}$ & $\begin{array}{r}4650 \\
3.81 \\
1398 \\
702 \\
763 \\
021 \\
556 \\
1087 \\
246 \\
021 \\
038 \\
1.73 \\
10036\end{array}$ & $\begin{array}{r}46.66 \\
287 \\
1393 \\
490 \\
786 \\
019 \\
711 \\
1099 \\
226 \\
044 \\
028 \\
238 \\
9987\end{array}$ & $\begin{array}{r}4579 \\
279 \\
13.88 \\
3.97 \\
870 \\
018 \\
750 \\
11.11 \\
186 \\
025 \\
028 \\
397 \\
10028\end{array}$ & $\begin{array}{r}48.32 \\
269 \\
1400 \\
455 \\
867 \\
019 \\
618 \\
1156 \\
250 \\
025 \\
024 \\
093 \\
10008\end{array}$ & $\begin{array}{r}4831 \\
283 \\
1367 \\
548 \\
853 \\
021 \\
612 \\
1119 \\
258 \\
039 \\
027 \\
061 \\
10019\end{array}$ & $\begin{array}{r}4829 \\
249 \\
1368 \\
508 \\
850 \\
020 \\
642 \\
1153 \\
243 \\
013 \\
024 \\
120 \\
10019\end{array}$ & $\begin{array}{r}4846 \\
2.39 \\
1415 \\
5.36 \\
785 \\
020 \\
625 \\
1156 \\
250 \\
011 \\
023 \\
1113 \\
10019\end{array}$ & $\begin{array}{r}4823 \\
271 \\
1320 \\
574 \\
858 \\
021 \\
608 \\
1144 \\
245 \\
017 \\
026 \\
113 \\
10020\end{array}$ & $\begin{array}{r}47.72 \\
2.67 \\
1408 \\
487 \\
9.29 \\
0.22 \\
571 \\
1145 \\
255 \\
022 \\
031 \\
107 \\
10016\end{array}$ & $\begin{array}{r}4759 \\
278 \\
1395 \\
592 \\
849 \\
021 \\
582 \\
1131 \\
253 \\
022 \\
026 \\
130 \\
10018\end{array}$ & $\begin{array}{r}4659 \\
286 \\
1344 \\
440 \\
957 \\
020 \\
668 \\
1116 \\
213 \\
0.55 \\
027 \\
215 \\
10000\end{array}$ & $\begin{array}{r}4779 \\
218 \\
1460 \\
660 \\
610 \\
019 \\
692 \\
1158 \\
220 \\
038 \\
017 \\
134 \\
10005\end{array}$ \\
\hline
\end{tabular}


Profile 105 - Remer Fjord-

\begin{tabular}{|c|c|c|c|c|c|c|c|c|c|c|c|c|c|c|}
\hline $\begin{array}{l}\text { Formation } \\
\text { Type } \\
\text { Height m } \\
\text { GGU No. }\end{array}$ & $\begin{array}{r}\mathrm{SF} \\
\mathrm{m}-\mathrm{h}-\mathrm{Ti} \\
1095 \\
215495\end{array}$ & $\begin{array}{r}\mathrm{SF} \\
1-\mathrm{Ti} \\
1158 \\
215496\end{array}$ & $\begin{array}{r}\mathrm{SF} \\
1-\mathrm{Ti} \\
1202 \\
215497\end{array}$ & $\begin{array}{r}\mathrm{SF} \\
\mathrm{I}-\mathrm{Ti} \\
1244 \\
215498\end{array}$ & $\begin{array}{r}\mathrm{SF} \\
1-\mathrm{Ti} \\
1304 \\
215499\end{array}$ & $\begin{array}{r}\mathrm{SF} \\
\mathrm{J}-\mathrm{Ti} \\
1368 \\
215500\end{array}$ & $\begin{array}{r}\text { SF } \\
1-T i \\
1397 \\
215501\end{array}$ & $\begin{array}{r}\text { SF } \\
\mathrm{m}-\mathrm{h}-\mathrm{Ti} \\
1472 \\
215502\end{array}$ & $\begin{array}{r}\mathrm{SF} \\
\mathrm{m}-\mathrm{h}-\mathrm{Ti} \\
1496 \\
215503\end{array}$ & $\begin{array}{r}\mathrm{SF} \\
1-\mathrm{Ti} \\
1526 \\
215504\end{array}$ & $\begin{array}{r}\mathrm{GF} \\
\mathrm{m}-\mathrm{Ti} \\
103 \\
215508\end{array}$ & $\begin{array}{r}\mathrm{GF} \\
\mathrm{m}-\mathrm{Ti} \\
175 \\
215509\end{array}$ & $\begin{array}{r}\mathrm{GF} \\
\mathrm{HFi} \\
194 \\
215510\end{array}$ & $\begin{array}{r}\mathrm{GF} \\
1-\mathrm{Ti} \\
300 \\
215511\end{array}$ \\
\hline $\begin{array}{l}\mathrm{SiO}_{2} \\
\mathrm{TiO}_{2} \\
\mathrm{Al}_{2} \mathrm{O}_{3} \\
\mathrm{Fe}_{2} \mathrm{O}_{3} \\
\mathrm{FeO} \\
\mathrm{MnO} \\
\mathrm{MgO} \\
\mathrm{CaO} \\
\mathrm{Na}_{3} \mathrm{O} \\
\mathrm{K}_{3} \mathrm{O} \\
\mathrm{P}_{2} \mathrm{O}_{3} \\
1.0 .1 .\end{array}$ & $\begin{array}{r}48.24 \\
259 \\
1416 \\
490 \\
820 \\
018 \\
669 \\
1131 \\
237 \\
028 \\
023 \\
091 \\
10006\end{array}$ & $\begin{array}{r}4754 \\
214 \\
1443 \\
722 \\
573 \\
017 \\
669 \\
1161 \\
227 \\
019 \\
018 \\
169 \\
9986\end{array}$ & $\begin{array}{r}4799 \\
211 \\
1444 \\
629 \\
628 \\
017 \\
636 \\
1189 \\
224 \\
027 \\
018 \\
183 \\
10005\end{array}$ & $\begin{array}{r}48.81 \\
216 \\
1412 \\
429 \\
891 \\
020 \\
662 \\
1130 \\
234 \\
032 \\
019 \\
081 \\
10007\end{array}$ & $\begin{array}{r}4878 \\
214 \\
1416 \\
460 \\
878 \\
020 \\
654 \\
1134 \\
240 \\
029 \\
019 \\
080 \\
100.22\end{array}$ & $\begin{array}{r}4876 \\
1.96 \\
1466 \\
457 \\
8.30 \\
020 \\
653 \\
1150 \\
2.35 \\
024 \\
017 \\
087 \\
10011\end{array}$ & $\begin{array}{r}4867 \\
177 \\
1456 \\
7.09 \\
611 \\
019 \\
661 \\
1166 \\
227 \\
023 \\
015 \\
0.76 \\
100.07\end{array}$ & $\begin{array}{r}4879 \\
246 \\
1379 \\
610 \\
785 \\
021 \\
617 \\
1105 \\
250 \\
036 \\
023 \\
059 \\
0010\end{array}$ & $\begin{array}{r}48.12 \\
270 \\
1317 \\
766 \\
775 \\
024 \\
595 \\
1091 \\
244 \\
022 \\
025 \\
091 \\
10032\end{array}$ & $\begin{array}{r}48.62 \\
201 \\
13.56 \\
571 \\
748 \\
020 \\
706 \\
1152 \\
229 \\
035 \\
017 \\
0.80 \\
9977\end{array}$ & $\begin{array}{r}4814 \\
235 \\
1374 \\
394 \\
893 \\
021 \\
704 \\
1124 \\
236 \\
028 \\
022 \\
136 \\
\frac{139}{99.81}\end{array}$ & $\begin{array}{r}47.89 \\
241 \\
1365 \\
602 \\
735 \\
020 \\
6.92 \\
1149 \\
245 \\
024 \\
022 \\
127 \\
10011\end{array}$ & $\begin{array}{r}48.16 \\
2.20 \\
13.47 \\
576 \\
784 \\
020 \\
672 \\
1156 \\
233 \\
023 \\
020 \\
132 \\
99.99\end{array}$ & $\begin{array}{r}48.31 \\
1.99 \\
1384 \\
452 \\
810 \\
019 \\
717 \\
1177 \\
228 \\
029 \\
018 \\
112 \\
9976\end{array}$ \\
\hline
\end{tabular}

Steno Gletscher (lower part)

Profile 106 - Rømer Fjord - Steno Gletscher (middle

Formation GF GF GF GF GF GF GF $\quad$ RFF RFF RFF RFF RFF SF

Type l-Ti l-Ti l-Ti l-Ti l-Ti h-Ti m-Ti $\quad$ lol-th h-Ti Ti-th u ol-th u ol-th m-h-Ti m-h-Ti

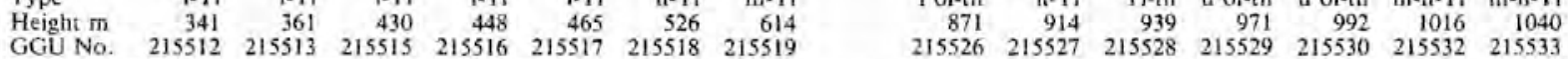

\begin{tabular}{|c|c|c|c|c|c|c|c|c|c|c|c|c|c|c|}
\hline $\mathrm{SiO}_{2}$ & 48.23 & 4881 & 4747 & 4841 & 48.66 & 4779 & 48.51 & 4570 & 4552 & 4681 & 46.89 & 4599 & 4778 & 47.87 \\
\hline $\mathrm{TiO}_{2}^{2}$ & 203 & 229 & 223 & 229 & 208 & 289 & 255 & 2.09 & 290 & 371 & 2.57 & 2.65 & 246 & 2.42 \\
\hline $\mathrm{Al}_{2}$ & 1371 & 1317 & 1390 & 1339 & 1370 & 1276 & 1305 & 13.86 & 1378 & 1339 & 1400 & 13.55 & 1622 & 14.53 \\
\hline $\mathrm{Fe}, \mathrm{O}$, & 459 & 546 & 680 & 487 & 429 & 758 & 432 & 416 & 5.16 & 573 & 264 & 325 & 514 & 506 \\
\hline $\mathrm{FeO}$ & 822 & 891 & 614 & 846 & 8.45 & 802 & 978 & 765 & 795 & 902 & 9.34 & 8.95 & 662 & 816 \\
\hline $\mathrm{MnO}$ & 020 & 024 & 018 & 020 & 0.20 & 028 & $0-22$ & 017 & 018 & 021 & 018 & 018 & 017 & $0-19$ \\
\hline $\mathrm{MgO}$ & 731 & 630 & 6.54 & 670 & 712 & 586 & 613 & 769 & 632 & 584 & 755 & 745 & 581 & 5.91 \\
\hline $\mathrm{CaO}$ & 1155 & 1082 & 11.83 & 1147 & 1141 & 1072 & 1139 & 1153 & 10.92 & 1074 & 1137 & 1155 & 1155 & 1165 \\
\hline $\mathrm{Na}_{2} \mathrm{O}$ & 230 & $2.5 i$ & 234 & 235 & 238 & 244 & 245 & 2.33 & 208 & 269 & 241 & 218 & 258 & 255 \\
\hline $\mathrm{K}, \mathrm{O}$ & 034 & 035 & 014 & 020 & 034 & 035 & 030 & 019 & 026 & 041 & 031 & 0.20 & 030 & 0.18 \\
\hline $\mathrm{P}_{2} \mathrm{O}$ & 0.18 & 023 & 021 & 021 & 019 & 028 & 025 & 016 & 026 & 038 & 026 & 0.26 & 025 & 0.21 \\
\hline 1.0.i. & 142 & 086 & 215 & $\frac{142}{407}$ & 117 & 118 & 1.11 & 451 & $\begin{array}{r}469 \\
\end{array}$ & 110 & 254 & 340 & 116 & 159 \\
\hline & 10008 & 99.95 & 99.93 & 99.97 & 9999 & 10015 & 10006 & $\overline{10004}$ & 10002 & 10003 & 10006 & 9961 & 10004 & 10032 \\
\hline
\end{tabular}

\begin{tabular}{|c|c|c|c|c|c|c|c|c|c|c|c|c|c|}
\hline & part) & Profile & $108-K$ & ap Dait & on valle, & & & & & & Profile & $1111-$ & cape at \\
\hline $\begin{array}{l}\text { Formation } \\
\text { Type } \\
\text { Height m } \\
\text { GGU No. }\end{array}$ & $\begin{array}{r}\text { SF } \\
m-h-T i \\
1081 \\
215534\end{array}$ & $\begin{array}{r}\text { RFF } \\
1 \text { ol-th } \\
462 \\
215561\end{array}$ & $\begin{array}{r}\text { RFF } \\
1 \text { ol-th } \\
491 \\
215562\end{array}$ & $\begin{array}{r}\text { RFF } \\
1 \text { ol-th } \\
495 \\
215564\end{array}$ & $\begin{array}{r}\text { RFF } \\
1 \text { ol-th } \\
515 \\
215565\end{array}$ & $\begin{array}{r}\text { RFF } \\
\text { Ti-th } \\
537 \\
215566\end{array}$ & $\begin{array}{r}\text { RFF } \\
\text { u ol-th } \\
557 \\
215567\end{array}$ & $\begin{array}{r}\text { RFF } \\
\text { u oi-th } \\
583 \\
215568\end{array}$ & $\begin{array}{r}\text { RFF } \\
\text { u ol-th } \\
596 \\
215569\end{array}$ & $\begin{array}{r}\text { SF } \\
\mathrm{m}-\mathrm{h}-\mathrm{Ti} \\
619 \\
215570\end{array}$ & $\begin{array}{r}\mathrm{SF} \\
\mathrm{I}-\mathrm{Ti} \\
234 \\
215600\end{array}$ & $\begin{array}{r}\mathrm{SF} \\
\mathrm{I}-\mathrm{Ti} \\
245 \\
21560 \mid\end{array}$ & $\begin{array}{r}\mathrm{SF} \\
\mathrm{m}-\mathrm{h}-\mathrm{Ti} \\
272 \\
215602\end{array}$ \\
\hline $\begin{array}{l}\mathrm{SiO}_{2} \\
\mathrm{TiO}_{3} \\
\mathrm{Al}_{2} \mathrm{O}_{3} \\
\mathrm{Fe}, \mathrm{O}_{2} \\
\mathrm{FeO} \\
\mathrm{MnO} \\
\mathrm{MgO} \\
\mathrm{CaO} \\
\mathrm{Na}, \mathrm{O} \\
\mathrm{K}, \mathrm{O} \\
\mathrm{P}, \mathrm{O}_{3} \\
\mathrm{l}_{2} .1\end{array}$ & $\begin{array}{r}4822 \\
246 \\
1430 \\
473 \\
790 \\
018 \\
651 \\
1179 \\
255 \\
026 \\
022 \\
119 \\
10031\end{array}$ & $\begin{array}{r}45.55 \\
247 \\
1419 \\
457 \\
8.40 \\
019 \\
6.82 \\
1088 \\
200 \\
032 \\
0.22 \\
482 \\
10043\end{array}$ & $\begin{array}{r}45.47 \\
2.28 \\
1400 \\
7.00 \\
586 \\
017 \\
7.23 \\
1139 \\
193 \\
015 \\
0.21 \\
428 \\
99.97\end{array}$ & $\begin{array}{r}45.90 \\
2.31 \\
1375 \\
630 \\
6.53 \\
0.19 \\
7.88 \\
11.21 \\
1.81 \\
0.42 \\
0.19 \\
3.44 \\
9993\end{array}$ & $\begin{array}{r}45.28 \\
2.16 \\
13.88 \\
3.98 \\
816 \\
019 \\
7.84 \\
11.60 \\
173 \\
016 \\
0.19 \\
484 \\
100.01\end{array}$ & $\begin{array}{r}45.62 \\
3.70 \\
13.32 \\
7.72 \\
7.13 \\
0.22 \\
5.99 \\
1069 \\
2.23 \\
015 \\
0.38 \\
2.96 \\
10010\end{array}$ & $\begin{array}{r}45.65 \\
240 \\
1365 \\
517 \\
674 \\
0.17 \\
747 \\
1161 \\
192 \\
022 \\
024 \\
471 \\
9995\end{array}$ & $\begin{array}{r}45.28 \\
2.74 \\
14.61 \\
7.63 \\
5.17 \\
0.19 \\
635 \\
10.40 \\
2.15 \\
0.31 \\
028 \\
5.07 \\
100.17\end{array}$ & $\begin{array}{r}45.81 \\
2.89 \\
13.66 \\
4.34 \\
8.48 \\
0.19 \\
7.17 \\
10.39 \\
2.72 \\
0.38 \\
0.30 \\
4.10 \\
10044\end{array}$ & $\begin{array}{r}47.16 \\
2.75 \\
14.60 \\
5.72 \\
7.55 \\
020 \\
6.85 \\
1094 \\
2.60 \\
036 \\
0.28 \\
1.65 \\
10065\end{array}$ & $\begin{array}{r}4894 \\
197 \\
1406 \\
574 \\
705 \\
020 \\
676 \\
1144 \\
291 \\
026 \\
016 \\
192 \\
10021\end{array}$ & $\begin{array}{r}4870 \\
208 \\
1392 \\
817 \\
508 \\
020 \\
705 \\
1163 \\
219 \\
017 \\
018 \\
0.97 \\
10034\end{array}$ & $\begin{array}{r}4838 \\
2.66 \\
13.48 \\
703 \\
7.81 \\
022 \\
602 \\
1057 \\
2.43 \\
029 \\
025 \\
117 \\
10031\end{array}$ \\
\hline
\end{tabular}

Kap Dalıon

Profile 112 - head of Kap Dalion valley

\begin{tabular}{|c|c|c|c|c|c|c|c|c|c|c|c|c|c|c|}
\hline $\begin{array}{l}\text { Formation } \\
\text { Type } \\
\text { Height m } \\
\text { GGU No. }\end{array}$ & $\begin{array}{r}\text { SF } \\
m-h-T i \\
295 \\
215603\end{array}$ & $\begin{array}{r}\text { SF } \\
m-h-T i \\
315 \\
215604\end{array}$ & $\begin{array}{r}\text { SF } \\
\mathrm{m}-\mathrm{h}-\mathrm{Ti} \\
353 \\
215605\end{array}$ & $\begin{array}{r}S F \\
m \cdot h \cdot T i \\
380 \\
215606\end{array}$ & $\begin{array}{r}\text { SF } \\
\mathrm{m}-\mathrm{h}-\mathrm{Ti} \\
390 \\
215607\end{array}$ & $\begin{array}{r}\text { SF } \\
\mathrm{m}-\mathrm{h}-\mathrm{Ti} \\
407 \\
215608\end{array}$ & $\begin{array}{r}\text { SF } \\
\mathrm{m}-\mathrm{h}-\mathrm{Ti} \\
933 \\
215615\end{array}$ & $\begin{array}{r}\text { SF } \\
\mathrm{m}-\mathrm{h}-\mathrm{Ti} \\
1004 \\
215617\end{array}$ & $\begin{array}{r}\mathrm{SF} \\
1-\mathrm{m}-\mathrm{Ti} \\
1030 \\
215618\end{array}$ & $\begin{array}{r}\text { SF } \\
\mathrm{m}-\mathrm{h}-\mathrm{T}_{1} \\
1047 \\
215619\end{array}$ & $\begin{array}{r}\text { SF } \\
m-h-T_{1} \\
1074 \\
215620\end{array}$ & $\begin{array}{r}\text { SF } \\
1-T i \\
1087 \\
215621\end{array}$ & $\begin{array}{r}\mathrm{SF} \\
1-\mathrm{Ti} \\
1100 \\
215622\end{array}$ & $\begin{array}{r}\text { SF } \\
h-S i \\
1155 \\
215623\end{array}$ \\
\hline $\begin{array}{l}\mathrm{SiO}_{2} \\
\mathrm{TiO} \\
\mathrm{Al}_{3} \mathrm{O}, \\
\mathrm{Fe}_{2} \mathrm{O}, \\
\mathrm{FeO} \\
\mathrm{MnO} \\
\mathrm{MgO} \\
\mathrm{CaO} \\
\mathrm{Na}, \mathrm{O} \\
\mathrm{K}, 0 \\
\mathrm{P}_{2} \mathrm{O} \\
\text { l.o.i. }\end{array}$ & $\begin{array}{r}4841 \\
255 \\
1356 \\
664 \\
801 \\
024 \\
615 \\
1065 \\
240 \\
033 \\
021 \\
121 \\
10036\end{array}$ & $\begin{array}{r}48.13 \\
297 \\
13.29 \\
497 \\
886 \\
024 \\
626 \\
1091 \\
236 \\
041 \\
029 \\
134 \\
10003\end{array}$ & $\begin{array}{r}4805 \\
3.22 \\
1308 \\
402 \\
1031 \\
022 \\
599 \\
1083 \\
243 \\
035 \\
032 \\
1.39 \\
10021\end{array}$ & $\begin{array}{r}4776 \\
332 \\
1307 \\
569 \\
878 \\
022 \\
583 \\
1082 \\
242 \\
042 \\
032 \\
165 \\
10030\end{array}$ & $\begin{array}{r}4720 \\
328 \\
1318 \\
710 \\
725 \\
023 \\
616 \\
1102 \\
229 \\
016 \\
032 \\
207 \\
10026\end{array}$ & $\begin{array}{r}48.93 \\
266 \\
14.00 \\
492 \\
873 \\
023 \\
5.65 \\
1066 \\
248 \\
0.38 \\
026 \\
138 \\
10028\end{array}$ & $\begin{array}{r}4752 \\
281 \\
1338 \\
612 \\
833 \\
023 \\
632 \\
1096 \\
229 \\
033 \\
025 \\
150 \\
10004\end{array}$ & $\begin{array}{r}4720 \\
231 \\
1416 \\
463 \\
863 \\
022 \\
714 \\
1138 \\
203 \\
023 \\
019 \\
189 \\
10001\end{array}$ & $\begin{array}{r}4769 \\
229 \\
1478 \\
630 \\
654 \\
018 \\
667 \\
1162 \\
215 \\
024 \\
018 \\
142 \\
10006\end{array}$ & $\begin{array}{r}4802 \\
247 \\
1475 \\
882 \\
448 \\
017 \\
568 \\
1106 \\
249 \\
020 \\
021 \\
1.54 \\
9989\end{array}$ & $\begin{array}{r}4776 \\
265 \\
1418 \\
465 \\
816 \\
020 \\
698 \\
1069 \\
211 \\
062 \\
023 \\
197 \\
10020\end{array}$ & $\begin{array}{r}4813 \\
186 \\
1506 \\
480 \\
667 \\
019 \\
662 \\
1224 \\
248 \\
025 \\
018 \\
184 \\
10032\end{array}$ & $\begin{array}{r}4909 \\
182 \\
1552 \\
717 \\
4.25 \\
017 \\
658 \\
1108 \\
242 \\
037 \\
016 \\
142 \\
10005\end{array}$ & $\begin{array}{r}5076 \\
195 \\
1479 \\
499 \\
620 \\
018 \\
631 \\
1100 \\
239 \\
041 \\
017 \\
082 \\
9997\end{array}$ \\
\hline
\end{tabular}




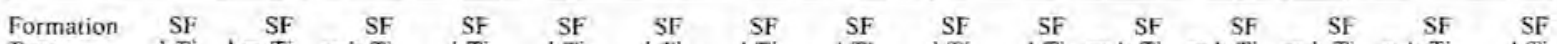
Type 1-Ti 1-m-Ti m-h-Ti 1-Ti 1-Ti 1-Ti 1-Ti 1-Ti 1-Ti l-Ti m-h-Ti m-h-Ti m-h-Ti m-h-Ti 1-Ti

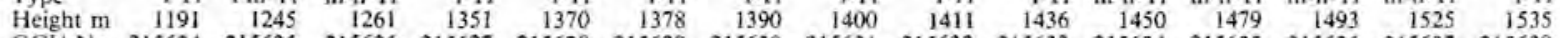

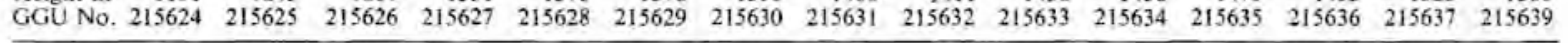

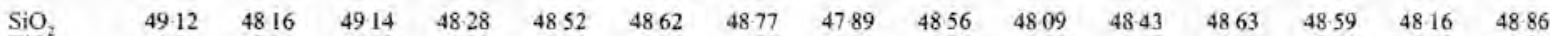

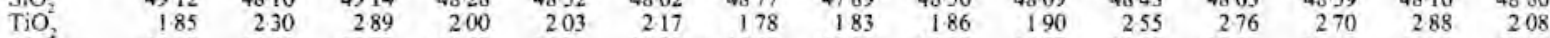

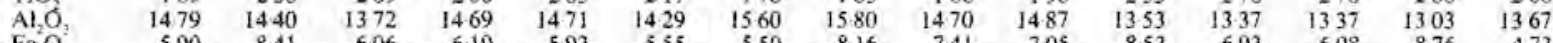
$\begin{array}{lllllllllllllllll}\mathrm{FeO}_{3} & 590 & 841 & 606 & 619 & 593 & 555 & 550 & 816 & 741 & 705 & 853 & 693 & 698 & 876 & 473 \\ \mathrm{FeO} & 625 & 516 & 766 & 678 & 714 & 793 & 701 & 478 & 577 & 588 & 573 & 787\end{array}$

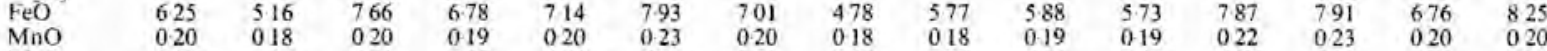

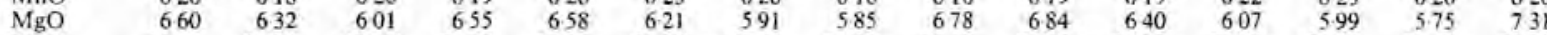

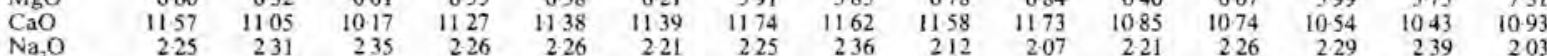

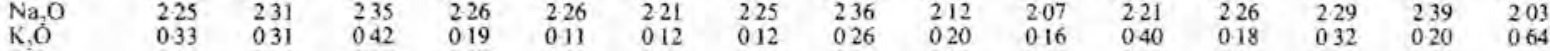
$\begin{array}{lllllllllllllllll}\mathrm{P}_{2} \mathrm{O} & 016 & 021 & 027 & 017 & 018 & 0.19 & 016 & 016 & 015 & 017 & 021 & 025 & 024 & 025 & 017\end{array}$ I.o.i. $\frac{083}{9985} \quad \frac{127}{10008} \quad \frac{107}{9996} \quad \frac{150}{10007} \quad \frac{1.49}{10053} \quad \frac{0.99}{9990} \quad \frac{1.04}{10008} \quad \frac{1.11}{10000} \quad \frac{107}{10038} \quad \frac{137}{10032} \quad \frac{113}{10016} \quad \frac{1.02}{10030} \quad \frac{1.32}{10048} \quad \frac{1.40}{10021} \quad \frac{1.58}{10045}$

Profile 117 - Pyramiden

\begin{tabular}{|c|c|c|c|c|c|c|c|c|c|c|c|c|c|c|}
\hline $\begin{array}{l}\text { Formation } \\
\text { Type } \\
\text { Height m } \\
\text { GGU No. }\end{array}$ & $\begin{array}{r}\text { SF } \\
\text { m-h-Ti } \\
1584 \\
215640\end{array}$ & $\begin{array}{r}\mathrm{SF} \\
\mathrm{m}-\mathrm{h}-\mathrm{Ti} \\
1605 \\
215641\end{array}$ & $\begin{array}{r}\text { RFF } \\
\text { Ti-th } \\
971 \\
215728\end{array}$ & $\begin{array}{r}\text { RFF } \\
\text { h-Ti } \\
975 \\
215729\end{array}$ & $\begin{array}{r}\text { RFF } \\
\text { Ti-th } \\
982 \\
215730\end{array}$ & $\begin{array}{r}\text { RFF } \\
\text { Ti-th } \\
1021 \\
215731\end{array}$ & $\begin{array}{r}\text { RFF } \\
\text { Ti-th } \\
1049 \\
215732\end{array}$ & $\begin{array}{r}\text { RFF } \\
\text { h-Ti } \\
1097 \\
215734\end{array}$ & $\begin{array}{r}\text { RFF } \\
\text { h-Ti } \\
1136 \\
215736\end{array}$ & $\begin{array}{r}\text { RFF } \\
\mathrm{m}-\mathrm{Ti} \\
1156 \\
215737\end{array}$ & $\begin{array}{r}\text { SF } \\
\mathrm{m}-\mathrm{h}-\mathrm{Ti} \\
1177 \\
215738\end{array}$ & $\begin{array}{r}\text { SF } \\
\mathrm{m}-\mathrm{h}-\mathrm{Ti} \\
1301 \\
215739\end{array}$ & $\begin{array}{r}S F \\
1-m-T i \\
1341 \\
215740\end{array}$ & $\begin{array}{r}\text { SF } \\
\text { m-h-Ti } \\
1352 \\
215796\end{array}$ \\
\hline $\begin{array}{l}\mathrm{SiO}_{2} \\
\mathrm{TiO}_{2} \\
\mathrm{Al}_{2} \mathrm{O}_{3} \\
\mathrm{Fe}_{2} \mathrm{O}_{3} \\
\mathrm{FeO} \\
\mathrm{MnO} \\
\mathrm{MgO} \\
\mathrm{CaO} \\
\mathrm{Na}_{2} \mathrm{O} \\
\mathrm{K}_{2} \mathrm{O} \\
\mathrm{P}_{2} \mathrm{O}_{3} \\
1.0 . i .\end{array}$ & $\begin{array}{r}4857 \\
258 \\
1323 \\
933 \\
560 \\
027 \\
614 \\
1054 \\
242 \\
037 \\
024 \\
077 \\
100-06\end{array}$ & $\begin{array}{r}4788 \\
328 \\
1340 \\
461 \\
999 \\
022 \\
572 \\
1054 \\
240 \\
042 \\
032 \\
137 \\
10015\end{array}$ & $\begin{array}{r}46.69 \\
3.56 \\
12.54 \\
6.88 \\
8 \cdot 19 \\
0.22 \\
661 \\
1056 \\
2.18 \\
0.13 \\
0.34 \\
2.92 \\
100.82\end{array}$ & $\begin{array}{r}47.53 \\
3.24 \\
14.55 \\
635 \\
7.10 \\
0.20 \\
5.56 \\
1085 \\
2.48 \\
0.15 \\
0.33 \\
2.44 \\
10077\end{array}$ & $\begin{array}{r}46.27 \\
3.49 \\
13.04 \\
7.63 \\
7.27 \\
022 \\
6.25 \\
10-56 \\
2.38 \\
017 \\
0.33 \\
3.11 \\
100-72\end{array}$ & $\begin{array}{r}46.61 \\
3.71 \\
13.35 \\
400 \\
10-77 \\
0.22 \\
615 \\
1038 \\
281 \\
041 \\
039 \\
1.30 \\
10009\end{array}$ & $\begin{array}{r}46.69 \\
372 \\
1409 \\
5.39 \\
8.87 \\
022 \\
5.28 \\
10.47 \\
275 \\
0.27 \\
0.38 \\
2.49 \\
100-62\end{array}$ & $\begin{array}{r}47.45 \\
3.18 \\
15.19 \\
5.36 \\
813 \\
0.19 \\
5.68 \\
1061 \\
2.42 \\
0.40 \\
0.34 \\
138 \\
100.31\end{array}$ & $\begin{array}{r}46.28 \\
3.05 \\
14.33 \\
6.22 \\
7.09 \\
0.20 \\
620 \\
1097 \\
261 \\
0.27 \\
0.31 \\
250 \\
10002\end{array}$ & $\begin{array}{r}47.17 \\
2.62 \\
13.36 \\
5.71 \\
8.42 \\
0.22 \\
639 \\
1108 \\
257 \\
023 \\
0.26 \\
2.18 \\
10022\end{array}$ & $\begin{array}{r}47.08 \\
2.42 \\
1415 \\
4.85 \\
7.88 \\
019 \\
643 \\
11.64 \\
2.57 \\
0.27 \\
0.24 \\
2.09 \\
99.81\end{array}$ & $\begin{array}{r}47.33 \\
2.22 \\
14.48 \\
5.88 \\
6.88 \\
0.20 \\
6.49 \\
11.70 \\
2.47 \\
0-11 \\
0.21 \\
2.44 \\
10042\end{array}$ & $\begin{array}{r}47.16 \\
2.18 \\
14.42 \\
6.22 \\
7.09 \\
0.21 \\
6.52 \\
1153 \\
2.41 \\
0.13 \\
0.21 \\
2.70 \\
100.79\end{array}$ & $\begin{array}{r}4665 \\
228 \\
1441 \\
635 \\
732 \\
022 \\
637 \\
11.47 \\
224 \\
011 \\
023 \\
228 \\
99.92\end{array}$ \\
\hline
\end{tabular}

\begin{tabular}{|c|c|c|c|c|c|c|c|c|c|c|c|c|c|c|c|}
\hline $\begin{array}{l}\text { Formation } \\
\text { Type } \\
\text { Height m } \\
\text { GGU No. }\end{array}$ & $\begin{array}{r}\mathrm{SF} \\
\mathrm{m} \cdot \mathrm{h}-\mathrm{Ti} \\
1370 \\
215797\end{array}$ & $\begin{array}{r}\text { SF } \\
\mathrm{m}-\mathrm{h}-\mathrm{Ti} \\
1401 \\
215798\end{array}$ & $\begin{array}{r}\text { SF } \\
\mathrm{m}-\mathrm{h}-\mathrm{Ti} \\
1410 \\
215799\end{array}$ & $\begin{array}{r}\mathrm{SF} \\
\mathrm{m}-\mathrm{b}-\mathrm{Ti} \\
1429 \\
215800\end{array}$ & $\begin{array}{r}S F \\
m-h-T i \\
1460 \\
215801\end{array}$ & $\begin{array}{r}\text { SF } \\
1-\mathrm{Ti} \\
1466 \\
215802\end{array}$ & $\begin{array}{r}\mathrm{SF} \\
\text { I-Ti } \\
\text { ISO8 } \\
215803\end{array}$ & $\begin{array}{r}\mathrm{SF} \\
1-\mathrm{Ti} \\
1516 \\
215804\end{array}$ & $\begin{array}{r}\text { SF } \\
1-\mathrm{Ti} \\
1534 \\
215805\end{array}$ & $\begin{array}{r}\mathrm{SF} \\
1-\mathrm{Ti} \\
1548 \\
215807\end{array}$ & $\begin{array}{r}\text { SF } \\
1-m-T i \\
1556 \\
215808\end{array}$ & $\begin{array}{r}\mathrm{SF} \\
1-\mathrm{Ti} \\
1596 \\
215809\end{array}$ & $\begin{array}{r}\mathrm{SF} \\
1-\mathrm{Ti} \\
1617 \\
215810\end{array}$ & $\begin{array}{r}\mathrm{SF} \\
1-\mathrm{Ti} \\
1671 \\
215811\end{array}$ & $\begin{array}{r}\mathrm{SF} \\
1-\mathrm{Ti} \\
1722 \\
215813\end{array}$ \\
\hline $\begin{array}{l}\mathrm{SiO}_{2} \\
\mathrm{TiO}_{2} \\
\mathrm{Al}_{2} \mathrm{O}_{3} \\
\mathrm{Fe}_{2} \mathrm{O}_{1} \\
\mathrm{FeO} \\
\mathrm{MnO} \\
\mathrm{MgO} \\
\mathrm{CaO} \\
\mathrm{Na}_{2} \mathrm{O} \\
\mathrm{K}_{2} \mathrm{O} \\
\mathrm{P}_{2} \mathrm{O}, \\
\text { l.o.i. }\end{array}$ & $\begin{array}{r}47.08 \\
260 \\
13.48 \\
5.62 \\
8.31 \\
0.22 \\
634 \\
11.05 \\
2.31 \\
0.23 \\
0.26 \\
241 \\
99.90\end{array}$ & $\begin{array}{r}4653 \\
2.79 \\
1366 \\
5.67 \\
8.72 \\
0.22 \\
605 \\
10.91 \\
241 \\
015 \\
028 \\
253 \\
9992\end{array}$ & $\begin{array}{r}46.64 \\
2.91 \\
1401 \\
5.53 \\
8.81 \\
0.20 \\
619 \\
1093 \\
2.26 \\
013 \\
0.27 \\
2.30 \\
100.18\end{array}$ & $\begin{array}{r}46.77 \\
2.66 \\
13.06 \\
5.82 \\
8.86 \\
0.22 \\
6.57 \\
10.95 \\
2.23 \\
0.15 \\
0.26 \\
2.35 \\
99.90\end{array}$ & $\begin{array}{r}46.71 \\
2.49 \\
14.31 \\
6.58 \\
7.10 \\
0.21 \\
613 \\
11.15 \\
2.27 \\
0.13 \\
0.24 \\
2.81 \\
100.13\end{array}$ & $\begin{array}{r}47.31 \\
1.97 \\
14.30 \\
5.15 \\
7.00 \\
0.18 \\
7.12 \\
11.37 \\
2.02 \\
0.29 \\
0.19 \\
3.01 \\
99.91\end{array}$ & $\begin{array}{r}46.90 \\
1.87 \\
14.80 \\
5.25 \\
658 \\
0.18 \\
7.18 \\
11.00 \\
2.24 \\
036 \\
0.18 \\
3.30 \\
99.84\end{array}$ & $\begin{array}{r}47.20 \\
1.77 \\
14.84 \\
5.27 \\
6.11 \\
0.20 \\
6.78 \\
10.59 \\
2.58 \\
0.17 \\
0.18 \\
404 \\
9972\end{array}$ & $\begin{array}{r}47.29 \\
2.09 \\
13.89 \\
5.62 \\
6.95 \\
0.19 \\
7.18 \\
11.52 \\
2.08 \\
0.17 \\
0.20 \\
2.47 \\
99.64\end{array}$ & $\begin{array}{r}47.22 \\
1.98 \\
14.64 \\
5.46 \\
672 \\
018 \\
6.87 \\
11.64 \\
2.09 \\
0.14 \\
0.19 \\
2.63 \\
99.74\end{array}$ & $\begin{array}{r}47.35 \\
2.29 \\
13.71 \\
5.38 \\
8.59 \\
0.22 \\
6.80 \\
11.16 \\
2.06 \\
0.19 \\
0.23 \\
1.86 \\
99.83\end{array}$ & $\begin{array}{r}4804 \\
2.17 \\
1446 \\
467 \\
869 \\
021 \\
602 \\
10.96 \\
215 \\
017 \\
0.22 \\
2.01 \\
99.76\end{array}$ & $\begin{array}{r}48.54 \\
2.03 \\
14.74 \\
4.55 \\
8.43 \\
020 \\
640 \\
11.30 \\
2.15 \\
0.23 \\
0.20 \\
1.35 \\
100 \cdot 12\end{array}$ & $\begin{array}{r}4831 \\
187 \\
1488 \\
422 \\
831 \\
0.20 \\
656 \\
1137 \\
2.09 \\
021 \\
019 \\
163 \\
9983\end{array}$ & $\begin{array}{r}48.28 \\
172 \\
15.75 \\
603 \\
652 \\
0.19 \\
6.35 \\
11.51 \\
209 \\
0.13 \\
017 \\
1.73 \\
10047\end{array}$ \\
\hline
\end{tabular}

Profile 126 - Bopladsdalen, botiom of profile

Profile 129 - Kastellet

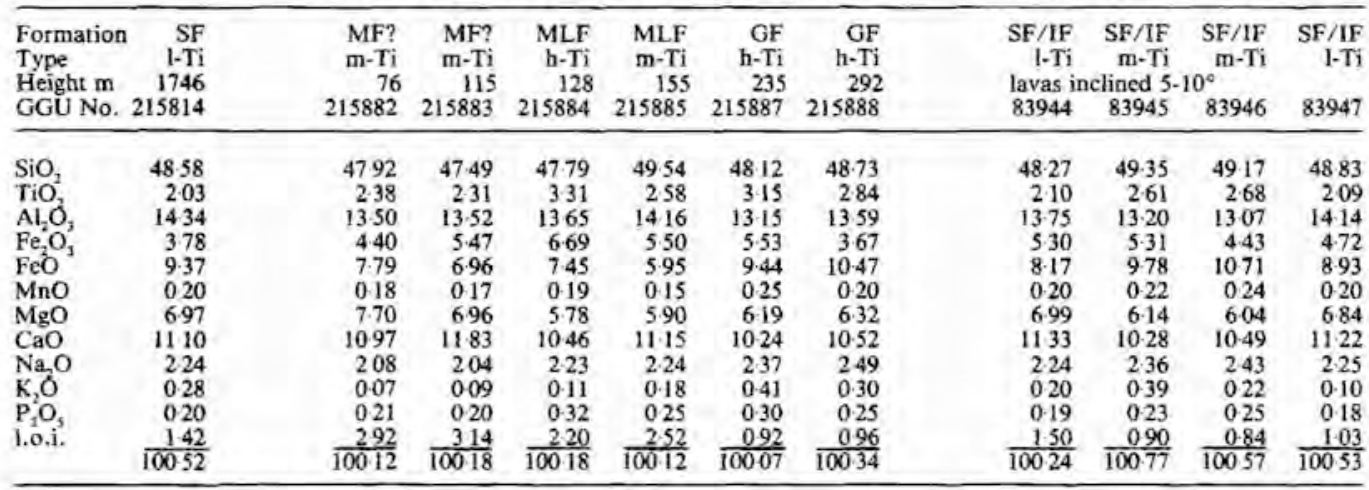


Inland tholeitic dykes

Milne Land

\begin{tabular}{|c|c|c|c|c|c|c|c|c|c|c|c|c|c|c|c|}
\hline GGU No. & 96691 & 96812 & 96828 & 96831 & 195601 & 195602 & 195603 & 195604 & 195605 & 195606 & 195607 & 195608 & 195609 & 234001 & 234002 \\
\hline $\mathrm{SiO}$ & 47.85 & 4846 & 48.42 & $48 \cdot 24$ & 4841 & 4842 & $48 \cdot 39$ & 4864 & 48.69 & 4851 & 4842 & 4837 & 4851 & 4822 & 48.03 \\
\hline $\mathrm{TiO}_{2}^{2}$ & 2.50 & 228 & 254 & 2.50 & 2.28 & 225 & 227 & 228 & 2.08 & 230 & 235 & 225 & 254 & 232 & 232 \\
\hline $\mathrm{Fe}_{2} \mathrm{O}_{3}$ & 380 & 422 & 354 & 603 & 249 & 269 & 3.20 & 264 & $3-02$ & 2.71 & 248 & $4 \cdot 33$ & 269 & 2.63 & 3.51 \\
\hline $\mathrm{FeO}^{3}$ & 948 & 851 & 1023 & 7.76 & 10.24 & 993 & 943 & 9.84 & 960 & 1011 & 1031 & 880 & 1101 & 1040 & 9.23 \\
\hline $\mathrm{MnO}$ & 020 & 019 & 0.21 & 0.22 & 020 & 019 & 0.19 & 0.19 & 0.20 & 0.19 & 0.20 & 0.19 & 021 & 020 & 0.20 \\
\hline $\mathrm{MgO}$ & 597 & 687 & 614 & 5.98 & 695 & 6.99 & 6.74 & 6.86 & 731 & 703 & 674 & 6.92 & 624 & 688 & 5.85 \\
\hline $\mathrm{CaO}$ & 1139 & 1180 & 1143 & 1124 & 11.57 & 1168 & 1166 & 1165 & 1161 & 1146 & 11.52 & 1145 & 1128 & 1141 & 11.48 \\
\hline $\mathrm{Na}_{2} \mathrm{O}$ & 253 & 226 & 261 & 238 & 240 & $2 \cdot 38$ & $2 \cdot 37$ & 2.45 & 239 & 240 & 245 & 236 & 254 & 242 & 2.41 \\
\hline $\mathrm{K}_{2} \mathrm{O}^{2}$ & 021 & 022 & 018 & 0.40 & 030 & 029 & 030 & 031 & 0.28 & $0-31$ & 0.31 & 0.30 & 0.25 & 0.33 & 0.27 \\
\hline $\mathrm{P}_{2} \mathrm{O}_{5}$ & 023 & 022 & 024 & 024 & 022 & 0.20 & 021 & 0.21 & 0.20 & 0.22 & 022 & 021 & 024 & 022 & 022 \\
\hline I.o.i. & 088 & 077 & $\frac{107}{0}$ & $\frac{117}{117}$ & 0.81 & 0.96 & 1.48 & 0.70 & 0.88 & 092 & $\frac{110}{10}$ & 109 & 086 & $\frac{103}{100}$ & 1.55 \\
\hline & 9841 & 99.71 & 9998 & 99.67 & 99.63 & 9986 & 10033 & 9973 & 10051 & 99.95 & 9983 & 100.19 & 99.85 & 9981 & 99.22 \\
\hline
\end{tabular}

Jameson Land Gàseland

\begin{tabular}{|c|c|c|c|c|c|c|c|c|c|c|c|c|c|}
\hline GGU No & 234243 & 234244 & 137563 & 96929 & 96930 & 96931 & 98842 & 104135 & 104136 & 167115 & 167131 & 167229 & 167250 \\
\hline $\mathrm{SiO}_{2}$ & 4801 & $48 \cdot 13$ & 4859 & 4866 & 4866 & 48.13 & 4848 & 48.57 & 48.94 & 48.26 & 4826 & 47.17 & 47.37 \\
\hline $\mathrm{TiO}_{2}$ & 231 & 235 & 232 & 233 & 209 & 304 & 240 & 2.42 & 201 & 292 & 285 & 253 & 248 \\
\hline $\mathrm{Fc}_{3} \mathrm{O}_{3}$ & 283 & 277 & 330 & 358 & 403 & 620 & 496 & 471 & 279 & 3.61 & 278 & 465 & 318 \\
\hline $\mathrm{FeO}$ & 1001 & 9.35 & 1004 & 961 & 8.54 & 8.17 & 812 & 855 & 955 & 1017 & 10.75 & 805 & 1038 \\
\hline $\mathrm{MnO}$ & 0.20 & 020 & 020 & 020 & 019 & 020 & 000 & 020 & 019 & 0.20 & 000 & 019 & 021 \\
\hline $\mathrm{MgO}$ & 691 & 6.51 & 640 & 675 & 710 & 429 & 666 & 645 & 706 & 627 & $6 \cdot 61$ & 610 & 6.18 \\
\hline $\mathrm{Na}, \mathrm{O}$ & 242 & 2.44 & 220 & 225 & 232 & 2.52 & $2 \cdot 30$ & 246 & 231 & 238 & 242 & 253 & 2.58 \\
\hline $\mathrm{K}_{2} \mathrm{O}$ & 030 & 030 & 030 & 0.30 & 028 & 041 & 027 & 022 & 030 & 038 & 037 & 045 & 032 \\
\hline $\mathrm{P}_{2} \mathrm{O}_{3}$ & 022 & 0.22 & 022 & 021 & 018 & 0.28 & 0.24 & 023 & 019 & 0.28 & 0.25 & 026 & 023 \\
\hline 1.o.i. & 0.79 & $\frac{124}{27}$ & $\frac{1.46}{10}$ & 084 & 091 & 133 & 199 & 106 & 0.88 & 118 & 142 & 145 & $\frac{0.79}{0.17}$ \\
\hline & 9910 & 9937 & 100.49 & 99.93 & 10015 & 99.84 & 99.84 & 9995 & 9971 & $99 \cdot 97$ & $100 \cdot 19$ & 99.47 & 9817 \\
\hline
\end{tabular}

South of Gasefjord and Scoresby Sund

Inland alkaline dykes (Gdseland and south of

\begin{tabular}{|c|c|c|c|c|c|c|c|c|c|c|c|c|c|c|}
\hline GGU No. & 96505 & 96528 & 98451 & 98520 & 98609 & 98679 & 98746 & 98890 & $98770 \mathrm{~A}$ & $98770 \mathrm{C}$ & 96921 & 167106 & 167123 & 167124 \\
\hline $\mathrm{SiO}_{2}$ & $48 \cdot 16$ & 4730 & 48.29 & 48.57 & 47.53 & 4748 & $47 \cdot 37$ & 46.90 & 59.12 & 49.27 & 4198 & 4309 & 4408 & 4421 \\
\hline $\mathrm{TiO}^{2}$ & 214 & 283 & 282 & 2.50 & 425 & $4 \cdot 30$ & 215 & 4.43 & 0.52 & 197 & 511 & 491 & 470 & 537 \\
\hline $\mathrm{Fe}_{2} \mathrm{O}_{3}^{3}$ & 493 & 391 & 467 & 2.97 & 523 & 6.57 & 5.21 & $3 \cdot 12$ & $2 \cdot 34$ & 458 & 684 & 587 & 648 & 647 \\
\hline $\mathrm{FeO}$ & $8 \cdot 14$ & 994 & 9.22 & 1067 & 1018 & 8.82 & $7 \cdot 14$ & $12 \cdot 65$ & 1.18 & $4 \cdot 14$ & 8.25 & 7.96 & 739 & 663 \\
\hline $\mathrm{MnO}$ & $\mathrm{na}$ & 0.21 & 0.19 & 0.21 & na & na & na & na & na & 025 & na & 018 & 019 & 016 \\
\hline $\mathrm{MgO}$ & 605 & 647 & 568 & 6.25 & 532 & $5-09$ & 6.79 & 5.51 & 113 & 3.26 & 689 & $5 \cdot 32$ & 506 & 495 \\
\hline $\mathrm{CaO}$ & 11.99 & 1092 & 1061 & 11.51 & 982 & 9.70 & 11.77 & 9.68 & 220 & 871 & 886 & 9.82 & 989 & 10.37 \\
\hline $\mathrm{Na}_{2} \mathrm{O}$ & 235 & 248 & 240 & 243 & 257 & 2.58 & 2.28 & 2.37 & 615 & 467 & 255 & 323 & 316 & 310 \\
\hline $\mathrm{K}_{2} \mathrm{O}$ & 030 & 036 & 027 & 017 & 0.72 & 0.86 & 0.31 & 0.77 & 3.80 & $3 \cdot 12$ & 0.63 & 0.72 & 085 & 075 \\
\hline $\mathrm{P}_{2} \mathrm{O}_{3}$ & 0.21 & 0.28 & 0.27 & 024 & 050 & 0.50 & $0-18$ & $0-51$ & 028 & 0.75 & 067 & 092 & 114 & 0.57 \\
\hline 1.o.i. & $\frac{1.54}{20}$ & $\frac{101}{0010}$ & $\frac{1.63}{16}$ & 0.97 & $\frac{109}{100}$ & $\frac{1.52}{1001}$ & 1.82 & 141 & $\frac{3.59}{100}$ & $\frac{430}{0.56}$ & 3.88 & 3.25 & 279 & $\frac{1.85}{8007}$ \\
\hline & $\widetilde{9963}$ & $\overline{9949}$ & $\overline{9976}$ & $\overline{10007}$ & $\overline{9964}$ & $\overline{99.91}$ & $\overline{99 \cdot 64}$ & $\overline{99.48}$ & $\overline{9863}$ & $\overline{9876}$ & $\overline{9929}$ & $\overline{9898}$ & $\overline{99.35}$ & $\overline{9883}$ \\
\hline
\end{tabular}

Gásefjord)

\begin{tabular}{lrrrr}
\hline GGU No. & 98768 & 98778 & 104144 & 167116 \\
\hline $\mathrm{SiO}_{2}$ & 41.90 & 4201 & 37.65 & 35.51 \\
$\mathrm{TiO}_{2}$ & 3.41 & 3.53 & 4.14 & 3.93 \\
$\mathrm{Al}_{2} \mathrm{O}_{2}$ & 778 & 947 & 8.10 & 7.38 \\
$\mathrm{Fe}_{2} \mathrm{O}_{3}$ & 6.09 & 7.55 & 8.81 & 6.37 \\
$\mathrm{FeO}$ & 642 & 514 & 6.22 & 8.69 \\
$\mathrm{MnO}$ & na & na & na & na \\
$\mathrm{MgO}$ & 1274 & 7.78 & 10.12 & 1060 \\
$\mathrm{CaO}$ & 10.71 & 1299 & 1590 & 14.17 \\
$\mathrm{Na}_{2} \mathrm{O}$ & 2.80 & 3.15 & 0.99 & 2.47 \\
$\mathrm{~K}_{2} 0$ & 2.17 & 200 & 0.84 & 2.39 \\
$\mathrm{P}_{2} \mathrm{O}_{1}$ & 0.53 & 095 & 1.14 & 135 \\
1.0 .1$. & 4.81 & 4.51 & 5.16 & 4.84 \\
& 99.37 & 9909 & 9907 & 9769 \\
\hline
\end{tabular}


Coastal dykes

Manby Romer Fjord region

Kap Dalton region

\begin{tabular}{|c|c|c|c|c|c|c|c|c|c|c|c|c|c|c|c|}
\hline GGU No & 215418 & 98341 & 98342 & 116389 & 116390 & 215401 & 215439 & 215440 & 215447 & 215474 & 215506 & 215507 & 215514 & 116353 & 116359 \\
\hline & 47.97 & 48.74 & 47.15 & 4886 & 45.80 & 4882 & $48 \cdot 34$ & 48.75 & 48.61 & 48.58 & 4871 & 48.50 & 48.13 & 49.28 & \\
\hline & & & & 2 & & 181 & 21 & 245 & 1.92 & & 18 & & & 2.15 & \\
\hline , & 1270 & 13.14 & 12.60 & 13.12 & 1347 & 13.67 & 1351 & 13.43 & 1388 & 131 & 13.76 & 1457 & 1404 & 14. & \\
\hline , & & & 8 & & & & & & & & 4 & & & & \\
\hline $3^{3}$ & & & & & & & & & & & & & & & \\
\hline no & & I & & & & & & & & & & & & & \\
\hline & & & & & & & & & & & & & & & \\
\hline 10 & 104 & 101 & 10.73 & 1061 & 13 & 11 & 111 & 11. & 11. & 10 & 12 & 12 & & 10 & \\
\hline${ }_{2} \mathrm{O}$ & & & & & & & & & & & & & & & \\
\hline & & & & & & & & & & & 0. & & & & \\
\hline $\mathrm{O}_{\text {, }}$ & 034 & 0.27 & 027 & 0.27 & 0.16 & 0.19 & 0.22 & 0 & 020 & 0 & 019 & 017 & & 0 & \\
\hline i. & 178 & $\frac{182}{18}$ & $\frac{239}{25}$ & 10 & 6.14 & 166 & 182 & 1. & 1.49 & 1 & $\frac{1.10}{10}$ & 1,34 & 2 & 1 & \\
\hline & & 9983 & & 10007 & 99.70 & 10035 & 10020 & $100 \cdot 16$ & 10034 & & 10002 & & 10025 & 100 & \\
\hline
\end{tabular}

Kap Dalton region

\begin{tabular}{|c|c|c|c|c|c|c|c|c|c|c|c|c|c|c|c|}
\hline $\mathrm{GGU} \mathrm{Na}$ & 116360 & 116372 & 179222 & 179223 & 179224 & 179225 & 179226 & 179227 & 179228 & 215535 & 215544 & 215558 & 215577 & 215578 & 215579 \\
\hline $\mathrm{SiO}_{2}$ & $48 \cdot 13$ & $48-41$ & 4851 & 4851 & 48.45 & 4904 & 4790 & 48.48 & 4867 & 4844 & 48.41 & $48 \cdot 11$ & $49 \cdot 14$ & 4778 & 4744 \\
\hline $\mathrm{TiO}_{2}^{2}$ & 210 & 184 & 212 & 2.39 & 207 & 203 & 165 & 241 & 241 & 300 & 226 & 304 & 238 & 1.59 & 3.09 \\
\hline $\mathrm{Fe}_{2} \mathrm{O}_{3}$ & 600 & 4.96 & 4.22 & 5.20 & 3.74 & 364 & 449 & 5.03 & 484 & 497 & $4 \cdot 89$ & 7.54 & 476 & $4 \cdot 79$ & 719 \\
\hline $\mathrm{FeO}$ & 7.79 & 8.04 & 836 & 9.31 & 1002 & 899 & 7.89 & 9.42 & 9.85 & 9.89 & 8.64 & 8.21 & 930 & 6.61 & 7.84 \\
\hline $\mathrm{MnO}$ & 0.21 & 020 & 0.19 & 0.22 & 0.22 & 0.20 & 020 & 022 & 0.23 & 0.23 & 0.22 & 023 & 0.22 & 018 & 023 \\
\hline $\mathrm{MgO}$ & 650 & 612 & 5.84 & 592 & 629 & 541 & 654 & 5.52 & 587 & 543 & 6.37 & 499 & 556 & $6 \cdot 67$ & 541 \\
\hline $\mathrm{CaO}$ & 1118 & 1171 & 11.51 & 1083 & 11.52 & 9.39 & 11.71 & 1066 & 1064 & 10.30 & 11.10 & 9.31 & 9.32 & 1256 & 9.57 \\
\hline $\mathrm{Na}_{2} \mathrm{O}$ & $2 \cdot 38$ & 233 & 247 & $2 \cdot 34$ & $2 \cdot 37$ & 302 & 2.28 & 250 & 244 & 269 & $2 \cdot 62$ & 258 & 367 & $2 \cdot 20$ & 269 \\
\hline $\mathrm{K}_{2} \mathrm{0}$ & 026 & 0.20 & $0-47$ & 0.24 & 0.30 & 1.41 & 0.16 & $0-38$ & 042 & 058 & 041 & 0.73 & 0.56 & 022 & 0.80 \\
\hline $\mathrm{P}_{2} \mathrm{O}_{5}$ & 0.22 & 018 & 022 & 0.27 & 0.20 & 022 & 017 & 026 & 0.26 & 035 & 025 & 037 & 026 & 0.15 & 045 \\
\hline 1.o.i. & 198 & 161 & 157 & 211 & 1.73 & 334 & 344 & 169 & 1.72 & 1.48 & 1.56 & 257 & 190 & 200 & 2.38 \\
\hline & $100 \cdot 18$ & 99.83 & 10011 & $100-23$ & 10034 & 100.19 & 10056 & 10023 & 10053 & 10013 & $100-35$ & 10012 & 10002 & 10020 & 10000 \\
\hline
\end{tabular}

Kap Dalton region

\begin{tabular}{lllllllllllllllll}
\hline GGU No. & 215580 & 215581 & 215590 & 215595 & 215596 & 215597 & 215610 & 215611 & 215612 & 215613 & 215614 & 215616 & 215638 & 215642 & 215643
\end{tabular}

\begin{tabular}{|c|c|c|c|c|c|c|c|c|c|c|c|c|c|c|c|}
\hline $\mathrm{SiO}_{2}$ & 48.27 & 48.75 & $49 \cdot 13$ & 46.87 & 4802 & 4855 & $48 \cdot 12$ & 48.74 & 48.87 & 49.42 & 49.04 & 47.87 & 47.36 & 48.55 & 4865 \\
\hline $\mathrm{TiO}_{2}^{-}$ & 2.61 & $2 \cdot 61$ & 292 & 302 & 194 & 245 & 172 & 199 & 2.48 & 271 & 155 & 3.46 & 3.90 & 230 & 1 \\
\hline $\mathrm{Al}_{2} \mathrm{O}_{3}$ & 13.77 & 13.40 & 1283 & 1286 & 13.79 & 1305 & 14.27 & 1369 & 1306 & 12.75 & 17.20 & 1266 & 1196 & 1536 & 15 \\
\hline $\mathrm{Fe}_{2} \mathrm{O}_{1}$ & $6-07$ & 546 & 606 & 699 & 5.67 & 457 & 379 & 3.34 & 5.25 & 4.98 & $3 \cdot 31$ & 434 & $4-60$ & 2.95 & \\
\hline $\mathrm{FeO}$ & 7.88 & 800 & 8.54 & $8 \cdot 30$ & 7.27 & 9.94 & 8.00 & 9.51 & 931 & 933 & 6.98 & 1067 & 12.43 & 868 & \\
\hline $\mathrm{MnO}$ & 0.23 & 0.20 & 023 & 0.24 & 0.20 & 0.23 & 019 & 0.21 & 023 & 0.23 & 016 & 0.23 & 0.25 & 018 & \\
\hline $\mathrm{MgO}$ & 524 & $5 \cdot 15$ & 491 & 533 & 681 & 632 & 7.37 & 6.89 & 5.49 & 5.21 & 546 & 5.59 & 5.10 & 608 & \\
\hline $\mathrm{CaO}$ & $10 \cdot 10$ & 836 & 914 & 9.58 & 11.68 & $10-76$ & 1211 & 11.74 & 9.74 & 8.22 & 12.37 & 1027 & 1018 & 11.68 & \\
\hline $\mathrm{Na}_{2} \mathrm{O}$ & 273 & 3.88 & 298 & 2.97 & $2 \cdot 35$ & 248 & 227 & 239 & 2.77 & 3.36 & 229 & 258 & 253 & 246 & \\
\hline $\mathrm{K}_{2} 0$ & 0.45 & 107 & 0.71 & 0.71 & 0.28 & 040 & 0.25 & $0-33$ & 0.46 & 105 & 041 & 0.62 & 0.48 & 0.50 & \\
\hline $\mathrm{P}_{2} \mathrm{O}$ & 0.32 & 0.33 & 0.39 & 0.36 & 0.19 & 0.27 & 0.17 & 0.21 & 0.32 & 0.35 & 015 & 041 & 0.39 & 0.25 & \\
\hline l.o.i. & 265 & $\frac{272}{0007}$ & $\frac{1.99}{190}$ & 2.66 & $\frac{2.47}{47}$ & $\frac{151}{15}$ & $\frac{144}{0070}$ & $\frac{1.16}{120}$ & $\frac{1.71}{0060}$ & $\frac{213}{71}$ & $\frac{1.32}{1.32}$ & $\frac{1.26}{005}$ & $\frac{0.80}{0098}$ & $\frac{123}{32}$ & 1. \\
\hline & & & & & & & 99.70 & & & & & & & & \\
\hline
\end{tabular}

Kap Dallon region

Knighton Bugt

\begin{tabular}{|c|c|c|c|c|c|}
\hline GGU No. & 215644 & 215645 & 215646 & 215647 & 229160 \\
\hline & 48.23 & 4850 & 48.76 & 47.15 & 4840 \\
\hline $\mathrm{TiO}_{2}$ & 234 & 204 & 2.36 & $2 \cdot 15$ & 225 \\
\hline $\mathrm{Al}_{2} \mathrm{O}_{3}$ & 1362 & 13.43 & 13.11 & 13.20 & 1360 \\
\hline $\mathrm{Fe}_{2} \mathrm{O}$, & $4 \cdot 14$ & 5.07 & 403 & 3.63 & 343 \\
\hline $\mathrm{FeO}$ & 9.25 & 8.62 & 1037 & 997 & $10 \cdot 12$ \\
\hline $\mathrm{MnO}$ & 021 & 0.22 & 0.23 & 0.21 & 021 \\
\hline $\mathrm{M} 8 \mathrm{O}$ & 641 & 6.36 & 611 & 6.18 & $6 \cdot 32$ \\
\hline $\mathrm{CaO}$ & 1119 & 11.10 & 1108 & 10.56 & 1131 \\
\hline $\mathrm{Na}, \mathrm{O}$ & 2.38 & 242 & 245 & 2.59 & 253 \\
\hline & & 024 & 0.37 & 049 & 039 \\
\hline $\mathrm{P}_{2} \mathrm{O}_{5}$ & 0.26 & 021 & 0.23 & 0.22 & 023 \\
\hline l.o.i. & $\frac{1.73}{100 \cdot 14}$ & $\frac{2.04}{100.25}$ & $\frac{1.18}{10028}$ & $\frac{322}{9957}$ & $\frac{1.16}{99.95}$ \\
\hline
\end{tabular}




\section{APPENDIX 3}

Trace element analyses of the Scoresby Sund basalts

Abbreviations for formations and types as in appendix 2.

1.dyke inland dykes

c.dyke coastal dykes

\begin{tabular}{|c|c|c|c|c|c|c|c|c|c|c|c|c|c|c|c|c|}
\hline $\begin{array}{l}\text { Formation } \\
\text { GGU No. } \\
\text { Type }\end{array}$ & $\begin{array}{l}\text { MLF } \\
96487 \\
\text { Mikis }\end{array}$ & $\begin{array}{l}\text { MLF } \\
96205 \\
\text { Mikis }\end{array}$ & $\begin{array}{l}\text { MLF } \\
96325 \\
\text { Mikis }\end{array}$ & $\begin{array}{l}\text { MLF } \\
96110 \\
\text { Mikis }\end{array}$ & $\begin{array}{c}\text { RFF } \\
98549 \\
\text { MORB }\end{array}$ & $\begin{array}{c}\text { RFF } \\
98550 \\
\text { MORB }\end{array}$ & $\begin{array}{c}\text { RFF } \\
98392 \\
\text { MORB }\end{array}$ & $\begin{array}{c}\text { RFF } \\
98393 \\
\text { MORB }\end{array}$ & $\begin{array}{l}\text { RFF } \\
215464 \\
\text { ol-thol }\end{array}$ & $\begin{array}{l}\text { RFF } \\
98871 \\
\text { ol-thol }\end{array}$ & $\begin{array}{c}\text { RFF } \\
98544 \\
\text { ol-thol }\end{array}$ & $\begin{array}{l}\text { RFF } \\
98387 \\
\text { ol-thol }\end{array}$ & $\begin{array}{c}\text { RFF } \\
215529 \\
\text { ol-thol }\end{array}$ & $\begin{array}{l}\text { RFF } \\
215484 \\
\text { ol-thol }\end{array}$ & $\begin{array}{l}\text { MLF } \\
96882 \\
\text { Hjern }\end{array}$ & $\begin{array}{l}\text { MLF } \\
96913 \\
\text { Hjørn }\end{array}$ \\
\hline $\mathrm{M}_{\mathrm{g}}$ ratio & 0.655 & 0.654 & 0.647 & 0.605 & 0.651 & 0.628 & 0.524 & 0.522 & 0.633 & 0.608 & 0.609 & 0.600 & 0.566 & 0.553 & 0.602 & 0.595 \\
\hline $\mathrm{Cr}$ & 774 & 704 & 678 & 567 & 428 & 367 & 144 & 154 & 579 & 501 & 461 & 422 & 383 & 320 & 486 & 413 \\
\hline $\mathrm{Ni}$ & 388 & 386 & 368 & 279 & 196 & 173 & 76 & 79 & 223 & 201 & I9I & 170 & 142 & 152 & 226 & 208 \\
\hline Sc & 29 & 30 & 28 & 30 & 32 & 34 & 38 & 38 & 29 & 30 & 24 & 27 & 29 & 24 & 32 & 24 \\
\hline V & 329 & 312 & 288 & 307 & 238 & 257 & 346 & 277 & 280 & 313 & 283 & 285 & 289 & 270 & 327 & 297 \\
\hline $\mathrm{Cu}$ & 144 & 151 & 208 & 153 & 120 & 126 & 175 & 199 & 113 & 137 & 117 & 124 & 186 & 176 & 195 & 184 \\
\hline $\mathrm{Zn}$ & 107 & 108 & 102 & 102 & 87 & 85 & 91 & 74 & 88 & 85 & 102 & 77 & 92 & 89 & 106 & 93 \\
\hline $\mathrm{Ba}$ & 108 & 119 & 54 & 115 & 54 & 51 & 49 & 44 & 73 & 78 & 106 & 93 & 81 & 68 & 90 & 82 \\
\hline $\mathrm{Sr}$ & 224 & 224 & 223 & 255 & 156 & 160 & 191 & 198 & 285 & 293 & 318 & 283 & 275 & 278 & 268 & 280 \\
\hline $\mathrm{Rb}$ & 3.3 & 4.7 & 5.2 & 1.8 & 0.0 & 2.9 & $<0.5$ & 2.3 & 1.7 & 1.8 & 2.8 & 1.0 & 4.0 & 1.9 & 3.8 & 5,5 \\
\hline$Y$ & 27 & 27 & 30 & 33 & 17 & 18 & 27 & 26 & 20 & 22 & 23 & 24 & 30 & 31 & 27 & 27 \\
\hline $\mathrm{Zr}$ & 149 & 152 & 161 & 176 & 48 & 56 & 97 & 91 & 101 & 116 & 114 & 125 & 162 & 173 & 144 & 144 \\
\hline $\mathrm{Nb}$ & 11.1 & 11.3 & 11.8 & 13.2 & 3.9 & 4.3 & 6.9 & 7.2 & 10.2 & 11.2 & 12.4 & 13.0 & 16.8 & 18.4 & 10.5 & 11.4 \\
\hline
\end{tabular}

Main basalts and high-Si basalts

\begin{tabular}{|c|c|c|c|c|c|c|c|c|c|c|c|c|c|c|c|}
\hline $\begin{array}{l}\text { Formation } \\
\text { GGU No. } \\
\text { Type }\end{array}$ & $\begin{array}{c}\text { MF } \\
98590 \\
\text { med-Tj }\end{array}$ & $\begin{array}{c}\text { MF } \\
98587 \\
\text { med-Ti }\end{array}$ & $\begin{array}{c}\mathrm{MF} \\
98641 \\
\text { med-Ti }\end{array}$ & $\begin{array}{c}\text { MF } \\
98758 \\
\text { med-Ti }\end{array}$ & $\begin{array}{c}\text { MF } \\
96928 \\
\text { high-Si }\end{array}$ & $\begin{array}{c}\text { MF } \\
98761 \\
\text { high-Si }\end{array}$ & $\begin{array}{c}\text { MF } \\
98788 \\
\text { high-Si }\end{array}$ & $\begin{array}{l}\text { MLF } \\
98844 \\
\text { med-Ti }\end{array}$ & $\begin{array}{l}\text { MLF } \\
98571 \\
\text { med-Ti }\end{array}$ & $\begin{array}{c}\text { MLF } \\
98839 \\
\text { high-Ti }\end{array}$ & $\begin{array}{c}\text { MLF } \\
96403 \\
\text { high-Ti }\end{array}$ & $\begin{array}{c}\text { MLF } \\
98670 \\
\text { high-Ti }\end{array}$ & $\begin{array}{l}\text { MLF } \\
98592 \\
\text { Ti-thol }\end{array}$ & $\begin{array}{c}\text { MLF } \\
98600 \\
\text { Ti-thol }\end{array}$ & $\begin{array}{l}\text { MLF } \\
98838 \\
\text { high-Si }\end{array}$ \\
\hline Mg ratio & 0.558 & 0.547 & 0.543 & 0.535 & 0.599 & 0.576 & 0.540 & 0.542 & 0.508 & 0.534 & 0,520 & 0.504 & 0.460 & 0.428 & 0.537 \\
\hline $\mathrm{Cr}$ & 353 & 313 & 358 & 365 & 456 & 390 & 922 & 297 & 153 & 300 & 315 & 214 & 168 & 195 & 296 \\
\hline $\mathrm{Ni}$ & 126 & 117 & 130 & 109 & 135 & 119 & 217 & 111 & 80 & 155 & 146 & 96 & 93 & 81 & 121 \\
\hline Sc & 35 & 34 & 33 & 34 & 33 & 29 & 31 & 32 & 38 & 30 & 29 & 39 & 36 & 39 & 29 \\
\hline V & 363 & 362 & 349 & 362 & 311 & 287 & 293 & 322 & 416 & 356 & 394 & 405 & 477 & 507 & 394 \\
\hline $\mathrm{Cu}$ & 140 & 194 & 175 & 183 & 157 & 145 & 141 & 190 & 174 & 297 & 281 & 271 & 286 & 333 & 266 \\
\hline $\mathrm{Zn}$ & 120 & 99 & 108 & 98 & 94 & 102 & 94 & 93 & 101 & 96 & 97 & 107 & 130 & 133 & 109 \\
\hline $\mathrm{Ba}$ & 88 & 52 & 79 & 88 & 189 & 203 & 199 & 101 & 74 & 86 & 90 & 81 & 117 & 120 & 182 \\
\hline $\mathrm{St}$ & 257 & 260 & 260 & 253 & 227 & 238 & 219 & 268 & 252 & 285 & 280 & 245 & 284 & 254 & 259 \\
\hline $\mathrm{Rb}$ & 1.4 & $<0.5$ & 4.2 & 2.9 & 18 & 10.5 & 15 & 1.8 & 1.5 & 2.3 & 4.5 & 5.5 & 4.4 & 16 & 13 \\
\hline$Y$ & 29 & 30 & 29 & 32 & 26 & 24 & 23 & 31 & 32 & 37 & 38 & 31 & 45 & 55 & 38 \\
\hline $\mathrm{Zr}$ & 148 & 155 & 149 & 160 & 158 & 138 & 136 & 161 & 155 & 204 & 212 & 159 & 241 & 278 & 224 \\
\hline $\mathrm{Nb}$ & 9.7 & 10.7 & 9.8 & 10.4 & 10.2 & 7.7 & 7.6 & 11.1 & 12.9 & 15.7 & 16.3 & 13.0 & 17.5 & 21.1 & 16.1 \\
\hline
\end{tabular}

\begin{tabular}{|c|c|c|c|c|c|c|c|c|c|c|c|c|c|c|c|c|c|}
\hline $\begin{array}{l}\text { Formation } \\
\text { GGU No. } \\
\text { Type }\end{array}$ & $\begin{array}{c}\text { GF } \\
98572 \\
\text { Ti-thol }\end{array}$ & $\begin{array}{c}\text { GF } \\
98511 \\
\text { Ti-thol }\end{array}$ & $\begin{array}{c}\text { GF } \\
98512 \\
\text { high-Ti }\end{array}$ & $\begin{array}{c}\text { GF } \\
98513 \\
\text { high-Ti }\end{array}$ & $\begin{array}{c}\text { GF } \\
98516 \\
\text { high-Ti }\end{array}$ & $\begin{array}{c}\text { GF } \\
98464 \\
\text { high-Ti }\end{array}$ & $\begin{array}{c}\text { GF } \\
98465 \\
\text { high-Ti }\end{array}$ & $\begin{array}{c}\text { GF } \\
98467 \\
\text { med-Ti }\end{array}$ & $\begin{array}{c}\text { GF } \\
98468 \\
\text { med-Ti }\end{array}$ & $\begin{array}{c}\text { GF } \\
98470 \\
\text { med-Ti }\end{array}$ & $\begin{array}{c}\text { GF } \\
98471 \\
\text { med-Ti }\end{array}$ & $\begin{array}{c}\text { GF } \\
98472 \\
\text { med-Ti }\end{array}$ & $\begin{array}{c}\text { GF } \\
98473 \\
\text { med-Ti }\end{array}$ & $\begin{array}{c}\text { GF } \\
98476 \\
\text { med-Ti }\end{array}$ & $\begin{array}{c}\text { GF } \\
98478 \\
\text { med-Ti }\end{array}$ & $\begin{array}{c}\text { GF } \\
98479 \\
\text { med-Ti }\end{array}$ & $\begin{array}{c}\text { GF } \\
98480 \\
\text { med-Ti }\end{array}$ \\
\hline Mg ratio & 0.480 & 0.482 & 0.513 & 0.513 & 0.480 & 0.481 & 0.466 & 0.513 & 0.523 & 0.530 & 0.521 & 0.522 & 0.505 & 0.496 & 0.519 & 0.512 & 0.525 \\
\hline $\mathrm{Cr}$ & 172 & 162 & 196 & 196 & 199 & 171 & 164 & 253 & 262 & 247 & 234 & 229 & 97 & 103 & 223 & 224 & 216 \\
\hline $\mathrm{Ni}$ & 89 & 85 & 102 & 106 & 102 & 90 & 93 & 109 & 119 & 107 & 105 & 93 & 81 & 82 & 88 & 88 & 95 \\
\hline Sc & 35 & 35 & 33 & 35 & 34 & 37 & 38 & 38 & 37 & 33 & 36 & 40 & 37 & 36 & 37 & 39 & 39 \\
\hline V & 444 & 419 & 402 & 412 & 419 & 416 & 427 & 383 & 389 & 355 & 393 & 365 & 406 & 411 & 425 & 431 & 407 \\
\hline $\mathrm{Zn}$ & 111 & 110 & 107 & 125 & 124 & 112 & 118 & 106 & 116 & 111 & 100 & 108 & 104 & 110 & 97 & 114 & 103 \\
\hline $\mathrm{Ba}$ & 123 & 123 & 54 & 74 & 51 & 85 & 109 & 85 & 99 & 73 & 82 & 97 & 65 & 56 & 78 & 69 & 98 \\
\hline $\mathrm{Sr}$ & 293 & 295 & 261 & 274 & 261 & 239 & 236 & 230 & 231 & 237 & 223 & 264 & 247 & 243 & 237 & 236 & 236 \\
\hline $\mathrm{Rb}$ & 7.2 & 8.8 & 2.8 & 1.4 & 18 & 10 & 3.5 & 1.3 & 1.4 & 0.7 & 1.8 & 14 & 0.9 & $<0.5$ & 0.9 & 1.9 & 1.4 \\
\hline$Y$ & 37 & 38 & 33 & 32 & 34 & 35 & 36 & 31 & 32 & 31 & 30 & 31 & 32 & 30 & 30 & 31 & 29 \\
\hline $\mathrm{Zr}$ & 226 & 226 & 168 & 173 & 177 & 175 & 183 & 148 & 151 & 148 & 137 & 144 & 151 & 48 & 145 & 147 & 141 \\
\hline $\mathrm{Nb}$ & 21.5 & 21.4 & is. 0 & 15.0 & 16.0 & 16.3 & 16.6 & 14.2 & 13.7 & 13.0 & 12.4 & 13.1 & 13.7 & 13.8 & 13.6 & 13.4 & 12.4 \\
\hline
\end{tabular}


Formation GF GF GF GF GF GF GF GF GF GF GF GF GF GF GF

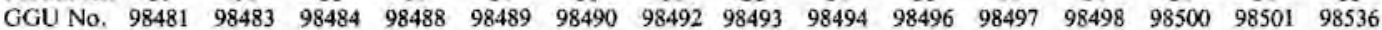
Type med-Ti med-Ti med-Ti med-Ti med-Ti med-Ti low-Ti low-Ti low-Ti low-Ti low-Ti low-Ti med-Ti med-Ti low-Ti

\begin{tabular}{|c|c|c|c|c|c|c|c|c|c|c|c|c|c|c|c|}
\hline Mg ratio & 0.550 & 0.543 & 0.526 & 0.523 & 0.503 & 0.534 & 0.542 & 0.510 & 0.535 & 0.530 & 0.536 & 0.547 & 0.521 & 0.542 & 0.527 \\
\hline $\mathrm{Cr}$ & 316 & 215 & 254 & 236 & 136 & 262 & 213 & 91 & 222 & 219 & 246 & 295 & 146 & 286 & 143 \\
\hline $\mathrm{Ni}$ & 120 & 110 & 106 & 100 & 96 & 109 & 104 & 86 & 91 & 84 & 104 & 115 & 86 & 116 & 92 \\
\hline Sc & 38 & 38 & 39 & 38 & 33 & 39 & 39 & 38 & 40 & 40 & 39 & 37 & 37 & 35 & 36 \\
\hline V & 375 & 372 & 397 & 401 & 374 & 384 & 359 & 367 & 381 & 369 & 367 & 362 & 399 & 343 & 333 \\
\hline $\mathrm{Cu}$ & 169 & 209 & 222 & 239 & 259 & 227 & 234 & 173 & 198 & 141 & 217 & 226 & 195 & 230 & 207 \\
\hline $\mathrm{Zn}$ & 91 & 98 & 96 & 96 & 114 & 107 & 108 & 106 & 88 & 89 & 104 & 99 & 104 & 99 & 112 \\
\hline $\mathrm{Ba}$ & 78 & 69 & 88 & 79 & 88 & 67 & 73 & 72 & 61 & 66 & 84 & 91 & 90 & 81 & 77 \\
\hline $\mathrm{Sr}$ & 234 & 240 & 259 & 229 & 216 & 192 & 201 & 206 & 198 & 224 & 202 & 215 & 218 & 231 & 212 \\
\hline $\mathbf{R b}$ & 5.6 & 7.4 & 12 & 11 & 5.5 & 1.0 & 2.0 & 1.7 & 1.7 & 3.9 & 5.9 & 2.9 & 5.6 & 7.0 & 4.7 \\
\hline $\mathrm{Y}$ & 28 & 28 & 29 & 30 & 33 & 30 & 31 & 32 & 29 & 30 & 26 & 28 & 31 & 30 & 28 \\
\hline $\mathrm{Zr}_{5}$ & 125 & 127 & 135 & 139 & 152 & 137 & 130 & 135 & 125 & 123 & 118 & 121 & 141 & 139 & 119 \\
\hline $\mathrm{Nb}$ & 12.0 & 12.2 & 12.1 & 12.9 & 13.3 & 11.9 & 11.6 & 11.2 & 10.8 & 10.7 & 10.7 & 10.5 & 12.8 & 12.8 & 10.8 \\
\hline
\end{tabular}

\begin{tabular}{|c|c|c|c|c|c|c|c|c|c|c|c|c|c|c|c|c|}
\hline $\begin{array}{l}\text { Formation } \\
\text { GGU No. } \\
\text { Type }\end{array}$ & $\begin{array}{c}\text { RFF } \\
215465 \\
\text { high-Ti }\end{array}$ & $\begin{array}{c}\text { RFF } \\
98873 \\
\text { high-Ti }\end{array}$ & $\begin{array}{c}\text { RFF } \\
215459 \\
\text { Ti-thol }\end{array}$ & $\begin{array}{c}\text { RFF } \\
98547 \\
\text { Ti-thol }\end{array}$ & $\begin{array}{c}\text { SF } \\
215620 \\
m-h-T i\end{array}$ & $\begin{array}{c}\text { SF } \\
215617 \\
\text { m-h-Ti }\end{array}$ & $\begin{array}{c}\text { SF } \\
215495 \\
\text { m-b-Ti }\end{array}$ & $\begin{array}{c}\mathrm{SF} \\
215486 \\
\mathrm{~m}-\mathrm{h}-\mathrm{Ti}\end{array}$ & $\begin{array}{c}\text { SF } \\
98878 \\
\text { Ti-thol }\end{array}$ & $\begin{array}{c}\text { SF } \\
215633 \\
\text { low-Ti }\end{array}$ & $\begin{array}{c}\text { SF } \\
215496 \\
\text { low-Ti }\end{array}$ & $\begin{array}{c}\mathrm{SF} \\
215501 \\
\text { low-Ti }\end{array}$ & $\begin{array}{c}\text { SF } \\
215625 \\
1-\mathrm{m}-\mathrm{Ti}\end{array}$ & $\begin{array}{c}\text { SF } \\
215629 \\
\text { low-Ti }\end{array}$ & $\begin{array}{c}\mathrm{SF} \\
215639 \\
\text { low-Ti }\end{array}$ & $\begin{array}{c}\mathrm{SF} \\
98286 \\
\mathrm{~m}-\mathrm{h}-\mathrm{Ti}\end{array}$ \\
\hline $\mathrm{Mg}$ ratio & 0.527 & 0.495 & 0.504 & 0.448 & 0.533 & 0.530 & 0.518 & 0.479 & 0.458 & 0.531 & 0.525 & 0.517 & 0.501 & 0.493 & 0.542 & 0.475 \\
\hline $\mathrm{Cr}$ & 214 & 153 & 235 & 119 & 245 & 114 & 262 & 138 & 88 & 211 & 136 & 155 & 169 & 187 & 167 & 77 \\
\hline $\mathrm{Ni}$ & 141 & 120 & 112 & 76 & 110 & 97 & 139 & 72 & 70 & 92 & 109 & 93 & 92 & 87 & 85 & 60 \\
\hline Sc & 25 & 30 & 25 & 33 & 38 & 40 & 32 & 33 & 33 & 44 & 31 & 35 & 44 & 41 & 40 & 40 \\
\hline $\mathrm{v}$ & 308 & 365 & 352 & 415 & 39 & 42 & 32 & 427 & 497 & 373 & 337 & 362 & 419 & 424 & 413 & 435 \\
\hline $\mathrm{Cu}$ & 219 & 214 & 250 & 363 & 205 & 189 & 234 & 284 & 323 & 179 & 181 & 182 & 229 & 233 & 212 & 286 \\
\hline $\mathrm{Zn}$ & 104 & 105 & 104 & 126 & 97 & 99 & 102 & 96 & 123 & 91 & 92 & 88 & 109 & 98 & 90 & 109 \\
\hline $\mathrm{Ba}$ & 79 & 102 & 472 & 128 & 198 & 63 & 71 & 100 & 82 & 60 & 73 & 59 & 83 & 54 & 101 & 84 \\
\hline $\mathrm{Sr}$ & 458 & 295 & 328 & 276 & 300 & 214 & 247 & 295 & 305 & 200 & 275 & 182 & 206 & 197 & 229 & 201 \\
\hline $\mathrm{Rb}$ & 2.7 & 2.7 & 20 & 9.0 & 12.8 & 1.9 & 4.4 & 6.3 & $<0.5$ & 2.9 & 1.7 & 4.2 & 6.3 & 3.2 & 7.9 & 4.7 \\
\hline $\mathrm{Y}$ & 32 & 29 & 35 & 41 & 28 & 26 & 31 & 34 & 41 & 25 & 25 & 27 & 29 & 27 & 26 & 33 \\
\hline $\mathrm{Zr}$ & 168 & 177 & 218 & 233 & 156 & 130 & 147 & 176 & 216 & 112 & 132 & 103 & 141 & 131 & 122 & 141 \\
\hline $\mathrm{Nb}$ & 17.7 & 16.8 & 24.7 & 25.5 & 12.8 & 9.8 & 11.8 & 15.7 & 20.2 & 8.6 & 11.2 & 8.5 & 11.6 & 9.0 & 8.4 & 12.8 \\
\hline
\end{tabular}

\begin{tabular}{|c|c|c|c|c|c|c|c|c|c|c|c|c|c|}
\hline $\begin{array}{l}\text { Formation } \\
\text { GGU No. } \\
\text { Type }\end{array}$ & $\begin{array}{c}\text { SF } \\
215605 \\
\text { m-h-Ti }\end{array}$ & $\begin{array}{c}\text { SF } \\
215608 \\
\mathrm{~m}-\mathrm{h}-\mathrm{Ti}\end{array}$ & $\begin{array}{c}\mathrm{SF} \\
215606 \\
\mathrm{~m}-\mathrm{h}-\mathrm{Ti}\end{array}$ & $\begin{array}{c}\text { SF } \\
215641 \\
m-h-T i\end{array}$ & $\begin{array}{c}\text { SF } \\
98561 \\
\text { high-Si }\end{array}$ & $\begin{array}{c}\text { IF } \\
\text { I16379 } \\
\text { low-Ti }\end{array}$ & $\begin{array}{c}\text { IF } \\
116382 \\
\text { low-Ti }\end{array}$ & $\begin{array}{c}\text { IF } \\
116344 \\
m-h-T i\end{array}$ & $\begin{array}{c}\text { IF } \\
116340 \\
\mathrm{~m}-\mathrm{b}-\mathrm{Ti}\end{array}$ & $\begin{array}{c}\text { IF } \\
116349 \\
\text { m-h-Ti }\end{array}$ & $\begin{array}{c}\text { IF } \\
116345 \\
\mathrm{~m}-\mathrm{h}-\mathrm{Ti}\end{array}$ & $\begin{array}{c}\text { IF } \\
116347 \\
\text { m-h-Ti }\end{array}$ & $\begin{array}{c}\text { IF } \\
116343 \\
\text { m-h-Ti }\end{array}$ \\
\hline $\mathrm{Mg}$ ratio & 0.465 & 0.465 & 0.459 & 0.450 & 0.539 & 0.517 & 0.503 & 0.485 & 0.468 & 0.466 & 0.465 & 0.444 & 0.398 \\
\hline $\mathrm{Cr}$ & 129 & 85 & 145 & 120 & 244 & 90 & 89 & 120 & 127 & 76 & 41 & 35 & 35 \\
\hline $\mathrm{Ni}$ & 71 & 57 & 79 & 65 & 88 & 78 & 70 & 69 & 67 & so & 37 & 36 & 33 \\
\hline $\mathrm{Sc}$ & 35 & 36 & 35 & 32 & 34 & 34 & 37 & 36 & 36 & 39 & 41 & 38 & 34 \\
\hline V & 437 & 399 & 414 & 355 & 325 & 312 & 382 & 366 & 411 & 445 & 465 & 488 & 430 \\
\hline $\mathrm{Cu}$ & 237 & 215 & 208 & 288 & 195 & 214 & 174 & 260 & 177 & 225 & 255 & 306 & 256 \\
\hline $\mathrm{Zn}$ & 114 & 102 & 112 & 109 & 102 & 77 & 89 & 97 & 95 & 95 & 97 & 121 & 113 \\
\hline $\mathrm{Ba}$ & 116 & 130 & 112 & 119 & 131 & 70 & 124 & 136 & 200 & 103 & 75 & 156 & 219 \\
\hline $\mathrm{Sr}$ & 274 & 273 & 278 & 266 & 193 & 236 & 258 & 214 & 328 & 243 & 187 & 268 & 261 \\
\hline $\mathrm{Rb}$ & 1.4 & 5.3 & 5.7 & 10 & 9.4 & 0.6 & 5.7 & 11 & 8.2 & 1.3 & 1.2 & 2.0 & 4.0 \\
\hline $\mathrm{Y}$ & 33 & 31 & 34 & 38 & 26 & 31 & 33 & 46 & 33 & 37 & 40 & 47 & 48 \\
\hline $\mathrm{Zr}$ & 205 & 178 & 215 & 195 & 118 & 117 & 133 & 190 & 179 & 189 & 138 & 231 & 267 \\
\hline $\mathrm{Nb}$ & 18.1 & 14.2 & 20 & 18.4 & 9.1 & 8.6 & 17.5 & 20.2 & 23 & 20.0 & 13.3 & 26.6 & 31.3 \\
\hline
\end{tabular}

\begin{tabular}{|c|c|c|c|c|c|c|c|c|c|c|c|c|}
\hline $\begin{array}{l}\text { Formation } \\
\text { GGU No. } \\
\text { Type }\end{array}$ & $\begin{array}{l}\text { i.dyke } \\
96930 \\
\text { Jow-Ti }\end{array}$ & $\begin{array}{c}\text { i.dyke } \\
96812 \\
\text { med-Ti }\end{array}$ & $\begin{array}{l}\text { i.dyke } \\
96828 \\
\text { med-Ti }\end{array}$ & $\begin{array}{l}\text { i.dyke } \\
167115 \\
\text { high-Ti }\end{array}$ & $\begin{array}{l}\text { i.dyke } \\
98890 \\
\text { Ti-thol }\end{array}$ & $\begin{array}{l}\text { c.dyke } \\
215507 \\
\text { low-Ti }\end{array}$ & $\begin{array}{l}\text { c.dyke } \\
215439 \\
\text { low-Ti }\end{array}$ & $\begin{array}{l}\text { c.dyke } \\
215580 \\
\text { m-h-Ti }\end{array}$ & $\begin{array}{l}\text { c.dyke } \\
215579 \\
\text { m-h-Ti }\end{array}$ & $\begin{array}{l}\text { c.dyke } \\
215590 \\
\text { m-h-Ti }\end{array}$ & $\begin{array}{l}\text { c.dyke } \\
98341 \\
\text { m-h-Ti }\end{array}$ & $\begin{array}{c}\text { Archaean } \\
133158 \\
\text { gneiss }\end{array}$ \\
\hline $\mathrm{Mg}$ ratio & 0.541 & 0.530 & 0.481 & 0.486 & 0.419 & 0.547 & 0.507 & 0.443 & 0.433 & 0.415 & 0.400 & - \\
\hline $\mathrm{Cr}$ & 175 & 304 & 168 & 162 & 143 & 194 & 68 & 21 & 62 & 43 & 50 & 36 \\
\hline $\mathrm{Ni}$ & 99 & 126 & 80 & 85 & 77 & 75 & 66 & 39 & 49 & 35 & 35 & 16 \\
\hline $\mathrm{Sc}$ & 32 & 39 & 35 & 31 & 38 & 33 & 32 & 27 & 29 & 32 & 44 & 3.9 \\
\hline V & 337 & 382 & 389 & 396 & 499 & 312 & 355 & 336 & 343 & 379 & 454 & 38 \\
\hline $\mathrm{Cu}$ & 226 & 249 & 284 & 269 & 407 & 187 & 213 & 180 & 202 & 329 & 222 & 48 \\
\hline $\mathrm{Zn}$ & 87 & 101 & 115 & 115 & 175 & 79 & 82 & 89 & 124 & 137 & 132 & 28 \\
\hline $\mathrm{Ba}$ & 75 & 98 & 64 & 98 & 183 & 72 & 89 & 137 & 155 & 193 & 107 & 291 \\
\hline $\mathrm{Sr}$ & 247 & 225 & 216 & 287 & 297 & 202 & 199 & 277 & 292 & 221 & 199 & 279 \\
\hline $\mathrm{Rb}$ & 4.4 & 5.5 & 2.9 & 7.2 & 15 & 5.2 & 7.4 & 5.7 & 19 & 17 & 9.0 & 32 \\
\hline $\mathrm{Y}$ & 26 & 30 & 35 & 32 & 49 & 32 & 38 & 38 & 49 & 55 & 45 & 6.4 \\
\hline $\mathrm{Zr}$ & 121 & 142 & 153 & 172 & 311 & 112 & 147 & 190 & 218 & 250 & 179 & 138 \\
\hline $\mathrm{Nb}$ & 11.1 & 13.2 & 14.4 & 14.5 & 37.9 & 12.1 & 14.9 & 26.9 & 26.2 & 30.9 & 19.4 & 3.7 \\
\hline
\end{tabular}




\section{Plate 1}

\section{Cross sections through the Scoresby Sund basalts}

\section{Plate 2}

\section{Compositional stratigraphy of the Scoresby Sund basalts}

The analysed profiles were projected onto a NW-SE line approximately perpendicular to the strike of the lavas and the direction of the coast, see index figure in upper left corner. Thus, the abscissa is given as distance from the coast as measured on the projection line. Profiles from which only single analyses exist are not shown, profile 76 has been omitted due to lack of space, and profiles 77-78 (Gronau Nunatakker) have been omitted due to their large projection distances. Each analysed sample is shown as a dot to the right of the coloumn, and it should thus be possible to locate the position of the analyses in the appendix Profile numbers are shown above the abscissa.

In the Milne Land Formation, some profiles are shown from which no analyses exist. In these, the correlation has been done petrographically.

For the Magga Dan and Milne Land Formations, the bottom of the Hjørnedal marker flow was defined as horizontal. The other formations are plotted separately, with horizontal bottoms, and for the Geikie Plateau Formation also with horizontal top. 
Bull. Grønlands Geol. Unders. 157

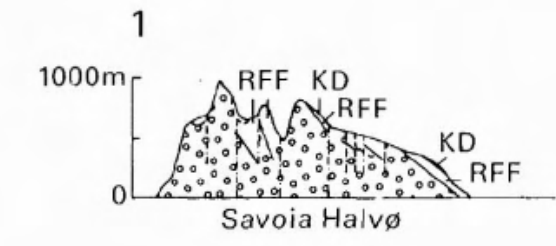

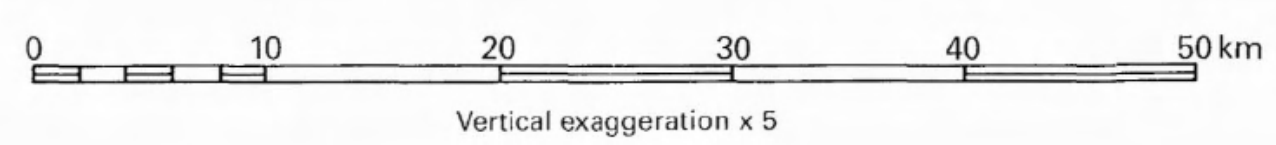

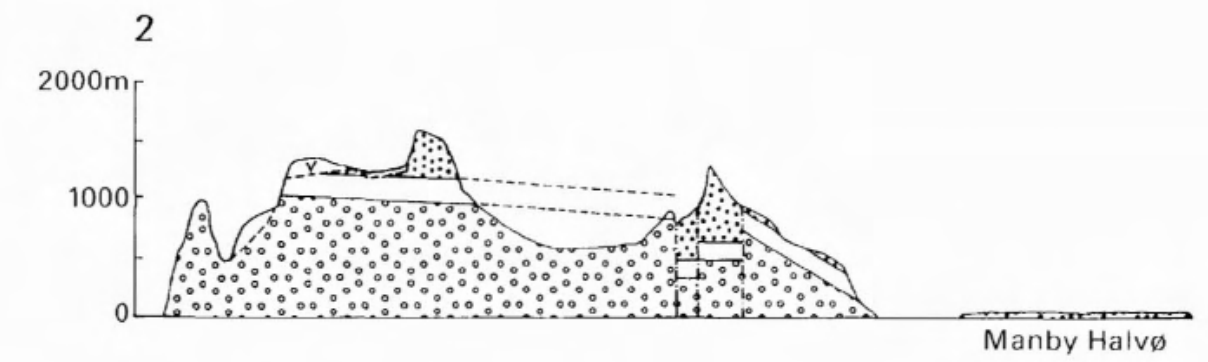

3

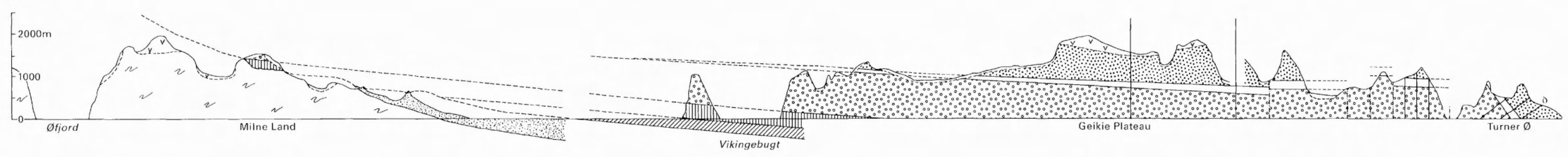

NW
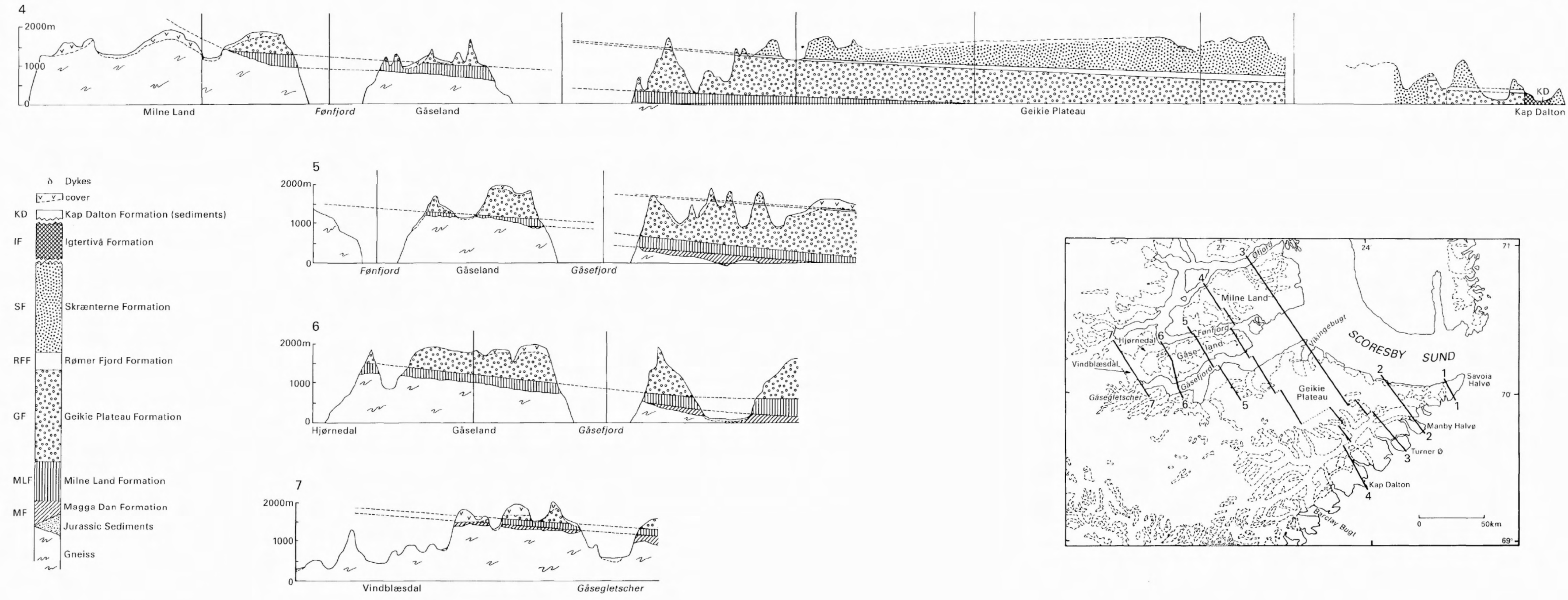
Bull. Grønlands Geol. Unders. 157

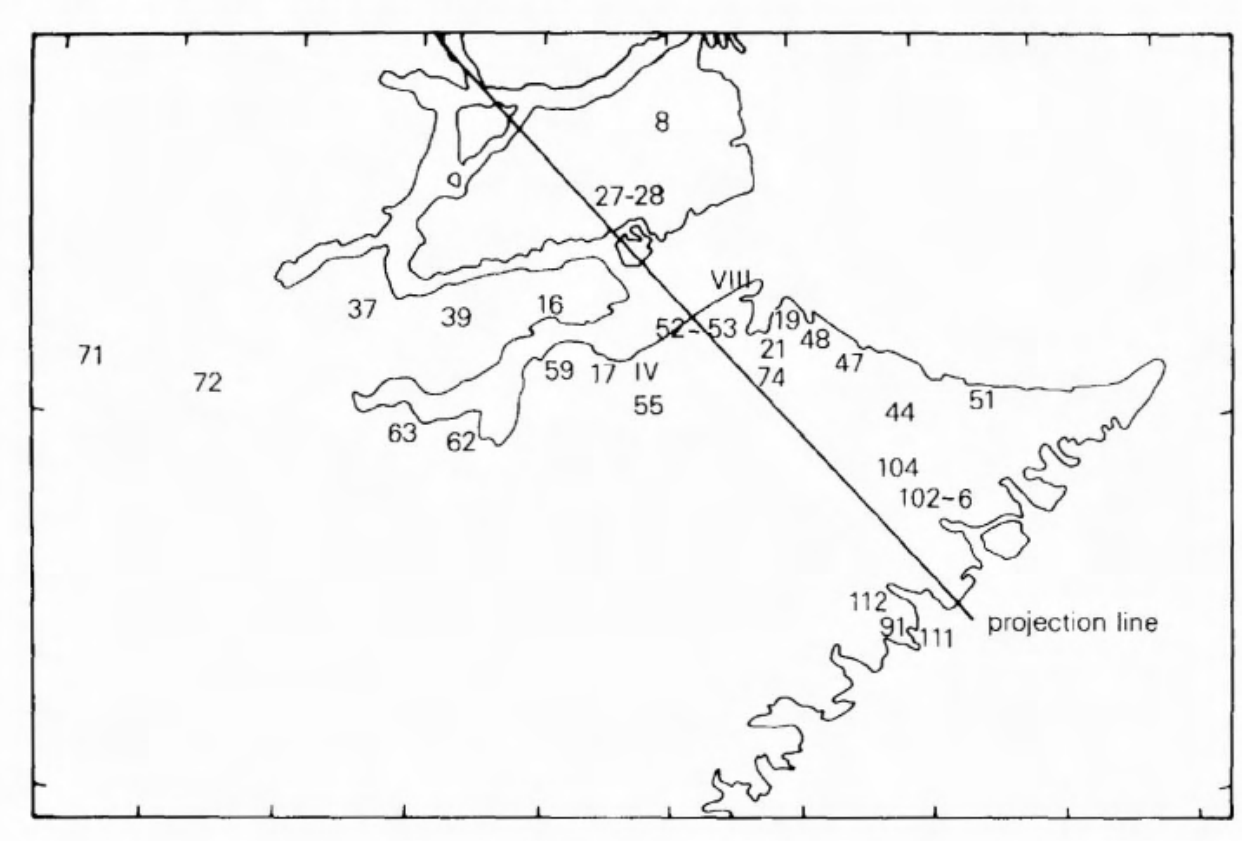

RØMER FJORD FORMATION

SKREENTERNE FORMATION

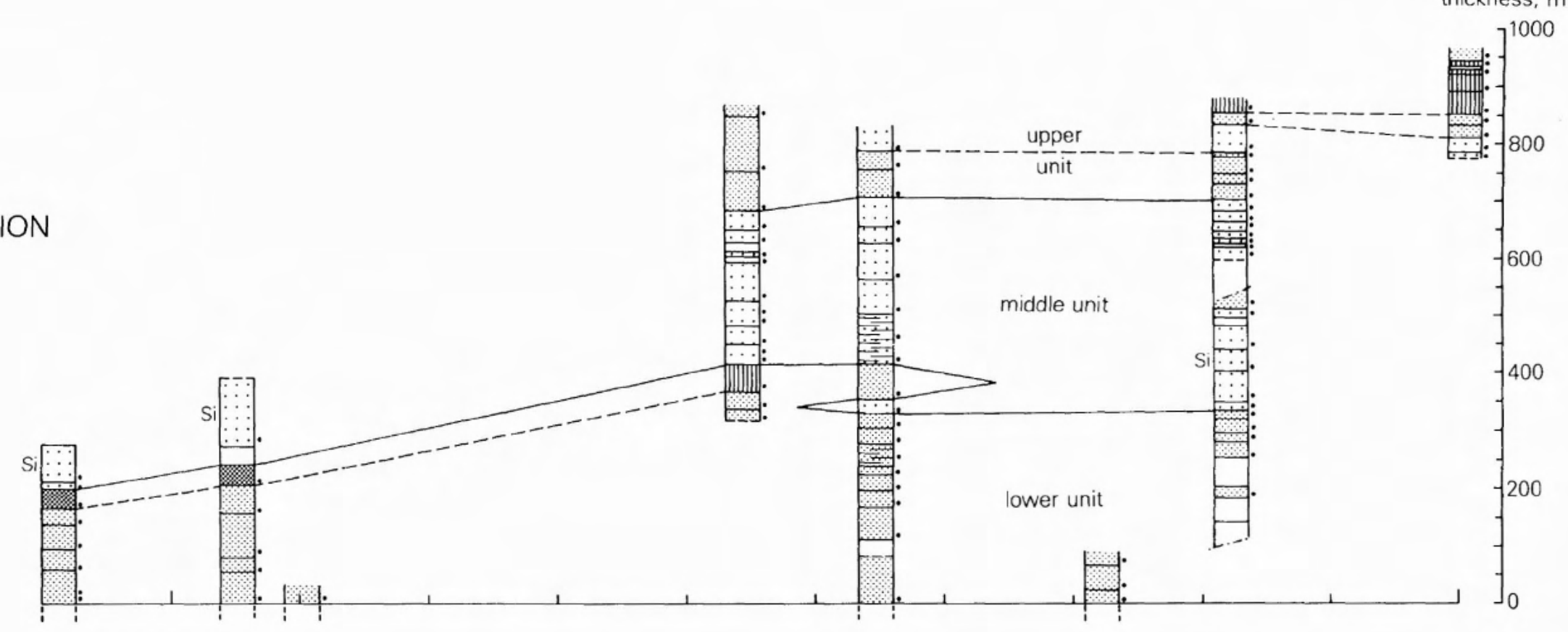

Iow- $\mathrm{Ti}$ basalt: $\mathrm{TiO}_{2}<$ appr. $2.25 \%$

med $-\mathrm{Ti}$ basalt: $\mathrm{TiO}_{2}=$ appr. $2.25 \%-2.8 \%$
SF and IF: $\mathrm{TiO}_{2}=$ appr. $2.25 \%-3.0 \%$

high - $\mathrm{Ti}$ basalt: $\mathrm{TiO}_{2}=2.8 \%-3.5 \%$
$\mathrm{SF}$ and IF: $\mathrm{TiO}_{2}=3.0 \%-3.5 \%$

Titano - tholeiite: $\mathrm{TiO}_{2}>3.5 \%$

Hjornedal marker flow

Mikis type basal

high - Si basalt

nephelinite tuff

compound flows

- analysed sample

vy basement

GEIKIE PLATEAU FORMATION
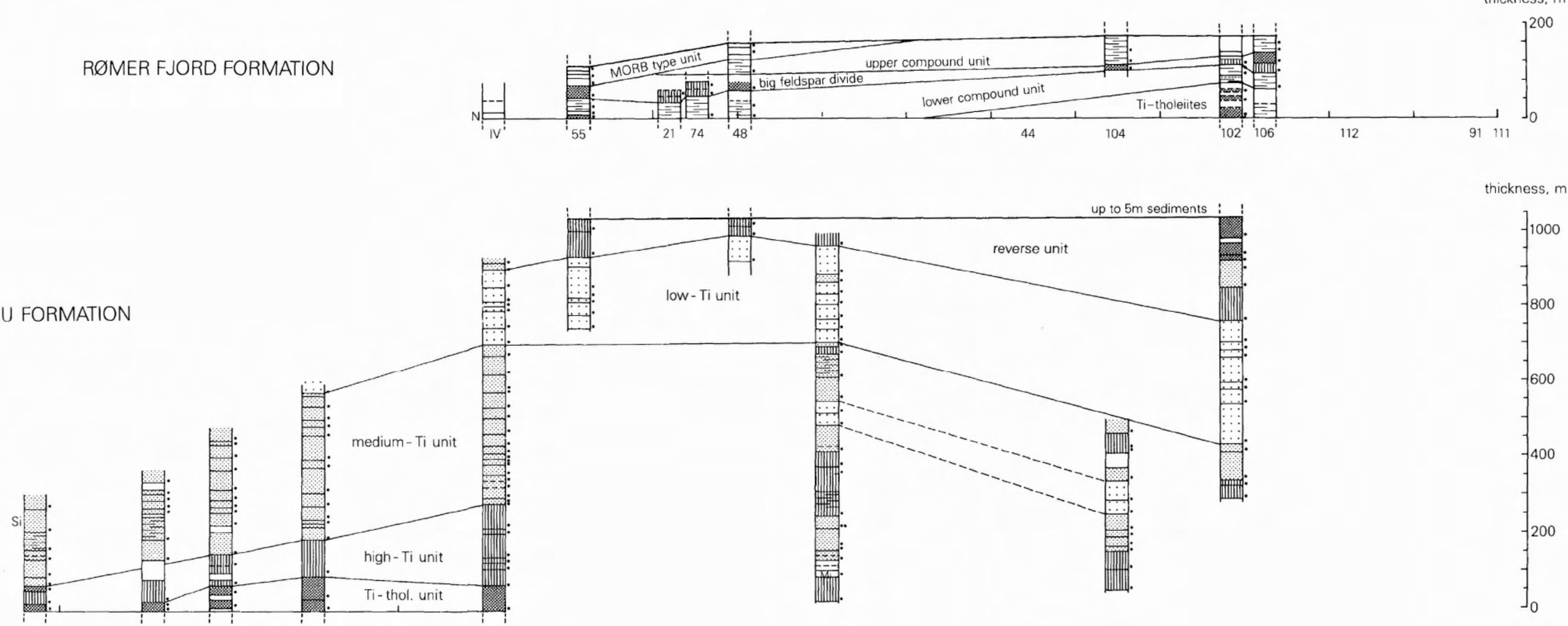

thickness
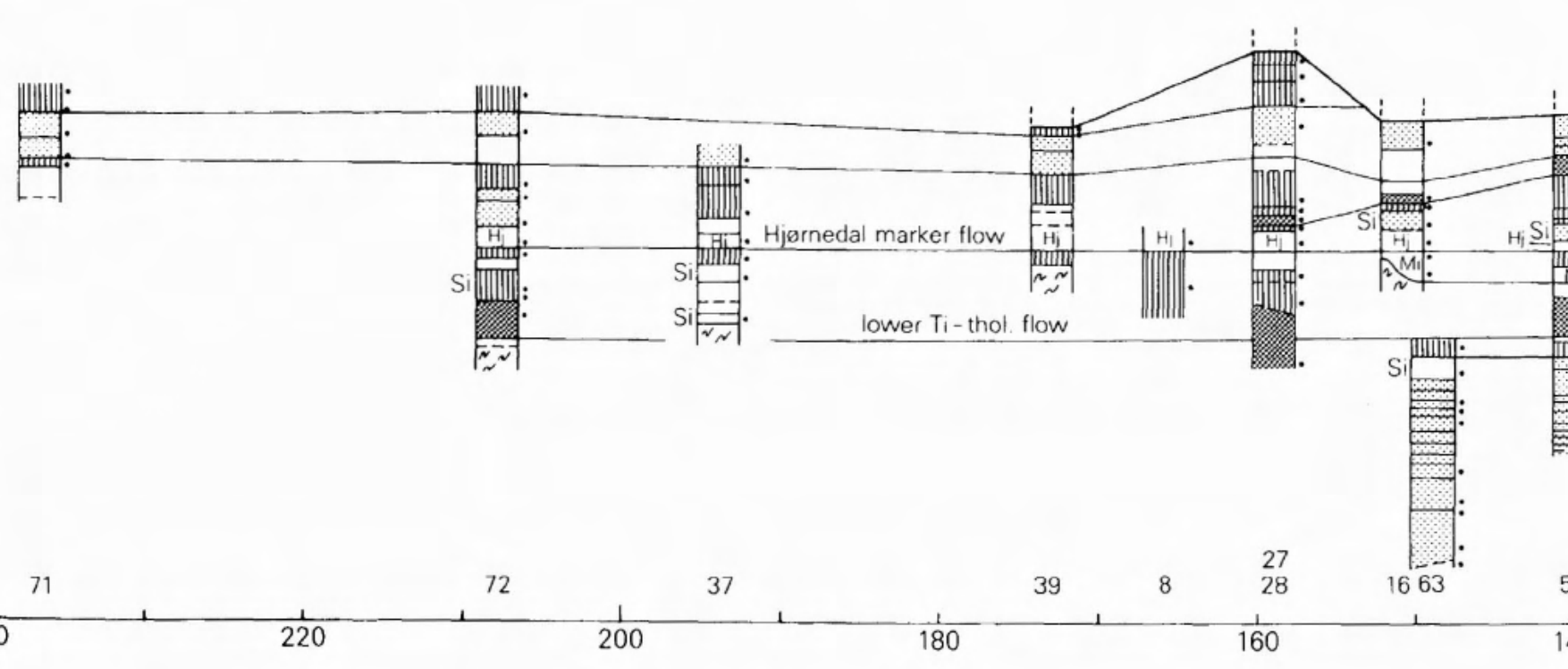